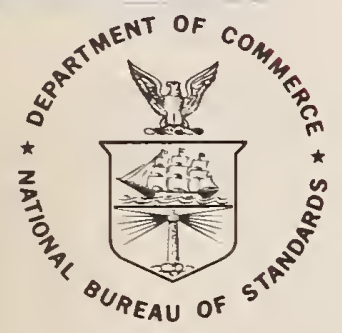

\title{
Test Problems and Results for OMNITAB 80
}

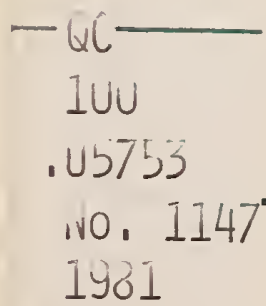




\section{NATIONAL BUREAU OF STANDARDS}

The National Bureau of Standards' was established by an act of Congress on March 3, 1901. The Bureau's overall goal is to strengthen and advance the Nation's science and technology and facilitate their effective application for public benefit. To this end, the Bureau conducts research and provides: (1) a basis for the Nation's physical measurement system, (2) scientific and technological services for industry and government, (3) a technical basis for equity in trade, and (4) technical services to promote public safety. The Bureau's technical work is performed by the National Measurement Laboratory, the National Engineering Laboratory, and the Institute for Computer Sciences and Technology.

THE NATIONAL MEASUREMENT LABORATORY provides the national system of physical and chemical and materials measurement; coordinates the system with measurement systems of other nations and furnishes essential services leading to accurate and uniform physical and chemical measurement throughout the Nation's scientific community, industry, and commerce; conducts materials research leading to improved methods of measurement, standards, and data on the properties of materials needed by industry, commerce, educational institutions, and Government; provides advisory and research services to other Government agencies; develops, produces, and distributes Standard Reference Materials; and provides calibration services. The Laboratory consists of the following centers:

Absolute Physical Quantities ${ }^{2}$ - Radiation Research - Thermodynamics and Molecular Science - Analytical Chemistry - Materials Science.

THE NATIONAL ENGINEERING LABORATORY provides technology and technical services to the public and private sectors to address national needs and to solve national problems; conducts research in engineering and applied science in support of these efforts; builds and maintains competence in the necessary disciplines required to carry out this research and technical service; develops engineering data and measurement capabilities: provides engineering measurement traceability services; develops test methods and proposes engineering standards and code changes; develops and proposes new engineering practices; and develops and improves mechanisms to transfer results of its research to the ultimate user. The Laboratory consists of the following centers:

Applied Mathematics - Electronics and Electrical Engineering ${ }^{2}$ - Mechanical Engineering and Process Technology $y^{2}$ - Building Technology - Fire Research Consumer Product Technology - Field Methods.

THE INSTITUTE FOR COMPUTER SCIENCES AND TECHNOLOGY conducts research and provides scientific and technical services to aid Federal agencies in the selection. acquisition, application, and use of computer technology to improve effectiveness and economy in Government operations in accordance with Public Law 89-306 (40 U.S.C. 759), relevant Executive Orders, and other directives; carries out this mission by managing the Federal Information Processing Standards Program, developing Federal ADP standards guidelines, and managing Federal participation in ADP voluntary standardization activities; provides scientific and technological advisory services and assistance to Federal agencies; and provides the technical foundation for computer-related policies of the Federal Government. The Institute consists of the following centers:

Programming Science and Technology- Computer Systems Engineering.

'Headquarters and Laboratories at Gaithersburg, MD, unless otherwise noted; mailing address Washington, DC 20234.

${ }^{2}$ Some divisions within the center are located at Boulder, CO 80303. 


\section{Test Problems and Results for OMNITAB 80}

Sally T. Peavy and Shirley G. Bremer

Center for Applied Mathematics

National Engineering Laboratory

National Bureau of Standards

Washington, DC 20234

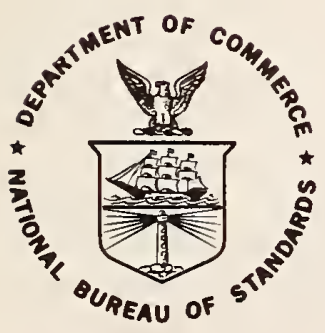

U.S. DEPARTMENT OF COMMERCE, Malcolm Baldrige, Secretary NATIONAL BUREAU OF STANDARDS, Ernest Ambler, Director Issued November 1981 


\section{National Bureau of Standards Technical Note 1147}

Nat. Bur. Stand. (U.S.), Tech. Note 1147, 316 pages (Nov. 1981)

CODEN: NBTNAE

Supersedes Technical Note 552

U.S. GOVERNMENT PRINTING OFFICE

WASHINGTON: 1981

For sale by the Superintendent of Documents, U.S. Government Printing Office, Washington, DC 20402 Price $\$ 8.50$

(Add 25 percent for other than U.S. mailing) 


\title{
Test Problems and Results for OMNITAB 80
}

\author{
Sally T. Peavy and Shirley G. Bremer
}

\begin{abstract}
The lack of test problems and results for many computer software packages is a great hindrance to both the systems programmer and the general user. In this publication a set of 69 test problems and results for the OMNITAB 80 system is provided to assist individuals in checking the installation of the OMNITAB 80 system on their particular computer. The general user will also find these descriptive examples instructive in the use of the OMNITAB 80 system.
\end{abstract}

Key words: Accuracy; ANS FORTRAN; computer system installation; examples; OMNITAB 80; software; test problems.

OMNITAB 80 is a high quality integrated general purpose programming language and statistical software computing system. The OMNITAB 80 computing system enables the nonprogrammer to use a digital computer to perform data, statistical, and numerical analysis without having any prior knowledge of computers or computer languages. The user writes simple instructions in his or her own native language to obtain accurate results simply and effectively. The instructions reference reliable, varied, and sophisticated algorithms for analysis and manipulation of data. The tedious task of formatting data for input and output is alleviated by OMNITAB 80 through free field input and readable and automatic output. If desired, considerable flexibility is allowed in the printing of results with user supplied formats. The system permits the user to perform simple arithmetic, complex arithmetic and trigonometric calculations, data manipulation, special function calculations, statistical analysis and operations on matrices and arrays. The OMNITAB 80 system may be used with equal ease either interactively or with submitted runs to the computer facility.

OMNITAB was originally conceived and developed by Joseph Hilsenrath and his co-workers and was fully documented in Hilsenrath et al. (1966). Since then OMNITAB has been completely rewritten and expanded, while carefully maintaining the original spirit and philosophy. OMNITAB II was made available in 1970 and was a machine independent system (see Hogben et al. 1971). The current version is called NBS OMNITAB 80 Version 6.0. This publication is the first of several which constitute the documentation of the OMNITAB 80 system. It contains 69 test problems and their results which can be used to determine whether a systems programmer has successfully installed and implemented the OMNITAB 80 system.

The OMNITAB 80 system was not only developed with the user in mind, but the systems programmer as well. All the subprograms in the system are written in a portable subset of American National Standard FORTRAN and checked with the PFORT Verifier. The use of any FORTRAN statement which cannot be successfully compiled on a large computer is avoided.

OMNITAB 80 is transportable to any computer configuration sufficiently large to accommodate it. Necessary modifications for a particular computer are outlined in Bremer et al. This is reference material, since all modifications are made prior to the distribution of the OMNITAB 80 system.

All FORTRAN compilers do not interpret FORTRAN statements in the same manner. Considerable effort has been expended to keep the need to make modifications to an absolute minimum. Thus, it is essential that the system analyst have a means of determining whether the system performs as it originally was designed to do. It is important to the user to know what to expect from a software system when he or she inputs his or her data as well as to know how to use the package. 
In 1970 a set of 52 test problems and results for OMNITAB II (Varner et al.) was published. OMNITAB 80 has many new instructions. The new set of test problems includes these new instructions as well as modifications of the original test problems for easier reading and understanding.

This note contains a set of 69 test problems and results for all of the OMNITAB 80 commands in Version 6.0 with the following exceptions: (a) PUNCH, NHISTOGRAM, EXTREMA, CONTENTS, and DESCRIBE; (b) commands related to interactive use of OMNITAB 80 such as CRT, INTERACTIVE, etc.; (c) commands invoking any language other than English or Spanish; (d) all the commands for using magnetic tapes or auxiliary memory units; and (e) commands related to the CALCOMP PLOTTER. The commands MAXMIN, a synonym for EXTREMA, and HISTOGRAM, similar to NHISTOGRAM, were both used. In most instances only one version of a command was used since it was too cumbersome to supply test problems for all possibilities. The test problems were constructed so as to minimize the output and make it possible to determine major errors at a glance. The test problems F1 through F10 reference the FORMAT instructions and are grouped together at the end. A table of contents is given on pages vi and vii.

The checks in the test problems are gross error checks. They are to be used to determine whether the entire OMNITAB system has been successfully installed. They are not intended as a definitive test for each instruction. Each instruction has undergone a far more rigorous testing for both programming and numerical accuracy. In addition, some errors which escaped detection in the initial testing were subsequently found in the extensive use of the instructions by users at the National Bureau of Standards and later corrected. The results of the test problems are based on the use of OMNITAB 80 with a computer having a 36 binary bit word length. When the same problems are run on a computer with a different word length and with different precisions the results may differ depending on the particular computer in use. The set of test problems and results is published here for convenient use and reference. The same set of test problems and results is available on the magnetic tape which contains the OMNITAB 80 system and can be ordered from the Office of Standard Reference Data, A.323 Physics Building, National Bureau of Standards, Washington, D.C. 20034.

The arrangement of the test problems is similar to the new OMNITAB 80 User's Reference Manual to be published later. Part $\mathrm{C}$ of the Manual describes each OMNITAB 80 instruction in detail. The test problems start with instructions listed in Part C, Section 3 through Section 13, except test 59 which is described in C.1.7.

Each set of test problems begins with the command OMNITAB. Information on the OMNITAB instruction includes the title of the test and, in parentheses, the section number or numbers associated with the commands being tested, as described in Part $\mathrm{C}$ of the new and unpublished OMNITAB 80 User's Reference Manual.

The command ACCURACY was added to the system primarily for the purpose of testing the implementation of new commands. The instruction has been used in this set of test problems and allows the reader to see at a glance whether anticipated results agree with the actual results. When used in conjunction with the instruction AVERAGE, it is possible to summarize the accuracy of a large set of calculations in a single number. The instruction ACCURACY compares two (sets of) numbers and gives the number of first significant digits they have in common. Further details are given in Hogben et al. (1971).

In each test problem the data used as input are assumed to be exact. The results determine whether the calculations have been performed successfully. If anyone desires to assess the effect of errors in input data on the final results he or she could use the instruction ROUND with the input data and repeat the test problem. For example, one could ROUND the original data to seven significant digits and see what effect this has on the final results.

Mathematical identities are frequently used to obtain a single result which simultaneously verifies several computed quantities. See, for example, test 12 on hyperbolic functions. For the special functions, frequent reference is made to Abramowitz and Stegun (1964).

This is a rare attempt to provide a comprehensive set of test problems and results for a computer software package. The results should be very useful, both to the user and the installer of the OMNITAB 80 system. Readers are encouraged to express their comments, experiences, and criticisms. The valuable assistance received from all members of the Statistical Engineering Division is gratefully acknowledged. A special thanks is extended to Ilse E. Putman and Carla G. Messina for preparing the text and the examples, respectively, for computerized phototypesetting. Last, but not least, we extend our appreciation to David Hogben for his valuable assistance. 


\section{References}

Abramowitz, Milton and Stegun, Irene (1964). Handbook of Mathematical Functions, NBS Applied Mathematics Series 55, Superintendent of Documents, U.S. Government Printing Office, Washington, D.C. 20402.

American National Standard Programming Language FORTRAN (1978). American National Standards Institute, New York.

Bremer, Shirley G., Peavy, Sally T., and Hogben, David. A Systems Programmer's Guide for Installing OMNITAB 80. NBS Technical Note in preparation.

Hilsenrath, J., Ziegler, G. G., Messina, C. G., Walsh, P. J., and Herbold, R. J. (1966). OMNITAB: A Computer Program for Statistical and Numerical Analysis. National Bureau of Standards Handbook 101, Superintendent of Documents, U.S. Government Printing Office, Washington, D.C. 20402. Reissued January 1968 with corrections.

Hogben, David and Peavy, Sally T. (1977). OMNITAB II User's Reference Manual 1977 Supplement. NBSIR 77-1276, Superintendent of Documents, U.S. Government Printing Office, Washington, D.C. 20402.

Hogben, David, Peavy, S. T., and Varner, R. N. (1970). OMNITAB II User's Reference Manual. NBS Technical Note 552, Superintendent of Documents, U.S. Government Printing Office, Washington, D.C. 20402.

Peavy, S. T., Varner, R. N., and Hogben, David (1970). Source Listing of OMNITAB II Program. NBS Special Publication 339, Superintendent of Documents, U.S. Government Printing Office, Washington, D.C. 20402.

Ryder, B. C. and Hall, A. D. (1975). The PFORT Verifier Computing Science Technical Report \#12, Bell Laboratories, Murray Hill, New Jersey 07974.

Varner, R. N. and Peavy, S. T. (1970). Test Problems and Results for OMNITAB II. NBS Technical Note 551, Superintendent of Documents, U.S. Government Printing Office, Washington, D.C. 20402. 


\section{TABLE OF CONTENTS FOR TEST PROBLEM LISTINGS}

OMNITAB prints PAGE and number at the extreme right of the top line of each page. The page number for this table of contents appears at the bottom of each page. Numbering does not begin anew with each set of instructions as does the OMNITAB page number.

Test No.

Omnitab Title Line

Page

CPLOT AND NCPLOT INSTRUCTIONS. (3.2)

NICE PLOT, TITLES, WIDTH AND LENGTH INSTR. (3.3), (3.4), (3.5)

TWOPLOT AND FOURPLOT INSTRUCTIONS. (3.6)

STEM LEAF INSTRUCTIONS. (3.8)

STATPLOT INSTRUCTION. (3.8)

PROBABILITY PLOT INSTRUCTIONS. (3.9) AND (7.5)

ARITHMETIC INSTRUCTIONS. (4.1)

CHANGE INSTRUCTION. (4.2)

MATHEMATICAL FUNCTIONS. (4.3)

SINE, COSINE, TANGENT AND COTANGENT INSTRUCTIONS. (4.4)

TRIGONOMETRIC FUNCTIONS. (4.4)

HYPERBOLIC FUNCTIONS. (4.4)

ROUND INSTRUCTION. (4.7)

SUM, PARPRODUCT, PARSUM AND RMS (ROOT MEAN SQUARE). (4.7)

PERCENTAGES, PROPORTIONS AND DAYS INSTRUCTIONS. (4.7)

EXPAND AND SHORTEN INSTRUCTIONS. (4.7) AND (5.3)

COMPLEX ARITHMETIC INSTRUCTIONS. (4.8)

DEMOTE AND PROMOTE INSTRUCTIONS. (5.2)

EXCHANGE INSTRUCTION. (5.2)

MOVE, AMOVE AND MMOVE INSTRUCTIONS. (5.2), (10.2) AND (11.2)

CENSOR, SELECT AND SEARCH INSTRUCTIONS. (5.3) AND (5.5)

INSERT, SEPARATE AND MAXMIN INSTRUCTIONS. (5.3) AND (8.5)

HIERARCHY, ORDER AND SORT INSTRUCTIONS. (5.4)

CHOOSE, RETAIN, OMIT AND DELETE INSTRUCTIONS. (5.6)

CODE, RECODE AND REPLACE INSTRUCTIONS. (5.6)

MAXIMUM AND MINIMUM INSTRUCTIONS. (6.1)

STATISTICAL ANALYSIS. (6.3)

POLYFIT INSTRUCTION. (6.4)

ONEWAY AND SONEWAY INSTRUCTIONS. (6.6)

TWOWAY AND STWOWAY INSTRUCTIONS. (6.6)

CORRELATION AND SCORRELATION INSTRUCTIONS. (6.7)

CONTINGENCY TABLE ANALYSIS. (6.8)

EXAMPLES OF TABLE AND NTABLE INSTRUCTIONS. (6.9)

PROBABILITY DENSITY FUNCTIONS. (7.1)

PROB DENS, CUMUL DIST AND PERCENT PT. (7.1), (7.2) AND (7.3)

PROB DENS, CUMUL DIST AND PERCENT PT. (7.1), (7.2) AND (7.3)

CUMULATIVE DIST AND PERCENT PT. (7.2) AND (7.3)

CUMULATIVE DISTRIBUTION AND PERCENT PT. (7.2) AND (7.3)

RANDOM NUMBER INSTRUCTIONS. (7.4)

EXAMPLES OF SAMPLE WITH AND WITHOUT REPEAT. (7.6)

EXAMPLES OF ELLIPTICAL INTEGRAL OF ORDERS 1 AND 2. (8.1)

ERROR AND COMPLEMENTARY ERROR INSTRUCTIONS. (8.1)

EXAMPLE OF GAMMA INSTRUCTION. (8.1)

SPECIAL INTEGRALS. (8.1)

STRUVE FUNCTIONS AND INTEGRAL OF J(0). (8.1) AND (12.10)

CHEBYSHEV, HERMITE, LAGUERRE AND LEGENDRE POLYS. (8.2) 
47 DIFFERENCES AND DIVDIFFERENCES INSTRUCTIONS. (8.3) 202

48 ISOLATE, ISETUP AND ITERATE INSTRUCTIONS. (8.4) 205

49 INTERPOLATE INSTRUCTION. (8.5)

50 GAUSS QUADRATURE INSTRUCTION. (8.6)

51

ARRAY AND MATRIX INSTRUCTIONS. (10.) AND (11.)

211

214

ACOALESCE AND AAVERAGE INSTRUCTIONS. (10.3)

216

MTRIAN, MINVERT AND MRAISE INSTRUCTIONS. (11.3)

223

MATRIX INSTRUCTIONS M(XX') AND M(X'X). (11.4)

225

BESSEL FUNCTIONS. (12.1), (12.2) AND (12.3)

229

BESSEL OF COMPLEX ARGS. (12.4), (12.5), (12.6) AND (12.7)

231

ZEROS OF BESSEL FUNCTIONS AND FUNCT. OF ORDER N. (12.8) (12.9)

235

THERMODYNAMIC FUNCTIONS. (13.3) AND (13.4)

VOCABULARY AND FOREIGN LANGUAGE INSTR. (1.7)

243

247

COUNT, DUPLICATE AND CLOSE UP INSTR. (5.1), (5.2) AND (5.3) 264

REGRESSION ANAL., BESTCP AND SPLIT PLOT. (6.4), (6.5), (6.6)

269

HARMONIC ANALYSIS INSTRUCTION. (8.5)

279

SOLVE LINEAR EQUATIONS AND INVERT MATRIX. (8.5) AND (11.5) 281

BRANCHING INSTRUCTIONS. (9.3) AND (9.4)

288

ARRAY AND MATRIX INSTRUCTIONS. (10.1), (10.2), (11.1), (11.3)

MATRIX INSTRUCTIONS M(AD), M(DA) AND M(V'A). (11.4)

291

EXAMPLES OF MATRIX INSTRUCTIONS M(XAX') AND M(X'AX): (11.4)

F8

EXAMPLES OF MATRIX INSTRUCTIONS M(XAX') AND M(X AX). (11.4)

297

F9 TEMP. SCALE CONVERSION AND ATOMIC WT. (13.1) AND (13.3)

299

F10 PHYSICAL CONSTANTS. (13.2)

303 

OMNITAB 80 TEST 1 CPLOT AND NCPLOT INSTRUCTIONS. (3.2)

PAGE 1
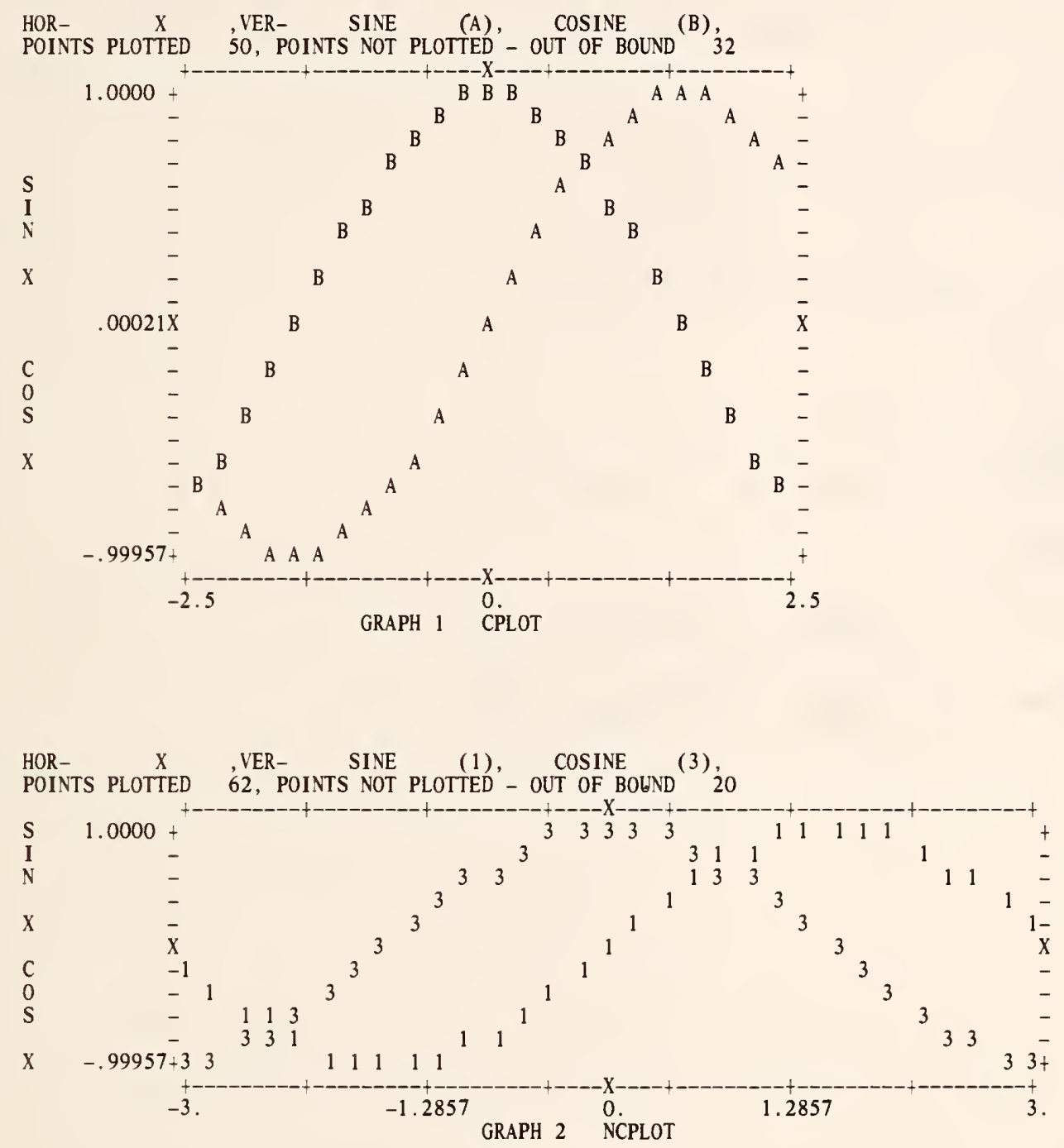
OMNITAB 80 TEST 1 CPLOT AND NCPLOT INSTRUCTIONS. (3.2)

LIST OF DATA, INSTRUCTIONS AND DIAGNOSTICS

LABEL $X$, SINE, COSINE

* INFORMATIVE DIAGNOSTIC FOR THE ABOVE INSTRUCTION (X) IS IN COL (1), (SINE) IS IN COL (2)

(COSINE) IS IN COL (3)

GENERATE NOS. FROM -4. IN STEPS OF (.2) THRU 4.0 IN X

* INFORMATIVE DIAGNOSTIC FOR THE abOVE INSTRUCTION NRMAX HAS BEEN RESET FROM O TO 41.

SIN OF X PUT IN SINE

COS OF X PUT IN COSINE

TITLEY SIN $X \quad \operatorname{COS} X$

TITLEX 75 CHARACTERS PER LINE

LENGTH 30 LINES PER PAGE

CPLOT SINE, SYMBOL 11. AND COSINE, SYMBOL 12. VS X FROM -2.5 TO +2.5

SPACE 5

WIDTH 90 CHARACTERS PER LINE

LENGTH 20 LINES PER PAGE

TITLEY SIN X COS X

TITLEX

GRAPH 2 NCPLOT

NCPLOT SINE, SYMBOL 1. AND COSINE, SYMBOL 3. VS X FROM -3.0 TO +3.0

NATIONAL BUREAU OF STANDARDS. WASHINGTON, D. C. 20234

OMNITAB 80 VERSION 6.00 MARCH 2, 1981 
OMNITAB 80 TEST 2 NICE PLOT, TITLES, WIDTH AND LENGTH INSTR. (3.3), (3 PAGE 1 INSTRUCTION IS NICE PLOT.

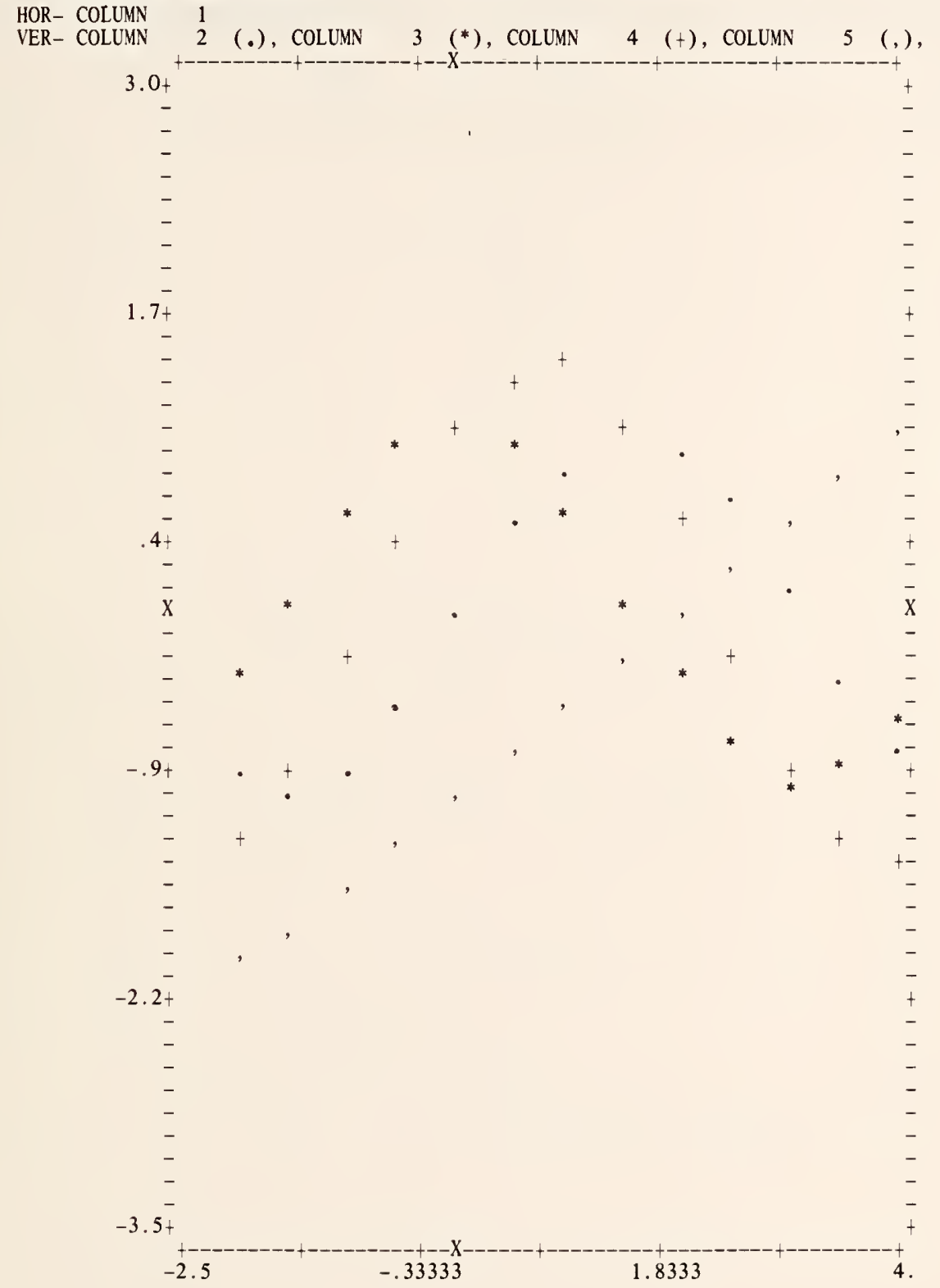


OMNITAB 80 TEST 2 NICE PLOT, TITLES, HIDTH AID LENGTH INSTR. (3.3), (3 PAGE 2 INSTRUCTION IS NICE NPLOT.

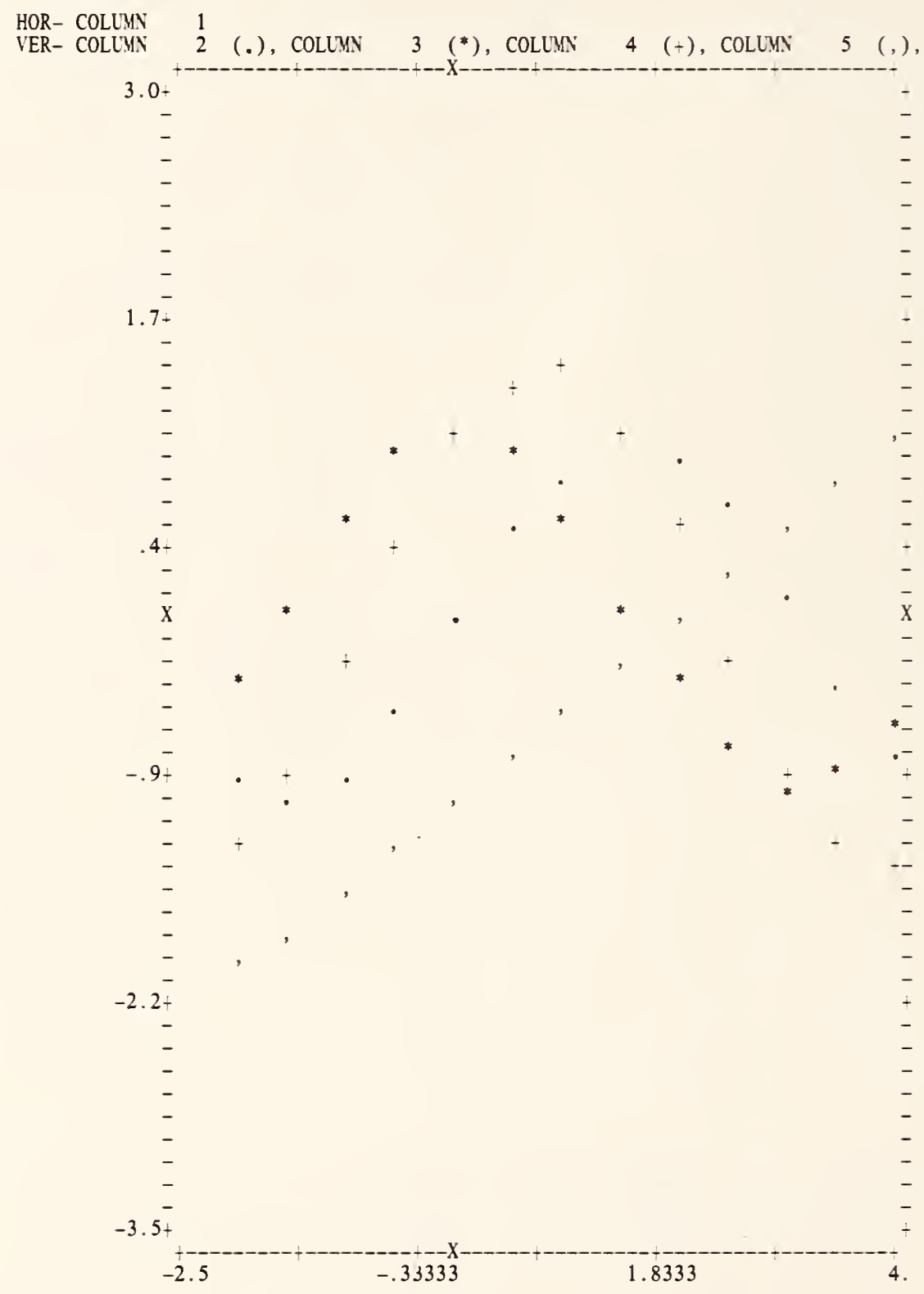

4 

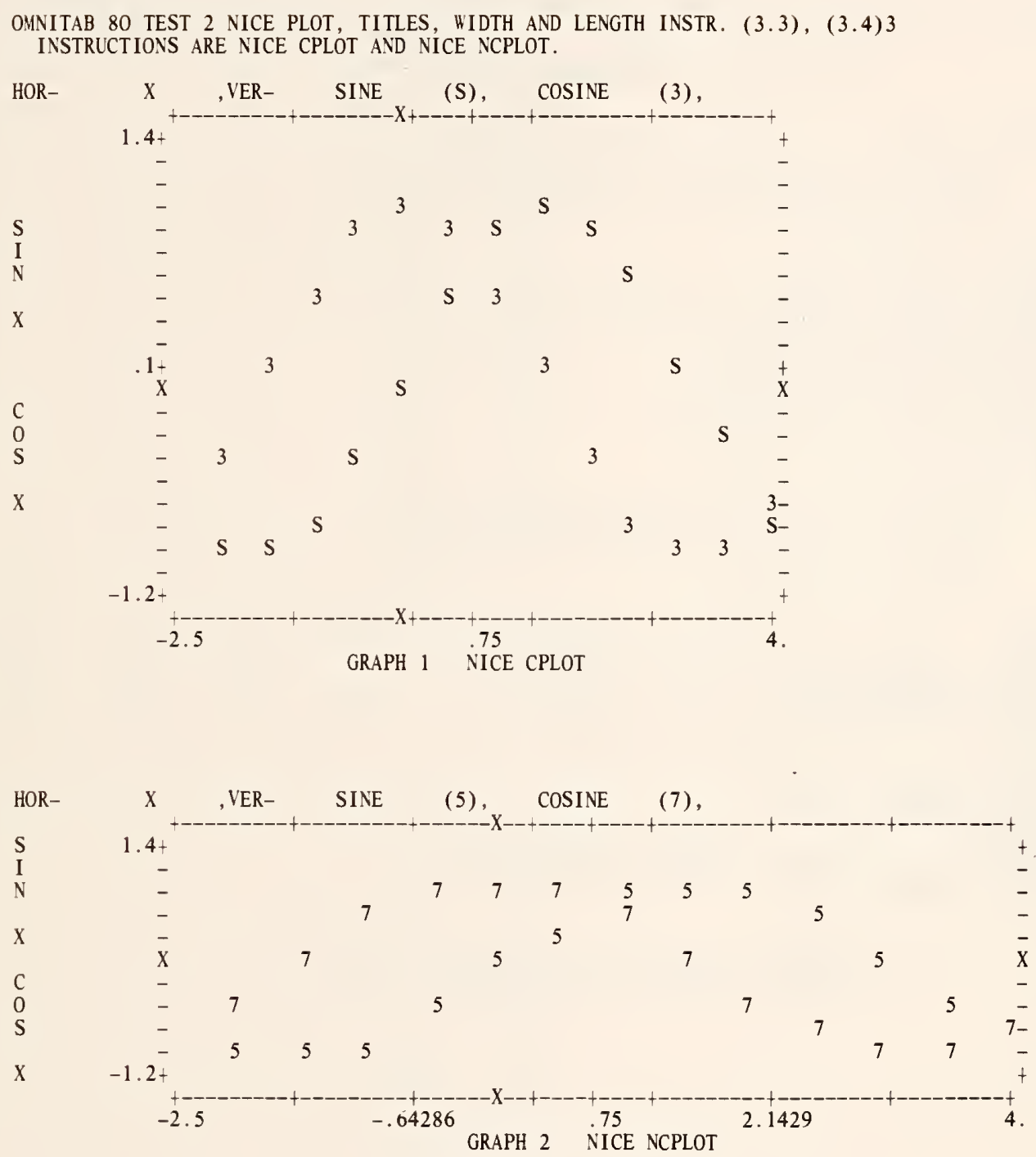
OMNITAB 80 TEST 2 NICE PLOT, TITLES, HidTH AND LENGTH INSTR. (3.3), (3.4), (3.5) PAGE 4

LIST OF DATA, INSTRUCTIONS AND DIAGNOSTICS

GENERATE NOS FROM -2.0 IN STEPS OF .5 THRU 4. IN COL 1

* INFORMATIVE DIAGNOSTIC FOR THE ABOVE INSTRUCTION NRMAX HAS BEEN RESET FROM O TO 13.

SIN OF COL 1 PUT IN COL 2

COS OF COL 1 PUT IN COL 3

ADD COL 2 TO COL 3 PUT RESULT IN COL 4

MULTIPLY COL $1 \mathrm{BY} .5$ THEN BY 1.0 ADD -1.0 PUT IN COL 5

WIDTH 80 CHARACTERS PER LINE

TITLE1 INSTRUCTION IS NICE PLOT

NICE PLOT COLS 23445 VERSUS COL 1

TITLE1 INSTRUCTION IS NICE NPLOT.

NEW PAGE

NICE NPLOT COLS 223445 VERSUS COL 1

LABEL $X$, SINE, COSINE

* INFORMATIVE DIAGNOSTIC FOR THE ABOVE INSTRUCTION (X) IS IN COL (1), (SINE) IS IN COL (2)

(COSINE) IS IN COL ( 3 )

TITLEY SIN $X \quad \cos X$

GRAPH 1 NICE CPLOT

WIDTH 75 CHARACTERS PER LINE

LENGTH 30 LINES PER PAGE

TITLE1 INSTRUCTIONS ARE NICE CPLOT AND NICE NCPLOT.

NICE CPLOT SINE, SYMBOL 29. AND COSINE, SYMBOL 3. VS X

SPACE 5

WIDTH 90 CHARACTERS PER LINE

LENGTH 20 LINES PER PAGE

TITLEY SIN X COS X

TITLEX

GRAPH 2 NICE NCPLOT

NICE NCPLOT SINE, SYMBOL 5. AND COSINE, SYMBOL 7. VS X

WIDTH 100 LINES PER PAGE

NATIONAL BUREAU OF STANDARDS. WASHINGTON, D. C. 20234

OMNITAB 80 VERSION 6.00 MARCH 2,1981 

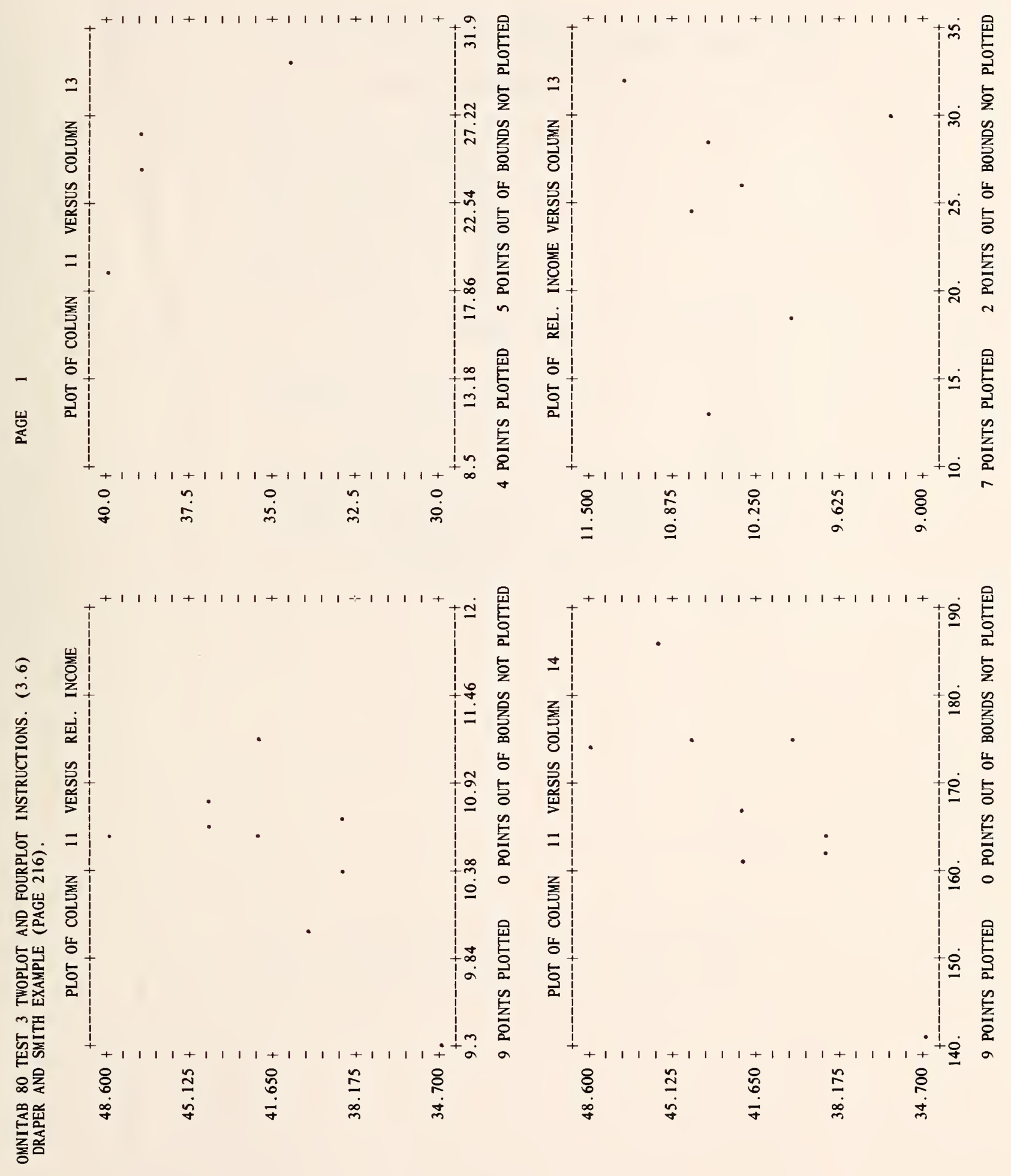
OMNITAB 80 TEST 3 TWOPLOT AND FOURPLOT INSTRUCTIONS. (3.6) DRAPER AND SMITH EXAMPLE (PAGE 216).

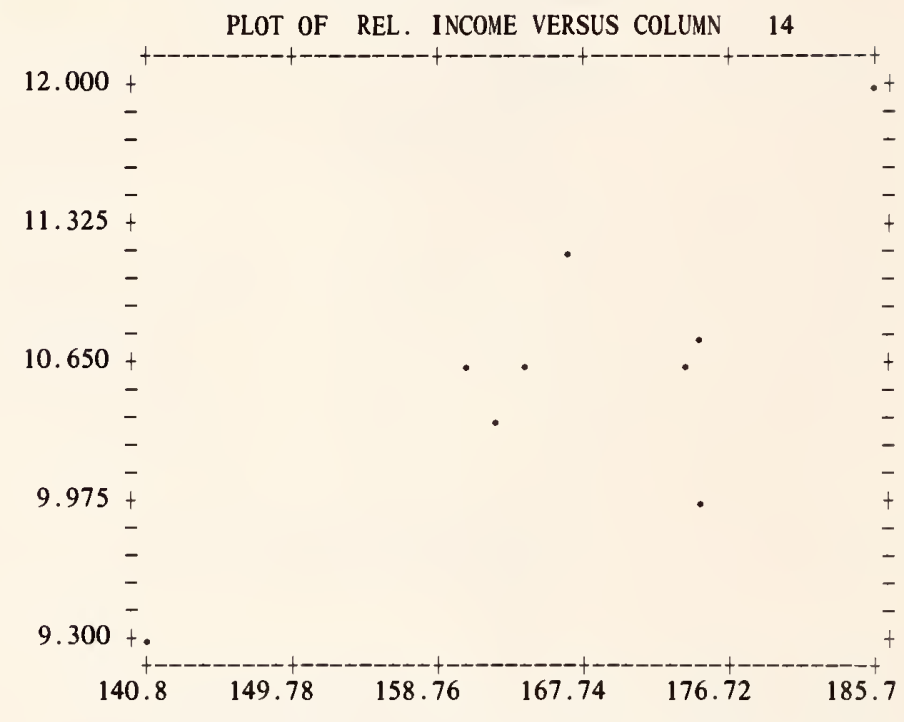

9 POINTS PLOTTED 0 POINTS OUT OF BOUNDS NOT PLOTTED

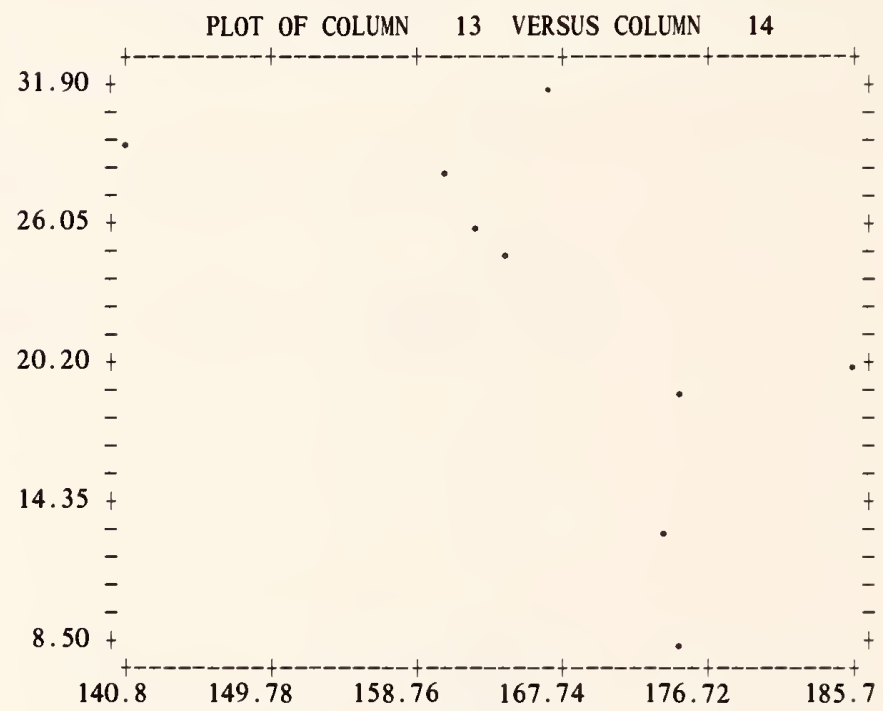

9 POINTS PLOTTED 0 POINTS OUT OF BOUNDS NOT PLOTTED 
LIST OF DATA, INSTRUCTIONS AND DIAGNOSTICS

$\begin{array}{rrrr}\text { READ } & \text { DATA INTO COLUMNS } 11, \\ 42.2 & 11.2 & 31.9 & 167.1 \\ 48.6 & 10.6 & 13.2 & 174.4 \\ 42.6 & 10.6 & 28.7 & 160.8 \\ 39.0 & 10.4 & 26.1 & 162.0 \\ 34.7 & 9.3 & 30.1 & 140.8 \\ 44.5 & 10.8 & 8.5 & 174.6 \\ 39.1 & 10.7 & 24.3 & 163.7 \\ 40.1 & 10.0 & 18.6 & 174.5 \\ 45.9 & 12.0 & 20.4 & 185.7\end{array}$

* INFORMATIVE DIAGNOSTIC FOR THE ABOVE INSTRUCTION NRMAX HAS BEEN RESET FROM 0 TO 9.

SCORRELATION FOR 4 VARIABLES IN COLS $11 * * * 14$ STORE 1,41 TITLE1 DRAPER AND SMITH EXAMPLE (PAGE 216).

LABEL REL. INCOME, 12

* INFORMATIVE DIAGNOSTIC FOR THE ABOVE INSTRUCTION (REL. INCOME) IS IN COL (12)

FOURPLOTS 11VS12, 11,30.,40.VS13, 11VS14, 140., 190., 12,9.,11.5VS13,10., 35 . WIDTH 80

TWOPLOTS PLOT ONE OF COL 12 VS COL 14, PLOT TWO OF COL 13 VS COL 14

NATIONAL BUREAU OF STANDARDS. WASHINGTON, D. C. 20234 OMNITAB 80 VERSION 6.00 MARCH 2, 1981 
STEM AND LEAF DISPLAY FOR COLUMN 9

\begin{tabular}{|c|c|c|c|c|}
\hline EPTH & SCRAHL & STEM & & LEAF \\
\hline $\begin{array}{r}1 \\
1 \\
2 \\
4 \\
4 \\
5 \\
6 \\
7 \\
9 \\
11 \\
13 \\
17 \\
23 \\
29\end{array}$ & $\begin{array}{l}\text { Y } \\
\text { H }\end{array}$ & $\begin{array}{l}-07 /-06 \\
-05 /-04 \\
-03 /-02 \\
-01 /-00 \\
+00 /+01 \\
-02 /-03 \\
-04 /-05 \\
-06 /-07 \\
-08 /-09 \\
+10 /+11 \\
-12 /-13 \\
-14 /-15 \\
-16 /-17 \\
+18 /+19 \\
+20 /+21 \\
-22 /-23 \\
-24 /-25 \\
-26 /-27 \\
+28 /+29 \\
+30 /+31 \\
+32 /-33 \\
+34 /-35 \\
+36 / \div 37\end{array}$ & 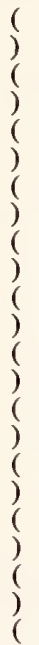 & $\begin{array}{l}8 / \\
/ 32 \\
\\
/ 9 \\
5 / \\
2 / \\
28 / \\
4 / 1 \\
36 / \\
01 / 48 \\
4469 / 37 \\
18 / 1999 \\
449 / 337 \\
0 / 117 \\
001249 / 127 \\
079 / 3666 \\
/ 7 \\
10\end{array}$ \\
\hline
\end{tabular}

SCRAHL $(\mathrm{N}=59, *=-77.000000, \mathrm{H}=147.50000, \mathrm{M}=204.00000, \mathrm{H}=246.50000, *=377.00000)$

EACH STEM LNIT IS 10 EACH LEAF LNIT IS 1 $-07 /-06$ ( 7 READS AS -77 $-36 /-37$ ( 7 READS AS 377

FOR THE ABOVE STEM AND LEAF DISPLAY, THE FOLLOHING VARIABLES HERE USED
$\mathrm{I}=$
$1, \mathrm{~J}=$
$2, \mathrm{~K}=$
$1, \mathrm{~L}=1$

THE FOLLOHING VALUES MUST BE EQUAL TO OR NEAR $201 \quad 0.0 \quad 0.0$.

$201 \quad 0.0000000-00 \quad 0.0000000-00$ 
LIST OF DATA, INSTRUCTIONS AND DIAGNOSTICS

SET IN COL 9 THE FOLLOWING DATA

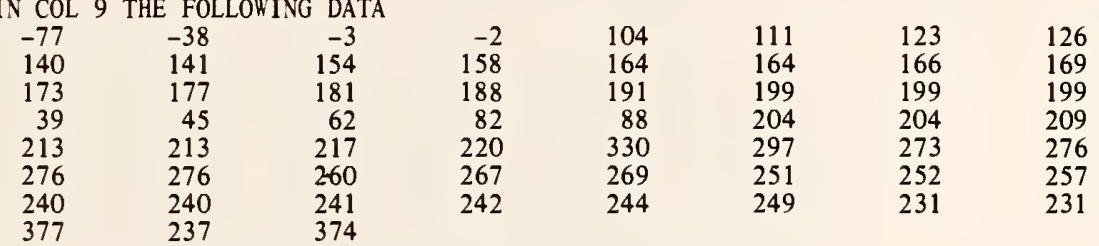

* INFORMATIVE DIAGNOSTIC FOR THE ABOVE INSTRUCTION -

NRMAX HAS BEEN RESET FROM O TO 59.

STEM LEAF OF COL $9, \mathrm{I}=1, \mathrm{~J}=2, \mathrm{~K}=1$ AND $\mathrm{L}=1$ PUT SCRAWL IN COL 1 AND DEPTH IN COL 2

SSTEM LEAF OF COL $9 \mathrm{I}=1, \mathrm{~J}=2, \mathrm{~K}=1, \mathrm{~L}=1$ PUT SCRAWL IN COL 3 AND DEPTH IN COL 4

SUB COL 1 FROM COL 3 PUT IN COL 5

SUB COL 2 FROM COL 4 PUT IN COL 6

SUM COL 5 ROW 1 THRU ROH 8 RESULT IN COL 7

SUM COL 6 ROW 2 THRU ${ }^{* *} 1,2 * *$ RESULT IN COL 8

RESET $V$ TO THE VALUE IN *1,2*

ADD 1.0 TO THE VALUE OF *V* AND PUT RESULT IN COL 11

SUM COL 2 ROW 2 THRU **1,11** RESULT IN COL 10

SPACE 2

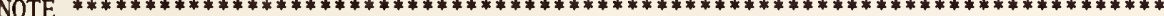

SPACE

$\begin{array}{llllll}\text { NOTE THE FOLLOWING VALUES MUST BE EQUAL TO OR NEAR } 201 & 0.0 & 0.0 .\end{array}$

SPACE

ABRIDGE ROW 1 FOR 3.0 COLS, COL 10 INT (0) -5 PLACES, COL 7,8,0, COL 8, 8, 0

$\$$ THE LAST TWO COLS (7 AND 8 ) ARE PRINTED AS FLOATING PT. NOS WITH 8 SIG. DIGS.

SPACE

NOTE

NATIONAL BUREAU OF STANDARDS. WASHINGTON, D. C. 20234

OMNITAB 80 VERSION 6.00 MARCH 2, 1981 

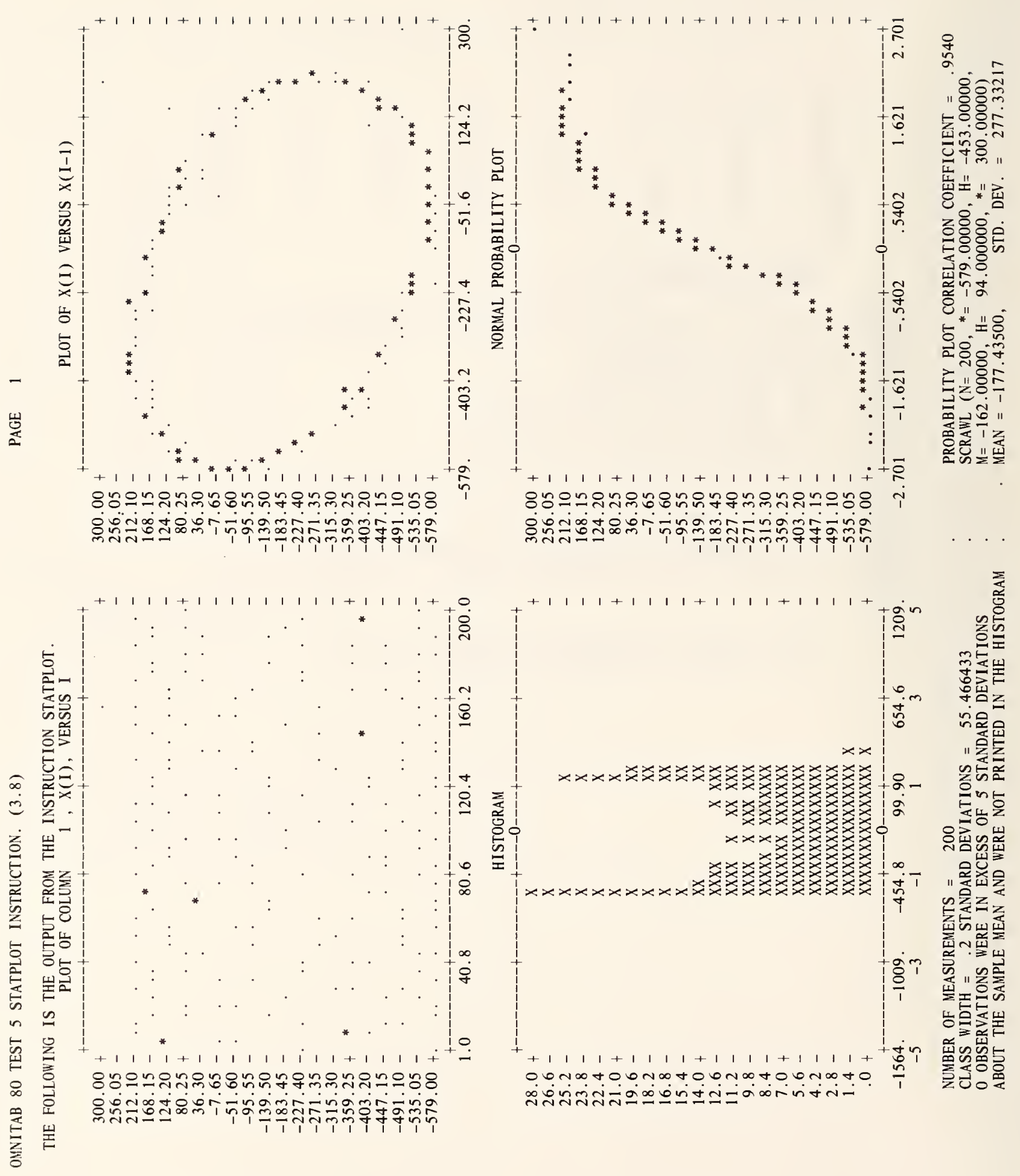
LIST OF DATA, INSTRUCTIONS AND DIAGNOSTICS

SET LEW BEAM DEFLECTION DATA INTO COLUMN 1

$-213-564-035-015+141+115-420-360+203-338$

$-431+194-220-513+154-125-559+092-021-579$

$-052+099-543-175+162-457-346+204-300-474$

$+164-107-572-008+083-541-224+180-420-374$

$+201-236-531+083+027-564-112+131-507-254$

$+199-311-495+143-046-579-090+136-472-338$

$+202-287-477+169-124-568+017+048-568-135$

$+162-430-422+172-074-577-013+092-534-243$

$+194-355-465+156-081-578-064+139-449-384$
+193

$+193-198-538+110-044-577-006+066-552-164$

$+161-460-344+205-281-504+134-028-576-118$

$+156-437-381+200-220-540+083+011-568-160$

$+172-414-408+188-125-572-032+139-492-321$

$+205-262-504+142-083-574-000+048-571-106$

$+137-501-266+190-391-406+194-186-553+083$

$-013-577-049+103-515-280+201+300-506+131$

$-045-578-080+138-462-361+201-211-554+032$

$+074-533-235+187-372-442+182-147-566+025$

$+068-535-244+194-351-463+174-125-570+015$

$+072-550-190+172-424-385+198-218-536+096$

* INFORMATIVE DIAGNOSTIC FOR THE ABOVE INSTRUCTION NRMAX HAS BEEN RESET FROM O TO 200.

TITLE3 THE FOLLOWING IS THE OUTPUT FROM THE INSTRUCTION STATPLOT. STATPLOTS OF COLUMN 1

NATIONAL BUREAU OF STANDARDS. WASHINGTON, D. C. 20234 OMNITAB 80 VERSION 6.00 MARCH 2, 1981 


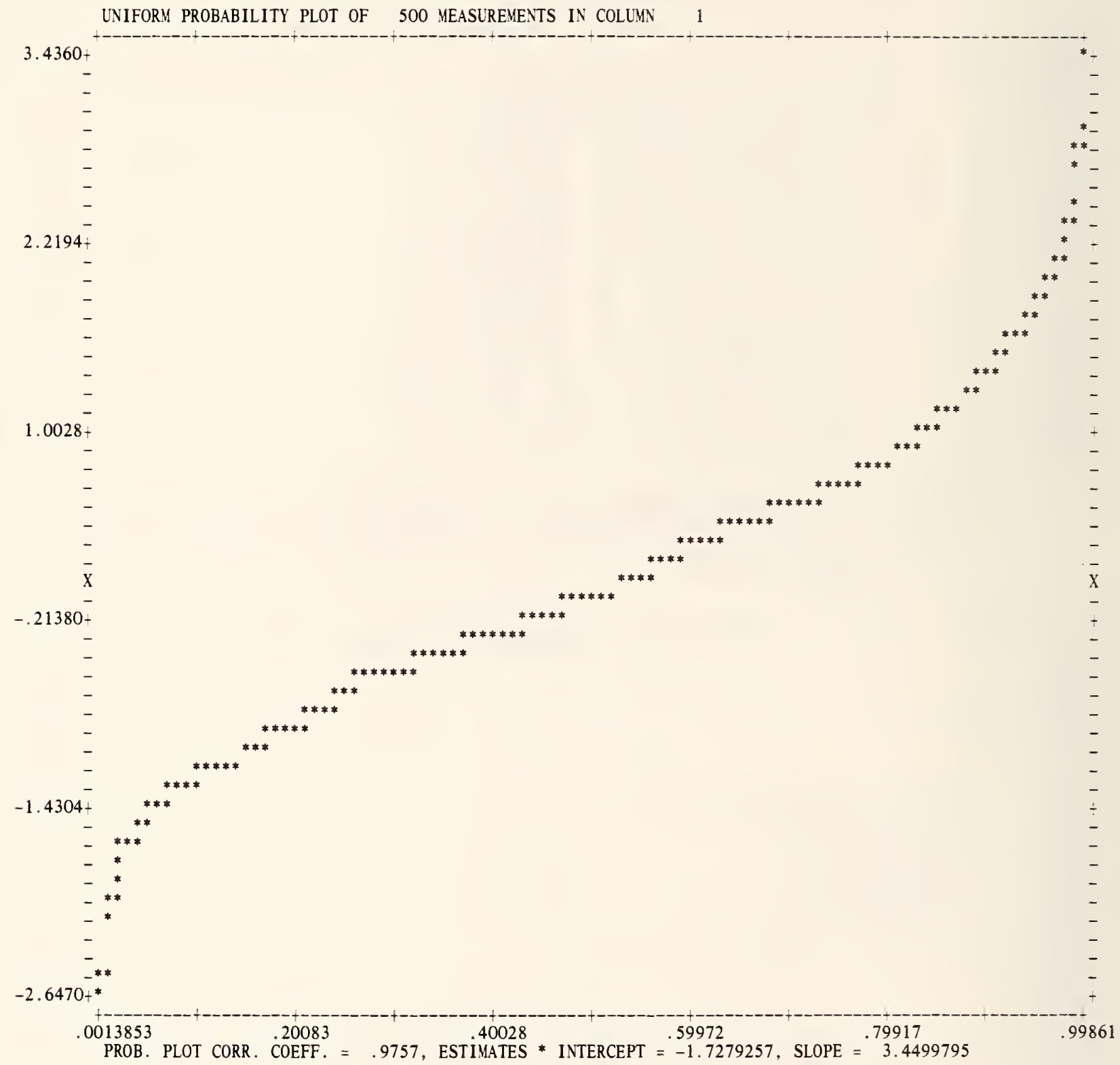


OMNITAB 80 TEST 6 PROBABILITY PLOT INSTRUCTIONS. (3.9) AND (7.5)

PAGE 2

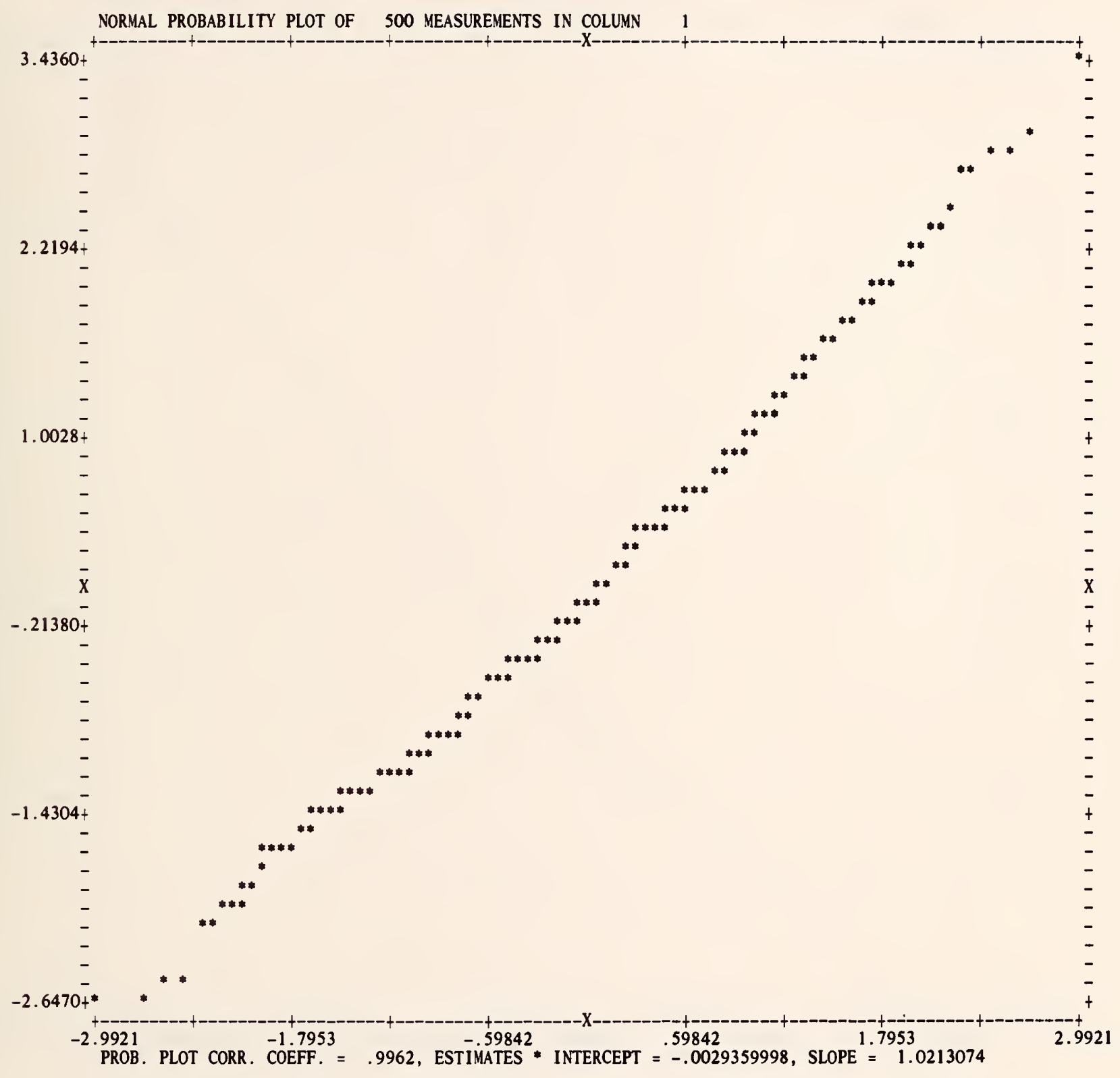




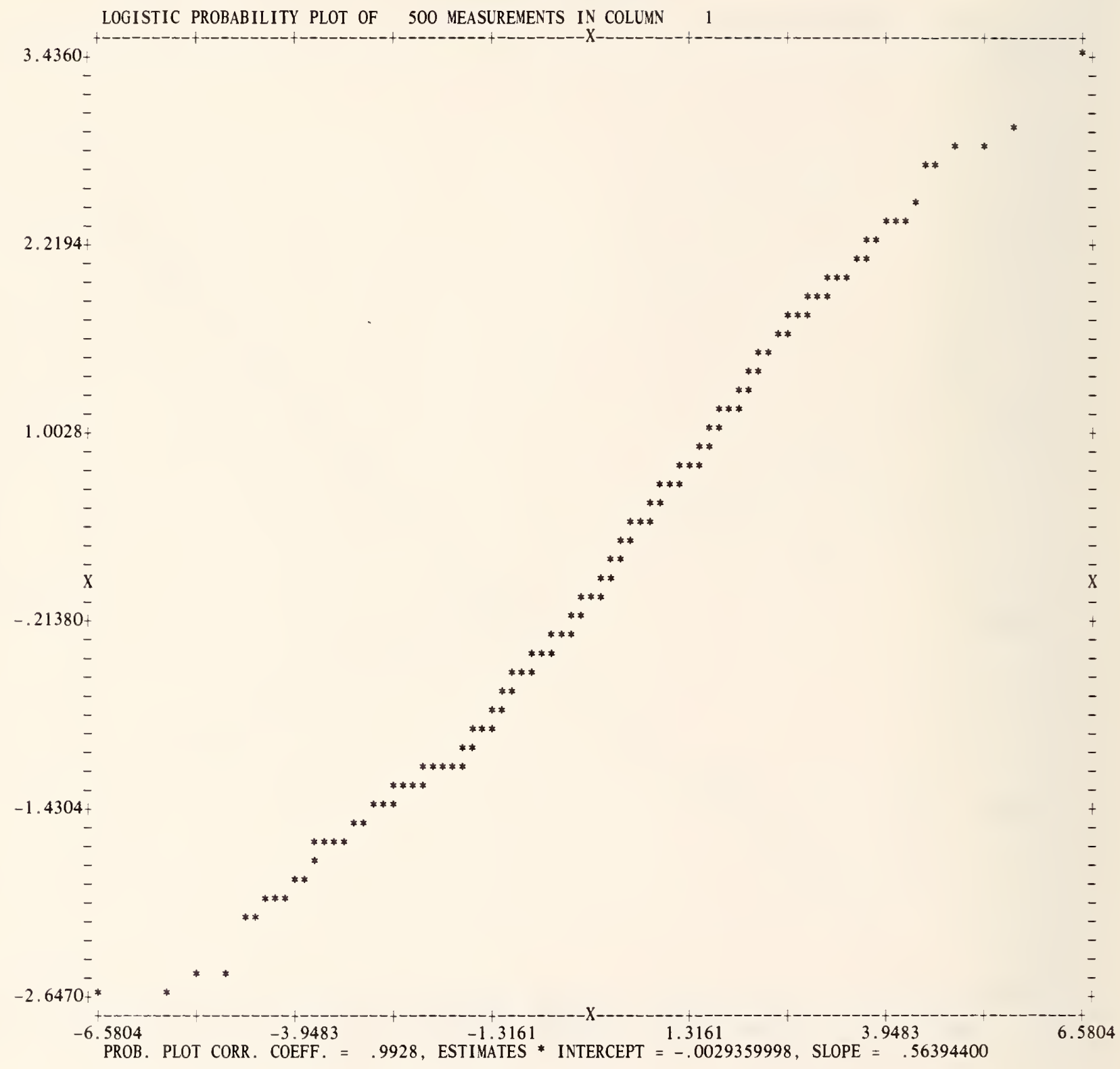


OMNITAB 80 TEST 6 PROBABILITY PLOT INSTRUCTIONS. (3.9) AND (7.5)

PAGE 4

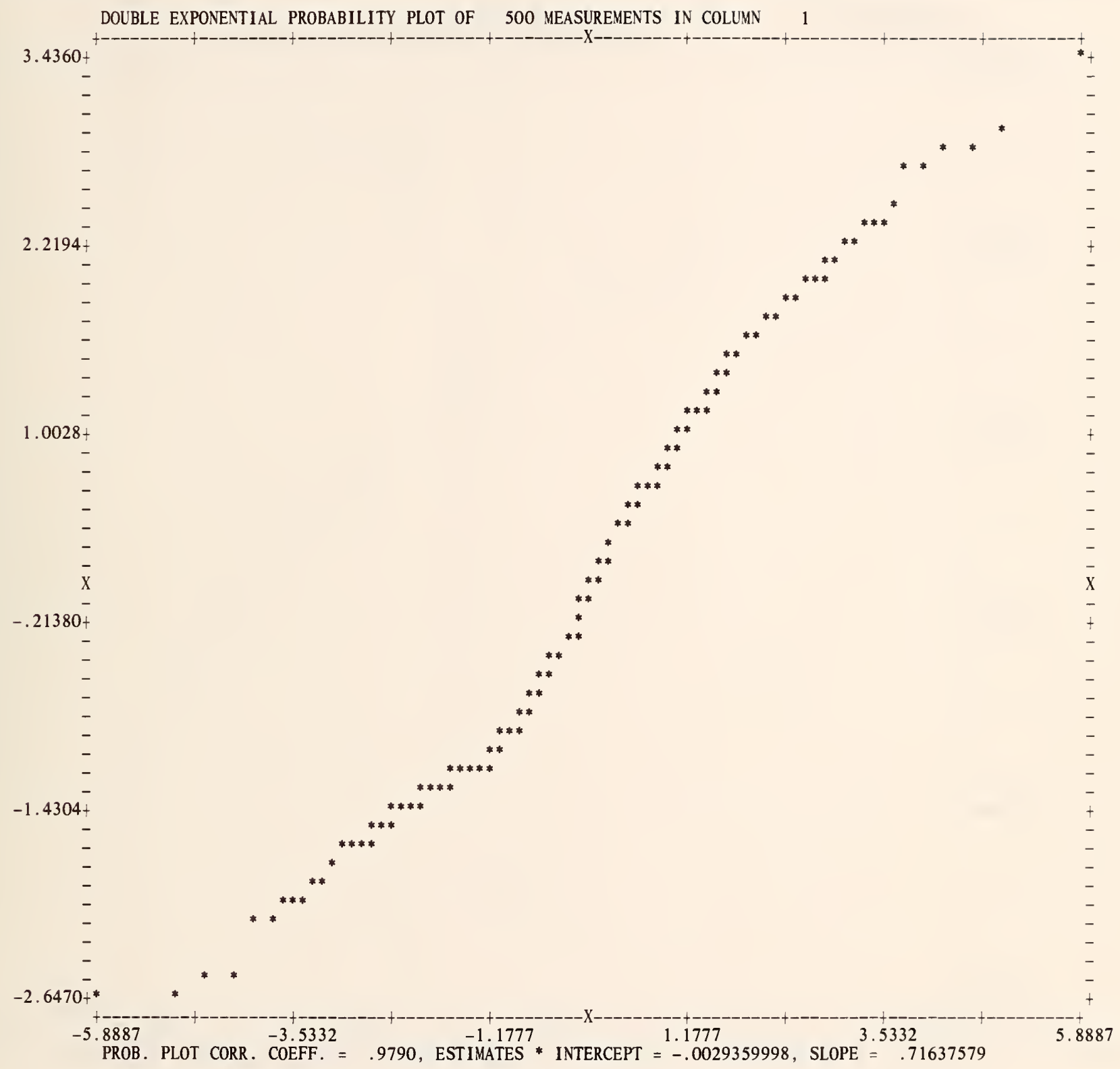

17 


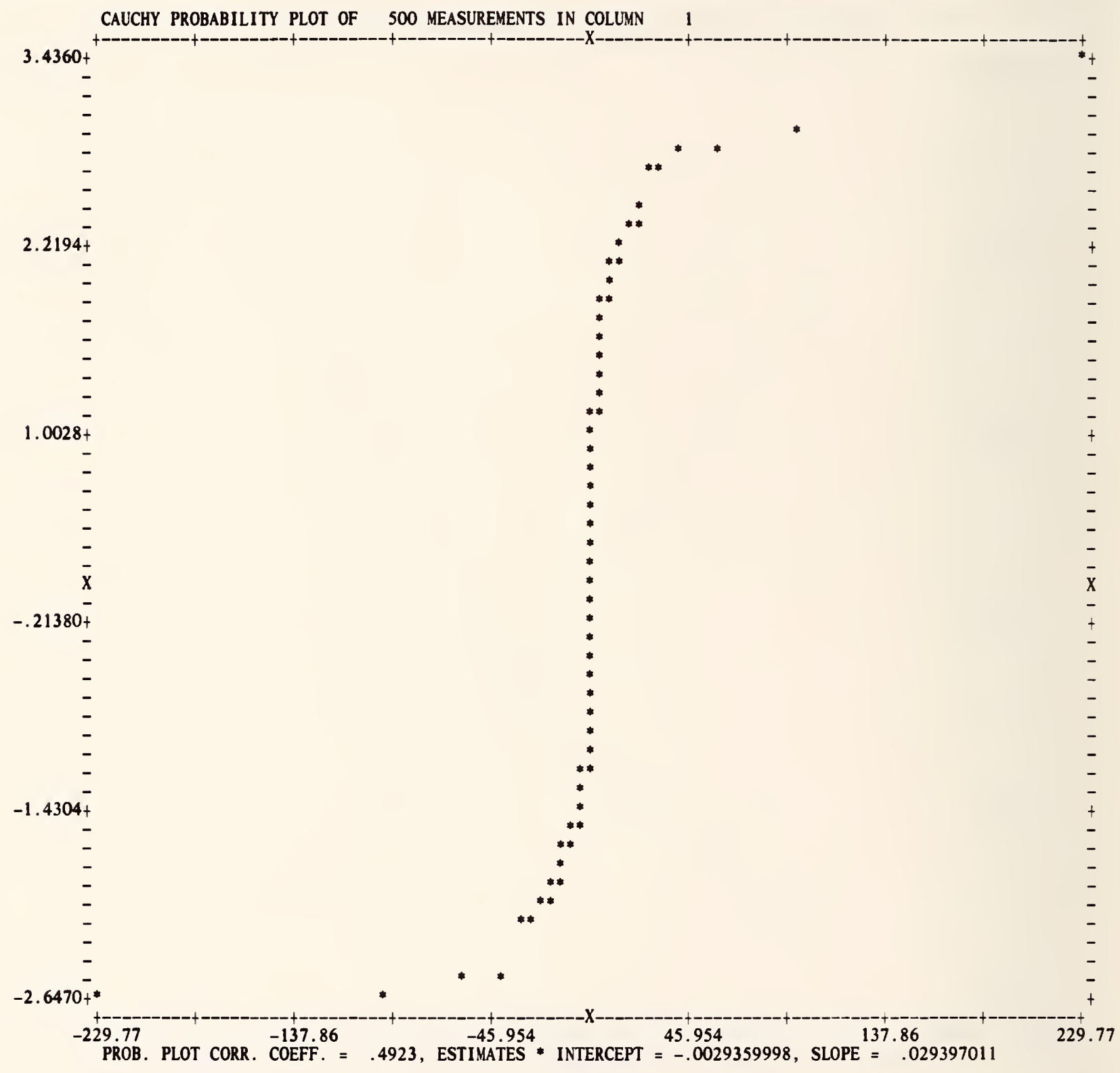


OMNITAB 80 TEST 6 PROBABILITY PLOT INSTRUCTIONS. (3.9) AND (7.5) Page 6

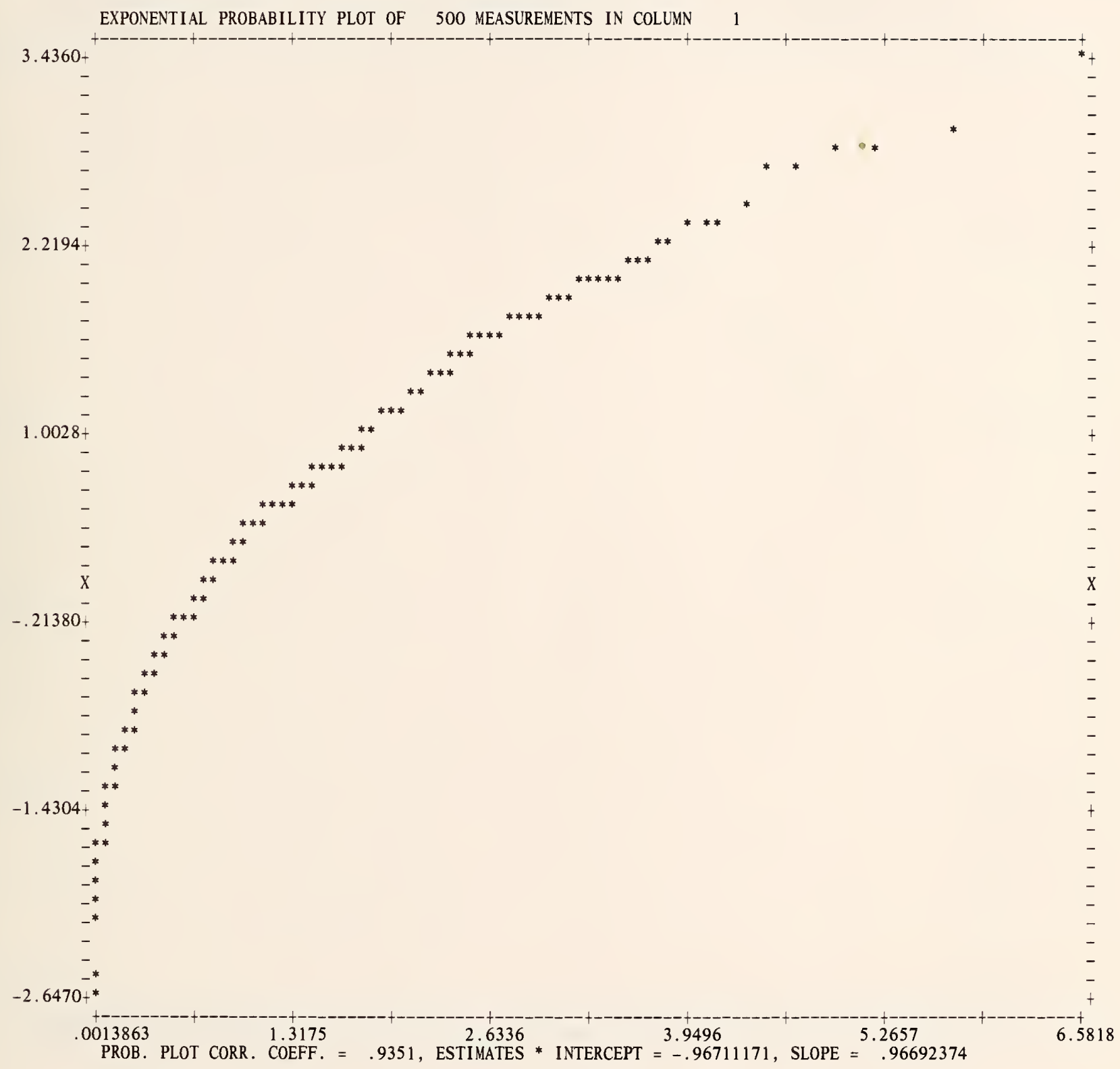


OMNITAB 80 TEST 6 PROBABILITY PLOT INSTRUCTIONS. (3.9) AND (7.5)

PAGE 7

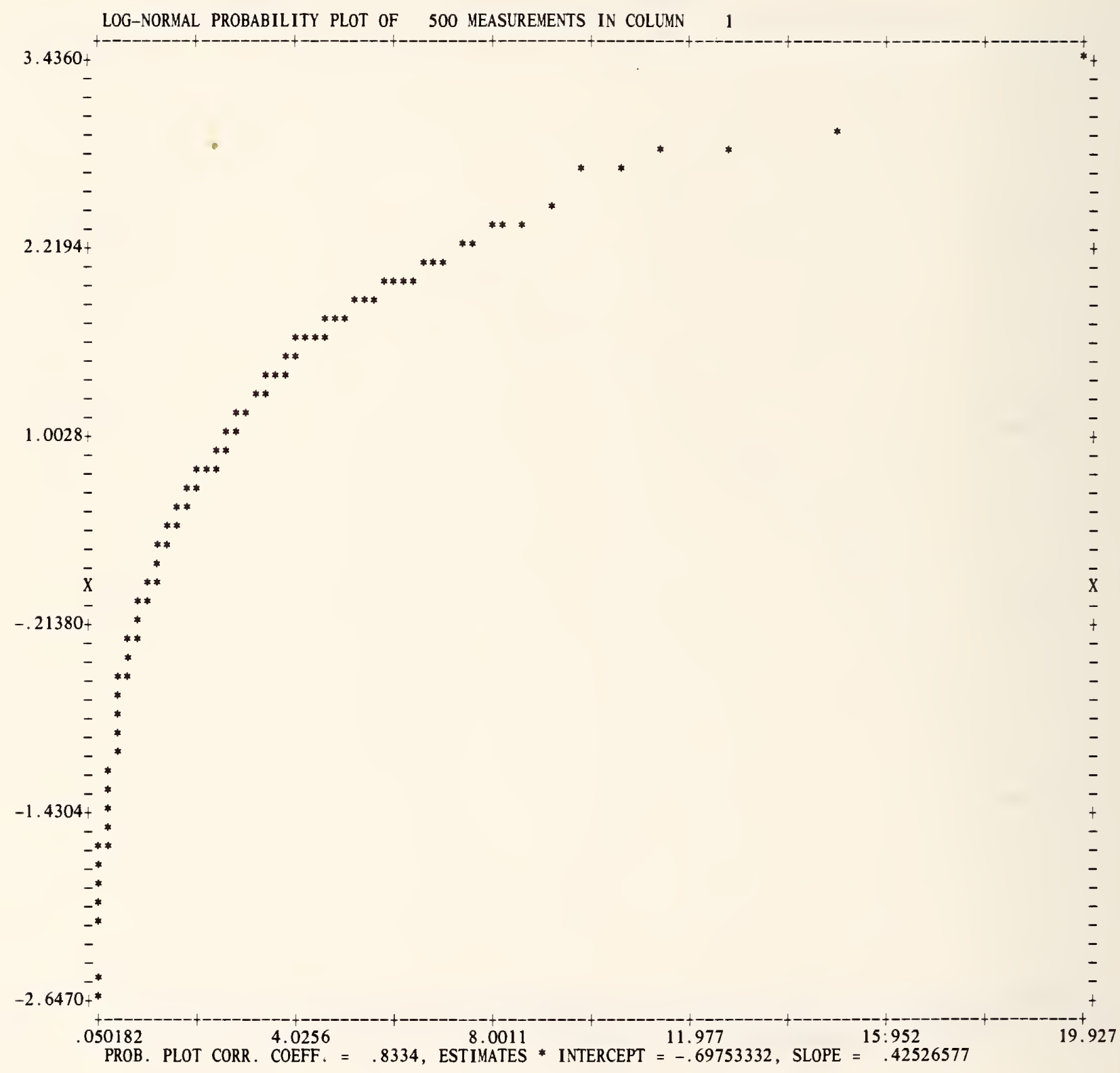


OMNITAB 80 TEST 6 PROBABILITY PLOT INSTRUCTIONS. (3.9) AND (7.5)

PAGE 8

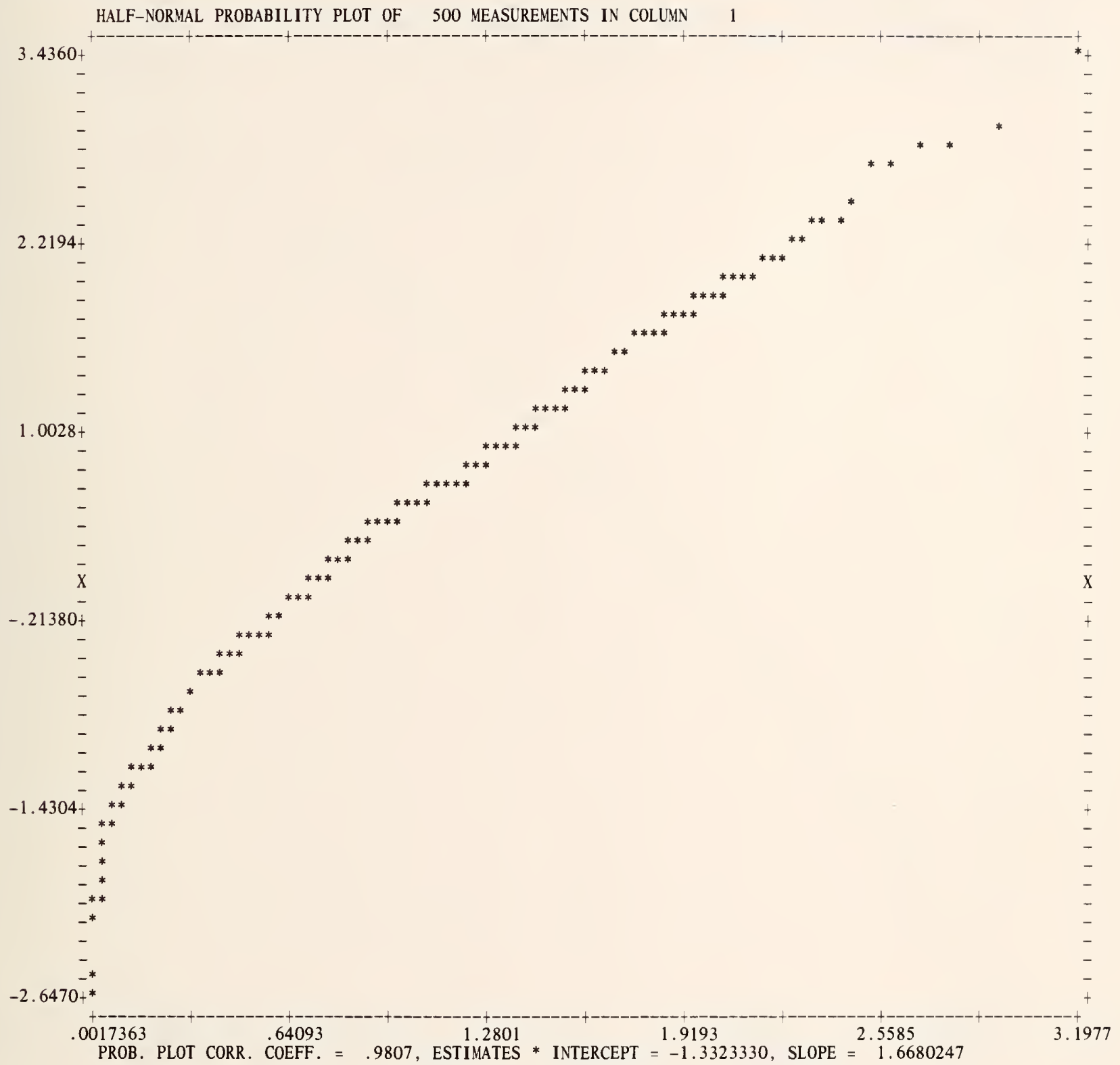

21 
OMNITAB 80 TEST 6 PROBABILITY PLOT INSTRUCTIONS. (3.9) AND (7.5) PAGE 9

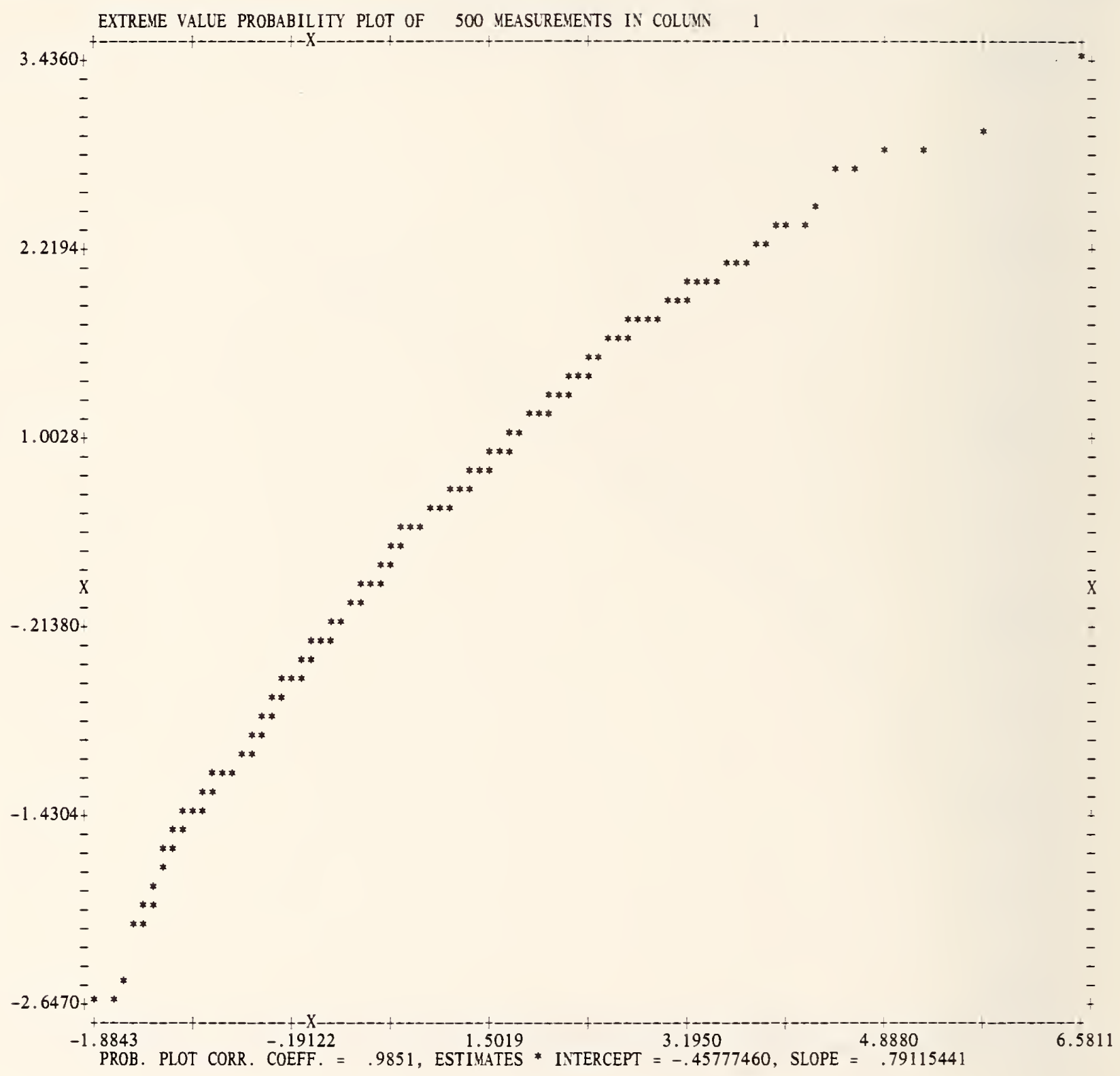


OMNITAB 80 TEST 6 PROBABILITY PLOT INSTRUCTIONS. (3.9) AND (7.5)

PAGE 10

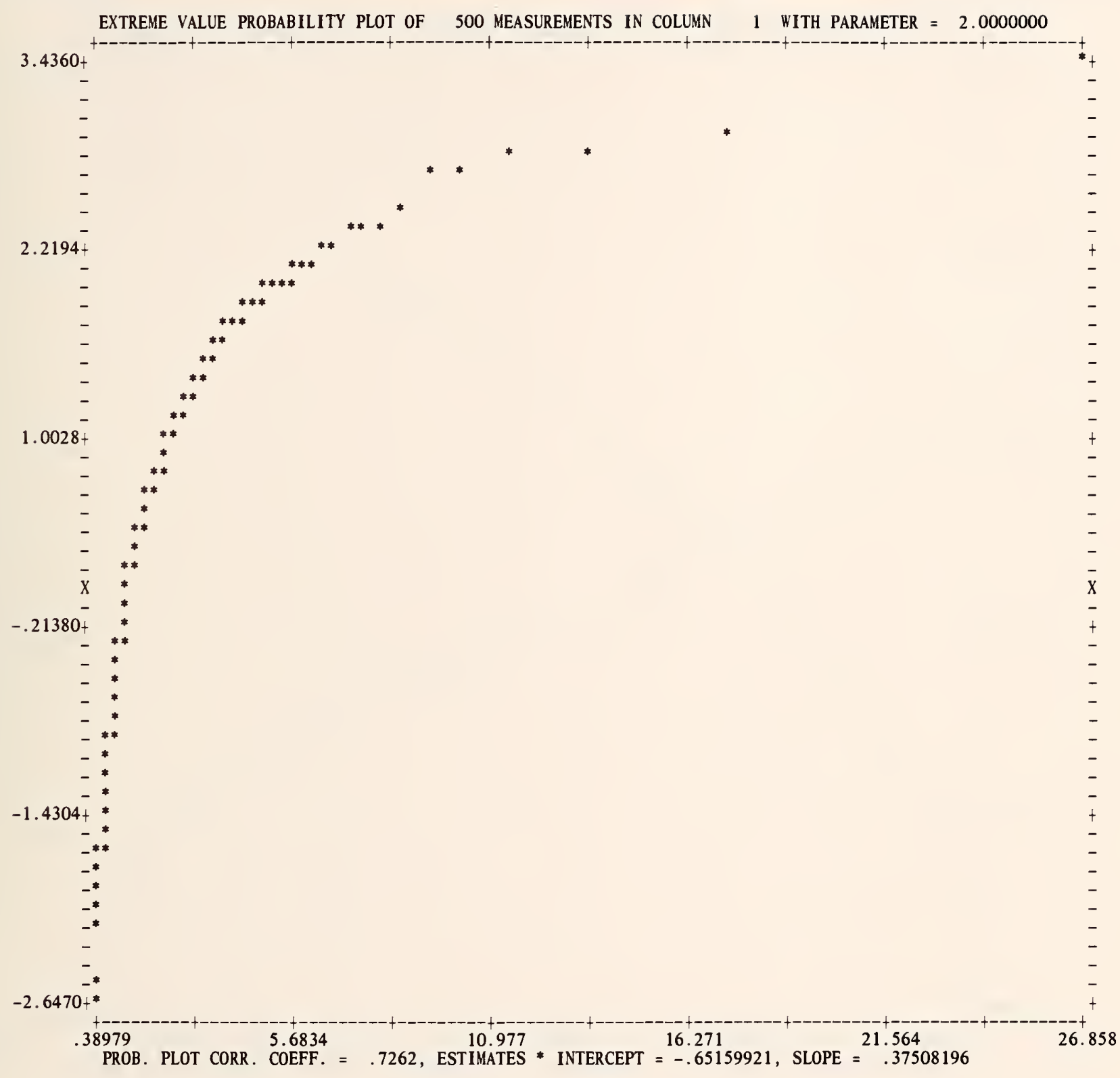




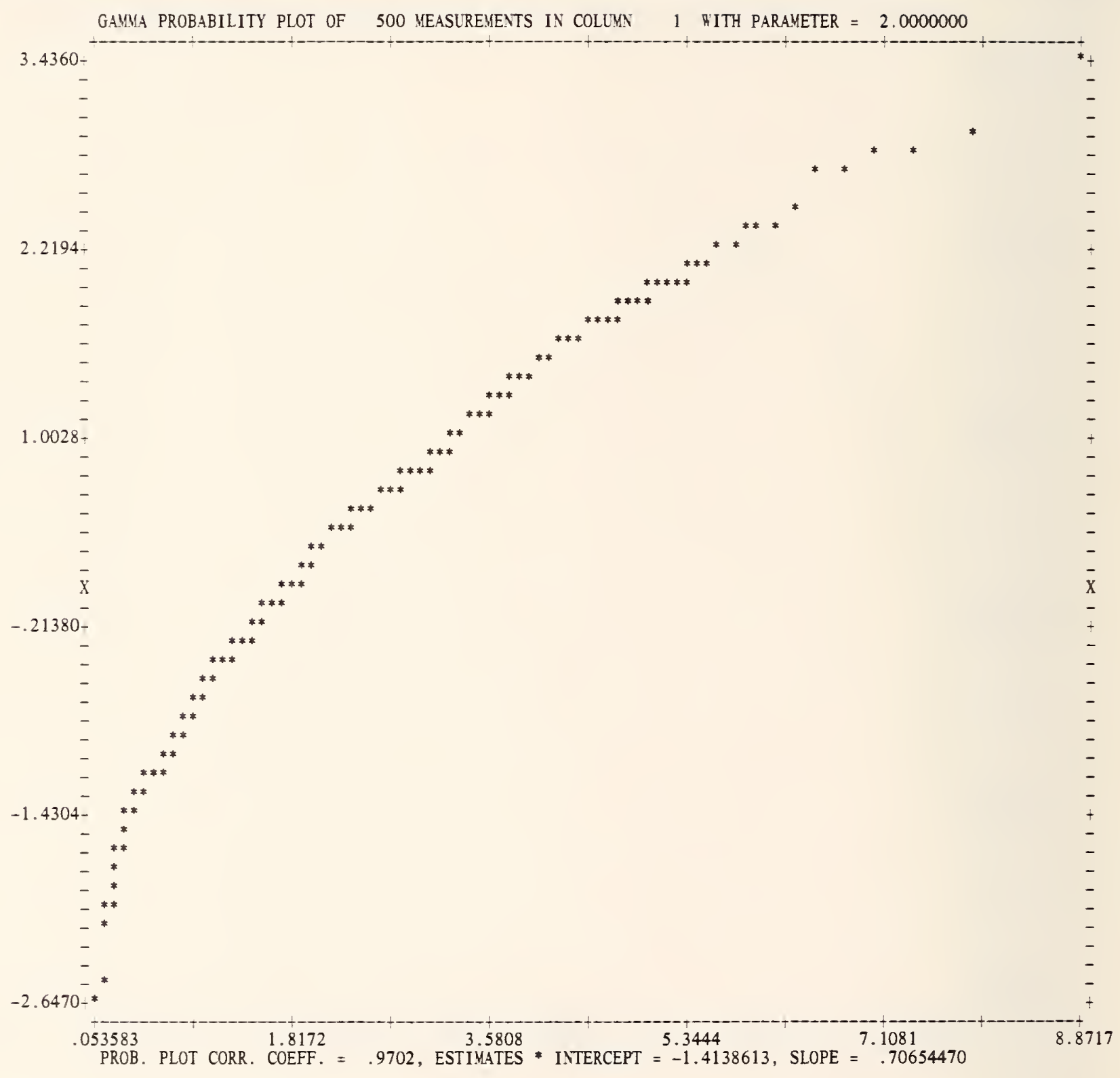




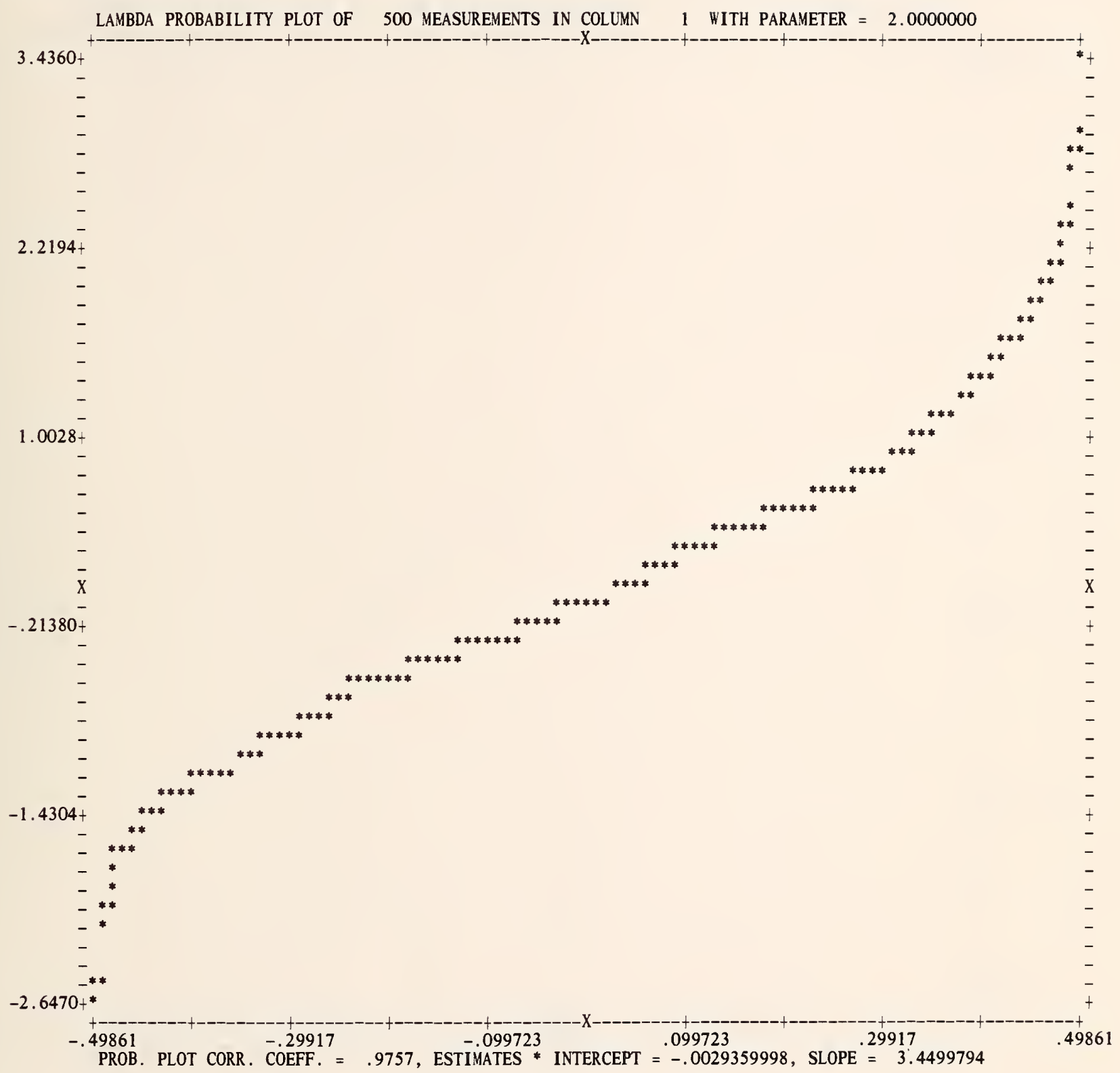


OMNITAB 80 TEST 6 PROBABILITY PLOT INSTRLCTIONS. (3.9) AND (7.5) PAGE 13

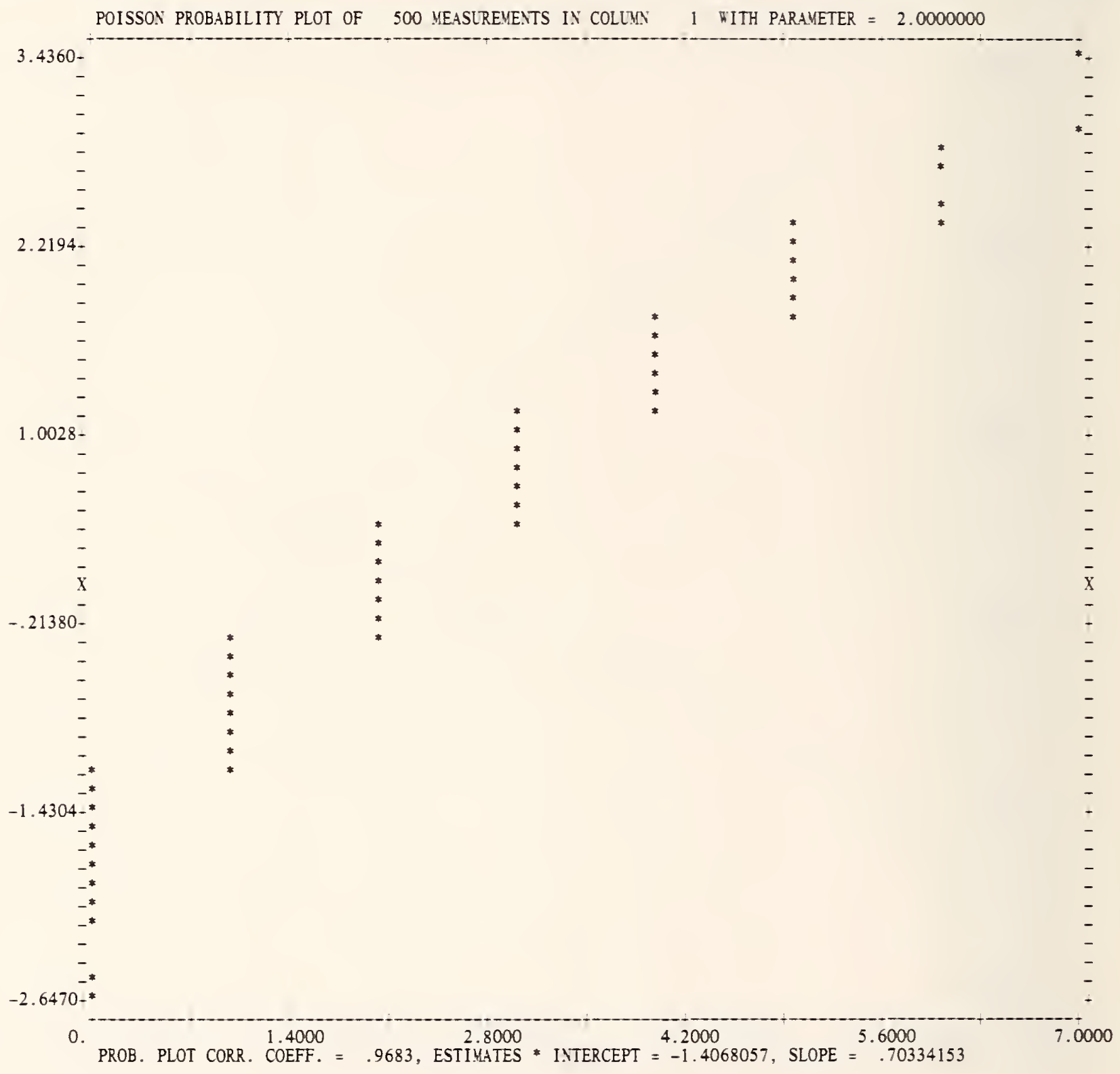




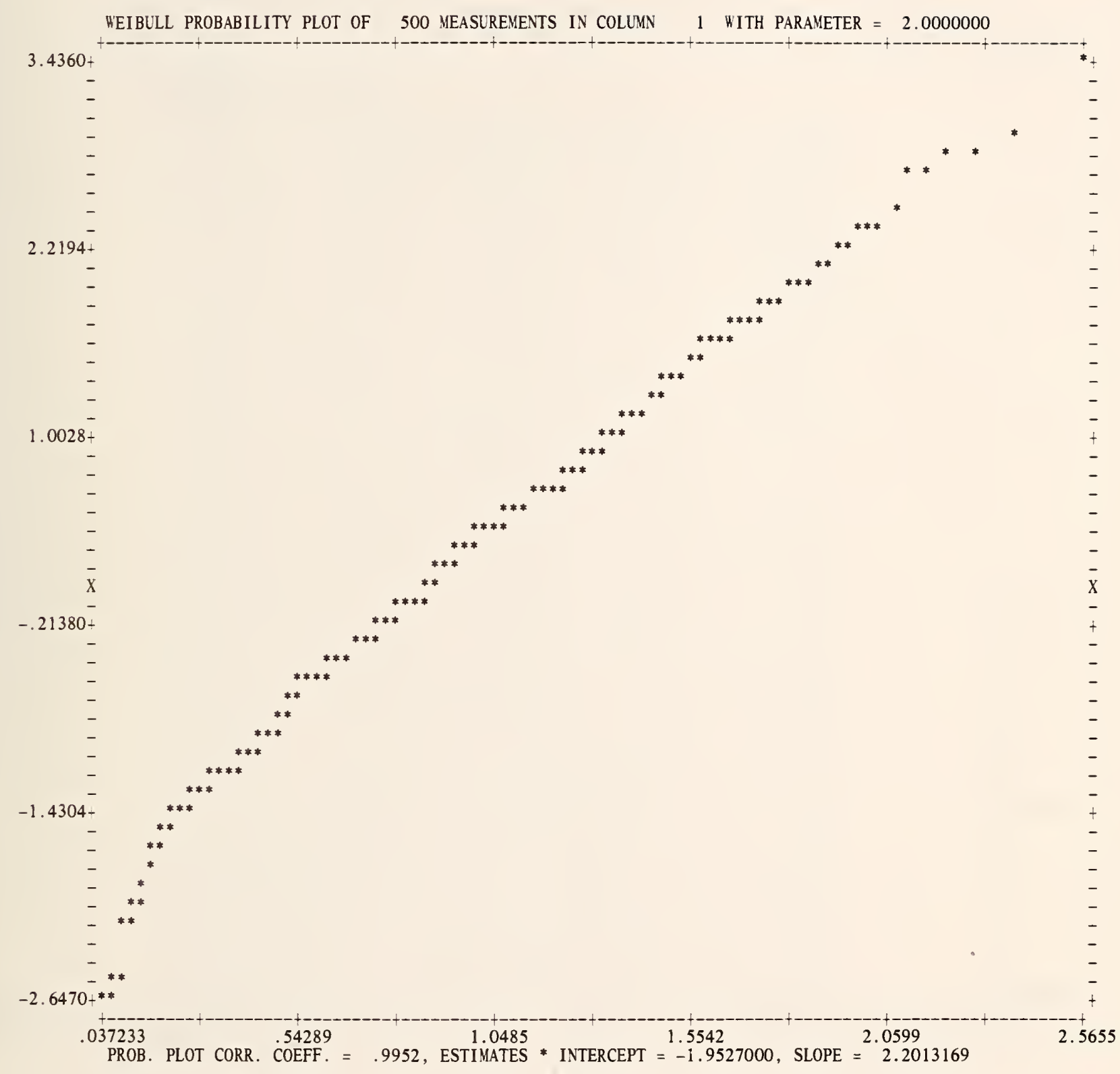




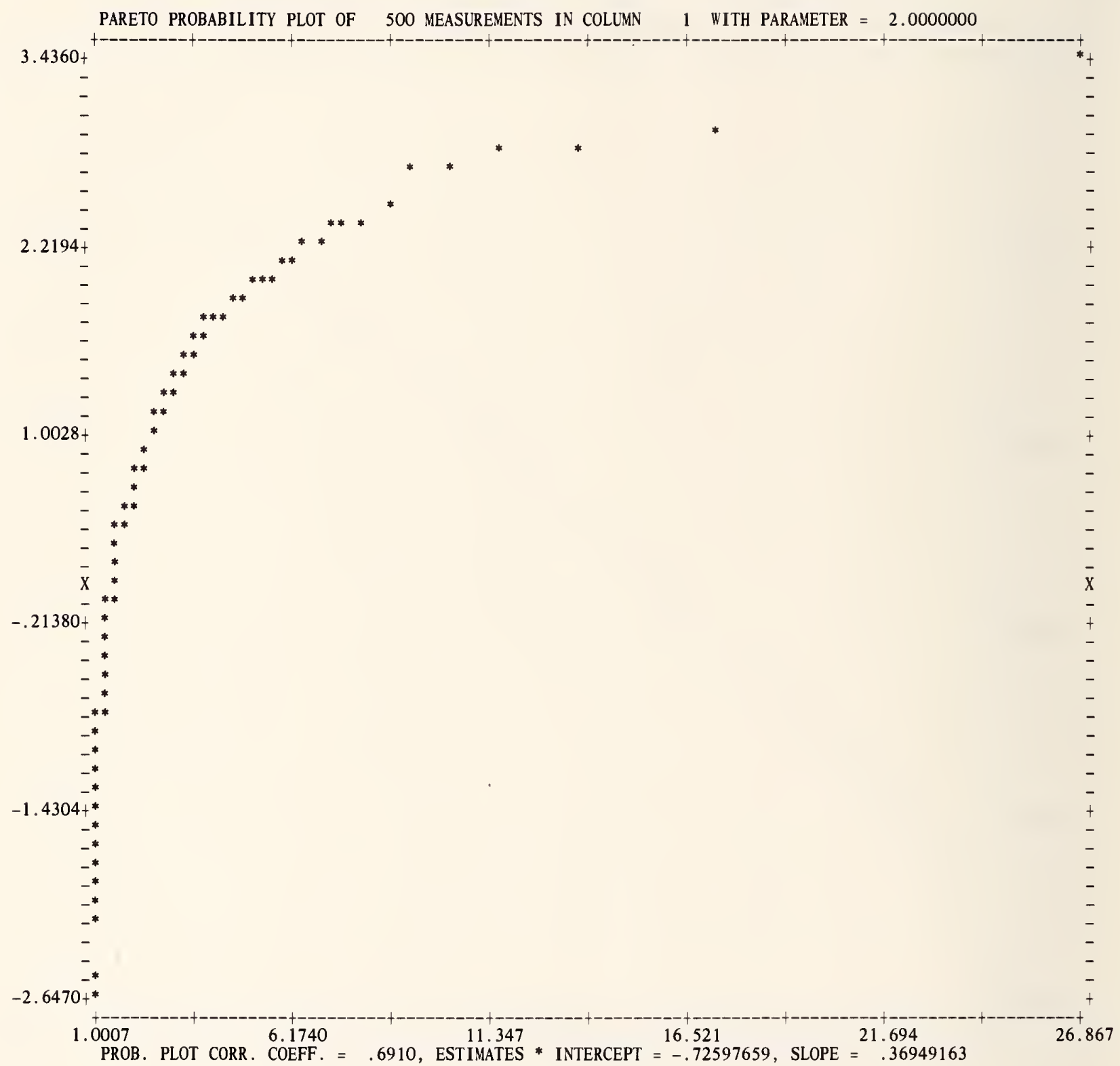


LIST OF DATA, INSTRUCTIONS AND DIAGNOSTICS

\begin{tabular}{|c|c|c|c|c|c|c|c|c|c|}
\hline $8 \mathrm{~T} \quad \mathrm{~T}$ & DATA & N C & & & & & & & \\
\hline & & & & 0.723 & 0.676 & -1.099 & -0.314 & -0.394 & -0.63 \\
\hline & & & & & & & & & \\
\hline & & & & & & & & & \\
\hline & & & & & & 45 & 0.428 & 297 & \\
\hline & & & & & & & 0.035 & & \\
\hline & & & & & & & & & \\
\hline 0. & & & & & & & & & -0 . \\
\hline & & & & & & & & & \\
\hline & & -0. & -0 . & -1 & & -0 . & -0 . & & \\
\hline & & & & & & & & & \\
\hline & & & & & & & & & \\
\hline & -0. & & & & & -0 & -0 & & -0 \\
\hline & & & & & & & & & \\
\hline & 0.2 & & & & & & & & \\
\hline & 0.7 & & & & -1 . & & & & \\
\hline & & & & & & & & & \\
\hline & -0. & -0 . & & & & -1 & & & \\
\hline & -0.9 & & & & -0 & & & & \\
\hline & & & & & & & & & \\
\hline & & -0 . & & -1 & & & -0 . & & \\
\hline & & & & & -0 & & & & \\
\hline & & & & -0 & & & & & \\
\hline & & 0. & & & & & & & \\
\hline & & & & & & & & & \\
\hline & 0.9 & -0 . & & -0 . & & & & $-c$ & \\
\hline & 0.2 & & & & & & & & \\
\hline & & & & & & & & & \\
\hline & & & & & & & & & \\
\hline & & & & & & & & & \\
\hline-0 . & 0.5 & & -0 . & & & & -0 & & \\
\hline & & & & & & & & & \\
\hline & & & & & & & & & \\
\hline & & & & -0 & -0 & -1 & & -0 & \\
\hline & & & & & & & & & \\
\hline & & & & & -1 . & & & & \\
\hline & & & & & & & & -1 & \\
\hline & & & & & & & & & \\
\hline & & & & & & & & & \\
\hline & & & & & & & & & \\
\hline & & & & & & & & & \\
\hline & & & & & & -0 & & -0 . & \\
\hline & & -0 & & -0 . & -0.5 & & & & \\
\hline & & & & & & & & -0 & \\
\hline & & & & & & & & & \\
\hline & & & & & & & & & \\
\hline & & & & & & & & & \\
\hline & & & & & -0 & & & -1 . & \\
\hline & & & & & & & & & \\
\hline
\end{tabular}


OMNITAB 80 TEST 6 PROBABILITY PLOT INSTRLCTIONS. (3.9) AND (7.5)

LIST OF DATA, INSTRLCTIONS AND DIAGNOSTICS

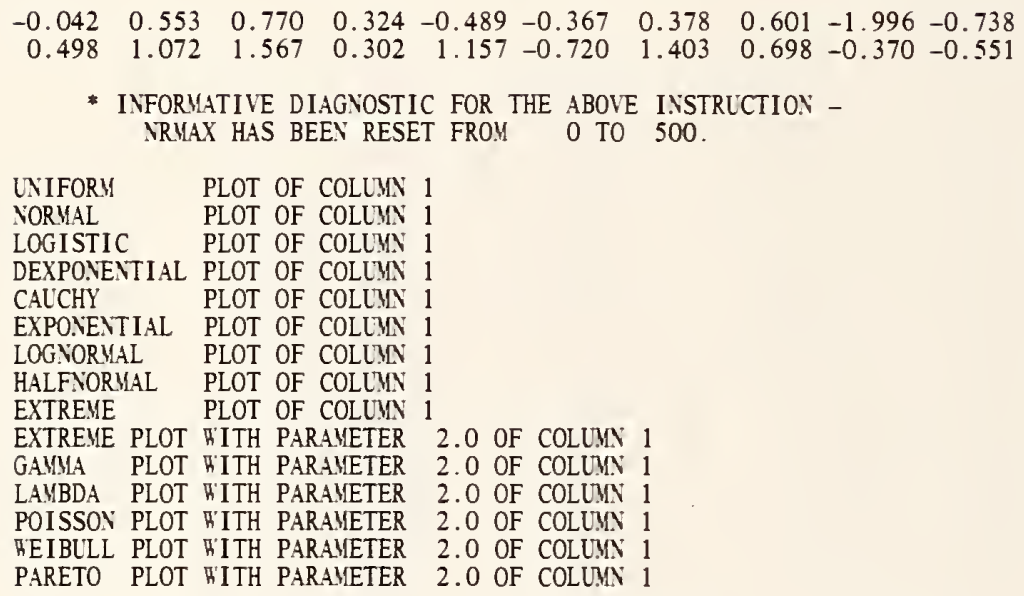

NATIONAL BUREAU OF STANDARDS. TASHINGTON, D. C. 20234 OMNITAB 80 VERSION $6.00 \quad$ MARCH 2,1981 
OMNITAB 80 TEST 7 ARITHMETIC INSTRUCTIONS. (4.1)

PAGE 1

COLUMNS 1 THROUGH 5 CONTAIN AN 11 BY 5 ARRAY DEFINED BY THE COMMANDS GENERATE, ADD AND MULTIPLY

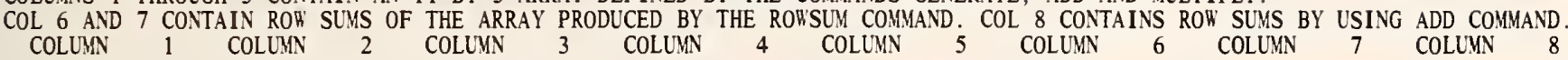

2.0000000

4.0000000

5.9876540

8.0000000

6.0000000

10.000000

23.876692

9.9753079

27.864346

30.000000

71.691654

30.000000

30.000000

7.9753080

13.950616

53.630229

5.9753080
7.9629620

47.654922
79.334686

17.925924

87.297647

11.950616

118.91599

21.901232

128.86661

129.18638

71.691654

71.691654

129.18638

9.9506160

13.938270

166.39883

25.876540

178.33710

13.925924

15.925924

221.78321

29.851848

235.70913

17.913578

285.0691

33.827156

300.98269
374.15780

17.901232

19.901232

356.25657

37.802464

455.23444

291.58506

291.58506

19.888886

22.000000

440.00000

42.000000

460.00000

396.48901

396.48900

517.19603

653.70612

806.01929

517.19602

653.70611

806.01929

974.13553

984.00000

984.00000

396.48900

517.19602

653.70611

806.01929

974.13553

COLUMNS 67 AND 8 SHOULD CONTAIN THE SAYE VALUES

THE FOLLOWING VALUES SHOULD BE CLOSE TO OR EQUAL TO ZERO.

0 .

0. 
OMNITAB 80 TEST 7 ARITHMETIC INSTRLCTIONS. (4.1)

PAGE 2

COLLYNS 1 THROLGH 5 CONTAIN AN 11 BY 5 ARRAY DEFINED BY THE COMANDS GENERATE, ADD AND MLLTIPLY.

COL 10 CONTAINS ROH BY ROR PRODUCT OF COLS 12 AND 3 USING PRODLCT COMMAND. COL 9 CONTAINS PRODLCT USING YYLT COMMAND. COLUMN 1 COLCMN 2 COLLMN 3 COLLMN 10 COLLMN 9

$\begin{array}{lcccc}2.0000000 & 4.0000000 & 8.0000000 & 64.000000 & 64.000000 \\ 3.9876540 & 5.9876540 & 23.876692 & * 5.7009643-02 * 5.7009643-02 \\ 5.9753080 & 7.9753080 & 47.654922 & * 2.2709915 \div 03 * 2.2709915-03 \\ 7.9629620 & 9.9629619 & 79.334686 & * 6.2939924-03 * 6.2939924-03 \\ 9.9506160 & 11.950616 & 118.91599 & * 1.4141013-04 * 1.4141013-04 \\ & & & & \\ 11.938270 & 13.938270 & 166.39883 & * 2.7688570-04 * 2.7688570-04 \\ 13.925924 & 15.925924 & 221.78321 & * 4.9187790-04 * 4.9187790-04 \\ 15.913578 & 17.913578 & 285.06911 & * 8.1264399-04 * 8.1264399-04 \\ 17.901232 & 19.901232 & 356.25657 & * 1.2691874-05 * 1.2691874-05 \\ 19.888886 & 21.888886 & 435.34555 & * 1.8952575-05 * 1.8952575-05 \\ 20.000000 & 22.000000 & 440.00000 & * 1.9360000-05 * 1.9360000-05\end{array}$

COLLMIS 9 AND 10 SHOLLD CONTAIN THE SAME VALUES.

THE FOLLOHIYG VALLE SHOLLD BE CLOSE TO OR EQUAL TO ZERO.

0. 
LIST OF DATA, INSTRUCTIONS AND DIAGNOSTICS

GENERATE NOS. STARTING WITH 2. IN STEPS OF 1.987654 THRU 20.0 STORE IN COL 1

* INFORMATIVE DIAGNOSTIC FOR THE ABOVE INSTRUCTION NRMAX HAS BEEN RESET FROM O TO 11.

ADD COLUMN 1 TO THE VALUE 2.0 AND STORE RESULTS IN COLUMN 2 MULTIPLY COLLMN 1 BY COLUMN 2 AND STORE PRODUCT IN COLUMN 3 ADD COLUMN 1 TO VALUES IN COLUMN 2 AND STORE SUM IN COL 4 ADD COL 1 TO COL 3 STORE IN COL 5

ROWSUM THE ENTIRE ARRAY ROW BY ROW STORE SUM IN COL 6

ROHSUM COLUMNS 1 THROUGH 5 AND STORE RESULTS IN COLUMN 7

ADD COLUMN 1 TO COL 2 STORE IN COL 8

ADD COLUMN 8 TO COL 3 STORE IN COL 8

ADD COLUMN 8 TO COL 4 STORE IN COL 8

ADD COLUMN 8 TO COL 5 STORE IN COL 8

TITLEICOLUMNS 1 THROUGH 5 CONTAIN AN 11 BY 5 ARRAY DEFINED BY THE

TITLE2COMMANDS GENERATE, ADD AND MULTIPLY.

TITLE3COL 6 AND 7 CONTAIN ROH SUMS OF THE ARRAY PRODUCED BY THE RO

TITLE4WSUM COMMAND. COL 8 CONTAINS ROW SUMS BY USING ADD COMMAND.

PRINT $1 * * * 8$

SUBTRACT COL 6 FROM COL 7 STORE IN COLUMN 9

SUBTRACT COL 8 FROM COL 7 STORE IN COLUMN 10

SPACE

NOTE

SPACE

NOTE COLUMNS 67 AND 8 SHOULD CONTAIN THE SAME VALUES.

NOTE THE FOLLOH'ING VALUES SHOULD BE CLOSE TO OR EQUAL TO ZERO.

SPACE

ABRIDGE ROW 1 OF COLUMNS 9 AND 10

SPACE

NOTE *******************************2)

PRODUCT OF COLUMNS 12 AND 3 ROW BY ROW AND STORE IN COL 10

MULT COL 1 BY COL 2 STORE IN COL 9

MULT COL 9 BY COL 3 STORE IN COL 9

TITLE3COL 10 CONTAINS ROW BY ROW PRODUCT OF COLS 12 AND 3 USING

TITLE4PRODUCT COMMAND. COL 9 CONTAINS PRODUCT USING MULT COMMAND.

SUBTRACT COL 9 FROM COLUMN 10 AND STORE COLUMN 11

SUM COL 11 STORE IN COLUMN 12

PRINT COLUMNS $1 * * * 3109$

SPACE

NOTE

NOTE COLUMNS 9 AND 10 SHOULD CONTAIN THE SAME VALUES

NOTE THE FOLLOWING VALUE SHOULD BE CLOSE TO OR EQUAL TO ZERO.

SPACE

ABRIDGE ROW 1 OF COLUMN 12

SPACE

NOTE

NATIONAL BUREAU OF STANDARDS. WASHINGTON, D. C. 20234

OMNITAB 80 VERSION 6.00 MARCH 2, 1981 
OWNITAB 80 TEST 8 CHANGE INSTRLCTION. (4.2)

COLLMS 1 THROLGH 8 TERE DEFINED BY THE READ COMMAND.

PAGE 1

\begin{tabular}{|c|c|c|c|c|c|c|c|}
\hline COLLMA & COLLMN & COLLM: & COLLYA & COLLMA & COLLXX & COLLMN & COLLXN \\
\hline $\begin{array}{l}1.0000000 \\
9.0000000\end{array}$ & $\begin{array}{c}2.0000000 \\
10.000000\end{array}$ & $\begin{array}{l}3.0000000 \\
11.000000\end{array}$ & $\begin{array}{l}4.0000000 \\
12.000000\end{array}$ & $\begin{array}{l}5.0000000 \\
13.000000\end{array}$ & $\begin{array}{c}6.0000000 \\
14.000000\end{array}$ & $\begin{array}{l}7.0000000 \\
15.000000\end{array}$ & $\begin{array}{l}8.0000000 \\
.16000000\end{array}$ \\
\hline
\end{tabular}

THE FOLLOFING VALLES RERE PRINTED BY THE COMMAND MPRINT.

THE SIGIS OF THE VALLES IN COLLMAS 2, 3 AND 8 HAVE BEEN CHAIGED.

\begin{tabular}{|c|c|c|c|c|c|c|c|}
\hline $\begin{array}{c}1.0000000 \\
9.0000000 \\
20.000000\end{array}$ & $\begin{array}{r}-2.0000000 \\
-10.000000 \\
-30.000000\end{array}$ & $\begin{array}{l}-3.0000000 \\
-11.000000 \\
-40.000000\end{array}$ & $\begin{array}{l}\text { 4. } 0000000 \\
12.000000 \\
0 .\end{array}$ & $\begin{array}{l}5.0000000 \\
13.000000 \\
0 .\end{array}$ & $\begin{array}{l}6.0000000 \\
14.000000 \\
0 .\end{array}$ & $\begin{array}{l}7.0000000 \\
15.000000 \\
0 .\end{array}$ & $\begin{array}{l}-8.0000000 \\
-.16000000 \\
0 .\end{array}$ \\
\hline
\end{tabular}

THE FOLLOTING VALLE SHOLLD BE CLOSE TO OR EQCAL TO ZERO.

0 . 
LIST OF DATA, INSTRUCTIONS AND DIAGNOSTICS

READ THE FOLLOWING VALUES INTO COLUMNS $1 * * 8$

1. 2. 3. 4. 5. 6. 7. 8 .

9. $10,11,12,13,14,15, .16$

20. $30 \quad 40$

* INFORMATIVE DIAGNOSTIC FOR THE ABOVE INSTRUCTION NRMAX HAS BEEN RESET FROM O TO 3.

TITLEICOLUMNS 1 THROUGH 8 HERE DEFINED BY THE READ COMMAND.

PRINT COLUMNS $1 * * * 8$

ROHSUY COLUMNS 23 AND 8 AND STORE IN COLUMN 9

CHANGE THE SIGNS OF THE VALUES IN COLUMNS 23 AND 8

ROXSUM COLUMNS 23 AND 8 AND STORE IN COLUMN 10

SPACE

NOTE THE FOLLORING VALUES RERE PRINTED BY THE COMMAND NPRINT.

NOTE THE SIGNS OF THE VALUES IN COLUMNS 2,3 AND 8 HAVE BEEN CHANGED.

SPACE

NPRINT COLLYNS $1 * * * 8$ WITH NO HEADINGS

ADD COLUMN 9 TO COLUMN 10 STORE IN COLUMN 11

SPACE 2

NOTE *****

SPACE

NOTE THE FOLLOKING VALUE SHOULD BE CLOSE TO OR EQUAL TO ZERO.

SPACE

ABRIDGE ROH 1 OF COLUMN 11

SPACE

NOTE

NATIONAL BUREAU OF STANDARDS. WASHINGTON, D. C. 20234

OMNITAB 80 VERSION 6.00 MARCH 2,1981 


\begin{tabular}{|c|c|c|c|c|}
\hline$\underset{\mathrm{X}}{\mathrm{COL}} 1$ & $\begin{array}{l}\operatorname{COL} 2 \\
\operatorname{EXP}(X)\end{array}$ & $\begin{array}{c}\operatorname{COL} 3 \\
\operatorname{EXP}(-X)\end{array}$ & $\begin{array}{c}\text { COL } 4 \\
\text { SATURAL LOG }(X)\end{array}$ & $\begin{array}{l}\text { COL } 5 \\
\text { LOG BASE } 10\end{array}$ \\
\hline $\begin{array}{l}.25000000 \\
.50000000 \\
.75000000 \\
1.0000000 \\
1.2500000\end{array}$ & $\begin{array}{l}1.2840254 \\
1.6487213 \\
2.1170000 \\
2.7182818 \\
3.4903429\end{array}$ & $\begin{array}{l}.77880079 \\
.60653066 \\
.47236655 \\
.36787944 \\
.28650480\end{array}$ & $\begin{array}{c}-1.3862944 \\
-.69314718 \\
-.28768207 \\
0 . \\
\quad .22314355\end{array}$ & $\begin{array}{l}-.60205999 \\
-.30103000 \\
-.12493874 \\
0 . \\
.096910013\end{array}$ \\
\hline $\begin{array}{l}1.5000000 \\
1.7500000 \\
2.0000000 \\
2.2500000 \\
2.5000000\end{array}$ & $\begin{array}{r}4.4816891 \\
5.7546027 \\
7.3890561 \\
9.4877359 \\
12.182494\end{array}$ & $\begin{array}{l}.22313016 \\
.17377394 \\
.13533528 \\
.10539922 \\
.082084998\end{array}$ & $\begin{array}{l}.40546511 \\
.55961579 \\
.69314718 \\
.81093021 \\
.91629073\end{array}$ & $\begin{array}{l}.17609126 \\
.24303805 \\
.30103000 \\
.35218252 \\
.39794001\end{array}$ \\
\hline $\begin{array}{l}2.7500000 \\
3.0000000 \\
3.2500000 \\
3.5000000 \\
3.7500000\end{array}$ & $\begin{array}{l}15.642632 \\
20.085537 \\
25.790340 \\
33.115452 \\
42.521082\end{array}$ & $\begin{array}{l}.063927861 \\
.049787068 \\
.038774208 \\
.030197383 \\
.023517746\end{array}$ & $\begin{array}{l}1.0116009 \\
1.0986123 \\
1.1786550 \\
1.2527630 \\
1.3217558\end{array}$ & $\begin{array}{l}.43933269 \\
.47712126 \\
.51188336 \\
.54406805 \\
.57403127\end{array}$ \\
\hline 4.0000000 & 54.598150 & .018315639 & 1.3862944 & .60205999 \\
\hline $\begin{array}{r}\text { COL } 2 \\
\operatorname{EXP}(X)\end{array}$ & $\begin{array}{c}\text { COL } 6 \\
\text { INTEGRAL PART } \\
\text { OF EXP }(X)\end{array}$ & $\begin{array}{c}\text { COL } 7 \\
\text { FRACTIONAL PART } \\
\text { OF } \operatorname{EXP}(X)\end{array}$ & & \\
\hline $\begin{array}{l}1.2840254 \\
1.6487213 \\
2.1170000 \\
2.7182818 \\
3.4903429\end{array}$ & $\begin{array}{l}1.0000000 \\
1.0000000 \\
2.0000000 \\
2.0000000 \\
3.0000000\end{array}$ & $\begin{array}{l}.28402542 \\
.64872128 \\
.11700001 \\
.71828184 \\
.49034294\end{array}$ & & \\
\hline $\begin{array}{c}4.4816891 \\
5.7546027 \\
7.3890561 \\
9.4877359 \\
12.182494\end{array}$ & $\begin{array}{r}4.0000000 \\
5.0000000 \\
7.0000000 \\
9.0000000 \\
12.000000\end{array}$ & $\begin{array}{l}.48168910 \\
.75460267 \\
.38905609 \\
.48773587 \\
.18249393\end{array}$ & & \\
\hline $\begin{array}{l}15.642632 \\
20.085537 \\
25.790340 \\
33.115452 \\
42.521082\end{array}$ & $\begin{array}{l}15.000000 \\
20.000000 \\
25.000000 \\
33.000000 \\
42.000000\end{array}$ & $\begin{array}{l}.64263189 \\
.085536957 \\
.79033995 \\
.11545181 \\
.52108192\end{array}$ & & \\
\hline 54.598150 & 54.000000 & .59815025 & & \\
\hline
\end{tabular}

THE FOLLOHING VALUES MUST BE EQUAL TO OR NEAR ZERO.
0 .
0 .
0. 
OMNITAB 80 TEST 9 MATHEMATICAL FUNCTIONS. (4.3)

LIST OF DATA, INSTRUCTIONS AND DIAGNOSTICS

GENERATE X FROM .25 IN INTERVALS OF .25 THRU 4. IN COL 1

* INFORMATIVE DIAGNOSTIC FOR THE ABOVE INSTRUCTION NRMAX HAS BEEN RESET FROM O TO 16.

EXP OF COL 1 STORE IN COL 2

NEGEXPONENT OF COL 1 STORE IN COL 3

DIVIDE COL 2 BY COL 3 STORE IN COL 21

LOGE COL 1 STORE IN COL 4

LOGTEN COL 1 STORE IN COL 5

ANTILOG OF COL 5 STORE IN COL 22

INTEGER PART OF COL 2 STORE IN COL 6

FRACTIONAL PART OF COL 2 STORE IN COL 7

SUBTRACT COL 6 FROM COL 2 MULT BY -1.0 ADD TO COL 7 STORE IN COL 23

NEW PAGE

NOTE

COL $1 \quad$ COL 2

$\operatorname{EXP}(X)$

COL 3

COL 5

NOTE

$\mathrm{X}$

$\operatorname{EXP}(-X)$

NATURAL LOG $(X)$

LOG BASE 10

NPRINT COLS $1 * * * 5$

SPACE 2

NOTE COL 2

NOTE $\quad \operatorname{EXP}(X)$

NOTE

SPACE

NPRINT COLS $266 \quad 7$

DEFINE 0.0 IN COL 17

SQUARE COL 2 STORE IN 18

DEFINE COL 1 INTO COL 19

ADD 1.0 TO 0.0 STORE IN COL 15

1/ SUBTRACT COL 21 FROM COL 18 STORE IN COL 21

3/ ABS COL 21 STORE IN 21

4/IFNE 0 . IS NOT=TO ANY VAL IN $210 F$ TOL $=1 . E-5$ DO NOT EXEC. REST OF STORED COM.

5/ INCREMENT INSTRUCTION 1 BY 11 AND 1

6/ INCREMENT INSTRUCTION 3 BY 1 AND 1

7/ INCREMENT INSTRUCTION 4 BY 00.01 AND 0.0

7.5/ IFEQ ANY VALUE IN COL 15 IS = TO 2. TERMINATE FOLLOWING REPEAT INST.

8/ REPEAT INSTRUCTIONS 1 THRU 7.5, 2 TIMES

10/RESTORE INSTRUCTION 1 TO 231723

11/ ADD 1.0 TO COL 15 STORE IN 15

REPEAT INSTRUCTIONS 8 THRU 11,2 TIMES

SPACE 2

NOTE *****

SPACE

NOTE THE FOLLOWING VALUES MUST BE EQUAL TO OR NEAR ZERO.

SPACE

ABRIDGE ROW 1 COL 212223

SPACE

NOTE

NATIONAL BUREAU OF STANDARDS. WASHINGTON, D. C. 20234 '

OMNITAB 80 VERSION 6.00 MARCH 2,1981 
OMNITAB 80 TEST 10 SINE, COSINE, TANGENT AND COTANGENT INSTRUCTIONS. (4.4)

$\begin{array}{ccccc}\text { COL } 1 & \text { COL 2 } & \text { COL 3 } & \text { COL } 4 & \text { COL 5 } \\ \text { X } & \text { SIN X } & \text { COS X } & \text { TAN X } & \text { COT X } \\ -1.0000000 & -.84147099 & .54030231 & -1.5574077 & -.64209261 \\ -.80000000 & -.71735609 & .69670671 & -1.0296385 & -.97121461 \\ -.59999999 & -.56464247 & .82533562 & -.68413679 & -1.4616960 \\ -.40000000 & -.38941834 & .92106099 & -.42279322 & -2.3652224 \\ -.20000000 & -.19866933 & .98006658 & -.20271003 & -4.9331549 \\ & & & & \\ .20000000 & .19866933 & .98006658 & .20271003 & 4.9331549 \\ .40000000 & .38941834 & .92106099 & .42279322 & 2.3652224 \\ .59999999 & .56464247 & .82533562 & .68413679 & 1.4616960 \\ .80000000 & .71735609 & .69670671 & 1.0296385 & .97121461 \\ 1.0000000 & .84147099 & .54030231 & 1.5574077 & .64209261\end{array}$

$(\operatorname{SIN}(X)) * * 2-(\operatorname{Cos}(X)) * * 2=1.0$.

$\operatorname{TAN}(X)-(\operatorname{SIN}(X) / \operatorname{COS}(X))=0$.

$\operatorname{COT}(X)-(\cos (X) / \operatorname{SIN}(X))=0$

THE FOLIOHING VALLES MLST BE EQUAL TO OR NEAR 1.0, 0.0 AND 0.0.
1.0000000
0 .
0 . 
OMNITAB 80 TEST 10 SINE, COSINE, TANGENT AND COTANGENT INSTRUCTIONS. (4.4)

$\begin{array}{ccccc}\text { COL } 1 & \begin{array}{c}\text { COL 6 } \\ \text { X }\end{array} & \begin{array}{c}\text { COL 7 } \\ \text { ARCSIN X }\end{array} & \begin{array}{c}\text { COL 8 } \\ \text { ARCCOS X }\end{array} & \begin{array}{c}\text { COL 9 } \\ \text { ARCTAN X }\end{array} \\ \begin{array}{cccc}\text { ARCCOT X } \\ -1.0000000\end{array} & 1.0000001 & 1.0000000 & 1.0000000 & 1.0000000 \\ -.80000000 & .80000004 & .80000000 & .80000000 & .80000000 \\ -.59999999 & .59999999 & .59999999 & .59999999 & .59999999 \\ -.40000000 & .40000000 & .40000001 & .40000000 & .40000000 \\ -.20000000 & .20000000 & .20000002 & .20000000 & .20000000 \\ & & & & \\ .20000000 & .20000000 & .20000002 & .20000000 & .20000000 \\ .40000000 & .40000000 & .40000001 & .40000000 & .40000000 \\ .59999999 & .59999999 & .59999999 & .59999999 & .59999999 \\ .80000000 & .79999995 & .80000000 & .80000000 & .80000000 \\ 1.0000000 & .99999997 & 1.0000000 & 1.0000000 & 1.0000000\end{array}$

THE FOLLOWING VALUES ARE NUMBER OF SIGNIFICANT DIGITS FOR THE

ABSOLUTE VALUES OF X, ARCSIN, ARCCOS, ARCTAN, AND ARCCOT.

(THE VALUE FOR NUMBER OF SIGNIFICANT DIGITS IS 8.0 FOR NBS COMPUTER.)
8.0000000
7.7129689
7.7500554
7.9811922
7.9811922 
OMNITAB 80 TEST 10 SINE, COSINE, TANGENT AND COTANGENT INSTRUCTIONS. (4.4) PaGE 3

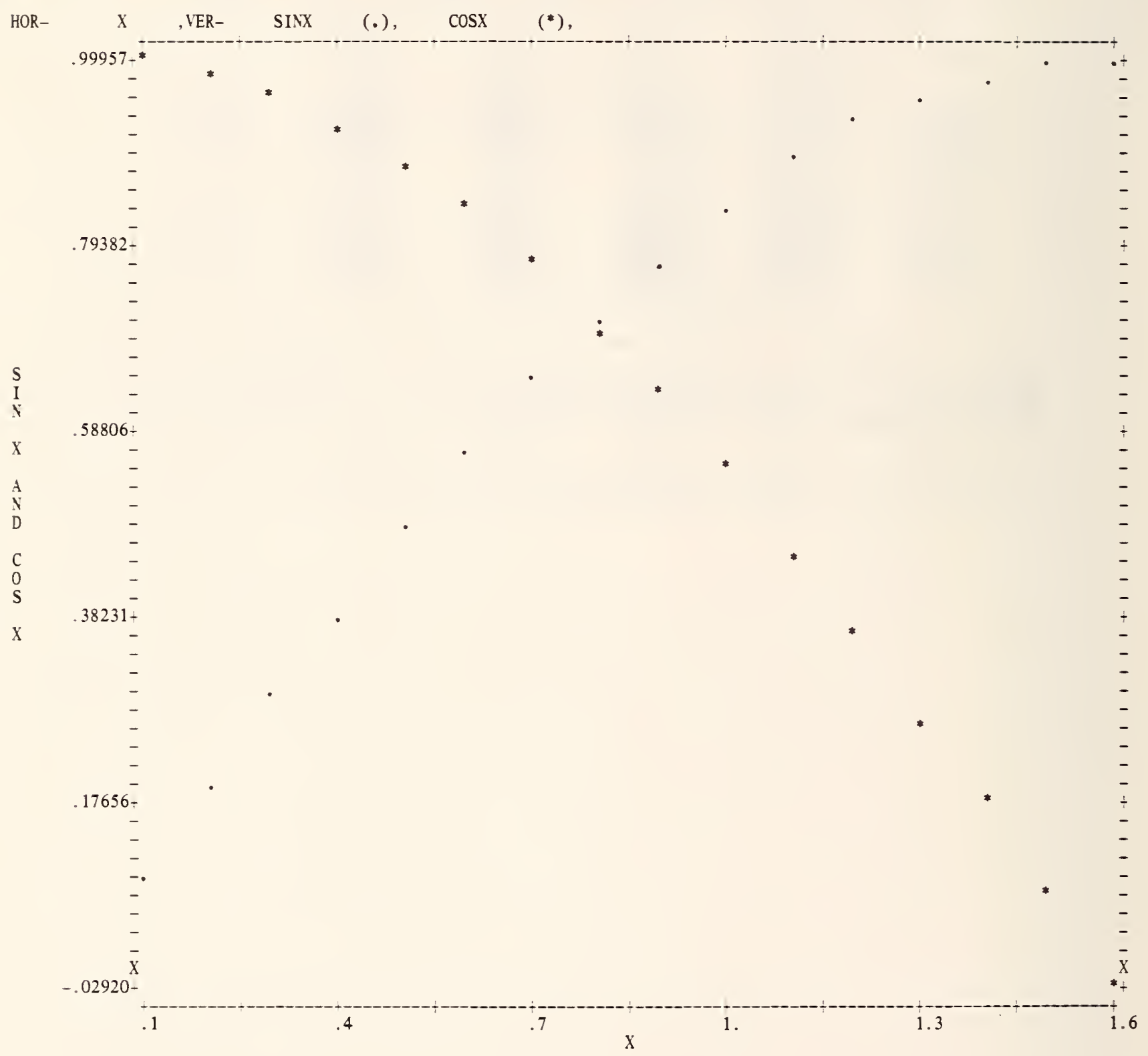


OMNITAB 80 TEST 10 SINE, COSINE, TANGENT AND COTANGENT INSTRUCTIONS. (4.4) PAGE 4

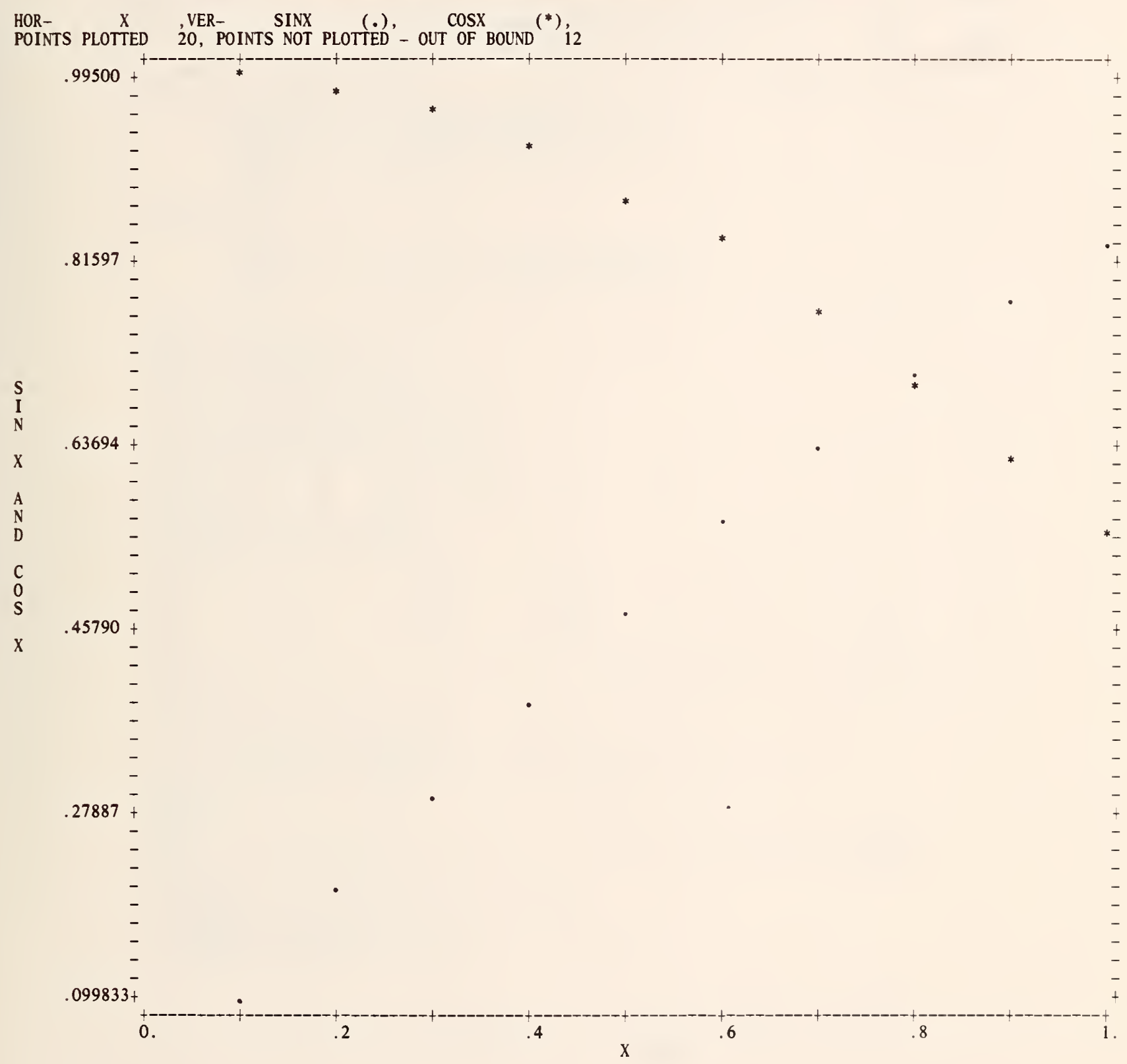


OMNITAB 80 TEST 10 SINE, COSINE, TANGENT AND COTANGENT INSTRLCTIONS. (4.4)

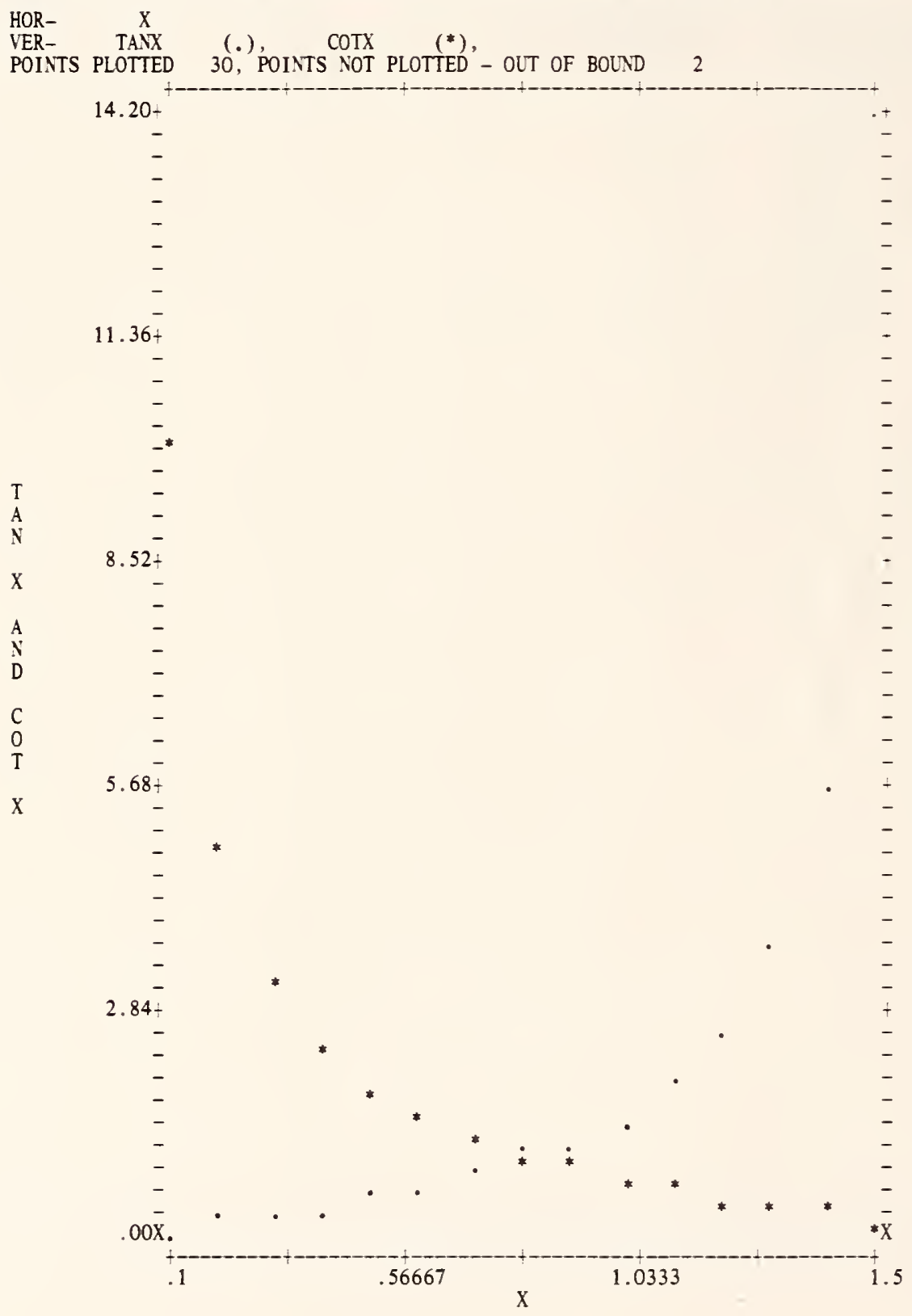


OMNITAB 80 TEST 10 SINE, COSINE, TANGENT AND COTANGENT INSTRUCTIONS. (4.4)

LIST OF DATA, INSTRUCTIONS AND DIAGNOSTICS

LABEL X, SINX, COSX, TANX, COTX

* INFORMATIVE DIAGNOSTIC FOR THE ABOVE INSTRUCTION -

(X) IS IN COL (1), (SINX) IS IN COL (2)

(COSX) IS IN COL (3), (TANX) IS IN COL (4)

(COTX) IS IN COL (5)

SET FOLLOWING DATA IN X

$-1 .,-.8,-.6,-.4,-.2, .2, .4, .6, .8,1$.

* INFORMATIVE DIAGNOSTIC FOR THE ABOVE INSTRUCTION -

NRMAX HAS BEEN RESET FROM O TO 10.

SIN OF X STORE RESULTS IN COL 2

COS OF X STORE RESULTS IN COL 3

TAN OF $X$ STORE RESULTS IN COL 4

COT OF X STORE RESULTS IN COL 5

ASIN OF SINX STORE RESULTS IN COL 6

ACOS OF COSX STORE RESULTS IN COL 7

ATAN OF TANX STORE RESULTS IN COL 8

ACOT OF COTX STORE RESULTS IN COL 9

EVALUATE $12=\operatorname{SINX} * * 2$. $+\cos X * * 2$.

EVALUATE $13=$ TANX $-(\operatorname{SINX} / \operatorname{COSX})$

EVALUATE $14=$ COTX $-(\operatorname{COSX} /$ SINX $)$

AVERAGE COL 12 STORE IN COL 12

AVERAGE COL 13 STORE IN COL 13

AVERAGE COL 14 STORE IN COL 14

NEW PAGE

NOTE COL 1 COL

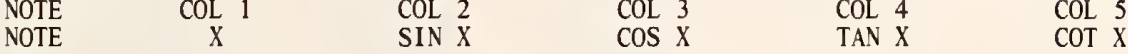

SPACE

SPACE 2

NOTE $* * * * * * * * * * * * * * * * * * * * * * * * * * * * * * * * * * * * * * * * * * * * * * * * * * * * * * * * * * * * * * * * * * * * * * * * * *$

SPACE

NOTE $(\operatorname{SIN}(X)) * * 2+(\operatorname{COS}(X)) * * 2=1.0$.

NOTE TAN $(X)-(\operatorname{SIN}(X) / \operatorname{COS}(X))=0$.

NOTE $\operatorname{COT}(X)-(\operatorname{COS}(X) / \operatorname{SIN}(X))=0$

NOTE THE FOLLOWING VALUES MUST BE EQUAL TO OR NEAR $1.0,0.0$ AND 0.0.

SPACE

ABRIDGE ROW 1 COLS $12 \quad 13 \quad 14$

SPACE

NOTE $* * * * * * * * * * * * * * * * * * * * * * * * * * * * 4)$

ADD COL 1 TO 0.0 STORE IN COL
$1 /$ ABSOLUTE COL 5 STORE IN 5

2/ACCURACY OF COL 5 VS COL 5 STORE IN COL 10

3/AVERAGE COL 10 STORE IN COL 10

4/INCREMENT INSTRUCTION 1 BY 11

5/INCREMENT INSTRUCTION 2 BY 0011 
LIST OF DATA, INSTRUCTIONS AND DIAGNOSTICS

6/INCREMENT INSTRUCTION 3 BY 11

REPEAT INSTRUCTIONS 1 THRU 6, 5 TIMES

NEW PAGE

NOTE COL $1-$ COL 6

NOTE $\quad X$

NPRINT COLS $16^{* * * 9}$

SPACE 2

NOTE *

NOTE

NOTE THE FOLLOWING VALUES ARE NUMBER OF SIGNIFICANT DIGITS FOR THE

NOTE ABSOLUTE VALUES OF X, ARCSIN, ARCCOS, ARCTAN, AND ARCCOT.

NOTE (THE VALUE FOR NUMBER OF SIGNIFICANT DIGITS IS 8.0 FOR NBS COMPUTER.)

SPACE

ABRIDGE ROW 1 COLS $10 * * * 14$

SPACE

NOTE $* * * * * * * * * * * * * * * * * * * * * * * * * * * * * * * * * * * * * * * * * * * * * * * * * * * * * * * * * * * * * * * * * * * * * * * * * * *$

GENERATE FROM 0.1 IN STEPS OF . 1 THRU 1.6 IN X

* INFORMATIVE DIAGNOSTIC FOR THE ABOVE INSTRUCTION NRMAX HAS BEEN RESET FROM 10 TO 16.

SIN OF COL 1 STORE IN COL 2

COS OF COL 1 STORE IN COL 3

TAN OF COL 1 STORE IN COL 4

COT OF COL 1 STORE IN COL 5

TITLEY

SIN $\mathrm{X}$ AND $\cos \mathrm{X}$

TITLEX

PLOT SINX AND COSX VS. $X$

NEW PAGE

NPLOT SINX AND COSX VS. $X$ HORIZONTAL LIMITS 0.0 THRU 1.0

TITLEX

TITLEY

$\mathrm{X}$

PAGE PLOT COLS 4 AND 5 (TAN AND COT) Y FROM 0.0 TO 14.2 VS. COL 1 FROM .1 TO 1.5

NATIONAL BUREAU OF STANDARDS. MASHINGTON, D. C. 20234 OMNITAB 80 VERSION 6.00 MARCH 2,1981 
OMNITAB 80 TEST 11 TRIGONOMETRIC FUNCTIONS. (4.4)

EVALUATE SINE, COSINE, TANGENT, AND COTANGENT OF $X, X$ IN DEGREES.

$\begin{array}{ccccc}\text { COL 1 } & \text { COL 2 } & \text { COL } 3 & \text { COL } 4 & \text { COL } 5 \\ \text { X DEGREES } & \text { SIN X } & \text { COS X } & \text { TAN X } & \text { COT X } \\ 5.0000000 & .087155742 & .99619470 & .087488662 & 11.430052 \\ 15.000000 & .25881904 & .96592583 & .26794919 & 3.7320509 \\ 45.000000 & .70710678 & .70710678 & .99999999 & 1.0000000 \\ 75.000000 & .96592582 & .25881907 & 3.7320505 & .26794921 \\ 125.00000 & .81915206 & -.57357642 & -1.4281481 & -.70020750 \\ & & & & \\ 175.00000 & .087155786 & -.99619470 & -.087488707 & -11.430047 \\ 200.00000 & -.34202011 & -.93969264 & .36397019 & 2.7474778 \\ 200.00000 & -.34202011 & -.93969264 & .36397019 & 2.7474778 \\ 300.00000 & -.86602545 & .49999992 & -1.7320512 & -.57735014 \\ 350.00000 & -.17364826 & .98480774 & -.17632707 & -5.6712789\end{array}$

FOLLOWING COLUMNS SHOULD CONTAIN VALUES EQUAL OR CLOSE TO 1.0 , ACCORDING TO RELATIONAL EXPRESSIONS OF TRIGNOMETRIC FUNCTIONS.

$\begin{array}{ccc}\text { COL } 14 & \begin{array}{c}\text { COL } 15 \\ \text { CIN } 2+\text { COS }^{* * 2}\end{array} & \begin{array}{c}\text { COL } 16 \\ \text { SEC**2-TAN**2 }\end{array} \\ \text { COSEC**2-COT**2 } \\ .99999999 & 1.0000000 & 1.0000019 \\ .99999999 & 1.0000000 & 1.0000004 \\ .99999999 & 1.0000000 & 1.0000000 \\ .99999999 & 1.0000001 & 1.0000000 \\ 1.0000000 & 1.0000000 & 1.0000000 \\ 1.0000000 & 1.0000000 & 1.0000000 \\ 1.0000000 & 1.0000000 & 1.0000000 \\ 1.0000000 & 1.0000000 & 1.0000000 \\ .99999999 & 1.0000001 & 1.0000000 \\ .99999999 & 1.0000000 & 1.0000005 \\ & & \\ & & \end{array}$

FOLLOWING VALUES MUST BE EQUAL TO OR NEAR ONE.
1.0000000
1.0000000
1.0000003 
OMNITAB 80 TEST 11 TRIGONOMETRIC FUNCTIONS. (4.4)

EVALUATE IN DEGREES THE ARCSIN, ARCCOS, ARCTAN, AND ARCCOT OF X.

\begin{tabular}{|c|c|c|c|c|}
\hline$\underset{\mathrm{X}}{\mathrm{COL}} 1$ & $\begin{array}{c}\operatorname{COL} 2 \\
\text { ARCSIN X }\end{array}$ & $\begin{array}{c}\operatorname{COL} 3 \\
\operatorname{ARCCOS} x\end{array}$ & $\begin{array}{c}\text { COL } 4 \\
\text { ARCTAN } X\end{array}$ & $\begin{array}{c}\mathrm{COL} 5 \\
\text { ARCCOT } X\end{array}$ \\
\hline $\begin{array}{l}.1000 \\
.2000 \\
.3000 \\
.4000 \\
.5000 \\
.6000 \\
.7000 \\
.8000 \\
.9000 \\
1.0000\end{array}$ & $\begin{array}{r}5.7392 \\
11.5370 \\
17.4576 \\
23.5782 \\
30.0000 \\
36.8699 \\
44.4270 \\
53.1301 \\
64.1581 \\
90.0000\end{array}$ & $\begin{array}{r}84.2608 \\
78.4630 \\
72.5424 \\
66.4218 \\
60.0000 \\
53.1301 \\
45.5730 \\
36.8699 \\
25.8419 \\
.0000\end{array}$ & $\begin{array}{r}5.7106 \\
11.3099 \\
16.6992 \\
21.8014 \\
26.5651 \\
30.9638 \\
34.9920 \\
38.6598 \\
41.9872 \\
45.0000\end{array}$ & $\begin{array}{l}84.2894 \\
78.6901 \\
73.3008 \\
68.1986 \\
63.4349 \\
59.0362 \\
55.0080 \\
51.3402 \\
48.0128 \\
45.0000\end{array}$ \\
\hline
\end{tabular}

THE VALUES IN THE FOLLOHING COLS SHOULD BE EQUAL TO OR NEAR 90.

COL 6

ARCSIN-ARCCOS ARCTAN+ARCCOT

$\begin{array}{ll}90.0000 & 90.0000 \\ 90.0000 & 90.0000 \\ 90.0000 & 90.0000 \\ 90.0000 & 90.0000 \\ 90.0000 & 90.0000 \\ 90.0000 & 90.0000 \\ 90.0000 & 90.0000 \\ 90.0000 & 90.0000 \\ 90.0000 & 90.0000 \\ 90.0000 & 90.0000\end{array}$

THE FOLLOWING VALLES MUST BE EQUAL TO OR NEAR 90.

$90.0000 \quad 90.0000$ 
SET FOLLOWING DATA IN COL 1

$5,15,45,75,125,175,200,200,300,350$

* INFORMATIVE DIAGNOSTIC FOR THE ABOVE INSTRUCTION NRMAX HAS BEEN RESET FROM O TO 10.

SIND OF COL 1 STORE RESULTS IN COL 2

COSD OF COL 1 STORE RESULTS IN COL 3

TAND OF COL 1 STORE RESULTS IN COL 4

COTD OF COL 1 STORE RESULTS IN COL 5

TITLE 1 EVALUATE SINE, COSINE, TANGENT, AND COTANGENT OF $X, X$ IN D TITLE2EGREES

NEW PAGE

$\begin{array}{llllll}\text { NOTE } & \text { COL } 1 & \text { COL } 2 & \text { COL } 3 & \text { COL } 4 & \text { COL } 5 \\ \text { NOTE } & X \text { DEGREES } & \text { SIN X } & \operatorname{COS} X & \text { TAN X } & \text { COT X }\end{array}$

NPRINT COLS $1 * * * 5$

1/SOUARE COL 2 STORE RESULT IN COL 10

2/INCREMENT INSTRUCTION 1 BY 1 AND 1

REPEAT INSTRUCTIONS 1 THRU 24 TIMES

ADD SIND $(X)$ SQUARED IN COL 10 TO $\operatorname{COSD}(X)$ SQUARED IN COL 11 AND STORE IN 14

RECIPROCAL OF COL 11 STORE IN COL 15

RECIPROCAL OF COL 10 STORE IN COL 16

SUBTRACT COL 12 FROM COL 15 STORE IN COL 15

SUBTRACT COL 13 FROM COL 16 STORE IN COL 16

SPACE 2

NOTE FOLLOWING COLUMNS SHOULD CONTAIN VALUES EQUAL OR CLOSE TO 1.0,

NOTE ACCORDING TO RELATIONAL EXPRESSIONS OF TRIGNOMETRIC FUNCTIONS.

SPACE

NOTE COL $14 \quad$ COL $15 \quad$ COL 16

NOTE $\operatorname{SIN}^{* * 2+\operatorname{COS}^{* * 2}} \quad$ SEC $^{* * 2-T_{A N}^{* * 2}} \quad \operatorname{COSEC}^{* * 2-\mathrm{COT}^{* * 2}}$

NPRINT COLS 141516

AVERAGE COL 14 STORE IN COL 14

AVERAGE COL 15 STORE IN COL 15

AVERAGE COL 16 STORE IN COL 16

SPACE 2

NOTE

SPACE

NOTE FOLLOWING VALUES MUST BE EQUAL TO OR NEAR ONE.

SPACE

ABRIDGE ROW 1 COLS 141516

SPACE

NOTE $* * * * * * * * 20$

RESET NRMAX 0

* INFORMATIVE DIAGNOSTIC FOR THE ABOVE INSTRUCTION NRMAX HAS BEEN RESET FROM 10 TO 0.

GENERATE NOS FROM .1 IN STEPS OF .1 THRU 1.0 IN COL 1 
LIST OF DATA, INSTRLCTIONS AID DIAGNOSTICS

* INFORMATIVE diAgNoSTIC FOR THE ABOVE IISTRLCTION NRYAX HAS BEEN RESET FROM O TO 10.

ASIND OF $X$ IN COL 1 STORE IN COL 2

ACOSD OF $X$ IS COL 1 STORE IS COL 3

ATAND OF X IN COL 1 STORE II COL 4

ACOTD OF X IN COL 1 STORE IS COL 5

TITLE1 EVALUATE IN DEGREES THE ARCSIN, ARCCOS, ARCTAN, AID ARCCOT

TITLE2 OF $\AA$

IEIV PAGE

FIXED 4

NOTE

$\underset{\mathrm{COL}}{\mathrm{C}}$

$\operatorname{COL} 2$

COL 3

ARCCOS $x$

COL 4

$\operatorname{COL} 5$

SPACE

NPRINT COLS $1 * * * 5$

ADD COL 2 TO COL 3 STORE RESLLTS IN COL 6

ADD COL 4 TO COL 5 STORE RESLLTS II COL 7

SPACE 2

NOTE THE VALLES IS THE FOLLONIYG COLS SHOLLD BE EQUAL TO OR IEAR 90.

SPACE

NOTE COL $6 \quad$ COL 7

NOTE ARCSIN-ARCCOS ARCTAN-ARCCOT

SPACE

IPRINT COL 6 AND 7

AVERAGE COL 6 STORE IN COL 6

AIERAGE COL 7 STORE IN COL 7

SPACE 2

NOTE ***

SPACE

VOTE THE FOLLOHING VALLES MLST BE EQUAL TO OR IEAR 90.

SPACE

ABRIDGE ROM 1 COLS 67

SPACE

VOTE

NATIONAL BUREAL OF STAIDARDS. HASHIYGTON, D. C. 20234

OYNITAB 80 IERSION 6.00 BLARCH 2,1981 


$\begin{array}{ccccc}\text { COL } 1 & \text { COL } 2 & \text { COL } 3 & \text { COL } 4 & \begin{array}{l}\text { COL } 5 \\ \text { COTH X }\end{array} \\ & \text { SINH X } & \text { COSH X } & \text { TANH X } & \\ .25000000 & .25261232 & 1.0314131 & .24491866 & 4.0829881 \\ .50000000 & .52109530 & 1.1276260 & .46211716 & 2.1639534 \\ .75000000 & .82231672 & 1.2946833 & .63514895 & 1.5744338 \\ 1.0000000 & 1.1752012 & 1.5430806 & .76159415 & 1.3130353 \\ 1.2500000 & 1.6019191 & 1.8884239 & .84828364 & 1.1788510 \\ & & & & \\ 1.5000000 & 2.1292794 & 2.3524096 & .90514825 & 1.1047914 \\ 1.7500000 & 2.7904143 & 2.9641883 & .94137554 & 1.0622753 \\ 2.0000000 & 3.6268604 & 3.7621957 & .96402758 & 1.0373147 \\ 2.2500000 & 4.6911682 & 4.7965675 & .97802611 & 1.0224676 \\ 2.5000000 & 6.0502044 & 6.1322894 & .98661430 & 1.0135673 \\ & & & & \\ 2.7500000 & 7.7893519 & 7.8532798 & .99185973 & 1.0082071 \\ 3.0000000 & 10.017875 & 10.067662 & .99505475 & 1.0049698 \\ 3.2500000 & 12.875783 & 12.914557 & .99699763 & 1.0030114 \\ 3.5000000 & 16.542627 & 16.572824 & .99817790 & 1.0018254 \\ 3.7500000 & 21.248782 & 21.272300 & .99889445 & 1.0011068 \\ 4.0000000 & 27.289917 & 27.308233 & .99932930 & 1.0006711 \\ 4.2500000 & 35.045574 & 35.059838 & .99959315 & 1.0004070 \\ 4.5000000 & 45.003011 & 45.014120 & .99975321 & 1.0002468 \\ 4.7500000 & 57.787816 & 57.796468 & .99985031 & 1.0001497 \\ 5.0000000 & 74.203209 & 74.209948 & .99990921 & 1.0000908\end{array}$

$(\operatorname{COSH}(X)) * * 2-(\operatorname{SINH}(X)) * * 2=1$

$(\operatorname{TANH}(X)) * * 2+(1 /(\operatorname{COSH}(X)) * * 2)=1$

$(\operatorname{COTH}(X)) * * 2-(1 /(\operatorname{SINH}(X)) * * 2)=1$

THE FOLLOWING VALUES MUST BE EQUAL TO OR NEAR ONE.
1.0000054
1.0000000
.99999995 


$\begin{array}{ccccc}\text { COL } 1 & \text { COL } 8 & \text { COL 9 } & \text { COL 10 } & \begin{array}{c}\text { COL 11 } \\ \text { X }\end{array} \\ \text { ARCSINH X } & \text { ARCCOSH X } & \text { ARCTANH X } & \\ .25000000 & .24999999 & .24999995 & .24999999 & .25000000 \\ .50000000 & .49999999 & .49999999 & .49999999 & .50000000 \\ .75000000 & .74999999 & .74999999 & .74999999 & .74999999 \\ 1.0000000 & .99999998 & .99999999 & .99999998 & 1.0000000 \\ 1.2500000 & 1.2500000 & 1.2500000 & 1.2500000 & 1.2500000 \\ & & & & \\ 1.5000000 & 1.5000000 & 1.5000000 & 1.5000000 & 1.5000000 \\ 1.7500000 & 1.7500000 & 1.7500000 & 1.7500000 & 1.7500001 \\ 2.0000000 & 2.0000000 & 2.0000000 & 2.0000001 & 2.0000001 \\ 2.2500000 & 2.2500000 & 2.2500000 & 2.2499998 & 2.2500000 \\ 2.5000000 & 2.5000000 & 2.5000000 & 2.5000001 & 2.5000004 \\ & & & & \\ 2.7500000 & 2.7500000 & 2.7500000 & 2.7499997 & 2.7500009 \\ 3.0000000 & 3.0000000 & 3.0000000 & 2.9999998 & 3.0000003 \\ 3.2500000 & 3.2500000 & 3.2500000 & 3.2499982 & 3.2500001 \\ 3.5000000 & 3.5000000 & 3.5000000 & 3.5000009 & 3.5000018 \\ 3.7500000 & 3.7500000 & 3.7500000 & 3.7499979 & 3.7500054 \\ & & & & \\ 4.0000000 & 4.0000000 & 4.0000000 & 3.9999993 & 4.0000015 \\ 4.2500000 & 4.2500000 & 4.2500000 & 4.2499909 & 4.2500113 \\ 4.5000000 & 4.5000000 & 4.5000000 & 4.4999921 & 4.5000250 \\ 4.7500000 & 4.7500000 & 4.7500000 & 4.7499846 & 4.7500097 \\ 5.0000000 & 4.9999999 & 5.0000000 & 5.0000163 & 5.0000617\end{array}$

THE FOLLONING VALUES MUST BE EQUAL TO OR NEAR ZERO.

* $-1.7881393-08 *-9.8720192-09 *-1.0196119-06 * 5.9159472-06$ 
OMNITAB 80 TEST 12 HYPERBOLIC FUNCTIONS.

$(4.4)$

LIST OF DATA, INSTRUCTIONS AND DIAGNOSTICS

GENERATE X STARTING WITH .25 IN STEPS OF .25 UP TO AND INCL 5. INTO COL 1

* INFORMATIVE DIAGNOSTIC FOR THE ABOVE INSTRUCTION NRMAX HAS BEEN RESET FROM O TO 20.

SINH OF X IN COL 1 STORE RESULTS IN COL 2

COSH OF X IN COL 1 STORE RESULTS IN COL 3

TANH OF $X$ IN COL 1 STORE RESULTS IN COL 4

COTH OF X IN COL 1 STORE RESULTS IN COL 5

1/ SQUARE COL 2 STORE IN COL 6

2/ INCREMENT 1 BY 11

REPEAT STATEMENTS 1 AND 24 TIMES

SUBTRACT COL 6 FROM COL 7 STORE IN 10

RECIPROCAL OF COL 7 MULT BY 1.0 ADD TO 8 AND STORE IN 11

RECIPROCAL OF COL 6 MULT BY -1.0 ADD TO 9 AND STORE IN 12

AVERAGE COL 10 STORE IN 10

AVERAGE COL 11 STORE IN 11

AVERAGE COL 12 STORE IN 12

NEW PAGE

NOTE

COL 1

COL 2

$\begin{array}{lllll}\text { NOTE } & X & \text { SINH } X & \text { COSH X } & \text { TANH X }\end{array}$

$\operatorname{col} 3$

$\begin{array}{lllll}\text { NOTE } & X & \text { SINH } X & \text { COSH X } & \text { TANH X }\end{array}$

COL 4

COL 5

NPRINT COLS $1 * * * 5$

SPACE 2

NOTE ***

SPACE

NOTE $(\operatorname{COSH}(X)) * * 2-(\operatorname{SINH}(X))^{* *} 2=1$

NOTE $(\operatorname{TANH}(X))^{* * 2}+\left(1 /(\operatorname{COSH}(X))^{* *} 2\right)=1$

NOTE $(\operatorname{COTH}(X))^{* * 2}-\left(1 /(\operatorname{SINH}(X))^{* * 2}\right)=1$

NOTE THE FOLLOWING VALUES MUST BE EQUAL TO OR NEAR ONE.

SPACE

ABR IDGE ROW 1 COLS 101112

SPACE

ASINH OF COL 2 STORE RESULTS IN COL 8

ACOSH OF COL 3 STORE RESULTS IN COL 9

ATANH OF COL 4 STORE RESULTS IN COL 10

ACOTH OF COL 5 STORE RESULTS IN COL 11

NEW PAGE

NOTE

NOTE

$\mathrm{COL} 1$

COL 8

COL 9

ARCSINH $X$

ARCCOSH $x$

COL 10

ARCTANH X

COL 11

SPACE

NPRINT COLS $18 * * * 11$

SPACE 2

1/ SUBTRACT COL 1 FROM COL 8 STORE RESULTS IN 8

2) AVERAGE COL 8 STORE IN 8

3/INCREMENT INSTRUCTION 1 BY 0

4/INCREMENT INSTRUCTION 2 BY 11

PERFORM INSTRUCTIONS 1 THRU 4,4 TIMES

NOTE $* * * * * * * * * * * * * * * * * * * * * * * * * * * * * * * * * * * * * * * * * * * * * * * * * * * * * * * * * * * * * * * * * * * * * * * * * * *$ 
OMNITAB 80 TEST 12 HYPERBOLIC FUNCTIONS. (4.4)

LIST OF DATA, INSTRUCTIONS AND DIAGYOSTICS

\section{SPACE}

NOTE THE FOLLOHING VALLES MUST BE EQUAL TO OR NEAR ZERO.

SPACE

ABRIDGE ROF 1 OF COLS $8 * * 11$

SPACE

NOTE ***

NATIONAL BUREAU OF STANDARDS. FASHINGTON, D. C. 20234

OMVITAB 80 VERSION 6.00 MARCH 2,1981 
OMNITAB 80 TEST 13 ROUND INSTRUCTION. (4.7) NUMBER OF SIGNIFICANT DIGITS PER COLUMN

\begin{tabular}{|c|c|c|c|c|c|c|c|}
\hline $\begin{array}{cc}8 & \\
& \\
\text { COLUMN } & 21\end{array}$ & $\begin{array}{ll}7 & \\
\text { COLUMN } & 22\end{array}$ & $\begin{array}{cc}6 \\
\text { COLUMN } 23\end{array}$ & COLUMN & COLUMN & $\begin{array}{r}3 \\
\text { COLUMN }\end{array}$ & COLUMN & $\begin{array}{r}1 \\
\text { COLUMN }\end{array}$ \\
\hline $\begin{array}{c}72.444443 \\
6.4748596 \\
1.6718015 \\
20.000000 \\
5.2533334\end{array}$ & $\begin{array}{c}72.444440 \\
6.4748600 \\
1.6718020 \\
20.000000 \\
5.2533330\end{array}$ & $\begin{array}{c}72.444400 \\
6.4748600 \\
1.6718000 \\
20.000000 \\
5.2533300\end{array}$ & $\begin{array}{c}72.444000 \\
6.4749000 \\
1.6718000 \\
20.000000 \\
5.2533000\end{array}$ & $\begin{array}{c}72.440000 \\
6.4750000 \\
1.6720000 \\
20.000000 \\
5.2530000\end{array}$ & $\begin{array}{c}72.400000 \\
6.4800000 \\
1.6700000 \\
20.000000 \\
5.2500000\end{array}$ & $\begin{array}{c}72.000000 \\
6.5000000 \\
1.7000000 \\
20.000000 \\
5.2000000\end{array}$ & $\begin{array}{c}70.000000 \\
6.0000000 \\
2.0000000 \\
20.000000 \\
5.0000000\end{array}$ \\
\hline $\begin{array}{c}41.923807 \\
9.0262909 \\
68.147674 \\
-.82094830 \\
.42543463\end{array}$ & $\begin{array}{c}41.923810 \\
9.0262910 \\
68.147670 \\
-.82094830 \\
.42543460\end{array}$ & $\begin{array}{c}41.923800 \\
9.0262901 \\
68.147700 \\
-.82094800 \\
.42543500\end{array}$ & $\begin{array}{c}41.924000 \\
9.0263000 \\
68.148000 \\
-.82095000 \\
.42544000\end{array}$ & $\begin{array}{c}41.920000 \\
9.0260000 \\
68.150000 \\
-.82100000 \\
.42540000\end{array}$ & $\begin{array}{c}41.900000 \\
9.0300000 \\
68.200000 \\
-.82100000 \\
.42500000\end{array}$ & $\begin{array}{c}42.000000 \\
9.0000000 \\
68.000000 \\
-.82000000 \\
.42000000\end{array}$ & $\begin{array}{l}40.000000 \\
9.0000000 \\
70.000000 \\
-.80000000 \\
.40000000\end{array}$ \\
\hline $\begin{array}{l}10.000000 \\
.13563949 \\
1.9525860 \\
1.0760000+03 \\
7.7772000+04\end{array}$ & $\begin{array}{l}10.000000 \\
.13563950 \\
1.9525860 \\
1.0760000+03 \\
7.7772000+04\end{array}$ & $\begin{array}{c}10.000000 \\
.13564000 \\
1.9525900 \\
* 1.0760000+03 \\
* 7.7772000+04\end{array}$ & $\begin{array}{c}10.000000 \\
.13564000 \\
1.9526000 \\
* 1.0760000+03 \\
* 7.7772000+04\end{array}$ & $\begin{array}{c}10.000000 \\
.13560000 \\
1.9530000 \\
* 1.0760000+03 \\
* 7.7770000+04\end{array}$ & $\begin{array}{c}10.000000 \\
.13600000 \\
1.9500000 \\
* 1.0800000+03 \\
* 7.7800000+04\end{array}$ & $\begin{array}{l}10.000000 \\
.14000000 \\
2.0000000 \\
1.1000000+03 \\
* 7.8000000+04\end{array}$ & $\begin{array}{l}10.000000 \\
.10000000 \\
2.0000000 \\
* 1.0000000+03 \\
* 8.0000000+04\end{array}$ \\
\hline
\end{tabular}

NUMBER OF SIGNIFICANT DIGITS PER COLUMN.

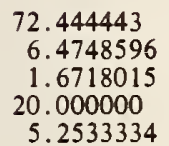

41.923807

9.0262909

68.147674

$-.82094830$

42543463

10.000000

.13563949

1.9525860

41.923810

9.0262910

68.147670

10.000000

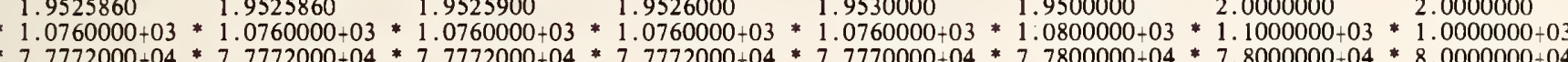

6

5

4

3

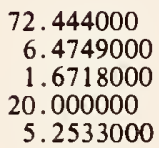

72.440000

6.4750000

1.6720000

6.4748600

20.000000

5. 2533300

$-.82094830$

41.923800

9.0262901

68.147700

$-.82094800$

.42543500

.13563950

10.000000

.13563900

1. 9525900

41.924000

9.0263000

68.148000

$-.82095000$

.42543000

20.000000
5.2530000

41.920000

9.0260000

68.150000

$-.82090000$

.42540000

10.000000

.13564000

10.000000

.13560000

1.9526000

1. 9530000
72.400000

6.4700000

1.6700000

20.000000

5. 2500000

41.900000

9.0300000

68.100000

$-.82100000$

.42500000

10.000000
.13600000
1.9500000
72.000000
6.5000000
1.7000000
20.000000
5.3000000

42.000000

9.0000000

68.000000

$-.82000000$

.43000000

10.000000
.14000000
2.0000000
70.000000

6.0000000

2.0000000

20.000000

5.0000000

40.000000

9.0000000

70.000000

.40000000

10.000000

10000000
$-.80000000$

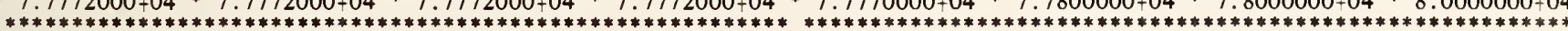

THE FOLLOWING VALUES SHOULD BE EQUAL TO OR NEAR ZERO.

THEY ARE NOT EXACTLY ZERO DUE TO USING THO DIFFERENT METHODS OF ROUNDING.

0 .

$0 . * 6.6682696-08 * 6.6657861-07 *-6.6667795-06$

.0073332945

$-.0073333348$

0 . 
LIST OF DATA, INSTRLCTIONS AND DIAGNOSTICS

SET IN COLLMY 21 DATA

7.2444443-01 6.4748596-00 $1.6718015 \div 00$

$\begin{array}{lcccc}2.0000000-01 & 5.2533334-00 & 4.1923807-01 & 9.0262909-00 & 6.8147674-01 \\ -8.2094830-01 & 4.2543463-01 & 1.0000000-01 & & \\ 1.3563949-01 & 1.9525860-00 & 1.0760000-03 & 7.7772000-04 & \end{array}$

* INFORMATIVE DIAGNOSTIC FOR THE ABOVE INSTRUCTION NRMAX HAS BEEN RESET FROM O TO 15.

DEFINE COLLMN 21 INTO COLLMN 1

SUBTRACT COLUMA 21 FROM 1 PLT IN COL 41

5/ ROLND 21 TO 7 SIGNIFICANT DIGITS AND STORE IN COL 22

6/ INCREMENT INSTRLCTION 5 BY $1,-1$ ALD 1

7/ROLXD COL 1 TO 7 SIG. DIGITS STORE IN COL 2

8/INCREMENT INSTRLCTION 7 BY $0,-1$ AND 1

9/SUBTRACT COL 2 FROM COL 22 STORE IY COL 32

10/INCREMENT INSTRUCTION 9 BY 1,1 AND 1

11/AVERAGE COL 32 STORE IN COL 42

12/INCREMENT INSTRLCTION 11 BY 1 AND 1

PERFORY INSTRLCTIONS 5 THRU 12,7 TIMES

TITLE1 NUMBER OF SIGNIFICAIT DIGITS PER COLLYN.

$\begin{array}{lllll}\text { TITLE3 } & 8 & 7 & 6 & 5 \\ \text { TITLE } & 4 & 3 & 2 & 1\end{array}$

PRIIT $21^{* * *} 28$

SPACE 2

NOTE NUMBER OF SIGNIFICANT DIGITS PER COLLMN.

$\begin{array}{lllll}\text { NOTE1 } & 8 & 7 & 6 & 5 \\ \text { VOTE } 2 & 4 & 3 & 2 & 1\end{array}$

YOTE

SPACE 2

PRINT NOTE

SPACE 2

NPRINT $1 * * * 8$

YTE1 $* * * * * * * * * * * * * * * * * * * * * * * * * * * * * * * * * * * * * * * * * * * * * * * * * * * * * * * * * * * * * * * * * * * * * * * * *)$

IOTE2 $* * * * * * * * * * * * * * * * * * * * * * * * * * * * * * * * * * * * * * * * * * * * * * * * * * * * * * * * * * * * * * * * * * * * * * * * * *)$

PRINT NOTE

SPACE

NOTE THE FOLLORING VALLES SHOULD BE EQUAL TO OR NEAR ZERO.

NOTE THEY ARE NOT EXACTLY ZERO DUE TO LSING THO DIFFERENT METHODS OF ROUNDING. SPACE

ABRIDGE ROH 1 COL $41^{* * * 48}$

SPACE

PRINT NOTE

MATIONAL BLREAU OF STANDARDS. HASHINGTON, D. C. 20234 OMNITAB 80 VERSION 6.00 MARCH 2,1981 
OMNITAB 80 TEST 14 SUM, PARPRODUCT, PARSUM AND RMS (ROOT MEAN SQUARE). (4.7) PAGE 1 RESULTS OF AVERAGE, SUM, PARPRODUCT, PARSUM AND RMS COMMANDS

COLUMN 1 WAS DEFINED BY READ COMMAND.

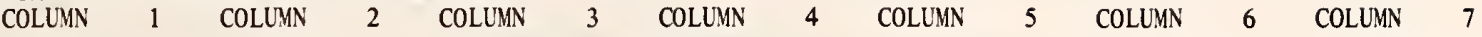

$\begin{array}{lrrrrrr}1.0000000 & 3.0000000 & 18.000000 & 17.000000 & 1.0000000 & 1.0000000 & 3.8297084 \\ 2.0000000 & 3.0000000 & 18.000000 & 17.000000 & 2.0000000 & 3.0000000 & 3.8297084 \\ 3.0000000 & 3.0000000 & 18.000000 & 17.000000 & 6.0000000 & 6.0000000 & 3.8297084 \\ 5.0000000 & 3.0000000 & 18.000000 & 17.000000 & 30.000000 & 11.000000 & 3.8297084 \\ 7.0000000 & 3.0000000 & 18.000000 & 17.000000 & 210.00000 & 18.000000 & 3.8297084 \\ 0 . & 3.0000000 & 18.000000 & 17.000000 & 0 . & 18.000000 & 3.8297084\end{array}$

COLUMN 2 CONTAINS AVERAGE OF COLUMN 1.

COLUMN 3 CONTAINS SUM OF COLUMN 1.

COLUMN 4 CONTAINS SUM OF ROWS 2 THRU 5 OF COLUMN 1.

COLUMN 5 CONTAINS PARTIAL PRODUCTS OF COLUMN 1

COLUMN 6 CONTAINS PARTIAL SUMS OF COLUMN 1.

COL 7 CONTAINS THE ROOT MEAN SQUARE OF THE VALUES IN COL 1.

THE FOLLOHING VALUES SHOLLD BE CLOSE TO OR EQUAL TO ZERO.
0.
0 .
0.
0 . 
LIST OF DATA, INSTRLCTIONS AND DIAGNOSTICS

READ THE FOLLOHING NIMBERS INTO COLLMN 1

1.0
2.0
3.0
5.0
7.0
0.0

* informatile diagNostic for the above instrlction IRMAX HAS BEEN RESET FROM O TO 6.

AIERAGE COLLYN 1 AND STORE RESLIT IN COLLMN 2

SLY COLLYN 1 AND STORE RESLIT II COLUMN 3

SLY COLLYN 1 RONS 2, 3, 4 AND 5 STORE RESLIT IN COLLYN 4

PARPRODLCT OF COLLMN 1 AND STORE RESLLT IN COLLMN 5

PARSLY OF COLLMA 1 AND STORE RESLLT IN COLLMN 6

RYS OF COLLYN 1 AND STORE RESLLT IN COLLYN 7

SOUARE COLLYM 1 AND STORE RESLLTS IN COLINN 11

SLM COLLMN 11 AND STORE RESULT IN COLUMN 12

DIVIDE COLLMN 12 BY 6.0 STORE IN COLUMN 12

SQRT OF COLLYN 12 STORE IN COLLMN 13

SLB COLLMN 7 FROM COLLMN 13 STORE IN COLLYN 8

TITLE1RESLLTS OF AIERAGE, SLY, PARPRODUCT, PARSLY AND RMS COMMANDS

TITLE3COLLYN 1 HAS DEFINED BY READ COMMAND.

PRINT COLLMSS 12234456 AND 7

SPACE 2

NOTE COLLMN 2 CONTAINS AVERAGE OF COLUMN 1.

NOTE COLLMN 3 CONTAIIS SLM OF COLLIN 1 .

TOTE COLLMN 4 CONTAINS SLY OF ROHS 2 THRU 5 OF COLLYN 1.

YOTE COLLYN 5 CONTAINS PARTIAL PRODLCTS OF COLUMN 1.

NOTE COLLMN 6 CONTAINS PARTIAL SLMS OF COLUMN 1 .

YOTE COL 7 CONTAINS THE ROOT MEAN SOLARE OF THE VALLES IN COL 1.

SLB *6, 3* FROM *6,6* STORE IN COLIMN 9

SLB 3.0 FROM COLLMN 2 AND STORE IN COLLMN 10

SPACE 2

NOTE***

SPACE

NOTE THE FOLLOHING VALLES SHOLLD BE CLOSE TO OR EQUAL TO ZERO.

SPACE

ABRIDGE ROH 6 OF COLLMAS 8910 AND 5

SPACE

NOTE

NATIONAL BLREAU OF STAIDARDS. HASHINGTON, D. C. 20234

OMNITAB 80 VERSION 6.00 MARCH 2,1981 
OMNITAB 80 TEST 15 PERCENTAGES, PROPORTIONS AND DAYS INSTRUCTIONS. (4.7)

\begin{tabular}{cccc} 
COLUMN & 8 & COLUMN 2 & \multicolumn{1}{l}{ COLUMN 3} \\
8.0000000 & 20.512820 & .20512820 \\
11.000000 & 28.205128 & .28205128 \\
14.000000 & 35.897435 & .35897436 \\
5.0000000 & 12.820513 & .12820513 \\
1.0000000 & 2.5641025 & .025641026
\end{tabular}

THE FOLLOHING VALUE MUST BE EQUAL TO OR NEAR ZERO.

0 .

THE TOTAL NUMBER OF DAYS BETWEEN 7/4/1776 AND 7/4/1976 IS

73049 
LIST OF DATA, INSTRUCTIONS AND DIAGNOSTICS

SET IN COL 8 THE FOLLOWING NUMBERS

$8,11,14,5$, AND 1

* INFORMATIVE diagnOSTIC FOR THE ABOVE INSTRUCTION NRMAX HAS BEEN RESET FROM O TO 5.

PERCENTAGES OF COL 8 PUT IN COL 2

PROPORTIONS OF COL 8 PUT IN COL 3

PRINT COLS 8,2 AND 3

MULTIPLY COL 3 BY 100. AND -1. ADD COL 2 PUT IN COL 3

SPACE 3

NOTE

NOTE THE FOLLORING VALUE MUST BE EQUAL TO OR NEAR ZERO.

SPACE

ABRIDGE ROW 1 OF COL 3

SPACE

NOTE $* * * * * * * * * * * * * * * * * * * * * * * * * * * * * * * * * * * * * * * * * * 1)$

READ INTO COL 11,12 AND 13 DATE OF INDEPENDENCE

$7 / 4 / 1776$

* INFORMATIVE DIAGNOSTIC FOR THE ABOVE INSTRUCTION NRMAX HAS BEEN RESET FROM 5 TO 1.

DAYS OF COLS 11,12 AND 13 PUT - IN COL 14

READ INTO COLS 21,22 AND 23 BICENTENNIAL DATE

$7 / 4 / 1976$

DAYS OF COLS 21, 22 AND 23 PUT IN COL 24

SUBTRACT COL 14 FROM COL 24 MULT BY 1. ADD 1. PUT IN COL 25

SPACE 3

NOTE ***

SPACE

NOTE THE TOTAL NUMBER OF DAYS BETHEEN 7/4/1776 AND 7/4/1976 IS

SPACE

FIXED 0

ABRIDGE ROW 1 OF COL 25

SPACE

NOTE

NATIONAL BLREAU OF STANDARDS. HASHINGTON, D. C. 20234 OMNITAB 80 VERSION 6.00 MARCH 2,1981 
OMNITAB 80 TEST 16 EXPAND AND SHORTEN INSTRUCTIONS. (4.7) AND (5.3)

PAGE 1

THE FOLLOHING IS AN EXAMPLE OF SHORTEN AND EXPAND COMMANDS. COLUMN 1 WAS DEFINED BY THE EXPAND COMMAND. COLUMNS 5 AND 6 "IERE DEFINED BY THE SHORTEN COMMAND.

\begin{tabular}{|c|c|c|c|}
\hline UMN & COLUMN & COLUMN & COLUMN \\
\hline $\begin{array}{l}1.0000000 \\
2.0000000 \\
3.0000000 \\
4.0000000 \\
5.0000000\end{array}$ & $\begin{array}{c}1.0000000 \\
4.0000000 \\
9.0000000 \\
16.000000 \\
25.000000\end{array}$ & $\begin{array}{l}1.0000000 \\
16.000000 \\
81.000000 \\
* 2.5600000+02 \\
* 6.2500000+02\end{array}$ & 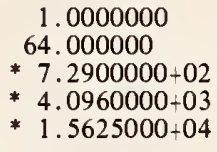 \\
\hline $\begin{array}{r}6.0000000 \\
7.0000000 \\
8.0000000 \\
9.0000000 \\
10.000000\end{array}$ & $\begin{array}{c}36.000000 \\
49.000000 \\
64.000000 \\
81.000000 \\
100.00000\end{array}$ & $\begin{array}{l}* 1.2960000+03 \\
* 2.4010000+03 \\
* 4.0960000+03 \\
* 6.5610000+03 \\
* 1.0000000+04\end{array}$ & $\begin{array}{l}* 4.6656000+0 \\
* 1.1764900+0 \\
* 2.6214400+0 \\
* 5.3144100+0 \\
* 1.0000000+0\end{array}$ \\
\hline
\end{tabular}

$$
\text { COLUMN } 6 \text { COLUMN } 7
$$

$\begin{array}{cc}1.0000000 & 1.0000000 \\ 2.0000000 & 4.0000000 \\ 3.0000000 & 9.0000000 \\ 4.0000000 & 16.000000 \\ 5.0000000 & 25.000000 \\ & \\ 6.0000000 & 36.000000 \\ 7.0000000 & 49.000000\end{array}$

THE FOLLOWING VALUES MUST BE EQUAL TO OR NEAR ZERO.
0.
0.
0 .
0.
0. 
LIST OF DATA, INSTRUCTIONS AND DIAGNOSTICS

GENERATE BEGIS: HITH 1. IN STEPS OF 1. THRU 10. STORE IN COLLMN 1

* informatile diagNostic fOR the abOlE instrcction SRMAX HAS BEEY RESET FROM O TO 10.

EXPAND VALLES IN COL 1 TO 6TH PORER IN INTERVALS OF 2 START STORING IN COLLMN 2 SHORTEY COLLMN 1 FOR COLLM 2 EQLAL TO 49. PLT SHORTEYED COLLYNS II 6 AND 7

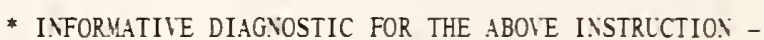
SRMAX HAS BEEY RESET FROM 10 TO 7.

RESET IRMAX TO 10

* INFORMATIVE DIAGYOSTIC FOR THE ABOIE INSTRLCTION IRMAX HAS BEEY RESET FROM 7 TO 10.

TITLE1THE FOLLOWING IS AN EXAYPLE OF SHORTEX AND EXPAND COMMANDS. TITLE2 COLLYN 1 HAS DEFINED BY THE EXPAND COMMAND. COLLYNS 5 AND 6 TITLE 3 HERE DEFISED BY THE SHORTEY CONMA.ND.

PRIIT COLLMNS 12234567

SQRT OF COLLMN 2 AND STORE IN COLLM 5

SUBTRACT COLLYN 5 FROM COLLM 1 AND STORE IN COLLMN 11

MULTIPLY COL 2 BY COL 2 MLLT BY -1.0 ADD TO COL 3 STORE IX゙ COL 12

MULTIPLY COL 2 BY COL 3 MULT BY -1.0 ADD TO COL 4 STORE IN COL 13

SLM COLLM 1 AND STORE IN COLLYN 1

SLY COLLYN 6 AND STORE IN COLLYN 6

SLBTRACT COLLMN 6 FROM COLLMN 1 AND STORE IN COLLMN 14

SLB THE VALLE 27.0 FROM COLLYN 14 AND STORE IN COLLYN 14

SLY COLLM 2 AND STORE IN COLLMN 2

SLM COLLM 7 AND STORE IN COLLMA 7

SLBTRACT COLLYN 7 FROM COLLMN 2 AND STORE IX COLLMN 15

SLB THE VALLE 245.0 FROM COLLYN 15 AND STORE IN COLLMY 15

SPACE 2

NOTE ****

SPACE

NOTE THE FOLLOHING VALLES MCST BE EQLAL TO OR NEAR ZERO.

SPACE

ABRIDGE ROH 1 OF COLCMNS 11, 12, 13, 14 AND 15,

SPACE

YOTE

NATIONAL BLREAU OF STANDARDS. HASHINGTON, D. C. 20234 OMNITAB 80 IERSION 6.00 MARCH 2,1981 
OMNITAB 80 TEST 17 COMPLEX ARITHMETIC INSTRUCTIONS. (4.8) \begin{tabular}{crrrrrrr} 
REAL & & X & IMAGINARY & \multicolumn{2}{c}{ REAL } & \multicolumn{2}{c}{ IMAGINARY } \\
COLLMN & 51 & COLUMN & 52 & COLUMN & 61 & COLUMN & 62
\end{tabular}

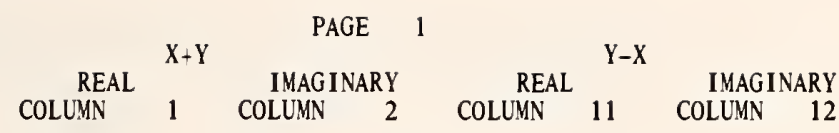

$\begin{array}{llll}0 . & 0 . & 0 . & 0 . \\ 0 . & 1.0000000 & 0 . & 1.0000000 \\ 0 . & 1.0000000 & 1.0000000 & 0 . \\ 1.0000000 & 0 . & 1.0000000 & 1.0000000 \\ 1.0000000 & 0 . & 1.0000000 & 0 . \\ & & & \\ 1.0000000 & 1.0000000 & 1.0000000 & 1.0000000 \\ 1.0000000 & 1.0000000 & 0 . & 0 . \\ 0 . & 0 . & 3.0000000 & 0 . \\ 0 . & 0.0000000 & 1.0000000 & 1.0000000 \\ 3.0000000 & 1.00000000 & -1.0000000 \\ 1.0000000 & 1.0000000 & -2.0000000 & -1.0000000 \\ 1.0000000 & -1.0000000 & 1.0000000 & -1.0000000 \\ 10.000000 & 2.0000000 & 10.000000 & 1.0000000 \\ 10.000000 & 1.0000000 & -1.2345678 & 10.000000 \\ 1.2345678 & 10.000000 & 0 . & 10.000000 \\ 0 . & & & \\ 0 & -1.2345678 & 0 . & -1.2345678\end{array}$

$0 . \quad 0$.

0 .

0.2 .0000000

1.0000000

1.0000000

2.0000000

0 .

0.

2. 0000000

1.0000000

0 .

$-1.0000000$

2.0000000

2.0000000

1.0000000

3.0000000

1.0000000

1.0000000

0 .

1.0000000

4.0000000

0 .

$-1.0000000$

2.0000000

20.000000

8.7654322

0.

$-2.0000000$

3. 0000000

11.000000

1.2345678

20.000000

0 .

$-2.4691356$

0.

$-1.0000000$

3.0000000

1.0000000

$-2.0000000$

1.0000000

$-1.2345678$

0 .

$-3.0000000$

0 .

0

$-11.234568$

$-1.2345678$

0.

$-1.0000000$

1.0000000 $-2.0000000$

2.0000000

0 .

$-1.0000000$

9. 0000000

0 .

0 .

THE FOLLONING VALUES MUST BE EQUAL TO OR NEAR ZERO. 


\begin{tabular}{|c|c|c|c|c|c|}
\hline NITAB 80 TES & COMPLEX AR & $\begin{array}{l}\text { UETIC INSTRU } \\
X^{*}(3 .\end{array}$ & $\begin{array}{l}\text { IONS. (4.8) } \\
1.0 I)\end{array}$ & $X *(3.5-1$. & $\begin{array}{c}\text { PAGE } \\
) /(3.5-1.0 \mathrm{I})\end{array}$ \\
\hline REAL & IMAGINARY & REAL & IUAGINARY & REAL & IMAGINARY \\
\hline COLLYN 51 & COLUMN $\quad 52$ & COLUMN 21 & COLUMN 22 & COLLMN & COLLYN $\quad 32$ \\
\hline $\begin{array}{l}0 . \\
0 . \\
0 . \\
1.0000000 \\
1.0000000\end{array}$ & $\begin{array}{l}0 . \\
1.0000000 \\
1.0000000 \\
0 . \\
0 .\end{array}$ & $\begin{array}{r}1 . \\
-1.0000000 \\
-1.0000000 \\
3.5000000 \\
3.5000000\end{array}$ & $\begin{array}{l}0 . \\
3.5000000 \\
3.5000000 \\
1.0000000 \\
1.0000000\end{array}$ & $\begin{array}{l}0 . \\
0 . \\
0 . \\
1.0000000 \\
1.0000000\end{array}$ & $\begin{array}{l}0 . \\
1.0000000 \\
1.0000000 \\
0 . \\
0 .\end{array}$ \\
\hline $\begin{array}{l}1.0000000 \\
1.0000000 \\
0 . \\
0 . \\
3.0000000\end{array}$ & $\begin{array}{l}1.0000000 \\
1.0000000 \\
0 . \\
0 . \\
1.0000000\end{array}$ & $\begin{array}{l}2.5000000 \\
2.5000000 \\
0 . \\
0 . \\
9.5000000\end{array}$ & $\begin{array}{l}4.5000000 \\
4.5000000 \\
0 . \\
0 . \\
6.5000000\end{array}$ & $\begin{array}{l}1.0000000 \\
1.0000000 \\
0 . \\
0 . \\
3.0000000\end{array}$ & $\begin{array}{l}1.0000000 \\
1.0000000 \\
0 . \\
0 . \\
1.0000000\end{array}$ \\
\hline $\begin{array}{c}1.0000000 \\
1.0000000 \\
10.000000 \\
10.000000 \\
1.2345678\end{array}$ & $\begin{array}{r}1.0000000 \\
-1.0000000 \\
2.0000000 \\
1.0000000 \\
10.000000\end{array}$ & $\begin{array}{l}2.5000000 \\
4.5000000 \\
33.000000 \\
34.000000 \\
-5.6790127\end{array}$ & $\begin{array}{l}4.5000000 \\
-2.5000000 \\
17.000000 \\
13.500000 \\
36.234568\end{array}$ & $\begin{array}{c}1.0000000 \\
1.0000000 \\
10.000000 \\
10.000000 \\
1.2345678\end{array}$ & $\begin{array}{r}1.0000000 \\
-1.0000000 \\
2.0000000 \\
1.0000000 \\
10.000000\end{array}$ \\
\hline 0 . & -1.2345678 & 1.2345678 & -4.3209873 & $*-1.1246159-09$ & -1.2345678 \\
\hline
\end{tabular}

THE FOLLOHING VALUES MUST BE EQUAL TO OR NEAR ZERO.

* 7.0288496-11

0 . 


\begin{tabular}{|c|c|c|c|c|c|}
\hline OMNITAB 80 TEST & COMPLEX A & $\begin{array}{l}\text { AMETIC INSTRU } \\
\text { POLAR COORI }\end{array}$ & $\begin{array}{l}\text { IONS } \quad(4.8) \\
\text { NATES }(X)\end{array}$ & CHANGE BACK TO & $\begin{array}{l}\text { PAGE } \\
\text { RECTANGULAR CC }\end{array}$ \\
\hline REAL & IMAGINARY & THETA(ANGLE) & RHO(RADIUS) & REAL & IMAG I NARY \\
\hline COLUMN $\quad 51$ & COLUMN $\quad 52$ & COLUMN 53 & COLUMN $\quad 54$ & COLUMN $\quad 55$ & COLUMN $\quad 56$ \\
\hline $\begin{array}{l}0 . \\
0 . \\
0 . \\
1.0000000 \\
1.0000000\end{array}$ & $\begin{array}{l}0 . \\
1.0000000 \\
1.0000000 \\
0 . \\
0 .\end{array}$ & $\begin{array}{l}0 . \\
1.0000000 \\
1.0000000 \\
1.0000000 \\
1.0000000\end{array}$ & $\begin{array}{l}0 . \\
1.5707963 \\
1.5707963 \\
0 . \\
0 .\end{array}$ & $\begin{array}{ll} & 0 . \\
* & 3.0794416-08 \\
& 3.0794416-08 \\
& 1.0000000 \\
& 1.0000000\end{array}$ & $\begin{array}{l}0 . \\
1.0000000 \\
1.0000000 \\
0 . \\
0 .\end{array}$ \\
\hline $\begin{array}{l}1.0000000 \\
1.0000000 \\
0 . \\
0 . \\
3.0000000\end{array}$ & $\begin{array}{l}1.0000000 \\
1.0000000 \\
0 . \\
0 . \\
1.0000000\end{array}$ & $\begin{array}{l}1.4142136 \\
1.4142136 \\
0 . \\
0 . \\
3.1622777\end{array}$ & $\begin{array}{l}.78539816 \\
.78539816 \\
0 . \\
0 . \\
.32175056\end{array}$ & $\begin{array}{l}1.0000000 \\
1.0000000 \\
0 . \\
0 . \\
3.0000000\end{array}$ & $\begin{array}{l}1.0000000 \\
1.0000000 \\
0 . \\
0 . \\
1.0000000\end{array}$ \\
\hline $\begin{array}{c}1.0000000 \\
1.0000000 \\
10.000000 \\
10.000000 \\
1.2345678\end{array}$ & $\begin{array}{r}1.0000000 \\
-1.0000000 \\
2.0000000 \\
1.0000000 \\
10.000000\end{array}$ & $\begin{array}{l}1.4142136 \\
1.4142136 \\
10.198039 \\
10.049876 \\
10.075920\end{array}$ & $\begin{array}{c}.78539816 \\
-.78539816 \\
.19739556 \\
.099668653 \\
1.4479611\end{array}$ & $\begin{array}{c}1.0000000 \\
1.0000000 \\
10.000000 \\
10.000000 \\
1.2345679\end{array}$ & $\begin{array}{r}1.0000000 \\
-1.0000000 \\
2.0000000 \\
1.0000000 \\
10.000000\end{array}$ \\
\hline 0 . & -1.2345678 & 1.2345678 & -1.5707963 & * $3.8017794-08$ & -1.2345678 \\
\hline
\end{tabular}

THE FOLLOWING VALUES MUST BE EQUAL TO OR NEAR ZERO.

*-1.0882027-08

0 . 
LIST OF DATA, INSTRLCTIONS AND DIAGNOSTICS

SET REAL PART OF X IN COLUMN 51

0.0 . 0.1.1.1.1.0.0.3.1. 1. 10. 10. 1.2345678

* INFORMATIVE DIAGNOSTIC FOR THE ABOVE INSTRLCTION NRMAX HAS BEEN RESET FROM 0 TO 15.

SET IMAGINARY PART OF X IN COLLMN 52

0.1 . 1.0.0.1. 1. 0.0. 1. 1. -1. 2. 1. 10. -1.2345678

* INFORMATIVE diagNOSTIC FOR THE ABOVE INSTRLCTION NRMAX HAS BEEN RESET FROM 15 TO 16.

SET REAL PART OF Y IN COLLYN 61

0. 0. 1. 1. 1. 1. 0.3. 1. 1. -2 . 1. 10. -1.2345678

* INFORMative diagNoSTIC FOR the abOVE INSTRLCTION NRMAX HAS BEEN RESET FROM 16 TO 14.

SET IMAGINARY PART OF Y IN COLLMN 62

0. 1. 0. 1. 0. 1. 0. 0. 1. $-1 .-1 .-1$. 1. 10. 10. -1.2345678

* informative diagNostic for the above instrlction NRMAX HAS BEEN RESET FROM 14 TO 16.

CADD $X$ IN COLS 51, 52 TO Y IN COLS 61, 62 PUT IN COLUMAS 1,2 CSUBTRACT X IN COLS 51, 52 FROM Y IN COLS 61,62 PUT IN COLS 11,12

TITLE1

TITLE2

TITLE3

$\begin{array}{lccc}\text { TITLE4 } & \text { REAL } & \text { IMAGINARY } & \text { REA } \\ \text { PRINT COLS } 51,52 & 61,62 & 1,2 & 11,12\end{array}$

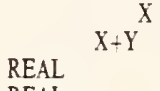

$\mathrm{X}+\mathrm{Y}$ X'

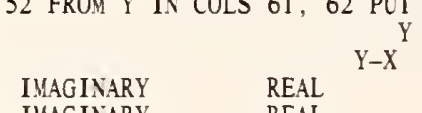

Y

CADD COLS 1, 2 TO COLS 11, 12 PUT IN COLS 41,42

CSUBTRACT COLS 11,12 FROM COLS 1,2 PUT IN COLS 43,44

CDIVIDE COLS 41,42 BY $(2.0,0.0)$ PUT IN COLS 45,46

CDIVIDE COLS 43,44 BY $(2.0,0.0)$ PUT IN COLS 47,48

SUBTRACT COL 45 FROM COL 61 STORE IN COL 31

SLBTRACT COL 46 FROM 62 STORE IN COL 32

SUBTRACT COL 47 FROM COL 51 AND PUT IN COL 33

SUBTRACT COL 48 FROM COL 52 AND PUT IN COL 34

AVERAGE COL 31 PUT RESULT IN COL 35

AVERAGE COL 32 PUT RESULT IN COL 36

AVERAGE COL 33 PUT RESULT IN COL 37

AVERAGE COL 34 PUT RESULT IN COL 38

SPACE 2

NOTE * *

SPACE

NOTE THE FOLLORING VALLES YUST BE EQUAL TO OR NEAR ZERO.

SPACE

ABRIDGE ROH 1 OF COLS $35 * * * 38$

SPACE 


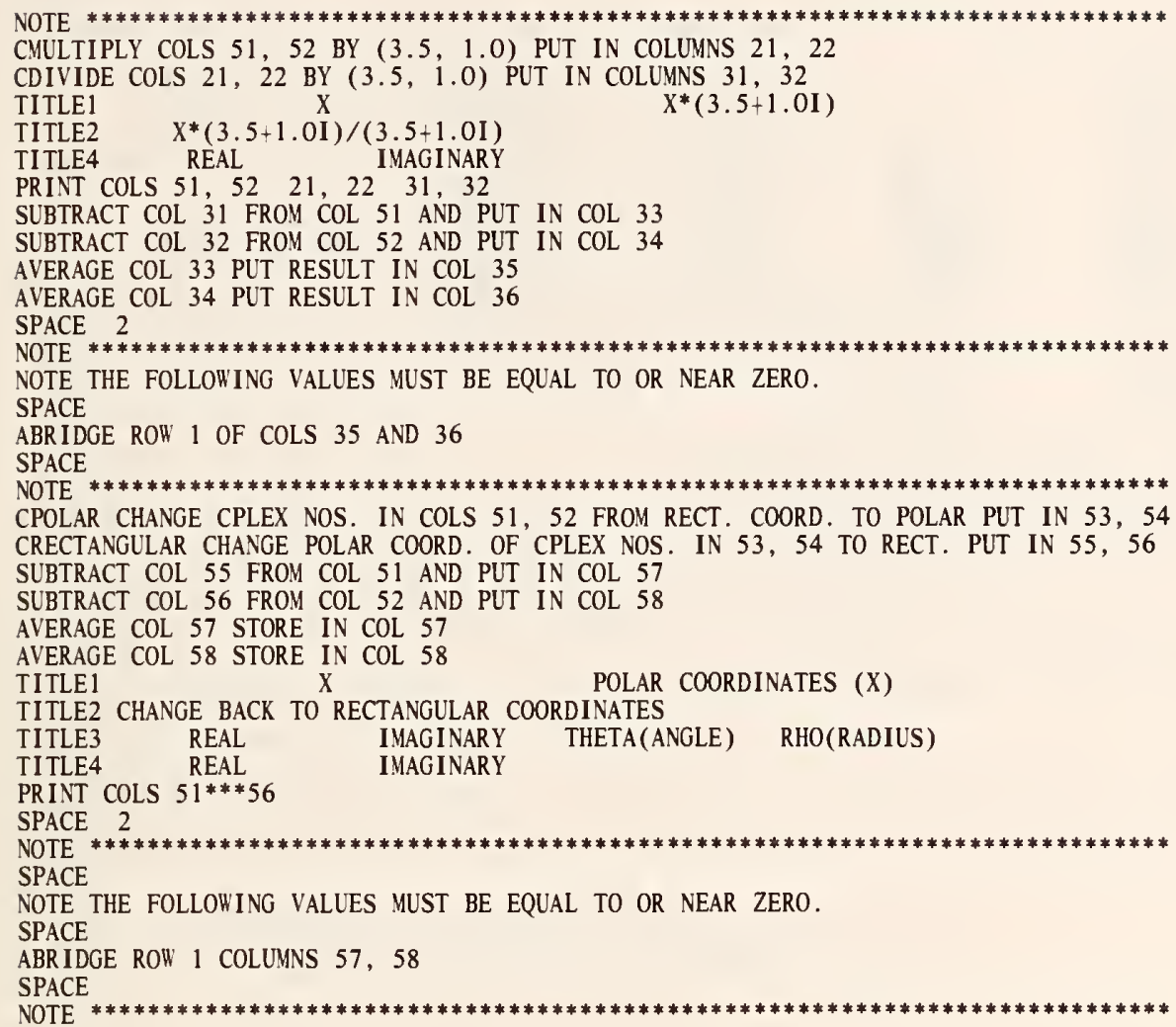

NATIONAL BUREAU OF STANDARDS. WASHINGTON, D. C. 20234 OMNITAB 80 VERSION $6.00 \quad$ MARCH 2,1981 
OMNITAB 80 TEST 18 DEMOTE AND PROMOTE INSTRUCTIONS. (5.2)

PAGE 1

THE FOLLOWING IS AN EXAMPLE OF PROMOTE AND DEMOTE.

COLUMN 1 WAS DEFINED BY THE GENERATE COMMAND. COLUMNS 2, 3, 4 AND 5 WERE DEFINED BY THE PROMOTE AND DEMOTE COMMANDS. COLUMN

COLUMN

2 COLUMN

3 COLUMN COLUMN $\quad 5$

1.0000000

0 .

2.0000000

3.0000000

$1.000+2.000$

4.0000000

1.0000000

0 .

2.0000000

0 .

0.

3.0000000

1.0000000

1.0000000

2.0000000

0 .

5.0000000

4.0000000

5.0000000

7.0000000

6.0000000

2.0000000

3.0000000

0.

4.0000000

1.0000000

2.0000000

3.0000000

5.0000000

3.0000000

9.0000000

7.0000000

4.0000000

6.0000000

4.0000000

7.0000000

5.0000000

5.0000000

8.0000000

6.0000000

10.000000

8.0000000

6. 0000000

10.000000

8.0000000

0 .

0.

9.0000000

10.000000

7.0000000

0 .

0.

0 .

0 .

COLUMN 1 WAS MOVED DOWN BY 2 ROW'S AND STORED IN COLUMN 2.

COLUMN 2 WAS MOVED DOWN BY 2 ROW'S AND STORED IN COLUMN 3

COLUMN 2 WAS MOVED UP BY 2 ROHS AND STORED IN COLUMN 4.

COLUMN 3 WAS MOVED UP BY 2 ROHS AND STORED IN COLUMN 5.

ROW 11 OF COL 9 CONTAINS SUM OF TERMS OF THE 8X2 ARRAY IN ROW 1 COL 6

THE FOLLOWING VALUE SHOULD BE CLOSE TO OR EQUAL TO ZERO.

0 . 
LIST OF DATA, INSTRUCTIONS AND DIAGNOSTICS

GENERATE STARTING WITH 1 IN STEPS OF 1 UP THRU 10 AND STORE VALUES IN COLUMN 1

* INFORMATIVE DIAGNOSTIC FOR THE ABOVE INSTRUCTION NRMAX HAS BEEN RESET FROM O TO 10.

DEMOTE BY 2 ROWS COLUMN 1 INTO COLUMN 2, COLUMN 2 INTO COLUMN 3

* INFORMATIVE DIAGNOSTIC FOR THE ABOVE INSTRUCTION NRMAX HAS BEEN RESET FROM 10 TO 12.

PROMOTE BY 2 ROWS COLUMN 2 INTO COLUMN 4, COLUMN 3 INTO COLUMN 5

TITLE1 THE FOLLOWING IS AN EXAMPLE OF PROMOTE AND DEMOTE.

TITLE3 COLUMN 1 WAS DEFINED BY THE GENERATE COMMAND. COLUMNS 2,3 ,

TITLE4 4 AND 5 WERE DEFINED BY THE PROMOTE AND DEMOTE COMMANDS

PRINT COLUMNS $1 * * * 5$

SPACE

NOTE COLUMN 1 WAS MOVED DOWN BY 2 ROWS AND STORED IN COLUMN 2.

NOTE COLUMN 2 WAS MOVED DOWN BY 2 ROWS AND STORED IN COLUMN 3.

NOTE COLUMN 2 WAS MOVED UP BY 2 ROWS AND STORED IN COLUMN 4.

NOTE COLUMN 3 WAS MOVED UP BY 2 ROWS AND STORED IN COLUMN 5.

ASUB ARRAY IN ROW 3 COL 2 SIZE 8 X 2 MINUS ROW 1 COL 4 SIZE $8 X 2$ PUT IN R=1, C=6

SAPROP OF ARRAY IN ROW 1 OF COL 6 SIZE 8 X2 STORE PROPERTIES IN COLUMN 9

NOTE ROW 11 OF COL 9 CONTAINS SUM OF TERMS OF THE 8X2 ARRAY IN ROW 1 COL 6

SPACE 2

NOTE *****

SPACE

NOTE THE FOLLOWING VALUE SHOULD BE CLOSE TO OR EQUAL TO ZERO.

SPACE

ABRIDGE ROW 11 OF COLUMN 9

SPACE

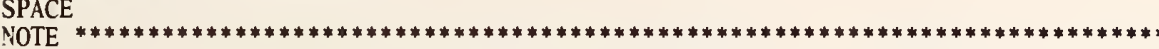

NATIONAL BUREAU OF STANDARDS. WASHINGTON, D. C. 20234

OMNITAB 80 VERSION $6.00 \quad$ MARCH 2,1981 
OMNITAB 80 TEST 19 EXCHANGE INSTRUCTION. (5.2) COLLMSS 1 THROUGH 8 RERE DEFINED BY THE READ COMMAND.

\begin{tabular}{|c|c|c|c|c|c|c|c|}
\hline COLEMA & COLLMN & COLUMN & COLLMN & COLLMN & COLLMN & COLUMN & COLUMN \\
\hline $\begin{array}{l}1.0000000 \\
9.0000000 \\
20.000000\end{array}$ & $\begin{array}{l}2.0000000 \\
10.000000 \\
30.000000\end{array}$ & $\begin{array}{l}3.0000000 \\
11.000000 \\
40.000000\end{array}$ & $\begin{array}{l}4.0000000 \\
12.000000 \\
50.000000\end{array}$ & $\begin{array}{l}5.0000000 \\
13.000000 \\
60.000000\end{array}$ & $\begin{array}{l}6.0000000 \\
14.000000 \\
70.000000\end{array}$ & $\begin{array}{l}7.0000000 \\
15.000000 \\
80.000000\end{array}$ & $\begin{array}{c}8.0000000 \\
.16000000 \\
90.000000\end{array}$ \\
\hline
\end{tabular}

THE FOLLORING YALUES RERE PRINTED BY THE COMMAND NPRINT.

COLLMN 1 WAS EXCHANGED FITH COLUMN 2, COLUMN 3 WITH COLLYN 4 AND COLLM 5 WITH COLLMN 6.
2.0000000
10.000000
1.0000000
9.0000000
4.0000000
3.0000000
12.000000
11.000000
6.0000000
5.0000000
14.000000
13.000000
7.0000000
15.000000
8.0000000
50.000000
40.000000
70.000000
60.000000
80.000000
.16000000 90.000000

THE FOLLORING VALLES SHOULD BE CLOSE TO OR EQUAL TO ZERO.

0 .

0 .

0 . 
LIST OF DATA, INSTRUCTIONS AND DIAGNOSTICS

READ THE FOLLONING VALUES INTO COLUMNS $1 * * * 8$

1. 2. 3. 4. 5. 6. 7. 8

9. 10. 11. 12, 13, 14, 15, .16

20. $30 \quad 40 \quad 50 \quad 60 \quad 70 \quad 80 \quad 90$

* INFORMATIVE DIAGNOSTIC FOR THE ABOVE INSTRUCTION -

NRMAX HAS BEEN RESET FROM O TO 3.

TITLE1 COLUMNS 1 THROUGH 8 WERE DEFINED BY THE READ COMMAND.

PRINT COLUMNS $1 * * * 8$

MOVE THE ARRAY STARTING IN ROW 1 OF COL 1 SIZE 3X1 PUT IN ROW 1 OF COL 9

MOVE THE ARRAY STARTING IN ROW 1 OF COL 3 SIZE 3X1 PUT IN ROW 1 OF COL 10

MOVE THE ARRAY STARTING IN ROW' 1 OF COL 5 SIZE 3X1 PUT IN ROW 1 OF COL 11

EXCHANGE COLUMN 1 WITH COLUMN 2, COLUMN 3 WITH COLUMN 4, COLUMN 5 WITH COLUMN 6 SPACE

NOTE THE FOLLONING VALUES WERE PRINTED BY THE COMMAND NPRINT.

NOTE COLUMN 1 WAS EXCHANGED WITH COLUMN 2, COLUMN 3 W!TH COLUMN 4 AND

NOTE COLUMN 5 WITH COLUMN 6.

SPACE

NPRINT COLUMNS 1 ***8 HITH NO HEADINGS

SUBTRACT COL 2 FROM COL 9 STORE IN COL 12

SUBTRACT COL 4 FROM COL 10 STORE IN COL 13

SUBTRACT COL 6 FROM COL 11 STORE IN COL 14

SPACE

NOTE

SPACE

NOTE THE FOLLOWING VALUES SHOULD BE CLOSE TO OR EQUAL TO ZERO.

SPACE

ABRIDGE ROH 1 OF COLUMNS $12 * * * 14$

SPACE

NOTE

NATIONAL BUREAU OF STANDARDS. WASHINGTON, D. C. 20234

OMNITAB 80 VERSION 6.00 MARCH 2,1981 
OMNITAB 80 TEST 20 MOVE, AMOVE AND MMOVE INSTRLCTIONS. (5.2), (10.2) AND (11.2) PAGE 1

COLLYNS 1 THROUGH 4 HAVE BEEN DEFINED BY READ COMMAND. THE VALLES OF ROHS 2 THROUGH 6 OF COLLMNS 2 THROUGH 4 HAVE BEEY

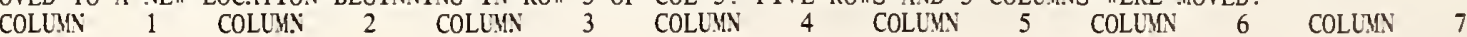

\begin{tabular}{|c|c|c|c|c|c|c|}
\hline $\begin{array}{l}1.0000000 \\
2.0000000 \\
3.0000000 \\
4.0000000 \\
5.0000000\end{array}$ & $\begin{array}{r}6.0000000 \\
7.0000000 \\
8.0000000 \\
9.0000000 \\
10.000000\end{array}$ & $\begin{array}{l}11.000000 \\
12.000000 \\
13.000000 \\
14.000000 \\
15.000000\end{array}$ & $\begin{array}{l}16.000000 \\
17.000000 \\
18.000000 \\
19.000000 \\
20.000000\end{array}$ & $\begin{array}{l}0 . \\
0 . \\
7.0000000 \\
8.0000000 \\
9.0000000\end{array}$ & $\begin{array}{l}0 . \\
0 . \\
12.000000 \\
13.000000 \\
14.000000\end{array}$ & $\begin{array}{l}0 . \\
0 . \\
17.000000 \\
18.000000 \\
19.000000\end{array}$ \\
\hline $\begin{array}{l}0 . \\
0 .\end{array}$ & $\begin{array}{l}0 . \\
0 .\end{array}$ & $\begin{array}{l}0 . \\
0 .\end{array}$ & $\begin{array}{l}0 . \\
0 .\end{array}$ & $\begin{array}{l}10.000000 \\
0 .\end{array}$ & $\begin{array}{l}15.000000 \\
0 .\end{array}$ & $\begin{array}{l}20.000000 \\
0 .\end{array}$ \\
\hline
\end{tabular}

THE FOLLOHING VALLE SHOULD BE CLOSE TO OR EQUAL TO ZERO.

0 .

ARRAYS A AND B HAVE BEEN FORMED BY AYOVE AND MMOVE COMMANDS.

THEIR ELEMENTS SHOULD ALL BE EQUAL.

ARRAY A

0.

12. 000000

13.000000

14.000000

15.000000

0.
0.

17.000000

18.000000

19.000000

20.000000

0 .

0 .
ARRAY B

0.

12. 000000

13.000000

14.000000

15.000000

0.

0.

0.

17.000000

18.000000

19.000000

20.000000

0.

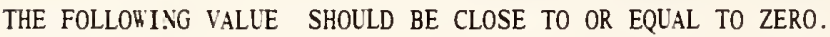

0 . 
OMNITAB 80 TEST 20 MOVE, AMOVE AND MMOVE INSTRUCTIONS. (5.2), (10.2) AND (11.2) PAGE 2

LIST OF DATA, INSTRUCTIONS AND DIAGNOSTICS

READ THE FOLLOWING VALUES INTO COLUMNS 1223 AND 4

$\begin{array}{rrrr}1 . & 6 . & 11 . & 16 . \\ 2 . & 7 . & 12 . & 17 . \\ 3 . & 8 . & 13 . & 18 . \\ 4 . & 9 . & 14 . & 19 . \\ \text { 5. } & 10 . & 15 . & 20 .\end{array}$

* INFORMATIVE DIAGNOSTIC FOR THE ABOVE INSTRUCTION NRMAX HAS BEEN RESET FROM O TO 5.

MOVE THE ARRAY BEGINNING IN ROW 2 OF COL 2 SIZE $5 X 3$ PUT IN ROW 3 OF COL 5 TITLE1 COLUMNS 1 THROUGH 4 HAVE BEEN DEFINED BY READ COMMAND. THE TITLE2VALUES OF ROH' 2 THROUGH 6 OF COLUMNS 2 THROUGH 4 HAVE BEEN TITLE3 MOVED TO A NEW LOCATION BEGINNING IN ROW 3 OF COL 5. FIVE R TITLE4OW'S AND 3 COLUMNS HERE MOVED.

RESET NRMAX TO 7

* INFORMATIVE diagNOSTIC FOR THE ABOVE INSTRUCTION NRMAX HAS BEEN RESET FROM 5 TO 7.

PRINT COLUMNS $1 * * * 7$

ASUB ARRAY IN ROW 2 COL 25 XX MINUS ARRAY IN ROW 3 COL $55 \times 3$ PUT IN ROW 2 COL 20 SMPROPERTIES OF MATRIX IN ROW 2 OF COL 20 SIZE 5X3 STORE PROPERTIES IN COL 30 SPACE 2

$\operatorname{NOTE} * * * * * * * * * * * * * * * * * * * * * * * * * * * * * * * * * * * * * * * * * * * * * * * * * * * * * * * * * * * * * * * * * *$

SPACE

NOTE THE FOLLOWING VALUE SHOULD BE CLOSE TO OR EQUAL TO ZERO.

SPACE

ABRIDGE ROW 11 OF COLUMN 30

SPACE

NOTE

AMOVE ARRAY IN ROW 3 OF COL 6 SIZE 4X2 STORE IN ROW 2 OF COLUMN 10

MMOVE MATRIX IN ROW 2 OF COL 3 SIZE 4X2 PUT IN ROW 2 OF COL 12

SPACE 2

NOTE ARRAYS A AND B HAVE BEEN FORMED BY AMOVE AND MMOVE COMMANDS.

NOTE THEIR ELEMENTS SHOULD ALL BE EQUAL.

SPACE

NOTE ARRAY A

ARRAY B

SPACE

NPRINT COLUMNS $10 * * * 13$

SUB COL 11 FROM COL 13 STORE IN COL 15

AVERAGE COL 15 STORE IN COL 15

SPACE 2

NOTE *

SPACE

NOTE THE FOLLOWING VALUE SHOULD BE CLOSE TO OR EQUAL TO ZERO.

SPACE

ABRIDGE ROW 1 OF COLUMN 15

SPACE

NOTE 
OMNITAB 80 TEST 20 MOVE, AMOVE AND MMOVE INSTRLCTIONS. (5.2), (10.2) AND (11.2) PAGE 3 LIST OF DATA, INSTRUCTIONS AND DIAGNOSTICS

NATIONAL BLREAU OF STANDARDS. WASHINGTON, D. C. 20234 OMNITAB 80 VERSION 6.00 MARCH 2,1981 
OMNITAB 80 TEST 21 CENSOR, SELECT AND SEARCH INSTRUCTIONS. (5.3) AND (5.5)

PAGE 1

THE FOLLOWING IS AN EXAMPLE OF THE CENSOR AND MATCH COMMANDS. COLUMN 1 WAS SET UP BY THE GENERATE COMMAND. COLUMNS 2 AND 3 WERE DEFINED BY THE CENSOR COMMAND. COLUMN 4 WAS DEFINED BY THE MATCH COMMAND.

COLUMN COLUMN COLUMN 3

$$
\text { COLUMN } 4
$$

$\begin{array}{rrrr}10.000000 & 1.0000000 & 10.000000 & 1.0000000 \\ 20.000000 & 1.0000000 & 20.000000 & 1.0000000 \\ 30.000000 & 1.0000000 & 30.000000 & 1.0000000 \\ 40.000000 & 1.0000000 & 40.000000 & 1.0000000 \\ 50.000000 & 1.0000000 & 50.000000 & 1.0000000 \\ & & & \\ 60.000000 & 60.000000 & 60.000000 & 1.0000000 \\ 70.000000 & 70.000000 & 70.000000 & 1.0000000 \\ 80.000000 & 80.000000 & 80.000000 & 1.0000000 \\ 90.000000 & 90.000000 & 90.000000 & 1.0000000 \\ 100.00000 & 100.00000 & 100.00000 & 1.0000000\end{array}$

COLUMNS 1 AND 3 SHOULD CONTAIN THE SAME VALUES.

THE VALUES IN COLUMN 4 SHOULD BE EQUAL TO ONE.

THE FOLLOWING VALUES MUST BE EQUAL TO OR NEAR ZERO.

0 .

0 . 
OMNITAB 80 TEST 21 CENSOR, SELECT AND SEARCH INSTRLCTIONS. (5.3) AND (5.5) THE FOLLORING IS AN EXAMPLE OF THE SELECT COMMAND.

COLLYITS 91011 AND 12 RERE DEFILED BY SELECT COYMUYD. COLLY 1 COLUM 2 COLLY 4 COLLYN

5 COLLYN 9

COLLYN 10

COLLMN 11

COLLYN 12

$\begin{array}{cccl}10.000000 & 1.0000000 & 5.0000000 & 0 . \\ 20.000000 & 1.0000000 & 10.000000 & 0 . \\ 30.000000 & 1.0000000 & 10.000000 & 0 . \\ 40.000000 & 1.0000000 & 12.000000 & 0 . \\ 50.000000 & 1.0000000 & 15.000000 & 0 . \\ & & & \\ 60.000000 & 60.000000 & 1.0000000 & 60.000000 \\ 70.000000 & 70.000000 & 2.0000000 & 70.000000 \\ 80.000000 & 80.000000 & 10.000000 & 80.000000 \\ 90.000000 & 90.000000 & 10.000000 & 90.000000 \\ 100.00000 & 100.00000 & 84.000000 & 100.00000\end{array}$

1.0000000
1.0000000
1.0000000
0.
0.
1.0000000
1.0000000
1.0000000
1.0000000
80.000000

1.0000000

1.0000000

$1.0000000 \quad 1.0000000$

$1.0000000 \quad 1.0000000$

0 .

1.0000000

0 .

0 .

5.0000000

5.0000000

5.0000000

0 .

0 .

$1.0000000 \quad 1.0000000$

$1.0000000 \quad 1.0000000$

$1.0000000 \quad 1.0000000$

5.0000000

5.0000000

5.0000000

5.0000000

90.000000

0 .

2.0000000

THE FOLLOHING VALUE MLST BE EQUAL TO OR NEAR ZERO.

0 . 
OMNITAB 80 TEST 21 CENSOR, SELECT AND SEARCH INSTRUCTIONS. (5.3) AND (5.5) THE FOLLOWING IS AN EXAMPLE OF THE SEARCH COMMAND.

COLUMN 13 H'AS DEFINED BY THE SEARCH COMMAND.

COLCMN

10.000000
20.000000
30.000000
40.000000
50.000000
60.000000
70.000000
80.000000
90.000000

COLUMN 2 COLUMN

COLUMN 13

90.000000

1.0000000

10.000000

1.0000000

1.0000000

20.000000

1.0000000

1.0000000

30.000000

1.0000000

1.0000000

40.000000

1.0000000

1.0000000

50.000000

1.0000000

100.00000

70.000000

60.000000

80.000000

70.000000

60.000000

90.000000

80.000000

70.000000

90.000000

80.000000

90.000000

100.00000

COLUMNS 2 AND 13 SHOULD CONTAIN THE SAME VALUES.

THE FOLLOH'ING VALUE MUST BE EQUAL TO OR NEAR ZERO.

0. 
OMNITAB 80 TEST 21 CENSOR, SELECT AND SEARCH INSTRLCTIONS. (5.3) AYD (5.5) PAGE 4 THE FOLLORING IS AN EXAMPLE OF THE THO WORD CENSOR COMMAND. COLLMA 1 IS DEFINED BY THE GENERATE COMMAID. COLLMN 8 TAS DEFINED BY THE FLIP COMYAID.

COLLMT 1 CEISOR LE CEISOR EQ

10.000000

20.000000

30.000000

40.000000

50.000000

2.0000000

2. 0000000

2. 0000000

2. 0000000

2.0000000

10.000000

20.000000

30.000000

40.000000

50.000000

CEXSOR GE

10.000000

20.000000

30.000000

40.000000

50.000000

60.000000

70.000000

60.000000

70.000000

80.000000

90.000000

90.000000

50.000000

70.000000

80.000000

90.000000

60.000000

2.0000000
2.0000000

2.0000000

100.00000
CEISOR LT

100.00000

90.000000

80.000000

70.000000

60.000000

50.000000

40.000000

80.000000

90.000000
CEISOR GT

10.000000

20.000000

30.000000

40.000000

50.000000

2. 0000000

2.0000000

2.0000000

2.0000000

2.0000000
CEISOR IE

COLLYX 8

100.00000

90.000000

30.000000

70.000000

60.000000

100.00000
50.000000

40.000000

30.000000

20.000000

10.000000
100.00000

90.000000

80.000000

70.000000

60.000000

50.000000

40.000000

30.000000

20.000000

10.000000

THE FOLLOHING VALLES MUST BE EQUAL TO OR IEAR 2.0 AID 6.2. 
OMNITAB 80 TEST 21 CENSOR, SELECT AND SEARCH INSTRUCTIONS. (5.3) AND (5.5)

LIST OF DATA, INSTRUCTIONS AND DIAGNOSTICS

GENERATE STARTING WITH 10 IN STEPS OF 10 THRU 100 AND STORE VALUES IN COLUMN 1

* INFORMATIVE DIAGNOSTIC FOR THE ABOVE INSTRUCTION -

NRMAX HAS BEEN RESET FROM 0 TO 10.

CENSOR COLUMN 1 FOR VALUES LESS OR EQUAL TO 50. REPLACE BY 1.0 STORE IN COL 2 CENSOR COL 2 FOR VALUES LESS OR EQUAL TO VALUES IN 1 REPLACE BY COL 1 PUT IN 3 MATCH COL 1 FOR VALUES EQUAL TO VALUES IN COL 3 REPLACE BY 1.0 PUT IN COLUMN 4 SUBTRACT COLUMN 1 FROM COLUMN 3 AND STORE IN COLUMN 20

AVERAGE COLUMN 20 AND STORE IN COLUMN 20

AVERAGE COLUMN 4 AND STORE IN COLUMN 21

SUBTRACT 1.0 FROM COLUMN 21 AND STORE IN COL 21

TITLE 1 THE FOLLOWING IS AN EXAMPLE OF THE CENSOR AND MATCH COMMAND

TITLE2S. COLUMN 1 WAS SET UP BY THE GENERATE COMMAND.

TITLE3 COLUMNS 2 AND 3 WERE DEFINED BY THE CENSOR COMMAND. COLUMN

TITLE44 WAS DEFINED BY THE MATCH COMMAND.

PRINT COLUMNS 1223 AND 4

SPACE 2

NOTE ****

SPACE

NOTE COLUMNS 1 AND 3 SHOULD CONTAIN THE SAME VALUES

NOTE THE VALUES IN COLUMN 4 SHOULD BE EQUAL TO ONE.

NOTE THE FOLLOHING VALUES MUST BE EQUAL TO OR NEAR ZERO.

SPACE

ABRIDGE ROW 1 OF COLUMNS 20 AND 21

SPACE

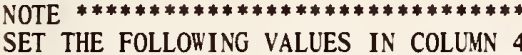

$\begin{array}{llllllllll}5.0 & 10.0 & 10.0 & 12.0 & 15.0 & 1.0 & 2.0 & 10.0 & 10.0 & 84.0\end{array}$

SELECT IN COL 1 VALUES APPROXIMATING COL 2 TO TOLERANCE .5 STORE IN COL 5

SELECT COL 2 VALUES APPROXIMATING COL 4 TO 10.0 STORE IN 9 TO 11 FREQ CT IN 12

TITLE1 THE FOLLOWING IS AN EXAMPLE OF THE SELECT COMMAND.

TITLE2

TITLE3 COLUMNS 91011 AND 12 WERE DEFINED BY SELECT COMMAND.

TITLE4

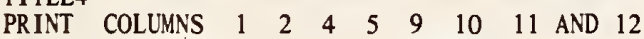

ROWSUM COLUMNS $59 \begin{array}{lllllll}10 & 11 & 12 & \text { STORE IN COL } 40\end{array}$

SET IN COLUMN 41

8.8.8.0.0.68. 78. 88.98. 272

SUBTRACT COLUMN 40 FROM COLUMN 41 STORE IN COL 40

AVERAGE COLUMN 40 STORE IN COLUMN 40

SPACE 2

NOTE ***

SPACE

NOTE THE FOLLOWING VALUE MUST BE EQUAL TO OR NEAR ZERO.

SPACE

ABRIDGE ROW 1 OF COLUMN 40

SPACE

NOTE ***************************4)

SEARCH COL 3 FOR NUMBERS IN COL 1 MOVE CORRESPONDING VALUES IN COL 2 TO COL 13 
LIST OF DATA, INSTRUCTIONS AND DIAGNOSTICS

TITLE1 THE FOLLORING IS AN EXAMPLE OF THE SEARCH COMMAND.

TITLE2

TITLE3 COLUMN 13 THAS DEFINED BY THE SEARCH COMMAND.

TITLE4

PRINT COLUMNS 123 AND 13

SUBTRACT COL 2 FROM COLLMN 13 STORE IN COL 30

AVERAGE COL 30 AND STORE RESULT IN COL 30

SPACE 2

NOTE *

SPACE

NOTE COLUMNS 2 AND 13 SHOULD CONTAIN THE SAME VALLES

NOTE THE FOLLORING VALUE MUST BE EQUAL TO OR NEAR ZERO.

SPACE

ABRIDGE ROH 1 OF COLUMN 30

SPACE

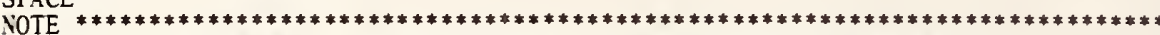

TITLE1 THE FOLLORING IS AN EXAYPLE OF THE THO RORD CENSOR COMMANDS

TITLE2. COLUMN 1 IS DEFINED BY THE GENERATE COMMAND.

TITLE 3 COLUMN 8 WAS DEFINED BY THE FLIP COMMAND.

LABEL CENSOR LE, 2, CENSOR EQ, 3, CENSOR GE, 4

* INFORMaTIVE diagNoSTIC FOR THE ABOVE INSTRUCTION (CENSOR LE) IS IN COL (2), (CENSOR EQ) IS IN COL (3) (CENSOR GE) IS IN COL (4)

LABEL CENSOR LT, 5, CENSOR GT, 6, CENSOR NE, 7

* INFORMATIVE DIAGNOSTIC FOR THE ABOVE INSTRUCTION (CENSOR LT) IS IN COL (5), (CENSOR GT) IS IN COL (6) (CENSOR NE) IS IN COL (7)

FLIP COLUNA 1 INTO COLUMN 8

CENSOR LE COL 1 FOR NOS 50. OR LESS, REPLACE BY 2.0 PUT IN COL 2

CENSOR EO COL 1 FOR VALLES EQUAL TO 60., REPLACE BY COL 8 PUT IN COLLYN 3

CENSOR GE COL 1 FOR NOS 70.0 AND GREATER, REPLACE BY 2.0 PUT IN COL 4

CEISOR LT COL 1 FOR VALLES LESS THAN 80.0 , REPLACE BY COL 8 PUT IN COLLMN 5

CENSOR GT COLUMN 1 FOR VALLES GREATER THAY 50. REPLACE BY 2.0 PUT IN COL 6

CENSOR NE COL 1 FOR VALUES OTHER THAN 30., REPLACE RITH COL 8 PUT IN COLLMN 7

PRINT COLUMNS $1,2,3,4,5,6,7$ AND 8

ADD COL 6 TO COL 2 PUT IN COL 9

SLBTRACT COL 1 FROM COL 9 PUT IN COL 9

ADD COL 3 TO COL 7 PUT IN COL 10

SUBTRACT COL 5 FROM COL 10 PUT IN COL 10

SLBTRACT COL 4 FROM COL 10 PUT IN COL 10

AVERAGE COLLYN 9 PUT RESULT IN COLLYN 9

AVERAGE COLUMN 10 PUT RESULT IN COLUMN 10

SPACE 2

NOTE 
OMNITAB 80 TEST 21 CENSOR, SELECT AND SEARCH INSTRUCTIONS. (5.3) AND (5.5)

LIST OF DATA, INSTRUCTIONS AND DIAGNOSTICS

SPACE

NOTE THE FOLLOHING VALUES MUST BE EQUAL TO OR NEAR 2.0 AND 6.2.

SPACE

ABRIDGE ROW 1 OF COLUMNS 910

NOTE

NATIONAL BUREAU OF STANDARDS. WASHINGTON, D. C. 20234

OMNITAB 80 VERSION 6.00 MARCH 2,1981 


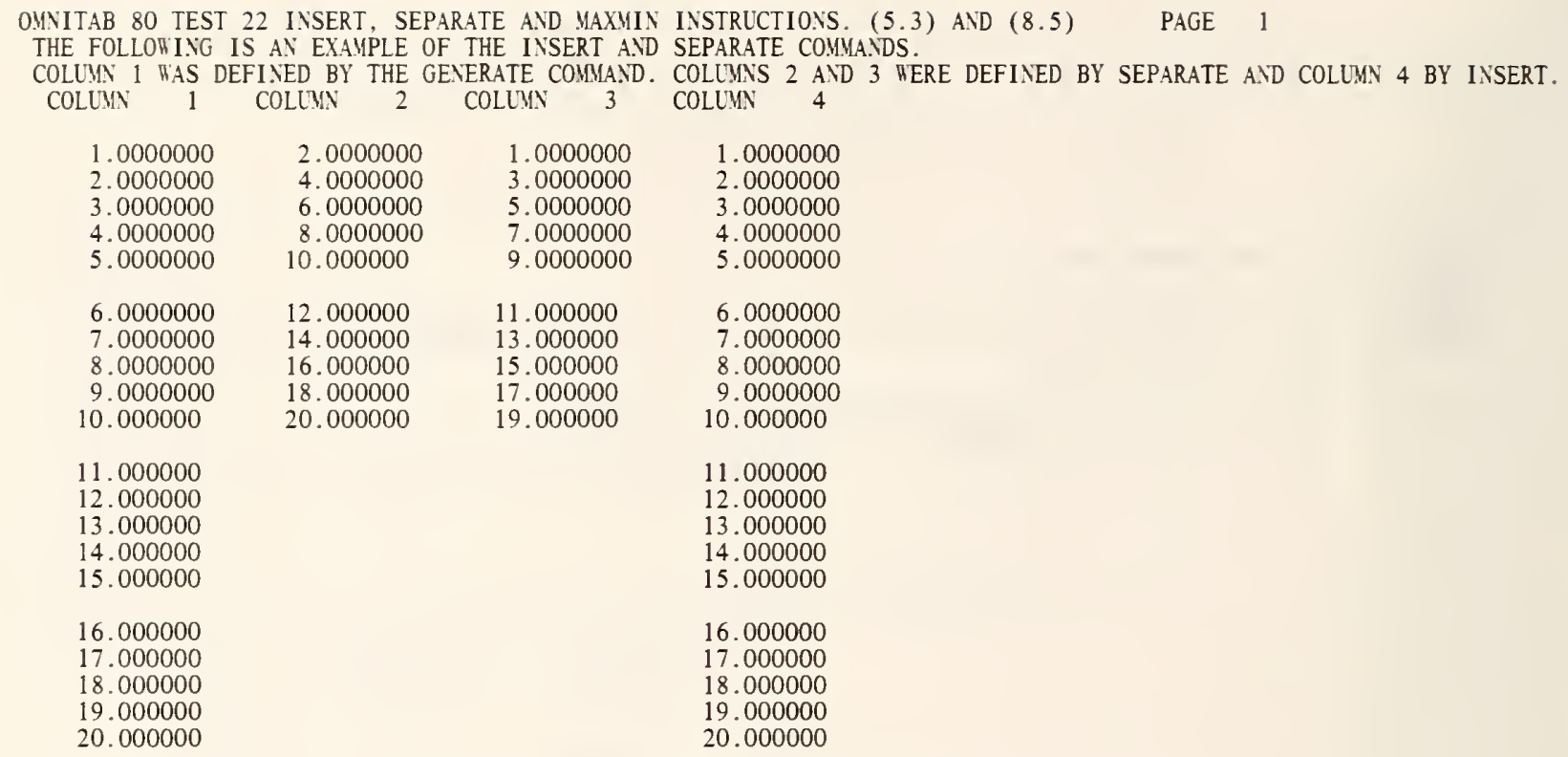

THE FOLLOR'ING VALLE SHOULD BE CLOSE TO OR EQUAL TO ZERO.

0 . 
OMNITAB 80 TEST 22 INSERT, SEPARATE AND MAXMIN INSTRUCTIONS. (5.3) AND (8.5) PAGE 2

THE FOLLOWING IS AN EXAMPLE OF THE MAXMIN COMMAND. X WAS DEFINED BY THE GENERATE COMMAND. Y $=\operatorname{COSD}(X)$.

COLLMNS 6 AND 7 CONTAIN MAXIMA VALUES OF FUNCTION Y. COLUMNS 8 AND 9 CONTAIN MINIMA VALUES OF FUNCTION Y.

$$
\mathrm{X}
$$$$
\text { Y }
$$

COLUMN

COLUMN

COLUMN $\quad \begin{array}{lll}8 & \\ & & \text { COLUMN } 9\end{array}$

$\begin{array}{cc}-10.000000 & .98480775 \\ 0 . & 1.0000000 \\ 10.000000 & .98480775 \\ 20.000000 & .93969262 \\ 30.000000 & .86602541 \\ 40.000000 & .76604445 \\ 50.000000 & .64278762 \\ 60.000000 & .50000001 \\ 70.000000 & .34202016 \\ 80.000000 & .17364819 \\ & \\ 90.000000 & * 1.5893255-08 \\ 100.00000 & -.17364816 \\ 110.00000 & -.34202012 \\ 120.00000 & -.49999997 \\ 130.00000 & -.64278758 \\ & \\ 140.00000 & -.76604442 \\ 150.00000 & -.86602538 \\ 160.00000 & -.93969262 \\ 170.00000 & -.98480775 \\ 180.00000 & -1.0000000 \\ 190.00000 & -.98480776 \\ 200.00000 & -.93969264 \\ 210.00000 & -.86602543 \\ 220.00000 & -.76604448 \\ 230.00000 & -.64278768 \\ 240.00000 & -.50000005 \\ 250.00000 & -.34202018 \\ 260.00000 & -.17364825 \\ 270.00000 & *-4.7679764-08 \\ 280.00000 & .17364810 \\ 290.00000 & .34202009 \\ 300.00000 & .49999992 \\ 310.00000 & .64278756 \\ 320.00000 & .76604442 \\ 330.00000 & .86602537 \\ 340.00000 & .93969260 \\ 350.00000 & .98480774 \\ 360.00000 & 1.0000000 \\ 370.00000 & .98480777 \\ & \end{array}$

THE FOLLOWING VALUES SHOULD BE CLOSE TO OR EQUAL TO ZERO.

* $1.9073486-06$

0 . 
OMNITAB 80 TEST 22 INSERT, SEPARATE AND MAXMIN INSTRUCTIONS. (5.3) AND (8.5)

LIST OF DATA, INSTRUCTIONS AND DIAGNOSTICS

GENERATE FROM 1 IN STEPS OF 1 THRU 20 AID STORE VALUES IN COL 1

- informative diagiostic for the above instrlction NRMAX HAS BEEN RESET FROM O TO 20.

SEPARATE FROM COLLMN 1 EVERY 2ND ROF STARTING TITH ROF 2 STORE IN COLLMA 2 SEPARATE FROM COL 1 EVERY 2ND ROW STARTING WITH ROW 1 AND STORE IN COL 3

INSERT IN COL 3 FROM COL 2 AT EVERY 2ND ROF STARTING AT 2ND RON STORE IN COL 4

* informative diagiostic for the above instrlction -

NRMAX HAS BEEN RESET FROM 20 TO 40

TITLE1 THE FOLLOFING IS AN EXAMPLE OF THE INSERT AID SEPARATE COMM TITLE2ANDS

TITLE3 COLLUN 1 MAS DEFINED BY THE GENERATE COMMAND. COLLMNS 2 AND TITLE4 3 WERE DEFINED BY SEPARATE AND COLUMN 4 BY INSERT.

RESET NRMAX 20

- INFORMATIVE DIAGNOSTIC FOR THE ABOVE INSTRUCTION NRMAX HAS BEEN RESET FROM 40 TO 20.

PRINT COLLMNS 123 AND 4

SPACE 2

SUB COL 1 FROM COL 4 STORE IY COLLYR 5

NOTE

SPACE

NOTE THE FOLLOHING VALLE SHOLZD BE CLOSE TO OR EQUAL TO ZERO.

ABRIDGE ROR' 1 OF COLLMY 5

SPACE

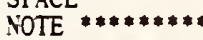

RESET NRMAX 0

- INFORMATIVE DIAGNOSTIC FOR THE ABOVE INSTRUCTION NRVAX HAS BEEN RESET FROY 20 TO 0.

GENERATE STARTING NITH -10 IN STEPS OF 10 THRU 370 AND STORE VALLES IN COLLMN 4

- INFORMATIVE DIAGNOSTIC FOR THE ABOVE INSTRLCTION NRMAX HAS BEEN RESET FROM OO TO 39.

COSD OF COLLYY 4 AND STORE IN COLUYN 5

MAXMIN X IN COL 4 Y IN COL 5 STORE MAXIMA IN COLS 6 AND 7 MINIMA IN COLS 8 AND 9 TITLE 1 THE FOLLOFING IS AY EXAMPLE OF THE MAXMIN COMMAND. $X$ WAS D

TITLE2EFINED BY THE GENERATE COMHATD. $Y=\operatorname{COSD}(X)$

TITLE3 COLLMNS 6 AND 7 CONTAIN MAXIMA VALLES OF FLXCTION Y.

TITLE4 COLUMNS 8 AND 9 CONTAIN MINIMA VALLES OF FUNCTION Y.

HEAD COL 4

HEAD COL 5/

PRINT COLLYNS 4***0

RESET NRMAX 2 
LIST OF DATA, INSTRUCTIONS AND DIAGNOSTICS

* INFORMATIVE DIAGNOSTIC FOR THE ABOVE INSTRUCTION NRMAX HAS BEEN RESET FROM 39 TO 2.

ROWSUM COLS $6 * * * 9$ STORE IN COLUMN 10

SET IN COL 11

$180.0 \quad 361.0$

SUBTRACT COL 10 FROM COL 11 STORE IN COL 12

SPACE 2

NOTE $* * * * * * * * * * * * * * * * * * * * * * * * * * * * * * * * * * * * * * * * * * * * * * * * * * * * * * * * * * * * * * * * * *$

SPACE

NOTE THE FOLLOWING VALUES SHOULD BE CLOSE TO OR EQUAL TO ZERO.

SPACE

NPRINT COLLMN 12

SPACE

NOTE

NATIONAL BUREAU OF STANDARDS. WASHINGTON, D. C. 20234 OMNITAB 80 VERSION 6.00

MARCH 2,1981 
OMNITAB 80 TEST 23 HIERARCHY, ORDER AND SORT INSTRUCTIONS. (5.4)

COLUMNS 1 AND 2 WERE DEFINED BY THE SET COMMAND

COLUMN 3 CONTAINS THE LOCATIONS OF THE SMALLEST TO LARGEST VALUES OF COLUMN 1.

$\begin{array}{llllll}\text { COLUMN } & 1 & \text { COLUMN } & 2 & \text { COLUMN } & 3\end{array}$

$\begin{array}{ccc}30.000000 & 1.2450000 & 5.0000000 \\ 3.5600000 & .44000000 & 10.000000 \\ 2.1400000 & 7.5800000 & 4.0000000 \\ 1.0000000 & 23.000000 & 3.0000000 \\ 0 . & 56.000000 & 2.0000000 \\ 5.7800000 & 45.000000 & 6.0000000 \\ 8.9000000 & 78.000000 & 7.0000000 \\ 9.0000000 & 96.000000 & 8.0000000 \\ 123.00000 & 2.0000000 & 1.0000000 \\ .12000000 & 0 . & 9.0000000\end{array}$

THE VALUES BELOH RESULTED FROM SORTING COLUMN 2 AND CARRYING ALONG THE CORRESPONDING VALUES OF COLUMNS 1 AND 3

\begin{tabular}{|c|c|c|}
\hline $\begin{array}{c}.12000000 \\
3.5600000 \\
30.000000 \\
123.00000 \\
2.1400000\end{array}$ & $\begin{array}{l}0 . \\
.44000000 \\
1.2450000 \\
2.0000000 \\
7.5800000\end{array}$ & $\begin{array}{c}9.0000000 \\
10.000000 \\
5.0000000 \\
1.0000000 \\
4.0000000\end{array}$ \\
\hline $\begin{array}{l}1.0000000 \\
5.7800000 \\
0 . \\
8.9000000 \\
9.0000000\end{array}$ & $\begin{array}{l}23.000000 \\
45.000000 \\
56.000000 \\
78.000000 \\
96.000000\end{array}$ & $\begin{array}{l}3.0000000 \\
6.0000000 \\
2.0000000 \\
7.0000000 \\
8.0000000\end{array}$ \\
\hline
\end{tabular}

THE VALUES BELOH ARE THE SORTED VALUES OF THE ABOVE COLUMNS.

$\begin{array}{ccc}0 . & 0 . & 1.0000000 \\ .12000000 & .44000000 & 2.0000000 \\ 1.0000000 & 1.2450000 & 3.0000000 \\ 2.1400000 & 2.0000000 & 4.0000000 \\ 3.5600000 & 7.5800000 & 5.0000000 \\ & & \\ 5.7800000 & 23.000000 & 6.0000000 \\ 8.9000000 & 45.000000 & 7.0000000 \\ 9.0000000 & 56.000000 & 8.0000000 \\ 30.000000 & 78.000000 & 9.0000000 \\ 123.00000 & 96.000000 & 10.000000\end{array}$

THE FOLLOHING VALUES SHOULD BE CLOSE TO OR EQUAL TO ZERO.

0 .

0 .
0 . 
OMNITAB 80 TEST 23 HIERARCHY, ORDER AND SORT INSTRUCTIONS. (5.4)

LIST OF DATA, INSTRUCTIONS AND DIAGNOSTICS

SET THE FOLLOWING VALUES INTO COLUMN 1

$\begin{array}{lllllllllll}30.0 & 3.56 & 2.14 & 1 . & 0.0 & 5.78 & 8.9 & 9 & 123 . & .12\end{array}$

* INFORMATIVE diagNOSTIC FOR THE ABOVE INSTRUCTION NRMAX HAS BEEN RESET FROM O TO 10.

SET THE FOLLOWING VALUES INTO COLUMN 2

$1.245 .447 .58 \quad 23 \quad 56 \quad 4578 \quad 662$

* INFORMATIVE DIAGNOSTIC FOR THE ABOVE INSTRUCTION NRMAX HAS BEEN RESET FROM 10 TO 9.

RESET NRMAX TO 10

* informative diagnostic for the above instruction NRMAX HAS BEEN RESET FROM 9 TO 10.

HIERARCHY OF COLUMN 1 STORE LOCATIONS OF SMALLEST TO LARGEST INTO COL 3 AVERAGE OF COLUMN 1 AND STORE IN COLUMN 4

AVERAGE OF COLUMN 2 AND STORE IN COLUMN 5

AVERAGE OF COLUMN 3 AND STORE IN COLUMN 6

TITLE 1 COLUMNS 1 AND 2 WERE DEFINED BY THE SET COMMAND.

TITLE3 COLUMN 3 CONTAINS THE LOCATIONS OF THE SMALLEST TO LARGEST

TITLE4VALUES OF COLUMN 1.

PRINT THE VALUES IN COLUMNS $1 * * * 3$

SORT COLUMN 2 AND CARRY ALONG THE CORRESPONDING VALUES OF COLUMNS 1 AND 3

AVERAGE OF COLUMN 1 STORE IN COL 7

AVERAGE OF COLUMN 2 STORE IN COL 8

SPACE

AVERAGE OF COLUMN 3 STORE IN COL 9

NOTE THE VALUES BELOW RESULTED FROM SORTING COLUMN 2 AND CARRYING ALONG THE NOTE CORRESPONDING VALUES OF COLUMNS 1 AND 3.

SPACE

NPRINT COLUMNS $1 * * * 3$ WITHOUT HEADINGS

ORDER COLUMNS $1 * * * 3$

AVERAGE OF COLUMN 1 STORE IN COLUMN 10

AVERAGE OF COLUMN 2 STORE IN COLUMN 11

AVERAGE OF COLUMN 3 STORE IN COLUMN 12

SPACE

NOTE THE VALUES BELOW ARE THE SORTED VALUES OF THE ABOVE COLUMNS

SPACE

NPR INT COLUMNS 1***3 WITHOUT HEADINGS

SUBTRACT COL 4 FROM COL 7 AND STORE IN COL 13

SUBTRACT COL 8 FROM COL 11 STORE IN COL 14

SUBTRACT COL 6 FROM COL 12 STORE IN COL 15

SPACE 2

NOTE ***

SPACE

NOTE THE FOLLOHING VALUES SHOULD BE CLOSE TO OR EQUAL TO ZERO.

SPACE 
OMNITAB 80 TEST 23 HIERARCHY, ORDER AND SORT INSTRUCTIONS. (5.4)

LIST OF DATA, INSTRUCTIONS AND DIAGNOSTICS

ABR IDGE ROW 1 OF COLUMN 131415

SPACE

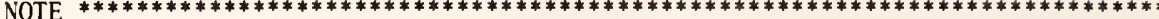

NATIONAL BUREAU OF STANDARDS. WASHINGTON, D. C. 20234

OMNITAB 80 VERSION $6.00 \quad$ MARCH 2,1981 
OMNITAB 80 TEST 24 CHOOSE, RETAIN, OMIT AND DELETE INSTRUCTIONS. (5.6) COLUMNS 5 AND 6 WERE DEFINED BY THE CHOOSE COMMAND.

\begin{tabular}{|c|c|c|c|c|c|}
\hline COLUMN & COLUMN & COLUMN & COLUMN & COLUMN & COLUMN \\
\hline $\begin{array}{r}6.0000000 \\
7.0000000 \\
7.0000000 \\
6.0000000 \\
-2.0000000\end{array}$ & $\begin{array}{l}25.000000 \\
23.000000 \\
25.000000 \\
25.000000 \\
26.000000\end{array}$ & $\begin{array}{l}40.000000 \\
48.000000 \\
40.000000 \\
49.000000 \\
40.000000\end{array}$ & $\begin{array}{l}101.00000 \\
-1.0000000 \\
104.00000 \\
109.00000 \\
106.00000\end{array}$ & $\begin{array}{l}6.0000000 \\
6.0000000 \\
6.0000000 \\
6.0000000 \\
6.0000000\end{array}$ & $\begin{array}{l}6.0000000 \\
7.0000000 \\
7.0000000 \\
6.0000000 \\
7.0000000\end{array}$ \\
\hline $\begin{array}{l}7.0000000 \\
6.0000000 \\
6.0000000 \\
6.0000000 \\
7.0000000\end{array}$ & $\begin{array}{l}24.000000 \\
-3.0000000 \\
25.000000 \\
23.000000 \\
24.000000\end{array}$ & $\begin{array}{l}48.000000 \\
40.000000 \\
49.000000 \\
-2.0000000 \\
48.000000\end{array}$ & $\begin{array}{l}102.00000 \\
103.00000 \\
108.00000 \\
105.00000 \\
108.00000\end{array}$ & 6.0000000 & $\begin{array}{l}6.0000000 \\
6.0000000 \\
6.0000000 \\
7.0000000 \\
6.0000000\end{array}$ \\
\hline $\begin{array}{r}-1.0000000 \\
6.0000000 \\
7.0000000 \\
7.0000000 \\
7.0000000\end{array}$ & $\begin{array}{l}24.000000 \\
25.000000 \\
26.000000 \\
25.000000 \\
26.000000\end{array}$ & $\begin{array}{l}48.000000 \\
49.000000 \\
-1.0000000 \\
48.000000 \\
49.000000\end{array}$ & $\begin{array}{c}102.00000 \\
101.00000 \\
-1.0000000 \\
103.00000 \\
107.00000\end{array}$ & & $\begin{array}{l}7.0000000 \\
7.0000000 \\
7.0000000 \\
0 . \\
0 .\end{array}$ \\
\hline
\end{tabular}

THE FOLLOWING VALUES SHOULD BE CLOSE TO OR EQUAL 15.0, 6.0 AND 13.0.
15.000000
6.0000000
13.000000 
OMNITAB 80 TEST 24 CHOOSE, RETAIN, OMIT AND DELETE INSTRUCTIONS. (5.6) COLUMNS 5 AND 6 HERE DEFINED BY THE CHOOSE COMMAND.

\begin{tabular}{|c|c|c|c|c|}
\hline COLUMN & COLUMN & COLUMN & COLUMN & COLUMN \\
\hline $\begin{array}{r}6.0000000 \\
7.0000000 \\
7.0000000 \\
6.0000000 \\
-2.0000000\end{array}$ & $\begin{array}{l}25.000000 \\
23.000000 \\
25.000000 \\
25.000000 \\
26.000000\end{array}$ & $\begin{array}{l}40.000000 \\
48.000000 \\
40.000000 \\
49.000000 \\
40.000000\end{array}$ & $\begin{array}{l}101.00000 \\
-1.0000000 \\
104.00000 \\
109.00000 \\
106.00000\end{array}$ & $\begin{array}{l}6.0000000 \\
7.0000000 \\
6.0000000 \\
7.0000000 \\
6.0000000\end{array}$ \\
\hline $\begin{array}{l}7.0000000 \\
6.0000000 \\
6.0000000 \\
6.0000000 \\
7.0000000\end{array}$ & $\begin{array}{l}24.000000 \\
-3.0000000 \\
25.000000 \\
23.000000 \\
24.000000\end{array}$ & $\begin{array}{l}48.000000 \\
40.000000 \\
49.000000 \\
-2.0000000 \\
48.000000\end{array}$ & $\begin{array}{l}102.00000 \\
103.00000 \\
108.00000 \\
105.00000 \\
108.00000\end{array}$ & $\begin{array}{l}7.0000000 \\
6.0000000 \\
7.0000000 \\
7.0000000\end{array}$ \\
\hline $\begin{array}{r}-1.0000000 \\
6.0000000 \\
7.0000000 \\
7.0000000 \\
7.0000000\end{array}$ & $\begin{array}{l}24.000000 \\
25.000000 \\
26.000000 \\
25.000000 \\
26.000000\end{array}$ & $\begin{array}{l}48.000000 \\
49.000000 \\
-1.0000000 \\
48.000000 \\
49.000000\end{array}$ & $\begin{array}{l}102.00000 \\
101.00000 \\
-1.0000000 \\
103.00000 \\
107.00000\end{array}$ & \\
\hline
\end{tabular}

THE FOLLORING VALUE SHOULD BE CLOSE TO OR EQUAL 9.0

9.0000000

\section{PAGE 2}

COLUMN 12 COLLMN 13 COLUMN 14

25.000000

25.000000

25.000000

24.000000

25.000000

40.000000

40.000000

49.000000

48.000000

49.000000

101.00000

104.00000

109.00000

102.00000

108.00000

24.000000

25.000000

25.000000

48.000000

108.00000

49.000000

48. 000000

101.00000

103.00000

107.00000 
OMNITAB 80 TEST 24 CHOOSE, RETAIN, OMIT AND DELETE INSTRUCTIONS. (5.6) COLUMNS 5 THRU 8 HERE DEFINED BY THE OMIT COMMAND.

\begin{tabular}{|c|c|c|c|c|c|c|c|}
\hline COLUMN & COLUMN & COLUMN & COLUMN & COLUMN & COLUMN & COLUMN & COLUMN \\
\hline $\begin{array}{r}6.0000000 \\
7.0000000 \\
7.0000000 \\
6.0000000 \\
-2.0000000\end{array}$ & $\begin{array}{l}25.000000 \\
23.000000 \\
25.000000 \\
25.000000 \\
26.000000\end{array}$ & $\begin{array}{l}40.000000 \\
48.000000 \\
40.000000 \\
49.000000 \\
40.000000\end{array}$ & $\begin{array}{l}101.00000 \\
-1.0000000 \\
104.00000 \\
109.00000 \\
106.00000\end{array}$ & $\begin{array}{l}6.0000000 \\
7.0000000 \\
7.0000000 \\
6.0000000 \\
7.0000000\end{array}$ & $\begin{array}{l}6.0000000 \\
7.0000000 \\
7.0000000 \\
6.0000000 \\
7.0000000\end{array}$ & $\begin{array}{l}6.0000000 \\
7.0000000 \\
7.0000000 \\
6.0000000 \\
7.0000000\end{array}$ & $\begin{array}{l}25.000000 \\
23.000000 \\
25.000000 \\
25.000000 \\
24.000000\end{array}$ \\
\hline $\begin{array}{l}7.0000000 \\
6.0000000 \\
6.0000000 \\
6.0000000 \\
7.0000000\end{array}$ & $\begin{array}{l}24.000000 \\
-3.0000000 \\
25.000000 \\
23.000000 \\
24.000000\end{array}$ & $\begin{array}{l}48.000000 \\
40.000000 \\
49.000000 \\
-2.0000000 \\
48.000000\end{array}$ & $\begin{array}{l}102.00000 \\
103.00000 \\
108.00000 \\
105.00000 \\
108.00000\end{array}$ & $\begin{array}{r}6.0000000 \\
6.0000000 \\
6.0000000 \\
7.0000000 \\
-1.0000000\end{array}$ & $\begin{array}{l}6.0000000 \\
6.0000000 \\
6.0000000 \\
7.0000000 \\
6.0000000\end{array}$ & $\begin{array}{r}6.0000000 \\
6.0000000 \\
6.0000000 \\
7.0000000 \\
-1.0000000\end{array}$ & $\begin{array}{l}-3.0000000 \\
25.000000 \\
23.000000 \\
24.000000 \\
24.000000\end{array}$ \\
\hline $\begin{array}{r}-1.0000000 \\
6.0000000 \\
7.0000000 \\
7.0000000 \\
7.0000000\end{array}$ & $\begin{array}{l}24.000000 \\
25.000000 \\
26.000000 \\
25.000000 \\
26.000000\end{array}$ & $\begin{array}{l}48.000000 \\
49.000000 \\
-1.0000000 \\
48.000000 \\
49.000000\end{array}$ & $\begin{array}{c}102.00000 \\
101.00000 \\
-1.0000000 \\
103.00000 \\
107.00000\end{array}$ & $\begin{array}{l}6.0000000 \\
7.0000000 \\
7.0000000 \\
7.0000000 \\
0 .\end{array}$ & $\begin{array}{l}7.0000000 \\
7.0000000 \\
7.0000000 \\
0 . \\
0 .\end{array}$ & $\begin{array}{l}6.0000000 \\
7.0000000 \\
7.0000000 \\
7.0000000 \\
0 .\end{array}$ & $\begin{array}{l}25.000000 \\
26.000000 \\
25.000000 \\
26.000000 \\
0 .\end{array}$ \\
\hline
\end{tabular}

THE FOLLOWING VALUES SHOULD BE CLOSE TO ARE EQUAL TO 15.0, 14.0 AND 13.0.
15.000000
14.000000
13.000000

PAGE 3 
OMNITAB 80 TEST 24 CHOOSE, RETAIN, OMIT AND DELETE INSTRUCTIONS. (5.6) COLUMNS 11 THRU 18 RERE DEFINED BY THE DELETE COMMAND.

$\begin{array}{rrrrrr}\text { COLLMN } 11 & \text { COLIMN } 12 & \text { COLLIN } 13 & \text { COLUMN } 14 & \text { COLUMN } & 15 \\ 6.0000000 & 25.000000 & 40.000000 & 101.00000 & 6.0000000 \\ 7.0000000 & 25.000000 & 40.000000 & 104.00000 & 7.0000000 \\ 6.0000000 & 25.000000 & 49.000000 & 109.00000 & 6.0000000 \\ -2.0000000 & 26.000000 & 40.000000 & 106.00000 & 7.0000000 \\ 7.0000000 & 24.000000 & 48.000000 & 102.00000 & 6.0000000 \\ & & & & \\ 6.0000000 & -3.0000000 & 40.000000 & 103.00000 & 7.0000000 \\ 6.0000000 & 25.000000 & 49.000000 & 108.00000 & 6.0000000 \\ 6.0000000 & 23.000000 & -2.0000000 & 105.00000 & 7.0000000 \\ 7.0000000 & 24.000000 & 48.000000 & 108.00000 & 7.0000000 \\ 6.0000000 & 25.000000 & 49.000000 & 101.00000 & \\ 7.0000000 & 25.000000 & 48.000000 & 103.00000 & \\ 7.0000000 & 26.000000 & 49.000000 & 107.00000 & \end{array}$

THE FOLLONING VALUES SHOULD BE CLOSE TO OR EQUAL TO 12.0 AND 9.0.

12.000000

9.0000000
PAGE 4

COLUMN 16 COLUMN 17 COLUMN 18

$\begin{array}{lll}25.000000 & 40.000000 & 101.00000\end{array}$

$25.000000 \quad 40.000000-104.00000$

$\begin{array}{lll}24.000000 & 48.000000 & 102.00000\end{array}$

$25.000000 \quad 49.000000 \quad 108.00000$

24.000000

25.000000

25.000000

26. 000000

48.000000

49.000000

48.000000

49.000000

108.00000

101.00000

103.00000

107.00000 
OMNITAB 80 TEST 24 CHOOSE, RETAIN, OMIT AND DELETE INSTRUCTIONS. (5.6)

LIST OF DATA, INSTRUCTIONS AND DIAGNOSTICS

$\begin{array}{cccc}\text { READ } & \text { DATA } & \text { INTO } & \text { COLUM } \\ 6 & 25 & 40 & 101 \\ 7 & 23 & 48 & -1 \\ 7 & 25 & 40 & 104 \\ 6 & 25 & 49 & 109 \\ -2 & 26 & 40 & 106 \\ 7 & 24 & 48 & 102 \\ 6 & -3 & 40 & 103 \\ 6 & 25 & 49 & 108 \\ 6 & 23 & -2 & 105 \\ 7 & 24 & 48 & 108 \\ -1 & 24 & 48 & 102 \\ 6 & 25 & 49 & 101 \\ 7 & 26 & -1 & -1 \\ 7 & 25 & 48 & 103 \\ 7 & 26 & 49 & 107\end{array}$

* INFORMATIVE diagnOSTIC FOR THE ABOVE INSTRUCTION NRMAX HAS BEEN RESET FROM O TO 15.

RESET $X$ TO *NRMAX*

TITLE 1 COLUMNS 5 AND 6 WERE DEFINED BY THE CHOOSE COMMAND. CHOOSE ROWS NITH 6. IN COLUMN 1 AND PUT IN COLUMN 5

* informative diagnostic FOR THE abOVE inSTRUCtion NRMAX HAS BEEN RESET FROM 15 TO 6.

RESET NRMAX TO ** X**

* INFORMATIVE DIAGNOSTIC FOR THE ABOVE INSTRUCTION NRMAX HAS BEEN RESET FROM 6 TO 15.

CHOOSE ROWS HITH VALUES BETWEEN 5. AND 8. IN COLUMN 1 AND PUT IN COL 6

* INFORMATIVE DIAGNOSTIC FOR THE ABOVE INSTRUCTION NRMAX HAS BEEN RESET FROM 15 TO 13.

RESET NRMAX TO $* * X^{* *}$

* INFORMATIVE DIAGNOSTIC FOR THE ABOVE INSTRUCTION NRMAX HAS BEEN RESET FROM 13 TO 15.

PRINT COLUMNS $1 * * * 6$

COUNT LENGTH OF COLUMN 1 PUT IN COLUMN 60

DEFINE VALUE IN ROW 1 OF COL 60 INTO ROW 1 OF COL 51

COUNT LENGTH OF COLUMN 5 PUT IN COLUMN 60

DEFINE VALUE IN ROW 1 OF COL 60 INTO ROW 1 OF COL 52

COUNT LENGTH OF COLUMN 6 PUT IN COLUMN 60

DEFINE VALUE IN ROW 1 OF COL 60 INTO ROW 1 OF COL 53

SPACE 
OMNITAB 80 TEST 24 CHOOSE, RETAIN, OMIT AID DELETE INSTRLCTIONS. (5.6)

LIST OF DATA, INSTRLCTIONS AND DIAGNOSTICS

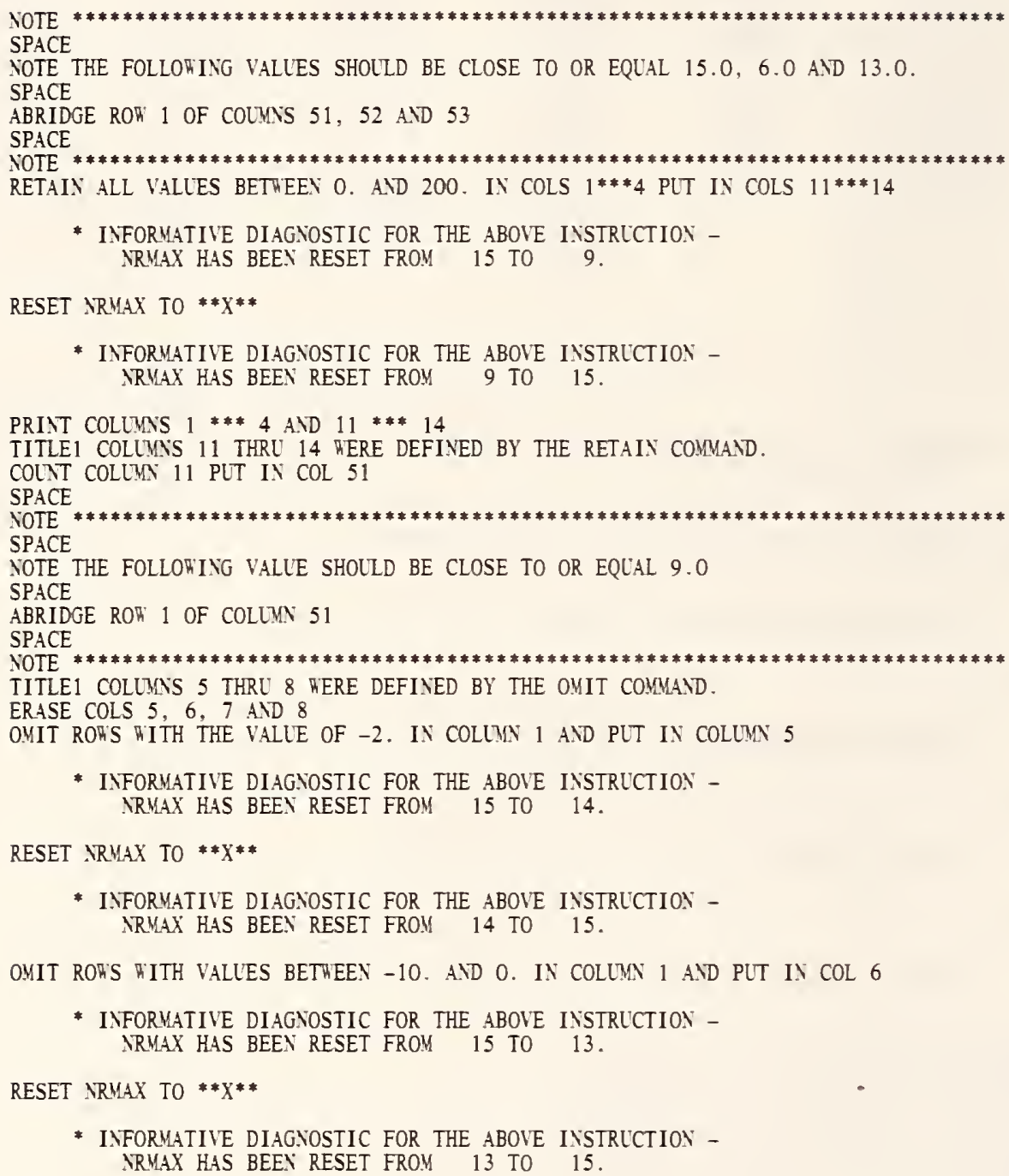

* INFORMATIVE DIAGNOSTIC FOR THE ABOVE INSTRUCTION IRMAX HAS BEEN RESET FROM 15 TO 14.

RESET IRMAX TO ** $X^{* *}$

* INFORMATIVE DIAGTOSTIC FOR tHE ABOVE INSTRLCTION NRMAX HAS BEEN RESET FROM 14 TO 15.

OMIT RORS RITH VALUES BETWEEN -10. AND 0. IN COLUMN 1 AND PUT IN COL 6

* INFORMATIVE DIAGNOSTIC FOR THE ABOVE INSTRUCTION NRMAX HAS BEEN RESET FROM 15 TO 13.

RESET IRMAX TO **X**

* informative diagyostic for the above instruction NRMAX HAS BEEI RESET FROM 13 TO 15. 
OMNITAB 80 TEST 24 CHOOSE, RETAIN, OMIT AND DELETE INSTRUCTIONS. (5.6)

LIST OF DATA, INSTRUCTIONS AND DIAGNOSTICS

OMIT ROWS WITH -2 . IN COL 1 CORR ROW OF COL 2 PUT IN COLS 7 AND 8

* INFORMATIVE DIAGNOSTIC FOR THE ABOVE INSTRUCTION NRMAX HAS BEEN RESET FROM 15 TO 14.

RESET NRMAX TO ${ }^{* *} X^{* *}$

* INFORMATIVE DIAGNOSTIC FOR THE ABOVE INSTRUCTION NRMAX HAS BEEN RESET FROM 14 TO 15.

PRINT COLUMNS $1 * * * 8$

COUNT LENGTH OF COLUMN 1 PUT IN COLUMN 60

DEFINE VALUE IN ROW 1 OF COL 60 INTO ROW 1 OF COL 51

COUNT LENGTH OF COLUMN 5 PUT IN COLUMN 60

DEFINE VALUE IN ROW 1 OF COL 60 INTO ROW 1 OF COL 52

COUNT LENGTH OF COLUMN 6 PUT IN COLUMN 60

DEFINE VALUE IN ROW 1 OF COL 60 INTO ROW 1 OF COL 53

SPACE

NOTE

SPACE

NOTE THE FOLLOWING VALUES SHOULD BE CLOSE TO ARE EQUAL TO 15.0, 14.0 AND 13.0 .

SPACE

ABRIDGE ROW 1 OF COLUMNS 51, 52 AND 53

SPACE

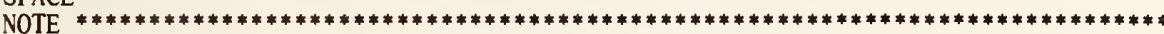

TITLE 1 COLUMNS 11 THRU 18 WERE DEFINED BY THE DELETE COMMAND.

ERASE $11 * * * 18$

DELETE ALL ROHS HAVING THE VALUE -1.0 IN COLS 1***4 PUT IN COLS 11***14

* INFORMATIVE DIAGNOSTIC FOR THE ABOVE INSTRUCTION NRMAX HAS BEEN RESET FROM 15 TO 12.

RESET NRMAX TO ** $\mathrm{X}^{* *}$

* INFORMATIVE DIAGNOSTIC FOR THE ABOVE INSTRUCTION NRMAX HAS BEEN RESET FROM 12 TO 15.

DELETE ALL VALUES BETWEEN -10 . AND 0 . IN COLS $1 * * * 4$ PUT IN COLS $15^{* * * 18}$

* INFORMATIVE DIAGNOSTIC FOR THE ABOVE INSTRUCTION NRMAX HAS BEEN RESET FROM 15 TO 9.

RESET NRMAX TO ** $X^{* *}$

* INFORMATIVE DIAGNOSTIC FOR THE ABOVE INSTRUCTION NRMAX HAS BEEN RESET FROM 9 TO 15.

PRINT COLUMNS $11 * * * 18$

COUNT COLUMN 11 PUT IN COL 60

DEFINE VALUE IN ROW 1 OF COL 60 INTO ROW 1 OF COL 52 
LIST OF DATA, INSTRUCTIONS AND DIAGNOSTICS

COUNT LENGTH OF COLUMN 15 PUT IN COLUMN 60

DEFINE VALUE IN ROW 1 OF COL 60 INTO ROW 1 OF COL 53

NOTE $* * * * * * * * * * * * * * * * * * * * * * * * * * * * * * * * * * * * * * * * * * * * * * * * * * * * * * * * * * * * * * * * * * * *$

SPACE

NOTE THE FOLLOWING VALUES SHOULD BE CLOSE TO OR EQUAL TO 12.0 AND 9.0.

SPACE

ABRIDGE ROW 1 OF COLUMNS 52 AND 53

SPACE

NOTE $* * * * * * * * * * * * * * * * * * * * * * * * * * * * * * * * * * * * * * * * * * * * * * * * * * * * * * * * * * * * * * * * * * * * * * * * *$

NATIONAL BUREAU OF STANDARDS. WASHINGTON, D. C. 20234

OMNITAB 80 VERSION 6.00 MARCH 2,1981 
OMNITAB 80 TEST 25 CODE, RECODE AND REPLACE INSTRUCTIONS. (5.6) COLUMNS 2, 3 AND 4 WERE DEFINED BY THE CODE COMMAND.

\begin{tabular}{|c|c|c|c|}
\hline COLUMN & COLUMN & COLUMN & COLLMN \\
\hline 12.600000 & 3.0000000 & 1.0000000 & 2.0000000 \\
\hline 36.400000 & 8.0000000 & 6.0000000 & 7.0000000 \\
\hline 27.100000 & 6.0000000 & 4.0000000 & 5.0000000 \\
\hline 6.2000000 & 2.0000000 & 0 . & 1.0000000 \\
\hline 3.7000000 & 1.0000000 & 0 . & 1.0000000 \\
\hline
\end{tabular}

THE FOLLOWING VALUE SHOULD BE CLOSE TO OR EQUAL TO ONE.

1.0000000 
OMIITAB 80 TEST 25 CODE, RECODE AND REPLACE INSTRUCTIONS. (5.6)

COLLMN 2 HAS DEFINED BY THE RECODE COMMAND.

$\begin{array}{rr}\text { COLLMN } 1 & \text { COLUMN } \\ & 2 \\ 40.000000 & 1.0000000 \\ 48.000000 & 2.0000000 \\ 40.000000 & 1.0000000 \\ 49.000000 & 3.0000000 \\ 40.000000 & 1.0000000 \\ & \\ 48.000000 & 2.0000000 \\ 40.000000 & 1.0000000 \\ 49.000000 & 3.0000000 \\ 49.000000 & 3.0000000 \\ 48.000000 & 2.0000000 \\ 48.000000 & 2.0000000 \\ 49.000000 & 3.0000000 \\ 48.000000 & 2.0000000 \\ 48.000000 & 2.0000000 \\ 49.000000 & 3.0000000\end{array}$

THE FOLLORING VALUE SHOULD BE CLOSE TO OR EQUAL TO ONE.

1.0000000 
OMNITAB 80 TEST 25 CODE, RECODE AND REPLACE INSTRUCTIONS. (5.6)

PAGE - 3 COLUMNS 3 AND 5 WERE DEFINED BY THE REPLACE COMMAND.

\begin{tabular}{|c|c|c|c|c|}
\hline COLUMN & COLUMN & COLUMN & COLUMN & COLUMN \\
\hline-1.0000000 & 1.0000000 & 8.0000000 & 1.0000000 & 7.0000000 \\
\hline-9.0000000 & 2.0000000 & -9.0000000 & 1.0000000 & -9.0000000 \\
\hline 2.0000000 & 1.0000000 & 2.0000000 & 1.0000000 & 7.0000000 \\
\hline 5.0000000 & 3.0000000 & 5.0000000 & 1.0000000 & 5.0000000 \\
\hline-9.0000000 & 1.0000000 & -9.0000000 & 1.0000000 & -9.0000000 \\
\hline
\end{tabular}

THE FOLLOWING VALUE SHOULD BE CLOSE TO OR EQUAL TO ZERO.

0 . 
TITLE 1 COLLMNS 2, 3 AND 4 HERE DEFISED BY THE CODE COMMAID.

SET DATA IN COLLYN 1

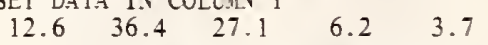

* isformatile diagiostic fOR the abole isstrlction -

NRVAX HAS BEEX RESET FROM O TO 5.

CODE COLLMN 1 STARTING AT 0.0 LSING LENGTH 5.0 AID PLT CODE IN COLLMN 2

CODE COLUM 1 STARTING AT 10.0 LSING LENGTH 5.0 AND PLT CODE IN COLLM 3

CODE COLLM 1 ISING LENGTH 5.0 AND PLT CODE IN COLLTK 4

PRINT COLLMNS $1,2,3$ AND 4

SLBTRACT COLLMN 4 FROM COLLYN 2 PLT RESLLTS IY COLUN 5

SPACE

NOTE

SPACE

YOTE THE FOLLORING VALle ShOLtd BE ClOSE TO OR EQLAL TO ONE.

SPACE

ABRIDGE ROT 1 OF COLLTN 5

SPACE

YOTE $* * * * * * * * * * * * * * * * * * * * * * * * * * * * * * * * * * * * * * *$

TITLE 1 COLLIM 2 THAS DEFINED BY THE RECODE COMMAID

SET DATA IN COLLYN 1

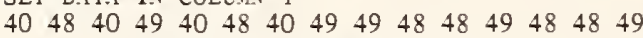

* inforyatite diagNostic for the abote instriction -

NRYAY HAS BEEY RESET FROM 5 TO 15.

RECODE COLLTA 1 INTO COLLTA 2

PRINT COLLMS 1 AID 2

SLY COLLM 2 PLT RESLIT IS COLLTN 3

SLBTRACT 1.0 FRON COLLMI 3 PLT RESLLTS IN" COLLMN 3

DIVIDE COLIMN 3 BY 30.0 PLT RESILT IN COLLMS 4

SPACE

YOTE

SPACE

SOTE THE FOLIORING VALLE SHOLLD BE CLOSE TO OR EQLAL TO ONE.

SPACE

ABRIDGE ROR 1 OF COLLMN 4

SPACE

YOTE $* * * * * * * * * * * * * * * * * * * * * * * * * * * * * * * * * * * * * * * * * * * * * *$

SET DATA IN COLLMN 1

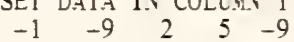

* INFORMATIVE DIAGMOSTIC FOR THE ABOVE IISTRLCTION -

NRMAY H.AS BEEY RESET FROM 15 TO 5.

REPLACE - 1.0 IN COLLN 1 BY 8.0 AND PLT IN COLLYN 3

REPLACE VALLES FROM -3.0 TO -3.0 IY COLLIN 1 BY 7.0 AND PLT IX COLLM 5 PRINT COLLMAS $1,23,4$ AND 5 
LIST OF DATA, INSTRUCTIONS AND DIAGNOSTICS

SUBTRACT COLUMN 5 FROM COLUMN 3 PUT RESULTS IN COLUMN 6

SPACE

NOTE

SPACE

NOTE THE FOLLOWING VALUE SHOULD BE CLOSE TO OR EQUAL TO ZERO.

SPACE

ABRIDGE ROW 2 OF COLUMN 6

SPACE

NOTE

NATIONAL BUREAU OF STANDARDS. WASHINGTON, D. C. 20234

OMNITAB 80 VERSION 6.00 MARCH 2,1981 
OMNITAB 80 TEST 26 MAXIMUM AND MINIMUM INSTRUCTIONS. (6.1) COLLYNS 1 AND 2 HERE DEFINED BY READ COMMAND

COLLMNS 3 THROUGH 8 RERE DEFINED BY THE MAXIMLY AND MINIMLY COMMANDS

PAGE 1

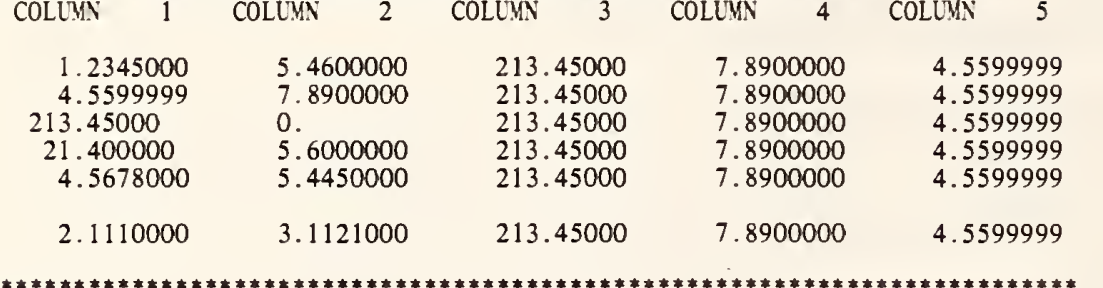

COLUMN 6

COLUMN 8

213.45000

213.45000

213.45000

213.45000

213.45000

THE FOLLOHING VALUE SHOULD BE CLOSE TO OR EQUAL TO 440.5845.

440.58450 
LIST OF DATA, INSTRUCTIONS AND DIAGNOSTICS

READ THE FOLLOWING VALUES INTO COLUMNS 1 AND 2

$\begin{array}{ll}1.2345 & 5.46 \\ 4.56 & 7.89 \\ 213.45 & 0.0 \\ 21.4 & 5.6 \\ 4.5678 & 5.445 \\ 2.111 & 3.1121\end{array}$

* INFORMATIVE DIAGNOSTIC FOR THE ABOVE INSTRUCTION NRMAX HAS BEEN RESET FROM O TO 6.

MAXIMUM VALUE OF COLUMN 1 IS STORED IN COLUMN 3 MAX OF COL 2 STORE IN COL 4 STORE CORRESPONDIN MINIMUM VALUE OF COLUMN I IS STORED IN COLUMN 6

MIN OF COL 2 STORE IN COL 7 STORE CORRESPONDING VALUE OF COL 1 INTO COL 8 TITLE1 COLUMNS 1 AND 2 WERE DEFINED BY READ COMMAND.

TITLE 3 COLUMNS 3 THROUGH 8 WERE DEFINED BY THE MAXIMUM AND MINIMUM TITLE4 COMMANDS.

PRINT THE VALUES IN COLUMNS $1 * * * 8$

RESET NRMAX 1

* INFORMATIVE DIAGNOSTIC FOR THE ABOVE INSTRUCTION NRMAX HAS BEEN RESET FROM 6 TO 1.

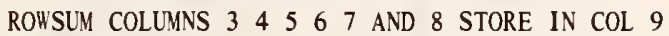
SPACE

NOTE

NOTE THE FOLLOWING VALUE SHOULD BE CLOSE TO OR EQUAL TO 440.5845.

SPACE

ABR IDGE ROW 1 OF COLUMN 9

SPACE

NOTE

NATIONAL BUREAU OF STANDARDS. WASHINGTON, D. C. 20234

OMNITAB 80 VERSION 6.00 MARCH 2,1981 


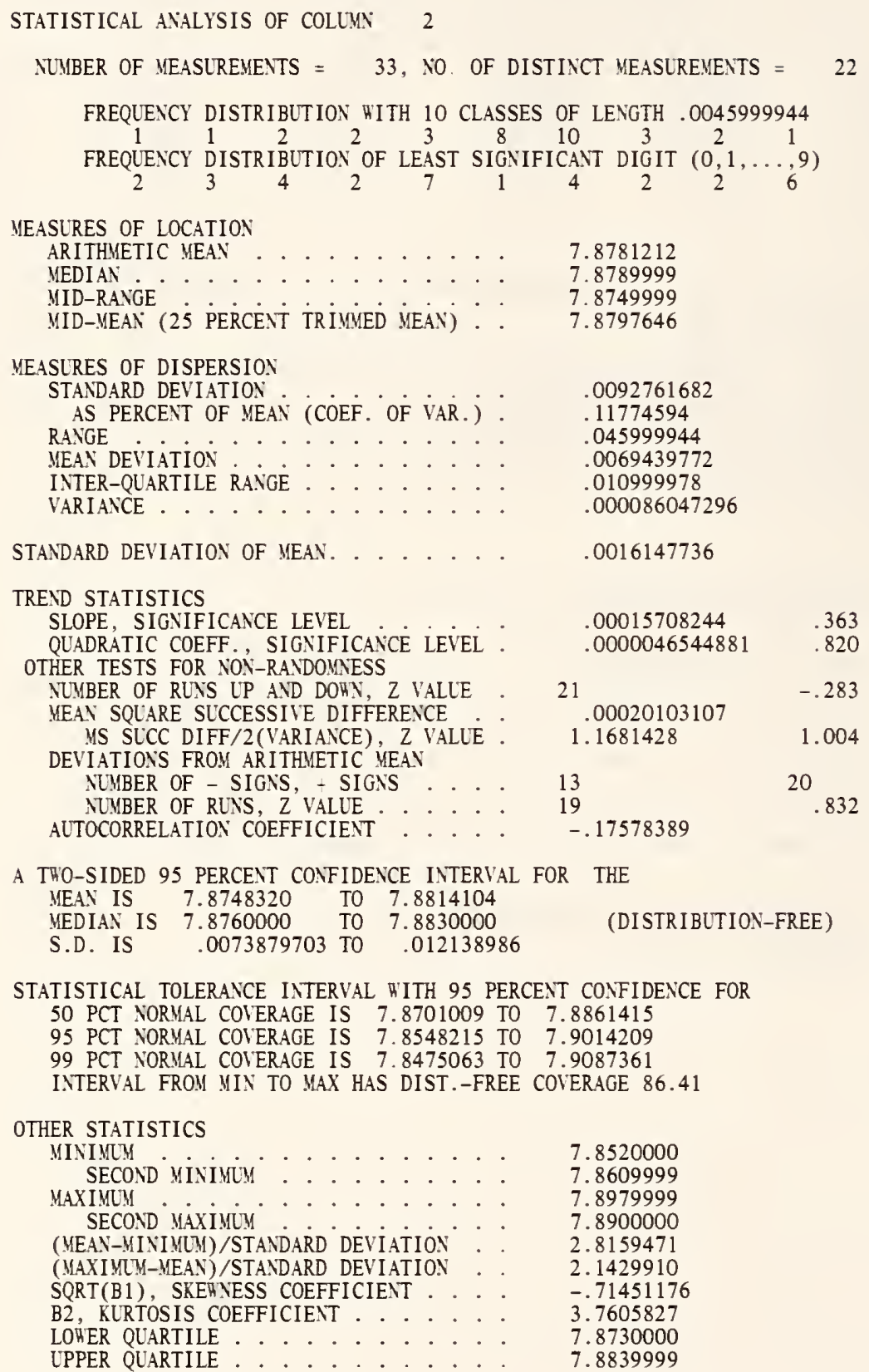

STATISTICAL TOLERANCE INTERVAL HITH 95 PERCENT CONFIDENCE FOR 50 PCT NORMAL COVERAGE IS 7.8701009 TO 7.8861415 95 PCT NORMAL COVERAGE IS 7.8548215 TO 7.9014209 99 PCT NORMAL COIERAGE IS 7.8475063 TO 7.9087361 INTERVAL FROM MIN TO MAX HAS DIST.-FREE COVERAGE 86.41

OTHER STATISTICS

MINIMLM

SECOND MINIVLY . . 7.8609999

MAXIMUY

SECOND MAXIMLY 7.8900000

(MEAN-MINIMUM)/STANDARD DEVIATION . . 2.8159471

(MAXIMLM-MEAN)/STANDARD DEVIATION . . 2.1429910

SQRT(B1), SREHXESS COEFFICIENT . . . - -.71451176

B2, KURTOSIS COEFFICIENT . . . 3.7605827

LOHER QUARTILE .......... . . . 7.8730000

UPPER QUARTILE ...... 7.8839999 
OMNITAB 80 TEST 27 STATISTICAL ANALYSIS. (6.3)

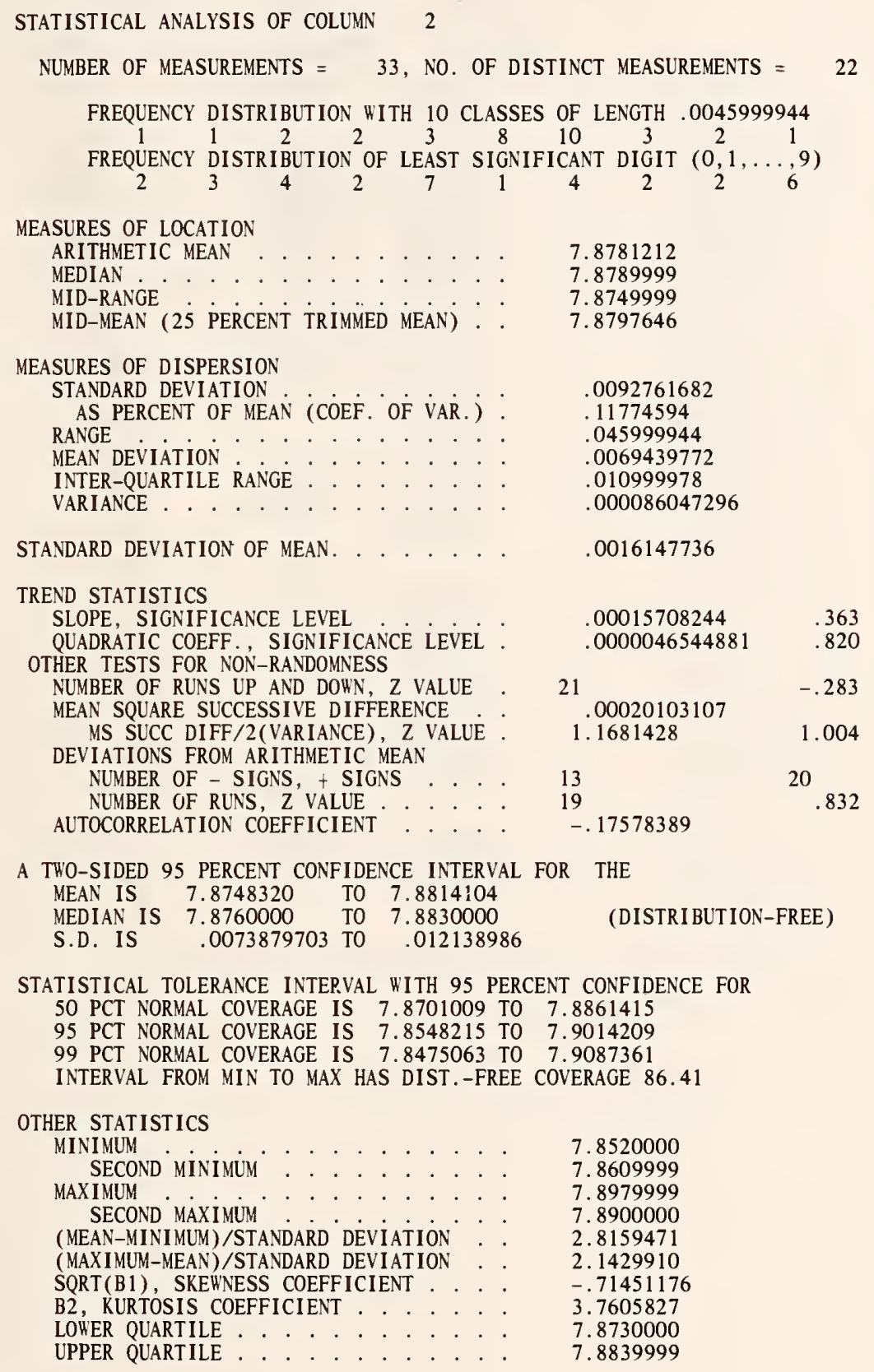


OBSERVATIONS

$X(I)$
7.8839999
7.8640000
7.8789999
7.8720000
7.8780000
7.8900000
7.8740000
7.8690000
7.8830000
7.8520000
7.8860000
7.8820000
7.8760000
7.8839999
7.8830000
7.8760000
7.8789999
7.8850000
7.8839999
7.8789999
7.8609999
7.8810000
7.8710000
7.8979999
7.8770000
7.8670000
7.8640000
7.8860000
7.8820000
7.8800000
7.8839999
7.8890000
7.8789999

RANK X(I)-MEAN

$25.5 \quad .00587875$

$3.5-.0141212$

$15.5 \quad .000878751$

$8.0-.00612122$

$13.0-.000121236$

$32.0 \quad .0118788$

$9.0-.00412124$

$6.0-.00912124$

$22.5 \quad .00487876$

$1.0-.0261212$

$29.5 \quad .00787878$

$20.5 \quad .00387877$

$10.5-.00212121$

$25.5 \quad .00587875$

$22.5 \quad 00487876$

$10.5-.00212121$

$15.5 \quad .000878751$

$28.0 \quad .00687879$

$25.5 \quad .00587875$

$15.5 \quad .000878751$

$2.0-.0171213$

$19.0 \quad .00287879$

$7.0-.00712121$

$33.0 \quad .0198787$

$12.0-.00112122$

$5.0-.0111212$

$3.5-.0141212$

$29.5 \quad .00787878$

$20.5 \quad .00387877$

$18.0 \quad .00187880$

$25.5 \quad .00587875$

$31.0 \quad .0108788$

$15.5 \quad .000878751$
ORDERED OBSERVATIONS

\begin{tabular}{rll} 
N0. & \multicolumn{1}{c}{$X(\mathrm{~J})$} & $X(\mathrm{~J}+1)-X(\mathrm{~J})$ \\
10 & 7.8520000 & .00899994 \\
21 & 7.8609999 & .00300002 \\
2 & 7.8640000 & 0. \\
27 & 7.8640000 & .00300002 \\
26 & 7.8670000 & .00199997 \\
8 & 7.8690000 & .00200003 \\
23 & 7.8710000 & $9.99987-04$ \\
4 & 7.8720000 & .00199997 \\
7 & 7.8740000 & .00200003 \\
13 & 7.8760000 & 0. \\
& & \\
16 & 7.8760000 & $9.99987-04$ \\
25 & 7.8770000 & $9.99987-04$ \\
5 & 7.8780000 & $9.99987-04$ \\
3 & 7.8789999 & 0. \\
17 & 7.8789999 & 0. \\
20 & 7.8789999 & 0. \\
33 & 7.8789999 & .00100005 \\
30 & 7.8800000 & $9.99987-04$ \\
22 & 7.8810000 & $9.99987-04$ \\
12 & 7.8820000 & 0. \\
& & \\
29 & 7.8820000 & $9.99987-04$ \\
9 & 7.8830000 & 0. \\
15 & 7.8830000 & $9.99987-04$ \\
1 & 7.8839999 & 0. \\
14 & 7.8839999 & 0. \\
19 & 7.8839999 & 0. \\
31 & 7.8839999 & .00100005 \\
18 & 7.8850000 & $9.99987-04$ \\
11 & 7.8860000 & 0. \\
28 & 7.8860000 & .00300002 \\
32 & 7.8890000 & $9.99987-04$ \\
6 & 7.8900000 & .00799996 \\
24 & 7.8979999 & \\
& &
\end{tabular}

FOLLOWING VALUES MUST BE EQUAL TO OR NEAR 7.580526, 7.87812, 0.0 AND 0.0 RESPECTIVELY.

7.5805213

$7.8781212 *-1.8062013-08$

0. 
OMNITAB 80 TEST 27 STATISTICAL ANALYSIS. (6.3)
RANGE
MEDIAN
STANDARD DEV.
.045999944
7.8789999
.0092761681

FOLLOWING VALUES ALL MUST BE EQUAL TO OR NEAR ZERO.

0 .

0 . $* 1.1641532-10$ 
OMNITAB 80 TEST 27 STATISTICAL ANALYSIS. (6.3)
COL 21
COL 22
COL 23

LOWER BOUNDARY UPPER BOUNDARY FREQUENCY

$\begin{array}{lll}7.8494444 & 7.8545555 & 1.0000000 \\ 7.8545555 & 7.8596666 & 0 . \\ 7.8596666 & 7.8647777 & 3.0000000 \\ 7.8647777 & 7.8698888 & 2.0000000 \\ 7.8698888 & 7.8749999 & 3.0000000 \\ & & \\ 7.8749999 & 7.8801110 & 9.0000000 \\ 7.8801110 & 7.8852221 & 10.000000 \\ 7.8852221 & 7.8903332 & 4.0000000 \\ 7.8903332 & 7.8954443 & 0 . \\ 7.8954443 & 7.9005554 & 1.0000000\end{array}$

THE RESULTS ABOVE IN COL 23 ARE DIFFERENT FROM THE FREQUENCIES IN THE STATISTICAL ANALYSIS PRINT OUT BECAUSE DIFFERENT METHODS FOR COMPUTING WERE USED.

THE FOLLOWING VALUES MUST BE EQUAL TO OR NEAR ZERO.

0 . -.00022140890 
OMNITAB 80 TEST 27 STATISTICAL ANALYSIS. (6.3)

HISTOGRAM WITH MID-POINTS IN COLUMN 26 , FREQUENCIES IN COLUMN 23

\begin{tabular}{|c|c|c|c|c|c|}
\hline MID-POINTS & $\mathrm{RCF}$ & $\mathrm{CF}$ & $\mathrm{RF}$ & \multicolumn{2}{|c|}{$\begin{array}{l}\text { FREQUENCY } \\
0--10---10---20\end{array}$} \\
\hline 7.8520000 & .030 & 1 & .030 & 1 & + \\
\hline 7.8571111 & .030 & 1 & .000 & 0 & \\
\hline 7.8622222 & .121 & 4 & .091 & 3 & $t+t$ \\
\hline 7.8673333 & .182 & 6 & .061 & 2 & tt \\
\hline 7.8724444 & .273 & 9 & .091 & 3 & $t+t$ \\
\hline 7.8775555 & .545 & 18 & .273 & 9 & $h+t+t+t+t$ \\
\hline 7.8826666 & .848 & 28 & .303 & 10 & $t+t+t+t+t+$ \\
\hline 7.8877777 & .970 & 32 & .121 & 4 & $t+t+$ \\
\hline 7.8928888 & .970 & 32 & .000 & 0 & \\
\hline 7.8979999 & 1.000 & 33 & .030 & 1 & + \\
\hline
\end{tabular}

RCF $=$ RELATIVE CUMULATIVE FREQUENCY

$\mathrm{CF}=$ CUMULATIVE FREQUENCY

$\mathrm{RF}=$ RELATIVE FREQUENCY

ABOVE PRINT OUT IS FROM HISTOGRAM COMMAND 
LIST OF DATA, INSTRUCTIONS AND DIAGNOSTICS

SET IN COL 2 THE FOLLOWING DATA

$7.884,7.864,7.879,7.872,7.878,7.890,7.874,7.869,7.883,7.852$

$7.886,7.882,7.876,7.884,7.883,7.876,7.879,7.885,7.884,7.879$

$7.861,7.881,7.871,7.898,7.877,7.867,7.864,7.886,7.882,7.880$

$7.884,7.889,7.879$

* informative diagnOSTIC FOR THE abOVE INSTRUCTION NRMAX HAS BEEN RESET FROM O TO 33.

BRIEF

STATISTICAL ANALYSIS OF COL 2

FULL

STATISTICAL ANALYSIS OF COL 2

SSTATISTICAL ANALYSIS OF COL 2 STORE RESULTS IN COLS 3, 4, 5 AND 6

RANKS OF COL 2 STORE RESULTS IN COL 10

SUBTRACT COL 10 FROM COL 4 STORE IN COL 11

AVERAGE COL 11 STORE IN COL 11

AVERAGE COL 3 STORE IN COL 4

AVERAGE COL 5 STORE IN COL 5

AVERAGE COL 6 STORE IN COL 6

SPACE 2

NOTE ***

SPACE

NOTE FOLLOWING VALUES MUST BE EQUAL TO OR NEAR 7.580526, 7.87812, 0.0

NOTE AND 0.0 RESPECTIVELY.

SPACE

ABRIDGE ROW 1 OF COLS 456611

SPACE

NOTE

RANGE OF NUMBERS IN COL 2 PUT IN COL 1

MEDIAN OF NUMBERS IN COL 2 PUT RESULT IN COL 41

STDDEVIATION OF NUMBER IN COL 2 PUT RESULT IN COL 42

NEW PAGE

NOTE RANGE MEDIAN STANDARD DEV.

SPACE

1 4 (ND) 42

ABRIDGE

SPACE 5

FROM VALUE IN *11,3* PUT IN COL 1

COL 41 FROM VALUE IN *5,3* PUT IN COL 41

SUBTRACT COL 42 FROM VALUE IN *9,3* PUT IN COL 42

VOTE $* * * * * * * * * * * * * * * * * * * * * * * * * * * * * * * * * * * * * * * * * * * * * * * * * * * * * * * * * * * * * * * * * * * * * * * * * * *$

SPACE

NOTE FOLLOWING VALUES ALL MUST BE EQUAL TO OR NEAR ZERO.

SPACE

ABRIDGE ROW 1 OF COLUMNS 14142

SPACE

NOTE $* * * * * * * * * * * * * * * * * * * * * * * * * * * * * * * * * * * * * * * * * * * * * * * * * * * * * * * * * * * * * * * * *$

FREQUENCY OF COL 2, 10 CELLS LOHER BND IN COL 21 UPPER IN COL 22 FREQ IN COL 23

* inFORMATIVE DIAGNOSTIC FOR THE ABOVE INSTRUCTION NRMAX HAS BEEN RESET FROM 33 TO 10. 
LIST OF DATA, INSTRUCTIONS AND DIAGNOSTICS

MOVE ROW 51 OF COL 3 SIZE $10 X 1$ TO ROW 1 OF COL 24

SUM COL 24 STORE IN COL 24

SUM COL 23 STORE IN COL 25

SUBTRACT COL 25 FROM COL 24 STORE IN COL 25

NEW PAGE

NOTE

$\operatorname{COL} 21$

COL 22

COL 23

SPACE

NOTE LOWER BOUNDARY UPPER BOUNDARY FREQUENCY

SPACE

NPRINT 212223

ADD COL 21 TO COL 22 MULTIPLY BY .5 ADD 0.0 AND STORE IN COL 26

RESET NRMAX TO 1

* INFORMATIVE DIAGNOSTIC FOR THE ABOVE INSTRUCTION NRMAX HAS BEEN RESET FROM 10 TO 1.

SUBTRACT 1.0 FROM VALUE IN *2,3* STORE IN COL 30

SQUARE VALUE IN *21,3* STORE IN COL 31

F PROBABILITY OF 1.0 AND COL 30 DEG OF FREEDOM IN COL 31 STORE IN COL 32

SUBTRACT VALUE IN *22,3* FROM COL 32 STORE IN COL 32

SPACE

NOTE1 THE RESULTS ABOVE IN COL 23 ARE DIFFERENT FROM THE FREQUEN

NOTE2CIES IN THE STATISTICAL ANALYSIS PRINT OUT BECAUSE

PRINT NOTE

NOTE DIFFERENT METHODS FOR COMPUTING WERE USED

SPACE 2

NOTE $* * * * * * * * * * * * * * * * * * * * * * * * * * * * * * * * * * * * * * * * * * * * * * * * * * * * * * * * * * * * * * * * * * * * *$

SPACE

NOTE THE FOLLOWING VALUES MUST BE EQUAL TO OR NEAR ZERO.

SPACE

ABRIDGE ROW 1 OF COL 2532

SPACE

NOTE $* * * * * * * * * * * * *$
RESET NRMAX TO 10

* informative diagnostic fOR the abOVE INSTRUCTION NRMAX HAS BEEN RESET FROM 1 TO 10.

HISTOGRAM MID PTS IN COL 26 FREQ. IN COL 23

SPACE 5

NOTE ABOVE PRINT OUT IS FROM HISTOGRAM COMMAND

NATIONAL BUREAU OF STANDARDS. WASHINGTON, D. C. 20234

OMNITAB 80 VERSION 6.00 MARCH 2,1981 
LEAST SQUARES FIT OF RESPONSE, COLUMN 2 ,

AS A POLYNOMIAL OF DEGREE 3. INDEPENDENT VARIABLE IS COLLMN 1 USING 7 NON-ZERO WEIGHTS $=1.0000000$

\begin{tabular}{|c|c|c|c|c|c|c|c|}
\hline ROW & $\begin{array}{l}\text { INDEP VAR. } \\
\text { COLUMN }\end{array}$ & $\begin{array}{l}\text { RESPONSE } \\
\text { COLUMN } 2\end{array}$ & $\begin{array}{l}\text { PREDICTED } \\
\text { RESPONSE }\end{array}$ & $\begin{aligned} \text { STD. } & \text { DEV. OF } \\
\text { PRED. } & \text { RESPONSE }\end{aligned}$ & RESIDUALS & $\begin{array}{l}\text { STD. } \\
\text { RES. }\end{array}$ & WEIGHTS \\
\hline $\begin{array}{l}1 \\
2 \\
3 \\
4 \\
5 \\
5 \\
6 \\
7\end{array}$ & $\begin{array}{l}10.000000 \\
20.000000 \\
30.000000 \\
40.000000 \\
50.000000 \\
60.000000 \\
70.000000\end{array}$ & $\begin{array}{c}3.4000000 \\
11.700000 \\
37.200000 \\
80.099999 \\
151.40000 \\
253.20000 \\
392.60000\end{array}$ & $\begin{array}{c}3.2380953 \\
12.326190 \\
36.290476 \\
80.714285 \\
151.18095 \\
253.27381 \\
392.57619\end{array}$ & $\begin{array}{l}.72044574 \\
.50285847 \\
.50285847 \\
.43165123 \\
.50285847 \\
.50285847 \\
.72044574\end{array}$ & $\begin{array}{r}.16190474 \\
-.62619044 \\
.90952384 \\
-.61428591 \\
.21904787 \\
-.073809660 \\
.023809552\end{array}$ & $\begin{array}{r}.81 \\
-1.13 \\
1.64 \\
-1.01 \\
.40 \\
-.13 \\
.12\end{array}$ & $\begin{array}{l}1.000 \\
1.000 \\
1.000 \\
1.000 \\
1.000 \\
1.000 \\
1.000\end{array}$ \\
\hline
\end{tabular}

DIAGNOSTIC INFORMATION FOR IDENTIFYING INFLUENTIAL MEASUREMENTS.

$\mathbf{I}=$ ROW, FOR 7 LARGEST VALUES, $\mathrm{T}(\mathrm{I})=$ STANDARDIZED RESIDUAL,

$\mathrm{H}(\mathbf{I})=$ DIAGONAL OF HAT MATR IX, $\quad \mathrm{D}(\mathbf{I})=$ COOK STATISTIC, WSSD $(I)=$ DANIEL-WOOD STATISTIC, V(I) $=$ VAR(YHAT) $/$ VAR (RESIDUAL $)$.

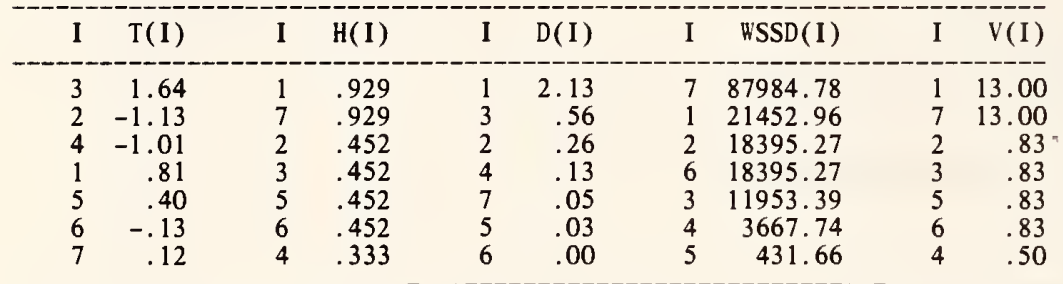

THE DURBIN-WATSON STATISTIC IS D $=3.6324348$ 
OMNITAB 80 TEST 28 POLYFIT INSTRUCTION. (6.4)

EXAMPLE FROM NBS HANDBOOK 91, PAGE 6-27.

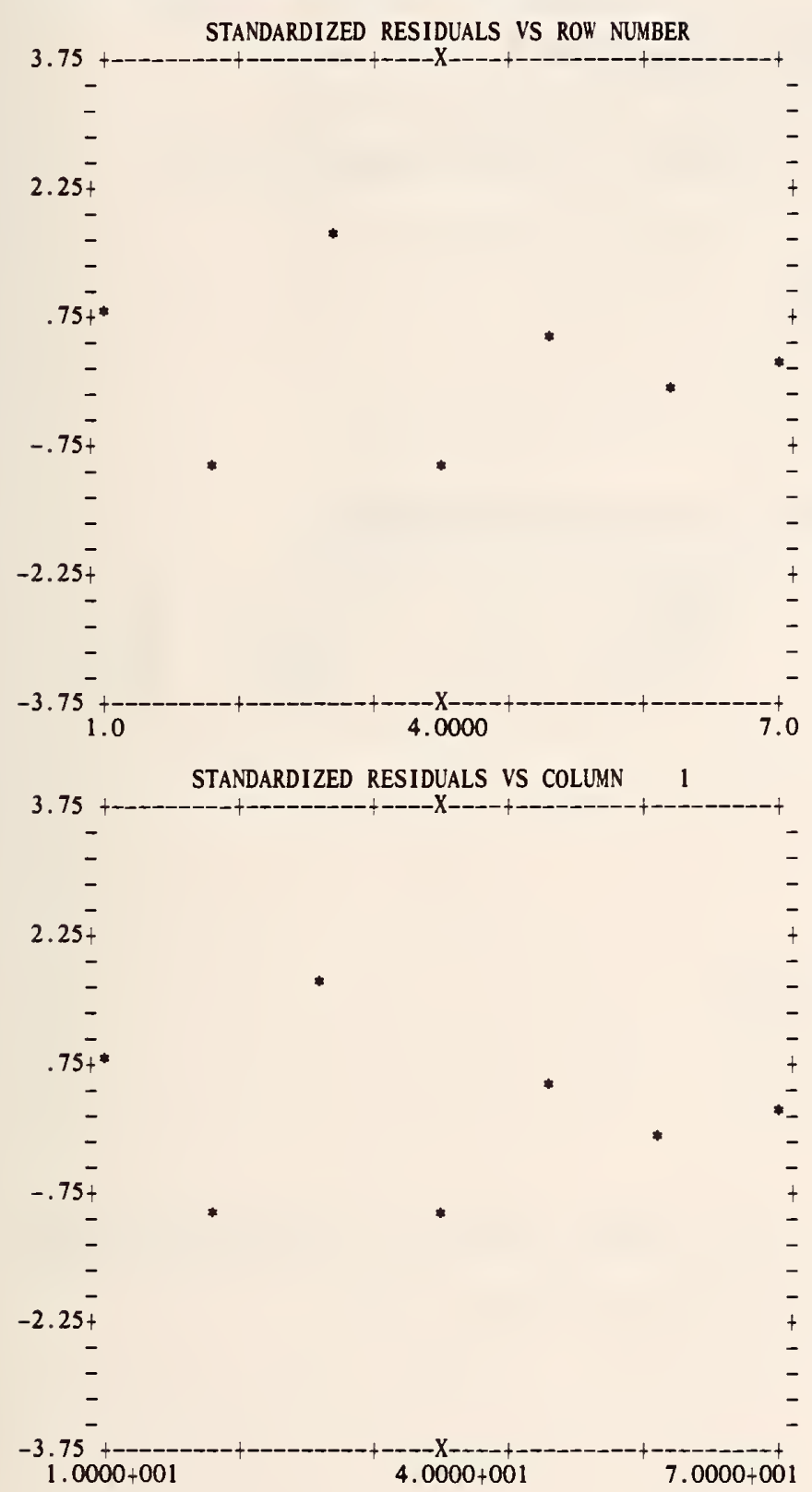

PAGE 2
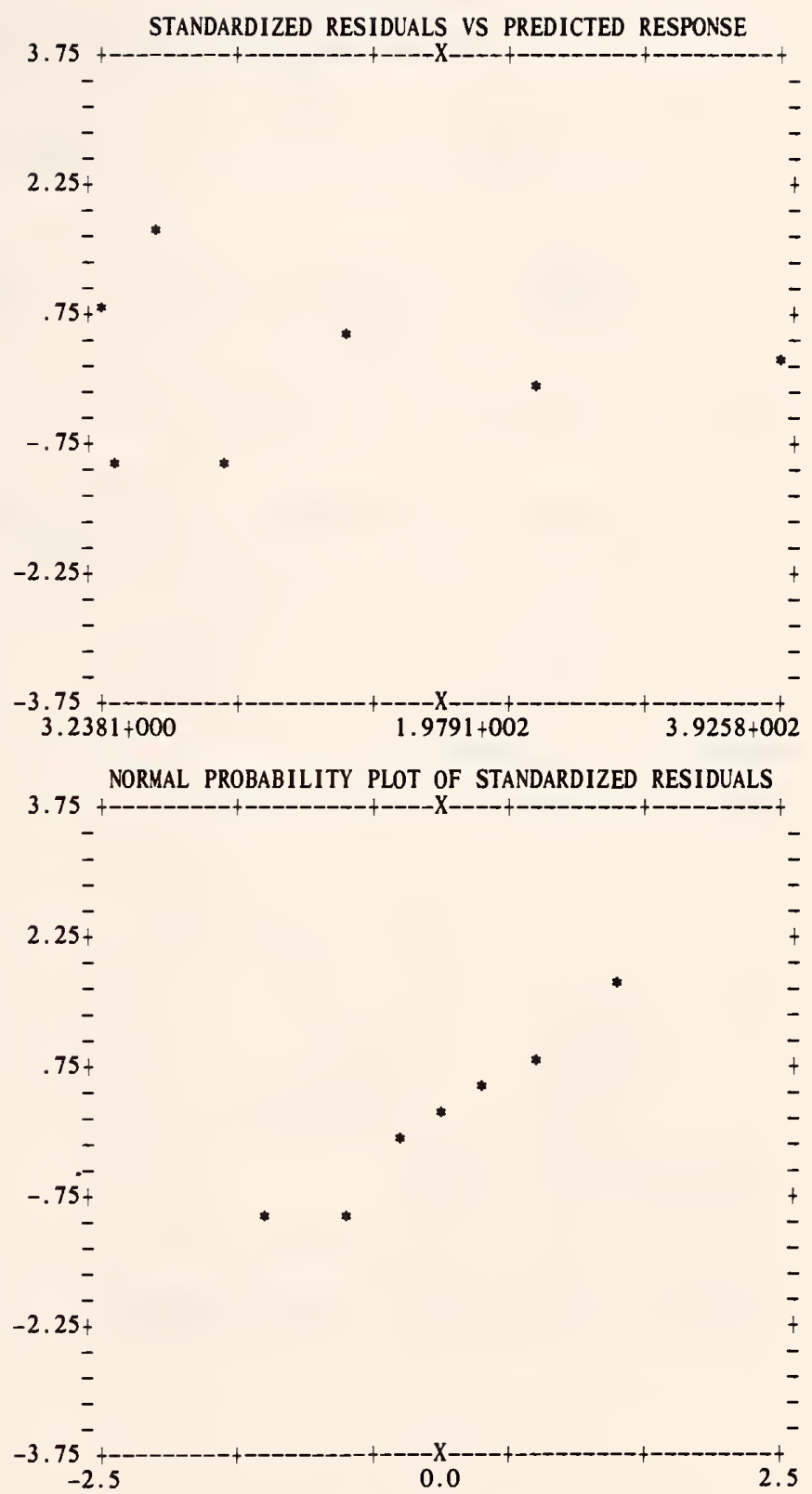
LEAST SQUARES FIT OF RESPONSE, COLUMN 2,

AS A POLYNOMIAL OF DEGREE 3. INDEPENDENT VAR IABLE IS COLUMN 1

USING 7 NON-ZERO NEIGHTS $=1.0000000$

SAMPLE VARIANCE-COVARIANCE MATRIX OF THE ESTIMATED COEFFICIENTS WITH CORRELATIONS ABOVE THE DIAGONAL.

$\begin{array}{ccccc}\text { TERM } & 0 & 1 & 2 & 3 \\ 0 & 4.7113046 & -.9547 & .8960 & -.8437 \\ 1 & -.45382909 & .047959634 & -.9835 & .9524 \\ 2 & .011977894 & -.0013264408 & 3.7929996-05 & -.9912 \\ 3 & -9.3161392-05 & 1.0610048-05 & -3.1053798-07 & 2.5878165-09\end{array}$

THERE ARE NO REPLICATIONS FOR A LACK OF FIT ANALYSIS OF VARIANCE.

ANALYSIS OF VARIANCE

-DEPENDENT ON ORDER INDEPENDENT VARIABLES ARE ENTERED, UNLESS VECTORS ARE ORTHOGONAL-

\begin{tabular}{|c|c|c|c|c|c|c|c|}
\hline TERM & SS=RED. DUE TO COEF & CUM. RESIDUAL MS & D.F. & $\mathrm{F}(\mathrm{COEF}=0)$ & $P(F)$ & $\mathrm{F}(\mathrm{COEFS}=0)$ & $P(F)$ \\
\hline $\begin{array}{l}0 \\
1 \\
2 \\
3\end{array}$ & $\begin{array}{c}123450.88 \\
111232.82 \\
14242.838 \\
187.04163\end{array}$ & $\begin{array}{rl}20944 & .063 \\
2886 & .3113 \\
47 & .179633 \\
. & 55896837\end{array}$ & $\begin{array}{l}6 \\
5 \\
4 \\
3\end{array}$ & $\begin{array}{r}220854.850 \\
198996.625 \\
25480.580 \\
334.619\end{array}$ & $\begin{array}{l}.000 \\
.000 \\
.000 \\
.000\end{array}$ & $\begin{array}{r}111416.669 \\
74937.274 \\
12907.599 \\
334.619\end{array}$ & $\begin{array}{l}.000 \\
.000 \\
.000 \\
.000\end{array}$ \\
\hline RESIDUAL & 1.6769051 & & 3 & & & & \\
\hline TOTAL & 249115.26 & & 7 & & & & \\
\hline
\end{tabular}

ESTIMATES FROM LEAST SQUARES FIT

\begin{tabular}{ccccc} 
TERM & COEFFICIENT & S.D. OF COEFF & RATIO & ACCURACY* \\
\hline 0 & 3.4428573 & 2.1705540 & 1.59 & 6.24 \\
1 & -.29900796 & .21899688 & -1.37 & 6.05 \\
2 & .018547619 & .0061587333 & 3.01 & 6.32 \\
3 & .00093055554 & .000050870586 & 18.29 & 7.03 \\
\hline RESIDUAL STANDARD DEVIATION & &
\end{tabular}

*THE NUMBER OF CORRECTLY COMPUTED DIGITS IN EACH COEFFICIENT USUALLY DIFFERS BY LESS THAN 1 FROM THE NUMBER GIVEN HERE.

THE NUMBER OF ITERATIONS WAS 2. SCALING WAS NOT USED.

THE AVERAGE NUMBER OF DIGITS IN AGREEMENT BETWEEN INITIAL SOLUTION AND IST ITERATION IS 6.02. 
OMNITAB 80 TEST 28 POLYFIT INSTRUCTION. (6.4)

PAGE 4

EXAMPLE FROM NBS HANDBOOK 91, PAGE 6-27.

THE CORRECT COEFFICIENTS (TO 8 SIGNIFICANT DIGITS) FOR A THIRD

DEGREE POLYNOMIAL FIT TO THE GIVEN DATA ARE

$3.4428571,-.29900794, .018547619$ AND .00093055556.

THE CORRECT RESIDUAL STANDARD DEVIATION IS . 74764180 .

THE FOLLOWING VALUES MUST BE EQUAL TO OR NEAR ZERO.

$$
0 .^{*}-3.7252903-08 * 4.6566129-10
$$

0 .

0.

THE DATA USED ABOVE ARE FROM N. B. S. HANDBOOK 91, 'EXPERIMENTAL STATISTICS,' PAGES 6-27.

THE RELATIONSHIP OF THE FOURIER COEFFICIENTS TO LEAST SQUARES PROBLEMS IS GIVEN IN DAVIS AND RABINOWITZ'S 'ADVANCES IN ORTHONORMALIZING

COMPUTATION,' A CHAPTER IN 'ADVANCES IN COMPUTERS,' EDITED BY

FRANZ ALT, PUBLISHED BY ACADEMIC PRESS, 1961. 
OMNITAB 80 TEST 28 POLYFIT INSTRUCTION. (6.4)

EXAMPLE FROM NBS HANDBOOK 91, PAGE 6-27.

$$
\begin{array}{rlrrl}
\mathrm{N} & \text { COEFFS. } \$ & \text { RESIDUALS \$\$ } & \text { SD OF PRED.Y } & \text { FOURIER \$\$\$ } \\
1.0 & 3.4428573 & .16190474 & .72044574 * 1.2345088+05 \\
2.0 & -.29900796 & -.62619044 & .50285847 * 1.1123282+05 \\
3.0 & .018547619 & .90952384 & .50285847 * 1.4242838+04 \\
4.0 & 9.3055554-04 & -.61428591 & .43165123 * 1.8704163+02 \\
5.0 & 2.1705540 & .21904787 & .50285847 & 1.6769051 \\
& & & & \\
6.0 & .21899688 & -.073809660 & .50285847 * 2.4911526+05 \\
7.0 & .0061587333 & .023809552 & .72044574 & \\
8.0 * 5.0870586-05 & & & \\
9.0 & 7.0000000 & & & \\
10 . & 4.0000000 & & & \\
11 . & 3.0000000 & & & \\
12 . & .74764188 & & & \\
13 . & .55896837 & & & \\
14 . & .99998666 & & &
\end{array}
$$

VARIANCE - COVARIANCE MATRIX.

$$
\begin{array}{llccc}
\text { 1. } & 4.7113046 & -.45382909 & .011977894 *-9.3161392-05 \\
\text { 2. } & -.45382909 & .047959634 & -.0013264408 * 1.0610048-05 \\
\text { 3. } & .011977894 & -.0013264408 * 3.7929996-05 & * 3.1053798-07 \\
\text { 4. } & * 9.3161392-05 * 1.0610048-05 *-3.1053798-07 * 2.5878165-09
\end{array}
$$

ABOVE OUTPUT IS A PRINT OUT OF THE INFORMATION STORED IN COLS 3-6, 11-14.

$\$ \quad \mathrm{~N}=1, \ldots, 4$ COEFFICIENTS.

$\mathrm{N}=5, \ldots, 8$ STANDARD DEVIATIONS OF THE COEFFICIENTS.

$\mathrm{N}=9$ NUMBER OF NON-ZERO WEIGHTS

$\mathrm{N}=10$ DEGREE PLUS 1 .

$\mathrm{N}=11$ DEGREES OF FREEDOM FOR RESIDUAL STANDARD DEV.

$\mathrm{N}=12$ RESIDUAL STANDARD DEV.

$\mathrm{N}=13$ RESIDUAL VARIANCE.

$\mathrm{N}=14$ MULTIPLE CORRELATION COEFF. SQUARED.

$\$ \$ N=1, \ldots, 7$ RESIDUALS: DEVS. OF PRED. VALUES FROM MEASUREMENTS.

S\$\$ $\mathrm{N}=1, \ldots, 4$ SQUARED FOURIER COEFFICIENTS

$\mathrm{N}=5$ RESIDUAL SUM OF SQUARES

$\mathrm{N}=6$ TOTAL SUM OF SQUARES. 
LIST OF DATA, INSTRUCTIONS AND DIAGNOSTICS

TITLE1EXAMPLE FROM NBS HANDBOOK 91, PAGE 6-27.

SET X IN COLUMN 1

$102030 \quad 40506070$

* INFORMATIVE DIAGNOSTIC FOR THE ABOVE INSTRUCTION -

NRMAX HAS BEEN RESET FROM 0 TO 7.

SET Y IN COLUMN 2

$\begin{array}{lllllll}3.4 & 11.7 & 37.2 & 80.1 & 151.4 & 253.2 & 392.6\end{array}$

POLYFIT Y IN COL 2 WTS 1 . DEG $3, X$ IN 1 PUT COEF 3 RES 4 SD PV 5 FC 6 VC $(1,11)$

$\$$ SD PV DENOTES STANDARD DEVIATIONS OF PREDICTED VALUES

$\$$ FC DENOTES FOURIER COEFFICIENTS

$\$$ VC DENOTES VARIANCE COVARIANCE MATRIX

HEAD 4/RESIDUALS \$\$

HEAD 3/COEFFS. \$

HEAD 5/SD OF PRED.Y

HEAD 6/FOURIER S\$S

NEW PAGE

NOTE $* * * * * 2$

SPACE

NOTE THE CORRECT COEFFICIENTS (TO 8 SIGNIFICANT DIGITS) FOR A THIRD

NOTE DEGREE POLYNOMIAL FIT TO THE GIVEN DATA ARE

SPACE

NOTE $3.4428571,-.29900794, .018547619$ AND .00093055556.

NOTE

NOTE THE CORRECT RESIDUAL STANDARD DEVIATION IS .74764180.

SPACE

NOTE THE FOLLOWING VALUES MLST BE EQUAL TO OR NEAR ZERO.

SPACE

RESET NRMAX 1

* INFORMATIVE DIAGNOSTIC FOR THE ABOVE INSTRUCTION -

NRMAX HAS BEEN RESET FROM 7 TO 1

SUBTRACT 3.4428573 FROM VALUE IN *1,3* STORE IN COL 20 SUBTRACT -.29900792 FROM VALUE IN *2,3* STORE IN COL 21 SUBTRACT .018547619 FROM VALUE IN *3,3* STORE IN COL 22 SUBTRACT .93055555-3 FROM VALUE IN *4,3* STORE IN COL 23 SUBTRACT .74764188 FROM VALUE IN *12,3* STORE IN COL 24 ABRIDGE ROW 1 COL $20^{* * *} 24$ SPACE

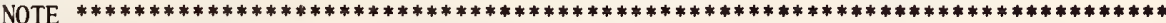
NOTE

NOTE THE DATA USED ABOVE ARE FROM N. B. S. HANDBOOK 91, 'EXPERIMENTAL

NOTE STATISTICS,' PAGES 6-27.

NOTE

NOTE THE RELATIONSHIP OF THE FOURIER COEFFICIENTS TO LEAST SOUARES PROBLEMS IS

NOTE GIVEN IN DAVIS AND RABINOWITZ'S 'ADVANCES IN ORTHONORMALIZING

NOTE COMPUTATION,' A CHAPTER IN 'ADVANCES IN COMPUTERS,' EDITED BY

NOTE FRANZ ALT, PUBLISHED BY ACADEMIC PRESS, 1961. 
OMNITAB 80 TEST 28 POLYFIT INSTRUCTION. (6.4)

LIST OF DATA, INSTRUCTIONS AND DIAGNOSTICS

GENERATE FROM 1 IN STEPS OF 1 THRU 14 IN COL 20

* informative diagnostic FOR THE abOVE INSTRUCTION NRMAX HAS BEEN RESET FROM 1 TO 14.

HEAD $20 \%$

PRINT COL 20 WITH 2. SIG DIGITS, COLS $3 * * 6$ WITH 8.0 SIG DIGITS

SPACE

NOTE VARIANCE - COVARIANCE MATRIX.

SPACE

RESET NRMAX 4

* INFORMATIVE DIAGNOSTIC FOR THE ABOVE INSTRUCTION NRMAX HAS BEEN RESET FROM 14 TO 4.

NPRINT COL 20 WITH 1. SIG DIGIT, COLS 11***14 WITH 8.0 SIG DIGITS

SPACE 2

NOTE ABOVE OUTPUT IS A PRINT OUT OF THE INFORMATION STORED IN COLS 3-6, 11-14.

SPACE

NOTE $\$ \quad \mathrm{~N}=1, \ldots, 4 \quad$ COEFFICIENTS

NOTE $\mathrm{N}=5, \ldots, 8$ STANDARD DEVIATIONS OF THE COEFFICIENTS.

NOTE $\quad \mathrm{N}=9$ NUMBER OF NON-ZERO WEIGHTS.

NOTE $\quad \mathrm{N}=10$ DEGREE PLUS 1.

NOTE $\mathrm{N}=11$ DEGREES OF FREEDOM FOR RESIDUAL STANDARD DEV.

NOTE $\mathrm{N}=12$ RESIDUAL STANDARD DEV.

NOTE $\quad \mathrm{N}=13$ RESIDUAL VARIANCE.

NOTE $\quad \mathrm{N}=14$ MULTIPLE CORRELATION COEFF. SQUARED.

SPACE

NOTE $\$$

SPACE

NOTE $\$ \$ \$ \quad N=1, \ldots, 4$ SQUARED FOURIER COEFFICIENTS.

NOTE $N=5$ RESIDUAL SUM OF SQUARES.

NOTE $\quad \mathrm{N}=6$ TOTAL SUM OF SQUARES.

NATIONAL BUREAU OF STANDARDS. WASHINGTON, D. C. 20234 OMNITAB 80 VERSION 6.00 MARCH 2,1981 
OMNITAB 80 TEST 29 ONEWAY AND SONEWAY INSTRUCTIONS. (6.6) AUTOMATIC OUTPUT FROM THE COMMAND ONEWAY.

ONEWAY ANALYSIS OF 30 MEASUREMENTS IN COLUMN CLASSIFIED INTO 6 GROUPS WITH NUMBERS IN COLUMN

1

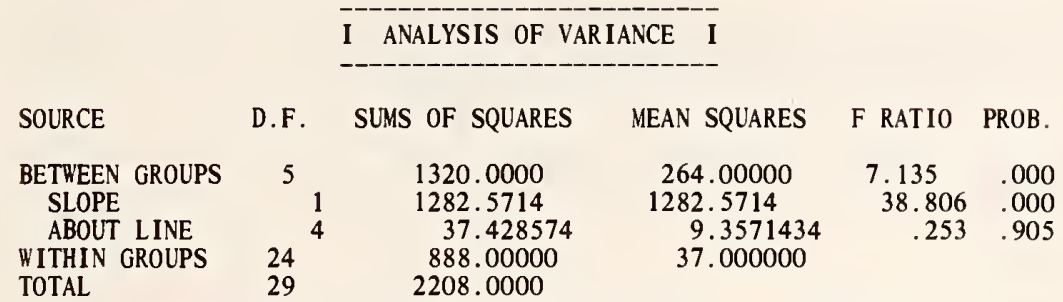

KRUSKAL-WALLIS RANK TEST FOR DIFFERENCE BETWEEN MEANS SIGNIFICANCE LEVEL IS APPROXIMATELY .001

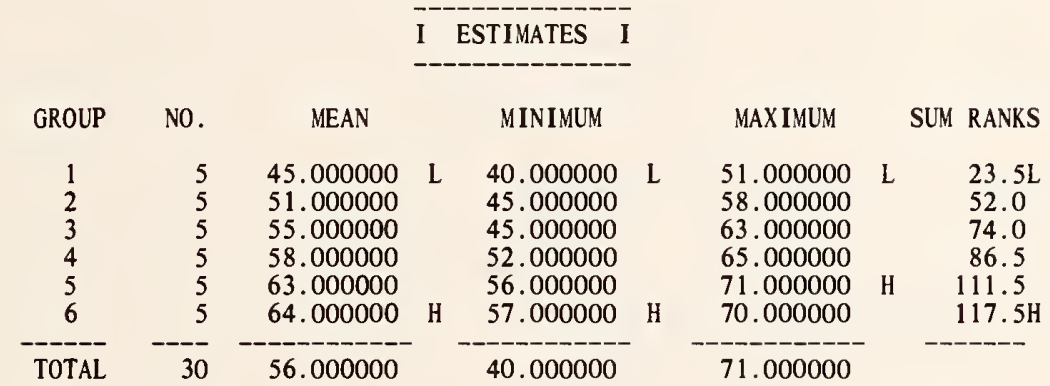

GROUP WITHIN S.D. S.D. OF MEAN 95 PCT CONF INT FOR MEAN

\begin{tabular}{|c|c|c|c|c|c|c|}
\hline $\begin{array}{r}1 \\
2 \\
3 \\
4 \\
5 \\
6 \\
\text { MODEL }\end{array}$ & $\begin{array}{l}4.3011627 \\
6.0415230 \\
7.6485293 \\
6.0415230 \\
6.6708320 \\
5.2440442 \\
\end{array}$ & L & $\begin{array}{l}1.9235384 \\
2.7018512 \\
3.4205263 \\
2.7018512 \\
2.9832868 \\
2.3452079\end{array}$ & $\mathrm{H}$ & 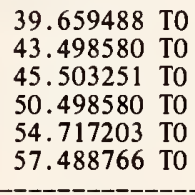 & $\begin{array}{l}50.340512 \\
58.501420 \\
64.496749 \\
65.501419 \\
71.282797 \\
70.511234\end{array}$ \\
\hline $\begin{array}{l}\text { FIXED } \\
\text { RANDOM } \\
\text { UNGROUPED }\end{array}$ & $\begin{array}{l}6.0827625 \\
7.2663608 \\
8.7257051\end{array}$ & & $\begin{array}{l}1.1105554 \\
2.9664794 \\
1.5930885\end{array}$ & & $\begin{array}{l}53.707927 \text { T0 } \\
48.374538 \text { T0 } \\
52.741768\end{array}$ & $\begin{array}{l}58.292073 \\
63.625462 \\
59.258232\end{array}$ \\
\hline
\end{tabular}


OMNITAB 80 TEST 29 ONEWAY AND SONEWAY INSTRUCTIONS. (6.6)

$$
\text { I PAIRWISE MULTIPLE COMPARISION OF MEANS I }
$$

THE MEANS ARE PUT IN INCREASING ORDER IN GROUPS SEPARATED BY ***. A MEAN IS ADJUDGED NON-SIGNIFICANTLY DIFFERENT FROM ANY MEAN IN THE SAME GROUP AND SIGNIFICANTLY DIFFERENT AT THE .05 LEVEL FROM ANY MEAN IN ANOTHER GROUP. ***** INDICATES ADJACENT GROUPS HAVE NO COMMON MEAN

- NEWMAN-KEULS TECHNIQUE, HARTLEY MODIFICATION

(APPROXIMATE, IF THE NUMBERS OF MEASUREMENTS IN THE GROUPS DIFFER)

$45.000000, \quad 51.000000$

***

$51.000000,55.000000, \quad 58.000000$

$55.000000, \quad 58.000000, \quad 63.000000, \quad 64.000000$

- SCHEFFE TECHNIQUE -

$45.000000,51.000000,55.000000, \quad 58.000000$

$1.000000, \quad 55.000000, \quad 58.000000,63.000000, \quad 64.000000$

$$
\text { I TESTS FOR HOMOGENEITY OF VARIANCES I }
$$

COCHRAN'S C $=$ MAX VARIANCE/SUM(VARIANCES) $=.2635$, APPROX SL $=.853$

BARTLETT-BOX F $=.272$, SIGNIFICANCE LEVEL $=.929$

MAXIMUM VARIANCE / MINIMUM VARIANCE $=3.1621621$

I MODEL II - COMPONENTS OF VARIANCE I

ESTIMATE OF BETWEEN COMPONENT OF VARIATION IS 45.400000 
OMNITAB 80 TEST 29 ONEWAY AND SONEWAY INSTRUCTIONS. (6.6) AUTOMATIC OUTPUT FROM THE COMMAND ONEWAY.

\section{BOX PLOTS I}

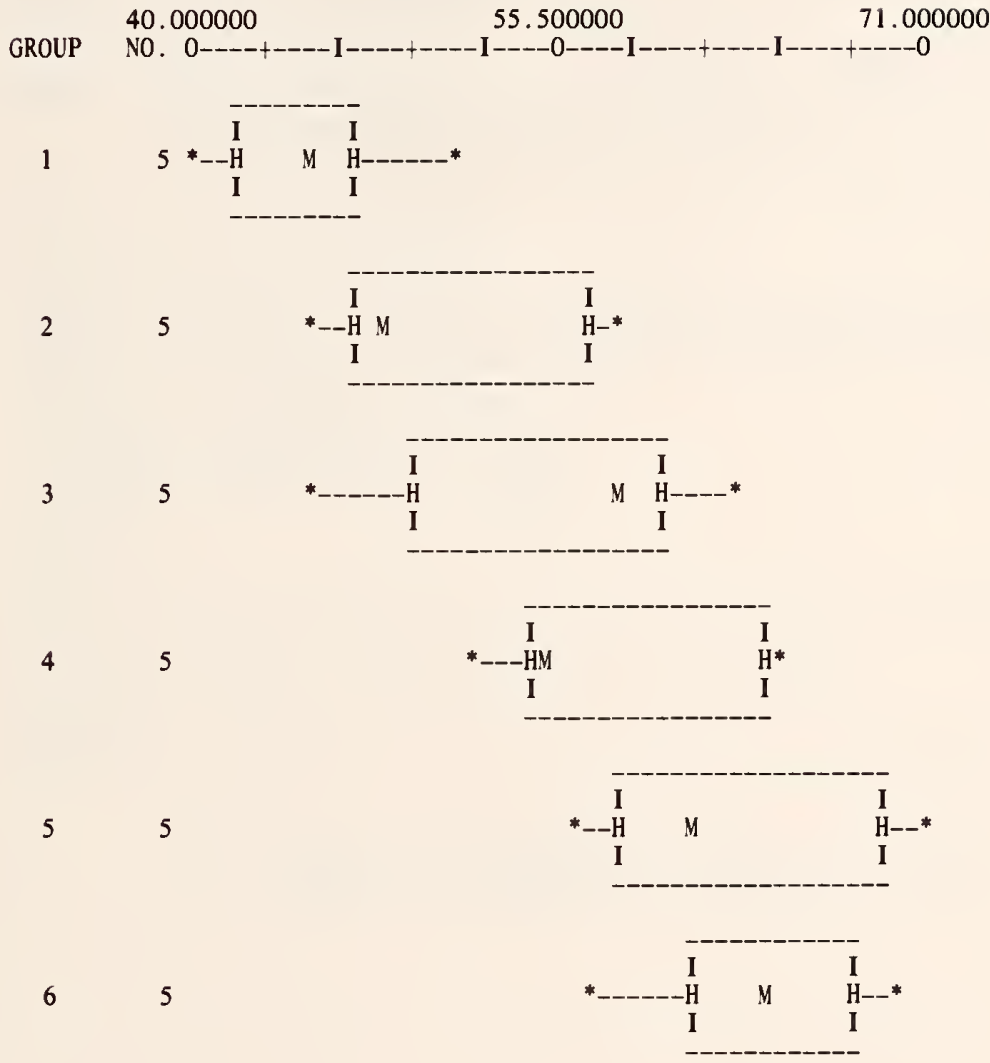




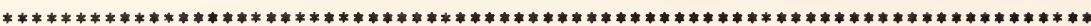
THE FOLLOWING VALUES MUST BE EQUAL TO OR NEAR ZERO.

0 .

0 .
0.

0. 
LIST OF DATA, INSTRUCTIONS AND DIAGNOSTICS

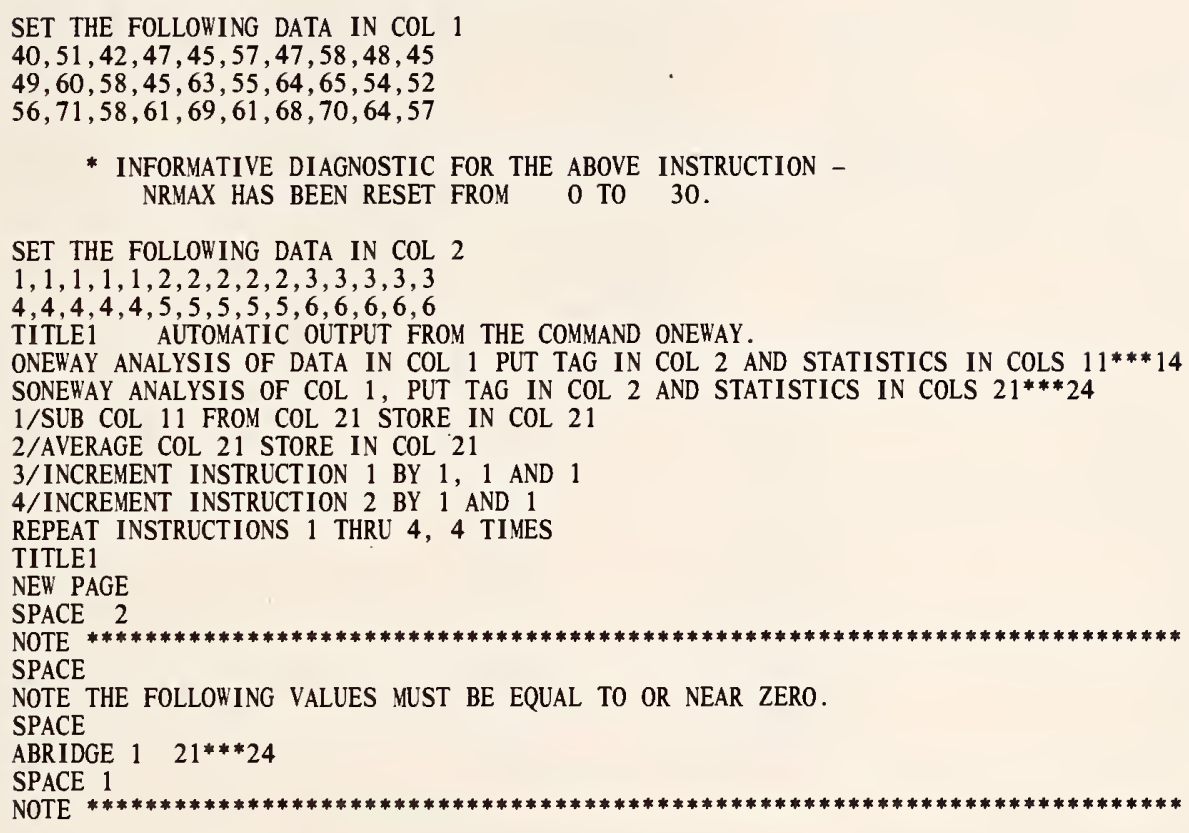

SET THE FOLLOWING DATA IN COL 2

$1,1,1,1,1,2,2,2,2,2,3,3,3,3,3$

$4,4,4,4,4,5,5,5,5,5,6,6,6,6,6$

TITLE1 AUTOMATIC OUTPUT FROM THE COMMAND ONEWAY.

ONEWAY ANALYSIS OF DATA IN COL 1 PUT TAG IN COL 2 AND STATISTICS IN COLS 11***14

SONEWAY ANALYSIS OF COL 1 , PUT TAG IN COL 2 AND STATISTICS IN COLS $21^{* * * 24}$

$1 /$ SUB COL 11 FROM COL 21 STORE IN COL 21

2/AVERAGE COL 21 STORE IN COL 21

3/INCREMENT INSTRUCTION 1 BY 1,1 AND 1

4/INCREMENT INSTRUCTION 2 BY 1 AND 1

REPEAT INSTRUCTIONS 1 THRU 4, 4 TIMES

TITLE1

NEW PAGE

SPACE 2

NOTE

SPACE

NOTE THE FOLLOWING VALUES MUST BE EQUAL TO OR NEAR ZERO.

SPACE

ABR IDGE $1 \quad 21 * * * 24$

SPACE 1

NOTE

NATIONAL BUREAU OF STANDARDS. WASHINGTON, D. C. 20234 OMNITAB 80 VERSION 6.00 MARCH 2,1981 
ANALYSIS OF VARIANCE FOR TWOWAY $3 \times \quad 4$ TABLE OF COLUMN 11

\begin{tabular}{|c|c|c|c|c|c|}
\hline SOURCE & D.F. & SUMS OF SQUARES & MEAN SQUARES & F RATIO & F PROB \\
\hline $\begin{array}{l}\text { BETWEEN ROHS } \\
\text { BETHEEN COLS } \\
\text { RESIDUALS } \\
\text { TOTAL }\end{array}$ & $\begin{array}{r}2 \\
3 \\
6 \\
11\end{array}$ & $\begin{array}{l}7.1666666 \\
24.916667 \\
22.833333 \\
54.916667\end{array}$ & $\begin{array}{l}3.5833333 \\
8.3055556 \\
3.8055555\end{array}$ & $\begin{array}{r}.942 \\
2.182\end{array}$ & $\begin{array}{l}.528 \\
.191\end{array}$ \\
\hline \multicolumn{6}{|c|}{ TUKEY'S TEST FOR NON-ADDITIVITY } \\
\hline $\begin{array}{l}\text { NON-ADDITIVITY } \\
\text { BALANCE } \\
\text { RESIDUALS }\end{array}$ & $\begin{array}{l}1 \\
5 \\
6\end{array}$ & $\begin{array}{c}7.9069895 \\
14.926344 \\
22.833333\end{array}$ & $\begin{array}{l}7.9069895 \\
2.9852688 \\
3.8055555\end{array}$ & 2.649 & .165 \\
\hline
\end{tabular}

\begin{tabular}{lccr} 
COEFFICIENT & ESTIMATE & RANK SUM \\
\hline GRAND & MEAN & 2.4166667 & \\
\hline ROW & 1 & $1.0833333 \mathrm{H}$ & $10.0 \mathrm{H}$ \\
ROW & 2 & $-.66666666 \mathrm{~L}$ & $7.0 \mathrm{~L}$ \\
ROW & 3 & -.41666666 & $7.0 \mathrm{~L}$ \\
\hline COLUMN & 1 & $2.2500000 \mathrm{H}$ & $11.0 \mathrm{H}$ \\
COLUMN & 2 & $-1.4166667 \mathrm{~L}$ & $5.0 \mathrm{~L}$ \\
COLUMN & 3 & -1.0833333 & $5.0 \mathrm{~L}$ \\
COLUMN & 4 & .25000001 & 9.0 \\
\hline
\end{tabular}

$\begin{array}{rrrrr}\text { SAMPLE STANDARD DEVIATIONS } & \ldots & \text { RANK SUM TEST STATISTICS } \ldots \\ \text { GRAND MEAN }= & .56314263 & \text { ROWS }- \text { KENDALL W } & = \\ \text { ROW EFFECT }= & .79640394 & & \text { FRIEDMAN CHISQ }= & 1.500 \\ \text { COL EFFECT }= & .97539166 & \text { COLS }- \text { KENDALL W } & = \\ \text { RESIDUAL } & 1.9507833 & & \text { FRIEDMAN CHISQ }= & 5.400\end{array}$

$3 \times \quad 4$ TABLE OF RESIDUALS, STANDARDIZED BY DIVIDING EACH RESIDUAL BY ITS STANDARD DEVIATION.

$\begin{array}{crrrr}\underset{\text { ROW }}{\text { COLUMN }} & 1 & 2 & 3 & 4 \\ 1 & 1.63 & -.06 & -1.03 & -.54 \\ 2 & -1.45 & .48 & -.48 & 1.45 \\ 3 & -.18 & -.42 & 1.51 & -.91\end{array}$

THE ABOVE OUTPUT IS FROM THE COMMAND TWONAY. 


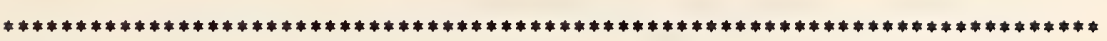

THE FOLLOWING VALUES MUST BE EQUAL TO OR NEAR ZERO.

$\begin{array}{lll}0 . & 0 . & 0 . \\ 0 . & 0 . & 0 .\end{array}$

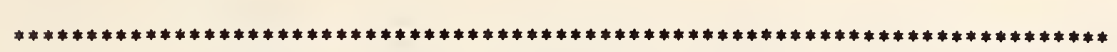


SET DATA IN COLUMN 11

$\begin{array}{llll}8 & 2 & 1 & 3 \\ 2 & 1 & 0 & 4 \\ 4 & 0 & 3 & 1\end{array}$

* INFORMATIVE DIAGNOSTIC FOR THE ABOVE INSTRLCTION IRMAX HAS BEEY RESET FROM 0 TO 12.

THOHAY ANALYSIS FOR 3 BY 4 TABLE, DATA IN COL 11, STORE IN 31 AND SLCC. COLS SFIT Y IN COL 11 HTS $=1$. FOR 6 VAR. IN COLS $31^{* * * 36}$ PUT IN COLS $41^{* * * 44} \mathrm{R}=1, \mathrm{C}=45$ RESET IRIAX 40

* INFORMATIVE DIAGNOSTIC FOR THE ABOVE INSTRUCTION NRMAX HAS BEEI RESET FROY 12 TO 40.

1/SLBTRACT COL 38 FROM COL 42, PUT INI COL 51

2/INCREMENT INSTRLCTION 1 BY 1,1 AID 1

3/AVERAGE COL 51 STORE IN COL 51

4/INCREMENT INSTRLCTION 3 BY 1 AND 1

PERFORY INSTRUCTIONS 1 THRU 4,3 TIMES

SPACE 2

NOTE THE ABOVE OUTPLT IS FROM THE COMMAND THOHAY.

NEW PAGE

NOTE

SPACE

NOTE THE FOLLOHING VALLES MUST BE EQUAL TO OR IEAR ZERO.

SPACE

ABRIDGE ROT 1 OF COLS 515253

MOVE DATA IN ROH 1 OF COL 37 SIZE $30 \times 4$ TO ROH 1 OF COL 41

RESET IRMAX 12

* inforMative diagiostic for the above instrLCtion IRVAX HAS BEEN RESET FROM 40 TO 12.

STHOHAY ANALYSIS FOR 3 BY 4 TABLE, DATA IN COL 11, STORE IN 31 AID SLCC. COLS RESET NRMAX 40

* inforyative diagiostic fOr the abOVE iNSTRLCTION NRYAX HAS BEEY RESET FROM 12 TO 40.

1/SUBTRACT COL 38 FROM COL 42, PUT IN COL 51

3/AVERAGE COL 51 STORE IN COL 51

PERFORY INSTRLCTIONS 1 THRU 4,3 TIMES

ABRIDGE ROH 1 OF COLS 515253

SPACE

NOTE

NATIONAL BLREAU OF STANDARDS. HASHINGTON, D. C. 20234 ONNITAB 80 VERSION 6.00 MARCH 2,1981 


\section{CORRELATION ANALYSIS FOR 7 VARIABLES WITH 16 OBSERVATIONS} SIMPLE CORRELATION COEFFICIENTS

$\begin{array}{ccccccc}\text { COLUMN } & 1 & 2 & 3 & 4 & 5 & 6 \\ 1 & 1.0000 & & & & & \\ 2 & .9916 & 1.0000 & & & & \\ 3 & .6206 & .6043 & 1.0000 & & & \\ 4 & .4647 & .4464 & -.1774 & 1.0000 & & \\ 5 & .9792 & .9911 & .6866 & .3644 & 1.0000 & \\ 6 & .9911 & .9953 & .6683 & .4172 & .9940 & 1.0000 \\ 8 & .9708 & .9835 & .5024 & .4570 & .9604 & .9713 \\ \text { COLUMN } & 8 & & & & & \\ 8 & 1.0000 & & & & & \end{array}$

SIGNIFICANCE LEVELS OF SIMPLE CORRELATION COEFF'S (ASSUMING NORMALITY)

$\begin{array}{ccccccc}\text { COLUMN } & 1 & 2 & 3 & 4 & 5 & 6 \\ 1 & .0000 & & & & & \\ 2 & .0000 & .0000 & & & & \\ 3 & .0103 & .0132 & .0000 & & & \\ 4 & .0697 & .0830 & .5109 & .0000 & & \\ 5 & .0000 & .0000 & .0033 & .1652 & .0000 & \\ 6 & .0000 & .0000 & .0047 & .1078 & .0000 & .0000 \\ 8 & .0000 & .0000 & .0473 & .0751 & .0000 & .0000 \\ \text { COLUMN } & 8 & & & & & \\ 8 & .0000 & & & & & \\ \text { PARTIAL CORRELATION } & \text { COEFFICIENTS } & \text { HITH } & 5 & \text { REMAINING VARIABLES FIXED } \\ \text { COLUMN } & 1 & 2 & 3 & 4 & 5 & 6 \\ 1 & 1.0000 & & & & & \\ 2 & .6296 & 1.0000 & & & & \\ 3 & .3712 & -.7952 & 1.0000 & & & \\ 4 & .2316 & -.5177 & -.8783 & 1.0000 & & \\ 5 & -.6525 & .7592 & .3876 & .0391 & 1.0000 & \\ 6 & -.1560 & .7213 & .9376 & .8527 & -.1753 & 1.0000 \\ 8 & .0554 & -.3344 & -.8080 & -.8479 & -.0717 & .7993 \\ \text { COLUMN } & 8 & & & & & \end{array}$


SIGNIFICANCE LEVELS OF PARTIAL CORRELATION COEF'S (ASSUMING NORMALITY)

$\begin{array}{ccccccc}\text { COLUMN } & 1 & 2 & 3 & 4 & 5 & 6 \\ 1 & .0000 & & & & & \\ 2 & .0379 & .0000 & & & & \\ 3 & .2610 & .0034 & .0000 & & & \\ 4 & .4931 & .1029 & .0004 & .0000 & & \\ 5 & .0295 & .0067 & .2389 & .9091 & .0000 & \\ 6 & .6468 & .0122 & .0000 & .0009 & .6061 & .0000 \\ 8 & .8715 & .3148 & .0026 & .0010 & .8340 & .0032 \\ \text { COLUMN } & 8 & & & & & \\ 8 & .0000 & & & & & \end{array}$

SPEARMAN RANK CORRELATION COEFFICIENTS (ADJUSTED FOR TIES)

\begin{tabular}{|c|c|c|c|c|c|c|}
\hline COLUMN & 1 & 2 & 3 & 4 & 5 & 6 \\
\hline $\begin{array}{l}1 \\
2 \\
3 \\
4 \\
5 \\
6 \\
8\end{array}$ & $\begin{array}{r}1.0000 \\
.9971 \\
.6647 \\
.2206 \\
.9971 \\
.9971 \\
.9824\end{array}$ & $\begin{array}{r}1.0000 \\
.6382 \\
.2235 \\
.9941 \\
.9941 \\
.9853\end{array}$ & $\begin{array}{r}1.0000 \\
-.3412 \\
.6853 \\
.6853 \\
.5647\end{array}$ & $\begin{array}{r}1.0000 \\
.2265 \\
.2265 \\
.2265\end{array}$ & $\begin{array}{r}1.0000 \\
1.0000 \\
.9765\end{array}$ & $\begin{array}{r}1.0000 \\
.9765\end{array}$ \\
\hline COLUMN & 8 & & & & & \\
\hline 8 & 1.0000 & & & & & \\
\hline \multicolumn{7}{|c|}{$\begin{array}{l}\text { SIGNIFICANCE LEVEL OF QUADRATIC FIT OVER LINEAR FIT } \\
\text { BASED ON F RATIO WITH } 1 \text { AND } 13 \text { DEGREES OF FREEDOM } \\
\text { (FOR EXAMPLE . } 1099 \text { IS THE SIGNIFICANCE LEVEL OF THE } \\
\text { QUADRATIC TERM WHEN COLUMN } 2 \text { IS FITTED TO COLUMN 1) }\end{array}$} \\
\hline COLUMN & 1 & 2 & 3 & 4 & 5 & 6 \\
\hline $\begin{array}{l}1 \\
2 \\
3 \\
4 \\
5 \\
6 \\
8\end{array}$ & $\begin{array}{l}1.0000 \\
.1099 \\
.0560 \\
.0007 \\
.0013 \\
.0896 \\
.8852\end{array}$ & $\begin{array}{r}.0465 \\
1.0000 \\
.1795 \\
.0018 \\
.0027 \\
.8106 \\
.3038\end{array}$ & $\begin{array}{r}.4560 \\
.5834 \\
1.0000 \\
.2827 \\
.5545 \\
.6234 \\
.7556\end{array}$ & $\begin{array}{r}.0001 \\
.0001 \\
.0028 \\
1.0000 \\
.0002 \\
.0001 \\
.0001\end{array}$ & $\begin{array}{r}.0009 \\
.0068 \\
.4280 \\
.0108 \\
1.0000 \\
.0000 \\
.0444\end{array}$ & $\begin{array}{l}.1908 \\
.6670 \\
.1796 \\
.0030 \\
.0000 \\
1.0000 \\
.6047\end{array}$ \\
\hline
\end{tabular}




$\begin{array}{cc}\text { COLUMN } & 8 \\ 1 & .6482 \\ 2 & .4973 \\ 3 & .1435 \\ 4 & .0006 \\ 5 & .0920 \\ 6 & .5806 \\ 8 & 1.0000\end{array}$

CONFIDENCE INTERVALS FOR SIMPLE CORRELATION COEFF'S (FISHER APPROX, 95 PER CENT LIMITS BELOW DIAGONAL, 99 PER CENT LIMITS ABOVE DIAGONAL

\begin{tabular}{|c|c|c|c|c|c|c|}
\hline COLUMN & 1 & 2 & 3 & 4 & 5 & 6 \\
\hline 1 & $\begin{array}{r}99.0000 \\
95.0000\end{array}$ & $\begin{array}{c}9980 \\
.9654\end{array}$ & .0116 & $\begin{array}{r}.8390 \\
-.2080\end{array}$ & .915850 & .9979 \\
\hline 2 & $\begin{array}{c}9972 \\
.9753\end{array}$ & $\begin{array}{r}99.0000 \\
95.0000\end{array}$ & -.01468 & -.2300 & $\begin{array}{c}9979 \\
.9633\end{array}$ & $\begin{array}{l}.9989 \\
.9804\end{array}$ \\
\hline 3 & $\begin{array}{l}.8537 \\
.1804\end{array}$ & $\begin{array}{c}.8464 \\
.1550\end{array}$ & $\begin{array}{l}99.0000 \\
95.0000\end{array}$ & -.7132 & .1263 & $\begin{array}{c}.9090 \\
.0929\end{array}$ \\
\hline 4 & -.0402 & -.0633 & $\begin{array}{r}.3490 \\
-.6187\end{array}$ & $\begin{array}{r}99.0000 \\
95.0000\end{array}$ & $\begin{array}{l}.7992 \\
-.3207\end{array}$ & $\begin{array}{r}.8206 \\
-.2637\end{array}$ \\
\hline 5 & $\begin{array}{c}.9929 \\
.9394\end{array}$ & $\begin{array}{r}9970 \\
.9738\end{array}$ & $\begin{array}{l}.8821 \\
.2893\end{array}$ & -.1602 & $\begin{array}{l}99.0000 \\
95.0000\end{array}$ & $\begin{array}{l}.9985 \\
.9750\end{array}$ \\
\hline 6 & $\begin{array}{c}9970 \\
.9740\end{array}$ & $\begin{array}{l}.9984 \\
.9860\end{array}$ & $\begin{array}{l}.8743 \\
.2580\end{array}$ & $\begin{array}{r}.7565 \\
-.0989\end{array}$ & $\begin{array}{l}.9980 \\
.9822\end{array}$ & $\begin{array}{l}99.0000 \\
95.0000\end{array}$ \\
\hline 8 & .91500 & $\begin{array}{l}.9944 \\
.9518\end{array}$ & $\begin{array}{l}.7991 \\
.0090\end{array}$ & -.0500 & $\begin{array}{l}.9865 \\
.8869\end{array}$ & .9171 \\
\hline COLUMN & 8 & & & & & \\
\hline 1 & $\begin{array}{l}.9929 \\
.8834\end{array}$ & & & & & \\
\hline 2 & $\begin{array}{c}9960 \\
.9329\end{array}$ & & & & & \\
\hline 3 & -.1605 & & & & & \\
\hline 4 & $\begin{array}{r}.8361 \\
-.2174\end{array}$ & & & & & \\
\hline 5 & .89904 & & & & & \\
\hline
\end{tabular}


OMNITAB 80 TEST 31 CORRELATION AND SCORRELATION INSTRUCTIONS. (6.7)

PAGE 4

$6 \quad .9930$

.8853

$8 \quad 99.0000$

95.0000 
THE OUTPUT ON THE PREVIOUS PAGE IS THE AUTOMATIC PRINT OUT OF CORRELATION.

THE DATA USED IN THIS PROBLEM WAS TAKEN FROM AN ARTICLE BY

JAMES W. LONGLEY IN ' JOURNAL OF THE AMERICAN STATISTICAL

ASSOCIATION', VOL. 62, (1967), PAGES 819-841.

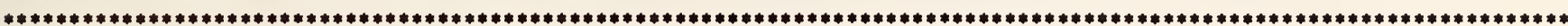

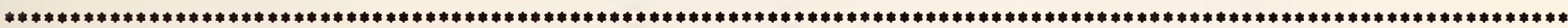

THE FOLLONING VALUES MUST BE EQUAL TO OR NEAR ZERO.

0 .
0 .

0.
0.

0. 
LIST OF DATA, INSTRUCTIONS AND DIAGNOSTICS

$\begin{array}{lcccccccc}\text { READ } & \text { DATA INTO COLS } & 1^{* * * 8} & & & & \\ 83.0 & 234289 & 2356 & 1590 & 107608 & 1947 & 347873.0 & 60343 \\ 88.5 & 259426 & 2325 & 1456 & 108632 & 1948 & 373875.5 & 61122 \\ 88.2 & 258054 & 3682 & 1616 & 109773 & 1949 & 375162.2 & 60171 \\ 96.2 & 328975 & 2099 & 3099 & 112075 & 1951 & 448295.2 & 63221 \\ 89.5 & 284599 & 3351 & 1650 & 110929 & 1950 & 402568.5 & 61187 \\ 98.1 & 346999 & 1932 & 3594 & 113270 & 1952 & 467845.1 & 63639 \\ 99.0 & 365385 & 1870 & 3547 & 115094 & 1953 & 487948.0 & 64989 \\ 100.0 & 363112 & 3578 & 3350 & 116219 & 1954 & 488313.0 & 63761 \\ 101.2 & 397469 & 2904 & 3048 & 117388 & 1955 & 522865.2 & 66019 \\ 104.6 & 419180 & 2822 & 2857 & 118734 & 1956 & 545653.6 & 67857 \\ 108.4 & 442769 & 2936 & 2798 & 120445 & 1957 & 571013.4 & 68169 \\ 110.8 & 444546 & 4681 & 2637 & 121950 & 1958 & 575882.8 & 66513 \\ 112.6 & 482704 & 3813 & 2552 & 123366 & 1959 & 614506.6 & 68655 \\ 114.2 & 502601 & 3931 & 2514 & 125368 & 1960 & 636488.2 & 69564 \\ 115.7 & 518173 & 4806 & 2572 & 127852 & 1961 & 655479.7 & 69331 \\ 116.9 & 554894 & 4007 & 2827 & 130081 & 1962 & 693887.9 & 70551\end{array}$

* INFORMATIVE DIAGNOSTIC FOR THE ABOVE INSTRUCTION NRMAX HAS BEEN RESET FROM O TO 16.

CORRELATION 7 VARIABLES IN COLS $1 * * * 6,8$ PUT IN ROW 1 OF COL 9 , ROW 8 OF COL 9 SCORRELATION 7 VARIABLES IN COLS $1^{* * * 6,8}$ PUT IN ROW 1 COL 19 AND ROW 8 COL 19 RESET NRMAX TO 14

* informative diagnostic FOR THE abOVE inStRUCTION NRMAX HAS BEEN RESET FROM 16 TO 14.

NEW PAGE

$\operatorname{NOTE} 1 * * * * * * * * * * * * * * * * * * * * * * * * * * * * * * * * * * * * * * * * * * * * * * * * * * * * * * * * * * * * * * * * * * * * * * * * * * *$ $\operatorname{NOTE} 2 * * * * * * * * * * * * * * * * * * * * * * * * * * * * * * * * * * * * * * * * * * * * * * * * * * * * * * * * * * * * *$

PRINT NOTE

SPACE

NOTE THE OUTPUT ON THE PREVIOUS PAGE IS THE AUTOMATIC PRINT OUT OF CORRELATION.

NOTE THE DATA USED IN THIS PROBLEM WAS TAKEN FROM AN ARTICLE BY

NOTE JAMES W. LONGLEY IN 'JOURNAL OF THE AMER ICAN STATISTICAL

NOTE ASSOCIATION', VOL. 62, (1967), PAGES 819-841.

SPACE

PRINT NOTE

1/SUBTRACT COL 9 FROM COL 19 STORE IN COL 19

2/AVERAGE COL 19 STORE IN COL 19

3/INCREMENT INSTRUCTION 1 BY 111 AND 1

4/ INCREMENT INSTRUCTION 2 BY 1 AND 1

REPEAT INSTRUCTIONS 1 THRU 4,7 TIMES

SPACE 2

PRINT NOTE

SPACE

NOTE THE FOLLOWING VALUES MUST BE EOUAL TO OR NEAR ZERO.

SPACE

ABRIDGE ROW 1 COLS $19 * * * 25$ 
OMNITAB 80 TEST 31 CORRELATION AND SCORRELATION INSTRUCTIONS. (6.7)

LIST OF DATA, INSTRUCTIONS AND DIAGNOSTICS

SPACE

PRINT NOTE

NATIONAL BUREAU OF STANDARDS. WASHINGTON, D. C. 20234

OMNITAB 80 VERSION 6.00 MARCH 2, 1981 


\begin{tabular}{|c|c|c|c|c|}
\hline \multicolumn{5}{|c|}{ 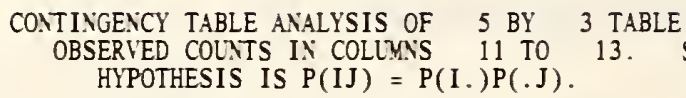 } \\
\hline $\begin{array}{l}\mathrm{COL} \\
\mathrm{ROW}\end{array}$ & 11 & 12 & 13 & TOTALS \\
\hline \multirow[t]{2}{*}{1} & $\begin{array}{l}1 \\
3.29\end{array}$ & 1 & $\begin{array}{l}11 \\
6.72\end{array}$ & 13 \\
\hline & -2.29 & -1.99 & 4.28 & \\
\hline \multirow[t]{2}{*}{2} & $\frac{1}{2} .78$ & $\begin{array}{l}0 \\
2.53\end{array}$ & $\begin{array}{l}10 \\
5.69\end{array}$ & 11 \\
\hline & -1.78 & -2.53 & 4.31 & \\
\hline \multirow[t]{2}{*}{3} & $\begin{array}{l}8 \\
7.08\end{array}$ & $\begin{array}{l}4 \\
6.44\end{array}$ & $\begin{array}{l}16 \\
14.48\end{array}$ & 28 \\
\hline & .92 & -2.44 & 1.52 & \\
\hline \multirow[t]{2}{*}{4} & 11 & $\begin{array}{l}7 \\
5.29\end{array}$ & $\begin{array}{c}5 \\
11.90\end{array}$ & 23 \\
\hline & 5.18 & 1.71 & -6.90 & \\
\hline \multirow[t]{2}{*}{5} & $\begin{array}{l}1 \\
3.03\end{array}$ & $\begin{array}{l}8 \\
2.76\end{array}$ & $\begin{array}{l}3 \\
6.21\end{array}$ & 12 \\
\hline & -2.03 & 5.24 & -3.21 & \\
\hline TOTALS & 22 & 20 & 45 & 87 \\
\hline
\end{tabular}

FREEMAY-TUKEY DEVIATES

$\begin{array}{rrrr}\text { COL } & 11 & 12 & 13 \\ \text { ROH } & & & \\ 1 & -1.35 & -1.18 & 1.50 \\ 2 & -1.07 & -2.33 & 1.60 \\ 3 & .41 & -.94 & .45 \\ 4 & 1.85 & .77 & -2.28 \\ 5 & -1.21 & 2.36 & -1.35\end{array}$

REFERENCE. FREEMAI， M. F. AND TLKEY, J. R. (1950). TRANSFORMATIONS RELATED TO THE ANGULAR AND THE SQUARE ROOT. ANX. MATH. STATIST, 21,607. 
ANALYSIS OF INFORMATION TABLES

\begin{tabular}{|c|c|c|c|}
\hline \multirow[b]{2}{*}{$\begin{array}{l}\text { COMPONENT DUE } \\
\text { TO HYPOTHESIS }\end{array}$} & \multicolumn{2}{|l|}{ INDEPENDENCE } & \multirow[b]{2}{*}{$\begin{array}{l}\text { CHI-SQUARED } \\
\text { PROBABILITY }\end{array}$} \\
\hline & $\begin{array}{l}\text { IKELIHOOD CHI-SQUARED } \\
\text { INFORMATION VALUE }\end{array}$ & D.F. & \\
\hline$P(I J)=1 / 15$ & 61.976 & 14 & .000 \\
\hline $\begin{array}{l}\mathrm{P}(\mathrm{I} .)=1 / 5 \\
\mathrm{P}(. \mathbf{J})=1 / 3 \\
\mathrm{P}(\mathrm{I} \mathbf{J})=\mathrm{P}(\mathrm{I} .) \mathrm{P}(. \mathrm{J})\end{array}$ & $\begin{array}{l}12.891 \\
12.525 \\
36.560\end{array}$ & $\begin{array}{l}4 \\
2 \\
8\end{array}$ & $\begin{array}{l}.012 \\
.002 \\
.000\end{array}$ \\
\hline (PEARSON CHI-SQUARED & 35.923 & 8 & $.000)$ \\
\hline \multicolumn{4}{|c|}{ HOMOGENEITY OF R SAMPLES } \\
\hline$P(R J)=1 / 3 \quad$ EACH SAMPLE & 49.085 & 10 & .000 \\
\hline $\begin{array}{l}\mathrm{P}(\mathrm{J})=1 / 3 \text { ALL SAMPLES } \\
\text { HOMOGENEITY OF R SAMPLES }\end{array}$ & $\begin{array}{l}12.525 \\
36.560\end{array}$ & $\begin{array}{l}2 \\
8\end{array}$ & $\begin{array}{l}.002 \\
.000\end{array}$ \\
\hline (PEARSON CHI-SQUARED & 35.923 & 8 & $.000)$ \\
\hline
\end{tabular}

REFERENCE ...

KU, H. H., VARNER, R. N., AND KULLBACK, S. (1971). ON THE ANALYSIS OF MULTIDIMENSIONAL CONTINGENCY TABLES, J. AMER. STATIST. ASSOC. , 66, 55 .

MEASURES OF ASSOCIATION

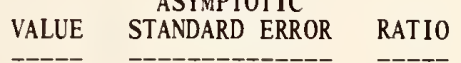

BASED ON CHI-SQUARED STATISTIC PHI (CRAMER) CONTINGENCY COEFFICIENT

\section{.454}

.541

BASED ON RANK ORDER CORRELATION KENDALL'S TAU

SPEARMAN'S RHO

KRUSKAL'S GAMMA

$\begin{array}{lll}-.344 & .073 & -4.713 \\ -.422 & .098 & -4.289 \\ -.478 & .100 & -4.795\end{array}$

BASED ON PROBABILITY OF PREDICTION LAMBDA A

LAMBDA B LAMBDA

$\begin{array}{lll}.119 & .088 & 1.353 \\ .262 & .103 & 2.531 \\ .178 & .089 & 1.998\end{array}$

NOTE ... DISCUSSIONS OF THESE MEASURES AND FORMULAS FOR COMPUTING STANDARD ERRORS MAY BE FOUND IN ...

GOODMAN, L. A. AND KRUSKAL, $W$. H., MEASURES OF ASSOCIATION FOR CROSS CLASSIFICATIONS. PART I, II, AND III, J. OF AMER. STATIST. ASSOC. VOL. 49,732. (1954). VOL. 54,123. (1959), VOL. 58,310 (1963).

KENDALl, M. AND STUART, A. (1973). THE ADVANCED THEORY OF STAT., V 2. HAYS, W. L. (1973). STATISTICS FOR THE SOCIAL SCIENCES. 2ND ED. 
OMNITAB 80 TEST 32 CONTINGENCY TABLE ANALYSIS. (6.8)

LIST OF DATA, INSTRUCTIONS AND DIAGNOSTICS

READ DATA INTO COLUMNS 11,12 AND 13

$\begin{array}{rrr}1 & 1 & 11 \\ 1 & 0 & 10 \\ 8 & 4 & 16 \\ 11 & 7 & 5 \\ 1 & 8 & 3\end{array}$

* informative diagnostic for the above instruction -

NRMAX HAS BEEN RESET FROM O TO 5.

CONTINGENCY TABLE ANALYSIS OF 5 X 3 TABLE STARTING IN COLUMN 11

NATIONAL BUREAU OF STANDARDS. WASHINGTON, D. C. 20234 OMNITAB 80 VERSION 6.00 MARCH 2,1981 
OMNITAB 80 TEST 33 EXAMPLES OF TABLE AND NTABLE INSTRUCTIONS. (6.9) PAGE 1 3-WAY TABLE OF FREQUENCIES OF 15 MEASUREMENTS

$$
\begin{aligned}
& \text { (1) = COLUMN } 7,2 \text { LEVELS } \\
& \text { (2) }=\text { AGE }, 4 \text { LEVELS } \\
& \text { (3) }=\text { COLUMN } 27,3 \text { LEVELS }
\end{aligned}
$$

\begin{tabular}{|c|c|c|}
\hline $40^{\circ}$ & $\begin{array}{l}6 \\
7\end{array}$ & \\
\hline 48 & $\begin{array}{l}6 \\
7\end{array}$ & \\
\hline 49 & $\begin{array}{l}6 \\
7\end{array}$ & \\
\hline & & \\
\hline
\end{tabular}

$\begin{array}{llllll}(2) & 23 & 24 & 25 & 26 & \text { TOTALS }\end{array}$

(3) (1

3-WAY TABLE OF FREQUENCIES OF 15 MEASUREMENTS

$$
\begin{aligned}
& \text { (1) = COLUMN } 7,2 \text { LEVELS } \\
& \begin{array}{l}
(2)=\text { AGE } \quad, 4 \text { LEVELS } \\
(3)=\text { COLUMN } 28,3 \text { LEVELS }
\end{array}
\end{aligned}
$$

(3) $\begin{array}{llllll}(2) & 23 & 24 & 25 & 26 & \text { TOTALS }\end{array}$

$\begin{array}{rrrrrrr}40.988 & 6 & 0 & 0 & 1 & 2 & 3 \\ & 7 & 0 & 0 & 1 & 0 & 1 \\ 48.988 & 6 & 0 & 0 & 0 & 0 & 0 \\ & 7 & 1 & 3 & 1 & 1 & 6 \\ 49.988 & 6 & 1 & 0 & 3 & 0 & 4 \\ & 7 & 0 & 0 & 0 & 1 & 1 \\ & & & \\ & \text { TOTALS } & 2 & 3 & 6 & 4 & 15\end{array}$

THE FOLLOWING VALUES SHOULD BE CLOSE TO OR EQUAL TO .98765 AND 0.0 . 
OMNITAB 80 TEST 33 EXAMPLES OF TABLE AND NTABLE INSTRLCTIONS. (6.9) 2 3-HAY TABLE OF SLYS OF 15 MEASLREMENTS IN COLLMN 50

(1) = COLUMN 7,2 LEVELS

(2) $=$ AGE, 4 LEVELS

(3) $=$ COLLM 27,3 LEVELS

(3) $\begin{array}{llllll}(2) & 23 & 24 & 25 & 26 & \text { TOTALS }\end{array}$

$\begin{array}{llllll}40 & 6 & * & * & 101 & 209\end{array}$

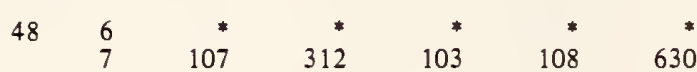

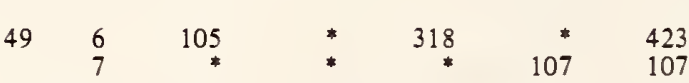

$\begin{array}{llllll}\text { TOTALS } & 212 & 312 & 626 & 424 & 1574\end{array}$

* 14 of the 24 CELls iN the table aRE EMPTy.

3-RAY TABLE OF SUMS OF 15 MEASLREMENTS IN COLLMN 50

(1) $=$ COLLXN 7,2 LEVELS
(2) $=$ AGE $\quad 4$ LEVELS

$(2)=$ AGE
$(3)=$ COLLMN 27,4 LEVELS

\begin{tabular}{|c|c|c|c|c|c|c|}
\hline (3) & $\begin{array}{l}\text { (2) } \\
\text { (1) }\end{array}$ & 23 & 24 & 25 & 26 & TOTALS \\
\hline 40 & $\begin{array}{l}6 \\
7\end{array}$ & * & * & $\begin{array}{l}101 \\
104\end{array}$ & $\begin{array}{r}209 \\
*\end{array}$ & $\begin{array}{l}310 \\
104\end{array}$ \\
\hline 48 & $\begin{array}{l}6 \\
7\end{array}$ & $\begin{array}{r}* \\
107\end{array}$ & $312^{*}$ & ${ }_{103}^{*}$ & $\begin{array}{r}* \\
108\end{array}$ & $\begin{array}{r}* \\
630^{*}\end{array}$ \\
\hline 49 & $\begin{array}{l}6 \\
7\end{array}$ & 105 & * & $\begin{array}{r}318 \\
*\end{array}$ & $\begin{array}{r}* \\
107\end{array}$ & $\begin{array}{l}423 \\
107\end{array}$ \\
\hline & & 212 & 312 & 626 & 424 & 1574 \\
\hline
\end{tabular}

* 14 OF THE 24 CELLS IN THE TABLE ARE EMPTY.

THE FOLLOHING VALLE SHOLLD BE CLOSE TO OR EQUAL TO ZERO.

0. 
OMNITAB 80 TEST 33 EXAMPLES OF TABLE AND NTABLE INSTRUCTIONS. (6.9) 3 3- WAY TABLE OF AVERAGES OF 15 MEASUREMENTS IN COLUMN 50

$$
\begin{aligned}
& \text { (1) = COLUMN } 7,2 \text { LEVELS } \\
& \text { (2) }=\text { AGE }, 4 \text { LEVELS } \\
& \text { (3) }=\text { COLUMN } 27,3 \text { LEVELS }
\end{aligned}
$$

\begin{tabular}{|c|c|c|c|c|c|}
\hline (3) & $\begin{array}{l}\text { (2) } \\
\text { (1) }\end{array}$ & 23 & 24 & 25 & 26 \\
\hline 40 & $\begin{array}{l}6 \\
7\end{array}$ & * & * & $\begin{array}{l}101.0 \\
104.0\end{array}$ & 104.5 \\
\hline 48 & $\begin{array}{l}6 \\
7\end{array}$ & $107.0^{*}$ & $104 .{ }^{*}$ & $103.0^{*}$ & $108.0^{*}$ \\
\hline 49 & $\begin{array}{l}6 \\
7\end{array}$ & 105.0 & * & 106.0 & $107.0^{*}$ \\
\hline
\end{tabular}

* 14 OF THE 24 CELls IN THE TABLE ARE EMPTY.

3-WAY TABLE OF AVERAGES OF 15 MEASUREMENTS IN COLUMN 50

(1) = COLUMN 7,2 LEVELS

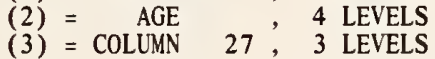

(3) $\begin{array}{lllll}(2) & 23 & 24 & 25 & 26\end{array}$

$\begin{array}{rlllll}40 & 6 & * & * & 101.0 & 104.5 \\ & 7 & * & * & 104.0 & *\end{array}$

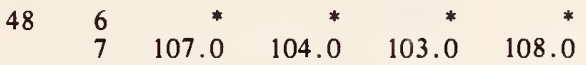

$\begin{array}{rrrrrr}49 & 6 & 105.0 & * & 106.0 & * \\ & 7 & * & * & * & 107.0\end{array}$

* 14 OF THE 24 CELLS IN THE TABLE ARE EMPTY.

THE FOLLOWING VALUE SHOULD BE CLOSE TO OR EQUAL TO ZERO.

0 . 
OMNITAB 80 TEST 33 EXAMPLES OF TABLE AND NTABLE INSTRUCTIONS. (6.9) 4 3- WAY TABLE OF STANDARD DEVIATIONS OF 15 MEASUREMENTS IN COLUMN 50

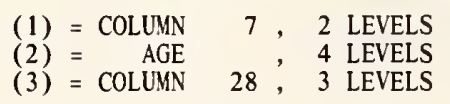

(3) $\begin{array}{lllll}(2) & 23 & 24 & 25 & 26\end{array}$

$\begin{array}{rrrrrr}40.988 & 6 & * & * & .0000 & 2.1213 \\ & 7 & * & * & .0000 & * \\ 48.988 & 6 & * & * & * & * \\ & 7 & .0000 & 3.4641 & .0000 & .0000 \\ 49.988 & 6 & .0000 & * & 4.3589 & * \\ & 7 & * & * & * & .0000\end{array}$

* 14 OF the 24 CELlS IN ThE TABLE aRE EMPTY.

3-WAY TABLE OF STANDARD DEVIATIONS OF 15 MEASUREMENTS IN COLUMN 50

(1) = COLUMN 7,2 LEVELS

(2) = AGE $\quad, 4$ LEVELS

(3) $=$ COLUMN $28 ; 3$ LEVELS

$\begin{array}{lllll}(2) & 23 & 24 & 25 & 26\end{array}$

(3) (1)

$\begin{array}{rrrrrr}40.988 & 6 & * & * & .0000 & 2.1213 \\ & 7 & * & * & .0000 & *\end{array}$

$\begin{array}{rrrrrr}48.988 & 6 & * & * & * & * \\ & 7 & .0000 & 3.4641 & .0000^{*} & .0000^{*}\end{array}$

$\begin{array}{rrrrrr}49.988 & 6 & .0000 & * & 4.3589 & * \\ & 7 & * & * & * & .0000^{*}\end{array}$

* 14 OF THE 24 CELLS IN the table aRE EMPTy.

THE FOLLOWING VALUE SHOULD BE CLOSE TO OR EQUAL TO ZERO.

0. 
OMNITAB 80 TEST 33 EXAMPLES OF TABLE AND NTABLE INSTRUCTIONS. (6.9) 5 3-WAY TABLE OF MINIMUMS OF 15 MEASUREMENTS IN COLUMN 50

$$
\begin{aligned}
& \text { (1) = COLUMN } 7,2 \text { LEVELS } \\
& \text { (2) }=\text { AGE } \quad, 4 \text { LEVELS }
\end{aligned}
$$

\begin{tabular}{|c|c|c|c|c|c|c|}
\hline (3) & $\begin{array}{l}(2) \\
\text { (1) }\end{array}$ & 23 & 24 & 25 & 26 & TOTALS \\
\hline 40 & $\begin{array}{l}6 \\
7\end{array}$ & * & $\begin{array}{l}* \\
*\end{array}$ & $\begin{array}{l}101 \\
104\end{array}$ & $\begin{array}{r}103 \\
*\end{array}$ & $\begin{array}{l}101 \\
104\end{array}$ \\
\hline 48 & $\begin{array}{l}6 \\
7\end{array}$ & $\begin{array}{r}* \\
107^{*}\end{array}$ & $\begin{array}{r}* \\
102\end{array}$ & ${ }^{*}{ }^{*}$ & $\begin{array}{r}* \\
108\end{array}$ & $\begin{array}{r}* \\
102\end{array}$ \\
\hline 49 & $\begin{array}{l}6 \\
7\end{array}$ & 105 & * & 101 & $\begin{array}{r}* \\
107\end{array}$ & $\begin{array}{l}101 \\
107\end{array}$ \\
\hline & & 105 & 102 & 101 & 103 & 101 \\
\hline
\end{tabular}

* 14 OF THE 24 CELLS IN THE TABLE ARE EMPTY.

3-WAY TABLE OF MINIMUMS OF 15 MEASUREMENTS IN COLUMN 50

\begin{tabular}{|c|c|c|c|c|c|c|}
\hline (3) & $\begin{array}{l}\text { (2) } \\
\text { (1) }\end{array}$ & 23 & 24 & 25 & 26 & TOTALS \\
\hline 40 & $\begin{array}{l}6 \\
7\end{array}$ & * & * & $\begin{array}{l}101 \\
104\end{array}$ & $\begin{array}{r}103 \\
*\end{array}$ & $\begin{array}{l}101 \\
104\end{array}$ \\
\hline 48 & $\begin{array}{l}6 \\
7\end{array}$ & $\begin{array}{r}* \\
107\end{array}$ & $\begin{array}{r}* \\
102\end{array}$ & $\begin{array}{r}* \\
103\end{array}$ & $\begin{array}{r}* \\
108\end{array}$ & $\begin{array}{r}* \\
102\end{array}$ \\
\hline 49 & $\begin{array}{l}6 \\
7\end{array}$ & $\begin{array}{r}105 \\
*\end{array}$ & * & $\begin{array}{r}101 \\
*\end{array}$ & $\begin{array}{r}* \\
107^{*}\end{array}$ & $\begin{array}{l}101 \\
107\end{array}$ \\
\hline & & 105 & 102 & 101 & 103 & 101 \\
\hline
\end{tabular}

$$
\begin{aligned}
& \text { (1) }=\text { COLUMN } 7,2 \text { LEVELS } \\
& \text { (2) }=\text { AGE }, 4 \text { LEVELS } \\
& \text { (3) }=\text { COLUMN } 27,3 \text { LEVELS }
\end{aligned}
$$

* 14 OF THE 24 CELLS IN THE TABLE ARE EMPTY.

THE FOLLOWING VALUE SHOULD BE CLOSE TO OR EQUAL TO ZERO.

0 . 
OMNITAB 80 TEST 33 EXAMPLES OF TABLE AND NTABLE INSTRUCTIONS. (6.9) 6 3-WAY TABLE OF MAXIMUMS OF 15 MEASUREMENTS IN COLUMN 50

(1) $=$ COLUMN 7,2 LEVELS

(2) = AGE, 4 LEVELS

(3) $=$ COLUMN 28,3 LEVELS

(3) $\begin{array}{llllll}(2) & 23 & 24 & 25 & 26 & \text { TOTALS }\end{array}$

$\begin{array}{lllllll}40.988 & 6 & * & * & 101 & 106 & 106 \\ & 7 & * & * & 104 & * & 104\end{array}$

$\begin{array}{rrrrrrr}48.988 & 6 & * & * & * & * & * \\ & 7 & 107 & 108 & 103 & 108 & 108\end{array}$

$\begin{array}{rrrrrrr}49.988 & 6 & 105 & * & 109 & * & 109 \\ & 7 & * & * & * & 107 & 107\end{array}$

$\begin{array}{llllll}\text { TOTALS } & 107 & 108 & 109 & 108 & 109\end{array}$

* 14 of THE 24 CELls in the TABLE aRE EMPTy.

3-WAY TABLE OF MAXIMUMS OF 15 MEASUREMENTS IN COLUMN 50

$(1)=$ COLUMN 7,2 LEVELS
$(2)=$ AGE

(3) $=$ COLUMN 28,3 LEVELS

(3) $\begin{array}{llllll}(2) & 23 & 24 & 25 & 26 & \text { TOTALS }\end{array}$

$\begin{array}{lllllll}40.988 & 6 & * & * & 101 & 106 & 106 \\ & 7 & * & * & 104 & * & 104\end{array}$

$\begin{array}{rrrrrrr}48.988 & 6 & * & * & * & * & * \\ & 7 & 107 & 108 & 103 & 108 & 108\end{array}$

$\begin{array}{rrrrrrr}49.988 & 6 & 105 & * & 109 & * & 109 \\ & 7 & * & * & * & 107 & 107\end{array}$

$\begin{array}{llllll}\text { TOTALS } & 107 & 108 & 109 & 108 & 109\end{array}$

* 14 OF THE 24 CELLS IN THE TABLE ARE EMPTY.

THE FOLLOWING VALUE SHOULD BE CLOSE TO OR EQUAL TO ZERO.

0. 
OMNITAB 80 TEST 33 EXAMPLES OF TABLE AND NTABLE INSTRUCTIONS. (6.9) 7 3-WAY TABLE OF RANGES OF 15 MEASUREMENTS IN COLUMN 50

(1) = COLUMN 7,2 LEVELS

(3) $=$ COLUMN 27,3 LEVELS

(3) $\begin{array}{llllll}(2) & 23 & 24 & 25 & 26 & \text { TOTALS }\end{array}$

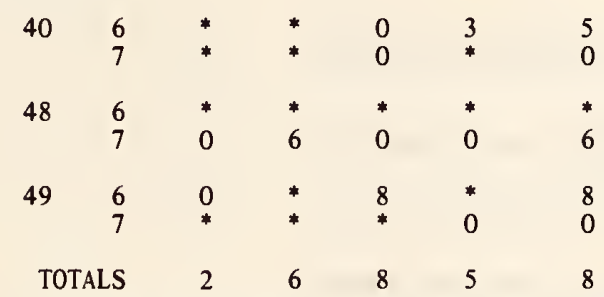

* 14 of THE 24 CELls IN THE TABLE aRE EMPTy.

3-WAY TABLE OF RANGES OF 15 MEASUREMENTS IN COLUMN 50
(1) $=$ COLUMN 7,2 LEVELS
(2) $=$ AGE 4 LEVELS
(3) $=$ COLUMN 28,3 LEVELS
$\begin{array}{llllll}(2) & 23 & 24 & 25 & 26 & \text { TOTALS }\end{array}$
(3) (1)

$\begin{array}{lllllll}40.988 & 6 & * & * & 0 & 3 & 5 \\ & 7 & * & * & 0 & * & 0\end{array}$

$\begin{array}{lllllll}48.988 & 6 & * & * & * & * & * \\ & 7 & 0 & 6 & 0 & 0 & 6\end{array}$

$\begin{array}{lllllll}49.988 & 6 & 0 & * & 8 & * & 8 \\ & 7 & * & * & * & 0 & 0\end{array}$

$\begin{array}{llllll}\text { TOTALS } & 2^{*} & 6 & 8 & 5 & 8\end{array}$

* 14 oF THE 24 CELLS IN THE TABLE aRE EMPTY.

THE FOLLOWING VALUES SHOULD BE CLOSE TO OR EQUAL TO .98765 AND 0.0 . 
OMNITAB 80 TEST 33 EXAMPLES OF TABLE AND NTABLE INSTRUCTIONS. (6.9) 8 3- WAY TABLE OF MEDIANS OF 15 MEASUREMENTS IN COLUMN 50

(1) = COLUMN 7,2 LEVELS

(2) = AGE $\quad, 4$ LEVELS

(3) $=$ COLUMN $28 ; 3$ LEVELS

(3) $\begin{array}{lllll}\text { (2) } & 23 & 24 & 25 & 26\end{array}$

$\begin{array}{llllll}40.988 & 6 & * & * & 101.0 & 104.5 \\ & 7 & * & * & 104.0 & *\end{array}$

$\begin{array}{lrrrrr}48.988 & 6 & & * & * & * \\ & 7 & 107.0 & 102.0 & 103.0 & 108.0\end{array}$

$\begin{array}{rrrrrr}49.988 & 6 & 105.0 & * & * & * \\ & 7 & * & * & * & 107.0\end{array}$

* $\quad 14$ OF THE 24 CELLS IN THE TABLE ARE EMPTY.

3-WAY TABLE OF MEDIANS OF 15 MEASUREMENTS IN COLUMN 50

(1) = COLUMN 7,2 LEVELS

$(2)=A G E \quad, 4$ LEVELS

(3) $=$ COLUMN $28 ; 3$ LEVELS

$\begin{array}{lllll}\text { (2) } & 23 & 24 & 25 & 26\end{array}$

(3) (1)

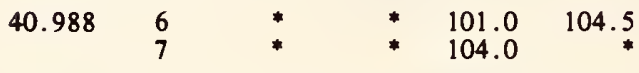

$\begin{array}{rrrrrr}48.988 & 6 & * & * & * & * \\ & 7 & 107.0 & 102.0 & 103.0 & 108.0\end{array}$

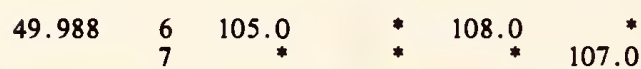

- 14 OF THE 24 CELlS IN THE TABLE ARE EMPTY.

THE FOLLONING VALUE SHOULD BE CLOSE TO OR EQUAL TO ZERO.

0 . 
OMNITAB 80 TEST 33 EXAMPLES OF TABLE AND NTABLE INSTRUCTIONS. (6.9) 10 3-WAY TABLE OF PERCENTAGES IN ROWS OF 15 MEASUREMENTS

$\begin{array}{llll}\text { (1) }=\text { COLLMN } 7, & 2 \text { LEVELS } \\ (2)= & \text { AGE } & 4 \text { LEVELS }\end{array}$

(3) $=$ COLUMN $27 ; 3$ LEVELS

$\begin{array}{rrrrrrr} & (2) & 23 & 24 & 25 & 26 & \text { TOTALS } \\ 40 & (1) & & & & & \\ & 7 & .00 & .00 & 33.33 & 66.67 & 100.00 \\ & 7 & .00 & .00 & 100.00 & .00 & 100.00 \\ 48 & 6 & .00 & .00 & .00 & .00 & 100.00 \\ & 7 & 16.67 & 50.00 & 16.67 & 16.67 & 100.00 \\ 49 & 6 & 25.00 & .00 & 75.00 & .00 & 100.00 \\ & 7 & .00 & .00 & .00 & 100.00 & 100.00\end{array}$

3-WAY TABLE OF PERCENTAGES IN ROWS OF 15 MEASUREMENTS

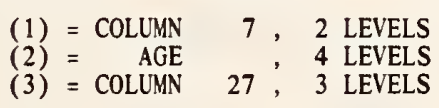

$\begin{array}{rrrrrrr} & (2) & 23 & 24 & 25 & 26 & \text { TOTALS } \\ \text { (3) } & (1) & & & & & \\ 40 & 6 & .00 & .00 & 33.33 & 66.67 & 100.00 \\ & 7 & .00 & .00 & 100.00 & .00 & 100.00 \\ 48 & 6 & .00 & .00 & .00 & .00 & 100.00 \\ & 7 & 16.67 & 50.00 & 16.67 & 16.67 & 100.00 \\ 49 & 6 & 25.00 & .00 & 75.00 & .00 & 100.00 \\ & 7 & .00 & .00 & .00 & 100.00 & 100.00\end{array}$

THE FOLLOWING VALUE SHOULD BE CLOSE TO OR EQUAL TO ZERO.

0 . 
OMNITAB 80 TEST 33 EXAMPLES OF TABLE AND NTABLE INSTRUCTIONS. (6.9) 9 3-HAY TABLE OF PERCENTAGES OF 15 MEASUREMENTS

$$
\begin{aligned}
& \text { (1) }=\text { COLUMN } 7,2 \text { LEVELS } \\
& \text { (2) }=\text { AGE }, 4 \text { LEVELS } \\
& \text { (3) }=\text { COLUMN } 27,3 \text { LEVELS }
\end{aligned}
$$

\begin{tabular}{|c|c|c|c|c|c|c|}
\hline (3) & $\begin{array}{l}\text { (2) } \\
\text { (1) }\end{array}$ & 23 & 24 & 25 & 26 & TOTALS \\
\hline 40 & $\begin{array}{l}6 \\
7\end{array}$ & $\begin{array}{l}.00 \\
.00\end{array}$ & $\begin{array}{l}.00 \\
.00\end{array}$ & $\begin{array}{l}6.67 \\
6.67\end{array}$ & $\begin{array}{r}13.33 \\
.00\end{array}$ & $\begin{array}{r}20.00 \\
6.67\end{array}$ \\
\hline 48 & $\begin{array}{l}6 \\
7\end{array}$ & $\begin{array}{r}.00 \\
6.67\end{array}$ & $\begin{array}{r}.00 \\
20.00\end{array}$ & $\begin{array}{r}.00 \\
6.67\end{array}$ & $\begin{array}{r}.00 \\
6.67\end{array}$ & $\begin{array}{r}.00 \\
40.00\end{array}$ \\
\hline 49 & $\begin{array}{l}6 \\
7\end{array}$ & $\begin{array}{r}6.67 \\
.00\end{array}$ & $\begin{array}{l}.00 \\
.00\end{array}$ & $\begin{array}{r}20.00 \\
.00\end{array}$ & $\begin{array}{r}.00 \\
6.67\end{array}$ & $\begin{array}{r}26.67 \\
6.67\end{array}$ \\
\hline & & 13.33 & 20.00 & 40.00 & 26.67 & 100.00 \\
\hline
\end{tabular}

\begin{tabular}{|c|c|c|c|c|c|}
\hline $\begin{array}{l}(1) \\
(2) \\
(3)\end{array}$ & $\begin{array}{l}=\text { COLUMN } \\
=\text { AGE } \\
=\text { COLUMN }\end{array}$ & $\begin{array}{r}7 ! \\
27\end{array}$ & $\begin{array}{ll}2 & \text { LEVELS } \\
4 & \text { LEVELS } \\
3 & \text { LEVELS }\end{array}$ & & \\
\hline $\begin{array}{l}(2) \\
(1)\end{array}$ & 23 & 24 & 25 & 26 & TOTALS \\
\hline $\begin{array}{l}6 \\
7\end{array}$ & $\begin{array}{l}.00 \\
.00\end{array}$ & $\begin{array}{l}.00 \\
.00\end{array}$ & $\begin{array}{l}6.67 \\
6.67\end{array}$ & $\begin{array}{r}13.33 \\
.00\end{array}$ & $\begin{array}{r}20.00 \\
6.67\end{array}$ \\
\hline $\begin{array}{l}6 \\
7\end{array}$ & $\begin{array}{r}.00 \\
6.67\end{array}$ & $\begin{array}{r}.00 \\
20.00\end{array}$ & $\begin{array}{r}.00 \\
6.67\end{array}$ & $\begin{array}{r}.00 \\
6.67\end{array}$ & $\begin{array}{r}.00 \\
40.00\end{array}$ \\
\hline $\begin{array}{l}6 \\
7\end{array}$ & $\begin{array}{r}6.67 \\
.00\end{array}$ & $\begin{array}{l}.00 \\
.00\end{array}$ & $\begin{array}{r}20.00 \\
.00\end{array}$ & $\begin{array}{r}.00 \\
6.67\end{array}$ & $\begin{array}{r}26.67 \\
6.67\end{array}$ \\
\hline TOTALS & 13.33 & 20.00 & 40.00 & 26.67 & 100.00 \\
\hline
\end{tabular}

3- WAY TABLE OF PERCENTAGES OF 15 MEASUREMENTS

THE FOLLOHING VALUE SHOULD BE CLOSE TO OR EQUAL TO ZERO.

0 . 
OMNITAB 80 TEST 33 EXAMPLES OF TABLE AND NTABLE INSTRUCTIONS. (6.9) 11 3-WAY TABLE OF PERCENTAGES IN COLUMNS OF 15 MEASUREMENTS

\begin{tabular}{|c|c|c|c|c|c|}
\hline & $\begin{array}{l}\text { (1) }= \\
\text { (2) }= \\
(3)=\end{array}$ & $\begin{array}{r}\text { COLUMN } \\
\text { AGE } \\
\text { COLUMN }\end{array}$ & $\begin{array}{r}7 \\
27\end{array}$ & $\begin{array}{ll}2 & \text { LEVELS } \\
4 & \text { LEVELS } \\
3 & \text { LEVELS }\end{array}$ & \\
\hline (3) & $\begin{array}{l}(2) \\
(1)\end{array}$ & 23 & 24 & 25 & 26 \\
\hline 40 & $\begin{array}{l}6 \\
7\end{array}$ & $\begin{array}{l}.00 \\
.00\end{array}$ & $\begin{array}{l}.00 \\
.00\end{array}$ & $\begin{array}{l}16.67 \\
16.67\end{array}$ & $\begin{array}{r}50.00 \\
.00\end{array}$ \\
\hline 48 & $\begin{array}{l}6 \\
7\end{array}$ & $\begin{array}{r}.00 \\
50.00\end{array}$ & $\begin{array}{r}.00 \\
100.00\end{array}$ & $\begin{array}{r}.00 \\
16.67\end{array}$ & $\begin{array}{r}.00 \\
25.00\end{array}$ \\
\hline 49 & $\begin{array}{l}6 \\
7\end{array}$ & $\begin{array}{r}50.00 \\
.00\end{array}$ & $\begin{array}{l}.00 \\
.00\end{array}$ & $\begin{array}{r}50.00 \\
.00\end{array}$ & $\begin{array}{r}.00 \\
25.00\end{array}$ \\
\hline & ALS & 100.00 & 100.00 & 100.00 & 100.00 \\
\hline
\end{tabular}

3-WAY TABLE OF PERCENTAGES IN COLUMNS OF 15 MEASUREMENTS
(1) $=$ COLUMN
(2) $=$ AGE
7,2 LEVELS
(3) $=$ COLUMN
$27, \quad 3$ LEVELS

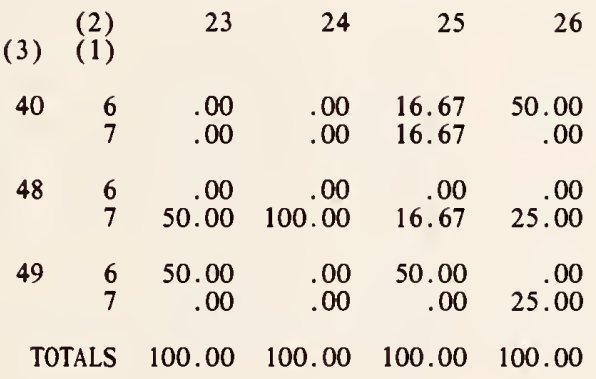

THE FOLLOWING VALUE SHOULD BE CLOSE TO OR EQUAL TO ZERO.

0 . 
OMNITAB 80 TEST 33 EXAMPLES OF TABLE AND NTABLE INSTRUCTIONS. (6.9) 12 3-H'AY TABLE OF PROPORTIONS OF 15 MEASUREMENTS

(1) $=$ COLUMN 7,2 LEVELS

$(2)=$ AGE
$(3)=$ COLUMN $28 ;$

$\begin{array}{llllll}\text { (2) } & 23 & 24 & 25 & 26 & \text { TOTALS }\end{array}$

\begin{tabular}{lllllll}
\hline .988 & 6 & .0000 & .0000 & .0667 & .1333 & .2000
\end{tabular}

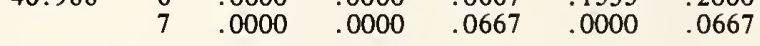

$\begin{array}{lllllll}48.988 & 6 & .0000 & .0000 & .0000 & .0000 & .0000 \\ & 7 & .0667 & .2000 & .0667 & .0667 & .4000\end{array}$

$\begin{array}{llllllll}49.988 & 6 & .0667 & .0000 & .2000 & .0000 & .2667\end{array}$

$\begin{array}{llllll}\text { TOTALS } & .1333 & .2000 & .4000 & .2567 & 1.0000\end{array}$

3-WAY TABLE OF PROPORTIONS OF 15 MEASUREMENTS

(1) $=$ COLUMN 7,2 LEVELS

(2) $=$ AGE, 4 LEVELS

(3) $=$ COLUMN 28,3 LEVELS

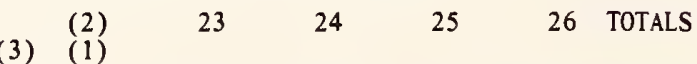

$\begin{array}{lllllll}40.988 & 6 & .0000 & .0000 & .0667 & .1333 & .2000\end{array}$

$\begin{array}{lllllll} & 7 & .0000 & .0000 & .0667 & .0000 & .0667 \\ 48.988 & 6 & .0000 & .0000 & .0000 & .0000 & .0000 \\ & 7 & .0667 & .2000 & .0667 & .0667 & .4000\end{array}$

$\begin{array}{lllllll}49.988 & 6 & .0667 & .0000 & .2000 & .0000 & .2667\end{array}$

$\begin{array}{llllll}\text { TOTALS } & .1333 & .2000 & .4000 & .2667 & 1.0000\end{array}$

THE FOLLOHING VALUE SHOULD BE CLOSE TO OR EQUAL TO ZERO.

0 . 
OMNITAB 80 TEST 33 EXAMPLES OF TABLE AND NTABLE INSTRUCTIONS. (6.9) 13 3-WAY TABLE OF PROPORTIONS IN ROWS OF 15 MEASUREMENTS

$$
\begin{aligned}
& \text { (1) = COLUMN } 7,2 \text { LEVELS } \\
& \text { (2) = AGE , } 4 \text { LEVELS } \\
& \text { (3) }=\text { COLUMN } 27,3 \text { LEVELS }
\end{aligned}
$$

$\begin{array}{rrrrrrr} & (2) & 23 & 24 & 25 & 26 & \text { TOTALS } \\ \text { (3) } & (1) & & & & & \\ 40 & 6 & .0000 & .0000 & .3333 & .6667 & 1.0000 \\ & 7 & .0000 & .0000 & 1.0000 & .0000 & 1.0000 \\ 48 & 6 & .0000 & .0000 & .0000 & .0000 & 1.0000 \\ & 7 & .1667 & .5000 & .1667 & .1667 & 1.0000 \\ & & & & & & \\ 49 & 6 & .2500 & .0000 & .7500 & .0000 & 1.0000 \\ & 7 & .0000 & .0000 & .0000 & 1.0000 & 1.0000\end{array}$

3-WAY TABLE OF PROPORTIONS IN ROWS OF 15 MEASUREMENTS

$$
\begin{aligned}
& \text { (1) = COLUMN } 7,2 \text { LEVELS } \\
& \text { (2) = AGE , } 4 \text { LEVELS } \\
& \text { (3) }=\text { COLUMN } 27,3 \text { LEVELS }
\end{aligned}
$$

$\begin{array}{rrrrrrr} & (2) & 23 & 24 & 25 & 26 & \text { TOTALS } \\ \text { (3) } & (1) & & & & & \\ 40 & 6 & .0000 & .0000 & .3333 & .6667 & 1.0000 \\ & 7 & .0000 & .0000 & 1.0000 & .0000 & 1.0000 \\ 48 & 6 & .0000 & .0000 & .0000 & .0000 & 1.0000 \\ & 7 & .1667 & .5000 & .1667 & .1667 & 1.0000 \\ & & & & & & \\ 49 & 6 & .2500 & .0000 & .7500 & .0000 & 1.0000 \\ & 7 & .0000 & .0000 & .0000 & 1.0000 & 1.0000\end{array}$

THE FOLLOWING VALUE SHOULD BE CLOSE TO OR EQUAL TO ZERO.

0 . 
OMNITAB 80 TEST 33 EXAMPLES OF TABLE AND NTABLE INSTRUCTIONS. (6.9) 14 3-FAY TABLE OF PROPORTIONS IN COLLMNS OF 15 MEASUREMENTS

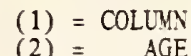
$(2)=$ AGE
$(3)=$ COLUM
7,2 LEVELS
$27 ; 3$ LEVELS

\begin{tabular}{|c|c|c|c|c|c|}
\hline 3) & $\begin{array}{l}(2) \\
(1)\end{array}$ & 23 & 24 & 25 & 26 \\
\hline 40 & $\begin{array}{l}6 \\
7\end{array}$ & $\begin{array}{l}.0000 \\
.0000\end{array}$ & $\begin{array}{l}.0000 \\
.0000\end{array}$ & $\begin{array}{l}.1667 \\
.1667\end{array}$ & $\begin{array}{l}.5000 \\
.0000\end{array}$ \\
\hline 48 & $\begin{array}{l}6 \\
7\end{array}$ & $\begin{array}{l}.0000 \\
.5000\end{array}$ & $\begin{array}{r}.0000 \\
1.0000\end{array}$ & $\begin{array}{l}.0000 \\
.1667\end{array}$ & $\begin{array}{l}.0000 \\
.2500\end{array}$ \\
\hline 49 & $\frac{6}{7}$ & $\begin{array}{l}.5000 \\
.0000\end{array}$ & $\begin{array}{l}.0000 \\
.0000\end{array}$ & $\begin{array}{l}.5000 \\
.0000\end{array}$ & $\begin{array}{l}.0000 \\
.2500\end{array}$ \\
\hline & & 1.0000 & 1.0000 & 1.0000 & 1.0 \\
\hline
\end{tabular}

3-HAY TABLE OF PROPORTIONS IN COLUMNS OF 15 MEASUREMENTS
(1) $=$ COLUXS
7,2 LEVELS
(2) $=\mathrm{AGE}$
(3) $=$ COLUMN
$7, \quad 2$ LEVELS
27,3 LEVELS

\begin{tabular}{|c|c|c|c|c|c|}
\hline 3) & $\begin{array}{l}(2) \\
\text { (1) }\end{array}$ & 23 & 24 & 25 & 26 \\
\hline 40 & $\begin{array}{l}6 \\
7\end{array}$ & $\begin{array}{l}.0000 \\
.0000\end{array}$ & $\begin{array}{l}.0000 \\
.0000\end{array}$ & $\begin{array}{l}.1667 \\
.1667\end{array}$ & $\begin{array}{l}.5000 \\
.0000\end{array}$ \\
\hline & $\begin{array}{l}6 \\
7\end{array}$ & $\begin{array}{l}.0000 \\
.5000\end{array}$ & $\begin{array}{r}.0000 \\
1.0000\end{array}$ & $\begin{array}{l}.0000 \\
.1667\end{array}$ & $\begin{array}{l}.0000 \\
.2500\end{array}$ \\
\hline & $\begin{array}{l}6 \\
7\end{array}$ & $\begin{array}{l}.5000 \\
.0000\end{array}$ & $\begin{array}{l}.0000 \\
.0000\end{array}$ & $\begin{array}{l}.5000 \\
.0000\end{array}$ & $\begin{array}{l}.0000 \\
.2500\end{array}$ \\
\hline & & 1.0000 & 1.0000 & 1.0000 & 1.0 \\
\hline
\end{tabular}

THE FOLLONING VALLE SHOLLD BE CLOSE TO OR EQUAL TO ZERO.

0 . 
OMNITAB 80 TEST 33 EXAMPLES OF TABLE AND NTABLE INSTRUCTIONS. (6.9) 15

LIST OF DATA, INSTRUCTIONS AND DIAGNOSTICS

$\begin{array}{lrrrr}\begin{array}{l}\text { READ DATA INTO COLUMNS } \\ \$\end{array} & 5 & 27 & 50 \\ & 6 & 25 & 40 & 101 \\ 7 & 23 & 48 & 107 \\ 7 & 25 & 40 & 104 \\ 6 & 25 & 49 & 109 \\ 6 & 26 & 40 & 106 \\ 7 & 24 & 48 & 102 \\ 6 & 26 & 40 & 103 \\ 6 & 25 & 49 & 108 \\ 6 & 23 & 49 & 105 \\ 7 & 24 & 48 & 108 \\ 7 & 24 & 48 & 102 \\ 6 & 25 & 49 & 101 \\ 7 & 26 & 48 & 108 \\ 7 & 25 & 48 & 103 \\ 7 & 26 & 49 & 107\end{array}$

$\$$

* INFORMATIVE DIAGNOSTIC FOR THE ABOVE INSTRUCTION NRMAX HAS BEEN RESET FROM O TO 15.

WIDTH OF 80 CHARACTERS PER LINE

HEAD COL 5/ AGE

TABLE FREQUENCY 3 WAY FOR DATA IN COLUMNS 7, 5 AND 27 STORE STARTING IN COL 41

ADD 0.98765 TO COLUMN 27 AND PUT IN COLUMN 28

SPACE 3

NTABLE FREQUENCY 3 WAY FOR DATA IN COLUMNS 7, 5 AND 28 STORE STARTING IN COL 31

ROW SUM COLS 32 THRU 35 PUT IN COL 39

ROW SUM COLS 42 THRU 45 PUT IN COL 49

SUBTRACT COL 49 FROM COL 39 PUT IN COL 39

AVERAGE COL 39 PUT IN COL 39

SUBTRACT COL 48 FROM COL 38 PUT IN COL 51

PROMOTE BY 1 ROW VALUES IN COL 51 PUT IN COL 51

SPACE 3

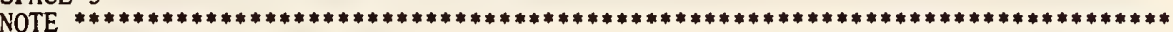

SPACE

NOTE THE FOLLOWING VALUES SHOULD BE CLOSE TO OR EQUAL TO .98765 AND 0.0 .

SPACE

ABRIDGE ROW 1 OF COL 51 AND 39

SPACE

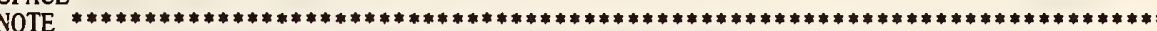

WIDTH OF 72 CHARACTERS PER LINE

TABLE SUM 3 WAY WITH LEVELS IN COLS 7, 5 AND 27 FOR DATA IN COL 50 PUT IN COL 41 SPACE 3

NTABLE SUM 3 WAY WITH LEVELS IN COLS 75 AND 27 FOR DATA IN COL 50 PUT IN COL 31

ROW SUM COLS 32 THRU 35 PUT IN COL 39

ROW SUM COLS 42 THRU 45 PUT IN COL 49

SUBTRACT COL 49 FROM COL 39 PUT IN COL 39 
OMNITAB 80 TEST 33 EXAYPLES OF TABLE AND NTABLE INSTRLCTIONS, (6.9) 16

LIST OF DATA, INSTRLCTIONS AND DIAGNOSTICS

AVERAGE COL 39 PLT IS COL 39

SPACE 3

YOTE

YOTE THE FOLLOHING VALLE SHOLLD BE CLOSE TO OR EQUAL TO ZERO.

SPACE

ABRIDGE ROH 1 OF COL 39

SPACE

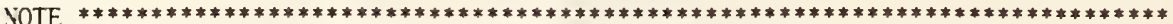

TABLE AVERAGE 3 THAY WITH LEVELS IN COLS 7, 5 ALD 27 DATA IN COL 50 PLT IN COL 11 SPACE 3

ITABLE AVERAGE 3 RAY RITH LEVELS IN COLS 75 AND 27 DATA IN COL 50 PUT IN COL 31 ROF SUM COLS 32 THRU 35 PUT IN COL 39

ROH SUY COLS 12 THRU 15 PUT IX COL 49

SLBTRACT COL 49 FROM COL 39 PLT IN COL 39

AVERAGE COL 39 PUT IN COL 39

SPACE

NOTE

SPACE

YOTE THE FOLLOHING VALLE SHOLLD BE CLOSE TO OR EQUAL TO ZERO.

SPACE

ABRIDGE ROH 1 OF COL 39

SPACE

SOTE ********************1\%

TABLE STDDEV 3 FAY HITH LEVELS IN COLS 7, 5 AND 28 DATA IN COL 50 PLT IN COL 41

SPACE 5

ITABLE STDDEV 3 HAY HITH LEVELS IN COLS 7, 5 AND 28 DATA IN COL 50 PUT IN COL 31

ROF SLY COLS 32 THRU 35 PLT IY COL 39

ROR SLM COLS 42 THRU 45 PUT IN COL 49

SUBTRACT COL 49 FROM COL 39 PLT IN COL 39

AVERAGE COL 39 PLT IN COL 39

SPACE 3

NOTE *

SPACE

NOTE THE FOLLOHING VALLE SHOLLD BE CLOSE TO OR EQLAL TO ZERO.

SPACE

ABRIDGE ROF' 1 OF COL 39

SPACE

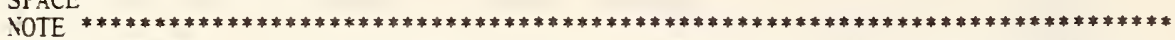

TABLE MINIMLY 3 RAY RITH LEVELS IN COLS 7, 5 AND 27 DATA IN COL 50 PUT IN COL 41 SPACE 3

NTABLE MINIMCY 3 FAY HITH LEVELS IN COLS 75 AND 27 DATA IN COL 50 PUT IN COL 11 ROH SUM COLS 42 THRU 45 PUT IN COL 49

ROF SLM COLS 12 THRU 15 PLT IN COL 39

SUBTRACT COL 49 FROM COL 39 PUT IN COL 39

AVERAGE COL 39 PUT IN COL 39

SPACE 3

NOTE ***

SPACE

NOTE THE FOLLOHING VALLE SHOULD BE CLOSE TO OR EQUAL TO ZERO. 
OMNITAB 80 TEST 33 EXAMPLES OF TABLE AND NTABLE INSTRUCTIONS. (6.9)

LIST OF DATA, INSTRUCTIONS AND DIAGNOSTICS

SPACE

ABRIDGE ROW 1 OF COL 39

SPACE

NOTE $* * * * * * * * * * * * * * * * * * * * * * * * * * * * * * * * * * * * * * * * * * * * * * * * * * * * * * * * * * * * * * * * * * * * * * *)$

TABLE MAXIMUM 3 WAY WITH LEVELS IN COLS 7, 5 AND 28 DATA IN COL 50 PUT IN COL 41 SPACE 3

NTABLE MAXIMUM 3 WAY WITH LEVELS IN COLS 75 AND 28 DATA IN COL 50 PUT IN COL 31 ROW SUM COLS 32 THRU 35 PUT IN COL 39

ROW SUM COLS 42 THRU 45 PUT IN COL 49

SUBTRACT COL 49 FROM COL 39 PUT IN COL 39

AVERAGE COL 39 PUT IN COL 39

SPACE 3

NOTE ***:

SPACE

NOTE THE FOLLOWING VALUE SHOULD BE CLOSE TO OR EQUAL TO ZERO.

SPACE

ABRIDGE ROW 1 OF COL 39

SPACE

NOTE $* * * * * * * * * * * * * * * * * * * * * * * * * * * * * * * * * * * * * * * * * * * * * * * * * * * * * * * * * * * * * * * * * * * * * * *$

TABLE RANGE 3 WAY WITH LEVELS IN COLS 7, 5 AND 27 DATA IN COL 50 PUT IN COL 31

SPACE 3

NTABLE RANGE 3 HAY WITH LEVELS IN COLS 7, 5 AND 28 DATA IN COL 50 PUT IN COL 41

ROW SUM COLS 32 THRU 35 PUT IN COL 39

ROW SUM COLS 42 THRU 45 PUT IN COL 49

SUBTRACT COL 49 FROM COL 39 PUT IN COL 39

AVERAGE COL 39 PUT IN COL 39

SUBTRACT COL 38 FROM COL 48 PUT IN COL 51

PROMOTE BY, 1 ROW VALUES IN COL 51 PUT IN COL 51

SPACE 3

NOTE $* * * * * * * * * * * * * * * * * * * * * * * * * * * * * * * * * * * * * * * * * * * * * * * * * * * * * * * * * * * * * * * * * * * * * * * * * * * *$

SPACE

NOTE THE FOLLOWING VALUES SHOULD BE CLOSE TO OR EQUAL TO .98765 AND 0.0 .

SPACE

ABRIDGE ROW 1 OF COL 51 AND 39

SPACE

NOTE $* * * * * * * * * * * * * * * * * * * * * * * * * * * * * * * * * * * * * * * * * * * * * * * * * * * * * * * * * * * * * * * * * * * * * * * * * * *$

TABLE MEDIAN 3 WAY WITH LEVELS IN COLS 7, 5 AND 28 DATA IN COL 50 PUT IN COL 31

SPACE 3

NTABLE MEDIAN 3 WAY WITH LEVELS IN COLS 7, 5 AND 28 DATA IN COL 50 PUT IN COL 41 SPACE 3

NOTE $* * * * * * * * * * * * * * * * * * * * * * * * * * * * * * * * * * * * * * * * * * * * * * * * * * * * * * * * * * * * * * * * * * * * * * * * * * *$

SPACE

NOTE THE FOLLOWING VALUE SHOULD BE CLOSE TO OR EQUAL TO ZERO.

SPACE

ABRIDGE ROW 1 OF COL 39

SPACE

NOTE $* * * * * * * * * * * * * * * * * * * * * * * * * * * * * * * * * * * * * * * * * * * * * * * * * * * * * * * * * * * * * * * * * * * * * * * * * * * *$

TABLE PERCENTAGES 3 WAY FOR DATA IN COLUMNS 7, 5 AND 27 STORE STARTING IN COL 31 SPACE 3

NTABLE PERCENTAGES 3 WAY FOR DATA IN COLUMNS 75 AND 27 STORE STARTING IN COL 41 
OMNITAB 80 TEST 33 EXAMPLES OF TABLE AND NTABLE INSTRLCTIONS. (6.9) 18

LIST OF DATA, INSTRLCTIONS AND DIAGNOSTICS

ROH SLY COLS 32 THRU 35 PLT IN COL 39

ROH SLM COLS 42 THRU 45 PLT IN COL 49

SLBTRACT COL 49 FROM COL 39 PUT IN COL 39

AVERAGE COL 39 PUT IN COL 39

SPACE 3

NOTE

NOTE THE FOLLOHING VALUE SHOULD BE CLOSE TO OR EQUAL TO ZERO

SPACE

ABRIDGE ROH 1 OF COL 39

SPACE

YOTE $* * * * * * * * * * * * * * * * * * * * * * * * * * * * * * * * * * * * * * * * * * * * * * * * * * * * * * * * * * * * * * * * * * * * *$

TABLE RPERCENTAGE 3 FiAY FOR DATA IN COLIMS 7,5 AND 27 STORE STARTING IN COL 31 SPACE 3

ITABLE RPERCENTAGE 3 FAY FOR DATA IN COLUMNS 7, 5 AND 27 START STORING IN COL 41

ROH SUY COLS 32 THRU 35 PUT IN COL 39

ROH SLM COLS 42 THRU 45 PUT IN COL 49

SUBTRACT COL 49 FROY COL 39 PUT IN COL 39

AVERAGE COL 39 PUT II COL 39

SPACE 3

YOTE $* * * * * * * * * * * * * * * * * * * * * * * * * * * * * * * * * * * * * * * * * * * * * * * * * * * * * * * * * * * * * * * * * * * * * * *$

SPACE

NOTE THE FOLLOHISG VALUE SHOULD BE CLOSE TO OR EQUAL TO ZERO.

SPACE

ABRIDGE ROH 1 OF COL 39

SPACE

YOTE $* * * * * * * * * * * * * * * * * * * * * * * * * * * * * * * * * * * * * * * * * * * * * * * * * * * * * * * * * * * * * * * * * * * *$

TABLE CPERCENTAGE 3 THAY FOR DATA IN COLLMN 7, 5 AND 27 STORE STARTING IN COL 31 SPACE 3

ITABLE CPERCENTAGE 3 HAY FOR DATA IN COLLYNS 7, 5 ATD 27 START STORING IN COL 41

ROF SLY COLS 32 THRU 35 PUT IN COL 39

ROW SLY COLS 42 THRU 45 PUT IN COL 49

SLBTRACT COL 49 FROM COL 39 PUT IN COL 39

AVERAGE COL 39 PUT IX COL 39

SPACE 3

NOTE

SPACE

NOTE THE FOLLOHING VALLE SHOLLD BE CLOSE TO OR EQLAL TO ZERO.

SPACE

ABRIDGE ROF 1 OF COL 39

SPACE

YOTE

-TABLE PROPORTIONS 3 HAY FOR DATA IN COLUMS 7, 5 AND 28 STORE STARTING IN COL 41 SPACE 3

ITABLE PROPORTIONS 3 WAY FOR DATA IN COLLYNS 7, 5 AND 28 START STORING IN COL 31

ROH SLM COLS 32 THRU 35 PUT IN COL 39

ROH SLY COLS 42 THRU 45 PUT IN COL 49

SLBTRACT COL 49 FROM COL 39 PLT IN COL 39

AVERAGE COL 39 PLT IN COL 39

SPACE 3 
LIST OF DATA, INSTRUCTIONS AND DIAGNOSTICS

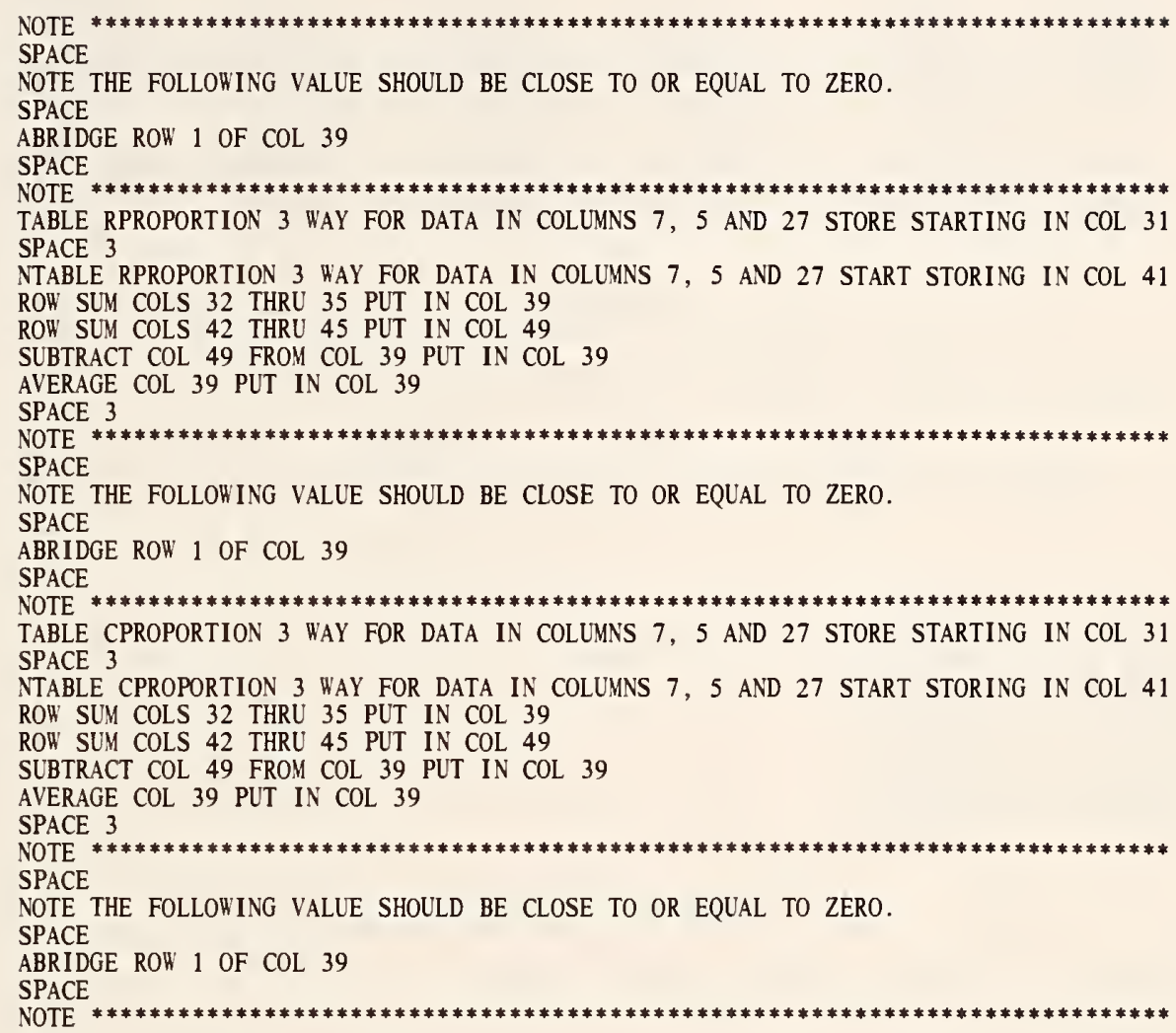

NATIONAL BUREAU OF STANDARDS. WASHINGTON, D. C. 20234 OMNITAB 80 VERSION 6.00 MARCH 2,1981 
OMNITAB 80 TEST 34 PROBABILITY DENSITY FLNCTIONS. (7.1)

EXAMPLES OF PROBABILITY DENSITY FLXCTIONS

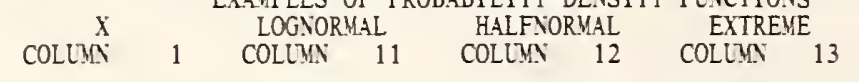

.20000000

.30000000

.40000000

.50000000

.60000000

.54626787

.64420326

.65544417

.62749608

.78208539

.78208539

.36105292

.73654028

.70413066

.58357382

.66644920

35316560

.34289876

.33070430

.31701327

.70000000

.80000000

.53479484

.48641578

.62450787

.57938311

.30222446

.28669712

.53217050

PAGE 1 REIBLLL
COLLMN 15 COLLMN COLLYY 17

.71487912 .52788156 .42001816 .34865221 .29750298

.25885953 .22854947 .20409898
.27525120

47647845

52254720

41015625

23224320

.087516455

.017203201

.00076545005

THE FOLLORING VALLES MLST EQUAL OR BE NEAR .565, .674, .321, .375 AND .253.

$$
.565
$$

.674

.321

.375

.253

$\mathrm{X}$

1. $2000000+000 \quad 3.8036289-001$

$1.3000000-000 \quad 3.3733001-00$

1.4000000-000 3.0184081-001

$1.5000000-000 \quad 2.7216553-001$

$1.6000000-000 \quad 2.4705294-00$

$1.7000000 \div 000 \quad 2.2557794-00$

$1.8000000-000 \quad 2.0704333-001$

$1.9000000-000 \quad 1.9091480-001$

THE FOLLOHING VALLE MLST BE EQUAL TO OR NEAR .27028603

2. 7028603-001 
OMNITAB 80 TEST 34 PROBABILITY DENSITY FUNCTIONS. (7.1)

\begin{tabular}{|c|c|c|c|c|}
\hline & BINOMIAL & NEGB I NOM I AL & POISSON & GEOMETRIC \\
\hline COLUMN & $\begin{array}{ll}\text { COLUMN } & 18\end{array}$ & $\begin{array}{ll}\text { COLUMN } 20 & 20\end{array}$ & $\begin{array}{ll}\text { COLUMN } & 19\end{array}$ & COLUMN 21 \\
\hline .0000000 & 1.1529215 & 1 & $1.8315639-002$ & $2.0000000-0$ \\
\hline .0000000 & 02 & 150 & & 1.6 \\
\hline & $90943-00$ & & & \\
\hline 000 & $36414-001$ & $8.2678115-012$ & 1. & 1.0240000 \\
\hline $00000+000$ & $9940-001$ & $3.8031933-011$ & $1.5-50$ & 8.1920000 \\
\hline & $5952-0$ & & & \\
\hline $0.0000000+0$ & $1.0909970-0$ & $4.8680874-010$ & $1.0419563-001$ & $5.2428800-002$ \\
\hline $7.0000000+00$ & $5.4549850-002$ & $1.4465174-009$ & $5.9540363-002$ & $4.1943040-002$ \\
\hline
\end{tabular}

THE FOLLOWING VALUES MUST EQUAL OR BE NEAR .121, .0.0, .119 AND .104.
121
.000
.119
.104 
LIST OF DATA, INSTRUCTIONS AND DIAGNOSTICS

GENERATE $0.2(0.1) 0.9$ IN COLUMN 1

* INFORMATIVE DIAGNOSTIC FOR THE ABOVE INSTRUCTION NRMAX HAS BEEN RESET FROM O TO 8 .

GENERATE $0.0(1.0) 7.0$ IN COLUMN 2

ADD 1.0 TO COLUMN 1 AND PUT IN COLUMN 3

$S$

LOGNORMAL DENSITY OF COLUMN 1 PUT IN COLLYN 11

HALFNORMAL DENSITY OF COLUMN 1 PUT IN COLUMN 12

EXTRENE DENSITY OF COLUMN 1 PUT IN COLUMN 13

$\$$

REIBULL DENSITY OF COLUYN 1, PARAMETER 0.5, PUT IN COLUMN 15

PARETO DENSITY OF COLUMN 3, PARAMETER 0.5, PUT IN COLUMN 16

BETA DENSITY OF COLUMN 1, PARAMETERS 3.0 AND 5.0, PUT IN COLUMN 17

BINOMIAL DENSITY OF COLUMN 2, $\mathrm{N}=20.0, \mathrm{P}=0.2$, PUT IN COLLMN 18

POISSON DENSITY OF COLUMN 2, $\quad \mathrm{P}=4.0$, PUT IN COLLYN 19

NEGBINOMIAL DENSITY OF COLUYN 2, $\mathrm{N}=20.0, \mathrm{P}=0.2$, PUT IN COLLMN 20

GEOMETRIC DENSITY OF COLUMN 2, $\quad \mathrm{P}=0.2$, PUT IN COLLMN 21

$S$

EXAMPLES OF PROBABILITY DENSITY FUNCTIONS

TITLE3 3 LOGNORMAL HALFNORYAL EXTREME

TITLE4 HEIBULL BETA

PR INT COLUMN 1 AND COLUMNS $11,12,13,15$ AND 17

AVERAGE COL 11 PUT IN COL 41

AVERAGE COL 12 PUT IN COL 42

AVERAGE COL 13 PUT IN COL 43

AVERAGE COL 15 PUT IN COL 44

AVERAGE COL 17 PUT IN COL 45

SPACE 3

NOTE

SPACE

NOTE THE FOLLOH'ING VALUES MUST EQUAL OR BE NEAR $.565, .674, .321, .375$ AND .253.

FIXED 3

SPACE

ABR IDGE ROH' 1 OF COLUMNS $41^{* * *} 45$

FLOATING

SPACE

NOTE *****

SPACE 3

NOTE PARETO

NPRINT COLUMN 3 AND COLUMN 16

AVERAGE COL 16 AND PUT IN 41

SPACE 3

NOTE **

SPACE

NOTE THE FOLLOHING VALLE MUST BE EQUAL TO OR NEAR .27028603

SPACE 
LIST OF DATA, INSTRUCTIONS AND DIAGNOSTICS

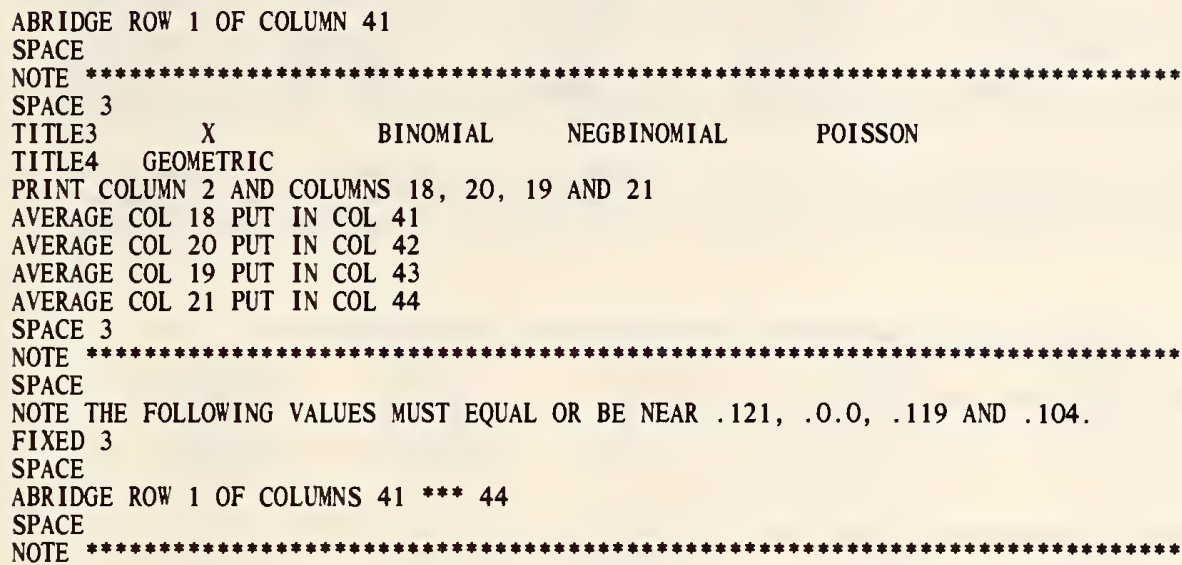

NATIONAL BUREAU OF STANDARDS. WASHINGTON, D. C. 20234 OMNITAB 80 VERSION $6.00 \quad$ MARCH 2,1981 


\begin{tabular}{|c|c|c|c|c|c|c|c|}
\hline \multicolumn{2}{|c|}{$\mathrm{x}$} & NORMAL & UNIFORM & CAUCHY & EXPONENT I AL & DEXPONENTIAL & \multirow{2}{*}{$\begin{array}{c}\text { LOGISTIC } \\
\text { COLUMN } \quad 16\end{array}$} \\
\hline COLUMN & 1 & COLUMN 11 & COLUMN $\quad 12$ & COLUMN 13 & COLUMN 14 & COLUMN 15 & \\
\hline \multirow{2}{*}{\multicolumn{2}{|c|}{.20000000}} & .39104269 & 1.0000000 & .30606720 & .81873076 & .40936538 & .247516 \\
\hline \multirow{2}{*}{\multicolumn{2}{|c|}{$\begin{array}{l}.30000000 \\
.39999999\end{array}$}} & .38138781 & 1.0000000 & .29202742 & .74081822 & .37040911 & .24445831 \\
\hline & & .36827014 & 1.0000000 & .27440508 & .67032006 & .33516003 & .24026075 \\
\hline \multicolumn{2}{|c|}{.50000000} & .35206533 & 1.0000000 & .25464791 & .60653066 & 6533 & .23500371 \\
\hline \multicolumn{2}{|c|}{.59999999} & .33322461 & 1.0000000 & .23405139 & .54881164 & .27440582 & .22878424 \\
\hline \multirow{2}{*}{\multicolumn{2}{|c|}{$\begin{array}{l}69999999 \\
.79999999\end{array}$}} & .31225394 & 1.0000000 & .21363080 & .49658531 & .24829265 & .221712 \\
\hline & & .28969156 & 1.0000000 & .19409140 & .44932897 & & .21390970 \\
\hline \multicolumn{2}{|c|}{.89999998} & .26608525 & 1.0000000 & .17586182 & .40656967 & 20328483 & .20550031 \\
\hline
\end{tabular}

THE FOLLOWING VALUES MUST BE EQUAL TO OR NEAR ZERO.
* 7.4505806-09
0. * 1.1175871-08
0 .
0. * 3.7252903-09 
OMNITAB 80 TEST 35 PROB DENS, CUMUL DIST AND PERCENT PT. (7.1), (7.2) AND (7.3) PAGE 2

\begin{tabular}{|c|c|c|c|c|}
\hline \multicolumn{5}{|c|}{ EXAMPLES OF CUMULATIVE DISTRIBTION FUNCTIONS } \\
\hline $\mathrm{X}$ & NORMAL & LOGNORMAL & HALFNORMAL & UNIFORM \\
\hline COLUMN & COLUMN 17 & COLUMN 18 & COLUMN 19 & COLUMN 20 \\
\hline 20000000 & . 57925969 & .053760290 & .15851939 & 20000000 \\
\hline .30000000 & 61791137 & .11430009 & .23582274 & .30000000 \\
\hline 39999999 & .65542170 & .17975718 & .31084341 & .39999999 \\
\hline .50000000 & .69146247 & 24410851 & 38292494 & .50000000 \\
\hline .59999999 & .72574693 & 30473654 & 45149386 & .59999999 \\
\hline 69999999 & .75803643 & 36066762 & .51607287 & 69999999 \\
\hline .79999999 & .78814468 & .41171192 & .57628936 & .79999999 \\
\hline .89999998 & .81593992 & 45804480 & 63187984 & .89999998 \\
\hline X & CAUCHY & EXPONENTIAL & DEXPONENTIAL & LOGISTIC \\
\hline .20000000 & .56283296 & .18126925 & .59063462 & .54983400 \\
\hline .30000000 & .59277358 & .25918178 & .62959089 & .57444251 \\
\hline .39999999 & .62111894 & .32967994 & .66483998 & .59868766 \\
\hline .50000000 & .64758362 & .39346934 & .69673467 & .62245933 \\
\hline .59999999 & .67202087 & .45118836 & .72559418 & .64565630 \\
\hline .69999999 & .69440011 & .50341469 & .75170735 & .66818777 \\
\hline . 79999999 & .71477671 & .55067103 & .77533551 & .68997448 \\
\hline .89999998 & .73326229 & .59343033 & .79671517 & .71094950 \\
\hline
\end{tabular}

THE FOLLOWING VALUES MUST BE EQUAL TO OR NEAR ZERO.

* 7.4505806-09*4.6566129-10*-1.8626451-09 0.

* $1.4901161-08 * 7.4505806-09 *-7.4505806-09 * 1.4901161-08$ 
OINITAB 80 TEST 35 PROB DENS, CUMLL DIST AND PERCENT PT. (7.1), (7.2) AND (7.3) PAGE 3 $\mathrm{X}$
COLUMN
.20000000
.30000000
.39999999
.50000000
.59999999
.69999999
.79999999
.89999998 EXAYPLES OF PERCENT POINT FUNCTIONS

\begin{tabular}{|c|c|c|c|}
\hline NORMAL & LOGNORMAL & HALFNORMAL & LNIFORM \\
\hline COLLMN 26 & COLUYN $\quad 27$ & COLUMN 28 & COLUMN 29 \\
\hline $\begin{array}{l}-.84162122 \\
-.52440055 \\
-.25334713 \\
0 . \\
.25334704\end{array}$ & $\begin{array}{r}.43101119 \\
.59191008 \\
.77619839 \\
1.0000000 \\
1.2883303\end{array}$ & $\begin{array}{r}.25334708 \\
.38532047 \\
.52440049 \\
.67448974 \\
.84162118\end{array}$ & $\begin{array}{l}.20000000 \\
.30000000 \\
.39999999 \\
.50000000 \\
.59999999\end{array}$ \\
\hline $\begin{array}{l}.52440049 \\
.84162118 \\
1.2815514\end{array}$ & $\begin{array}{l}1.6894457 \\
2.3201253 \\
3.6022240\end{array}$ & $\begin{array}{l}1.0364333 \\
1.2815515 \\
1.6448535\end{array}$ & $\begin{array}{r}69999999 \\
.79999999 \\
.89999998\end{array}$ \\
\hline
\end{tabular}

$\begin{array}{ccccc}X & \text { CAUCHY } & \text { EXPONENTIAL } & \text { DEXPONENTIAL } & \text { LOGISTIC } \\ 20000000 & -1.3763819 & .22314355 & -.91629074 & -1.3862944 \\ 30000000 & -.72654254 & .35667494 & -.51082563 & -.84729788 \\ 39999999 & -. .32491974 & .51082560 & -.22314358 & -.40546516 \\ 50000000 & *-1.2194766-16 & .69314718 & 0 . & . \\ 59999999 & .32491965 & .91629070 & .22314352 & .40546505 \\ 69999999 & .72654247 & 1.2039728 & .51082558 & .84729780 \\ 79999999 & 1.3763818 & 1.6094379 & .91629068 & 1.3862943 \\ 89999998 & 3.0776830 & 2.3025849 & 1.6094377 & 2.1972244\end{array}$

THE FOLLOWING VALUES MUST BE EQUAL TO OR NEAR ZERO.

$*-7.4505806-09 * 3.7252903-09 * 7.4505806-09 * 2.9802322-08$ 
LIST OF DATA, INSTRUCTIONS AND DIAGNOSTICS

$s$ DIMENSION $10 \times 200$

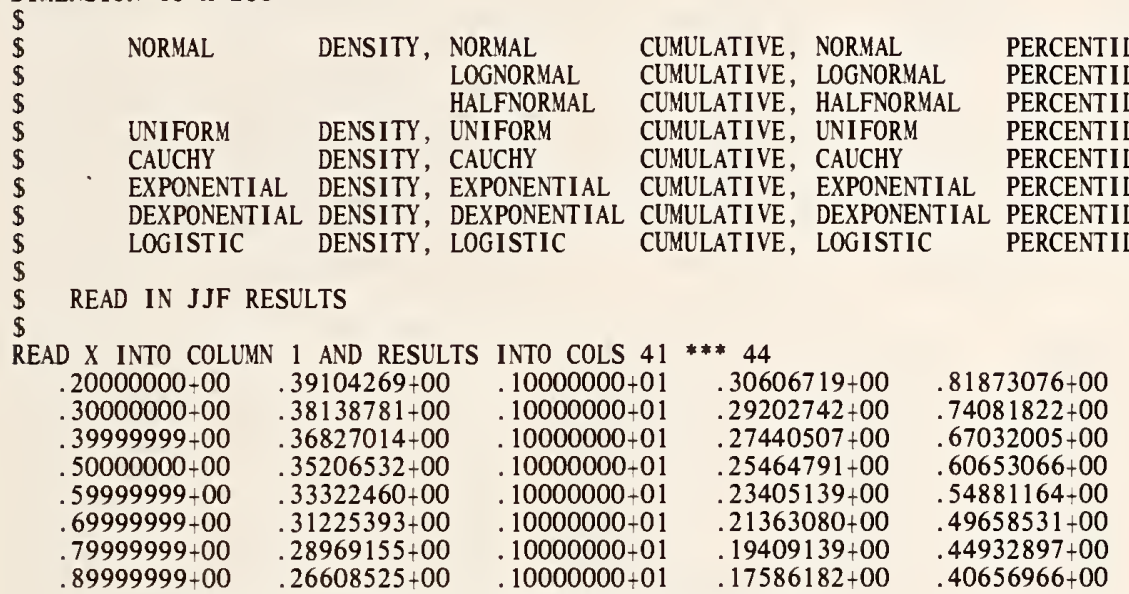

* informative diagnostic FOR THE abOVE INSTRUCTION NRMAX HAS BEEN RESET FROM 0 TO 8.

READ RESULTS INTO COLS $45 * * * 49$

$40936538+00$

$.37040911+00$

$.33516002+00$

$30326533+00$

$.27440582+00$

$.24829265+00$

$22466449+00$

$.20328483+00$

READ RESULTS INTO

$.20000000+00$

$.30000000+00$

$.39999999+00$

$.50000000+00$

$.59999999+00$

$69999999+00$

$79999999+00$

$89999999+00$

$24751657+00$

$.24445832+00$

$.24026075+00$

$.23500371+00$

$.22878424+00$

$.22171287+00$

$21390970+00$

$.20550031+00$

COLS $50 * * * 54$

$.56283295+00$

$.59277357+00$

$62111893+00$

$.64758361+00$

$.67202087+00$

$.69440010+00$

$.71477670+00$

$.73326229+00$

READ RESULTS INTO COLS 55***59

$.55900899+00-.84162122+00$

$.52327631+00-.52440055+00$

$-.52440055+00$
$-.25334713-00$

$\begin{array}{rr}45476079+00 & -.44703484-07\end{array}$
$57925969+00$ $.61791137+00$ $.65542170+00$

$69146247+00$

$.72574694+00$

$75803643+00$

$.78814468+00$

$.81593992+00$

$.18126924+00$

$.25918178+00$

$32967995+00$

$.39346935+00$

$.45118837+00$

$.50341469+00$

$.55067104+00$

$.59343034+00$

$.43101119+00$

$.59191008+00$

$77619839+00$

$.99999996-00$
53760290-01

$.11430009+00$

$.17975718+00$

$24410851+00$

$.30473655+00$

$.36066762+00$

$41171192+00$

$.45804480+00$

$.59063463+00$ $.62959090+00$ $.66483998+00$

$.69673468+00$

$.72559419+00$

$.75170735+00$

$.77533552+00$

$.79671517+00$

$.25334708+00$

$.38532047+00$

$.52440049+00$

$.67448971+00$
$15851939+00$

$.23582274+00$

$31084341+00$

$38292494+00$

$.45149389+00$

$51607287+00$

$57628936+00$

$.63187984+00$

$54983399+00$

$.57444251+00$ $59868766+00$ $62245933+00$

$.64565630+00$ $66818777+00$

$68997448+00$

$.71094950+00$

$.20000000+00$

.30000000+00

$39999999+00$

$.50000000+00$ 
OMNITAB 80 TEST 35 PROB DENS, CUMUL DIST AND PERCENT PT. (7.1), (7.2) AND (7.3) PAGE

LIST OF DATA, INSTRUCTIONS AND DIAGNOSTICS

$\begin{array}{cllll}.42236416+00 & .25334708+00 & .12883304+01 & .84162122+00 & .59999999+00 \\ .39139469+00 & .52440049+00 & .16894457+01 & .10364333+01 & .69999999+00 \\ .36194384+00 & .84162118+00 & .23201253+01 & .12815515+01 & .79999999+00 \\ .33406930+00 & .12815515+01 & .36022243+01 & .16448535+01 & .89999999+00 \\ \text { READ RESULTS INT0 COLS 60***64 } & & & & \\ -.13763819+01 & .22314354+00 & -.91629074+00 & -.13862944+01 & -.47588500+00 \\ -.72654254+00 & .35667494+00 & -.51082563+00 & -.84729788+00 & -.18562676+00 \\ -.32491972+00 & .51082561+00 & -.22314356+00 & -.40546514+00 & .87421557-01 \\ -.15893255-07 & .69314715+00 & -.74505806-08 & -.37252904-07 & .36651292+00 \\ .32491967+00 & .91629072+00 & .22314354+00 & .40546508+00 & .67172699+00 \\ . .72654244+00 & .12039728+01 & .51082558+00 & .84729780+00 & .10309304+01 \\ .13763818+01 & .16094378+01 & .91629064+00 & .13862943+01 & .14999399+01 \\ . .30776831+01 & .23025850+01 & .16094378+01 & .21972245+01 & .22503673+01\end{array}$

NORMAL DENSITY OF COLUMN 1 PUT IN COLUMN 11

UNIFORM $\quad$ DENSITY OF COLUMN 1 PUT IN COLUMN 12

CAUCHY DENSITY OF COLUMN 1 PUT IN COLUMN 13

EXPONENTIAL DENSITY OF COLUMN 1 PUT IN COLUMN 14

DEXPONENTIAL DENSITY OF COLUMN 1 PUT IN COLUMN 15

LOGISTIC DENSITY OF COLUMN 1 PUT IN COLUMN 16

NORMAL CUMULATIVE OF COLUMN 1 PUT IN COLUMN 17

LOGNORMAL CUMULATIVE OF COLUMN 1 PUT IN COLUMN 18

HALFNORMAL CUMULATIVE OF COLUMN 1 PUT IN COLUMN 19

UNIFORM CUMULATIVE OF COLUMN 1 PUT IN COLUMN 20

CAUCHY CUMULATIVE OF COLUMN 1 PUT IN COLUMN 21

EXPONENTIAL CUMULATIVE OF COLUMN 1 PUT IN COLUMN 22 DEXPONENTIAL CUMULATIVE OF COLUMN 1 PUT IN COLUMN 23

LOGISTIC CUMULATIVE OF COLUMN 1 PUT IN COLUYN 24

NORMAL PERCENTILE OF COLUMN 1 PUT IN COLUMN 26

LOGNORMAL PERCENTILE OF COLUMN 1 PUT IN COLUMN 27

HALFNORMAL PERCENTILE OF COLUMN 1 PUT IN COLUMN 28

UNIFORM PERCENTILE OF COLUMN 1 PUT IN COLUMN 29

CAUCHY PERCENTILE OF COLUMN 1 PUT IN COLUMN 30

EXPONENTIAL PERCENTILE OF COLUMN 1 PUT IN COLUMN 31

DEXPONENTIAL PERCENTILE OF COLUMN 1 PUT IN COLUMN 32 LOGISTIC PERCENTILE OF COLUMN 1 PUT IN COLUMN 33 $\$$

SUBTRACT COL 41 FROM COL 11 AND PUT IN COL 71 SUBTRACT COL 42 FROM COL 12 AND PUT IN COL 72 SUBTRACT COL 43 FROM COL 13 AND PUT IN COL 73 SUBTRACT COL 44 FROM COL 14 AND PUT IN COL 74 SUBTRACT COL 45 FROM COL 15 AND PUT IN COL 75 SUBTRACT COL 46 FROM COL 16 AND PUT IN COL 76 SUBTRACT COL 47 FROM COL 17 AND PUT IN COL 77 SUBTRACT COL 48 FROM COL 18 AND PUT IN COL 78 SUBTRACT COL 49 FROM COL 19 AND PUT IN COL 79 SUBTRACT COL 50 FROM COL 20 AND PUT IN COL 80 SUBTRACT COL 51 FROM COL 21 AND PUT IN COL 81 SUBTRACT COL 52 FROM COL 22 AND PUT IN COL 82 SUBTRACT COL 53 FROM COL 23 AND PUT IN COL 83 
OMNITAB 80 TEST 35 PROB DENS, CUMUL DIST AND PERCENT PT. (7.1), (7.2) AND (7.3) PAGE 6

LIST OF DATA, INSTRUCTIONS AND DIAGNOSTICS

SUBTRACT COL 54 FROM COL 24 AND PUT IN COL 84 SUBTRACT COL 56 FROM COL 26 AND PUT IN COL 86 SUBTRACT COL 57 FROM COL 27 AND PUT IN COL 87 SUBTRACT COL 58 FROM COL 28 AND PUT IN COL 88 SUBTRACT COL 59 FROM COL 29 AND PUT IN COL 89 SUBTRACT COL 60 FROM COL 30 AND PUT IN COL 90 SUBTRACT COL 61 FROM COL 31 AND PUT IN COL 91 SUBTRACT COL 62 FROM COL 32 AND PUT IN COL 92 SUBTRACT COL 63 FROM COL 33 AND PUT IN COL 93

PARSUM COL 71 AND PUT IN COL 101 PARSUM COL 72 AND PUT IN COL 102

PARSUM COL 73 AND PUT IN COL 103

PARSUM COL 74 AND PUT IN COL 104

PARSUM COL 75 AND PUT IN COL 105

PARSUM COL 76 AND PUT IN COL 106

PARSUM COL 77 AND PUT IN COL 107

PARSUM COL 78 AND PUT IN COL 108

PARSUM COL 79 AND PUT IN COL 109

PARSUM COL 80 AND PUT IN COL 110

PARSUM COL 81 AND PUT IN COL 111

PARSUM COL 82 AND PUT IN COL 112

PARSUM COL 83 AND PUT IN COL 113

PARSUM COL 84 AND PUT IN COL 114

PARSUM COL 86 AND PUT IN COL 116

PARSUM COL 87 AND PUT IN COL 117

PARSUM COL 88 AND PUT IN COL 118

PARSUM COL 89 AND PUT IN COL 119

PARSUM COL 90 AND PUT IN COL 120

PARSUM COL 91 AND PUT IN COL 121

PARSUM COL 92 AND PUT IN COL 122

PARSUM COL 93 AND PUT IN COL 123

$\$$

TITLE1 EXAMPLES OF PROBABILITY DENSITY FUNCTIONS

TITLE3 3 NORMAL NOFORM CAUCHY

TITLE4 EXPONENTIAL DEXPONENTIAL LOGISTIC

PRINT COLUMN 1 AND COLUMNS $11^{* * * 16}$

SPACE 3

NOTE

SPACE

NOTE THE FOLLOWING VALUES MUST BE EQUAL TO OR NEAR ZERO.

SPACE

ABRIDGE ROW 1 OF COLUMNS $101 * * * 103$

ABRIDGE ROW 1 OF COLUMNS $104^{* * *} 106$

SPACE

NOTE

TITLE 1

TITLE3

TITLE4

$X$

EXAMPLES OF CUMULATIVE DISTRIBTION FUNCTIONS

UNIFORM

NORMAL LOGNORMAL HALFNORMAL


OMNITAB 80 TEST 35 PROB DENS, CUMUL DIST AND PERCENT PT. (7.1), (7.2) AND (7.3) PAGE 7 LIST OF DATA, INSTRUCTIONS AND DIAGNOSTICS

PRINT COLUMN 1 AND COLUMNS $17 * * * 20$

SPACE 3

NOTE1 $\quad X \quad$ CAUCHY EXPONENTIAL DEXPONENTIA

NOTE2L

PR INT NOTE

NPR INT COLUMN 1 AND COLUMNS $21 * * * 24$

SPACE 3

NOTE $* * * * * * * * * * * * * * * * * * * * * * * * * * * * * * * * * * * * * * * * * * * * * * * * * * * * * * * * * * * * * * * * * * * * * * * * * * * *)$

SPACE

NOTE THE FOLLOWING VALUES MUST BE EQUAL TO OR NEAR ZERO.

SPACE

ABRIDGE ROW 1 OF COLUMNS $107 * * * 110$

ABR IDGE ROW 1 OF COLUMNS $111^{* * *} 114$

SPACE

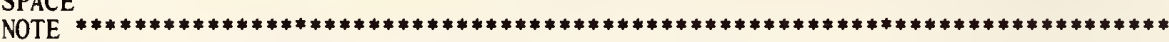

TITLE1 EXAMPLES OF PERCENT POINT FUNCTIONS

PRINT COLUMN 1 AND COLUMNS $26 * * 29$

SPACE 3

PRINT NOTE

NPRINT COLUMN 1 AND COLUMNS 30**33

SPACE 3

NOTE * *

SPACE

NOTE THE FOLLOWING VALUES MUST BE EQUAL TO OR NEAR ZERO.

SPACE

ABRIDGE ROW 1 OF COLUMNS $116 * * * 119$

ABRIDGE ROW 1 OF COLUMNS $120 * * * 123$

SPACE

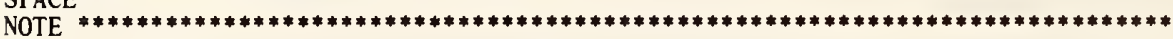

NATIONAL BUREAU OF STANDARDS. WASHINGTON, D. C. 20234

OMNITAB 80 VERSION 6.00 MARCH 2, 1981 
OMNITAB 80 TEST 36 PROB DENS, CUMUL DIST AND PERCENT PT. (7.1), (7.2) AND (7.3) PAGE

\begin{tabular}{|c|c|c|c|c|c|c|}
\hline $\mathrm{x}$ & LAMBDA DEN & $\begin{array}{l}\text { EXAMPLD } \\
\text { GAMMA }\end{array}$ & LAMBDA & WEIBULL & $\begin{array}{l}\text { PARETO } \\
\text { PAS. }\end{array}$ & EXTREME \\
\hline COLUMN & COLUMN 11 & COLUMN $\quad 12$ & COLUMN 13 & COLUMN 14 & COLUMN 15 & COLUMN 16 \\
\hline $\begin{array}{l}.20000000 \\
.30000000 \\
.39999999 \\
.50000000 \\
.59999999\end{array}$ & $\begin{array}{l}.35089626 \\
.34755898 \\
.34285709 \\
.33675984 \\
.32922624\end{array}$ & $\begin{array}{l}.47291074 \\
.56142197 \\
.62890662 \\
.68268950 \\
.72667832\end{array}$ & $\begin{array}{l}.57053280 \\
.60546780 \\
.64000034 \\
.67399311 \\
.70730495\end{array}$ & $\begin{array}{l}.36059268 \\
.42173472 \\
.46871439 \\
.50693130 \\
.53911036\end{array}$ & $\begin{array}{l}.087129067 \\
.12294198 \\
.15484574 \\
.18350342 \\
.20943058\end{array}$ & $\begin{array}{l}.10687792 \\
.16109809 \\
.20574066 \\
.24311673 \\
.27499717\end{array}$ \\
\hline $\begin{array}{r}69999999 \\
.79999999 \\
.89999998\end{array}$ & $\begin{array}{r}32020409 \\
.30962830 \\
.29741726\end{array}$ & $\begin{array}{l}.76327643 \\
.79409678 \\
.82028750\end{array}$ & $\begin{array}{r}.73978901 \\
.77129269 \\
.80165958\end{array}$ & $\begin{array}{l}.56684516 \\
.59115828 \\
.61274941\end{array}$ & $\begin{array}{l}.23303501 \\
.25464400 \\
.27452375\end{array}$ & $\begin{array}{r}30263476 \\
.32692189 \\
.34850853\end{array}$ \\
\hline
\end{tabular}

THE FOLLOWING VALUES MUST BE EQUAL TO OR NEAR ZERO.
* 3.7252903-09*3.7252903-09
0. * 3.7252903-09*-3.7252903-09* 5.5879354-09

$X$
.20000000
.30000000
.39999999
.50000000
.59999999
.69999999
.79999999
89999998

EXAMPLES OF PERCENT POINT FUNCTIONS.

$\begin{array}{ccccc}\text { GAMMA } & \text { LAMBDA } & \text { WEIBULL } & \text { PARETO } & \text { EXTREME } \\ .032092377 & -.89442721 & .049793044 & 1.5625000 & .38605710 \\ .074235929 & -.57787494 & .12721701 & 2.0408163 & .68986902 \\ .13749794 & -.28428233 & .26094280 & 2.7777777 & 1.1910593 \\ .22746821 & 0 . & .48045301 & 4.0000000 & 2.0813690 \\ .35416313 & .28428222 & .83958864 & 6.2499996 & 3.8322569 \\ & & & & \\ .53709706 & .57787490 & 1.4495504 & 11.111110 & 7.8605829 \\ .82118717 & .89442715 & 2.5902902 & 24.999997 & 20.083124 \\ 1.3527716 & 1.2649110 & 5.3018973 & 99.999968 & 90.083256\end{array}$

THE FOLLOWING VALUES MUST BE EQUAL TO OR NEAR ZERO.
* 4.6566129-10*-7.4505806-09*6.5192580-09
0.
0. 
LIST OF DATA, INSTRUCTIONS AND DIAGNOSTICS

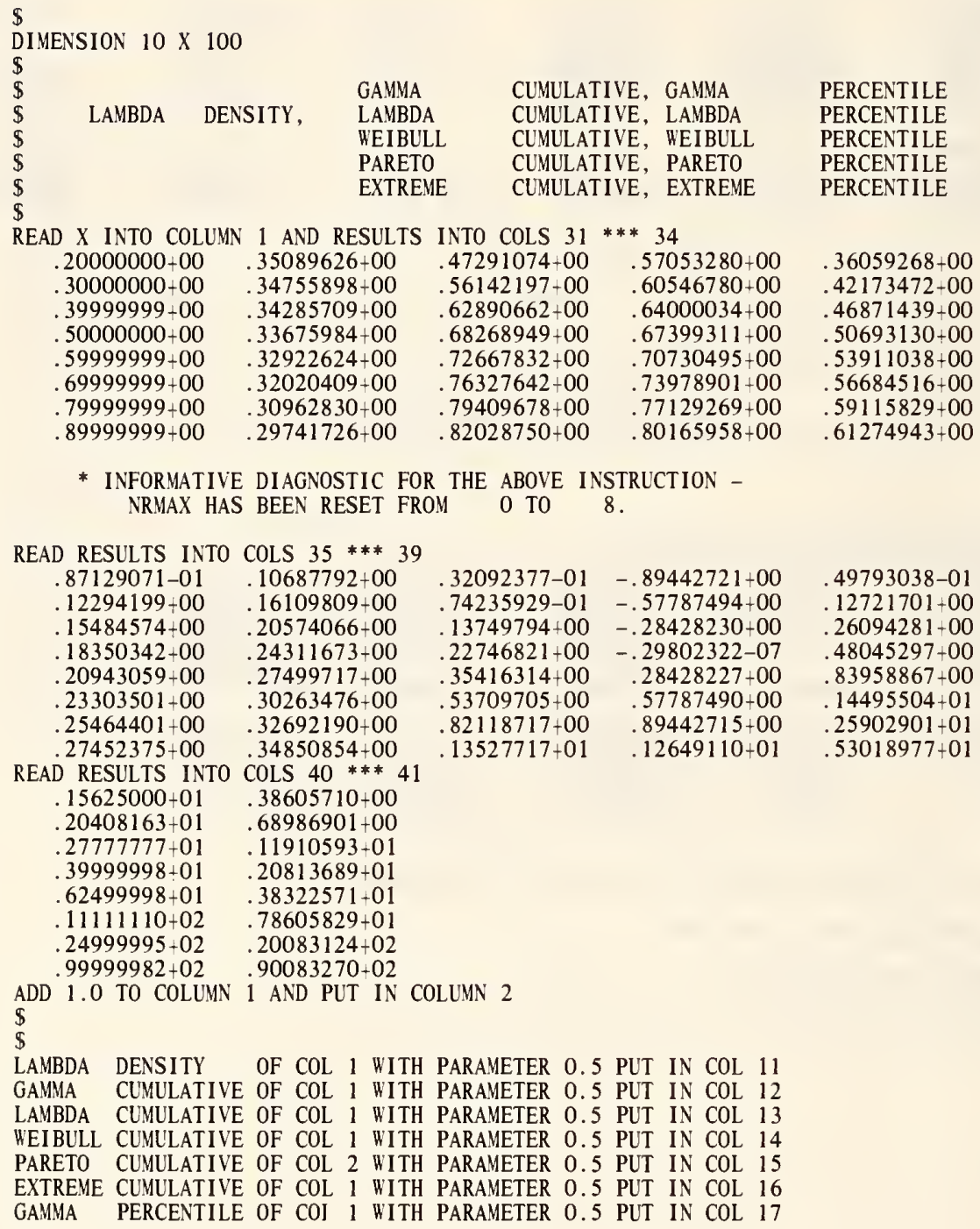


OMNITAB 80 TEST 36 PROB DENS, CUMUL DIST AND PERCENT PT. (7.1), (7.2) AND (7.3) PAGE 3

LIST OF DATA, INSTRUCTIONS AND DIAGNOSTICS LAMBDA PERCENTILE OF COL 1 WITH PARAMETER 0.5
WEIBULL PERCENTILE OF COL 1 WITH PARAMETER 0.5
PARET0 PERCENTILE OF COL 1 WITH PARAMETER 0.5
EXTREME PERCENTILE OF COL 1 WITH PARAMETER 0.5
$\$$
SUBTRACT COL 31 FROM COL 11 AND PUT IN COL 51
SUBTRACT COL 32 FROM COL 12 AND PUT IN COL 52
SUBTRACT COL 33 FROM COL 13 AND PUT IN COL 53
SUBTRACT COL 34 FROM COL 14 AND PUT IN COL 54
SUBTRACT COL 35 FROM COL 15 AND PUT IN COL 55
SUBTRACT COL 36 FROM COL 16 AND PUT IN COL 56
SUBTRACT COL 37 FROM COL 17 AND PUT IN COL 57
SUBTRACT COL 38 FROM COL 18 AND PUT IN COL 58
SUBTRACT COL 39 FROM COL 19 AND PUT IN COL 59
SUBTRACT COL 40 FROM COL 20 AND PUT IN COL 60
SUBTRACT COL 41 FROM COL 21 AND PUT IN COL 61
$\$$

PARSUM COL 51 AND PUT IN COL 81

PARSUM COL 52 AND PUT IN COL 82

PARSUM COL 53 AND PUT IN COL 83

PARSUM COL 54 AND PUT IN COL 84

PARSUM COL 55 AND PUT IN COL 85

PARSUM COL 56 AND PUT IN COL 86

PARSUM COL 57 AND PUT IN COL 87

PARSUM COL 58 AND PUT IN COL 88

PARSUM COL 59 AND PUT IN COL 89

PARSUM COL 60 AND PUT IN COL 90

PARSUM COL 61 AND PUT IN COL 91

$\$$

TITLE1

TITLE2 DISTRIBUTION FUNCTIONS.

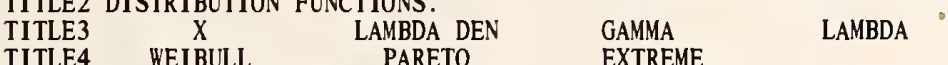

PR INT COLUMN 1 AND COLUMNS $11 * * * 16$

SPACE 3

NOTE $1 * * * * * * * * * * * * * * * * * * * * * * * * * * * * * * * * * * * * * * * * * * * * * * * * * * * * * * *$

NOTE $2 * * * * * * * * * * * * * * * * * * * * * * * * * *$

PRINT NOTE

SPACE

NOTE THE FOLLOWING VALUES MUST BE EQUAL TO OR NEAR ZERO.

SPACE

ABRIDGE ROW 1 OF COLUMNS $81 * * * 86$

SPACE

PRINT NOTE

SPACE 3

NOTE

EXAMPLES OF PERCENT POINT FUNCTIONS.

NOTE1 1 GAMMA LAMBDA WEIBULL

NOTE2 PARETO EXTREME

PRINT NOTE

NPRINT COLUMN 1 AND COLUMNS $17 * * 21$ 
OMNITAB 80 TEST 36 PROB DENS, CUMUL DIST AND PERCENT PT. (7.1), (7.2) AND (7.3) PAGE 4 LIST OF DATA, INSTRUCTIONS AND DIAGNOSTICS

SPACE 3

NOTE $* * * * * * * * * * * * * * * * * * * * * * * * * * * * * * * * * * * * * * * * * * * * * * * * * * * * * * * * * * * * * * * * * * * *$

SPACE

NOTE THE FOLLOWING VALUES MUST BE EQUAL TO OR NEAR ZERO.

SPACE

ABRIDGE ROW 1 OF COLUMNS $87 * * * 91$

SPACE

NOTE $* * * * * * * * * * * * * * * * * * * * * * * * * * * * * * * * * * * * * * * * * * * * * * * * * * * * * * * * * * * * * * * * * * * * * *$

NATIONAL BUREAU OF STANDARDS. WASHINGTON, D. C. 20234

OMNITAB 80 VERSION 6.00 MARCH 2,1981 
OMNITAB 80 TEST 37 CUMULATIVE DIST AND PERCENT PT. (7.2) AND (7.3)

PAGE 1

\begin{tabular}{|c|c|c|c|c|}
\hline $\mathrm{X}$ & BINOMIAL & NEGBINOMI AL & POISSON & GEOMETRIC \\
\hline COLUMN & COLUMN 11 & COLUMN 12 & COLUMN 13 & COLUMN 14 \\
\hline 1.0000000 & .069175296 & * $1.7826192-13$ & .091578195 & .36000000 \\
\hline 2.0000000 & .20608473 & * 1.5875478 & .23810331 & .48800000 \\
\hline 3.0000000 & .41144888 & * 9.8553578-12 & .43347012 & .59040000 \\
\hline 4.0000000 & .62964828 & * 4.7887276-11 & .62883694 & .67232000 \\
\hline 5.0000000 & .80420779 & * 1.9392983-10 & .78513039 & .73785600 \\
\hline 6.0000000 & .91330750 & * $6.8073831-10$ & .88932602 & .79028480 \\
\hline 7.000 & .96785734 & * 2.1272552-09 & .94886638 & .83222 \\
\hline 8.000 & .99001822 & $* 6.0328511-09$ & .97863656 & .86578 \\
\hline
\end{tabular}

THE FOLLOWING VALUES MUST BE EQUAL TO OR NEAR ZERO.

* 4.6566129-09*-9.3132257-10*2.2351742-08*-1.7296413-18

$* * * * * * * * * * * * * * * * * * * * * * * * * * * * * * * * * * * * * * * * * * * * * * * * * * * * * * * * * * * * * * * * * * * * * * * * * * *$

\begin{tabular}{rccc}
\multicolumn{5}{c}{ EXAMPLES OF PERCENT } & POINT FUNCTIONS \\
BINOMIAL & NEGBINOMIAL & POISSON & GEOMETRIC \\
1.0000000 & 1.0000000 & 1.0000000 & 1.0000000 \\
2.0000000 & 2.0000000 & 2.0000000 & 2.0000000 \\
3.0000000 & 3.0000000 & 3.0000000 & 3.0000000 \\
4.0000000 & 4.0000000 & 4.0000000 & 4.0000000 \\
5.0000000 & 5.0000000 & 5.0000000 & 5.0000000 \\
& & & \\
6.0000000 & 6.0000000 & 6.0000000 & 6.0000000 \\
7.0000000 & 7.0000000 & 7.0000000 & 7.0000000 \\
8.0000000 & 8.0000000 & 8.0000000 & 8.0000000
\end{tabular}

THE FOLLOWING VALUES MUST BE EQUAL TO OR NEAR ZERO.
0 .
0 .
0 .
0 . 
LIST OF DATA, INSTRLCTIONS AND DIAGNOSTICS

$\$$
$\$$
$\$$
$S$
$\$$
$\$$
$\$$
$\$$

READ IN JJF RESULTS

$\begin{array}{cccc}\text { READ X INTO COLLMN } 1 \text { AND RESLLTS INTO COLS } 2^{* * *} & 5 \\ .10000000-01 & .69175291-01 & .91578196-01 & .35999998-00 \\ .20000000-01 & .20608472-00 & .23810331-00 & .48799998-00 \\ .30000000-01 & .41144886-00 & .43347012-00 & .59039998+00 \\ .40000000-01 & .62964826-00 & .62883694-00 & .67231998-00 \\ .50000000-01 & .80420779-00 & .78513039-00 & .73785599-00 \\ .60000000-01 & .91330748-00 & .88932602-00 & .79028478-00 \\ .70000000-01 & .96785733+00 & .94886638-00 & .83222783-00 \\ .80000000-01 & .99001821-00 & .97863656-00 & .86578226-00 \\ .10000000-01 & .10000000-01 & .10000000-01 & .10000000-01 \\ .20000000-01 & .20000000-01 & .20000000-01 & .20000000-01 \\ .30000000-01 & .30000000-01 & .40000000-01 & .30000000-01 \\ .40000000-01 & .40000000-01 & .40000000-01 & .40000000-01 \\ .50000000+01 & .50000000-01 & .60000000-01 & .50000000-01 \\ .60000000-01 & .60000000+01 & .70000000-01 & .60000000-01 \\ .70000000-01 & .70000000-01 & .80000000-01 & .70000000-01 \\ .80000000-01 & .80000000-01 & .90000000-01 & .80000000-01\end{array}$

BINOMIAL CLMULATIVE, BINOMIAL PERCENTILE MEGBIYOMIAL CLMLLATIVE, IEGBIYOMIAL PERCENTILE

POISSON CLYULATIVE, POISSON PERCEITILE GEOMETRIC CLMULATIVE, GEOMETRIC PERCENTILE

* INFORMATIIE diagNostic fOR the abOVE INSTRLCTION -

NRMAX HAS BEEY RESET FROM O TO 16.

MOVE ROH 1 OF COL 2 SIZE $8 X 4$ TO ROH 1 OF COL 21 YOVE ROH 9 OF COL 1 SIZE $8 X 4$ TO ROH 1 OF COL 25 RESET NRMAX TO 8

* INFORMATIVE diagiostic FOR the abOVE INSTRLCTIOA NRMAX HAS BEEY RESET FROM 16 TO 8.

$\$$

BINOMIAL CUMULATIVE OF COL 1 HITH $X=20 ., P=0.2$, PLT IN COL 11 POISSON CLYULATIVE OF COL 1 HITH LAYBDA $=4.0$, PLT IN COL 13 GEOMETRIC CUMULATIVE OF COL 1 HITH $\quad \mathrm{P}=0.2$, PLT IN COL 14 NEGBINOMIAL CUMLATIVE OF COL 1 HITH $\mathrm{X}=20 ., \mathrm{P}=0.2$, PLT IN COL 12 BINOMIAL PERCENTILE OF COL 11 HIITH $x=20, P=0.2$, PLT IN COL 15 POISSON PERCENTILE OF COL 13 HITH LAMBDA $=4.0$, PUT IN COL 17 GEOMETRIC PERCENTILE OF COL 14 HITH $\quad P=0.2$, PLT IN COL 18 NEGBINOMIAL PERCENTILE OF COL 12 HITH $N=20 ., P=0.2$, PLT IN COL 16 $S$

SUBTRACT COL 21 FROM COL 11 AND PLT IN COL 31 SUBTRACT COL 22 FROM COL 13 AND PUT IN COL 32 SUBTRACT COL 23 FROM COL 14 AND PLT IN COL 33 SUBTRACT COL 24 FRON COL 12 AND PLT IN COL 34 
LIST OF DATA, INSTRUCTIONS AND DIAGNOSTICS

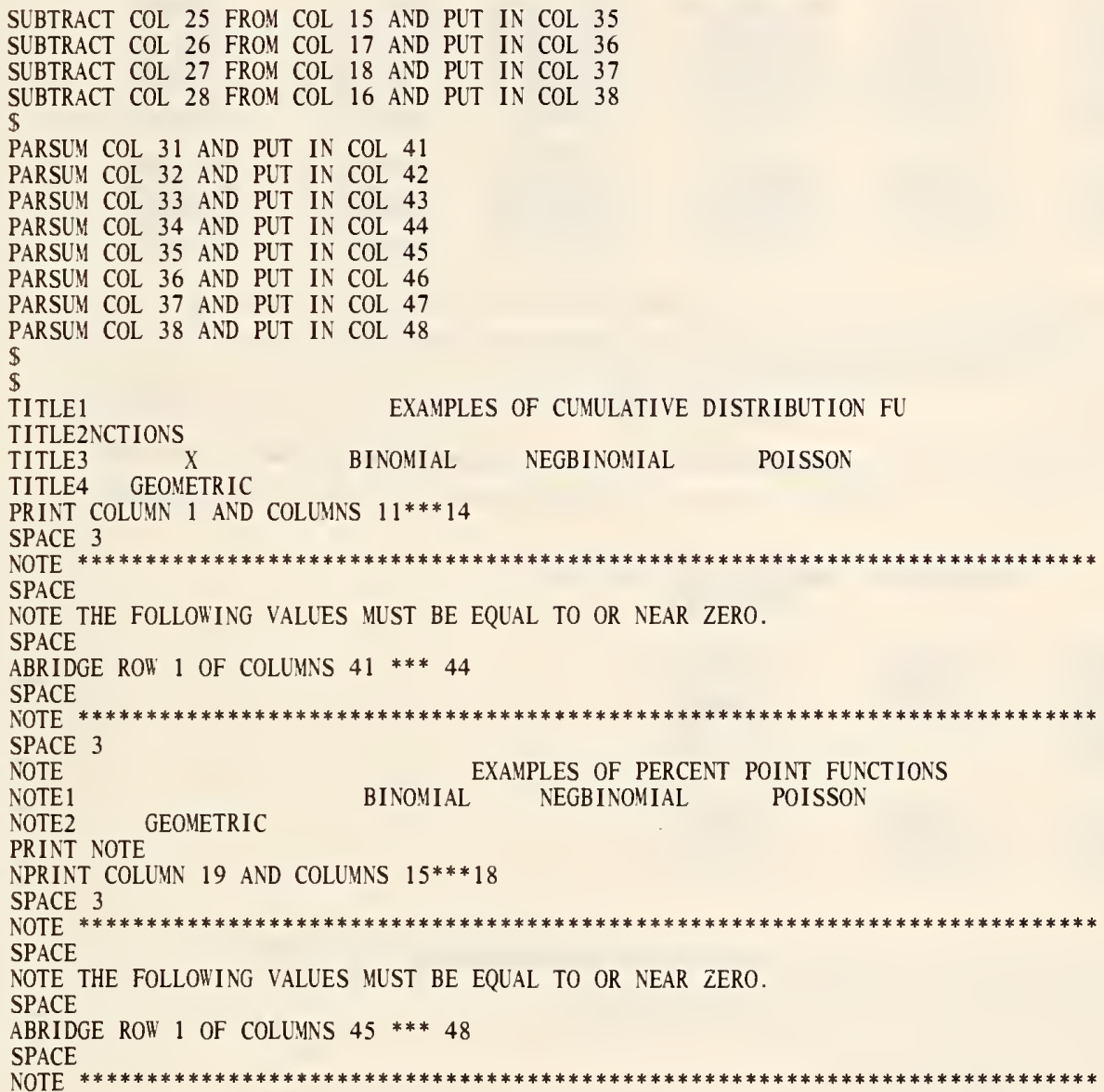

NATIONAL BUREAU OF STANDARDS. WASHINGTON, D. C. 20234 OMNITAB 80 VERSION $6.00 \quad$ MARCH 2,1981 
OMNITAB 80 TEST 38 CUMULATIVE DISTRIBUTION AND PERCENT PT. (7.2) AND (7.3)

\begin{tabular}{|c|c|c|c|}
\hline \multicolumn{4}{|c|}{ T CHISQUARED } \\
\hline COLUMN & COLUMN 11 & COLUMN 12 & COLUMN \\
\hline 20000000 & .57531974 & .00088611276 & .049036206 \\
\hline .30000000 & .61187547 & .0023570045 & 1037535 \\
\hline 39999999 & .64716344 & .0046705807 & 16674804 \\
\hline .50000000 & 68085057 & .0078768630 & 23197282 \\
\hline .59999999 & .71266985 & .011996927 & 29580291 \\
\hline . 69999999 & 74242552 & .017031450 & 35625157 \\
\hline .79999999 & .76999296 & .022966755 & .41236100 \\
\hline . 89999998 & .79531439 & .029778413 & . 46379254 \\
\hline
\end{tabular}

THE FOLLOWING VALUES MUST BE EQUAL TO OR NEAR ZERO.

* 7.4505806-09 0. *-4.6566129-10

$X$

20000000

30000000

.39999999

50000000

59999999

69999999

.79999999

.89999998
EXAMPLES OF PERCENT POINT FUNCTIONS CHISQUARED

$\begin{array}{cc}-.91954378 & 2.3425343 \\ -.55942965 & 2.9999081 \\ -.26718090 & 3.6554995 \\ 0 . & 4.3514602 \\ .26718083 & 5.1318669 \\ & \\ .55942961 & 6.0644299 \\ .91954374 & 7.2892760 \\ 1.4758839 & 9.2363565\end{array}$

THE FOLLOWING VALUES MUST BE EQUAL TO OR NEAR ZERO.

$*-7.4505806-09 * 2.9802322-08$ 
OMNITAB 80 TEST 38 CUMULATIVE DISTRIBUTION AND PERCENT PT. (7.2) AND (7.3)

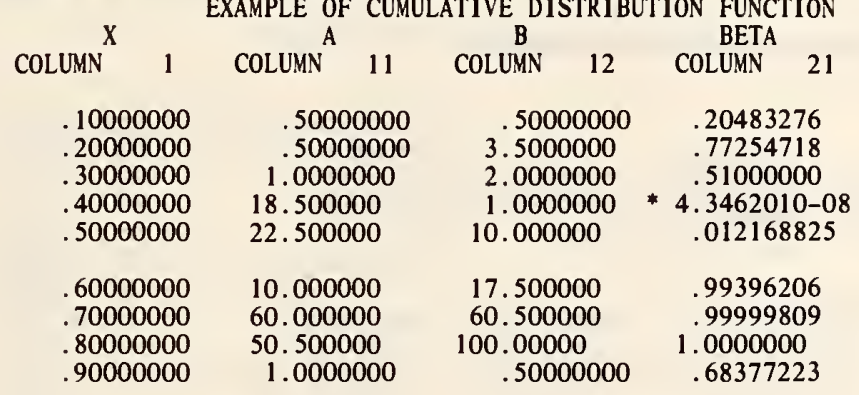

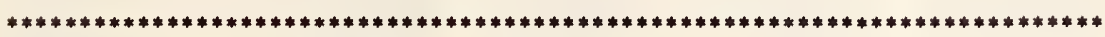

THE FOLLOWING VALUES MUST BE EQUAL TO OR NEAR ZERO.

*-7.4505806-09*2.9064735-08 
LIST OF DATA, INSTRUCTIONS AND DIAGNOSTICS

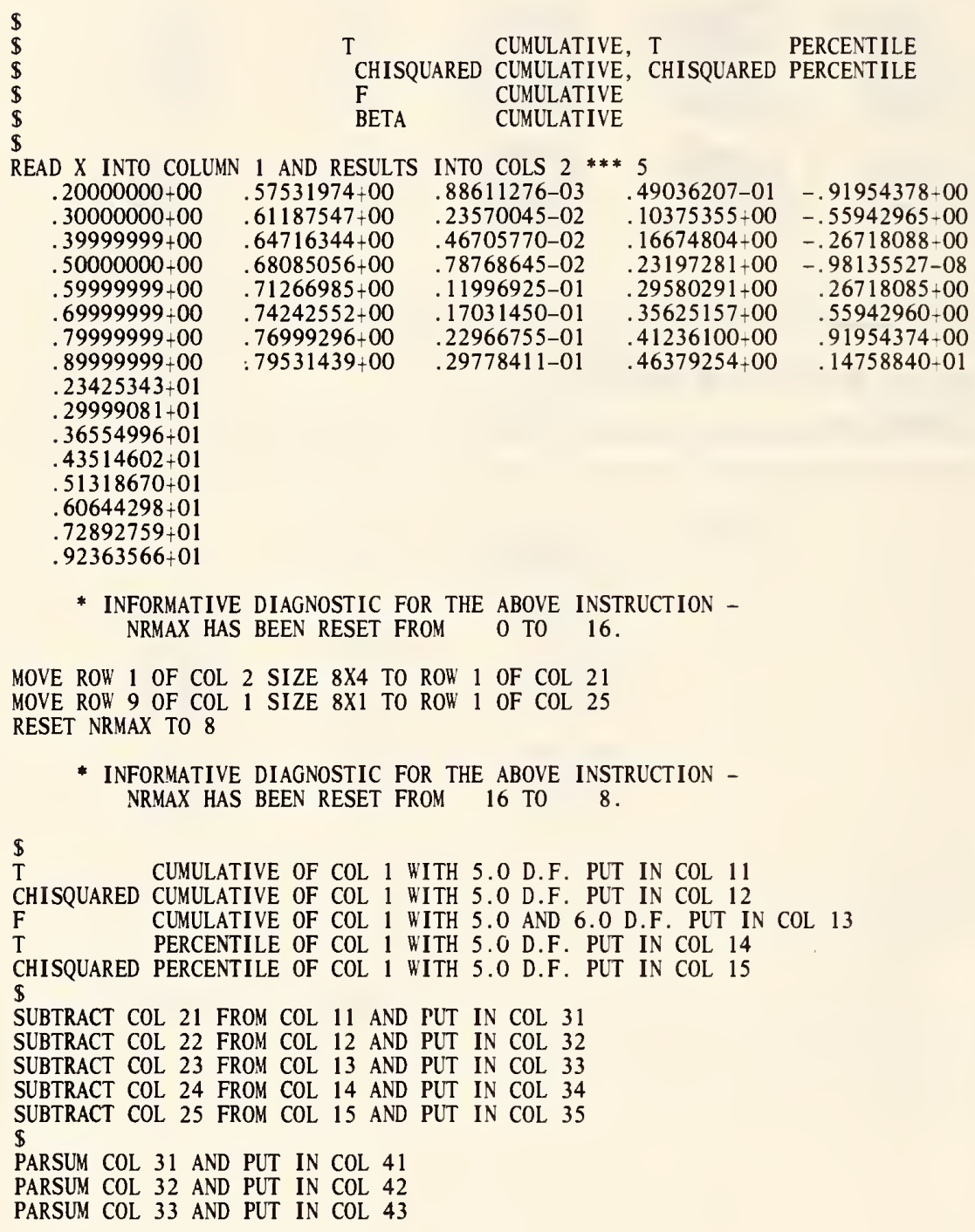


LIST OF DATA, INSTRUCTIONS AND DIAGNOSTICS

PARSUM COL 34 AND PUT IN COL 44

PARSUM COL 35 AND PUT IN COL 45

$\$$

$\begin{array}{lll}\text { TITLE1 } & \\ \text { TITLE3 } & X \quad \text { EXAMPLES OF CUMULATIVE DISTRIBUTION FUNCTIONS }\end{array}$

PRINT COLUMN 1 AND COLUMNS $11^{* * *} 13$

SPACE 3

NOTE ***

SPACE

NOTE THE FOLLOWING VALUES MUST BE EQUAL TO OR NEAR ZERO.

SPACE

ABRIDGE ROW 1 OF COLS $41 * * 43$

SPACE

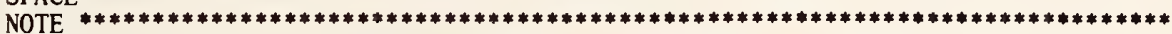

SPACE 3

NOTE

NOTE

SPACE

EXAMPLES OF PERCENT POINT FUNCTIONS

$\$$

NPRINT COLUMN 1 AND COLUMNS 14 AND 15

SPACE 3

NOTE ****

SPACE

NOTE THE FOLLOWING VALUES MUST BE EQUAL TO OR NEAR ZERO.

SPACE

ABRIDGE ROW 1 OF COLS 44 AND 45

SPACE

NOTE $* * * * * * * * * * * * * * * * * * * * * * * * * * * * * * * * * * * * * * * * * * * * * * * * * * * * * * * * * * * * * * * * * * * * * * *$

GENERATE NOS STARTING WITH .1 IN STEPS OF 0.1 THRU .9 IN COL 1

* INFORMATIVE diagNOSTIC FOR THE ABOVE INSTRUCTION NRMAX HAS BEEN RESET FROM 8 TO 9.

SET NUMERATOR DEGREES OF FREEDOM INTO COL 2

$1,7,4,2,20,35,121,200$ AND 1

SET DENOMINATOR DEGREES OF FREEDOM INTO COL 3

$1,1,2,37,45,20,120,101$ AND 2

DIVIDE COL 3 BY 2.0 AND PUT A IN COL 11

DIVIDE COL 2 BY 2.0 AND PUT B IN COL 12

BETA CUMULATIVE OF COL $1, A=$ COL $11, B=$ COL 12 PUT IN COL 21

$\$$

$\$$

DIVIDE COL 3 BY COL 2 AND PUT IN COL 4

SUBTRACT COL 1 FROM 1.0 AND PUT IN COL 5

DIVIDE COL 5 BY COL 1 AND PUT IN COL 6

MULTIPLY COL 4 BY COL 6 AND PUT IN COL 10

F PROBAB ILITY COL 2, 3, 10, PUT IN 22

F CUMULATIVE COL 10, 2, 3 AND PUT IN 23

SUBTRACT COL 23 FROM 1.0 AND PUT IN COL 24 
LIST OF DATA, INSTRLCTIONS AND DIAGNOSTICS

SUBTRACT COL 21 FROM 22 AND PUT IN COL 31

SUBTRACT COL 21 FROM COL 24 AND PUT IN COL 32

SUY COL 31 AND PUT IN COL 41

SUY COL 32 AND PUT IN COL 42

TITLE1 EXAMPLE OF CUMULATIVE DISTRIBUTION FUNCTION

TITLE3 3 A $\quad$ B

PRINT COLUMN 1 AND COLUMNS 11,12 AND 21

SPACE 3

NOTE ***,

SPACE

NOTE THE FOLLOHING VALUES MUST BE EQUAL TO OR NEAR ZERO.

SPACE

ABRIDGE ROW 1 OF COLS 41 AND 42

SPACE

NOTE *

NATIONAL BLREAU OF STANDARDS. HASHINGTON, D. C. 20234

OMNITAB 80 VERSION 6.00 MARCH 2,1981 
OMNITAB 80 TEST 39 RANDOM NUMBER INSTRUCTIONS, (7.4)

PAGE 1

$\begin{array}{ccllll}\text { COLUMN } 1 & \text { COLUMN } 2 & \text { COLUMN } 3 & \text { COLUMN } 4 & \text { COLUMN } 5 \\ .38174057 & 5.0680000 & & .97418261 & 1.0396345 & .0037880444 \\ 1.0018944 & .56210667 & 1.4778752 & .50540576 & 2.3000000 \\ .81148265 & -.022678865 & -.012298160 & 1.6512011 & 2.5760000 \\ -.055414933 & 1.1417662 & 4.9159999 & .034876147 & 2.0216545\end{array}$

THE FOLLOWING VALUE MUST BE EQUAL TO OR NEAR 6.594304.

6.5943040 


\begin{tabular}{|c|c|c|c|}
\hline $\begin{array}{c}\text { MNITAB } 80 \text { TEST } \\
\text { UNIFORM } \\
1.0\end{array}$ & $\begin{array}{l}39 \text { RANDOM NUMBER } \\
\text { RANDOM NUMBERS } \\
3473.0\end{array}$ & $\begin{array}{l}\text { INSTRUCTIONS } \\
\text { STARTING } \\
\text { NOS IN COL } 1\end{array}$ & $\begin{array}{l}(7.4) \\
\text { VALUE } \\
3473.0\end{array}$ \\
\hline COLUMN 1 & COLUMN 2 & COLUMN 3 & COLUMN 4 \\
\hline $\begin{array}{l}.031860352 \\
.033569336 \\
.56024170 \\
.78155518 \\
.78375244\end{array}$ & $\begin{array}{l}.21527100 \\
.24884033 \\
.80908203 \\
.59063721 \\
.37438965\end{array}$ & $\begin{array}{l}.031860352 \\
.033569336 \\
.56024170 \\
.78155518 \\
.78375244\end{array}$ & $\begin{array}{l}.21527100 \\
.24884033 \\
.80908203 \\
.59063721 \\
.37438965\end{array}$ \\
\hline $\begin{array}{l}.011657715 \\
.41015625 \\
.53076172 \\
.53369141 \\
.091735840\end{array}$ & $\begin{array}{l}.38604736 \\
.79620361 \\
.32696533 \\
.86065674 \\
.95239258\end{array}$ & $\begin{array}{l}.011657715 \\
.41015625 \\
.53076172 \\
.53369141 \\
.091735840\end{array}$ & $\begin{array}{r}.38604736 \\
.79620361 \\
.32696533 \\
.86065674 \\
.95239258\end{array}$ \\
\hline $\begin{array}{l}.12353516 \\
.12524414 \\
.65191650 \\
.87322998 \\
.87542725\end{array}$ & $\begin{array}{l}.075927734 \\
.20117188^{\circ} \\
.85308838 \\
.72631836 \\
.60174561\end{array}$ & $\begin{array}{l}.12353516 \\
.12524414 \\
.65191650 \\
.87322998 \\
.87542725\end{array}$ & $\begin{array}{l}.075927734 \\
.20117188 \\
.85308838 \\
.72631836 \\
.60174561\end{array}$ \\
\hline $\begin{array}{l}.10333252 \\
.50183105 \\
.62243652 \\
.62536621 \\
.18341064\end{array}$ & $\begin{array}{l}.70507813 \\
.20690918 \\
.82934570 \\
.45471191 \\
.63812256\end{array}$ & $\begin{array}{l}.10333252 \\
.50183105 \\
.62243652 \\
.62536621 \\
.18341064\end{array}$ & $\begin{array}{l}.70507813 \\
.20690918 \\
.82934570 \\
.45471191 \\
.63812256\end{array}$ \\
\hline FIKSI IT. & SECOND THENTY & FIRS & FORTY \\
\hline
\end{tabular}

THE FOLLOH'ING VALUE MUST BE EQUaL TO OR NEAR ZERO.

0 . 
LIST OF DATA, INSTRUCTIONS AND DIAGNOSTICS

$\$$ DIMENSION $250 \times 8$ RESET 250

* INFORMATIVE DIAGNOSTIC FOR THE ABOVE INSTRUCTION NRMAX HAS BEEN RESET FROM O TO 250.

$\$$

BETA RANDOM WITH PARAMETERS $=3$. AND $=5$. IN COLUMN 1

BINOMIAL RANDOM WITH $N=10$. AND PARAM $=0.5$ IN COLUMN 2

CAUCHY RANDOM IN COLUMN 3

CHISQUARED RANDOM WITH PARAM = 1.0 IN COLUMN 4

DEXPONENTI AL RANDOM

IN COLUMN 5

1/AVERAGE COLUMN 1 PUT RESULT IN COLUMN 1

2/INCREMENT INSTRUCTION 1 BY 1 AND 1

PERFORM INSTRUCTIONS 1 THRU 2, 5 TIMES

MTRANSPOSE ROW 1 OF COLUMN 1 SIZE 1 BY 5 INTO ROW 1 OF COLUMN 8

EXPONENTIAL RANDOM IN COLUMN 1

EXTREME RANDOM IN COLUMN 2

F RANDOM WITH D.F. $=5$. AND D.F. $=7$. IN COLUMN 3

GAMMA RANDOM WITH PARAM $=0.5$ IN COLUMN 4

GEOMETRIC RANDOM WITH PARAM $=0.3$ IN COLUMN 5

1/AVERAGE COLUMN 1 PUT RESULT IN COLUMN 1

PERFORM INSTRUCTIONS 1 THRU 2,5 TIMES

MTRANSPOSE ROW 1 OF COLUMN 1 SIZE 1 BY 5 INTO ROW 6 OF COLUMN 8

HALFNORMAL RANDOM IN COLUMN 1

LAMBDA $\quad$ WITH PARAM $=0.5$ IN COLUMN 2

LOGISTIC RANDOM IN COLUMN 3

$\begin{array}{lll}\text { LOGNORMAL RANDOM } & \text { IN COLUMN } 4\end{array}$

NEGBINOMIAL RANDOM WITH N $=10$. AND PARAM $=0.8$ IN COLUMN 5

1/AVERAGE COLUMN 1 PUT RESULT IN COLUMN 1

PERFORM INSTRUCTIONS 1 THRU 2, 5 TIMES

MTRANSPOSE ROW 1 OF COLUMN 1 SIZE 1 BY 5 INTO ROW 11 OF COLUMN 8

NORMAL RANDOM

PARETO RANDOY

\begin{tabular}{lll} 
POISSON & RANDOM & WITH PARAM $=5.0$ IN COLUMN \\
\hline
\end{tabular}

T RANDOM $\quad$ WITH PARAM $=10$. IN COLUMN 4

H'EIBULL RANDOM WITH PARAM $=0.5$ IN COLUMN 5

1/AVERAGE COLUMN 1 PUT RESULT IN COLUMN 1

PERFORM INSTRUCTIONS 1 THRU 2, 5 TIMES

MTRANSPOSE ROW 1 OF COLUMN 1 SIZE 1 BY 5 INTO ROW 16 OF COLUMN 8

1/AVERAGE COLUMN 1 PUT RESULT IN COLUMN 1

PERFORM INSTRUCTIONS 1 THRU 2, 5 TIMES

MTRANSPOSE ROW 1 OF COLUMN 8 SIZE 5 BY 1 INTO ROW 1 OF COLUMN 1 MTRANSPOSE ROW 6 OF COLUMN 8 SIZE 5 BY 1 INTO ROW 2 OF COLUMN 1

MTRANSPOSE ROW 11 OF COLUMN 8 SIZE 5 BY 1 INTO ROW 3 OF COLUMN 1 MTRANSPOSE ROW 16 OF COLUMN 8 SIZE 5 BY 1 INTO ROW 4 OF COLUMN 1 RESET NRMAX $=4$

* INFORMATIVE DIAGNOSTIC FOR THE ABOVE INSTRUCTION NRMAX HAS BEEN RESET FROM 250 TO 4. 
PRINT COLLMNS $1 * * * 5$

ROH SUM COLUMN 1 THRU COLUMN 5 PUT IN COLUMN 6

AVERAGE COLUMN 6 INTO COLLMN 6

SPACE 2

NOTE ***

SPACE

NOTE THE FOLLOHING VALUE MUST BE EQUAL TO OR NEAR 6.594304.

SPACE

ABRIDGE ROH 1 OF COLUYN 6

SPACE

NOTE $* * * * * * * * * *$
RESET IRYAX 20

* INFORMative diagiostic fOR the abOVE INSTRUCTION IRMAX HAS BEEN RESET FROM 4 TO 20.

UNIFORM RANDOM NLYBERS STARTING TITH 1.0 PUT IN COLUMN 1

UNIFORM RANDOM NUMBERS STARTING WITH THE 21 ST RANDOM NUMBER PUT IN COLUNN 2 RESET IRHAX 40

* INFORMATIVE DIAGNOSTIC FOR THE ABOVE INSTRUCTION NRMAX HAS BEEN RESET FROM 20 TO 40.

UNIFORM RANDOM NUMBERS, STARTING FITH INTEGER 1, PUT IN COLUYN 3 MOVE DATA STARTING IN ROF 21 OF COLUNN 3 SIZE 20X1 INTO RON 1 OF COLUMN 4 RESET NRYAX 20

* INFORMaTIVE diagNOSTIC FOR THE ABOVE INSTRUCTION NRMAX HAS BEEN RESET FROM 40 TO 20.

SUBTRACT COLUMN 2 FROM COLLYN 4 PUT IN COLLMN 5 TITLE1 UNIFORM RANDOM NUMBERS STARTING VALLE $\begin{array}{lllll}\text { TITLE } 3 & 1.0 & 3473.0 & \text { NOS IN COL } 1 & 3473.0\end{array}$ PRINT COLLYNS $1 * * * 4$ AVERAGE COLUMN 4 STORE IN COLUMN 4

SPACE 2

NOTE FIRST THENTY SECOND THENTY FIRST FORTY

SPACE 2

NOTE

SPACE

YOTE THE FOLLOHING VALUE YUST BE EQUAL TO OR NEAR ZERO.

SPACE

ABRIDGE ROW 1 COLUN 5

SPACE

NOTE

NATIONAL BUREAU OF STANDARDS. MASHINGTON, D. C. 20234 OMNITAB 80 VERSION 6.00 MARCH 2,1981 


\begin{tabular}{|c|c|c|}
\hline COLUMN & 7 & COLUMN \\
\hline & $\begin{array}{l}1 \\
1 \\
2 \\
2 \\
2 \\
1 \\
1 \\
2 \\
2 \\
1\end{array}$ & \\
\hline
\end{tabular}

$* * * * * * * * * * * * * * * * * * * * * * * * * * * * * * * * * * * * * * * * * * * * * * * * * * * * * * * * * * * * * * * * * * * * * * * * *$

THE FOLLOWING VALUES MUST BE EQUAL TO OR NEAR 1.5 AND 5.5

1.5

5.5 
LIST OF DATA, INSTRLCTIONS AND DIAGNOSTICS

SAYPLE R'ITHR OF SIZE 10 FROM A POPLLATION OF SIZE 2 PUT IN COL 7

* informative diagnostic for the above instrlction -

NRYAX HAS BEEN RESET FROM O TO 10.

SAMPLE RITHOUTR OF SIZE 10 FROM A POPLLATION OF SIZE 10 PUT IN COL 13

FIXED 0, PRINT ZERO DIGITS AFTER DECIMAL PT.

PRINT COLS 7 AND 13

AVERAGE COL 7 PUT IN COL 8

AVERAGE COL 13 PUT IN COL 9

FIXED 1, PRINT ONE DIGIT AFTER DECIMAL PT.

SPACE 3

NOTE *****

SPACE

NOTE THE FOLLORING VALUES YUST BE EQUAL TO OR NEAR 1.5 AND 5.5

SPACE

ABRIDGE ROH 1 OF COLS 8 AND 9

SPACE

NOTE

NATIONAL BUREAU OF STANDARDS. HASHINGTON, D. C. 20234

OMNITAB 80 VERSION 6.00 MARCH 2,1981




\begin{tabular}{|c|c|c|c|c|c|}
\hline $\begin{array}{c}\text { OMNITAB } 80 \text { TEST } \\
\text { COL } 1 \\
\mathrm{X}^{1}\end{array}$ & $\begin{array}{c}\text { EXAMPLES OF } \\
\text { COL } 2 \\
K(X) \\
\text { ELLIPT } 1 \mathrm{ST}\end{array}$ & $\begin{array}{l}\text { IPTICAL INT } \\
\text { COL } 3 \\
\text { E (X) } \\
\text { ELLIPT 2ND }\end{array}$ & $\begin{array}{l}\text { L OF ORDERS } \\
\begin{array}{c}\text { COL } 4 \\
Y \\
Y=1-X\end{array}\end{array}$ & $\begin{array}{l}\text { AND } 2 .(8.1) \\
\text { COL } 5 \\
\text { K (Y) } \\
\text { ELLIPT 1ST }\end{array}$ & $\begin{array}{c}\text { PAGE } \\
\text { COL } 6 \\
\text { E (Y) } \\
\text { ELLIPT 2ND }\end{array}$ \\
\hline $\begin{array}{l}0 . \\
.050000000 \\
.10000000 \\
.15000000 \\
.20000000\end{array}$ & $\begin{array}{l}1.5707963 \\
1.5910034 \\
1.6124413 \\
1.6352567 \\
1.6596236\end{array}$ & $\begin{array}{l}1.5707963 \\
1.5509734 \\
1.5307576 \\
1.5101218 \\
1.4890351\end{array}$ & $\begin{array}{c}1.0000000 \\
.95000000 \\
.90000001 \\
.85000001 \\
.80000001\end{array}$ & $\begin{array}{l}0 . \\
2.9083373 \\
2.5780921 \\
2.3890165 \\
2.2572054\end{array}$ & $\begin{array}{l}1.0000000 \\
1.0604737 \\
1.1047747 \\
1.1433958 \\
1.1784899\end{array}$ \\
\hline $\begin{array}{l}.25000000 \\
.30000000 \\
.35000000 \\
.40000000 \\
.45000000\end{array}$ & $\begin{array}{l}1.6857504 \\
1.7138894 \\
1.7443506 \\
1.7775194 \\
1.8138839\end{array}$ & $\begin{array}{l}1.4674622 \\
1.4453631 \\
1.4226911 \\
1.3993921 \\
1.3754020\end{array}$ & $\begin{array}{l}.75000000 \\
.70000000 \\
.65000001 \\
.60000001 \\
.55000001\end{array}$ & $\begin{array}{l}2.1565157 \\
2.0753631 \\
2.0075984 \\
1.9495678 \\
1.8989249\end{array}$ & $\begin{array}{l}1.2110560 \\
1.2416706 \\
1.2707075 \\
1.2984280 \\
1.3250245\end{array}$ \\
\hline .50000000 & 1.8540747 & 1.3506439 & .50000000 & 1.8540747 & 1.3506439 \\
\hline
\end{tabular}

LET $\mathrm{Y}=1-\mathrm{X}, \quad \mathrm{K}(\mathrm{X})$ AND $\mathrm{K}(\mathrm{Y})$ ARE ELLIPTICAL INTEGRALS OF 1ST ORDER, AND $E(X)$ AND $E(Y)$ ARE ELLIPTICAL INTEGRALS OF 2ND ORDER, THEN $\mathrm{E}(\mathrm{X}) * \mathrm{~K}(\mathrm{Y})+\mathrm{E}(\mathrm{Y}) * \mathrm{~K}(\mathrm{X})-\mathrm{K}(\mathrm{X}) * \mathrm{~K}(\mathrm{Y})=\mathrm{PI} / 2$ (HANDBOOK OF MATH. FUNC. AMS $55 \mathrm{PG}$ 591). THEREFORE THE FOLLOWING VALUE MUST BE EQUAL TO OR NEAR 1.5707963.

1.5707963 
LIST OF DATA, INSTRUCTIONS AND DIAGNOSTICS

GENERATE FROM 0. IN STEPS OF .05 THRU . 5 IN COL 1

* INFORMATIVE DIAGNOSTIC FOR THE ABOVE INSTRUCTION NRMAX HAS BEEN RESET FROM O TO 11.

SUBTRACT COL 1 FROM 1.0 STORE IN COL 4

ELLIPTICAL FIRST ORDER OF COL 1 STORE IN COL 2

ELLIPTICAL SECOND ORDER OF COL 1 STORE IN COL 3

ELLIPTICAL FIRST ORDER OF COL 4 STORE IN COL 5

** ARITHMETIC FAULT IN ABOVE INSTRUCTION. ZERO RETURNED 1 TIMES $X$ FOR ELLIPTICAL INTEGRAL IS GREATER THAN OR EQUAL TO ONE.

ELLIPTICAL SECOND ORDER OF COL 4 STORE IN COL 6

** ARITHMETIC FAULT IN ABOVE INSTRUCTION. ZERO RETURNED 1 TIMES SQRT, LOG OR RAISE OF NEGATIVE NUMBER.

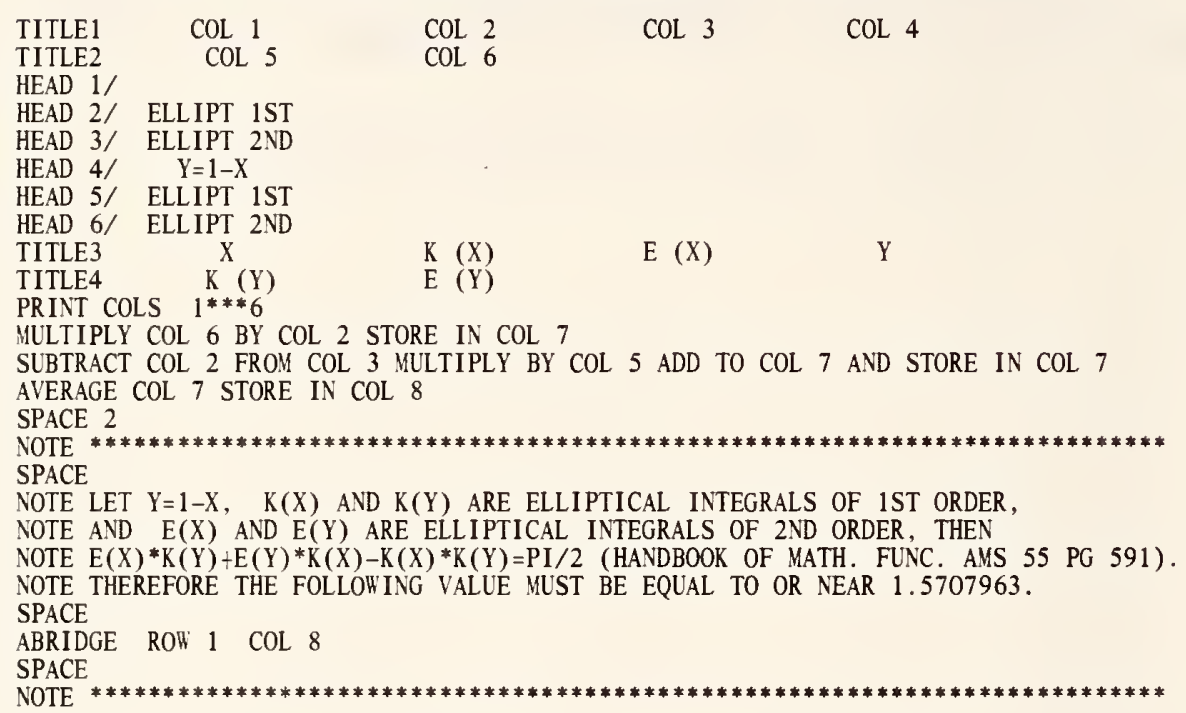

NATIONAL BUREAU OF STANDARDS. WASHINGTON, D. C. 20234 OMNITAB 80 VERSION 6.00 MARCH 2,1981 


\begin{tabular}{|c|c|c|c|c|}
\hline OMNITAB 80 TES & $\begin{array}{l}42 \text { ERROR AND } \\
\text { EXACT } \\
\text { ERF }(X)\end{array}$ & $\begin{array}{l}\text { IPLEMENTARY E } \\
\text { COMPUTED } \\
\text { ERF }(X)\end{array}$ & $\begin{array}{l}\text { OR INSTRUCTIO } \\
\operatorname{EXACT} \\
\operatorname{ERFC}(X)\end{array}$ & $\begin{array}{l}\text { - }(8.1) \\
\text { COMPUTED } \\
\text { ERFC }(X)\end{array}$ \\
\hline COLUMN & COLUMN 11 & COLUMN 21 & COLUMN 12 & COLUMN 22 \\
\hline $\begin{array}{r}0 . \\
.10000000 \\
.20000000 \\
.30000000 \\
.40000000\end{array}$ & $\begin{array}{l}0 . \\
.11246292 \\
.22270259 \\
.32862676 \\
.42839236\end{array}$ & $\begin{array}{l}0 . \\
.11246292 \\
.22270259 \\
.32862676 \\
.42839235\end{array}$ & $\begin{array}{c}1.0000000 \\
.88753709 \\
.77729742 \\
.67137325 \\
.57160765\end{array}$ & $\begin{array}{c}1.0000000 \\
.88753708 \\
.77729741 \\
.67137324 \\
.57160765\end{array}$ \\
\hline $\begin{array}{l}.50000000 \\
.59999999 \\
.70000000 \\
.80000000 \\
.90000000\end{array}$ & $\begin{array}{l}.52049988 \\
.60385609 \\
.67780118 \\
.74210095 \\
.79690821\end{array}$ & $\begin{array}{l}.52049988 \\
.60385609 \\
.67780119 \\
.74210096 \\
.79690821\end{array}$ & $\begin{array}{l}.47950013 \\
.39614391 \\
.32219882 \\
.25789905 \\
.20309180\end{array}$ & $\begin{array}{l}.47950012 \\
.39614391 \\
.32219881 \\
.25789904 \\
.20309179\end{array}$ \\
\hline $\begin{array}{l}1.0000000 \\
1.1000000 \\
1.2000000 \\
1.3000000 \\
1.4000000\end{array}$ & $\begin{array}{l}.84270079 \\
.88020507 \\
.91031398 \\
.93400794 \\
.95228512\end{array}$ & $\begin{array}{l}.84270079 \\
.88020507 \\
.91031397 \\
.93400794 \\
.95228512\end{array}$ & $\begin{array}{l}.15729922 \\
.11979493 \\
.089686021 \\
.065992072 \\
.047714889\end{array}$ & $\begin{array}{l}.15729921 \\
.11979493 \\
.089686025 \\
.065992055 \\
.047714882\end{array}$ \\
\hline $\begin{array}{l}1.5000000 \\
1.6000000 \\
1.7000000 \\
1.8000000 \\
1.9000000\end{array}$ & $\begin{array}{l}.96610515 \\
.97634838 \\
.98379046 \\
.98909049 \\
.99279042\end{array}$ & $\begin{array}{l}.96610515 \\
.97634839 \\
.98379046 \\
.98909050 \\
.99279043\end{array}$ & $\begin{array}{l}.033894852 \\
.023651630 \\
.016209543 \\
.010909513 \\
.0072095841\end{array}$ & $\begin{array}{l}.033894854 \\
.023651617 \\
.016209542 \\
.010909499 \\
.0072095710\end{array}$ \\
\hline 2.0000000 & .99532226 & 99532226 & .0046777427 & .0046777350 \\
\hline
\end{tabular}

THE FOLLOWING VALUE MUST BE EQUAL TO OR NEAR ZERO.

* 4.2574746-09 
OMNITAB 80 TEST 42 ERROR AND COMPLEMENTARY ERROR INSTRUCTIONS. (8.1)

LIST OF DATA, INSTRUCTIONS AND DIAGNOSTICS

GENERATE FROM 0. IN STEPS OF 1 THRU 20 PUT IN COL $1 \$ 21$ VALUES

* INFORMATIVE DIAGNOSTIC FOR THE ABOVE INSTRUCTION NRMAX HAS BEEN RESET FROM O TO 21.

DIVIDE COLUMN 1 BY 10.0 AND PUT IN COLUMN 1

SET IN COLUMN $11 \$$ AMS 55, 310-311 VALUES OF ERF

$\begin{array}{llllll}0.00000000 & 0.11246292 & 0.22270259 & 0.32862676 & 0.42839236 & 0.52049988 \\ 0.60385609 & 0.67780119 & 0.74210096 & 0.79690821 & 0.84270079 & 0.88020507 \\ 0.91031398 & 0.93400794 & 0.95228512 & 0.96610515 & 0.97634838 & 0.98379046\end{array}$

$\begin{array}{lll}0.91031398 & 0.93400794 & 0.95228512 \\ 0.98909050 & 0.99279043 & 0.99532226\end{array}$

SUBTRACT COLUMN 11 FROM 1.0 AND PUT CERF IN COLUMN 12

ERROR OF COLUMN 1 PUT IN COLUMN 21

CERF OF COLUMN 1 PUT IN COLUMN 22

ADD COLUMN 21 TO COLUMN 22 AND PUT IN COLUMN 23

SUBTRACT COLUMN 23 FROM 1. PUT IN COLUMN 33

AVERAGE COLUMN 33 PUT IN COLUMN 43

TITLE1

TITLE2 COMPUTED

$\begin{array}{lclll}\text { TITLE3 } & X & \operatorname{ERF}(X) & \operatorname{ERF}(X) & \operatorname{ERFC}(X)\end{array}$

TITLE4 $\operatorname{ERFC}(X)$

EXACT

PRINT COLUMNS $1,11,21,12,22$

SPACE 2

NOTE $*$ SPACE

SPACE

NOTE THE FOLLOHING VALUE MUST BE EQUAL TO OR NEAR ZERO.

SPACE

ABRIDGE ROW 1 OF COLUMN 43

SPACE

NOTE $* * * * * * * * * * * * * * * * * * * * * * * * * * * * * * * * * * * * * * * * * * * * * * * * * * * * * * * * * * * * * * * * * * * * * * *$

NATIONAL BUREAU OF STANDARDS. WASHINGTON, D. C. 20234 OMNITAB 80 VERSION $6.00 \quad$ MARCH 2,1981 
OMNITAB 80 TEST 43 EXAMPLE OF GAMMA INSTRUCTION. (8.1)

$\begin{array}{ccc}\begin{array}{c}\text { X } \\ \text { COLUMN }\end{array} & \begin{array}{c}\text { GAMMA(X) } \\ \text { COLUMN }\end{array} 2 & \begin{array}{c}\text { GAMMA }(2.5) \\ \text { COLUMN }\end{array} \\ & & \\ 1.0000000 & 1.0000000 & 1.3293404 \\ 2.0000000 & 1.0000000 & 1.3293404 \\ 5.0000000 & 24.000000 & 1.3293404 \\ 1.5000000 & .88622692 & 1.3293404 \\ 2.5000000 & 1.3293404 & 1.3293404 \\ 1.1050000 & .94935418 & 1.3293404 \\ 1.2250000 & .91191561 & 1.3293404 \\ 1.7350000 & .91573621 & 1.3293404 \\ 1.9950000 & .99789636 & 1.3293404 \\ 25.000000 & * 6.2044840+23 & 1.3293404 \\ -.50000000 & -3.5449077 & 1.3293404 \\ -1.5000000 & 2.3632718 & 1.3293404 \\ -2.5000000 & -.94530872 & 1.3293404 \\ -4.5000000 & -.060019601 & 1.3293404 \\ -1.7350000 & 2.6734055 & 1.3293404 \\ & & \\ .50000000 & 1.7724538 & 1.3293404 \\ .75000000 & 1.2254167 & 1.3293404 \\ .25000000 & 3.6256099 & 1.3293404 \\ -.75000000 & -4.8341466 & 1.3293404 \\ -.25000000 & -4.9016668 & 1.3293404 \\ -1.2500000 & 3.9213335 & 1.3293404 \\ -.50399999 & -3.5446437 & 1.3293404 \\ -1.5730000 & 2.3024101 & 1.3293404 \\ -2.6110000 & -.88813674 & 1.3293404 \\ -3.6350000 & .24512766 & 1.3293404\end{array}$

THE FOLLOWING VALUE MUST BE EQUAL TO OR NEAR ZERO.

0. 
LIST OF DATA, INSTRUCTIONS AND DIAGNOSTICS

SET IN COLLBN 1

$1.000, \quad 2.000, \quad 5.000, \quad 1.500, \quad 2.500$

$1.105, \quad 1.225, \quad 1.735, \quad 1.995, \quad 25.000$

$-0.500,-1.500,-2.500,-4.500,-1.735$

$0.500, \quad 0.750, \quad 0.250,-0.750,-0.250$

$-1.250,-0.504,-1.573,-2.611,-3.635$

* INFORMATIVE DIAGNOSTIC FOR the aBOVE INSTRLCTION IRMAX HAS BEEX RESET FROM O TO 25.

GAMMA OF COLUMN 1 PUT IN COLLMN 2

GAMMA OF 2.5 PLT IN COLLMN 3

TITLE3 $X$ GAMA $(X)$

PRINT COLLMNS 1,2 AVD 3

GAMA (2.5)

SLBTRACT VALLE IN *5,2* FROM COL 3 PUT IN COL 4

AVERAGE COL 4 PUT IN COL 4

SPACE 3

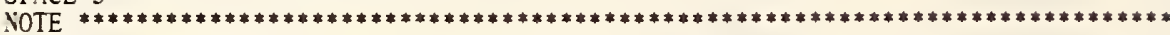

SPACE

NOTE THE FOLLOHING VALUE YLST BE EQLAL TO OR NEAR ZERO.

SPACE

ABRIDGE ROF 1 OF COL 4

SPACE

NOTE

VATIONAL BLREAL OF STANDARDS. HASHINGTON, D. C. 20234 OMNITAB 80 VERSION 6.00

MARCH 2,1981 
OMNITAB 80 TEST 44 SPECIAL INTEGRALS. (8.1)

\begin{tabular}{|c|c|c|c|c|}
\hline$x$ & $E I(X)$ & $\operatorname{EXP}(-X) \operatorname{EI}(X)$ & $E N(X)$ & $\operatorname{EXP}(X) \operatorname{EN}(X)$ \\
\hline OLUMN & COLUMN & COLUMN 3 & COLUMN & COLUMN 5 \\
\hline $\begin{array}{r}1.0000000 \\
2.0000000 \\
3.0000000 \\
5.0000000 \\
20.000000\end{array}$ & $\begin{array}{c}1.8951178 \\
4.9542344 \\
9.9338325 \\
40.185276 \\
* 2.5615653+07\end{array}$ & $\begin{array}{l}.69717488 \\
.67048271 \\
.49457640 \\
.27076625 \\
.052797795\end{array}$ & $\begin{array}{c}.14849551 \\
.037534262 \\
.010641925 \\
* 9.9646904-04 \\
* 9.4048564-11\end{array}$ & $\begin{array}{l}65264 \\
34277 \\
74878 \\
88912 \\
629090\end{array}$ \\
\hline
\end{tabular}

THE FOLLOWING VALUES SHOULD BE EQUAL TO OR NEAR ZERO.

*3.2782555-07*1.1920929-08 
OMNITAB 80 TEST 44 SPECIAL INTEGRALS. (8.1)

PAGE 2

\begin{tabular}{|c|c|c|c|c|}
\hline$X$ & $\mathrm{CI}(\mathrm{X})$ & $\operatorname{SI}(X)$ & $\mathrm{CHI}(\mathrm{X})$ & SHI $(X)$ \\
\hline COLUMN & COLUMN & COLUMN & COLUMN & COLUMN 5 \\
\hline 1.0000000 & .33740392 & .94608307 & .83786694 & 1.0572509 \\
\hline 2.0000000 & .42298083 & 1.6054130 & 2.4526669 & 5674 \\
\hline 3.0000000 & .11962979 & 1.8486525 & 4.9603921 & 4.9734405 \\
\hline 5.0000000 & -.19002975 & 1.5499312 & 20.092063 & 20.093212 \\
\hline 20.000000 & .044419821 & 1.5482417 & * $\quad 1.2807826+07$ & * $1.2807826+07$ \\
\hline
\end{tabular}

THE FOLLOWING VALUES SHOULD BE EQUAL TO OR NEAR .7344, 7.498 AND .25

$.73440000 \quad 7.4980000 \quad .25000000$ 


\section{LIST OF DATA, INSTRUCTIONS AND DIAGNOSTICS}

SET IN COLUMN 1

1., 2., 3., 5., AND 20

* INFORMATIVE DIAGNOSTIC FOR THE ABOVE INSTRUCTION -

NRMAX HAS BEEN RESET FROM O TO 5.

EINTEGRAL OF COLUMN 1 PUT IN COLUMN 2

NEGEINTEGRAL OF COLUMN 1 PUT IN COLUMN 3

DIVIDE COLUMN 2 BY COLUMN 3 PUT IN COLUMN 14

EXPONENTIAL OF COLUMN 1 PUT IN COLUMN 15

SUBTRACT COLUMN 15 FROM COLUMN 14 AND PUT IN COLUMN 14

AVERAGE COLUMN 14 PUT IN COLUMN 14

$\begin{array}{lllll}\text { TITLE3 } & X & \operatorname{EI}(X) & \operatorname{EXP}(-X) E I(X) & \operatorname{EN}(X)\end{array}$

TITLE4 $\operatorname{EXP}(X) \operatorname{EN}(X)$

IN COLUMN 4

EEXPINTEGRAL FOR $\mathrm{N}=2$ OF COLUMN 1 PUT IN COLUMN 5

DIVIDE COLUMN 5 BY COLUMN 4 PUT IN COLUMN 11

SUBTRACT COLUMN 15 FROM COLUMN 11 PUT IN COLUMN 11

AVERAGE COLUMN 11 PUT IN COLUMN 11

PRINT $1 * * * 5$

SPACE 3

NOTE $* * *$

SPACE

NOTE THE FOLLOWING VALUES SHOULD BE EQUAL TO OR NEAR ZERO.

SPACE

ABRIDGE ROW 1 OF COL 14 AND 11

SPACE

NOTE $* * * * * * * * * * * * * * * * * * * * * * * * * * * * * * * * * * * *$
COSINTEGRAL OF COLUMN 1 PUT IN COLUMN 2

HCOSINTEGRAL OF COLUMN 1 PUT IN COLUMN 4

SININTEGRAL OF COLUMN 1 PUT IN COLUMN 3

HSININTEGRAL OF COLUMN 1 PUT IN COLUMN 5

$\begin{array}{lllll}\text { TITLE } 3 & X & \text { CI }(X) & \text { SI }(X) & \text { CHI }(X)\end{array}$

TITLE4 SHI $(X)$
PRINT $1 * * * 5$

SUM COLUMN 4 PUT RESULT IN COL 6

SUM COLUMN 5 PUT RESULT IN COL 7

SUBTRACT COL 6 FROM COL 7 PUT IN COL 6

SUM COLUMN 2 PUT RESULT IN COL 8

SUM COLUMN 3 PUT RESULT IN COL 9

ROUND COL 8 TO 4 SIG. DIGITS PUT IN COL 8

ROUND COL 9 TO 4 SIG. DIGITS PUT IN COL 9

SPACE 3

NOTE

SPACE

NOTE THE FOLLOWING VALUES SHOULD BE EQUAL TO OR NEAR .7344, 7.498 AND .25

SPACE

ABRIDGE ROW 1 OF COLS 8,9 AND 6

SPACE

NOTE 
LIST OF DATA, INSTRUCTIONS AND DIAGNOSTICS

NATIONAL BUREAU OF STANDARDS. WASHINGTON, D. C. 20234 OMNITAB 80 VERSION 6.00 MARCH 2,1981 
OMNITAB 80 TEST 45 STRUVE FUNCTIONS AND INTEGRAL OF $J(0)$. (8.1) AND (12.10)

$\begin{array}{cccc}\begin{array}{c}\text { COL } 1 \\ X\end{array} & \begin{array}{l}\text { COL } 2 \\ \text { H ZERO }(X)\end{array} & \begin{array}{l}\text { COL } \\ \text { H ONE }(X)\end{array} & \begin{array}{c}\text { COL } 4 \\ \text { INTEGRAL OF J ZERO }\end{array} \\ 0 . & 0 . & 0 . & 0 . \\ .50 & .30955591 & .052173744 & .48968051 \\ 1.0 & .56865662 & .19845734 & .91973041 \\ 1.5 & .73672347 & .41028848 & 1.2414495 \\ 2.0 & .79085885 & .64676373 & 1.4257703 \\ 2.5 & .72995774 & .86315421 & 1.4679809 \\ 3.0 & .57430615 & 1.0201096 & 1.3875673 \\ 3.5 & .36082077 & 1.0915723 & 1.2233057 \\ 4.0 & .13501457 & 1.0697267 & 1.0247342 \\ 4.5 & -.058543316 & .96597435 & .84186254 \\ 5.0 & -.18521682 & .80781195 & .71531191\end{array}$

INTEGRAL OF J ZERO $=X * J 0+(P I * X / 2) *(H 0 * J 1-H 1 * J 0)$,

WHERE $J 1=J$ ONE $(X), H 1=H$ ONE $(X)$,

WHERE JO $=J$ ZERO $(X), H O=H$ ZERO $(X)$, AND

$J 1=J$ ONE $(X), \quad H 1=H$ ONE $(X)$.

HANDBOOK MATHEMATICAL FUNCTIONS AMS 55 PAGE 480.

THEREFORE THE FOLLOWING VALUE MUST BE NEAR OR EQUAL TO ZERO.

* $-1.4562498-08$ 
LIST OF DATA, INSTRECTIONS AND DIAGNOSTICS

GENERATE FROM 0.0 IN STEPS OF .5 THRU 5.0 AND STORE IN COL 1

* iaformatile diagNostic fOR the abOIE instruction NRMAX HAS BEEY RESET FROM O TO 11.

STRUVE ZERO OF VALLES IN COL 1 AND STORE IN COL 2

STRUTE OSE OF VALLES IN COL 1 AID STORE IN COL 3

INTJO INTEGRAL OF J ZERO OF COL 1 AND STORE IN COL 4

IEH PAGE

VIOTE $\quad$ COL 1 COL 2 COL 3 COL 4

NOTE $X$ H ZERO $(X)$ H ONE $(X)$ INTEGRAL OF J ZERO

SPACE

IPRINT COL 1 HITH 2. SIGNIFICANT DIGITS AND COLS 2, 3 AND 4 HITH 8.0 SIG DIGITS

BJZERO OF COL 1 AND STORE IN COL 5

BJONE OF COL 1 AND STORE IN COL 6

MULTIPLY COL 3 BY COL 5 MULTIPLY BY -1.0 ADD TO COL 7 AND STORE IN COL 7

MULT COL $2 \mathrm{BY}$ COL 6 MULTIPLY BY $1.0 \mathrm{ADD}$ TO COL 7 AND STORE IN COL 7

DIVIDE COL 1 BY 2.0 AND STORE IN COL 8

MULT COL 1 BY COL 5 AND STORE IN COL 9

MULT COL 8 BY *PI* MULTIPLY BY COL 7 ADD COL 9 AND STORE IN COL 7

SLBTRACT COL 4 FROM COL 7 AID STORE IN COL 7

AIERAGE COL 7 AND STORE IN COL 7

SPACE 2

NOTE *

SPACE

NOTE INTEGRAL OF J ZERO $=\mathrm{X} * \mathrm{JO} 0-(\mathrm{PI} * \mathrm{X} / 2) *(\mathrm{HO} * \mathrm{~J} 1-\mathrm{H} 1 * \mathrm{JO})$,

YOTE HHERE $\mathrm{J} 1=\mathrm{J}$ ONE $(\mathrm{X}), \mathrm{H} 1=\mathrm{H}$ ONE $(X)$,

NOTE HHERE JO $=\mathrm{J}$ ZERO $(X)$, HO $=H$ ZERO $(X)$, ATD

NOTE $\quad J 1=J$ ONE $(X), H 1=H$ ONE $(X)$.

NOTE HANDBOOK MATHEMATICAL FCXCTIONS AMS 55 PAGE 480.

NOTE THEREFORE THE FOLLOWING VALUE MUST BE NEAR OR EQUAL TO ZERO

SPACE

ABRIDGE ROH' $1 \mathrm{COL} 7$

SPACE

YOTE

NATIONAL BLREAU OF STANDARDS. HASHINGTON, D. C. 20234

OMNITAB 80 VERSION 6.00 MARCH 2,1981 
4TH ORDER T CHEBYSHEV POLYNOMIAL

$\begin{array}{ccccc}\begin{array}{c}\text { COL } 1 \\ \text { X }\end{array} & \begin{array}{c}\text { COL } 3 \\ \text { ORDER } 1\end{array} & \begin{array}{c}\text { COL } 4 \\ \text { ORDER } 2\end{array} & \begin{array}{c}\text { COL } 5 \\ \text { ORDER } 3\end{array} & \begin{array}{c}\text { COL } 6 \\ \text { ORDER } 4\end{array} \\ .25000000 & .25000000 & -.87500000 & -.68750000 & .53125000 \\ .50000000 & .50000000 & -.50000000 & -1.0000000 & -.50000000 \\ .75000000 & .75000000 & .12500000 & -.56250000 & -.96875000 \\ 1.0000000 & 1.0000000 & 1.0000000 & 1.0000000 & 1.0000000 \\ 1.2500000 & 1.2500000 & 2.1250000 & 4.0625000 & 8.0312500 \\ 1.5000000 & 1.5000000 & 3.5000000 & 9.0000000 & 23.500000 \\ 1.7500000 & 1.7500000 & 5.1250000 & 16.187500 & 51.531250 \\ 2.0000000 & 2.0000000 & 7.0000000 & 26.000000 & 97.000000\end{array}$

4TH ORDER U CHEBYSHEV POLYNOMIAL

$\begin{array}{ccccc}\text { COL } 1 & \text { COL } 12 & \text { COL } 13 & \text { COL } 14 & \text { COL } 15 \\ \text { X } & \text { ORDER 1 } & \text { ORDER } 2 & \text { ORDER 3 } & \text { ORDER } 4 \\ .25000000 & .50000000 & -.75000000 & -.87500000 & .31250000 \\ .50000000 & 1.0000000 & 0 . & -1.0000000 & -1.0000000 \\ .75000000 & 1.5000000 & 1.2500000 & .37500000 & -.68750000 \\ 1.0000000 & 2.0000000 & 3.0000000 & 4.0000000 & 5.0000000 \\ 1.2500000 & 2.5000000 & 5.2500000 & 10.625000 & 21.312500 \\ & & & & \\ 1.5000000 & 3.0000000 & 8.0000000 & 21.000000 & 55.000000 \\ 1.7500000 & 3.5000000 & 11.250000 & 35.875000 & 114.31250 \\ 2.0000000 & 4.0000000 & 15.000000 & 56.000000 & 209.00000\end{array}$

LET TN $=\mathrm{T}(\mathrm{X})$ OF ORDER $\mathrm{N}, \mathrm{VN}=\mathrm{U}(\mathrm{X})$ ORDER $\mathrm{N}$, AND VN1 $=\mathrm{U}(\mathrm{X})$ ORDER $\mathrm{N}-1$ WHERE T AND U ARE THE T AND U CHEBYSHEV POLYNOMIALS RESPECTIVELY, THEN TN-VN $+X^{*} \mathrm{VN} 1=0$.

REFERENCE - HANDBOOK MATHEMATICAL FUNCTIONS AMS 55 PAGE 777.

THE FOLLOWING VALUES MUST BE EQUAL TO OR NEAR ZERO.

0 .

0 .

0 .

0. 
3RD ORDER LAGUERRE POLYNOMIAL

$\mathrm{COL} 1$
$\mathrm{X}$
.25000000
.50000000
.75000000
1.0000000
1.2500000
1.5000000
1.7500000
2.0000000

$\begin{array}{lcc}\text { COL } 2 & \text { COL } 3 & \text { COL } 4 \\ \text { ORDER } 1 & \text { ORDER } 2 & \text { ORDER } 3 \\ .75000000 & .53125000 & .34114583 \\ .50000000 & .12500000 & -.14583333 \\ .25000000 & -.21875000 & -.47656250 \\ 0 . & -.50000000 & -.66666666 \\ -.25000000 & -.71875000 & -.73177083 \\ -.50000000 & -.87500000 & -.68750000 \\ -.75000000 & -.96875000 & -.54947916 \\ -1.0000000 & -1.0000000 & -.33333333\end{array}$

3RD ORDER NORMALIZED LAGUERRE

$\begin{array}{cccc}\text { COL } 1 & \text { COL 12 } & \text { COL 13 } & \text { COL 14 } \\ \text { X } & \text { ORDER 1 } & \text { ORDER 2 } & \text { ORDER 3 } \\ .25000000 & .75000000 & 1.0625000 & 2.0468750 \\ .50000000 & .50000000 & .25000000 & -.87500000 \\ .75000000 & .25000000 & -.43750000 & -2.8593750 \\ 1.0000000 & 0 . & -1.0000000 & -4.0000000 \\ 1.2500000 & -.25000000 & -1.4375000 & -4.3906250 \\ & & & \\ 1.5000000 & -.50000000 & -1.7500000 & -4.1250000 \\ 1.7500000 & -.75000000 & -1.9375000 & -3.2968750 \\ 2.0000000 & -1.0000000 & -2.0000000 & -2.0000000\end{array}$

LET $\mathrm{Y}=\mathrm{X} / 2$ AND LX(N) $=\mathrm{L}$ OF ORDER $\mathrm{N}$,

THEN $\operatorname{LX}(3)-8^{*} \operatorname{LY}(3)+12^{*} \operatorname{LY}(2)-6 \operatorname{LY}(1) \div 1.0=0$., AND FOR YORMALIZED LAGUERRE

$\operatorname{LX}(3)-8 * \operatorname{LY}(3)-36 * \operatorname{LY}(2)-36 * \operatorname{LY}(1) \div 6=0$.

REFERENCE - HAYDBOOK MATHEMATICAL FUNCTIONS AMS 55 PAGE 785.

THE FOLLOHING VALUES YUST BE EQUAL OR NEAR TO ZERO.

* 3.7252903-09

0 . 
4TH ORDER HERMITE POLYNOMIAL

$\begin{array}{ccccr}\begin{array}{c}\text { COL } 1 \\ \text { X }\end{array} & \begin{array}{c}\text { COL } 2 \\ \text { ORDER } 1\end{array} & \begin{array}{c}\text { COL } 3 \\ \text { ORDER } 2\end{array} & \begin{array}{c}\text { COL } 4 \\ \text { ORDER } 3\end{array} & \begin{array}{c}\text { COL } 5 \\ \text { ORDER } 4\end{array} \\ .25000000 & .50000000 & -1.7500000 & -2.8750000 & 9.0625000 \\ .50000000 & 1.0000000 & -1.0000000 & -5.0000000 & 1.0000000 \\ .75000000 & 1.5000000 & .25000000 & -5.6250000 & -9.9375000 \\ 1.0000000 & 2.0000000 & 2.0000000 & -4.0000000 & -20.000000 \\ 1.2500000 & 2.5000000 & 4.2500000 & .62500000 & -23.937500 \\ 1.5000000 & 3.0000000 & 7.0000000 & 9.0000000 & -15.000000 \\ 1.7500000 & 3.5000000 & 10.250000 & 21.875000 & 15.062500 \\ 2.0000000 & 4.0000000 & 14.000000 & 40.000000 & 76.000000\end{array}$

LET $\mathrm{Y}=\mathrm{SQRT}(2) * \mathrm{X} / 2$, AND HX(N)=H OF ORDER $\mathrm{N}$ FOR EITHER $X$ OR $\mathrm{Y}$, THEN HX(4)-. $5 *$ HY (4) $-2 * H Y(1) * H Y(3)-3 *(H Y(2)) * * 2=0.0$.

REFERENCE - HANDBOOK MATHEMATICAL FUNCTIONS AMS 55 PAGE 785.

THE FOLLOWING VALUE MUST BE EQUAL TO OR NEAR ZERO.

* 7.3015690-07 
ONNITAB 80 TEST 46 CHEBYSHEV, HERMITE, LAGLERRE AND LEGENDRE POLYS. (8.2)

4TH ORDER LEGENDRE POLYNOMIAL

$\begin{array}{cccc}\text { COL } 1 & \text { COL } 2 & \text { COL } 3 & \text { COL } 4 \\ \text { X } & \text { ORDER } 1 & \text { ORDER } 2 & \text { ORDER } 3 \\ .25000000 & .25000000 & -.40625000 & -.33593750 \\ .50000000 & .50000000 & -.12500000 & -.43750000 \\ .75000000 & .75000000 & .34375000 & -.070312504 \\ 1.0000000 & 1.0000000 & 1.0000000 & 1.0000000 \\ 1.2500000 & 1.2500000 & 1.8437500 & 3.0078125 \\ & & & \\ 1.5000000 & 1.5000000 & 2.8750000 & 6.1874999 \\ 1.7500000 & 1.7500000 & 4.0937500 & 10.773437 \\ 2.0000000 & 2.0000000 & 5.5000000 & 17.000000\end{array}$

$3^{*}(\mathrm{P}$ ORDER $3(X))-5^{*} X-(\mathrm{P}$ ORDER $2(X))+2^{*}(\mathrm{P}$ ORDER $1(X))=0.0$.

REFERENCE - HANDBOOK MATHEMATICAL FUNCTIONS AVS 55 PAGE 334.

FOLLOHING VALLE MUST BE EQUAL TO OR NEAR ZERO.

* $-1.9073486-06$ 
LIST OF DATA, INSTRUCTIONS AND DIAGNOSTICS

GENERATE X FROM .25 IN STEPS OF .25 THRU 2.0 AND STORE IN COL 1

* INFORMATIVE DIAGNOSTIC FOR THE ABOVE INSTRUCTION -

$$
\text { NRMAX HAS BEEN RESET FROM } 0 \text { TO } 8 .
$$

TCHEBYSHEV POL OF ORDER $4, X$ IN 1 PUT IN $2 \$$ ORDERS 1 THRU 4 STORED IN COLS 2-5 UCHEBYSHEV POL 4TH ORDER, $X$ IN COL 1 , START STORING IN COL 12

NEW PAGE

NOTE

$\begin{array}{ll}\text { NOTE } & \text { 4TH ORDER T CHEBYSHEV POLYNOMIAL } \\ \text { SPAE } & \end{array}$

$\begin{array}{lccccc}\text { NOTE } & \text { COL } 1 & \text { COL } 3 & \text { COL } 4 & \text { COL } 5 & \text { COL } 6 \\ \text { NOTE } & \mathrm{X} & \text { ORDER } 1 & \text { ORDER } 2 & \text { ORDER } 3 & \text { ORDER } 4\end{array}$

SPACE

ORDER 1 ORDER 2 ORDER 3

ORDER 4

NPRINT $1 * * 5$

SPACE

NOTE

SPACE

4TH ORDER U CHEBYSHEV POLYNOMIAL

$\begin{array}{lccccc}\text { COL } 1 & \text { COL } 12 & \text { COL } 13 & \text { COL } 14 & \text { COL 15 } 15 \\ \text { NOTE } & \text { X } 13 & \text { ORDER } 1 & \text { ORDER } 2 & \text { ORDER } 3 & \text { ORDER } 4\end{array}$

NPR INT $112^{* * * 15}$

DEFINE 1.0 IN COL 11

BEGIN

1 MULTIPLY COL 1 BY COL 11 MULT BY -1.0 ADD TO COL 12 STORE IN COL 6

2 SUBTRACT COL 6 FROM COL 2 STORE IN COL 6

3 AVERAGE COL 6 STORE IN COL 6

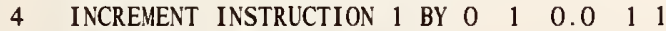

5 INCREMENT INSTRUCTION 2 BY 11

$\begin{array}{llllll}6 & \text { INCREMENT INSTRUCTION } & 3 & \text { BY } & 1 & 1\end{array}$

FINISH

PERFORM INSTRUCTIONS 1 THRU 6 4 TIMES

SPACE 2

NOTE ****

SPACE

NOTE LET TN $=T(X)$ OF ORDER $N, V N=U(X)$ ORDER $N$, AND VN1 $=U$ (X) ORDER N-1

NOTE WHERE $T$ AND $U$ ARE THE T AND U CHEBYSHEV POLYNOMIALS RESPECTIVELY,

NOTE THEN TN-VN+X*VN1=0.

NOTE REFERENCE - HANDBOOK MATHEMATICAL FUNCTIONS AMS 55 PAGE 777.

NOTE THE FOLLOWING VALUES MUST BE EQUAL TO OR NEAR ZERO.

SPACE

ABRIDGE ROW 1 COLS $6,7,8$ AND 9

SPACE

NOTE $\neq * * * * * * * * * * * * * * * * * * * * * * * * * * * * * * * * * * * * * * * * * * * * * * * * * * * * * * * * * * * * * * * * * * * * * * * * * *$

LAGUERRE POLYNOMIAL OF 3RD ORDER, X IN COL 1 STORE STARTING IN COL 2

NORMLAGUERRE ORDER $5, X$ IN COL 1 STORE STARTING IN COL 12

DIVIDE COL 1 BY 2.0 STORE IN COL 6

LAGUERRE OF 3RD ORDER, X IN COL 6 STORE IN COL 7

NORMLAGUERRE OF 3RD ORDER, $X$ IN COL 6 STORE IN COL 17

NEW PAGE

NOTE

3RD ORDER LAGUERRE POLYNOMIAL

SPACE 
OMNITAB 80 TEST 46 CHEBYSHEV, HERMITE, LAGUERRE AND LEGENDRE POLYS. (8.2)

LIST OF DATA, INSTRUCTIONS AND DIAGNOSTICS

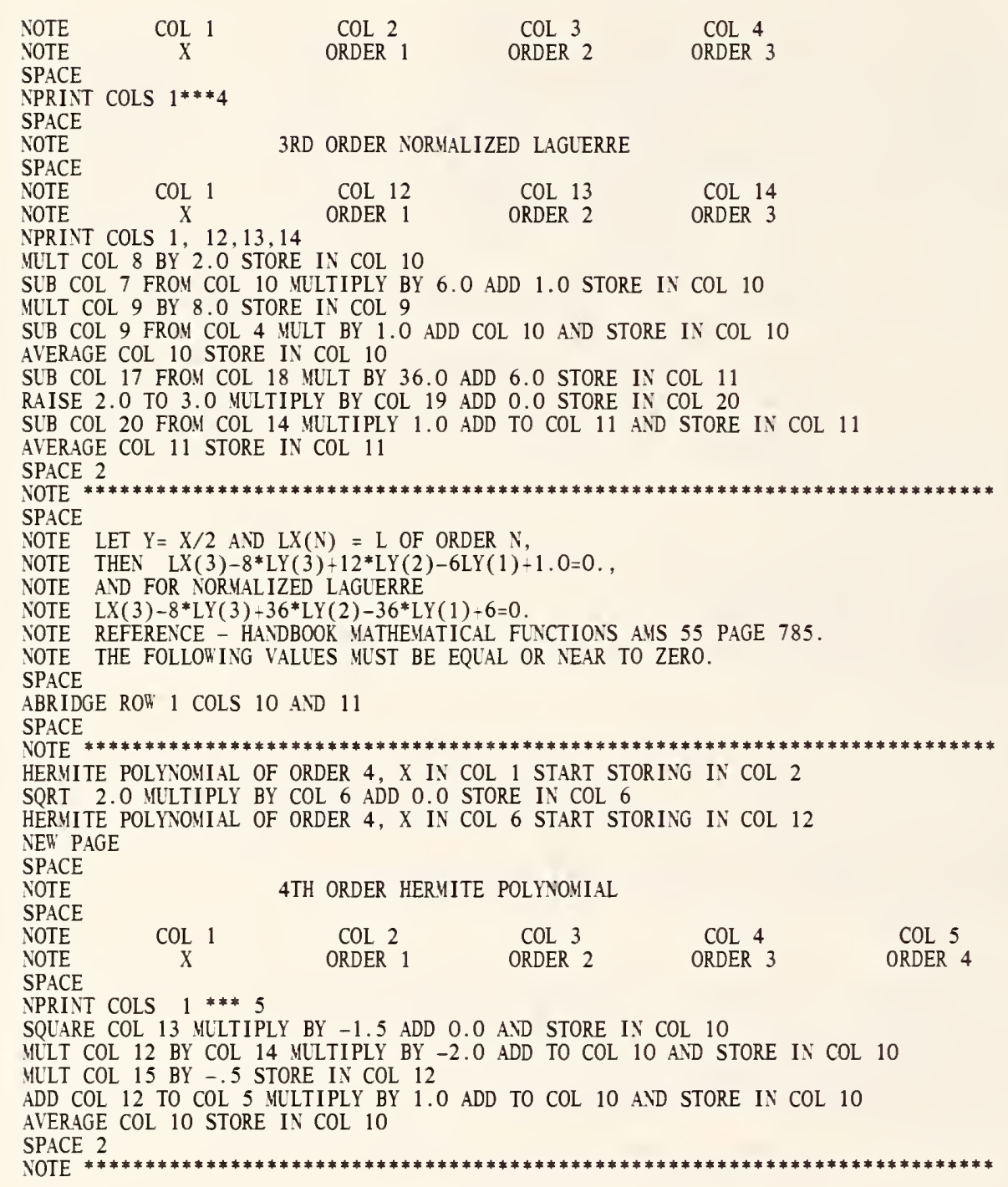


OMNITAB 80 TEST 46 CHEBYSHEV, HERMITE, LAGUERRE AND LEGENDRE POLYS. (8.2)

LIST OF DATA, INSTRUCTIONS AND DIAGNOSTICS

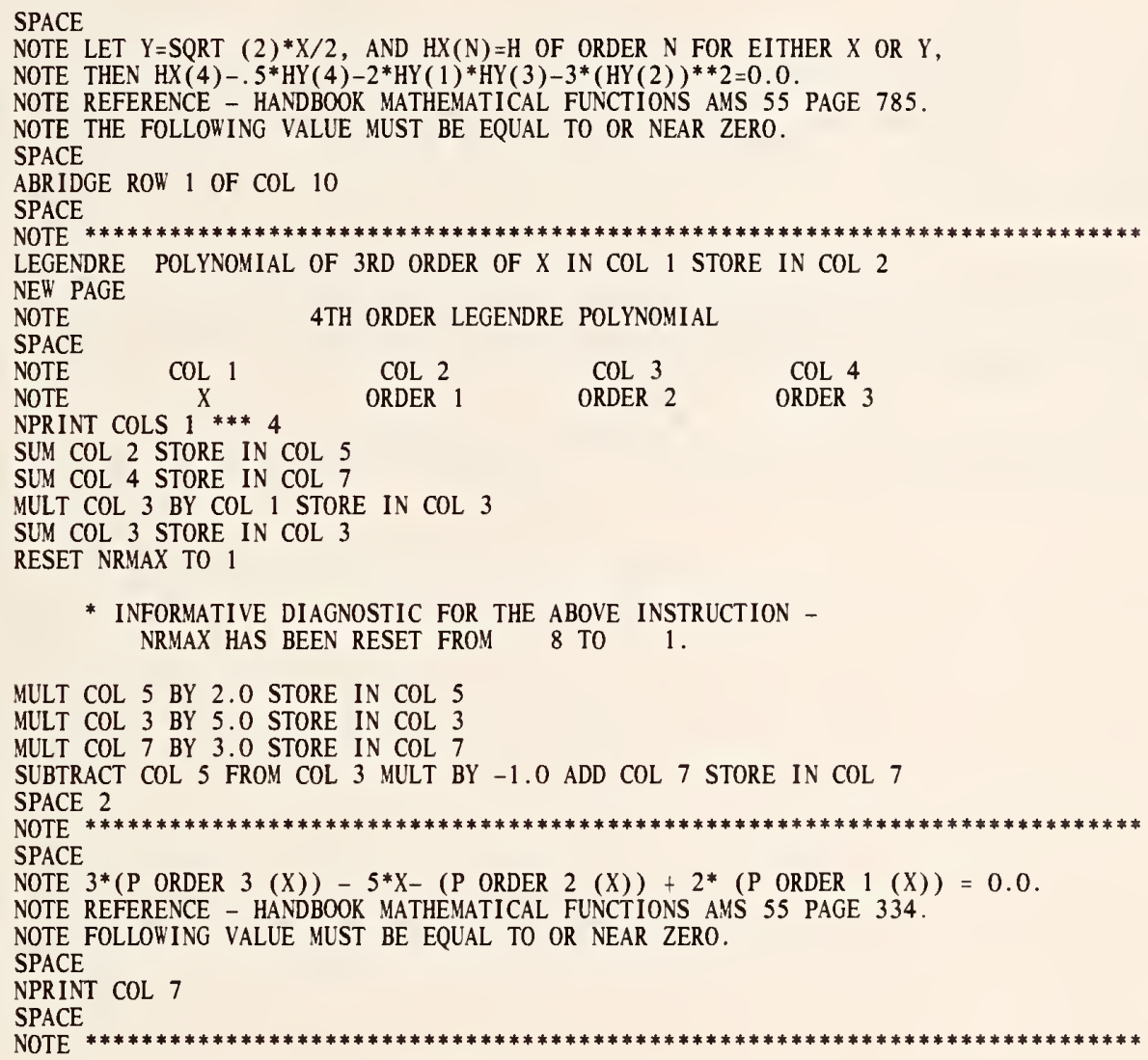

NATIONAL BUREAU OF STANDARDS. WASHTNGTON, D. C. 20234 OMNITAB 80 VERSION 6.00 MARCH 2,1981 
OMNITAB 80 TEST 47 DIFFERENCES AND DIVDIFFERENCES INSTRLCTIONS. (8.3)

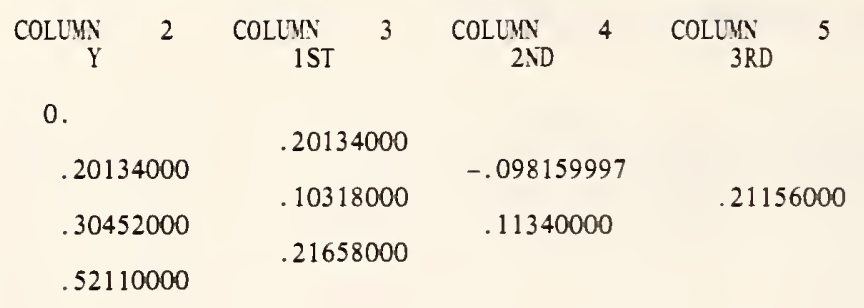

THE FOLLOHING VALUES SHOULD BE EQUAL TO OR NEAR ZERO.

0 .

0 .

0 . 
OMNITAB 80 TEST 47 DIFFERENCES AND DIVDIFFERENCES INSTRUCTIONS. (8.3)

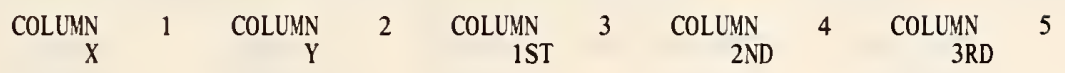

0 .

0.

.20000000

.

.30000000

.20134000

.30452000

.50000000

.52110000

$\begin{array}{ll}1.0067000 & \\ 1.0318000 & .083666841 \\ 1.0829000 & .17033313\end{array}$

.17333259

$* * * * * * * * * * * * * * * * * * * * * * * * * * * * * * * * * * * * * * * * * * * * * * * * * * * * * * * * * * * * * * * * * * * * * * * * * * * *$

THE FOLLOWING VALUES SHOULD BE EQUAL TO OR NEAR ZERO.

0 .

0 .

0 . 
LIST OF DATA, INSTRUCTIONS AND DIAGNOSTICS

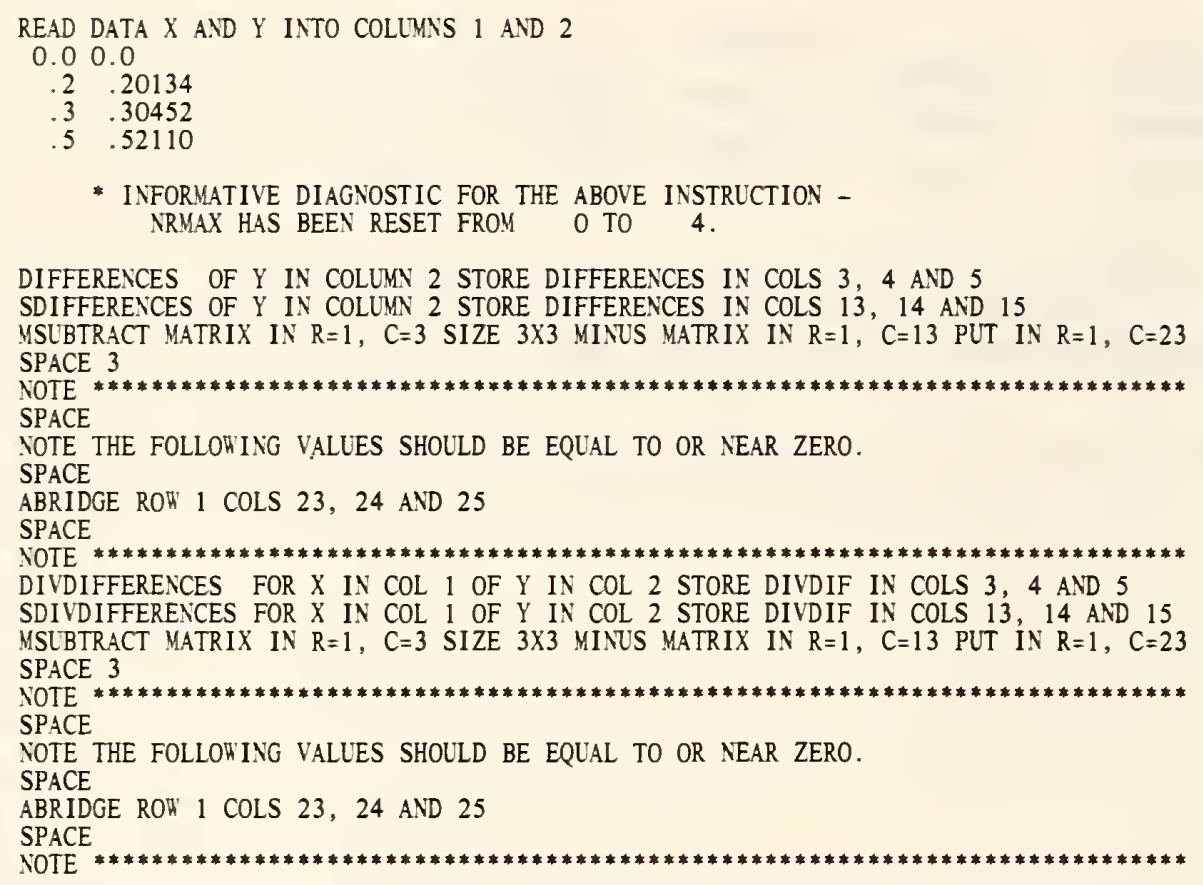

NATIONAL BUREAU OF STANDARDS. HASHINGTON, D. C. 20234 OMNITAB 80 VERSION 6.00 MARCH 2,1981 
OMNITAB 80 TEST 48 ISOLATE, ISETUP AND ITERATE INSTRUCTIONS. (8.4)

PAGE 1

THE FOLLOWING IS AN EXAMPLE OF THE ISOLATE COMMAND. COLUMN 1 WAS DEFINED BY THE GENERATE COMMAND.

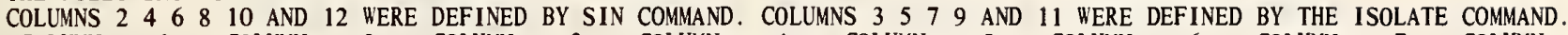

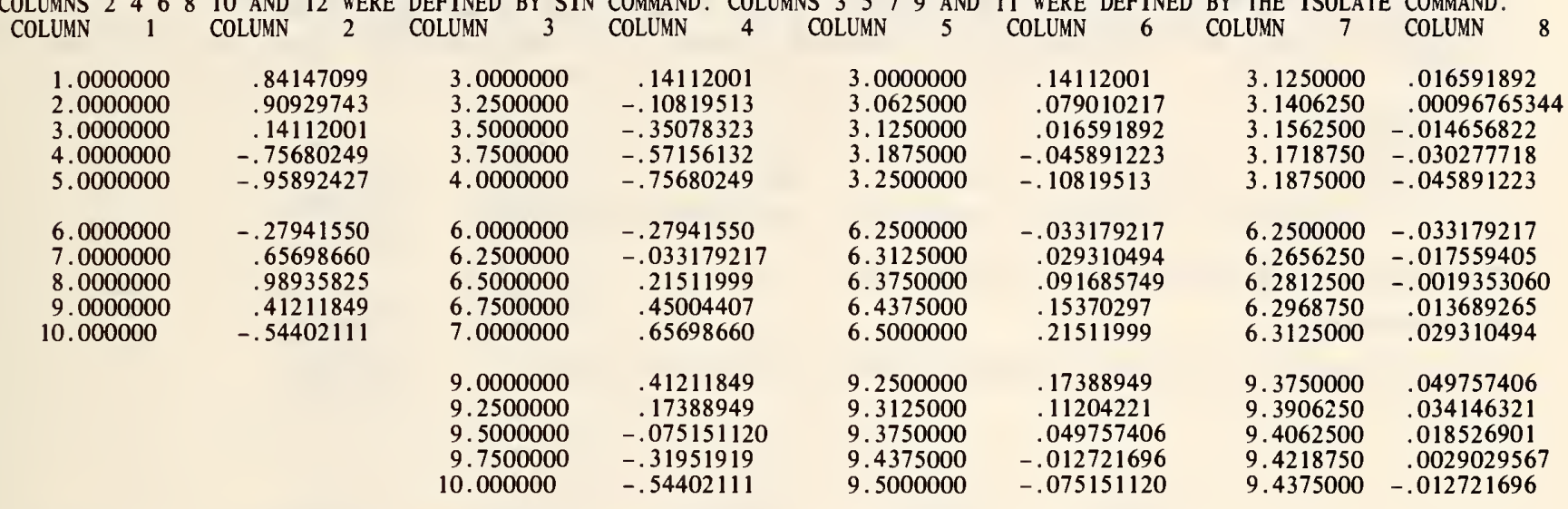

\begin{tabular}{llrr} 
COLUMN 9 & \multicolumn{1}{c}{ COLUMN 10 } & COLUMN 11 & \multicolumn{1}{c}{ COLUMN 12 } \\
3.1406250 & .00096765344 & $3.1406250 * 9.6765344-04$ \\
3.1445313 & -.0029385922 & $3.1416016 *-8.9089102-06$ \\
3.1484375 & -.0068447929 & 3.1425781 & $*-9.8547126-04$ \\
3.1523438 & -.010750889 & 3.1435547 & -.0019620327 \\
3.1562500 & -.014656822 & 3.1445313 & -.0029385922 \\
& & & \\
6.2812500 & -.0019353060 & 6.2812500 & -.0019353060 \\
6.2851563 & .0019709416 & 6.2822266 & $*-9.5874453-04$ \\
6.2890625 & .0058771590 & 6.2832031 & $* 1.7817820-05$ \\
6.2929688 & .0097832867 & $6.2841797 * 9.9438016-04$ \\
6.2968750 & .013689265 & 6.2851563 & .0019709416 \\
& & & \\
9.4218750 & .0029029567 & 9.4218750 & .0029029567 \\
9.4257813 & -.0010032891 & 9.4228516 & .0019263971 \\
9.4296875 & -.0049095195 & 9.4238281 & $9.4983562-04$ \\
9.4335938 & -.0088156750 & 9.4248047 & $*-2.6726731-05$ \\
9.4375000 & -.012721696 & 9.4257813 & -.0010032891
\end{tabular}


OMNITAB 80 TEST 48 ISOLATE, ISETUP AND ITERATE INSTRUCTIONS. (8.4)

PAGE 2

THE FOLLOWING IS AN EXAMPLE OF THE ISOLATE COMMAND. COLUMN 1 R'AS DEFINED BY THE GENERATE COMMAND.

COLUMNS 2466810 AND 12 MERE DEFINED BY SIN COMMAND. COLUMNS 3579 AND 11 RERE DEFINED BY THE ISOLATE COMMAND. COLUMN 45

3.1411133

6.2827148

9.4243164

THE FOLLONING VALUE MUST BE EQUAL TO OR NEAR ZERO.

* 2.3841858-07 
THE FOLLOWING IS AN EXAMPLE OF THE ISETUP AND ITERATE COMMANDS.

$\begin{array}{ccccc}X & Y=S I N(X) & \text { BRACKETING X'S } & \text { BRACKETING Y'S } & \text { DESIRED Y } \\ .30000000 & 0 . & .35000000 & .34246927 & .30000000 \\ .32500000 & .099833416 & .55000000 & .52203400 & .50000000 \\ .35000000 & .19866933 & & & \\ .37500000 & .29552021 & & & \\ .40000000 & .38941834 & & & \\ & & & & \\ .50000000 & .47942554 & & & \\ .52500000 & .56464247 & & & \\ .55000000 & & & & \\ .57500000 & & & & \\ .59999999 & & & & \end{array}$

THE FOLLOWING ARE THE RESULTS OF THE ITERATE COMMAND.

$\begin{array}{lllll}.30000000 & .29552021 & .31250000 & .30741449 & .30000000 \\ .30625000 & .31930878 & .51250000 & .49031927 & .50000000 \\ .31250000 & .34289781 & & & \\ .31874999 & .36627252 & & & \\ .32500000 & .38941834 & & & \\ & & & & \\ .50000000 & .47942554 & & & \\ .50624999 & .50121301 & & & \\ .51249999 & .52268723 & & & \\ .51874998 & .54383479 & & & \\ .52500000 & .56464247 & & & \end{array}$

THE FOLLOWING ARE THE RESULTS OF THE ITERATE COMMAND.

$\begin{array}{lllll}.30000000 & .29552021 & .30312500 & .29850273 & .30000000 \\ .30156250 & .30148525 & .52187499 & .49850398 & .50000000 \\ .30312500 & .30743851 & & & \\ .30468750 & .31337976 & & & \\ .30625000 & .31930878 & & & \\ & & & & \\ .51874998 & .47942554 & & & \\ .52031248 & .48490103 & & & \\ .52187498 & .49035757 & & & \\ .52343748 & .49579496 & & & \end{array}$

THE FOLLOWING ARE THE RESULTS OF THE ITERATE COMMAND.

$\begin{array}{ll}.30468750 & .29552021 \\ .30507812 & .29701256 \\ .30546874 & .29850418 \\ .30585936 & .29999508 \\ .30625000 & .30148525 \\ & \\ .52343748 & .49579496 \\ .52382810 & .49715129 \\ .52421873 & .49850641 \\ .52460936 & .49986031 \\ .52500000 & .50121301\end{array}$

THE FOLLOWING ARE THE RESULTS OF THE ITERATE COMMAND.

$\begin{array}{ll}.30468750 & .29999508 \\ .30478515 & .30036769 \\ .30488281 & .30074025 \\ .30498046 & .30111277 \\ .30507812 & .30148525 \\ & \\ .52343748 & .49986031 \\ .52353513 & .50019859 \\ .52363279 & .50053680 \\ .52373044 & .50087494 \\ .52382810 & .50121301\end{array}$


THE FOLLOHING ARE THE RESULTS OF THE ITERATE COMMAND.

\begin{tabular}{|c|c|c|c|c|}
\hline $\begin{array}{l}30468750 \\
.30471191 \\
.30473632 \\
.30476073 \\
.30478515\end{array}$ & $\begin{array}{r}.29999508 \\
.30008823 \\
.30018139 \\
.30027454 \\
.30036769\end{array}$ & $\begin{array}{l}.30473632 \\
.52358396\end{array}$ & $\begin{array}{l}.30004166 \\
.49998717\end{array}$ & $\begin{array}{l}30000000 \\
.50000000\end{array}$ \\
\hline $\begin{array}{l}.52353513 \\
.52355954 \\
.52358395 \\
.52360836 \\
.52363279\end{array}$ & $\begin{array}{l}.49986031 \\
.49994488 \\
.50002945 \\
.50011402 \\
.50019859\end{array}$ & & & \\
\hline
\end{tabular}

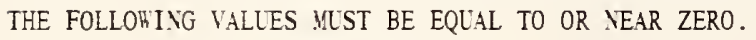

0 . $* 7.4505806-09$ 
OMNITAB 80 TEST 48 ISOLATE, ISETUP AND ITERATE INSTRUCTIONS. (8.4)

LIST OF DATA, INSTRUCTIONS AND DIAGNOSTICS

GENERATE TRIAL VALUES OF X FROM 1 IN STEPS OF 1 THRU 10 IN COL 1

* INFORMATIVE DiAGNOSTIC FOR THE ABOVE INSTRUCTION NRMAX HAS BEEN RESET FROM O TO 10.

1/ SIN OF X IN COLUMN 1 PUT Y=SIN(X) IN COLUMN 2

2/ ISOLATE $X$ IN COLUMN 1 FOR Y IN COLUMN 2 EQUAL TO 0.0 STORE IN COLS 3 AND 45

3/ INCREMENT INSTRUCTION 1 BY 2 AND 2

4/ INCREMENT INSTRUCTION 2 BY 2, 2, 0.0, 2 AND 0

REPEAT INSTRUCTIONS 1 THROUGH 4,6 TIMES

* INFORMATIVE DIAGNOSTIC FOR THE ABOVE INSTRUCTION -

NRMAX HAS BEEN RESET FROM 10 TO 15.

IN INSTRUCTION AT STATEMENT NUMBER 2.0

CYCLE NO. 1 OF 6 OF EXTERNAL PERFORM STATEMENT.

TITLE1 THE FOLLOWING IS AN EXAMPLE OF THE ISOLATE COMMAND. COLUMN

TITLE2 1 WAS DEFINED BY THE GENERATE COMMAND.

TITLE3 COLUMNS $24468 \quad 10$ AND 12 WERE DEFINED BY SIN COMMAND. COLU

TITLE4MNS 35799 AND 11 WERE DEFINED BY THE ISOLATE COMMAND.

PRINT COLUMNS $1^{* * *} 8$

SPACE 2

NOTE COLUMN 9 COLUMN 10 COLUMN 11 COLUMN 12

NPR INT COLUMNS $9 * * * 12$

RESET NRMAX TO 3

* INFORMATIVE DIAGNOSTIC FOR THE ABOVE INSTRUCTION NRMAX HAS BEEN RESET FROM 15 TO 3.

PRINT COLUMN 45

SUM COLUMN 45 AND STORE IN COLUMN 46

SUBTRACT THE VALUE 18.8481445 FROM COLUMN 46 AND STORE IN COLUMN 46

AVERAGE COLUMN 46 AND STORE IN COLUMN 46

SPACE

NOTE

SPACE

NOTE THE FOLLOHING VALUE MUST BE EQUAL TO OR NEAR ZERO.

SPACE

ABRIDGE ROW 1 OF COLUMN 46

SPACE

NOTE

ERASE

* INFORMATIVE DIAGNOSTIC FOR THE ABOVE INSTRUCTION NRMAX HAS BEEN RESET FROM 3 TO 0.

GENERATE DESIRED Y EQUAL THRU .3 IN STEPS OF .2 THRU .5 IN COLUMN 14

* INFORMATIVE DIAGNOSTIC FOR THE ABOVE INSTRUCTION NRMAX HAS BEEN RESET FROM O TO 2 . 
LIST OF DATA, INSTRUCTIONS AND DIAGNOSTICS

GENERATE TRIAL VALUES OF X EQUAL TO 0 IN STEPS OF . 1 THRU . 6 IN COLUMN 1

- INFORYATIVE DIAGNOSTIC FOR THE ABOVE INSTRUCTION NRMAX HAS BEEN RESET FROM 2 TO 7.

NOTE1 THE FOLLOR'ING ARE THE RESULTS OF THE ITERATE COMMAND.

1/ SIN $X$ IN COLUNN 1 PUT $Y=S I N(X)$ IN COLUNN 12

2/ ITERATE $X$ IN COLUMN 1 Y IN COLLMN 12 DESIRED Y IN COLUMN 14 STORE IN COL 1

2.2/ SPACE

2.5/ PRINT NOTE

2.6/ SPACE

3/ NPRINT COLUMNS $1,12,2,3$ AND 4

SIN $X$ IN COLUMN 1 PUT $Y=S I N(X)$ IN COLUMN 12

ISETUP $X$ IN COL $1, Y=S I N(X)$ IN COL 12, DESIRED Y IN COL 14 STORE IN COL 1

- INFORMATIVE DIAGNOSTIC FOR THE ABOVE INSTRUCTION NRYAX HAS BEEN RESET FROM 7 TO 10

TITLE1

TITLE2

TITLE3

TITLE4

NEH PAGE

NOTE THE FOLLORIING IS AN EXAMPLE OF THE ISETUP AND ITERATE COMMANDS.

SPACE

NOTE $X \quad Y=S I N(X) \quad$ BRACKETING $X$ 'S BRACKETING $Y$ 'S DESIRED $Y$

NPRINT COLUMNS $1112 \quad 2 \quad 3$ AND 4

REPEAT INSTRUCTIONS 1 THROUGH 3, 5 TIMES

SUM COLUMN 2 STORE IN COLUMN 45

SUM COLUMN 3 STORE IN COLUMN 46

SUBTRACT THE VALUE .82832028 FROM COL 45 AND STORE IN COL 45

SUBTRACT THE VALUE .80002882 FROM COL 46 AND STORE IN COLUMN 46

SPACE

NOTE

SPACE

NOTE THE FOLLORING VALUES MUST BE EQUAL TO OR NEAR ZERO.

SPACE

ABRIDGE ROR 1 OF COLLMNS 45 AND 46

SPACE

NOTE

NATIONAL BUREAU OF STANDARDS. WASHINGTON, D. C. 20234

OMNITAB 80 VERSION 6.00 MARCH 2, 198 
OMNITAB 80 TEST 49 INTERPOLATE INSTRUCTION. (8.5)

\begin{tabular}{|c|c|c|c|c|c|c|c|}
\hline $\begin{array}{c}\text { COL } 1 \\
X-T A B L E\end{array}$ & $\begin{array}{c}\text { COL } 2 \\
\text { Y-TABLE SIN }\end{array}$ & $\begin{array}{rll} & \text { COL } & 3 \\
X & \text { TO BE } & \text { INTR }\end{array}$ & $\begin{array}{c}\text { COL } 4 \\
\text { EXACT VALUE }\end{array}$ & $\begin{array}{l}\text { COL } 5 \\
\text { ORDER } 2\end{array}$ & $\begin{array}{l}\text { COL } 7 \\
\text { ORDER } 4\end{array}$ & $\begin{array}{l}\text { COL } 9 \\
\text { ORDER } 6\end{array}$ & $\begin{array}{c}\text { COL } 10 \\
\text { ORDER } 9\end{array}$ \\
\hline $\begin{array}{l}0 . \\
.15000000 \\
.30000000 \\
.45000000 \\
.59999999\end{array}$ & $\begin{array}{r}0 . \\
.14943813 \\
.29552021 \\
.43496553 \\
.56464247\end{array}$ & $\begin{array}{c}-.15000000 \\
-.049999999 \\
.050000001 \\
.15000000 \\
.25000000\end{array}$ & $\begin{array}{c}-.14943813 \\
-.049979168 \\
.049979170 \\
.14943813 \\
.24740396\end{array}$ & $\begin{array}{c}-.14943813 \\
-.049812709 \\
.049812711 \\
.14943813 \\
.24682618\end{array}$ & $\begin{array}{c}-.14951348 \\
-.049991465 \\
.049983094 \\
.14943813 \\
.24740160\end{array}$ & $\begin{array}{c}-.14943469 \\
-.049978781 \\
.049979080 \\
.14943814 \\
.24740398\end{array}$ & $\begin{array}{c}-.14943302 \\
-.049978746 \\
.049979079 \\
.14943814 \\
.24740398\end{array}$ \\
\hline $\begin{array}{l}.74999999 \\
.89999999 \\
1.0500000 \\
1.2000000 \\
1.3500000\end{array}$ & $\begin{array}{l}.68163875 \\
.78332690 \\
.86742322 \\
.93203908 \\
.97572336\end{array}$ & $\begin{array}{l}.35000000 \\
.45000000 \\
.55000000 \\
.65000000 \\
.75000000\end{array}$ & $\begin{array}{l}.34289781 \\
.43496553 \\
.52268723 \\
.60518640 \\
.68163876\end{array}$ & $\begin{array}{l}.34200198 \\
.43496553 \\
.52141682 \\
.60364123 \\
.68163875\end{array}$ & $\begin{array}{l}.34289405 \\
.43496554 \\
.52268198 \\
.60517994 \\
.68163875\end{array}$ & $\begin{array}{l}.34289779 \\
.43496554 \\
.52268719 \\
.60518637 \\
.68163873\end{array}$ & $\begin{array}{l}.34289780 \\
.43496555 \\
.52268723 \\
.60518643 \\
.68163871\end{array}$ \\
\hline $\begin{array}{l}1.5000000 \\
1.6500000 \\
1.8000000 \\
1.9500000 \\
2.1000000\end{array}$ & $\begin{array}{l}.99749499 \\
.99686503 \\
.97384764 \\
.92895972 \\
.86320937\end{array}$ & $\begin{array}{r}.85000000 \\
.95000000 \\
1.0500000 \\
1.1500000 \\
1.2500000\end{array}$ & $\begin{array}{l}.75128040 \\
.81341550 \\
.86742322 \\
.91276394 \\
.94898462\end{array}$ & $\begin{array}{l}.74943086 \\
.81135900 \\
.86742322 \\
.91050046 \\
.94660050\end{array}$ & $\begin{array}{l}.75127275 \\
.81340697 \\
.86742322 \\
.91275454 \\
.94897468\end{array}$ & $\begin{array}{l}.75128039 \\
.81341553 \\
.86742322 \\
.91276389 \\
.94898456\end{array}$ & $\begin{array}{l}.75128043 \\
.81341560 \\
.86742322 \\
.91276393 \\
.94898461\end{array}$ \\
\hline \multirow[t]{3}{*}{$\begin{array}{l}2.2500000 \\
2.4000000\end{array}$} & $\begin{array}{l}.77807321 \\
.67546320\end{array}$ & $\begin{array}{l}1.3500000 \\
1.4500000 \\
1.5500000 \\
1.6500000 \\
1.7500000\end{array}$ & $\begin{array}{l}.97572336 \\
.99271299 \\
.99978376 \\
.99686503 \\
.98398595\end{array}$ & $\begin{array}{l}.97572336 \\
.99023777 \\
.99728500 \\
.99686503 \\
.98152010\end{array}$ & $\begin{array}{l}.97572336 \\
.99270269 \\
.99977335 \\
.99686503 \\
.98397566\end{array}$ & $\begin{array}{l}.97572336 \\
.99271293 \\
.99978370 \\
.99686503 \\
.98398588\end{array}$ & $\begin{array}{l}.97572336 \\
.99271301 \\
.99978375 \\
.99686503 \\
.98398590\end{array}$ \\
\hline & & $\begin{array}{l}1.8500000 \\
1.9500000 \\
2.0500000 \\
2.1500000 \\
2.2500000\end{array}$ & $\begin{array}{l}.96127521 \\
.92895972 \\
.88736238 \\
.83689879 \\
.77807320\end{array}$ & $\begin{array}{l}.95888500 \\
.92895972 \\
.88512616 \\
.83483064 \\
.77807320\end{array}$ & $\begin{array}{l}.96126527 \\
.92895972 \\
.88735305 \\
.83689018 \\
.77807318\end{array}$ & .96127529 & \\
\hline & & $\begin{array}{l}2.3500000 \\
2.4500000 \\
2.5500000 \\
2.6500000\end{array}$ & $\begin{array}{l}.71147336 \\
.63776471 \\
.55768373 \\
.47203056\end{array}$ & $\begin{array}{l}.70966653 \\
.64125986 \\
.57285319 \\
.50444652\end{array}$ & & & \\
\hline
\end{tabular}

THE FOLLOWING VALUES INDICATE NUMBER OF SIGNIFICANT DIGITS FOR EACH ORDER OF INTERPOLATION. THE NUMBERS SHOULD BE EQUAL TO OR NEAR 4.2, 4.9, 5.7, 6.5, 7.1 AND 7.2.
4.2
4.9
5.7
6.5 .
7.1
7.2 
OMNITAB 80 TEST 49 INTERPOLATE INSTRUCTION. (8.5)

LIST OF DATA, INSTRUCTIONS AND DIAGNOSTICS

GENERATE NOS. FROM 0. IN STEPS OF . 15 THRU 2.4 STORE IN COL 1

* INFORMATIVE DIAGNOSTIC FOR THE ABOVE INSTRUCTION NRMAX HAS BEEN RESET FROM O TO 17.

SIN OF COL 1 STORE IN COL 2

GENERATE NOS. FROM -.15 IN STEPS OF . 1 THRU 2.65 STORE IN COL 3

* INFORMATIVE DIAGNOSTIC FOR THE ABOVE INSTRUCTION -

NRMAX HAS BEEN RESET FROM 17 TO 29.

SIN OF COL 3 STORE IN COL 4

BEGIN INSTRUCTIONS TO BE REPEATED

1 INTERPOLATE TABLE IN COLS 1, 2 LEN 17 FOR 29 VAL OF X IN 3 ORDER 2 PUT IN 5

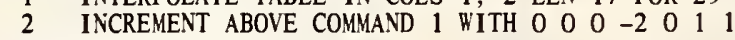

FINISH REPEAT INSTRUCTIONS

REPEAT INSTRUCTIONS 1 THRU 2, 5 TIMES

t++++++EXTRAPOLATION DONE FOR MORE THAN ONE DELTA

INTERPOLATE TABLE IN COLS 12 LEN OF 17 FOR 20 VAL OF X IN 3 ORDER 9 PUT IN 10

HEAD COL1/ X-TABLE

HEAD COL2/ Y-TABLE SIN

HEAD COL $3 / X$ TO BE INTR

HEAD COL4/ EXACT VALUE

HEAD COL5/ ORDER 2

HEAD COL7/ ORDER 4

HEAD COL9/ ORDER 6

HEAD COL1O/ ORDER 9

TITLE3 3 COL

TITLE4 COL 5 COL 7

PRINT COLUMNS $1,2,3,4,5,7,9$ AND 10

COL 3

COL 9

COL 4

1) RESET NRMAX TO 29

$1.5 /$ INCREMENT INSTRUCTION 1 BY -2

2) ACCURACY OF DIGITS IN COL 5 VS COL 4 AND STORE IN COL 11

2.5/ AVERAGE COL 11 STORE IN COL 11

$3 /$ INCREMENT INSTRUCTION 2 BY 1,0 AND 1

4/ INCREMENT INSTRUCTION 2.5 BY 1 AND 1

REPEAT INSTRUCTIONS 1 THRU 4, 6 TIMES

* INFORMATIVE DIAGNOSTIC FOR THE ABOVE INSTRUCTION NRMAX HAS BEEN RESET FROM 29 TO 27.

IN INSTRUCTION AT STATEMENT NUMBER 1.0

CYCLE NO. 2 OF 6 OF EXTERNAL PERFORM STATEMENT.

* INFORMATIVE DIAGNOSTIC FOR THE ABOVE INSTRUCTION NRMAX HAS BEEN RESET FROM 27 TO 25.

IN INSTRUCTION AT STATEMENT NUMBER 1.0

CYCLE NO. 3 OF 6 OF EXTERNAL PERFORM STATEMENT.

* INFORMATIVE diagNOSTIC FOR THE abOVE INSTRUCTION NRMAX HAS BEEN RESET FROM 25 TO 23. 
LIST OF DATA, INSTRUCTIONS AND DIAGNOSTICS

IN INSTRUCTION AT STATEMENT NUMBER 1.0

CYCLE NO. 4 OF 6 OF EXTERNAL PERFORM STATEMENT.

- INFORMATIVE DIAGNOSTIC FOR THE ABOVE INSTRUCTION -

NRMAX HAS BEEN RESET FROM 23 TO 21 .

IN INSTRUCTION AT STATEMENT NUMBER 1.0

CYCLE NO. 5 OF 6 OF EXTERNAL PERFORM STATEMENT.

* INFORMATIVE DIAGNOSTIC FOR THE ABOVE INSTRUCTION -

NRMAX HAS BEEN RESET FROM 21 TO 19.

IN INSTRUCTION AT STATEMENT NUMBER 1.0

CYCLE NO. 6 OF 6 OF EXTERNAL PERFORM STATEMENT.

SPACE 2

NOTE $1 * * * * * * * * * * * * * * * * * * * * * * * * * * * * * * * * * * * * * * * * * * * * * * * * * * * * * * * * * *$

NOTE2 $* * * * * * * * * * * * * * * * * * * * * * * * * * * * * * * * * * * *$

PRINT NOTE

SPACE

NOTE1THE FOLLOWING VALUES INDICATE NUMBER OF SIGNIFICANT DIGITS F

NOTE2OR EACH ORDER OF INTERPOLATION.

PRINT NOTE

NOTE THE NUMBERS SHOULD BE EQUAL TO OR NEAR $4.2,4.9,5.7,6.5,7.1$ AND 7.2 .

SPACE

ABRIDGE ROW 1 COLS $11^{* * *} 16$ HITH 2.0 SIG. DIGITS

SPACE

NOTE $1 * * * * * * * * * * * * * * * * * * * * * * * * * * * * * * * * * * * * * 1$

NOTE2 $* * * * * * * * * * * * * * * * * * * * * * * * * * * * * * * * * *$

PRINT NOTE

NATIONAL BUREAU OF STANDARDS. WASHINGTON, D. C. 20234

OMNITAB 80 VERSION 6.00 MARCH 2, 1981 
OMNITAB 80 TEST 50 GAUSS QUADRATURE INSTRUCTION. (8.6)

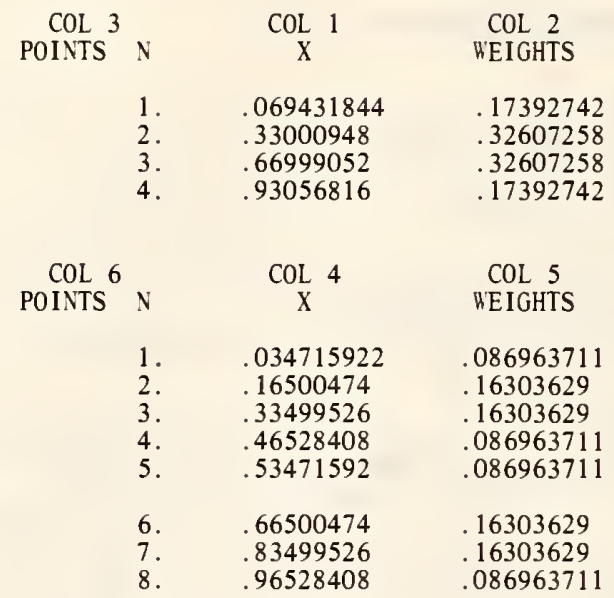

THE FOLLOWING VALUE MUST BE EQUAL TO OR NEAR ZERO.

* 7.4505806-09 
LIST OF DATA, INSTRUCTIONS AND DIAGNOSTICS

GAUSS QUADRATURE 4 PTS. $A=0.0$ AND $B=1.0$ STORE X IN COL 1 WTS. IN COL 2

* INFORMATIVE DIAGNOSTIC FOR THE ABOVE INSTRUCTION NRMAX HAS BEEN RESET FROM 0 TO 4.

GENERATE FROM 1 STEPS OF 1 THRU 4 IN COL 3

NEW' PAGE

NOTE $\mathrm{COL} 3 \quad \mathrm{COL} 1 \quad \mathrm{COL} 2$

NOTE POINTS $N$ WEIGHTS

SPACE

NPRINT COLS 3 WITH 1 . SIGNIFICANT DIG., 1 AND 2 WITH 8 . SIG DIGITS

GAUSS QUADRATURE 8 PTS. $A=0.0$ AND $B=1.0$ STORE $X$ IN COL 4 WTS. IN COL 5

* INFORMATIVE DIAGNOSTIC FOR THE ABOVE INSTRUCTION NRMAX HAS BEEN RESET FROM 4 TO 8.

GENERATE FROM 1 IN STEPS OF 1 THRU 8 IN COL 6

SPACE 2

$\begin{array}{llll}\text { NOTE } & \text { COL } 6 & \text { COL } 4 & \text { COL } 5\end{array}$

NOTE POINTS $N$ X WEIGHTS

SPACE
NPRINT COL 6 WITH 1.0 SIG DIG., COLS 4 AND 5 WITH 8. SIG DIG.

MULTIPLY COL 1 BY COL 2 STORE IN COL 7

MULTIPLY COL 4 BY COL 5 STORE IN COL 8

SUM COL 7 STORE IN COL 7

SUM COL 8 STORE IN COL 8

SUBTRACT COL 8 FROM COL 7 STORE IN COL 9

SPACE 2

NOTE

SPACE

NOTE THE FOLLOWING VALUE MUST BE EQUAL TO OR NEAR ZERO

SPACE

ABRIDGE ROW 1 COL 9

SPACE

NOTE

NATIONAL BUREAU OF STANDARDS. WASHINGTON, D. C. 20234

OMNITAB 80 VERSION 6.00 MARCH 2,1981 
PROPERTIES OF THE $4 X 4$ MATRIX ( MATRIXA ) STARTING AT $(2,1)$

ROR - FOR PROPERTIES STORED IN COLLMN 30

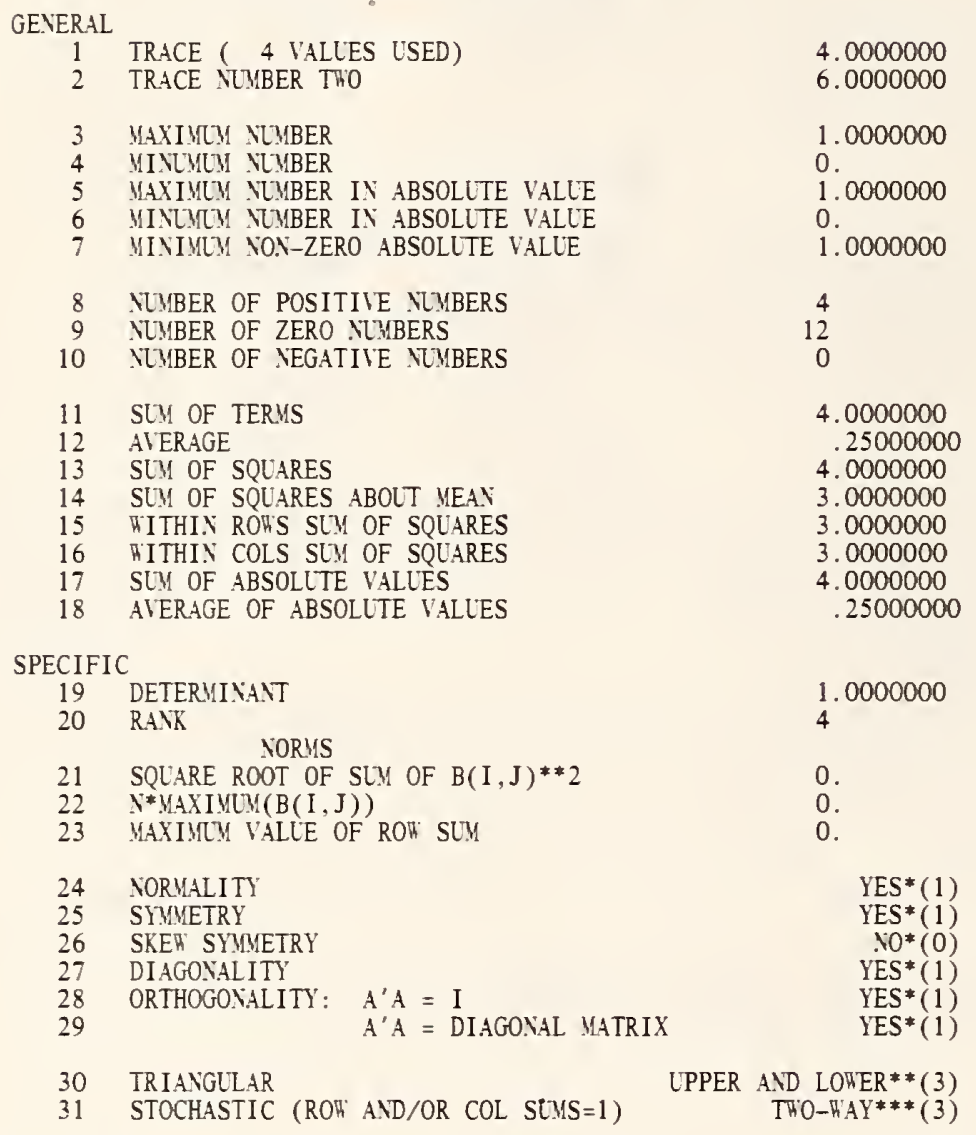

* if a.sher is No: $(R, C)=0$. If ANSher is ies: $(R, C)=1$, If eXAct or $(R, C)=2$, IF TOLERANCE IS MET.

TRIANGLLAR

** $(R, C)=0$, IF ANSRER IS NO. $(R, C)=1$, IF UPPER PART OF MATRIX $=0$.

$(R, C)=2$, IF LORER PART $=0 . \quad(R, C)=3$, IF ALL OFF DIAGONAL TERYS $=0$.

STOCHASTIC
$* * *(\mathrm{R}, \mathrm{C})=0$, IF MATRIX IS NOT STOCHASTIC. $(\mathrm{R}, \mathrm{C})=1$, IF EACH ROH SLM $=1$

$(R, C)=2$, IF EACH COL SLM $=1 .(R, C)=3$, IF EACH ROH AND COL SLM $=1$. 
PROPERTIES OF THE 4X4 ARRAY ( ARRAYC ) STARTING AT $(2,11)$

ROW - FOR PROPERTIES STORED IN COLUMN 32 GENERAL

1 TRACE ( 4 VALUES USED) $\quad 4.0000000$

2 TRACE NUMBER TWO 6.0000000

3 MAXIMUM NUMBER

4 MINUMUM NUMBER

5 MAXIMUM NUMBER IN ABSOLUTE VALUE

6 MINUMUM NUMBER IN ABSOLUTE VALUE

7 MINIMUM NON-ZERO ABSOLUTE VALUE

1.0000000

0 .

1.0000000

0 .

8 NUMBER OF POSITIVE NUMBERS

9 NUMBER OF ZERO NUMBERS

10 NUMBER OF NEGATIVE NUMBERS

4
12

11 SUM OF TERMS

12 AVERAGE

13 SUM OF SQUARES

14 SUM OF SQUARES ABOUT MEAN

15 WITHIN ROWS SUM OF SQUARES

16 WITHIN COLS SUM OF SQUARES

17 SUM OF ABSOLUTE VALUES

18 AVERAGE OF ABSOLUTE VALUES

12
0

4.0000000

25000000

4.0000000

3.0000000

3.0000000

3.0000000

4.0000000

.25000000

THE ABOVE IS AN EXAMPLE OF THE AUTOMATIC PRINTOUT FROM APROPERTIES. 
OMNITAB 80 TEST 51 ARRAY AND MATRIX INSTRUCTIONS. (10.) AND (11.)

PAGE 3

MATRIX A RAS DEFINED BY THE MIDENTITY COMMAND, COL 5 BY THE MVECDIAGONAL COMMAND AND COL 6 BY THE MVECMAT COMMAND.

MATRIX A

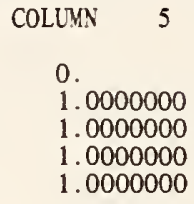

COLUMN 6

0 .

1.0000000

$\begin{array}{ll}0 . & 0 . \\ 0 . & 0 . \\ 1.0000000 & 0 . \\ & 1.0000000\end{array}$

0.
0.
0.

0.

1.0000000

1.0000000

0 .

0.

0.

0 .

1.0000000

0 .

0 .

0 .

1.0000000

0.

0.

0 .

1.0000000

THE FOLLOHING VALUE MUST BE EQUAL TO OR NEAR ZERO.

0 . 
OMNITAB 80 TEST 51 ARRAY AND MATRIX INSTRUCTIONS. (10.) AND (11.)

THE FOLLOHING IS AN EXAMPLE OF MTRANSPOSE, MMULT AND MEIGEN

PAGE 4

MATRIX A WAS DEFINED BY THE READ COMMAND. MATRIX B IS THE TRANSPOSE OF MATRIX A

MATRIX A
4.0000000
4.0000000
-2.0000000
4.0000000
$-2.0000000$
$-6.0000000$
$-6.0000000$
$-6.0000000$
$-6.0000000$
4.0000000
4.0000000
MATRIX C EQUALS MATRIX A TIMES MATRIX B.

$\begin{array}{rrrr}72.000000 & 56.000000 & -64.000000 & -64.000000 \\ 56.000000 & 72.000000 & -64.000000 & -64.000000 \\ -64.000000 & -64.000000 & 72.000000 & 56.000000 \\ -64.000000 & -64.000000 & 56.000000 & 72.000000\end{array}$

MATRIX $B=A^{\prime}$

4.0000000

4.0000000

$-2.0000000$

$-6.0000000$
$-6.0000000$

$-2.0000000$

4.0000000

4.0000000
4.0000000

4.0000000

$-6.0000000$

$-2.0000000$

THE FOLLOWING RESULTS ARE FROM THE MEIGEN COMMAND.

$\begin{array}{rrrrr}\text { E-VALUES } & \text { VECTOR } 1 & \text { VECTOR } 2 & \text { VECTOR } 3 & \text { VECTOR 4 } \\ *-1.1802143-07 & .50000000 *-2.3403118-08 & .70710678 & .50000000 \\ 15.999998 & .49999999 *-1.5923433-08 & -.70710678 & .50000000 \\ 16.000000 & .49999995 & -.70710680 & * 4.4801595-09 & -.49999998 \\ * 2.5599998+02 & .50000003 & .70710674 & 0 . & -.50000001\end{array}$

THE FOLLORING VALUE MUST BE EQUAL TO OR NEAR ZERO.

$*-4.7683716-06$

THE COMMANDS MERASE, MZERO AND AZERO HAVE BEEN EXECUTED.

THE FOLLOWING VALUES MUST BE EQUAL TO OR NEAR ZERO.

0 .

0 . 
OMNITAB 80 TEST 51 ARRAY AND MATRIX INSTRLCTIONS. (10.) AND (11.)

LIST OF DATA, INSTRUCTIONS AND DIAGNOSTICS

ALABEL ARRAYC, 2, 11, 4X4

* INFORMative diagnostic FOR the ABOVE INSTRUCtion -

(ARRAYC) IS IN ROH (2) COL (11) SIZE (4X4)

MLABEL MATRIXA, 2, 1, 4X4

* INFORMATIVE diAgNOSTIC FOR THE ABOVE INSTRUCTION (YATRIXA) IS IN ROH (2) COL (1) SIZE (4X4)

MIDENTITY MATRIX A BEGIN IN ROR 2 OF COLUMN 1 SIZE 4 X 4

MPROPERTIES OF MATRIXA STORE PROPERTIES IN COL 30

SMPROPERTIES OF MATRIXA STORE PROPERTIES IN COL 31

RESET NRMAX EQUAL TO 4

* INFORMATIVE diagNoSTIC FOR THE ABOVE INSTRLCTION -

IRYAX HAS BEEN RESET FROM O TO 4.

SUBTRACT COLUMN 30 FROM COLUMN 31 STORE IN COL 31

AVERAGE COLUMN 31 STORE IN COLUMN 31

MVECDIAGONAL MATRIX A IY ROR 2 OF COLUYN 1 SIZE 4X4 INTO ROR 2 OF COLUMN 5

MVECMAT VECTORIZE MATRIX A IN ROH 2 OF COL 1 SIZE 4X4 INTO COLUMN 6 ROR' BY ROH

MBATVEC MAKE COL 6 INTO MATRIX B ROR' BY ROW AND PUT IN ROH 2 OF COL 7 SIZE 4X4

MDIAGONAL SET THE DIAGONAL OF MATRIX C IN ROH' 2 OF COL 11 SIZE 4 X4 EQUAL TO 1.0

APROPERTIES OF ARRAYC STORE PROPERTIES IN COL 32

SPACE

SPACE

NOTE THE ABOVE IS AN EXAYPLE OF THE AUTOMATIC PRINTOUT FROM APROPERTIES

SPACE

VOTE $\# * * * * * * * * * * * * * * * * * * * * * * * * * * * * * * * * * * * * * * * * * * * * * * * * * * * * * * * * * * * * * * * * *$

MVECDIAG MAKE MATRIX $C$ IN $R=2, C=11$ SIZE $4 X 4$ INTO A VECTOR AND PUT IN $R=2, C=15$

MVECMAT VECTORIZE ROH' BY ROW' MATRIX IN ROH 2 OF COL 15 SIZE 4X4, INTO COL 16

MMATVEC MAKE COL 16 INTO MATRIX D ROR BY ROR', PUT IN ROH 2 OF COL 17, SIZE 4X4

ASUBTRACT MATRIX B $R=2, C=7$ SIZE 4X4, FROM $D \quad R=2, C=17$ SIZE $=4 X 4$ PUT IN $R=1, C=33$

ROH SUM COLS $33^{* * *} 36$ STORE IN COLUYN 37

AVERAGE COLUMN 37 AND STORE IN COLUYN 37

TITLE1 MATRIX A KAS DEFINED BY THE MIDENTITY COMMAND, COL 5 BY THE

TITLE2 MVECDIAGONAL COMMAND AND COL 6 BY THE MVEMAT COMMAND.

RESET NRYAX TO 16

* informative diagnostic for the above instrlction -

NRMAX HAS BEEN RESET FROM 4 TO 16.

HEAD COL 1/ MATRIX A

HEAD COL 2/

HEAD COL 3/

HEAD COL 4/ 
PRINT COLUMNS $1 * * * 6$

SPACE 2

NOTE

NOTE THE FOLLOWING VALUE MUST BE EQUAL TO OR NEAR ZERO.

SPACE

ABRIDGE ROW 1 OF COLUMN 37

SPACE

NOTE $* * 4$

READ THE FOLLOWING DATA INTO COLUMNS 12, 13, 14 AND 15

$\begin{array}{llll}4 & 4 & -2 & -6\end{array}$

$\begin{array}{llll}-2 & -6 & 4 & 4 \\ -6 & -2 & 4 & 4\end{array}$

$\begin{array}{rrrr}-6 & -2 & 4 & 4 \\ 4 & 4 & -6 & -2\end{array}$

* INFORMATIVE DIAGNOSTIC FOR THE ABOVE INSTRUCTION NRMAX HAS BEEN RESET FROM 16 TO 4.

ATRANSPOSE MATRIX B IN ROW 1 OF COL 12 SIZE 4X4, PUT IN MATRIX C ROW 1 OF COL 16 MMULT MATRIX $C$ IN $R=1 \quad C=16$ SIZE $4 X 4$ BY MATRIX $B \quad R=1 \quad C=12$ SIZE $4 X 4$ STORE $R=9 \quad C=12$ MEIGEN MATRIX IN $R=9, C=12$ SIZE 4 X4 PUT EIGENVAL IN COL 20 EIGENVEC IN $R=1, C=21$ TITLE1 THE FOLLOWING IS AN EXAMPLE OF MTRANSPOSE, MMULT AND MEIGEN

TITLE2.

TITLE3 MATRIX A WAS DEFINED BY THE READ COMMAND. MATRIX B IS THE T

TITLE4RANSPOSE OF MATRIX A.

HEAD COL 12/ MATRIX A

HEAD COL 13/

HEAD COL 14/

HEAD COL 15/

HEAD COL 16/ MATRIX B=A'

HEAD COL $17 /$

HEAD COL $18 /$

HEAD COL 19/

RESET NRMAX TO 4

PRINT COLUMNS $12 * * * 19$

SPACE 2

NOTE MATRIX C EQUALS MATRIX A TIMES MATRIX B.

SPACE

APRINT MATRIX C BEGINNING ROW 9 OF COL 12 SIZE $4 X 4$

SPACE 2

NOTE THE FOLLOWING RESULTS ARE FROM THE MEIGEN COMMAND.

SPACE

NOTE

SPACE

E-VALUES

VECTOR 1

VECTOR

VECTOR 3

VECTOR 4

NPRINT COLUMNS $20 * * * 24$

ROWSUM COLUMNS $20 * * * 24$ STORE IN COLUMN 25

AVERAGE COLUMN 25 AND STORE IN COLUMN 25

SUBTRACT THE VALUE 72.5 FROM COLUMN 25 STORE IN COLUMN 25

SPACE 2

NOTE 
LIST OF DATA, INSTRUCTIONS AND DIAGNOSTICS

SPACE

NOTE THE FOLLOWING VALUE MUST BE EQUAL TO OR NEAR ZERO.

SPACE

ABRIDGE ROW 1 OF COLUMN 25

SPACE

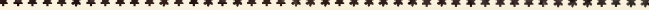

MERASE MATRIX BEGINNING IN ROW 1 OF COLUMN 20 SIZE $4 X 2$

MZERO MATRIX BEGINNING IN ROW 1 OF COLUMN 22 SIZE $4 X 2$

AZERO MATRIX BEGINNING IN ROW 1 OF COLUMN 24 SIZE 4 X2

ROWSUM COLUMNS 20***24 STORE IN COLUMN 26

AVERAGE COLUMN 26 AND STORE IN COLUMN 26

SPACE

NOTE THE COMMANDS MERASE, MZERO AND AZERO HAVE BEEN EXECUTED.

NOTE THE FOLLOWING VALUES MUST BE EQUAL TO OR NEAR ZERO.

SPACE

ABRIDGE ROW 1 OF COLUMNS 25 AND 26

SPACE

NOTE $* * * * * * * * * * * * * * * * * * * * * * * * * * * * * * * * * * * * * * * * * * * * * * * * * * * * * * * * * * * * * * * * * * * * * * * * * * *$

NATIONAL BUREAU OF STANDARDS. WASHINGTON, D. C. 20234

OMNITAB 80 VERSION 6.00 MARCH 2,1981 
OMNITAB 80 TEST 52 ACOALESCE AND AAVERAGE INSTRUCTIONS. (10.3)

PAGE 1

THE FOLLOWING ARE EXAMPLES OF THE ACOALESCE AND AAVERAGE INSTRUCTIONS. ARRAY A IS THE ORIGINAL ARRAY.

ARRAY B CONTAINS THE RESULTS OF ACOALESCE. ARRAY C CONTAINS THE RESULTS OF AAVERAGE.

$\begin{array}{ll}\text { ARRAY A } & \\ 1.0000000 & 0 . \\ 0 . & 2.0000000 \\ 1.0000000 & 2.0000000 \\ 0 . & 1.0000000 \\ 2.0000000 & 1.0000000\end{array}$

$\begin{array}{ll}1.0000000 & 2.0000000 \\ 1.0000000 & 3.0000000 \\ 0 . & 1.0000000 \\ 2.0000000 & 0 . \\ 3.0000000 & 1.0000000\end{array}$

ARRAY B

$\begin{array}{llll}1.0000000 & 2.0000000 & 1.0000000 & 3.0000000 \\ 0 . & 3.0000000 & 3.0000000 & 3.0000000 \\ 2.0000000 & 1.0000000 & 3.0000000 & 1.0000000 \\ 0 . & 0 . & 0 . & 0 . \\ 0 . & 0 . & 0 . & 0 .\end{array}$

ARRAY C

$\begin{array}{llll}1.0000000 & 1.0000000 & .50000000 & 1.5000000 \\ 0 . & 1.5000000 & 1.5000000 & 1.5000000 \\ 2.0000000 & 1.0000000 & 3.0000000 & 1.0000000 \\ 0 . & 0 . & 0 . & 0 .\end{array}$

0 .

0 .

0 .

0 .

THE FOLLOWING VALUE MUST BE EQUAL TO OR NEAR ZERO.

0 . 
LIST OF DATA, INSTRUCTIONS AND DIAGNOSTICS

DIMENSION HORKSHEET SIZE OF 5 ROH'S AND 16 COLLMNS READ THE FOLLOHING DATA INTO COLLMNS $1 * * * 4$

$\begin{array}{llll}1 & 0 & 1 & 2\end{array}$

$\begin{array}{llll}0 & 2 & 1 & 3\end{array}$

$\begin{array}{llll}1 & 2 & 0 & 1 \\ 0 & 1 & 2 & 0\end{array}$

$\begin{array}{llll}2 & 1 & 3 & 1\end{array}$

* INFORMATIVE DIAGNOSTIC FOR THE ABOVE INSTRUCTION NRMAX HAS BEEN RESET FROM O TO 5 .

ACOALESCE ON FIRST COL OF ARRAY A IN $R=1, C=1$ SIZE 5 X 4 PUT ARRAY B IN $R=1, C=5$ AAVERAGE ON FIRST COL OF ARRAY A IN $R=1, C=1$ SIZE $5 X 4$ PUT ARRAY $C$ IN $R=1, C=9$ TITLE1 THE FOLLOHING ARE EXAMPLES OF THE ACOALESCE AND AAVERAGE IN TITLE2STRUCTIONS. ARRAY A IS THE ORIGINAL ARRAY.

TITLE3 ARRAY B CONTAINS THE RESULTS OF ACOALESCE. ARRAY C CONTAINS TITLE4 THE RESULTS OF AAVERAGE.

NEH PAGE

SPACE

NOTE

SPACE

ARRAY A

ARRAY B

NPRINT COLUMNS $1 * * * 8$

SPACE 2

NOTE

SPACE

NPRINT COLUMNS 13***16 AND 9***12

ROHSLY THE ENTIRE HORKSHEET AND STORE SLM IN COLUMN 13

SET THE FOLLOHING VALUES IN COLLMN 14

$\begin{array}{lllll}-15.0 & -19.5 & -18.0 & -3.0 & -7.0\end{array}$

ADD COLUMN 13 TO COLLMN 14 AND STORE IN COLUMN 14

AVERAGE COLUMN 14 AND STORE IN COLUMN 14

SPACE 2

NOTE ****

SPACE

NOTE THE FOLLOHING VALUE MUST BE EQUAL TO OR NEAR ZERO.

SPACE

ABRIDGE ROH 1 OF COLUMN 14

SPACE

NOTE

NATIONAL BUREAU OF STANDARDS. HASHINGTON, D. C. 20234 ONNITAB 80 VERSION 6.00 MARCH 2,1981 
OMNITAB 80 TEST 53 MTRIAN, MINVERT AND MRAISE INSTRUCTIONS. (11.3) AND (11.5) PAGE 1 THE FOLLOHING IS AN EXAMPLE OF THE MTRIAN COMMAND.

MATRIX A IS THE ORIGINAL MATRIX.

$\mathrm{ROH} / \mathrm{COL}$

$\begin{array}{ll}3 & \\ 4 & \\ 5 & \\ 6 & 6\end{array}$

$\begin{array}{rr}2 & 3 \\ 4.0000 & 6.0000 \\ 6.0000 & 25.0000 \\ 8.0000 & 20.0000 \\ 0.0000 & 27.0000\end{array}$

4

8.0000

20.0000

36.0000

30.0000

10.0000

27.0000

30.0000

36.0000

MATRIX B IS THE LOWER TRIANGULAR MATRIX OF MATRIX A.

(B TIMES B-TRANSPOSE EQUALS A).

ROW'COL

$\begin{array}{lll}3 & 7 & 8 \\ 3 & 2.0000 & .0000 \\ 5 & 3.0000 & 4.0000 \\ 6 & 4.0000 & 2.0000 \\ & 5.0000 & 3.0000\end{array}$

9

.0000

.0000

4. 0000

.0000

.0000

.0000

1.0000

MATRIX C IS THE INVERSE OF MATRIX B

$\mathrm{ROH} / \mathrm{COL} \quad 11 \quad 12$

$\begin{array}{rrr}3 & .5000 & .0000 \\ 4 & -.3750 & .2500\end{array}$

$-.3125$

.2500

$-.1250$

$-1.0625$

$-.6250$

13

.0000

.0000

.0000

.0000

0000

$-.2500$

1.0000

THE FOLLOHING VALUES MUST BE EQUAL TO OR NEAR ZERO.

5.96046-008 $\quad .00000$ 
OMNITAB 80 TEST 53 MTRIAN, MINVERT AND MRAISE INSTRUCTIONS. (11.3) AND (11.5) PAGE 2 THE FOLLOHING IS AN EXAMPLE OF THE MRAISE COMMAND.

$\begin{array}{cccrr}\text { MATRIX A } & \text { IS THE } & \text { ORIGINAL MATRIX. } & & \\ \text { ROH'COL } & 7 & 8 & 9 & 10 \\ 3 & 2.00 & .00 & .00 & .00 \\ 4 & 3.00 & 4.00 & .00 & .00 \\ 5 & 4.00 & 2.00 & 4.00 & .00 \\ 6 & 5.00 & 3.00 & 1.00 & 1.00\end{array}$

MATRIX B IS MATRIX A RAISED TO THE SECOND POHER.

ROW/COL $25 \quad 26 \quad 27$

$\begin{array}{rrrrr}3 & 25 & & & \\ 3 & 4.00 & .00 & .00 & 28 \\ 4 & 18.00 & 16.00 & .00 & .00 \\ 5 & 30.00 & 16.00 & 16.00 & .00 \\ 6 & 28.00 & 17.00 & 5.00 & 1.00\end{array}$

THE FOLLOHING VALLE MUST BE EQUAL TO OR NEAR ZERO.

.00 
LIST OF DATA, INSTRUCTIONS AND DIAGNOSTICS

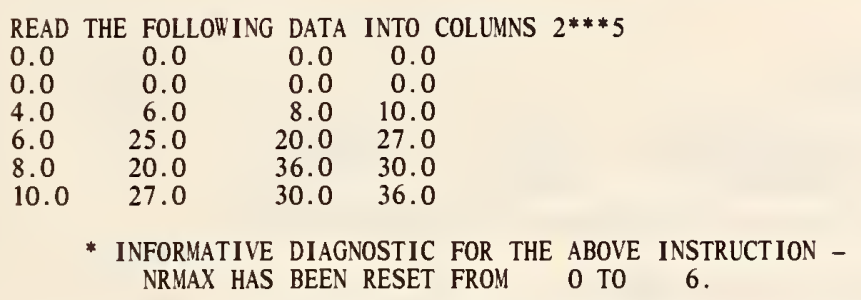

MTRIAN MATRIX IN $\mathrm{R}=3 \quad \mathrm{C}=2$ SIZE $4 X 4$ PUT TRIANGULAR IN $\mathrm{R}=3 \quad \mathrm{C}=7$ INVERSE IN $\mathrm{R}=3 \quad \mathrm{C}=11$ MINVERT MATRIX IN ROW 3 OF COL 7 SIZE 4 X4 AND PUT INVERSE IN ROW 3 OF COL 15 ++++ SMALLEST ERROR BOUND ON INVERTED MATRIX IS .0

MSUB MATRIX IN $R=3 \quad \mathrm{C}=11$ SIZE 4 X4 MINUS MATRIX IN $\mathrm{R}=3 \quad \mathrm{C}=15 \quad 4 X 4$ PUT IN $\mathrm{R}=3 \mathrm{C}=19$

TITLE1 THE FOLLOWING IS AN EXAMPLE OF THE MTRIAN COMMAND.

NEW PAGE

SPACE

NOTE MATRIX A IS THE ORIGINAL MATRIX.

FIXED 4 DIGITS AFTER DECIMAL POINT

MPR INT MATRIX A IN ROH 3 OF COL 2, SIZE 4 X4

SPACE

NOTE MATRIX B IS THE LOHER TRIANGULAR MATRIX OF MATRIX A.

NOTE (B TIMES B-TRANSPOSE EQUALS A).

MPRINT MATRIX B IN ROW 3 OF COL 7 SIZE $4 X 4$

SPACE

NOTE MATRIX C IS THE INVERSE OF MATRIX B

MPR INT MATRIX $C$ IN $R=3 \quad \mathrm{C}=11 \quad$ SIZE $=4 X 4$

ROHSUM COLUMNS $7 * * * 10$ PUT IN COLUMN 23

ROWSUM COLUMNS $19 * * * 22$ PUT IN COLUMN 24

AVERAGE COLUMN 23 AND STORE IN COLUMN 23

SUBTPACT 4.8333333 FROM COLUMN 23 AND STORE IN COLUMN 23

AVERAGE COLUMN 24 AND STORE IN COLUMN 24

FLOATING 6 SIGNIFICANT DIGITS

SPACE 2

NOTE *

SPACE

NOTE THE FOLLOWING VALUES MUST BE EQUAL TO OR NEAR ZERO.

SPACE

ABRIDGE ROW 1 OF COLUMNS 23 AND 24

SPACE

NOTE

MRAISE MATRIX A IN $R=3 \quad C=7$ SIZE $4 X 4$ TO 2ND POWER STORE IN $R=3 \quad C=25$

MMULT MATRIX A IN $\mathrm{R}=3 \mathrm{C}=7$ SIZE $4 X 4$ BY MATRIX IN $\mathrm{R}=3 \quad \mathrm{C}=7 \quad 4 X 4$ PUT IN $\mathrm{R}=3 \quad \mathrm{C}=29$

MSUB MATRIX IN $R=3 \quad \mathrm{C}=25$ SIZE $4 X 4$ FROM MATRIX IN $\mathrm{R}=3 \quad \mathrm{C}=29 \quad 4 X 4$ PUT IN $\mathrm{R}=3 \quad \mathrm{C}=33$

ROHSUM COLUMNS $33^{* * * 36}$ AND STORE IN COLUMN 37

AVERAGE COLUMN 37 AND PUT IN COLUMN 37

TITLE1 THE FOLLOWING IS AN EXAMPLE OF THE MRAISE COMMAND.

NEW PAGE

SPACE 
OMNITAB 80 TEST 53 MTRIAN, MINVERT AND MRAISE INSTRUCTIONS. (11.3) AND (11.5) PAGE

LIST OF DATA, INSTRUCTIONS AND DIAGNOSTICS

FIXED 2 DIGITS AFTER DECIMAL POINT

NOTE MATRIX A IS THE ORIGINAL MATRIX.

MPRINT MATRIX A IN ROF 3 OF COL 7 SIZE $4 X 4$

SPACE

NOTE MATRIX B IS MATRIX A RAISED TO THE SECOND PONER.

MPRINT MATRIX IN ROH 3 OF COL 25 SIZE 4 X4

SPACE 2

NOTE ***

SPACE

NOTE THE FOLLONING VALUE MLST BE EQUAL TO OR NEAR ZERO.

SPACE

ABRIDGE ROW 1 OF COLUMN 37

SPACE

NOTE

NATIONAL BLREAU OF STANDARDS. NASHINGTON, D. C. 20234

OMNITAB 80 VERSION 6.00 MARCH 2,1981 
THE FOLLOWING IS AN EXAMPLE OF $M\left(X X^{\prime}\right)$ AND $M\left(X^{\prime} X\right)$.

MATRIX X

$\mathrm{ROH} / \mathrm{COL}$

$\begin{array}{lr} & 3 \\ 2 & 5.0000000 \\ 3 & 5.0000000 \\ 4 & -2.0000000\end{array}$

4
6.0000000
6.0000000

5

5

3.0000000

2.0000000

6.0000000

MATRIX $X X^{\prime}$

$\begin{array}{cc}\text { ROW } / \text { COL } & 37 \\ 1 & 110.00000 \\ 2 & 75.000000 \\ 3 & 50.000000\end{array}$

38

75.000000

65.000000

39

20.000000

20.000000

49.000000

MATRIX Y

ROW/COL

$\begin{array}{lr}2 & 0 \\ 3 & -14\end{array}$

0.

$-14.000000$

4.000000

2.0000000

5.0000000

5.0000000

MATRIX Y'Y

ROH/COL

40
2

28.000000

$-70.000000$

41

42

$-28.000000$

20.000000

$-70.000000$

$30.000000 \quad 50.000000$

THE FOLLOHING VALUE MUST BE EQUAL TO OR NEAR ZERO.

0.

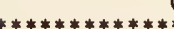


LIST OF DATA, INSTRUCTIONS AND DIAGNOSTICS

READ THE FOLLOWING DATA INTO COLUMNS $1 * * * 5$

$\begin{array}{lllll}1.0 & 2.0 & 3 . & 4 . & 1 .\end{array}$

$0.0 \quad 4.0 \quad 5.6 .7$.

$\begin{array}{rrrrr}-14.0 & 2.0 & 5.6 . & 6\end{array}$

$-2.0 \quad 3.0-2.3 .6$

* INFORMATIVE DIAGNOSTIC FOR THE ABOVE INSTRUCTION -

NRMAX HAS BEEN RESET FROM O TO 4

$M\left(X X^{\prime}\right)$ MULTIPLY MATRIX $X$ IN $R=2, C=3$ SIZE $3 X 3$ BY ITS TRANSPOSE, PUT IN $R=1, C=37$ $M\left(X^{\prime} X\right)$ MULTIPLY TRANSPOSE OF MATRIX $X$ IN $R=2, C=1$ SIZE $2 X 3$ BY $X$ PUT IN $R=2, C=40$ NEW PAGE

NOTE THE FOLLOWING IS AN EXAMPLE OF $M\left(X X^{\prime}\right)$ AND $M\left(X^{\prime} X\right)$

SPACE 2

NOTE MATRIX $X$

SPACE

MPRINT MATRIX X IN ROW 2 OF COLUMN 3 SIZE 3 X3

SPACE 2

NOTE MATRIX $X X^{\prime}$

SPACE

MPRINT MATRIX IN ROW 1 OF COLUMN 37 SIZE $3 X 3$

SPACE 2

NOTE MATRIX Y

SPACE

MPRINT MATRIX Y IN ROW 2 OF COLUMN 1 SIZE $2 X 3$

SPACE 2

NOTE MATRIX Y'Y

SPACE

MPRINT MATRIX IN ROW 2 OF COLUMN 40 SIZE $3 X 3$

ROWSUM COLUMNS 37***42 AND STORE IN COLUMN 43

AVERAGE COLUMN 43 AND STORE IN COLUMN 43

SUBTRACT THE VALUE 161. FROM COLUMN 43 AND STORE IN COLUMN 43

SPACE 2

NOTE ***

SPACE

NOTE THE FOLLOWING VALUE MUST BE EQUAL TO OR NEAR ZERO.

SPACE

ABRIDGE ROW 1 OF COLUMN 43

NOTE $* * * * * * * * * * * * * * * * * * * * * * * * * * * * * * * * * * * * * * * * * * * * * * * * * * * * * * * * * * * * * * * * * * * * * * * * * * *)$

NATIONAL BUREAU OF STANDARDS. WASHINGTON, D. C. 20234

OMNITAB 80 VERSION 6.00 MARCH 2,1981 
OMNITAB 80 TEST 55 BESSEL FUNCTIONS. (12.1), (12.2) AND (12.3) BESSEL FUNCTIONS $J$ AND Y FOR ORDERS 0 AND 1.

\begin{tabular}{|c|c|c|c|c|}
\hline$\underset{X}{\mathrm{COL}} 1$ & J ${ }_{\text {ZERO }}{ }^{2}(X)$ & $\begin{array}{ll} & \text { COL } 3 \\
\text { J } & \text { ONE }(X)\end{array}$ & $\begin{array}{l}\text { COL } 4 \\
Y \text { ZERO }(X)\end{array}$ & $\begin{array}{ll} & \text { COL } 5 \\
\mathrm{Y} & \mathrm{ONE}(\mathrm{X})\end{array}$ \\
\hline $\begin{array}{l}1.0000000 \\
1.5000000 \\
2.0000000 \\
2.5000000 \\
3.0000000\end{array}$ & $\begin{array}{l}.76519768 \\
.51182767 \\
.22389078 \\
-.048383776 \\
-.26005195\end{array}$ & $\begin{array}{l}.44005058 \\
.55793650 \\
.57672480 \\
.49709410 \\
.33905896\end{array}$ & $\begin{array}{l}.088256964 \\
.38244892 \\
.51037567 \\
.49807036 \\
.37685001\end{array}$ & $\begin{array}{r}-.78121281 \\
-.41230863 \\
-.10703243 \\
.14591814 \\
.32467442\end{array}$ \\
\hline $\begin{array}{l}3.5000000 \\
4.0000000 \\
4.5000000 \\
5.0000000\end{array}$ & $\begin{array}{l}-.38012774 \\
-.39714981 \\
-.32054251 \\
-.17759677\end{array}$ & $\begin{array}{c}.13737753 \\
-.066043328 \\
-.23106043 \\
-.32757914\end{array}$ & $\begin{array}{l}.18902194 \\
-.016940739 \\
-.19470501 \\
-.30851762\end{array}$ & $\begin{array}{l}.41018842 \\
.39792571 \\
.30099732 \\
.14786314\end{array}$ \\
\hline
\end{tabular}

RELATIONAL EXPRESSION OF BESSEL FUNCTIONS ARE DEFINED AS FOLLOWS.

LET YO $=Y$ ZERO $(X)$, YONE $=Y$ ONE $(X)$,

J0 $=\mathbf{J}$ ZERO $(X), \quad J O N E=J$ ONE $(X)$,

THEN Y0*JONE-YONE*J0-2/(PI*X) $=0$.

HANDBOOK OF MATHEMATICAL FUNCTIONS AMS 55 PAGE 360.

THEREFORE THE FOLLOWING VALUE MUST BE EQUAL TO OR NEAR ZERO.

*-5.1740143-09 
OMNITAB 80 TEST 55 BESSEL FUNCTIONS. (12.1), (12.2) AND (12.3) BESSEL FUNCTIONS I AND $\mathrm{K}$ FOR ORDERS 0 AND 1

\begin{tabular}{|c|c|c|c|c|}
\hline$\underset{\mathrm{X}}{\mathrm{COL}} 1$ & $\begin{array}{l}\text { COL } 2 \\
\text { I }{ }^{2 E R 0}(X)\end{array}$ & $\begin{array}{lll} & \text { COL } & 3 \\
I & \text { ONE } & (X)\end{array}$ & $\begin{array}{l}\text { COL } 4 \\
\text { K ZERO } \\
\text { ZX) }\end{array}$ & $\begin{array}{lll} & \text { COL } & 5 \\
\mathrm{~K} & \mathrm{ONE} & (\mathrm{X})\end{array}$ \\
\hline $\begin{array}{l}1.0000000 \\
1.5000000 \\
2.0000000 \\
2.5000000 \\
3.0000000\end{array}$ & $\begin{array}{l}1.2660659 \\
1.6467232 \\
2.2795853 \\
3.2898391 \\
4.8807926\end{array}$ & $\begin{array}{r}.56515910 \\
.98166642 \\
1.5906368 \\
2.5167162 \\
3.9533702\end{array}$ & $\begin{array}{l}.42102444 \\
.21380556 \\
.11389387 \\
.062347553 \\
.034739504\end{array}$ & $\begin{array}{l}.60190722 \\
.27738780 \\
.13986588 \\
.073890815 \\
.040156431\end{array}$ \\
\hline $\begin{array}{l}3.5000000 \\
4.0000000 \\
4.5000000 \\
5.0000000\end{array}$ & $\begin{array}{l}7.3782034 \\
11.301922 \\
17.481172 \\
27.239872\end{array}$ & $\begin{array}{c}6.2058349 \\
9.7594651 \\
15.389223 \\
24.335642\end{array}$ & $\begin{array}{l}.019598897 \\
.011159676 \\
.0063998572 \\
.0036910983\end{array}$ & $\begin{array}{l}.022239393 \\
.012483499 \\
.0070780949 \\
.0040446134\end{array}$ \\
\hline$\underset{X}{\mathrm{COL}} 1$ & $\begin{array}{l}\text { COL } 2 \\
\text { I } \quad \text { ZERO }(X) \\
{ }^{*} \operatorname{EXP}(-X)\end{array}$ & $\begin{array}{ll} & \text { COL } 3 \\
1 \text { ONE }(X) \\
* \operatorname{EXP}(-X)\end{array}$ & $\begin{array}{c}\text { COL } 4 \\
\mathrm{~K} \underset{\mathrm{ZERO}}{ }{ }^{\mathrm{EXXP}(X)}(\mathrm{X})\end{array}$ & $\begin{array}{c}\text { COL } 5 \\
\mathrm{~K} \underset{\mathrm{ONE}}{ }(\mathrm{X}) \\
{ }^{*} \operatorname{EXP}(X)\end{array}$ \\
\hline $\begin{array}{l}1.0000000 \\
1.5000000 \\
2.0000000 \\
2.5000000 \\
3.0000000\end{array}$ & $\begin{array}{l}.46575961 \\
.36743361 \\
.30850832 \\
.27004644 \\
.24300035\end{array}$ & $\begin{array}{l}.20791041 \\
.21903939 \\
.21526929 \\
.20658465 \\
.19682671\end{array}$ & $\begin{array}{l}1.1444631 \\
.95821005 \\
.84156821 \\
.75954869 \\
.69776160\end{array}$ & $\begin{array}{c}1.6361535 \\
1.2431659 \\
1.0334768 \\
.90017442 \\
.80656347\end{array}$ \\
\hline $\begin{array}{l}3.5000000 \\
4.0000000 \\
4.5000000 \\
5.0000000\end{array}$ & $\begin{array}{l}.22280244 \\
.20700192 \\
.19419828 \\
.18354081\end{array}$ & $\begin{array}{l}.18739998 \\
.17875084 \\
.17095882 \\
.16397227\end{array}$ & $\begin{array}{l}.64902633 \\
.60929766 \\
.57609679 \\
.54780756\end{array}$ & $\begin{array}{l}.73646755 \\
.68157594 \\
.63714980 \\
.60027386\end{array}$ \\
\hline
\end{tabular}

RELATIONAL EXPRESSION OF BESSEL FUNCTIONS ARE DEFINED AS FOLLOHS.

LET KO $=\mathrm{K}$ ZERO $(\mathrm{X})$, KONE $=\mathrm{K}$ ONE $(\mathrm{X})$,

IO $=\mathrm{I}$ ZERO $(X), I O N E=I$ ONE $(X)$,

THEN KO*IONE-KONE*IO-1/X=0.

HANDBOOK OF MATHEMATICAL FUNCTIONS AMS 55 PAGE 375.

THEREFORE THE FOLLOHING VALUES MUST BE EQUAL TO OR NEAR ZERO.

$*-8.6923440-09 *-7.4505806-09$ 
OMNITAB 80 TEST 55 BESSEL FUNCTIONS. (12.1), (12.2) AND (12.3)

LIST OF DATA, INSTRUCTIONS AND DIAGNOSTICS

GENERATE X FROM 1.0 IN STEPS OF .5 THRU 5.0 IN COL 1

* informative diagnostic for the abOVE INSTRUCTION -

NRMAX HAS BEEN RESET FROM O TO 9.

BJZERO OF COL 1 STORE IN COL 2

BJONE OF COL 1 STORE IN COL 3

BYZERO OF COL 1 STORE IN COL 4

BYONE OF COL 1 STORE IN COL 5

TITLE1 BESSEL FUNCTIONS J AND Y FOR ORDERS 0 AND 1.

NEW PAGE

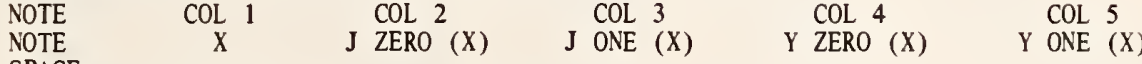

SPACE

NPRINT COLS $1 * * * 5$

MULTIPLY COL 4 BY COL 3 STORE IN COL 6

MULTIPLY COL 5 BY COL 2 MULTIPLY -1.0 ADD TO COL 6 AND STORE IN COL 6

MULTIPLY COL 1 BY *PI* STORE IN COL 7

DIVIDE 2.0 BY COL 7 MULT -1.0 ADD TO COL 6 AND STORE IN COL 6

AVERAGE COL 6 STORE IN COL 6

SPACE 2

NOTE ***

SPACE

NOTE RELATIONAL EXPRESSION OF BESSEL FUNCTIONS ARE DEFINED AS FOLLOHS.

NOTE LET YO $=Y$ ZERO. $(X)$, YONE $=Y$ ONE $(X)$,

NOTE JO $=$ J ZERO $(X)$, JONE $=$ J ONE $(X)$,

NOTE THEN YO*JONE-YONE*JO-2/(PI*X) $=0$.

NOTE HANDBOOK OF MATHEMATICAL FUNCTIONS AMS 55 PAGE 360.

NOTE THEREFORE THE FOLLOWING VALUE MUST BE EQUAL TO OR NEAR ZERO.

SPACE

ABRIDGE ROW' 1 OF COL 6

SPACE

NOTE $* * * * * * * * * * * * * * * * * * * * * * * * * * * * * * * * * * * * * * * * * * * * * * * * * * * * * * * * * * * * * * * * * * * * *$

BIZERO OF COL 1 STORE IN COL 2

BIONE OF COL 1 STORE IN COL 3

BKZERO OF COL 1 STORE IN COL 4

BKONE OF COL 1 STORE IN COL 5

MULTIPLY COL 2 BY COL 5 STORE IN COL 6

MULTIPLY COL 3 BY COL 4 MULT BY 1.0 ADD TO COL 6 AND STORE IN COL 6

DIVIDE 1.0 BY COL 1 MULTIPLY BY -1.0 ADD TO COL 6 AND STORE IN COL 6

AVERAGE COL 6 STORE IN COL 6

TITLE1 BESSEL FUNCTIONS I AND $K$ FOR ORDERS 0 AND 1

NEW PAGE

NOT

NOTE $\quad X$

$\mathrm{COL} 1 \quad \mathrm{COL} 2$

I ZERO $(\mathrm{X})$

COL 3

COL 4

COL 5

SPACE

I ONE $(\mathrm{X})$

K ZERO (X)

K ONE $(X)$

NPRINT COLS $1 * * * 5$

EXIZERO OF COL 1 STORE IN COL 2

EXIONE OF COL 1 STORE IN COL 3

EXKZERO OF COL 1 STORE IN COL 4 
OMNITAB 80 TEST 55 BESSEL FUNCTIONS. (12.1), (12.2) AND (12.3)

LIST OF DATA, INSTRUCTIONS AND DIAGNOSTICS

EXKONE OF COL 1 STORE IN COL 5

MULTIPLY COL 2 BY COL 5 STORE IN COL 7

MULTIPLY COL 3 BY COL 4 MULT BY 1.0 ADD TO COL 7 AND STORE IN COL 7

DIVIDE $1.0 \mathrm{BY}$ COL 1 MULTIPLY BY -1.0 ADD TO COL 7 AND STORE IN COL 7

AVERAGE COL 7 STORE IN COL 7

SPACE

NOTE

COL $1 \quad$ COL 2

NOTE

$\mathrm{X}$

I ZERO $(X)$

COL 3

I ONE $(X)$

COL 4

$\mathrm{K}$ ZERO $(X)$

COL 5

NOTE

${ }^{*} \operatorname{EXP}(-X)$

*EXP $(-X)$

${ }^{*} \operatorname{EXP}(X)$

$\mathrm{K}$ ONE $(X)$

${ }^{*} \operatorname{EXP}(X)$

NPRINT COLS $1 * * * 5$

SPACE 2

YOTE

SPACE

NOTE RELATIONAL EXPRESSION OF BESSEL FUNCTIONS ARE DEFINED AS FOLLOTS.

NOTE LET $K O=K$ ZERO $(X), K O N E=K$ ONE $(X)$,

NOTE IO =I ZERO $(X)$, IONE=I ONE $(X)$,

NOTE THEN $K O * I O N E+K O N E * I 0-1 / X=0$.

NOTE HANDBOOK OF MATHEMATICAL FUNCTIONS AMS 55 PAGE 375.

NOTE THEREFORE THE FOLLOR'ING VALUES MUST BE EQUAL TO OR NEAR ZERO.

SPACE

ABRIDGE ROW 1 OF COLS 6 AND 7

SPACE

NOTE

NATIONAL BUREAU OF STANDARDS. HASHINGTON, D. C. 20234

OMNITAB 80 VERSION 6.00 MARCH 2,1981 
OMNITAB 80 TEST 56 BESSEL OF COMPLEX ARGS. (12.4), (12.5), (12.6) AND (12.7) PAGE 1 BESSEL FUNCTIONS COMPLEX ARGUMENTS OF ORDER 0 , PHI $=\mathrm{PI} / 4$.

\begin{tabular}{|c|c|c|c|c|}
\hline COL 1 & $\begin{array}{l}\mathrm{COL} 2 \\
\mathrm{I}(\mathrm{Z} * \mathrm{EX})\end{array}$ & $\begin{array}{c}\text { COL } 3 \\
\left.\left(I^{*} \mathrm{PI} / 4\right)\right)^{-1}\end{array}$ & $\begin{array}{l}\mathrm{COL} 4 \\
\mathrm{~K}\left(\mathrm{Z}^{*} \operatorname{EXP}(\mathrm{I}\right.\end{array}$ & $\begin{array}{l}\text { COL } 5 \\
* \mathrm{PI} / 4))\end{array}$ \\
\hline$Z$ & REAL PART & IMAGINARY & REAL PART & IMAGINARY \\
\hline $\begin{array}{l}1.0000000 \\
2.0000000 \\
3.0000000 \\
4.0000000 \\
5.0000000\end{array}$ & $\begin{array}{r}.98438178 \\
.75173418 \\
-.22138025 \\
-2.5634165 \\
-6.2300825\end{array}$ & $\begin{array}{c}.24956604 \\
.97229163 \\
1.9375868 \\
2.2926903 \\
.11603438\end{array}$ & $\begin{array}{c}.28670621 \\
-.041664514 \\
-.067029233 \\
-.036178848 \\
-.011511727\end{array}$ & $\begin{array}{l}-.49499463 \\
-.20240007 \\
-.051121884 \\
.0021983993 \\
.011187586\end{array}$ \\
\hline $\begin{array}{l}6.0000000 \\
7.0000000 \\
8.0000000 \\
9.0000000 \\
0.000000\end{array}$ & $\begin{array}{c}-8.8583159 \\
-3.6329302 \\
20.973955 \\
73.935729 \\
138.84047\end{array}$ & $\begin{array}{c}-7.3347465 \\
-21.239403 \\
-35.016725 \\
-24.712783 \\
56.370458\end{array}$ & $\begin{array}{c}-.00065303750 \\
.0019220216 \\
.0014858341 \\
.00063716419 \\
.00012946633\end{array}$ & $\begin{array}{r}.0072164915 \\
.0027003651 \\
.00036958396 \\
-.00031915291 \\
-.00030752457\end{array}$ \\
\hline
\end{tabular}

BESSEL FUNCTIONS COMPLEX ARGUMENTS OF ORDER 1 , PHI=PI/4

\begin{tabular}{|c|c|c|c|c|}
\hline COL 1 & $\begin{array}{l}\mathrm{COL}{ }_{\mathrm{I}\left(\mathrm{Z}^{*} \mathrm{EXI}\right.}\end{array}$ & $\begin{array}{r}\mathrm{COL} 7 \\
(\mathrm{I} * \mathrm{PI} / 4))^{2}\end{array}$ & $\begin{array}{l}\mathrm{COL} 8 \\
\mathrm{~K}\left(\mathrm{Z}^{*} \mathrm{EXP}(\mathrm{I}\right.\end{array}$ & $\begin{array}{l}\text { COL } 9 \\
\left.\left.{ }_{*} \mathrm{PI} / 4\right)\right)\end{array}$ \\
\hline Z & REAL PART & IMAGI NARY & REAL PART & IMAG INARY \\
\hline $\begin{array}{l}1.0000000 \\
2.0000000 \\
3.0000000 \\
4.0000000 \\
5.0000000\end{array}$ & $\begin{array}{r}.30755663 \\
.29977544 \\
-.48745418 \\
-2.5638217 \\
-5.7979079\end{array}$ & $\begin{array}{l}.39586826 \\
.99707765 \\
1.7326442 \\
1.8692484 \\
-.35977666\end{array}$ & $\begin{array}{c}.24199597 \\
-.080049397 \\
-.080270222 \\
-.039166010 \\
-.011577754\end{array}$ & $\begin{array}{l}-.74032227 \\
-.23080593 \\
-.049898308 \\
.0053512965 \\
.012737390\end{array}$ \\
\hline $\begin{array}{l}6.0000000 \\
7.0000000 \\
8.0000000 \\
9.0000000 \\
0.000000\end{array}$ & $\begin{array}{c}-7.8766769 \\
-2.3171651 \\
21.673535 \\
72.054291 \\
131.87864\end{array}$ & $\begin{array}{c}-7.4621992 \\
-20.368926 \\
-32.506861 \\
-20.719209 \\
59.477610\end{array}$ & $\begin{array}{c}-.00028834994 \\
.0021488969 \\
.0015669748 \\
.00065005053 \\
.00012351960\end{array}$ & $\begin{array}{r}.0076760896 \\
.0027435871 \\
.00032285705 \\
-.00035578180 \\
-.00032280186\end{array}$ \\
\hline
\end{tabular}

THE FOLLOWING VALUES MUST BE EQUAL TO OR NEAR ZERO.

*-5.1222742-09*3.7834980-09 
OMNITAB 80 TEST 56 BESSEL OF COMPLEX ARGS. $(12.4),(12.5),(12.6)$ AND $(12.7) \quad$ PAGE 2 BESSEL FUNCTIONS COMPLEX ARGUMENTS OF ORDER 0 , $\mathrm{PHI}=\mathrm{PI} / 4$.

\begin{tabular}{|c|c|c|c|c|}
\hline COL 1 & $\begin{array}{l}\text { COL } 2 \\
\text { EXP }(-Z) \\
\text { I }(Z * \text { EXF }\end{array}$ & $\begin{array}{r}\text { COL } 3 \\
\operatorname{RT}(2))^{*} \\
* P I / 4))\end{array}$ & $\begin{array}{l}\text { COL } 4 \\
\text { EXP }(Z / S \\
\text { K }(Z * E X F\end{array}$ & $\begin{array}{l}\text { COL } 5 \\
T(2))^{*} \\
\left.\left.{ }^{*} \mathrm{PI} / 4\right)\right)\end{array}$ \\
\hline Z & REAL PART & IMAGINARY & REAL PART & IMAG INARY \\
\hline $\begin{array}{l}0000000 \\
0000000 \\
0000000 \\
0000000 \\
0000000\end{array}$ & $\begin{array}{l}.48536783 \\
.18275916 \\
-.026537570 \\
-.15151265 \\
-.18156449\end{array}$ & $\begin{array}{l}.12305320 \\
.23638036 \\
.23226482 \\
.13551117 \\
.0033816124\end{array}$ & $\begin{array}{r}.58147316 \\
-.17137658 \\
-.55916756 \\
-.61210372 \\
-.39500569\end{array}$ & $\begin{array}{c}-1.0039060 \\
-.83252215 \\
-.42646615 \\
.037194341 \\
.38388335\end{array}$ \\
\hline $\begin{array}{l}.0000000 \\
.0000000 \\
.0000000 \\
.0000000 \\
.000000\end{array}$ & $\begin{array}{c}-.12729042 \\
-.025740030 \\
.073272289 \\
.12735653 \\
.11792078\end{array}$ & $\begin{array}{l}-.10539734 \\
-.15048537 \\
-.12233055 \\
-.042568515 \\
.047876879\end{array}$ & $\begin{array}{c}-.045445780 \\
.27127281 \\
.42531519 \\
.36990016 \\
.15243425\end{array}$ & $\begin{array}{r}.50220559 \\
.38112769 \\
.10579221 \\
-.18528146 \\
-.36208084\end{array}$ \\
\hline
\end{tabular}

BESSEL FUNCTIONS COMPLEX ARGUMENTS OF ORDER 1 , PHI=PI/4.

\begin{tabular}{|c|c|c|c|c|}
\hline \multirow{2}{*}{$\begin{array}{c}\text { COL } 1 \\
\text { Z }\end{array}$} & \multicolumn{2}{|c|}{$\begin{array}{c}\text { COL } 6 \quad \text { COL } 7 \\
\operatorname{EXP}(-Z / S Q R T(2))^{*} \\
I\left(Z^{*} \operatorname{EXP}\left(I^{*} \mathrm{PI} / 4\right)\right)\end{array}$} & \multicolumn{2}{|c|}{$\begin{array}{l}\text { COL } 8 \quad \text { COL } 9 \\
\text { EXP(Z/SQRT(2)) } \\
\text { K }\left(Z^{*} \operatorname{EXP}\left(I^{*} \mathrm{PI} / 4\right)\right)\end{array}$} \\
\hline & REAL PART & IMAG INARY & REAL PART & IMAGINARY \\
\hline $\begin{array}{l}1.0000000 \\
2.0000000 \\
3.0000000 \\
4.0000000 \\
5.0000000\end{array}$ & $\begin{array}{l}.15164655 \\
.072880425 \\
-.058432716 \\
-.15153659 \\
-.16896955\end{array}$ & $\begin{array}{c}.19519025 \\
.24240626 \\
.20769769 \\
.11048333 \\
-.010485041\end{array}$ & $\begin{array}{r}.49079564 \\
-.32926321 \\
-.66962581 \\
-.66264302 \\
-.39727131\end{array}$ & $\begin{array}{c}-1.5014587 \\
-.94936258 \\
-.41625890 \\
.090537667 \\
.43706228\end{array}$ \\
\hline $\begin{array}{c}6.0000000 \\
7.0000000 \\
8.0000000 \\
9.0000000 \\
10.000000\end{array}$ & $\begin{array}{c}-.11318467 \\
-.016417573 \\
.075716262 \\
.12411569 \\
.11200792\end{array}$ & $\begin{array}{l}-.10722879 \\
-.14431787 \\
-.11356237 \\
-.035689463 \\
.050515863\end{array}$ & $\begin{array}{c}-.020066670 \\
.30329384 \\
.44854146 \\
.37738121 \\
.14543255\end{array}$ & $\begin{array}{c}.53418966 \\
.38722801 \\
.092416785 \\
-.20654605 \\
-.38006840\end{array}$ \\
\hline
\end{tabular}

THE FOLLOHING VALUES MUST BE EQUAL TO OR NEAR ZERO.

$*$ *4.6566129-09*4.5984052-09 
OMNITAB 80 TEST 56 BESSEL OF COMPLEX ARGS. (12.4), (12.5), (12.6) AND (12.7) PAGE 3 BESSEL FUNCTIONS COMPLEX ARGUMENTS OF ORDER 0 PHI $=30$ DEGREES OR .523598775 RADIANS

\begin{tabular}{|c|c|c|c|c|}
\hline COL 1 & $\operatorname{CoL}{ }_{I\left(Z^{*} E X I\right.}$ & $\begin{array}{r}\text { COL } 3 \\
\left.\mathrm{P}\left(\mathbf{I}^{*} \mathrm{PHI}\right)\right)\end{array}$ & $\begin{array}{l}\text { COL } 4 \\
K\left(Z^{*} \text { EXP }\right.\end{array}$ & $\begin{array}{l}\text { COL } 5 \\
\left.\left(I^{*} \mathrm{PHI}\right)\right)\end{array}$ \\
\hline$Z$ & REAL PART & IMÁGINARY & REAL PART & IMAGINARY \\
\hline $\begin{array}{l}1.0000000 \\
2.0000000 \\
3.0000000 \\
4.0000000 \\
5.0000000\end{array}$ & $\begin{array}{l}1.1167501 \\
1.3463908 \\
1.1557921 \\
-.95624276 \\
-8.4114261\end{array}$ & $\begin{array}{l}.23003206 \\
1.0809681 \\
3.0026294 \\
6.4823126 \\
11.016143\end{array}$ & $\begin{array}{l}.36238959 \\
.048685394 \\
-.0090476354 \\
-.011997036 \\
-.0066857185\end{array}$ & $\begin{array}{l}-.32126957 \\
-.14140496 \\
-.051315125 \\
-.014896471 \\
-.0027524014\end{array}$ \\
\hline $\begin{array}{l}6.0000000 \\
7.0000000 \\
8.0000000 \\
9.0000000 \\
10.000000\end{array}$ & $\begin{array}{c}-27.417000 \\
-65.537291 \\
-121.48827 \\
-151.42078 \\
13.941978\end{array}$ & $\begin{array}{c}12.101181 \\
-5.6731651 \\
-80.956392 \\
-289.50409 \\
-735.81133\end{array}$ & $\begin{array}{r}-.0027680361 \\
*-8.8970518-04 \\
*-1.8934144-04 \\
* 7.3247812-06 \\
* 3.5164107-05\end{array}$ & $\begin{array}{l}* 3.0865415-04 \\
* 6.2478134-04 \\
* 3.8441522-04 \\
* 1.7001488-04 \\
* 5.8180746-05\end{array}$ \\
\hline
\end{tabular}

BESSEL FUNCTIONS COMPLEX ARGUMENTS OF ORDER 1 PHI $=30$ DEGREES

\section{COL 1}

Z

1.0000000
2.0000000
3.0000000
4.0000000

5.0000000

6.0000000

7.0000000

8.0000000

9.0000000

10.000000
COL 6 REAL PART
COL 7

(I))
COL 8 K(Z*EXP(I*PHI) *EXP(I*PHI)

K( $(Z * E X P(I * P H I))$
REAL PART IMAGINARY

$$
\begin{array}{cccl}
.43071045 & .31377427 & .43914511 & -.51609738 \\
.78785283 & 1.0378416 & .043382938 & -.17529605 \\
.64916390 & 2.6807601 & -.014118098 & -.057716939 \\
-1.3246755 & 5.7005536 & -.014103119 & -.015767526 \\
-8.2791920 & 9.5750115 & -.0073764499 & -.0026735305 \\
-25.943990 & 9.9659038 & -.0029510440 * 4.3872466-04 \\
-61.186409 & -7.8292065 & *-9.2250587-04 * 6.9273014-04 \\
-112.10820 & -80.535762 & *-1.8796503-04 * 4.1048924-04 \\
-135.53557 & -279.79750 & * 1.2192358-05 * 1.7787054-04 \\
32.627300 & -703.13503 & * 3.8062966-05 * 5.9819189-05
\end{array}
$$

THE FOLLOWING VALUES MUST BE EQUAL TO OR NEAR ZERO.

*-6.3329935-09*2.9831426-09 
OMNITAB 80 TEST 56 BESSEL OF COMPLEX ARGS. (12.4), (12.5), (12.6) AND (12.7) PAGE 4 BESSEL FUNCTIONS COMPLEX ARGUMENTS OF ORDER $0 . \quad$ PHI $=45$ DEGREES OR .785398163 RADIANS.

$\mathrm{COL} 1$

Z

1.0000000

2.0000000

3.0000000

4.0000000

5.0000000

6.0000000

7.0000000

8.0000000

9.0000000

10.000000
COL 3

$\operatorname{EXP}\left(-\mathrm{Z}^{*} \operatorname{COS}(\mathrm{PHI})\right)^{*}$

I $\left(Z^{*} \operatorname{EXP}\left(I^{*} \mathrm{PHI}\right)\right)$

REAL PART IMAGINARY

.19519024

.24240626

.20769769

.11048333

$-.010485037$

$-.15153659$

$-.16896955$

$-.11318467$

$-.016417579$

.075716257

.12411569

.11200792

$-.10722878$

$-.14431787$

$-.11356237$

$-.035689469$

.050515857

$$
\begin{aligned}
& \text { COL } 4 \text { COL } 5 \\
& \operatorname{EXP}\left(Z^{*} \operatorname{COS}(\mathrm{PHI})\right)^{*} \\
& \mathrm{~K}\left(\mathrm{Z}^{*} \operatorname{EXP}\left(I^{*} \mathrm{PHI}\right)\right)
\end{aligned}
$$

$$
\text { REAL PART IMAGINARY }
$$

\begin{tabular}{|c|c|c|c|c|}
\hline $\mathrm{COL} 1$ & $\begin{array}{l}\text { COL } 6 \\
\operatorname{EXP}\left(-Z^{*}\right. \\
\text { I }\left(Z^{*} E\right.\end{array}$ & $\begin{array}{r}\text { COL } 7 \\
(\mathrm{PHI}))^{*} \\
(\mathrm{I} * \mathrm{PHI}))\end{array}$ & $\begin{array}{l}\mathrm{COL} 8 \\
\operatorname{EXP}\left(Z^{*} C\right. \\
\mathrm{K}\left(Z^{*} \mathrm{EX}\right.\end{array}$ & $\begin{array}{c}\text { COL }{ }^{9} \\
(\text { (PHI }))^{*} \\
\left.\left(I^{*} \mathrm{PHI}\right)\right)^{2}\end{array}$ \\
\hline Z & REAL PART & IMAGINARY & REAL PART & IMAGINARY \\
\hline $\begin{array}{l}1.0000000 \\
2.0000000 \\
3.0000000 \\
4.0000000 \\
5.0000000\end{array}$ & $\begin{array}{l}.15164655 \\
.072880426 \\
-.058432714 \\
-.15153659 \\
-.16896955\end{array}$ & $\begin{array}{c}.19519024 \\
.24240626 \\
.20769769 \\
.11048333 \\
-.010485037\end{array}$ & $\begin{array}{r}.49079566 \\
-.32926320 \\
-.66962580 \\
-.66264302 \\
-.39727132\end{array}$ & $\begin{array}{c}-1.5014587 \\
-.94936258 \\
-.41625892 \\
.090537650 \\
.43706227\end{array}$ \\
\hline $\begin{array}{l}6.0000000 \\
7.0000000 \\
8.0000000 \\
9.0000000 \\
0.000000\end{array}$ & $\begin{array}{c}-.11318467 \\
-.016417579 \\
.075716257 \\
.12411569 \\
.11200792\end{array}$ & $\begin{array}{r}-.10722878 \\
-.14431787 \\
-.11356237 \\
-.035689469 \\
.050515857\end{array}$ & $\begin{array}{c}-.020066690 \\
.30329382 \\
.44854146 \\
.37738122 \\
.14543257\end{array}$ & $\begin{array}{l}.53418966 \\
.38722802 \\
.092416807 \\
-.20654603 \\
-.38006839\end{array}$ \\
\hline
\end{tabular}

$\begin{array}{cc}.49079566 & -1.5014587 \\ -.32926320 & -.94936258 \\ -.66962580 & -.41625892 \\ -.66264302 & .090537650 \\ -.39727132 & .43706227 \\ -.020066690 & .53418966 \\ .30329382 & .38722802 \\ .44854146 & .092416807 \\ .37738122 & -.20654603 \\ .14543257 & -.38006839\end{array}$

BESSEL FUNCTIONS COMPLEX ARGLMENTS OF ORDER 1, PHI=45 DEGREES.

THE FOLLOHING VALUES MUST BE EQUAL TO OR NEAR ZERO.

*-2.7939677-09*3.4866389-09 
LIST OF DATA, INSTRUCTIONS AND DIAGNOSTICS

GENERATE FROM 1.0 IN STEPS OF 1.0 THRU 10. AND PUT IN COL 1

* INFORMATIVE DIAGNOSTIC FOR THE ABOVE INSTRUCTION NRMAX HAS BEEN RESET FROM O TO 10.

KBIZERO OF VALUES IN COL 1 PUT REAL RESULTS IN COL 2, COMPLEX RESULTS IN COL 3 KBKZERO OF VALUES IN COL 1 PUT REAL RESULTS IN COL 4, COMPLEX RESULTS IN COL 5 TITLE1 BESSEL FUNCTIONS COMPLEX ARGUMENTS OF ORDER $0, \mathrm{PHI}=\mathrm{PI} / 4$.

NEW PAGE

NOTE

COL 1

NOTE $\quad Z$
COL 2 I $Z$ *EXP( I*PI/4)
IMAGINARY
COL 4 COL 5 $\mathrm{K}(\mathrm{Z} * \operatorname{EXP}(\mathrm{I} * \mathrm{PI} / 4))$

SPACE

KBIONE OF VALUES IN COL 1 PUT REAL RESULTS IN COL 6, COMPLEX RESULTS IN COL 7 KBKONE OF VALUES IN COL 1 PUT REAL RESULTS IN COL 8 , COMPLEX RESULTS IN COL 9 SPACE

NOTE

SPACE

NOTE BESSEL FUNCTIONS COMPLEX ARGUMENTS OF ORDER $1, \mathrm{PHI}=\mathrm{PI} / 4$

NOTE COL 1

$\mathrm{Z}$
$\mathrm{COL} 6$ COL 7 I $\left(2 * \operatorname{EXP}\left(I^{*} \mathrm{PI} / 4\right)\right)$
REAL PART IMAGINARY

SPACE

COL 8 COL 9 $K(Z * \operatorname{EXP}(I * \mathrm{PI} / 4))$

SPACE 1 COLS $6 * * * 9$

MULT COL 2 BY COL 8 STORE IN COL 11

MULT COL 3 BY COL 9 MULTIPLY BY -1 . ADD TO COL 11 AND PUT IN COL 11

MULT COL 6 BY COL 4 MULTIPLY BY 1.0 ADD TO COL 11 AND STORE IN COL 11

MULT COL 7 BY COL 5 MULTIPLY BY -1.0 ADD TO COL 11 AND STORE IN COL 11

SQRT 2.0 STORE IN COL 10

DIVIDE COL 10 BY COL 1 MULTIPLY BY .5 ADD 0.0 STORE IN COL 10

SUBTRACT COL 10 FROM COL 11 STORE IN COL 11

MULT COL 2 BY COL 9 MULTIPLY BY 1.0 ADD TO COL 10 AND STORE IN COL 12

MULT COL 3 BY COL 8 MULTIPLY BY 1.0 ADD TO COL 12 AND STORE IN COL 12

MULT COL 6 BY COL 5 MULTIPLY BY 1.0 ADD TO COL 12 AND STORE IN COL 12

SPACE

MULT COL 7 BY COL 4 MULTIPLY BY 1.0 ADD TO COL 12 AND STORE IN COL 12

SPACE 2

NOTE ****

SPACE

NOTE THE FOLLOWING VALUES MUST BE EQUAL TO OR NEAR ZERO.

SPACE

AVERAGE COL 11 STORE IN COL 11

AVERAGE COL 12 STORE IN COL 12

ABRIDGE ROW 1 OF COLS 11 AND 12

SPACE

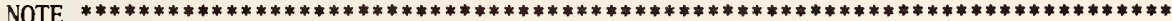

KEXIZERO OF VALUES IN COL 1 PUT REAL RESULTS IN COL 2, COMPLEX RESULTS IN COL 3

KEXKZERO OF VALUES IN COL 1 PUT REAL RESULTS IN COL 4 , COMPLEX RESULTS IN COL 5

KEXIONE OF VALUES IN COL 1 PUT REAL RESULTS IN COL 6, COMPLEX RESULTS IN COL 7

KEXKONE OF VALUES IN COL 1 PUT REAL RESULTS IN COL 8, COMPLEX RESULTS IN COL 9 
OMNITAB 80 TEST 56 BESSEL OF COMPLEX ARGS. (12.4), (12.5), (12.6) AND (12.7)

LIST OF DATA, INSTRUCTIONS AND DIAGNOSTICS

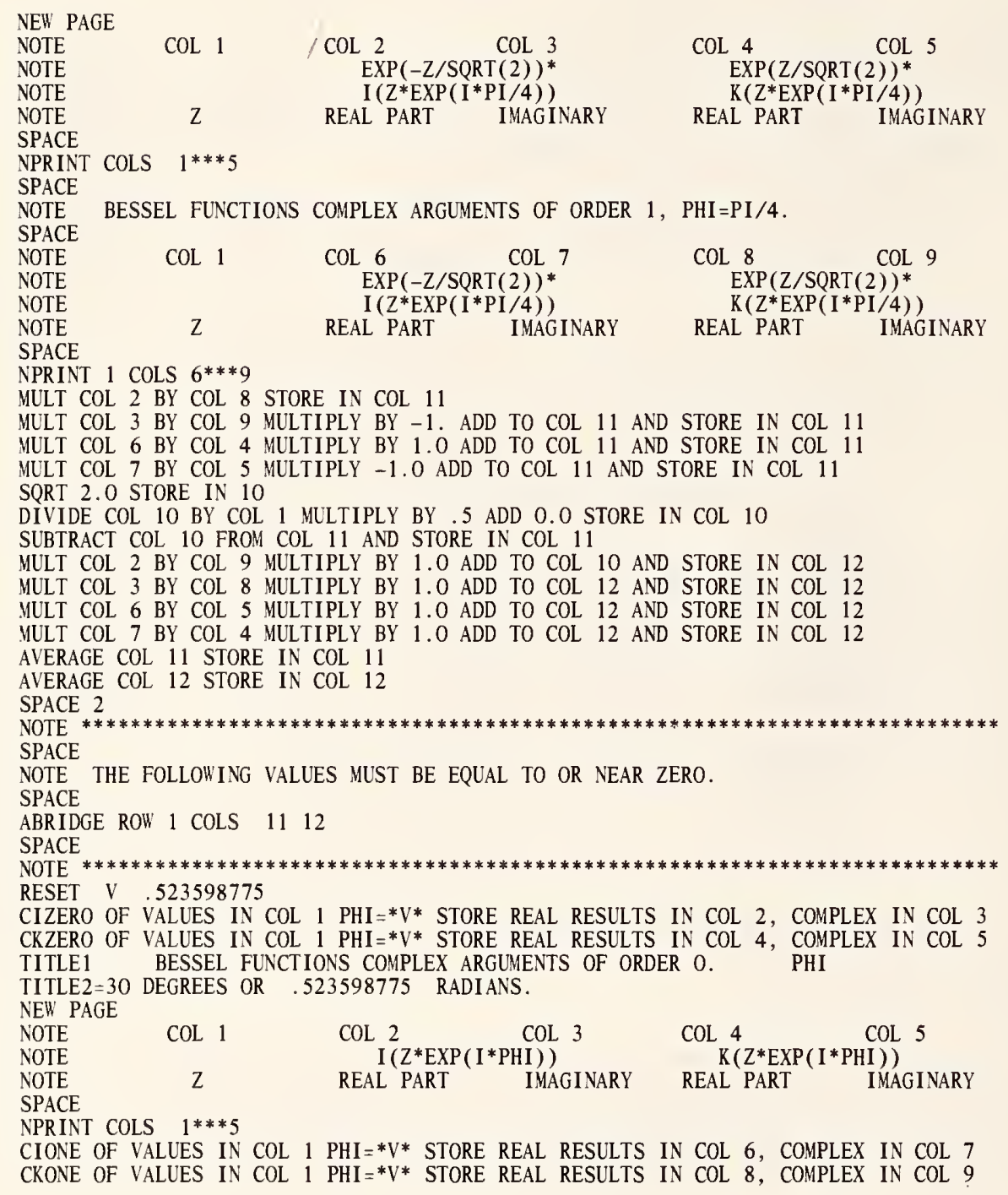


OMNITAB 80 TEST 56 BESSEL OF COMPLEX ARGS. (12.4), (12.5), (12.6) AND (12.7)

LIST OF DATA, INSTRUCTIONS AND DIAGNOSTICS

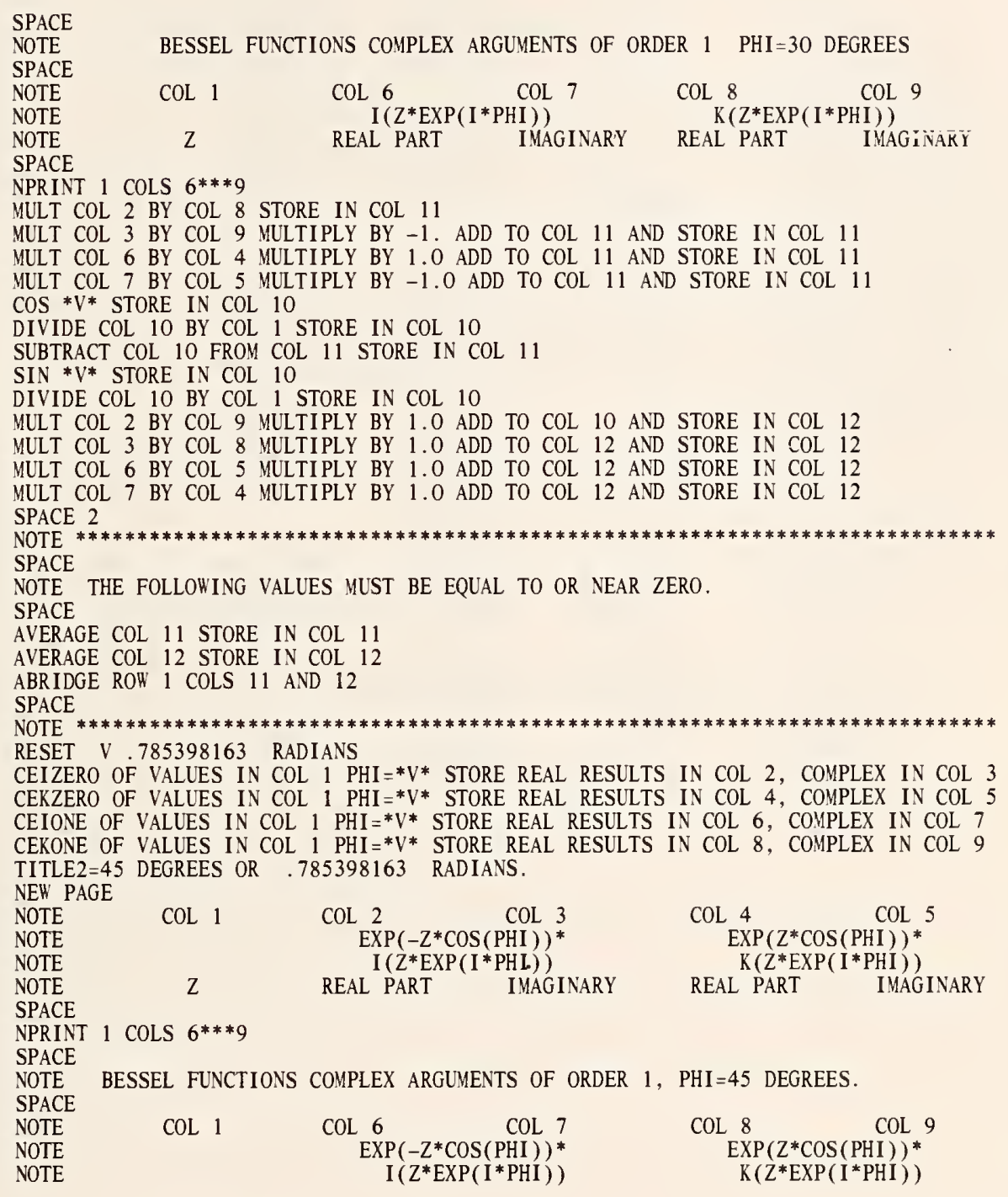


OMNITAB 80 TEST 56 BESSEL OF COMPLEX ARGS. (12.4), (12.5), (12.6) AND (12.7) PAGE 8

LIST OF DATA, INSTRUCTIONS AND DIAGNOSTICS

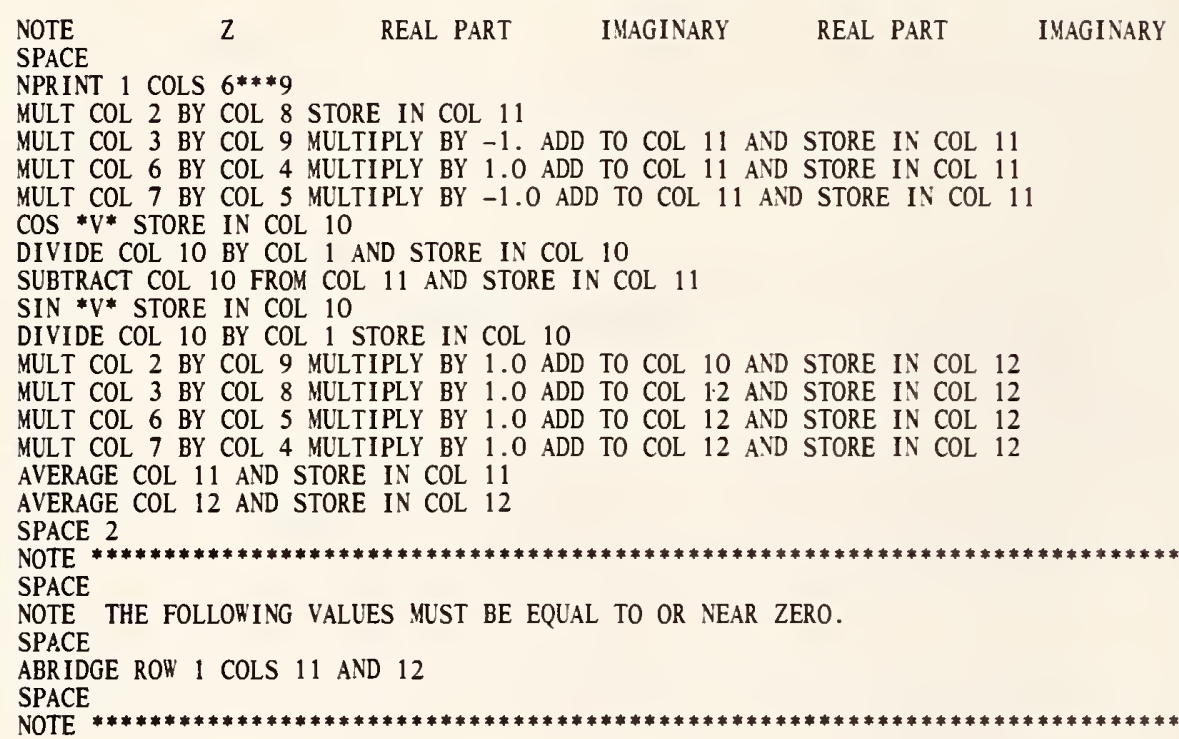

NATIONAL BUREAU OF STANDARDS. WASHINGTON, D. C. 20234 OMNITAB 80 VERSION 6.00 MARCH 2,1981 
OMNITAB 80 TEST 57 ZEROS OF BESSEL FUNCTIONS AND FUNCT OF ORDER N. (12.8) (12.9) PAGE 1 ZEROS OF J ORDER 0 AND 1 AND THEIR DERIVATIVES.

$\mathrm{COL} 8$
$\mathrm{~N}$
0.
1.0
2.0
3.0
4.0
5.0
6.0
7.0
8.0
9.0

$\mathrm{COL} 1$ ZEROS J 0

2.4048256

5.5200781

8.6537279

11.791534

14.930918

18.071064

21. 211637

24. 352471

27.493479

30.634606

10. $\quad 33.775820$

11. $\quad 36.917098$

12.40 .058425

13. 43.199791

14. 46.341188

15. $\quad 49.482610$

16. 52.624052

$17 . \quad 55.765511$

18 . $\quad 58.906984$

$19 . \quad 62.048469$

20. $\quad 65.189964$

21. 68.331469

22. 71.472981

23 . 74.614500

24 . $\quad 77.756025$

25. 80.897555

26. 84.039090

$27 . \quad 87.180630$

28. 90.322172

$29 . \quad 93.463718$
COL 2

DERIV J 0

51914749

$-.34026480$

.27145230

$-.23245983$

.20654643

$-.18772880$

.17326589

$-.16170155$

.15218121

$-.14416598$

.13729694

$-.13132463$

.12606950

$-.12139862$

.11721120

$-.11342919$

.10999114

$-.10684789$

.10395957

$-.10129350$

.098822554

$-.096524040$

.094378794

$-.092370505$

.090485194

$-.088710802$

.087036863

$-.085454242$

.083954928

$-.082531861$
$\mathrm{COL} 3$ ZEROS J ONE

3.8317060

7.0155866

10.173468

13.323692

16.470630

19.615858

22.760084

25.903672

29.046829

32.189680

35.332307

38.474766

41.617094

44.759319

47.901461

51.043535

54.185554

57.327525

60.469458

63.611356

66.753226

69.895071

73.036895

76.178699

79. 320487

82.462259

85.604019

88.745767

91.887504

95.029231
COL 4

DERIV J ONE

$-.40275940$

.30011575

$-.24970488$

.21835941

$-.19646537$

.18006337

$-.16718460$

.15672499

$-.14801111$

.14060580

$-.13421124$

.12861662

$-.12366796$

.11924981

$-.11527369$

.11167050

$-.10838535$

.10537405

$-.10260057$

.10003515

$-.097653016$

095433339

$-.093358452$

.091413272

$-.089584822$

.087861876

$-.086234663$

.084694634

$-.083234273$

.081846938

SUM $1 /(X * * 4)=.03125$ FOR J ZERO $(X)=0$.

THE FOLLOWING VALUES MUST BE EQUAL TO OR NEAR .03125 AND 0.0 RESPECTIVELY.

$.031249877 * 3.1044086-11$ 
OMNITAB 80 TEST 57 ZEROS OF BESSEL FUNCTIONS AND FUNCT OF ORDER N. (12.8) (12.9) PAGE 2 RESULTS OF $J N(X), I N(X), K N(X)$ FOR $N=0$ (1) 29.

\begin{tabular}{|c|c|c|c|}
\hline $\begin{array}{c}\mathrm{N} \\
\mathrm{COL} 8 \\
0 . \\
1.0 \\
2.0 \\
3.0 \\
4.0\end{array}$ & $\begin{array}{c}J \mathrm{~N}(5) \\
\mathrm{COL} 1 \\
-.17759677 \\
-.32757914 \\
.046565116 \\
.36483123 \\
.39123236\end{array}$ & $\begin{array}{c}\text { I N (2) } \\
\text { COL 2 } \\
2.2795853 \\
1.5906368 \\
.68894845 \\
.21273996 \\
.050728570\end{array}$ & $\begin{array}{c}\mathrm{KN}(1) \\
\mathrm{COL} 3 \\
.42102444 \\
.60190722 \\
1.6248389 \\
7.1012628 \\
44.232416\end{array}$ \\
\hline $\begin{array}{l}5.0 \\
6.0 \\
7.0 \\
8.0 \\
9.0\end{array}$ & $\begin{array}{l}.26114054 \\
.13104873 \\
.053376410 \\
.018405217 \\
.0055202831\end{array}$ & $\begin{array}{r}.0098256792 \\
.0016001734 \\
* 2.2463914-04 \\
* 2.7699369-05 \\
* 3.0441859-06\end{array}$ & $\begin{array}{l}* 3.6096059+02 \\
* 3.6538383+03 \\
* 4.4207020+04 \\
* 6.2255212+05 \\
* 1.0005041+07\end{array}$ \\
\hline $\begin{array}{l}10 . \\
11 . \\
12 . \\
13 . \\
14 .\end{array}$ & $\begin{array}{r}.0014678026 \\
* \quad 3.5092745-04 \\
* 7.6278131-05 \\
* 1.5207582-05 \\
* 2.8012958-06\end{array}$ & $\begin{array}{l}* 3.0169639-07 \\
* 2.7222023-08 \\
* 2.2541310-09 \\
* 1.7245163-10 \\
* 1.2259834-11\end{array}$ & $\begin{array}{l}* 1.8071329+08 \\
* 3.6242708+09 \\
* \quad 7.9914671+10 \\
* 1.9215764+12 \\
* 5.0040900+13\end{array}$ \\
\hline $\begin{array}{l}15 . \\
16 . \\
17 . \\
18 . \\
19 .\end{array}$ & $\begin{array}{l}* 4.7967433-07 \\
* 7.6750156-08 \\
* 1.1526677-08 \\
* 1.6312443-09 \\
* 2.1828258-10\end{array}$ & $\begin{array}{l}* 8.1394325-13 \\
* 5.0685714-14 \\
* 2.9718290-15 \\
* 1.6462152-16 \\
* 8.6416033-18\end{array}$ & $\begin{array}{l}* 1.4030668+15 \\
* 4.2142045+16 \\
* 1.3499485+18 \\
* 4.5940391+19 \\
* 1.6552040+21\end{array}$ \\
\hline $\begin{array}{l}20 . \\
21 . \\
22 . \\
23 . \\
24 .\end{array}$ & $\begin{array}{l}\text { * } 2.7703300-11 \\
\text { * } 3.3438200-12 \\
\text { * } 3.8478737-13 \\
\text { * } 4.2308846-14 \\
\text { * } 4.4540221-15\end{array}$ & $\begin{array}{l}* 4.3105606-19 \\
* 2.0482232-20 \\
* 9.2917755-22 \\
* 4.0326091-23 \\
* 1.6774623-24\end{array}$ & $\begin{array}{l}* \quad 6.2943693+22 \\
* 2.5194029+24 \\
* 1.0587787+26 \\
* 4.6611455+27 \\
* 2.1451857+29\end{array}$ \\
\hline $\begin{array}{l}25 . \\
26 . \\
27 . \\
28 . \\
29 .\end{array}$ & $\begin{array}{l}* 4.4976606-16 \\
* 4.3638521-17 \\
* 4.0745521-18 \\
* 3.6664192-19 \\
* 3.1837336-20\end{array}$ & $\begin{array}{l}* 6.6995569-26 \\
* 2.5730921-27 \\
* 9.5173970-29 \\
* 3.3948943-30 \\
* 1.1693106-31\end{array}$ & $\begin{array}{l}* 1.0301553+31 \\
* \quad 5.1529215+32 \\
* 2.6805494+34 \\
* 1.4480119+36 \\
* 8.1115474+37\end{array}$ \\
\hline
\end{tabular}

(SUM OF $(\mathrm{J} \mathrm{N}(X)) * * 2) * 2+(\mathrm{J} \text { ZERO }(X))^{* * 2=1 .,}$ FOR $N=1$ THRU INFINITY. (IN THIS EXAMPLE $\left.N=0, \ldots, 29\right)$. (SUM OF (I N $(X))^{* * 2}$.) +I ZERO $(X)-\operatorname{EXP}(X)=0$., FOR $N=1$ THRU INFINITY. (IN THIS EXAMPLE N=0, ., 29). HANDBOOK OF MATHEMATICAL FUNCTIONS AMS 55 PAGES 363 AND 376. THE FOLLOWING VALUES MUST EQUAL OR BE NEAR $1.0,0.0$ AND 0.0 RESPECTIVELY.
1.0000000
$0 . * 5.5879354-09$ 
OMNITAB 80 TEST 57 ZEROS OF BESSEL FUNCTIONS AND FUNCT OF ORDER N. (12.8) (12.9) PAGE

LIST OF DATA, INSTRUCTIONS AND DIAGNOSTICS

TITLE 1 ZEROS OF J ORDER 0 AND 1 AND THEIR DERIVATIVES.

RESET NRMAX TO 30

* INFORMATIVE DIAGNOSTIC FOR THE ABOVE INSTRUCTION -

NRMAX HAS BEEN RESET FROM O TO 30.

ZEROS BJZERO OF J ZERO FOR N FROM ZERO THRU TWENTY-NINE PUT IN COL 1 DERIV COL 2 ZEROS BJONE OF J ZERO FOR N FROM ZERO THRU TWENTY-NINE PUT IN COL 3 DERIV COL 4 SQUARE COL 1 AND STORE IN COL 6

SQUARE COL 6 AND STORE IN COL 6

DIV 1.0 BY COL 6 AND STORE IN COL 6

SUM COL 6 AND STORE IN COL 6

BJZERO OF FIRST KIND OF FIRST ORDER OF COL 3 AND STORE IN COL 7

SUBTRACT COL 7 FROM COL 4 AND STORE IN COL 7

AVERAGE COL 7 AND STORE IN COL 7

GENERATE FROM 0.0 IN STEPS OF 1.0 THRU 29 AND STORE IN COL 8

NEW PAGE

$\begin{array}{llrrrr}\text { NOTE } & \text { COL } 8 & \text { COL } 1 & \text { COL } 2 & \text { COL } 3 & \text { COL } 4 \\ \text { NOTE } & \text { N } & \text { ZEROS J } & \text { DERIV J } 0 & \text { ZEROS J ONE } & \text { DERIV J } 0 \text { E }\end{array}$ $\begin{array}{lcccc}\text { NOTE } & \text { ZEROS J O } & \text { DERIV J } 0 & \text { ZEROS J ONE } \\ \text { NPRINT COL } 8 & \text { WITH } 2.0 \text { SIG. DIGITS AND COLS } 1 * * * 4 & \text { WITH } 8.0 \text { SIG DIGITS }\end{array}$

SPACE 2

NOTE

SPACE

NOTE SUM $1 /\left(X^{* * 4}\right)=.03125$ FOR J ZERO $(X)=0$

NOTE THE FOLLOWING VALUES MUST BE EQUAL TO OR NEAR 03125 AND 0.0 RESPECTIVELY.

SPACE

ABRIDGE ROW 1 COLS 6 AND 7

SPACE

NOTE

TITLE1 RESULTS OF J N (X), I N (X), K N (X) FOR N=0 (1) 29.

BESJN OF $X=5.0$ AND STORE RESULTS IN COL 1

BESIN OF $X=2.0$ AND STORE RESULTS IN COL 2

BESKN OF $X=1.0$ AND STORE RESULTS IN COL 3

NEW PAGE

$\begin{array}{lllll}\text { NOTE } & \mathrm{N} & \mathrm{J} \mathrm{N}(5) & \mathrm{I} ~ \mathrm{~N}(2) & \mathrm{K} \mathrm{N}(1)\end{array}$

NOTE COL 8 COL 1 COL 2 COL 3

NPRINT COL 8 WITH 2.0 SIG. DIGITS COLS 1,2 AND 3 WITH 8.0 SIGNIFICANT DIGITS

SQUARE COL 1 AND STORE IN COL 1

$1 /$ MULT COL 1 BY 2. AND STORE IN COL 10

2/SUM COL 10 AND STORE IN COL 10

3 /SUBTRACT * $1,1 *$ FROM COL 10 AND STORE IN COL 10

4/INCREMENT INSTRUCTION 1 BY 1,0 . AND 1

5/INCREMENT INSTRUCTION 2 BY 1 AND 1

6/INCREMENT INSTRUCTION 3 BY *0, $1 *, 1$ AND 1

EXECUTE INSTRUCTIONS 1 THRU 6, 2 TIMES

DIV 1.0 BY COL 3 AND STORE IN COL 12

AVERAGE COL 12 AND STORE IN COL 12

RESET NRMAX 1

* INFORMATIVE DIAGNOSTIC FOR THE ABOVE INSTRUCTION NRMAX HAS BEEN RESET FROM 30 TO 1. 
SUB . 16061621 FROM COL 12 AND STORE IN COL 12

EXPONENTIAL OF 2. AND STORE IS COL 4

SLBTRACT COL 4 FROM COL 11 AID STORE ISี COL 11

SPACE 2

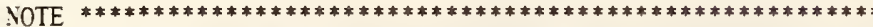

SPACE

NOTE 1 (SLM OF $(\mathrm{J} X(\mathrm{X})) * * 2) * 2 .-(\mathrm{J} \text { ZERO }(\mathrm{X}))^{* * 2} 2=1 ., \quad$ FOR $\mathrm{X}=1$ THRU

YOTE2 INFINITY. (IN THIS EXAYPLE $\mathrm{N}=0, \ldots, 29$ ).

PRINT NOTE

NOTE1 (SLM OF $(\mathrm{I} N(X)) * * 2$.) - I ZERO $(X)-\operatorname{EXP}(X)=0 ., \quad$ FOR $N=1 \mathrm{TH}$

NOTE2RU INFINITY. (IN THIS EXAMPLE $N=0, \ldots, 29$ ).

PRINT NOTE

NOTE

NOTE HATDBOOK OF MATHEMATICAL FU.TCTIONS AMS 55 PAGES 363 AND 376.

NOTE THE FOLLORING VALUES MUST EQUAL OR BE NEAR $1.0,0.0$ AND 0.0 RESPECTIVELY.

SPACE

NPRINT COLS 10, 11 AND 12

SPACE

NOTE

NATIONAL BLREAU OF STANDARDS. HASHINGTON, D. C. 20234

ONNITAB 80 VERSION $6.00 \quad$ MARCH 2,1981 


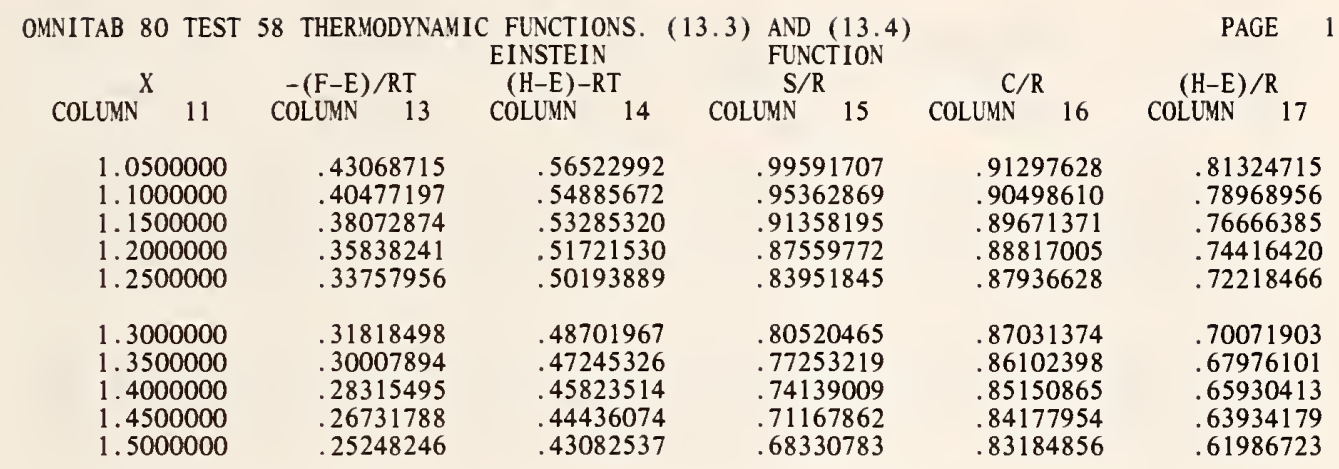

MOLECULAR WEIGHTS OF

HATER PROPANAL TETRATOMIC PHOSP URANIUM OXIDE

$\begin{array}{llll}18.015200 & 60.095600 & 123.89504 & 842.08219\end{array}$ 


\begin{tabular}{|c|c|c|c|c|c|}
\hline $\begin{array}{l}\text { MNITAB } 80 \text { TEST } \\
\text { TEMPERATURE }\end{array}$ & $\begin{array}{c}8 \text { THERMODYNAY } \\
\text { TRANSLATIO } \\
-(\mathrm{F}-\mathrm{E}) / \mathrm{RT}\end{array}$ & 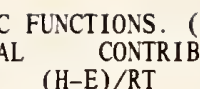 & $\begin{array}{l}\text { 3) AND (13. } \\
\text { IONS } \\
\mathrm{S} / \mathrm{R}\end{array}$ & $\begin{array}{l}\text { HATER } \\
\mathrm{C} / \mathrm{R}\end{array}$ & $\begin{array}{r}\text { PAGE } \\
(H-E) / R\end{array}$ \\
\hline COLUMN 4 & COLUMN 5 & COLUMN 6 & COLUMN 7 & COLUMN & COLUMN \\
\hline $\begin{array}{l}100.00000 \\
200.00000 \\
300.00000 \\
400.00000 \\
500.00000\end{array}$ & $\begin{array}{l}12.184799 \\
13.917667 \\
14.931330 \\
15.650535 \\
16.208394\end{array}$ & $\begin{array}{l}2.5000000 \\
2.5000000 \\
2.5000000 \\
2.5000000 \\
2.5000000\end{array}$ & $\begin{array}{l}14.684799 \\
16.417667 \\
17.431330 \\
18.150535 \\
18.708394\end{array}$ & $\begin{array}{l}2.5000000 \\
2.5000000 \\
2.5000000 \\
2.5000000 \\
2.5000000\end{array}$ & $\begin{array}{c}250.00000 \\
500.00000 \\
750.00000 \\
1000.0000 \\
1250.0000\end{array}$ \\
\hline $\begin{array}{c}600.00000 \\
700.00000 \\
800.00000 \\
900.00000 \\
1000.0000\end{array}$ & $\begin{array}{l}16.664198 \\
17.049575 \\
17.383403 \\
17.677860 \\
17.941262\end{array}$ & $\begin{array}{l}2.5000000 \\
2.5000000 \\
2.5000000 \\
2.5000000 \\
2.5000000\end{array}$ & $\begin{array}{l}19.164198 \\
19.549575 \\
19.883403 \\
20.177860 \\
20.441262\end{array}$ & $\begin{array}{l}2.5000000 \\
2.5000000 \\
2.5000000 \\
2.5000000 \\
2.5000000\end{array}$ & $\begin{array}{l}1500.0000 \\
1750.0000 \\
2000.0000 \\
2250.0000 \\
2500.0000\end{array}$ \\
\hline $\begin{array}{l}1100.0000 \\
1200.0000 \\
1300.0000 \\
1400.0000 \\
1500.0000\end{array}$ & $\begin{array}{l}18.179537 \\
18.397066 \\
18.597172 \\
18.782443 \\
18.954925\end{array}$ & $\begin{array}{l}2.5000000 \\
2.5000000 \\
2.5000000 \\
2.5000000 \\
2.5000000\end{array}$ & $\begin{array}{l}20.679537 \\
20.897066 \\
21.097172 \\
21.282443 \\
21.454925\end{array}$ & $\begin{array}{l}2.5000000 \\
2.5000000 \\
2.5000000 \\
2.5000000 \\
2.5000000\end{array}$ & $\begin{array}{l}2750.0000 \\
3000.0000 \\
3250.0000 \\
3500.0000 \\
3750.0000\end{array}$ \\
\hline
\end{tabular}

THE FOLLOWING VALUES MUST BE EQUAL TO OR NEAR ZERO.

*-2.3841858-08*-4.7683716-08*-4.7683716-08 *-9.5367431-08 


\begin{tabular}{|c|c|c|c|c|c|}
\hline OMNITAB 80 TEST & 58 THERMODYNAI & $\begin{array}{l}\text { C FUNCTIONS. } \\
\text { MIC } 0 \mathrm{OF}\end{array}$ & $\begin{array}{l}\text { 3.3) AND }(13 \\
\text { ATOMIC } \\
\mathrm{S} / \mathrm{R}\end{array}$ & XYGEN & $\begin{array}{r}\text { PAGE } \\
(H-E) / R\end{array}$ \\
\hline $\begin{array}{l}\text { TEMPERATURE } \\
\text { COLUMN } \quad 41\end{array}$ & $\begin{array}{rr}-(\mathrm{F}-\mathrm{E}) / \mathrm{RT} \\
\mathrm{COLUMN} & 42\end{array}$ & $\begin{array}{c}(\mathrm{H}-\mathrm{E}) / \mathrm{RT} \\
\text { COLUMN }\end{array}$ & $\begin{array}{l}\text { S/R } \\
\text { COLUMN }\end{array}$ & $\begin{array}{c}\mathrm{C} / \mathrm{R} \\
\text { COLUMN }\end{array}$ & $\begin{array}{l}(\mathrm{H}-\mathrm{E}) / \mathrm{R} \\
\text { COLUMN }^{4}\end{array}$ \\
\hline $\begin{array}{l}1000.0000 \\
1500.0000 \\
2000.0000 \\
2500.0000 \\
3000.0000\end{array}$ & $\begin{array}{l}18.802985 \\
19.816648 \\
20.535853 \\
21.093712 \\
21.549516\end{array}$ & $\begin{array}{l}2.5000000 \\
2.5000000 \\
2.5000000 \\
2.5000000 \\
2.5000000\end{array}$ & $\begin{array}{l}21.302985 \\
22.316648 \\
23.035853 \\
23.593712 \\
24.049516\end{array}$ & $\begin{array}{l}2.5000000 \\
2.5000000 \\
2.5000000 \\
2.5000000 \\
2.5000000\end{array}$ & $\begin{array}{l}2500.0000 \\
3750.0000 \\
5000.0000 \\
6250.0000 \\
7500.0000\end{array}$ \\
\hline $\begin{array}{l}3500.0000 \\
4000.0000 \\
4500.0000 \\
5000.0000 \\
5500.0000\end{array}$ & $\begin{array}{l}21.934893 \\
22.268721 \\
22.563179 \\
22.826580 \\
23.064856\end{array}$ & $\begin{array}{l}2.5000000 \\
2.5000000 \\
2.5000000 \\
2.5000000 \\
2.5000000\end{array}$ & $\begin{array}{l}24.434893 \\
24.768721 \\
25.063179 \\
25.326580 \\
25.564856\end{array}$ & $\begin{array}{l}2.5000000 \\
2.5000000 \\
2.5000000 \\
2.5000000 \\
2.5000000\end{array}$ & $\begin{array}{r}8750.0000 \\
10000.000 \\
11250.000 \\
12500.000 \\
13750.000\end{array}$ \\
\hline $\begin{array}{l}6000.0000 \\
6500.0000 \\
7000.0000 \\
7500.0000 \\
8000.0000\end{array}$ & $\begin{array}{l}23.282384 \\
23.482491 \\
23.667761 \\
23.840243 \\
24.001589\end{array}$ & $\begin{array}{l}2.5000000 \\
2.5000000 \\
2.5000000 \\
2.5000000 \\
2.5000000\end{array}$ & $\begin{array}{l}25.782384 \\
25.982491 \\
26.167761 \\
26.340243 \\
26.501589\end{array}$ & $\begin{array}{l}2.5000000 \\
2.5000000 \\
2.5000000 \\
2.5000000 \\
2.5000000\end{array}$ & $\begin{array}{l}15000.000 \\
16250.000 \\
17500.000 \\
18750.000 \\
20000.000\end{array}$ \\
\hline
\end{tabular}

THE FOLLOWING VALUES MUST BE EQUAL TO OR NEAR ZERO.
0.
0.
0.
0.
0.
0. 


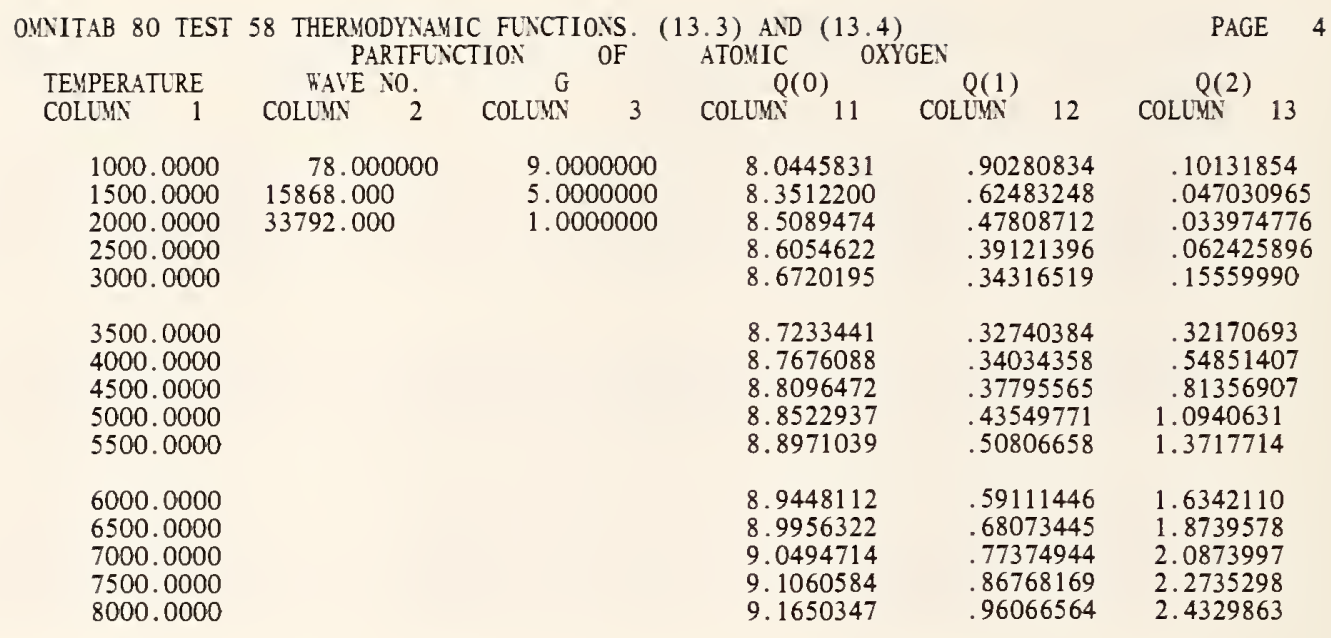




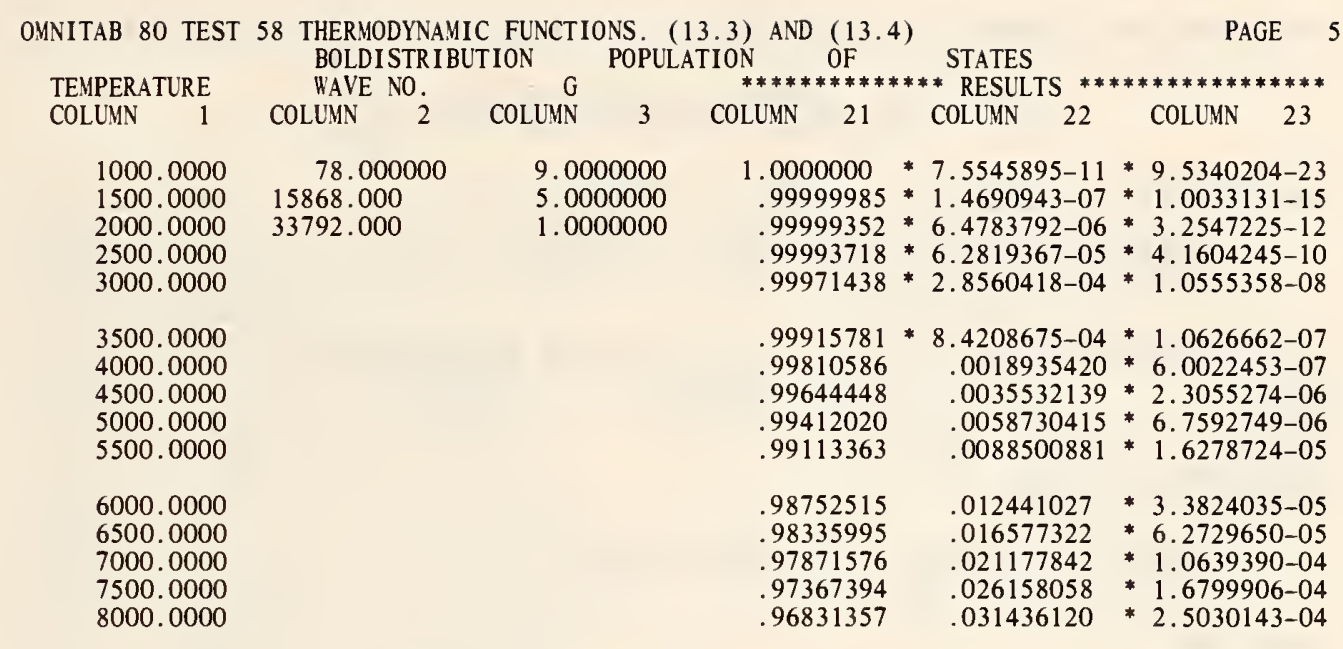

THE FOLLOWING VALUE SHOULD BE EQUAL TO OR NEAR ZERO.

0 . 
LIST OF DATA, INSTRUCTIONS AND DIAGNOSTICS

GENERATE FROM 1.05 IN STEPS OF .05 THRU 1.5 AND PUT IN COL 1

* informative diagnOSTIC FOR THE abOVE instruction NRMAX HAS BEEN RESET FROM O TO 10

ADD 0. TO 1.43879 AND PUT IN COL 2

EINSTEIN OF TEMPS IN COL 2, WAVE NOS. IN COL 1 AND PUT TABLE STARTING IN COL 11 TITLE1

TITLE3

TITLE4

$\begin{array}{cc}X & -(\text { F-E }) / R T \\ C / R & (\mathrm{H}-\mathrm{E}) / \mathrm{R}\end{array}$ EINSTEIN (H-E)-RT FUNCTION

PRINT COLS $11,13^{* * * 17}$

ERASE ENTIRE WORKSHEET

* INFORMATIVE DIAGNOSTIC FOR THE ABOVE INSTRUCTION NRMAX HAS BEEN RESET FROM 10 TO 0

RESET NRMAX TO 10

* INFORMATIVE DIAGNOSTIC FOR THE ABOVE INSTRUCTION NRMAX HAS BEEN RESET FROM O TO 10.

SPACE 2

NOTE ****

SPACE

NOTE

NOTE

MOLECULAR REIGHTS OF

WATER

PROPANAL TETRATOMIC PHOSP URANIUM OXIDE

MOLWT OF WATER $\mathrm{H}=1$ ATOMIC NO., 2 PARTS, $0=8$ ATOMIC NO., 1 PART AND PUT IN COL 1

MOLWT PROPANOL $\mathrm{C}=6$ ATOMIC NO., 3 PARTS, $\mathrm{H}=1,8,0=8,1$, PUT IN COL 2

MOLHT TETRATOMIC PHOSP $\mathrm{PH}=15$ ATOMIC NO, 4 PARTS, PUT IN COL 3

MOLWT URANIUM OXIDE U $=92$ ATOMIC NO., 3 PARTS, $0=8,8$ PARTS, PUT IN COL 4

SPACE

ABRIDGE ROW 1 COLS $1 * * * 4$

SPACE

OTE $* * * * * * * * * * * * *$

RESET NRMAX TO 0

* INFORMATIVE DIAGNOSTIC FOR THE ABOVE INSTRUCTION NRMAX HAS BEEN RESET FROM 10 TO 0.

GENERATE FROM 100. IN STEPS OF 100. THRU 1500. AND PUT IN COL 61

* INFORMATIVE DIAGNOSTIC FOR THE ABOVE INSTRUCTION -

NRMAX HAS BEEN RESET FROM 0 TO 15

ADD 1.98717 TO 0 . AND PUT IN COL 28

PFTRANSLATIONAL OF TEMP IN COL 61 , MOL MT. $=$ TO VALUE IN $* 1,1^{*}$, PUT IN COL 4

TITLE1

TRANSLATIONAL

CONTRIBUTIONS OF

TITLE2 WATER

TITLE3

TITLE4

TEMPERATURE

$-(\mathrm{F}-\mathrm{E}) / \mathrm{RT}$

(H-E)/RT

S/R 
PRINT COLS 4***9

MULTIPLY COL 5 BY COL 28 AND PUT IN COL 10 MULTIPLY COL 7 BY COL 28 AND PUT IN COL 11 MULTIPLY COL 8 BY COL 28 AND PUT IN COL 12 LOG OF COL 61 AND PUT IN 21

LOGE OF VALUE IN *1, 1* AND STORE IN COL 22 ADD COL 2.5 TO 0. AND PUT IN COL 23

MULTIPLY COL 23 BY COL 21 AND PUT IN COL 24

MULTIPLY 1.5 BY COL 22 AND PUT IN COL 25

ADD 0. TO -3.66495 AND PUT IN COL 26

ROWSUM 24***26 AND PUT IN COL 31

ADD COL 23 TO COL 31 AND PUT IN COL 32

MULTIPLY COL 31 BY COL 28 AND PUT IN COL 33

MULTIPLY COL 32 BY COL 28 AND PUT IN COL 34

SUBTRACT COL 5 FROM COL 31 AND PUT IN COL 31

SUB COL 7 FROM COL 32 AND PUT IN COL 32

SUB COL 10 FROM COL 33 AND PUT IN COL 33

SUB COL 11 FROM COL 34 AND PUT IN COL 34

1/ AVERAGE COL 31 AND STORE IN COL 31

2/ INCREMENT INSTRUCTION 1 BY 1 AND 1

EXECUTE INSTRUCTIONS 1 THRU 2, 4 TIMES

SPACE 2

NOTE

SPACE

NOTE THE FOLLOWING VALUES MUST BE EQUAL TO OR NEAR ZERO.

SPACE

ABRIDGE ROW 1 COLS $31 * * * 34$

SPACE

NOTE

ERASE ENTIRE WORKSHEET

* INFORMATIVE diagnOSTIC FOR THE aBOVE INSTRUCTION NRMAX HAS BEEN RESET FROM 15 TO 0.

TITLE1 PTATOMIC OF ATOMIC

TITLE2OXYGEN

GENERATE FROM 1000. IN STEPS OF 500. THRU 8000. AND PUT IN COL 1

* INFORMATIVE DIAGNOSTIC FOR THE ABOVE INSTRUCTION NRMAX HAS BEEN RESET FROM O TO 15.

SET INTO COL 2 THE FOLLOHING DATA

78. 15868.33792 .

* INFORMATIVE DIAGNOSTIC FOR THE ABOVE INSTRUCTION NRMAX HAS BEEN RESET FROM 15 TO 3.

SET INTO COL 3 THE FOLLOWING DATA

9. 5. 1

RESET NRMAX TO 15 
* INFORMATIVE diAgNOSTIC FOR THE ABOIE IISTRLCTION SRMAX HAS BEEN RESET FROM 3 TO 15.

PFATOMIC TEMP IN COL 1 MOL HT $=31.9988$ HALE YO. IN COL 2 DEGEIS IN 3 PLT IN 41 PFTRAISLATIONAL OF TEMP IN COL 1 , MOL RT $=31.9988$, PLT IN COL 31 AND BEYOND 1/SLBTRACT COL 41 FROM COL 31 AND STORE IN COL 31

2/AIERAGE COL 31 AID STORE II COL 31

3/INCREMENT IISTRLCTION 1 BY 1,1 AND 1

4/IXCREMENT INSTRLCTION 2 BY 1 AID 1

REPEAT INSTRLCTIONS 1 THRL 4,6 TIMES

PRINT COLS $41 * * * 46$

SPACE 2

NOTE *

SPACE

NOTE THE FOLLOHING VALLES MTST BE EQLAL TO OR IEAR ZERO.

SPACE

ABRIDGE ROF 1 COLS $31 * * * 36$

SP.ACE

YOTE

PARTFLYCTION TEMP IN COL 1 WAIE YO. IN COL 2 DEGEYS IN COL 3 PUT IN COL 11

IITLE1 PARTFLTCTIOS

$\mathrm{OF}$

ATOMIC

TITLE2YGEN

TITLE3 TEMPERTILRE THIE NO.
TITLE4

PRINT COLS 1 (1) $3,11,12$ (2) 13

BOLDISTRIBLTION TEMP IN COL 1 WAIE NO. IN COL 2 DEGENS IN COL 3 PUT IN COL 2

RONSLY COLS $21 * * * 23$ IITTO COL 24

SLBTRACT COL 24 FROM 1.0 STORE IN COL 24

TITLE1

TITLE2 STATES

TITLE3 TEMPERTTIRE TAIE VO:

TITIF $+* * *$ RESUTS $* * * * * * * * * * * * * * * *$

PRINT COLS $1,2,3,21,22$ AID 23

SP.ACE 2

NOTE

SP.ACE

NOTE THE FOLIOTING VALLE SHOLID BE EQLAL TO OR IEAR ZERO.

SPACE

ABRIDGE ROF 1 COL 24

SPACE

NOTE

WATIONAL BLREAL OF STANDARDS. TASHINGTON, D. C. 20234 ONIITAB 80 IERSION 6.00 MARCH 2,1981 
LIST OF COMMANDS. ONLY THE FIRST SIX LETTERS ARE PRINTED.

\begin{tabular}{|c|c|c|c|c|c|c|c|}
\hline \multicolumn{2}{|l|}{ ENGLIS } & \multicolumn{2}{|l|}{ ENGLIS } & \multicolumn{2}{|l|}{ ENGLIS } & \multicolumn{2}{|l|}{ ENGLIS } \\
\hline AADD & & AAVERA & & ABRIDG & & ABRIDG & A \\
\hline ABS & & ABSOLU & & ACCURA & & ACOALE & \\
\hline ACOS & & $\mathrm{ACOSD}$ & & $\mathrm{ACOSH}$ & & ACOT & \\
\hline ACOTD & & ACOTH & & $\mathrm{ADD}$ & & ADEFIN & \\
\hline ADIV & & ADIVID & & AERASE & & ALABEL & \\
\hline AMOVE & & AMULT & & AMULTI & · & ANTILO & \\
\hline APRINT & & APRINT & A & APROPE & & ARAISE & \\
\hline ASIN & & ASIND & & ASINH & & ASUB & \\
\hline ASUBTR & & ATAN & & ATAND & & ATANH & \\
\hline ATOM IC & & ATRANS & & AVERAG & & AVERAG & \\
\hline AZERO & & BACKSP & TAPE A & BACKSP & UNIT A & BEGIN & \\
\hline BERNOU & & BESIN & & BESJN & & BESKN & \\
\hline BESTCP & & BETA & & BINOMI & & BIONE & \\
\hline BIZERO & & BJONE & & BJZERO & & BKONE & \\
\hline BKZERO & & BOLDIS & & BR IEF & & BYONE & \\
\hline BYZERO & & CADD & & CALCOM & AXIS & CALCOM & FAST \\
\hline CALCOM & PAPER & CALCOM & PLOT & CALCOM & SIZE & CALCOM & SLOW \\
\hline CALCOM & SPEED & CALCOM & TAPE & CAUCHY & & CDIVID & \\
\hline CEIONE & & CEIZER & & CEKONE & & CEKZER & \\
\hline CENSOR & & CENSOR & $\mathrm{EQ}$ & CENSOR & $\mathrm{GE}$ & CENSOR & GT \\
\hline CENSOR & LE & CENSOR & LT & CENSOR & $\mathrm{NE}$ & CERF & \\
\hline CGS & & CHANGE & & CHISQU & & CHOOSE & \\
\hline CIONE & & CIZERO & & CKONE & & CKZERO & \\
\hline CLOSE & UP & CMULTI & & CODE & & COMPAR & \\
\hline CONTEN & & CONTIN & & CORREL & & $\cos$ & \\
\hline COSD & & $\mathrm{COSH}$ & & COSINT & & COT & \\
\hline COTD & & СOTH & & COUNT & & CPERCE & \\
\hline CPLOT & & CPOLAR & & CPROPO & & CREAD & TAPE A \\
\hline CREAD & TAPE Q & CREAD & UNIT A & CREAD & UNIT Q & CRECTA & \\
\hline CRT & & CSET & TAPE A & CSET & UNIT A & CSUBTR & \\
\hline CTOF & & CUMULA & & DANSK & & DAYS & \\
\hline DEFINE & & DELETE & & DEMOTE & & DENSIT & \\
\hline DESCRI & & DEUTSC & & DEXPON & & DIFFER & \\
\hline DIM & & DIMENS & & DISCRE & & DIV & \\
\hline DIVDIF & & DIVIDE & & DUPLIC & & EEXPIN & \\
\hline EINSTE & & EINTEG & & ELLIPT & FIRST & ELLIPT & SECOND \\
\hline ENDFIL & TAPE A & ENDFIL & UNIT A & ENGLIS & & ERASE & \\
\hline ERROR & & ESPANO & & EVALUA & & EXCHAN & \\
\hline EXECUT & & EXIONE & & EXIZER & & EXKONE & \\
\hline EXKZER & & EXP & & EXPAND & & EXPINT & \\
\hline EXPONE & & EXTREM & & & & & PROBAB \\
\hline FINISH & & FIT & & FIXED & & FLEXIB & \\
\hline FLIP & & FLOATI & & FORMAT & A & FOURPL & \\
\hline FRACTI & & FRANCA & & FREQUE & & FREQUE & \\
\hline FTOC & & FULL & & GAMMA & & GAMMA & \\
\hline GAUSS & QUADRA & GENERA & & GEOMET & & HALFNO & \\
\hline HARMON & & HCOSIN & & HEAD & & HERMIT & \\
\hline HIERAR & & HISTOG & & HSININ & & HYPERG & \\
\hline IFEQ & & IFGE & & IFGT & & IFLE & \\
\hline IFLT & & IFNE & & INCREM & & INSERT & \\
\hline
\end{tabular}


OMNITAB 80 TEST 59 VOCABULARY AND FOREIGN LANGUAGE INSTR. (1.7) PAGE 2

LIST OF COMMANDS. ONLY THE FIRST SIX LETTERS ARE PRINTED.

\begin{tabular}{|c|c|c|c|c|c|c|c|}
\hline ENGLIS & & \multicolumn{2}{|l|}{ ENGLIS } & \multicolumn{2}{|l|}{ ENGLIS } & \multicolumn{2}{|l|}{ ENGL IS } \\
\hline INTEGE & & INTERA & & INTERP & & INT JO & \\
\hline INVERT & & ISETUP & & ISOLAT & & ITAL IA & \\
\hline ITERAT & & JAPANE & & KBIONE & & KBIZER & \\
\hline KBKONE & & KBKZER & & KEXION & & KEXIZE & \\
\hline KEXKON & & KEXKZE & & LABEL & & LAGUER & \\
\hline LAMBDA & & LARFIT & & LEGEND & & LENGTH & \\
\hline LIST & & LOCAL & & LOG & & LOGE & \\
\hline LOGIST & & LOGNOR & & LOGTEN & & & $A D$ \\
\hline M & AV & M & DA & $\mathrm{M}$ & V & M & $X$ \\
\hline M & $X$ & M & $\mathrm{XAX}$ & M & $X X$ & MADD & \\
\hline MATCH & & MAX & & MAXIMU & & MAXIMU & \\
\hline MAXMIN & & MDEFIN & & MDIAGO & & MEDIAN & \\
\hline MEDIAN & & MEIGEN & & MERASE & & MIDENT & \\
\hline MIN & & MINIMU & & MINIMU & & MINVER & \\
\hline MKRONE & & MLABEL & & MMATVE & & MMOVE & \\
\hline MMULT & & MMULTI & & MOLWT & & MORTHO & \\
\hline MOVE & & MPR INT & & MPR INT & A & MPROPE & \\
\hline MRAISE & & MSCALA & & MSUB & & MSUBTR & \\
\hline MTRANS & & MTR IAN & & MULT & & MULT IN & \\
\hline MULTIP & & MVECDI & & MVECMA & & MZERO & \\
\hline NCCHIS & & $\mathrm{NCF}$ & & NCPLOT & & NCT & \\
\hline NEDERL & & NEGBIN & & NEGEIN & & NEGEXP & \\
\hline NEW & PAGE & NHISTO & & NICE & CPLOT & NICE & NCPLOT \\
\hline NICE & NPLOT & NICE & PLOT & No & LIST & NORMAL & \\
\hline NORMLA & & NORSK & & NOTE & & NOTE1 & \\
\hline NOTE2 & & NPLOT & & NPR INT & & NPR INT & A \\
\hline NTABLE & & NULL & & OMIT & & OMNITA & \\
\hline ONEWAY & & ORDER & & PAGE & PLOT & PARETO & \\
\hline PARPRO & & PARSUM & & PARTFU & & PASCAL & \\
\hline PERCEN & & PERCEN & & PERCEN & & PERFOR & \\
\hline PFATOM & & PFTRAN & & PLOT & & PLOT & \\
\hline POISSO & & POLYFI & & PORTUG & & PRINT & \\
\hline PR INT & A & PR INT & NOTE & PRODUC & & PROMOT & \\
\hline PROPOR & & PROPOR & & PUNCH & & PUNCH & A \\
\hline RAISE & & RANDOM & & RANGE & & RANGE & \\
\hline RANKS & & READ & & READ & A & READ & TAPE A \\
\hline READ & TAPE $Q$ & READ & UNIT A & READ & UNIT Q & RECIPR & \\
\hline RECODE & & REMOTE & & REPEAT & & REPLAC & \\
\hline RESET & & RESET & V & RESTOR & & RETAIN & \\
\hline REW IND & TAPE A & REWIND & UNIT A & RMS & & ROUND & \\
\hline RON & SUM & ROW'SUM & & RPERCE & & RPROPO & \\
\hline SAMPLE & WITHOU & SAMPLE & HITHR & SAPROP & & $\begin{array}{l}\text { SCAN } \\
\text { SEAPCH }\end{array}$ & \\
\hline SCORRE & & SDIFFE & & SDIVDI & & SEARCH & \\
\hline SELECT & & SEPARA & & SET & & SET & TAPE A \\
\hline SET & UNIT A & SFIT & & SHORTE & & & \\
\hline SIN & & SIND & & SINH & & SININT & \\
\hline SKIP & TAPE A & SKIP & UNIT A & SLOVEN & & SMPROP & \\
\hline SOLVE & & SONEW'A & & SORT & & SPACE & \\
\hline SPLIT & PLOT & SPOLYF & & SQRT & & SQUARE & \\
\hline SRANGE & & SSTAT I & & SSTEM & LEAF & STATIS & \\
\hline
\end{tabular}


OMNITAB 80 TEST 59 VOCABULARY AND FOREIGN LANGUAGE INSTR. (1.7) PAGE 3

LIST OF COMMANDS. ONLY THE FIRST SIX LETTERS ARE PRINTED.

\begin{tabular}{|c|c|c|c|c|c|c|}
\hline ENGLIS & & ENGLIS & & ENGLIS & ENGLIS & \\
\hline STATPL & & STDDEV & & STDDEV & STEM & LEAF \\
\hline STOP & & STRUVE & ONE & STRUVE ZERO & STWOWA & \\
\hline SUB & & SUBTRA & & SUM & SUM & \\
\hline SVENSK & & & & TABLE & TAN & \\
\hline TAND & & TANH & & TAPE & TCHEBY & \\
\hline TERMIN & & TITLE1 & & TITLE2 & TITI & \\
\hline TITLE4 & & TITLEX & & TITLEY & TWOPLO & \\
\hline TWOWAY & & UCHEBY & & UNIFOR & UNIT & \\
\hline VOCABU & & WEIBUL & & WIDTH & WRITE & TAPE \\
\hline WRITE & TAPE $Q$ & WRITE & UNIT A & UNIT Q & YUGOSL & \\
\hline $\begin{array}{l}\text { ZEROS } \\
\text { COLUMN }\end{array}$ & BJONE & ZEROS & BJZERO & & & \\
\hline
\end{tabular}

ASTERISK INDICATES NO TRANSLATION OR COMMANDS ARE THE SAME.

DISTRIBUTION AND PROPERTY NAMES ARE PRINTED, BUT

NOT ALL COMBINATIONS ARE NECESSARILY VALID.

EACH COMMAND OF TABLE MAKING TWO-WORD COMMANDS IS PRINTED SEPARATELY.

A AFTER A COMMAND STANDS FOR A FORMAT OR UNIT QUALIFIER.

$V$ AFTER A RESET COMMAND STANDS FOR A VARIABLE QUALIFIER.

$Q$ AFTER A UNIT COMMAND STANDS FOR BOTH A UNIT AND A FORMAT QUALIFIER. 
LIST OF COMMANDS. ONLY THE FIRST SIX LETTERS ARE PRINTED.

\begin{tabular}{|c|c|c|c|c|c|c|c|}
\hline ENGLIS & & ESPANO & & ENGLIS & & ESPANO & \\
\hline AADD & & AADICI & & AAVERA & & AMEDIA & \\
\hline ABR IDG & & ABREVI & & ABR IDG & A & ABREVI & A \\
\hline${ }^{*} \mathrm{ABS}$ & & $\mathrm{ABS}$ & & ${ }^{*} \mathrm{ABSOLU}$ & & ABSOLU & \\
\hline ACCLRA & & EXACT I & & ACOALE & & ADELCO & \\
\hline *ACOS & & ACOS & & ACOSD & & ACOSG & \\
\hline *ACOSH & & $\mathrm{ACOSH}$ & & ${ }^{*} \mathrm{ACOT}$ & & ACOT & \\
\hline ACOTD & & ACOTG & & ${ }^{*} \mathrm{ACOTH}$ & & ACOTH & \\
\hline $\mathrm{ADD}$ & & ADICIO & & ${ }^{*}$ ADEFIN & & ADEFIN & \\
\hline${ }^{*} \mathrm{ADIV}$ & & ADIV & & ${ }^{*} \mathrm{ADIVID}$ & & ADIVID & \\
\hline AERASE & & ABORRA & & ${ }^{*} \mathrm{ALABEL}$ & & ALABEL & \\
\hline AMOVE & & AMOVER & & *AMULT & & AYLLT & \\
\hline *AMULTI & & AMULTI & & ${ }^{*}$ ANT ILO & & ANTILO & \\
\hline APR INT & & AIMPRI & & APR INT & A & AIMPRI & A \\
\hline APROPE & & APROPI & & ARAISE & & APOTEX & \\
\hline ASIN & & ASEN & & ASIND & & ASENG & \\
\hline ASINH & & ASENH & & ASUB & & ASUSTR & \\
\hline ASUBTR & & ASUSTR & & ATAN & & ATANG & \\
\hline ATAND & & ATANGG & & ATANH & & ATANGH & \\
\hline ATONIC & & PESOAT & & *ATRANS & & ATRANS & \\
\hline AVERAG & & PROYED & & *AVERAG & & AVERAG & \\
\hline AZERO & & ACERO & & *BACKSP & TAPE A & BACKSP & TAPE A \\
\hline BACKSP & UNIT A & BACKSP & UNIDAE & BEGIN & & EMPEZA & \\
\hline *BERNOU & & BERNOU & & *BESIN & & BESIN & \\
\hline *BESJN & & BESJN & & ${ }^{*} \mathrm{BESKN}$ & & BESKN & \\
\hline${ }^{*} \mathrm{BESTCP}$ & & BESTCP & & *BETA & & BETA & \\
\hline${ }^{*}$ B I NOMI & & BINOMI & & ${ }^{*} \mathrm{BIONE}$ & & BIONE & \\
\hline${ }^{*}$ B IZERO & & B I ZERO & & ${ }^{*} \mathrm{BJONE}$ & & BJONE & - \\
\hline${ }^{*}$ BJ ZERO & & BJZERO & & ${ }^{*}$ BKONE & & BKONE & \\
\hline${ }^{*}$ BKZERO & & BKZERO & & BOLDIS & & BOLTZM & \\
\hline *BR IEF & & BRIEF & & ${ }^{*} \mathrm{BYONE}$ & & BYONE & \\
\hline${ }^{*}$ BYZERO & & BYZERO & & CADD & & CADICI & \\
\hline${ }^{*} \mathrm{CALCOM}$ & AXIS & CALCON & AXIS & * CALCOM & FAST & CALCON & FAST \\
\hline${ }^{*} \mathrm{CALCON}$ & PAPER & CALCON & PAPER & ${ }^{*} \mathrm{CALCOM}$ & PLOT & CALCOM & PLOT \\
\hline${ }^{*} \mathrm{CALCON}$ & SIZE & CALCON & SIZE & ${ }^{*}$ CALCOM & SLOW & CALCON & SLOH \\
\hline${ }^{*}$ CALCONI & SPEED & CALCON & SPEED & ${ }^{*}$ CALCOM & TAPE & CALCON & TAPE \\
\hline${ }^{*} \mathrm{CAUCHY}$ & & CAUCHY & & ${ }^{*}$ CDIVID & & CDIYID & \\
\hline${ }^{*}$ CEIONE & & CEIONE & & ${ }^{*}$ CEIZER & & CEIZER & \\
\hline${ }^{*}$ CEKONE & & CEKONE & & ${ }^{*}$ CEKZER & & CEKZER & \\
\hline CENSOR & & CENSUR & & CENSOR & $E Q$ & CENSUR & IG \\
\hline CENSOR & $\mathrm{GE}$ & CENSUR & MAI & CENSOR & $\mathrm{GT}$ & CENSUR & MA \\
\hline CENSOR & LE & CENSUR & MEI & CENSOR & LT & CENSUR & ME \\
\hline CENSOR & $\mathrm{NE}$ & CENSUR & NOI & ${ }^{*}$ CERF & & CERF & \\
\hline${ }^{*} \mathrm{CGS}$ & & CGS & & CHANGE & & CAMBIA & \\
\hline${ }^{*} \mathrm{CHISQU}$ & & CHISQU & & ${ }^{*} \mathrm{CHOOSE}$ & & CHOOSE & \\
\hline${ }^{*} \mathrm{CIONE}$ & & CIONE & & ${ }^{*}$ C IZERO & & CIZERO & \\
\hline${ }^{*} \mathrm{CKONE}$ & & CKONE & & ${ }^{*}$ CKZERO & & CKZERO & \\
\hline CLOSE & UP & COMPAC & & ${ }^{*}$ CIULTI & & CYULTI & \\
\hline${ }^{*} \mathrm{CODE}$ & & CODE & & ${ }^{*}$ COMPAR & & COMPAR & \\
\hline${ }^{*} \mathrm{CONTEN}$ & & CONTEN & & ${ }^{*}$ CONTIN & & CONT IN & \\
\hline${ }^{*}$ CORREL & & CORREL & & ${ }^{*} \cos$ & & $\cos$ & \\
\hline
\end{tabular}


LIST OF COMMANDS. ONLY THE FIRST SIX LETTERS ARE PRINTED.

\begin{tabular}{|c|c|c|c|c|c|c|c|}
\hline ENGLIS & & ESPANO & & ENGLIS & & ESPANO & \\
\hline COSD & & COSG & & ${ }^{*} \mathrm{COSH}$ & & $\mathrm{COSH}$ & \\
\hline${ }^{*} \cos I N T$ & & COSINT & & ${ }^{*} \mathrm{COT}$ & & $\mathrm{COT}$ & \\
\hline COTD & & COTG & & ${ }^{*} \mathrm{COTH}$ & & COTH & \\
\hline COUNT & & CUENTA & & ${ }^{*}$ CPERCE & & CPERCE & \\
\hline *CPLOT & & CPLOT & & ${ }^{*}$ CPOLAR & & CPOLAR & \\
\hline${ }^{*}$ CPROPO & & CPROPO & & ${ }^{*}$ CREAD & TAPE A & CREAD & TAPE A \\
\hline *CREAD & TAPE Q & CREAD & TAPE $Q$ & CREAD & UNIT A & CREAD & UNIDAE \\
\hline CREAD & UNIT Q & CREAD & UNIDAU & CRECTA & & CCARTE & \\
\hline${ }^{*}$ CRT & & CRT & & ${ }^{*}$ CSET & TAPE A & CSET & TAPE A \\
\hline CSET & UNIT A & CSET & UNIDAE & CSUBTR & & CSUSTR & \\
\hline CTOF & & CENTAF & & ${ }^{*}$ CUMULA & & CUMULA & \\
\hline *DANSK & & DANSK & & *DAYS & & DAYS & \\
\hline *DEFINE & & DEFINE & & *DELETE & & DELETE & \\
\hline DEMOTE & & TRASLA & & ${ }^{*}$ DENSIT & & DENSIT & \\
\hline *DESCRI & & DESCR I & & *DEUTSC & & DEUTSC & \\
\hline *DEXPON & & DEXPON & & ${ }^{*}$ DIFFER & & DIFFER & \\
\hline *DIM & & DIM & & *DIMENS & & DIMENS & \\
\hline *DISCRE & & DISCRE & & *DIV & & DIV & \\
\hline *DIVDIF & & DIVDIF & & *DIVIDE & & DIVIDE & \\
\hline *DUPLIC & & DUPLIC & & *EEXPIN & & EEXPIN & \\
\hline *EINSTE & & EINSTE & & *EINTEG & & EINTEG & \\
\hline ELLIPT & FIRST & ELIPTI & PRIMER & ELLIPT & SECOND & ELIPTI & SEGUND \\
\hline${ }^{*}$ ENDFIL & TAPE A & ENDFIL & TAPE A & ENDFIL & UNIT A & ENDFIL & UNIDAE \\
\hline *ENGLIS & & ENGLIS & & ERASE & & BORRA & \\
\hline ERROR & & ERF & & *ESPANO & & ESPANO & \\
\hline *EVALUA & & EVALUA & & EXCHAN & & INTERC & \\
\hline EXECUT & & REALIZ & & *EXIONE & & EXIONE & \\
\hline *EXIZER & & EXIZER & & *EXKONE & & EXKONE & \\
\hline *EXKZER & & EXKZER & & ${ }^{*}$ EXP & & EXP & \\
\hline *EXPAND & & EXPAND & & *EXPINT & & EXPINT & \\
\hline *EXPONE & & EXPONE & & *EXTREM & & EXTREM & \\
\hline & & FSNEDE & & $\mathrm{F}$ & PROBAB & PROB & FSNEDE \\
\hline FINISH & & TERMIN & & FIT & & ADJUST & \\
\hline FIXED & & FIJA & & ${ }^{*}$ FLEXIB & & FLEXIB & \\
\hline FLIP & & VOLTEA & & FLOATI & & FLOTAN & \\
\hline *FORMAT & A & FORMAT & A & *FOURPL & & FOURPL & \\
\hline FRACTI & & PARTEF & & *FRANCA & & FRANCA & \\
\hline FREQUE & & FRECUE & & *FREQUE & & FREQUE & \\
\hline FTOC & & FAHRAC & & *FULL & & FULL & \\
\hline *GAMMA & & GAMMA & & ${ }^{*}$ GAMMA & & GAMMA & \\
\hline GAUSS & QUADRA & INTEGR & GAUSSI & ${ }^{*}$ GENERA & & GENERA & \\
\hline${ }^{*} \mathrm{GEOMET}$ & & GEOMET & & *HALFNO & & HALFNO & \\
\hline *HARMON & & HARMON & & ${ }^{*} \mathrm{HCOSIN}$ & & HCOSIN & \\
\hline HEAD & & ENCABE & & HERMIT & & POLHER & \\
\hline HIERAR & & JERARQ & & *HISTOG & & HISTOG & \\
\hline *HSININ & & HSININ & & ${ }^{*}$ HYPERG & & HYPERG & \\
\hline IFEQ & & SIIG & & *IFGE & & IFGE & \\
\hline *IFGT & & IFGT & & IFLE & & SIMENI & \\
\hline IFLT & & SIMEIG & & IFNE & & SINOIG & \\
\hline *INCREM & & INCREM & & ${ }^{*}$ INSERT & & INSERT & \\
\hline
\end{tabular}


OMNITAB 80 TEST 59 VOCABLLARY AND FOREIGN LANGUAGE INSTR. (1.7) PAGE 6

LIST OF COMMANDS, ONLY THE FIRST SIX LETTERS ARE PRINTED.

\begin{tabular}{|c|c|c|c|c|c|c|c|}
\hline ENGLIS & & ESPAIO & & ENGLIS & & ESPANO & \\
\hline INTEGE & & PARTEE & & *INTERA & & INTERA & \\
\hline * INTERP & & INTERP & & *INTJ0 & & $\begin{array}{l}\text { INTJO } \\
\text { INT }\end{array}$ & \\
\hline I.IVERT & & INVIER & & ISETLP & & INICIA & \\
\hline ISOLAT & & AISLA & & *ITALIA & & ITAL IA & \\
\hline ITERAT & & ITERA & & * JAPANE & & JAPANE & \\
\hline * KBIONE & & KBIONE & & * KB IZER & & KBIZER & \\
\hline * KBKONE & & KBKONE & & *KBKZER & & KBKZER & \\
\hline * KEX ION & & KEXION & & * KEXIZE & & KEXIZE & \\
\hline *KEXKON & & KEXKON & & *KEXKZE & & KEXKZE & \\
\hline * LABEL & & LABEL & & LAGLER & & POLLAG & \\
\hline *LAMBDA & & LAMBDA & & *LARFIT & & LARFIT & \\
\hline LEGEND & & POLLE & & *LENGTH & & LENGTH & \\
\hline LIST & & LISTA & & * LOCAL & & LOCAL & \\
\hline${ }^{*}$ LOG & & LOG & & LOGE & & LOGNAT & \\
\hline * LOGIST & & LOGIST & & *LOGNOR & & LOGNOR & \\
\hline LOGTEN & & LOGDEC & & *y & $A D$ & Y & $A D$ \\
\hline *yI & $\mathrm{AV}$ & Y & $\mathrm{AV}$ & $*_{M}$ & $\mathrm{DA}$ & is & $\mathrm{DA}$ \\
\hline$* \mathrm{M}$ & $\mathrm{V}$ & i & V & $* M$ & $X$ & M & $X$ \\
\hline$*$ *M & $\mathrm{X}$ & Y & $\mathrm{X}$ & $* M$ & XAX & M & $\mathrm{XAX}$ \\
\hline$* \mathrm{M}$ & $\mathrm{XX}$ & II & $\mathrm{XX}$ & YADD & & MADICI & \\
\hline MATCH & & EXTRAE & & * MAX & & MAX & \\
\hline MLAXIMU & & MAXIMO & & *YAXIMU & & MAXIMU & \\
\hline * MAXMIN & & MAXYIN & & *MDEFIN & & MDEF IN & \\
\hline *MDI AGO & & MDIAGO & & *MED IAY & & MEDIAN & \\
\hline * MED IAN & & MEDIAN & & * MEIGEN & & MEIGEN & \\
\hline YERASE & & MBORRA & & *YIDENT & & MIDENT & \\
\hline * MIN & & YIS & & YISIMU & & MISIMO & \\
\hline *MISIMU & & YISINU & & YINVER & & MISVIE & \\
\hline * MKRONE & & MKRONE & & * YLABEL & & YLABEL & \\
\hline MATVE & & MVECAM & & MNOVE & & MNOVER & \\
\hline * MULL T & & MMULT & & * MEULLT I I & & MMULTI & \\
\hline MOLRT & & PESOMO & & YORTHO & & MORTON & \\
\hline YOVE & & YOVER & & YPRINT & & MIMPR I & \\
\hline MPR INT & A & MIMPRI & A & MPROPE & & MPROPI & \\
\hline MRAISE & & MPOTEN & & MSCALA & & MPRODE & \\
\hline YSLB & & MSUSTR & & MSUBTR & & MSLSTR & \\
\hline * MTRANS & & MTRAIS & & * YTR IAN & & WTRIAN & \\
\hline * MLLT & & YLLT & & * YLLTIS & & YULTIN & \\
\hline * YULTIP & & MULTIP & & MVECDI & & MEXTRA & \\
\hline SVECMA & & MMATAV & & MZERO & & MCERO & \\
\hline * $\mathrm{XCCHIS}$ & & NCCHIS & & $* \mathrm{NCF}$ & & XCF & \\
\hline * NCPLOT & & NCPLOT & & $* Y C T$ & & NCT & \\
\hline * NEDERL & & NEDERL & & * LEGBIN & & NEGBIN & \\
\hline * NEGEIS & & SEGEIN & & * NEGEXP & & NEGEXP & \\
\hline IER & PAGE & NUEVA & PAGIVA & *NHISTO & & NHISTO & \\
\hline * YICE & CPLOT & NICE & CPLOT & * NICE & NCPLOT & VICE & NCPLOT \\
\hline$* \mathrm{NICE}$ & NPLOT & NICE & NPLOT & *NICE & PLOT & NICE & PLOT \\
\hline so & LIST & No & LISTAR & *NORMAL & & NORMAL & \\
\hline YORYLA & & NORMPO & & *NORSK & & NORSK & \\
\hline NOTE & & NOTA & & NOTE1 & & NOTA1 & \\
\hline
\end{tabular}


LIST OF COMMANDS. ONLY THE FIRST SIX LETTERS ARE PRINTED.

\begin{tabular}{|c|c|c|c|c|c|c|c|}
\hline ENGLIS & & ESPANO & & ENGLIS & & ESPANO & \\
\hline NOTE2 & & N0TA2 & & *NPLOT & & NPLOT & \\
\hline NPR INT & & NIMPR I & & NPR INT & A & NIMPR I & A \\
\hline *NTABLE & & NTABLE & & NULL & & NULO & \\
\hline *OMIT & & OM IT & & *OMNITA & & OMNITA & \\
\hline ONEWAY & & ANAVSI & & ORDER & & ORDENA & \\
\hline PAGE & PLOT & GRAFIC & RED & PARETO & & RAYLEI & \\
\hline PAR PRO & & PRODPA & & PARSUM & & SUMAPA & \\
\hline PARTFU & & FUNCPA & & *PASCAL & & PASCAL & \\
\hline * PERCEN & & PERCEN & & *PERCEN & & PERCEN & \\
\hline *PERCEN & & PERCEN & & PERFOR & & REALIZ & \\
\hline *PFATOM & & PFATOM & & *PFTRAN & & PFTRAN & \\
\hline PLOT & & GRAFIC & & PLOT & & GRAFIC & \\
\hline *POISSO & & POISSO & & POLYFI & & AJUSPO & \\
\hline *PORTUG & & PORTUG & & PR INT & & IMPRIM & \\
\hline PR INT & A & IMPR IM & A & PR INT & NOTE & IMPREM & NOTA \\
\hline *PRODUC & & PRODUC & & PROMOT & & TRASAR & \\
\hline *PROPOR & & PROPOR & & * PROPOR & & PROPOR & \\
\hline PUNCH & & PERFOR & & PUNCH & A & PERFOR & A \\
\hline RAISE & & POTENC & & RANDOM & & ALEATO & \\
\hline *RANGE & & RANGE & & *RANGE & & RANGE & \\
\hline RANKS & & RANGOS & & READ & & LEE & \\
\hline READ & A & LEE & A & ${ }^{*}$ READ & TAPE A & READ & TAPE A \\
\hline *READ & TAPE Q & READ & TAPE $Q$ & READ & UNIT A & READ & UNIDAE \\
\hline READ & UNIT Q & READ & UNIDAU & ${ }^{*} \mathrm{REC} I \mathrm{IPR}$ & & RECIPR & \\
\hline *RECODE & & RECODE & & *REMOTE & & REMOTE & \\
\hline REPEAT & & REALIZ & & *REPLAC & & REPLAC & \\
\hline RESET & & REDIME & & RESET & V & REDIME & V \\
\hline RESTOR & & RESTAU & & ${ }^{*}$ RETA IN & & RETAIN & \\
\hline *REW IND & TAPE A & REW IND & TAPE A & REWIND & UNIT A & REW I ND & UNIDAE \\
\hline RMS & & $\mathrm{RCM}$ & & ROUND & & REDOND & \\
\hline ROW & SUM & SUMA & FILA & ROHSUM & & SUMAFI & \\
\hline *RPERCE & & RPERCE & & *RPROPO & & RPROPO & \\
\hline * SAMPLE & WITHOU & SAMPLE & WITHOU & ${ }^{*}$ SAMPLE & WITHR & SAMPLE & WITHR \\
\hline *SAPROP & & SAPROP & & SCAN & & EXPLOR & \\
\hline * SCORRE & & SCORRE & & ${ }^{*}$ SD IFFE & & SDIFFE & \\
\hline *SDIVDI & & SDIVDI & & SEARCH & & BUSCA & \\
\hline SELECT & & SELECC & & ${ }^{*}$ SEPARA & & SEPARA & \\
\hline SET & & COLOCA & & *SET & TAPE A & SET & TAPE A \\
\hline SET & UNIT A & SET & UNIDAE & SFIT & & SADJUS & \\
\hline SHORTE & & ACORTA & & ${ }^{*} \mathrm{SI}$ & & SI & \\
\hline SIN & & SEN & & SIND & & SENG & \\
\hline SINH & & SENH & & ${ }^{*}$ SININT & & SININT & \\
\hline *SK IP & TAPE A & SKIP & TAPE A & SKIP & UNIT A & SKIP & UNIDAE \\
\hline *SLOVEN & & SLOVEN & & * SMPROP & & SMPROP & \\
\hline SOLVE & & RESUEL & & SONEWA & & SANAVS & \\
\hline SORT & & CLASIF & & SPACE & & ESPACI & \\
\hline *SPLIT & PLOT & SPL IT & PLOT & SPOLYF & & SAJUSP & \\
\hline & & RAIZCU & & SQUARE & & CUADRA & \\
\hline *SRANGE & & SRANGE & & SSTATI & & SANEST & \\
\hline SSTEM & LEAF & STALLO & $\mathrm{HOJ} \mathrm{A}$ & STATIS & & ANESTA & \\
\hline
\end{tabular}


OMNITAB 80 TEST 59 VOCABULARY AND FOREIGN LANGUAGE INSTR. (1.7) PAGE 8

LIST OF COMMANDS. ONLY THE FIRST SIX LETTERS ARE PRINTED.

\begin{tabular}{|c|c|c|c|c|c|c|c|}
\hline ENGLIS & & ESPANO & & ENGLIS & & ESPANO & \\
\hline *STATPL & & STATPL & & *STDDEV & & STDDEV & \\
\hline *STDDEV & & STDDEV & & STEM & LEAF & TALLO & $\mathrm{HOJA}$ \\
\hline *STOP & & STOP & & STRUVE & ONE & STRUVE & UNO \\
\hline STRUVE & ZERO & STRUVE & CERO & STKOK'A & & SAOVDO & \\
\hline SUB & & SUSTRA & & SUBTRA & & SUSTRA & \\
\hline SUM & & SUMA & & ${ }^{*}$ SLY & & SUM & \\
\hline *SVENSK & & SVENSK & & ${ }^{*} \mathrm{~T}$ & & $\mathrm{~T}$ & \\
\hline *TABLE & & TABLE & & TAN & & TANG & \\
\hline TAND & & TANGG & & TANH & & TANGH & \\
\hline *TAPE & & TAPE & & TCHEBY & & VCHEBI & \\
\hline *TERMIN & & TERYIN & & TITLEI & & TITUL1 & \\
\hline TITLE2 & & TITUL2 & & TITLE 3 & & TITUL 3 & \\
\hline TITLE4 & & TITUL4 & & TITLEX & & TITULX & \\
\hline TITLEY & & TITULY & & ${ }^{*}$ THOPLO & & THOPLO & \\
\hline TWOHAY & & ANAVDO & & UCHEBY & & UCHEB I & \\
\hline *UNIFOR & & UNIFOR & & UNIT & & UNIDAD & \\
\hline *VOCABU & & VOCABU & & * R'EIBUL & & REIBLL & \\
\hline WIDTH & & LINE & & * R'RITE & TAPE A & WRITE & TAPE A \\
\hline * WRITE & TAPE Q & RRITE & TAPE Q & WRITE & UNIT A & WRITE & UNIDAE \\
\hline NRITE & UNIT Q & HRITE & UNIDAU & *YUGOSL & & YUGOSL & \\
\hline ZEROS & BJONE & CEROS & BJUNO & ZEROS & BJZERO & CEROS & BJCERO \\
\hline COLUMN & & & & 442 ENC & & I $447 \mathrm{~F}$ & \\
\hline
\end{tabular}

ASTERISK INDICATES NO TRANSLATION OR COMMANDS ARE THE SAYE.

DISTRIBUTION AND PROPERTY NAYES ARE PRINTED, BUT

NOT ALL COMBINATIONS ARE NECESSARILY VALID.

EACH COMMAND OF TABLE MAKING THO-HORD COMMANDS IS PRINTED SEPARATELY.

A AFTER A COMMAND STANDS FOR A FORMAT OR LNIT QUALIFIER.

$\checkmark$ AFTER A RESET COMMAND STANDS FOR A VARIABLE QUALIFIER.

$Q$ AFTER A UNIT COMMAND STANDS FOR BOTH A UNIT AND A FORYAT QUALIFIER. 
OMNITAB 80 TEST 59 VOCABULARY AND FOREIGN LANGUAGE INSTR. (1.7)

LIST OF DATA, INSTRUCTIONS AND DIAGNOSTICS

WIDTH 80

VOCABULARY

ESPANOL

VOCABULARY

NATIONAL BUREAU OF STANDARDS. WASHINGTON, D. C. 20234

OMNITAB 80 VERSION 6.00

MARCH 2, 1981 
OMNITAB 80 TEST F1 COLNT, DUPLICATE AND CLOSE LP INSTR. (5.1), (5.2) AND (5.3) PAGE 1

RESLITS FROM DLPLICATING 2 TIMES THE VALLES IN A 5X3 ARRAY BEGINNING IN ROW' 2 COL 3 . RESULTS ARE STORED BEGINNING IN ROH 2 COL 6. COLS 3-5 MERE DEFINED BY GENERATE, SET AND ADD COMMANDS. COLS 6-8 RERE DEFINED BY DUPLICATE COMMAND.

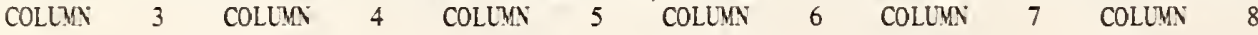

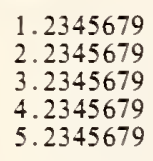

6.2345679

7. 2345679

8.2345679

9. 2345679

10.234568

11. 234568

12.234568

13.234568

14.234568

15.000000

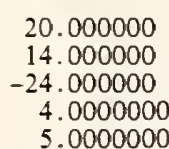

14.000000

12.000000

0 .

0 .

30.000000

5.0000000

7. 0000000

8.0000000

$-25.000000$
30.000000

24.000000

$-14.000000$

14. 000000

15.000000

24.000000

22.000000

10.000000

10.000000

10.000000

0.

2.2345679

3. 2345679

4. 2345679

5. 2345679

6. 2345679

2. 2345679

3.2345679

4. 2345679

5. 2345679

6. 2345679

40.000000

15.000000

17.000000

18.000000

$-15.000000$
0.

14. 000000

$-24.000000$

4. 0000000

5.0000000

14.000000

14.000000

$-24.000000$

4.0000000

5.0000000

14.000000

0 .

24.000000

$-14.000000$

14.000000

15.000000

24.000000

24.000000

$-14.000000$

14.000000

15.000000

24.000000

THE FOLLOHING VALLE SHOLLD BE CLOSE TO OR EQUAL TO ZERO.

0. 
OMNITAB 80 TEST F1 COUNT, DUPLICATE AND CLOSE UP INSTR. (5.1), (5.2) AND (5.3) PAGE 2 RESULTS FROM COUNT COMMAND. COL 9 CONTAINS NO. OF VALUES IN COL 4 . COL 10 CONTAINS THE NO. OF VALUES IN COL 6. THE COUNT BEGINS AT THE FIRST NON-ZERO VALUE STARTING AT NRMAX AND GOING TO ROW ONE.

\begin{tabular}{|c|c|c|c|}
\hline COLUMN & COLUMN & COLUMN & COLUMN \\
\hline $\begin{array}{r}20.000000 \\
14.000000 \\
-24.000000 \\
4.0000000 \\
5.0000000\end{array}$ & $\begin{array}{l}0 . \\
2.2345679 \\
3.2345679 \\
4.2345679 \\
5.2345679\end{array}$ & $\begin{array}{l}15.000000 \\
15.000000 \\
15.000000 \\
15.000000 \\
15.000000\end{array}$ & $\begin{array}{l}11.000000 \\
11.000000 \\
11.000000 \\
11.000000 \\
11.000000\end{array}$ \\
\hline $\begin{array}{l}14.000000 \\
12.000000 \\
0 . \\
0 . \\
0 .\end{array}$ & $\begin{array}{l}6.2345679 \\
2.2345679 \\
3.2345679 \\
4.2345679 \\
5.2345679\end{array}$ & $\begin{array}{l}15.000000 \\
15.000000 \\
15.000000 \\
15.000000 \\
15.000000\end{array}$ & $\begin{array}{l}11.000000 \\
11.000000 \\
11.000000 \\
11.000000 \\
11.000000\end{array}$ \\
\hline $\begin{array}{r}30.000000 \\
5.0000000 \\
7.0000000 \\
8.0000000 \\
-25.000000\end{array}$ & 6.2345679 & $\begin{array}{r}15.000000 \\
15.000000 \\
15.000000 \\
15.000000 \\
15.000000\end{array}$ & $\begin{array}{l}11.000000 \\
11.000000 \\
11.000000 \\
11.000000 \\
11.000000\end{array}$ \\
\hline
\end{tabular}

THE FOLLOHING TWO NUMBERS SHOULD BE 15. AND 11.

$15.000000 \quad 11.000000$ 
OMNITAB 80 TEST F1 COUNT, DUPLICATE AND CLOSE UP INSTR. (5.1), (5.2) AND (5.3) PAGE 3

RESULTS FROM COUNT COMMAND. COL 9 CONTAINS NO. OF VALUES IN COL 4. COL 10 CONTAINS THE NO. OF VALUES IN COL 6.

THE COUNT BEGINS AT THE FIRST NON-ZERO VALUE STARTING AT NRMAX AND GOING TO ROW ONE.

RESULTS FROM CLOSE UP COMMAND. THE VALUE 14.0 IS REMOVED FROM COL 4.

THE VALUE 30.0 IS REMOVED FROM COLUMNS 4 AND 5, AND 15. FROM COLLMN 9.

$\begin{array}{ccrrr}\text { OLD COL } 4 & \text { NEW COL } 4 & \text { OLD COL } 5 & \text { NEW COL } 5 & \text { OLD COL } 9 \\ 20.000000 & 20.000000 & 30.000000 & 24.000000 & 15.000000 \\ 14.000000 & -24.000000 & 24.000000 & -14.000000 & 15.000000 \\ -24.000000 & 4.0000000 & -14.000000 & 14.000000 & 15.000000 \\ 4.0000000 & 5.0000000 & 14.000000 & 15.000000 & 15.000000 \\ 5.0000000 & 12.000000 & 15.000000 & 24.000000 & 15.000000 \\ 14.000000 & 0 . & 24.000000 & 22.000000 & 15.000000 \\ 12.000000 & 0 . & 22.000000 & 10.000000 & 15.000000 \\ 0 . & 0 . & 10.000000 & 10.000000 & 15.000000 \\ 0 . & 5.0000000 & 10.000000 & 10.000000 & 15.000000 \\ 0 . & 7.0000000 & 10.000000 & 40.000000 & 15.000000 \\ 30.000000 & 8.0000000 & 40.000000 & 15.000000 & 15.000000 \\ 5.0000000 & -25.000000 & 15.000000 & 17.000000 & 15.000000 \\ 7.0000000 & & 17.000000 & 18.000000 & 15.000000 \\ 8.0000000 & & 18.000000 & -15.000000 & 15.000000 \\ -25.000000 & & -15.000000 & 0 . & 15.000000 \\ & & & & \\ & & & & \\ & & & & \end{array}$

THE FOLLOHING VALUES SHOULD BE 58. 30. AND 225.0.
58.000000
30.000000
225.00000 
OMNITAB 80 TEST F1 COUNT, DUPLICATE AND CLOSE UP INSTR. (5.1), (5.2) AND (5.3)

LIST OF DATA, INSTRUCTIONS AND DIAGNOSTICS

GENERATE NOS. START WITH 1.23456789 IN STEPS OF 1.0 THRU 15. STORE IN COL 3

* INFORMATIVE DIAGNOSTIC FOR THE ABOVE INSTRUCTION -

NRMAX HAS BEEN RESET FROM O TO 15.

SET THE FOLLOWING NUMBERS IN COLUMN 4

$20.014 .0-24.0 \quad 4$. 5. 14. 12. 0.00 .00 .030 . 5. 7. $8.0-25.0$

ADD THE CONSTANT 10. TO COLUMN 4 AND STORE RESULT IN COL 5

DUPLICATE 2 TIMES THE ARRAY IN ROW' 2 OF COL 3 SIZE 5X3 STORE IN ROW 2 OF COL 6

TITLE1 RESULTS FROM DUPLICATING 2 TIMES THE VALUES IN A $5 X 3$ ARRAY

TITLE2BEGINNING IN ROW 2 COL 3. RESULTS ARE STORED BEGINNING IN

TITLE3ROW 2 COL 6 . COLS $3-5$ WERE DEFINED BY GENERATE, SET AND ADD

TITLE4COMMANDS. COLS 6-8 WERE DEFINED BY DUPLICATE COMMAND.

PRINT COLUMNS $3,4,5,6,7$ AND 8

MSUB A IN ROW 2 OF COL 3 SIZE $5 \times 3$ MINUS B IN $R=2, C=6$ SIZE $5 \times 3$ PUT IN $R=2, C=9$

MSUBTRACT A IN $\mathrm{R}=7, \mathrm{C}=6$ SIZE $5 \times 3$ MINUS $\mathrm{B}$ IN $\mathrm{R}=2, \mathrm{C}=3$ SIZE $5 \times 3$ PUT IN $\mathrm{R}=2, \mathrm{C}=12$

SMPROPERTIES OF MATRIX IN ROW 2 OF COL 9 SIZE 5X6 STORE PROPERTIES IN COL 15 SPACE

NOTE $* * * * * * * * * * * * * * * * * * * * * * * * * * * * * * * * * * * * * * * * * * * * * * * * * * * * * * * * * * * * * * * * * * * * *$

SPACE

NOTE THE FOLLOWING VALUE SHOULD BE CLOSE TO OR EQUAL TO ZERO.

SPACE

ABRIDGE ROW 11 OF COLUMN 15

SPACE

NOTE $* * * * * * * * * * * * * * * * * * * * * * * * * * * * * * * * * * * * * * * * * * * * * * * * * * * * * * * * * * * * * * * * * * * *$

COUNT THE LENGTH OF COLUMN 4 AND VECTORIZE COUNT IN COLUMN 9

COUNT THE LENGTH OF COLUMN 6 AND VECTORIZE COUNT IN COLUMN 10

TITLE1 RESULTS FROM COUNT COMMAND. COL 9 CONTAINS NO. OF VALUES IN

TITLE2 COL 4 . COL 10 CONTAINS THE NO. OF VALUES IN COL 6.

TITLE3 THE COUNT BEGINS AT THE FIRST NON-ZERO VALUE STARTING AT NR

TITLE4MAX AND GOING TO ROW ONE.

PRINT COLUMNS $4,6,9$ AND 10

SPACE

NOTE

SPACE

NOTE THE FOLLOWING TWO NUMBERS SHOULD BE 15. AND 11 .

SPACE

ABRIDGE ROW 1 OF COLUMNS 9 AND 10

SPACE

NOTE

MOVE THE VECTOR IN ROW 1 OF COL 4 SIZE 15X1, STORE IN ROW 1 OF COL 11

MOVE THE VECTOR IN ROW 1 OF COL 5 SIZE 15X1, STORE IN ROW 1 OF COL 12

MOVE THE VECTOR IN ROW 1 OF COL 9 SIZE 15X1, STORE IN ROW 1 OF COL 13

CLOSE UP ROWS HAVING THE VALUE 14.0 IN COLUMN 4

CLOSE UP ROWS HAVING THE VALUE 30.0 IN COLUMNS 4 AND 5

CLOSE UP ROWS HAVING THE VALUE 15.0 IN COLUMN 9

NEW PAGE

NOTE RESULTS FROM CLOSE UP COMMAND. THE VALUE 14.0 IS REMOVED FROM COL 4.

NOTE THE VALUE 30.0 IS REMOVED FROM COLUMNS 4 AND 5, AND 15. FROM COLUMN 9.

SPACE 
LIST OF DATA, INSTRUCTIONS AND DIAGNOSTICS

FORMAT C (18A3)

READ C FORMAT, 1 LINE INTO COLS $23 * * 40$

* INFORMATIVE DIAGNOSTIC FOR THE ABOVE INSTRUCTION NRMAX HAS BEEN RESET FROM 15 TO 1.

1 DATA CARD(S) READ BUT NOT LISTED

FORMAT D $(4 X, 3 A 3,6 X, 3 A 3,7 X, 3 A 3,5 X, 3 A 3,7 X, 3 A 3,6 X, 3 A 3)$

RESET NRMAX 1

NPRINT D FORMAT, COLS $23 * * 40$

RESET NRMAX 15

* INFORMATIVE diagNOSTIC FOR THE ABOVE INSTRUCTION NRMAX HAS BEEN RESET FROM 1 TO 15.

SPACE

NPRINT COLUMNS $11,4,12,5,13$ AND 9

SUM COLUMN 11 STORE IN COLUMN 14

SUM COLUMN 12 STORE IN COLUMN 15

SUM COLUMN 13 STORE IN COLUMN 16

SUM COLUMN 4 STORE IN COLUMN 17

SUM COLUMN 5 STORE IN COLUMN 18

SUM COLUMN 9 STORE IN COLUMN 19

SUBTRACT COLUMN 17 FROM COLUMN 14 STORE IN COLUMN 20

SUBTRACT COLUMN 18 FROM COLUMN 15 STORE IN COLUMN 21

SUBTRACT COLUMN 19 FROM COLUMN 16 STORE IN COLUMN 22

SPACE

NOTE $* * * * * * * * * * * * * * * * * * * * * * * * * * * * * * * * * * * * * * * * * * * * * * * * * * * * * * * * * * * * * * * * * * *$

SPACE

NOTE THE FOLLOHING VALUES SHOULD BE 58. 30. AND 225.0.

SPACE

ABRIDGE ROW 1 OF COLUMNS 20, 21 AND 22

SPACE

NOTE

NATIONAL BUREAU OF STANDARDS. WASHINGTON, D. C. 20234 OMNITAB 80 VERSION 6.00 MARCH 2,1981 
OMNITAB 80 TEST F2 REGRESSION ANAL., BESTCP AND SPLIT PLOT. (6.4), (6.5), (6.6) PAGE 1

LEAST SQUARES FIT OF RESPONSE, COLUMN 37, AS A LINEAR FUNCTION OF 2 INDEPENDENT VARIABLES IN COLUMNS 10, 11 USING ZERO WEIGHTS IN COLUMN 10

\begin{tabular}{|c|c|c|c|c|c|c|c|}
\hline ROW & $\begin{array}{l}\text { INDEP VAR. } \\
\text { COLUMN } 11\end{array}$ & $\begin{array}{l}\text { RESPONSE } \\
\text { COLUMN } 37\end{array}$ & $\begin{array}{l}\text { PREDICTED } \\
\text { RESPONSE }\end{array}$ & $\begin{aligned} \text { STD. } & \text { DEV. OF } \\
\text { PRED. } & \text { RESPONSE }\end{aligned}$ & RESIDUALS & $\begin{array}{l}\text { STD. } \\
\text { RES. }\end{array}$ & WEIGHTS \\
\hline $\begin{array}{l}1 \\
2 \\
3 \\
4 \\
5\end{array}$ & $\begin{array}{l}35.000000 \\
45.000000 \\
55.000000 \\
65.000000 \\
75.000000\end{array}$ & $\begin{array}{l}114.00000 \\
124.00000 \\
143.00000 \\
158.00000 \\
166.00000\end{array}$ & $\begin{array}{l}113.40000 \\
127.20000 \\
141.00000 \\
154.80000 \\
168.60000\end{array}$ & $\begin{array}{l}2.5139610 \\
1.7776389 \\
1.4514361 \\
1.7776389 \\
2.5139610\end{array}$ & $\begin{array}{r}.59999999 \\
-3.2000000 \\
2.0000000 \\
3.2000000 \\
-2.6000000\end{array}$ & $\begin{array}{r}.29 \\
-1.18 \\
.69 \\
1.18 \\
-1.27\end{array}$ & $\begin{array}{l}1.000 \\
1.000 \\
1.000 \\
1.000 \\
1.000\end{array}$ \\
\hline
\end{tabular}

DIAGNOSTIC INFORMATION FOR IDENTIFYING INFLUENTIAL MEASUREMENTS.

$I=$ ROW, FOR 5 LARGEST VALUES, T(I) = STANDARDIZED RESIDUAL,

$H(I)=$ DIAGONAL OF HAT MATRIX, $\quad$ D(I) = COOK STATISTIC,

WSSD $(I)=$ DANIEL-WOOD STATISTIC, V(I) $=$ VAR(YHAT) $/$ VAR (RESIDUAL).

\begin{tabular}{|c|c|c|c|c|c|c|c|c|c|}
\hline I & $T(I)$ & I & $\mathrm{H}(\mathrm{I})$ & I & $D(I)$ & I & WSSD(I) & I & $V(I)$ \\
\hline $\begin{array}{l}5 \\
2 \\
4 \\
3 \\
1\end{array}$ & $\begin{array}{r}-1.27 \\
-1.18 \\
1.18 \\
.69 \\
.29\end{array}$ & $\begin{array}{l}1 \\
5 \\
2 \\
4 \\
3\end{array}$ & $\begin{array}{l}.600 \\
.600 \\
.300 \\
.300 \\
.200\end{array}$ & $\begin{array}{l}5 \\
2 \\
4 \\
1 \\
3\end{array}$ & $\begin{array}{r}1.20 \\
.30 \\
.30 \\
.06 \\
.06\end{array}$ & $\begin{array}{l}1 \\
5 \\
2 \\
4 \\
3\end{array}$ & $\begin{array}{r}72.32 \\
72.32 \\
18.08 \\
18.08 \\
.00\end{array}$ & $\begin{array}{l}1 \\
5 \\
2 \\
4 \\
3\end{array}$ & $\begin{array}{r}1.50 \\
1.50 \\
.43 \\
.43 \\
.25\end{array}$ \\
\hline
\end{tabular}

THE DURBIN-WATSON STATISTIC IS D $=2.4227848$ 
OMNITAB 80 TEST F2 REGRESSION ANAL., BESTCP AND SPLIT PLOT. (6.4), (6.5), (6.6) PAGE 2

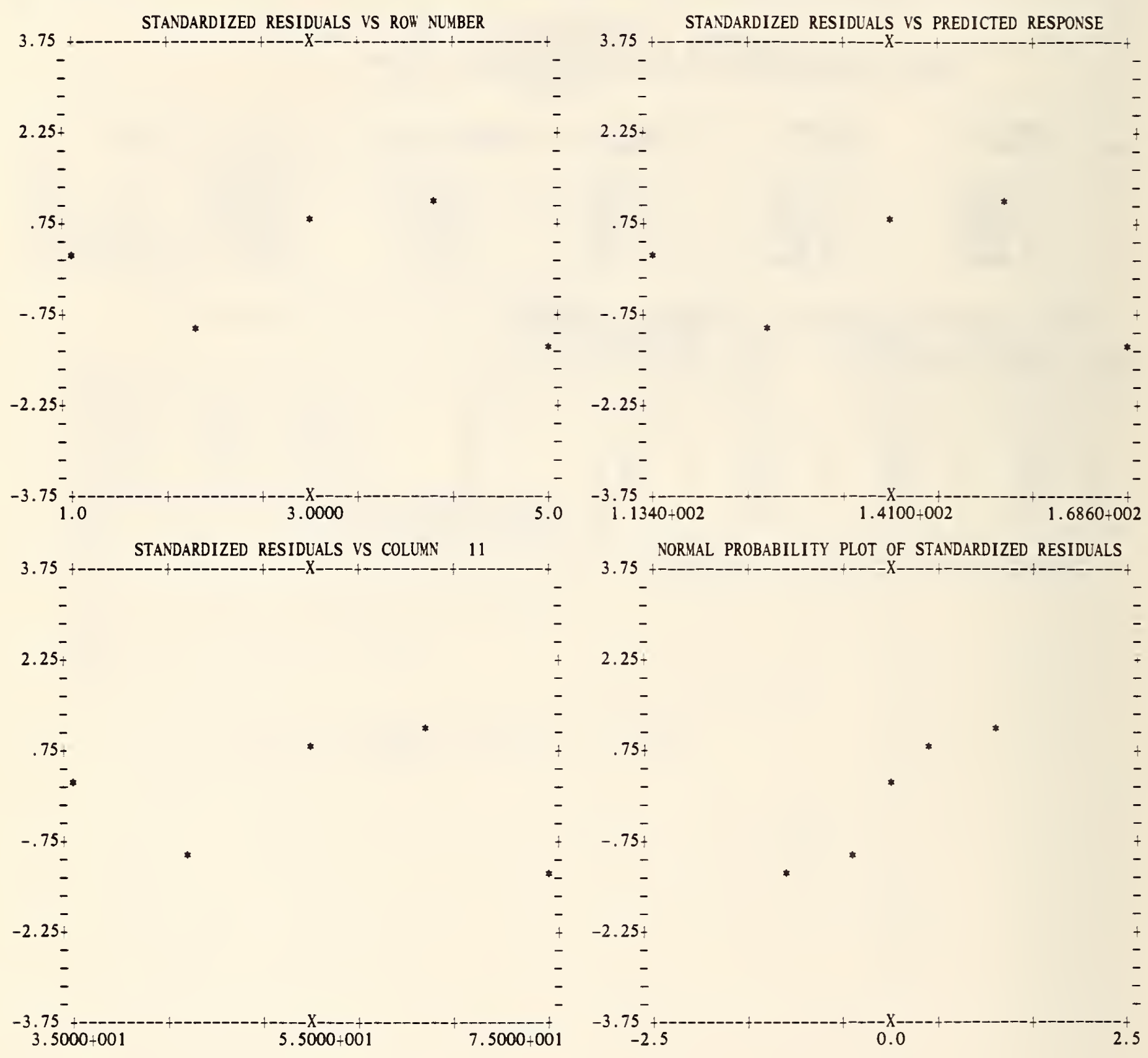


OMNITAB 80 TEST F2 REGRESSION ANAL., BESTCP AND SPLIT PLOT. $(6.4),(6.5),(6.6) \quad$ PAGE 3

LEAST SQUARES FIT OF RESPONSE, COLUMN 37, AS A LINEAR FUNCTION OF 2 INDEPENDENT VARIABLES IN COLUMNS 10, 11 USING 5 NON-ZERO WEIGHTS AND 0 ZERO WEIGHTS IN COLUMN 10

SAMPLE VARIANCE-COVARIANCE MATRIX OF THE ESTIMATED COEFFICIENTS WITH CORRELATIONS ABOVE THE DIAGONAL.

COLUMN

10

11

$10 \quad 33.969999 \quad-.9685$

$11 \quad-.57933332 \quad .010533333$

THERE ARE NO REPLICATIONS FOR A LACK OF FIT ANALYSIS OF VARIANCE.

ANALYSIS OF VARIANCE

-DEPENDENT ON ORDER INDEPENDENT VARIABLES ARE ENTERED, UNLESS VECTORS ARE ORTHOGONAL-

\begin{tabular}{|c|c|c|c|c|c|c|c|c|}
\hline INDEP VAR & & SS=RED. DUE TO COEF. & CLM. RESIDUAL MS & D.F. & $\mathrm{F}(\mathrm{COEF}=0)$ & $P(F)$ & $\mathrm{F}(\mathrm{COEFS}=0)$ & $\mathrm{P}(\mathrm{F})$ \\
\hline $\begin{array}{l}\text { COLUMN } \\
\text { COLUMN }\end{array}$ & $\begin{array}{l}10 \\
11\end{array}$ & $\begin{array}{c}99405.000 \\
1904.4000\end{array}$ & $\begin{array}{c}483.99999 \\
10.533333\end{array}$ & $\begin{array}{l}4 \\
3\end{array}$ & $\begin{array}{r}9437.183 \\
180.797\end{array}$ & $\begin{array}{l}.000 \\
.001\end{array}$ & $\begin{array}{r}4808.990 \\
180.797\end{array}$ & $\begin{array}{l}.000 \\
.001\end{array}$ \\
\hline RESIDUAL & & 31.600000 & & 3 & & & & \\
\hline TOTAL & & 101341.00 & & 5 & & & & \\
\hline
\end{tabular}

ESTIMATES FROM LEAST SQUARES FIT

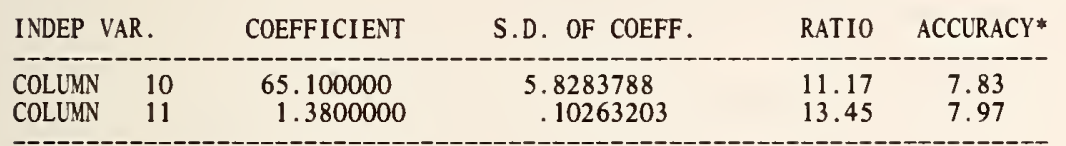

$\begin{array}{ll}\text { RESIDUAL STANDARD DEVIATION }= & 3.2455097 \\ \text { BASED ON DEGREES OF FREEDOM } & 5-2=3\end{array}$

*THE NUMBER OF CORRECTLY COMPUTED DIGITS IN EACH COEFFICIENT USUALLY DIFFERS BY LESS THAN 1 FROM THE NUMBER GIVEN HERE.

THE NUMBER OF ITERATIONS WAS 2. SCALING WAS NOT USED.

THE AVERAGE NUMBER OF DIGITS IN AGREEMENT BETWEEN INITIAL SOLUTION AND IST ITERATION IS 7.83.

THE EXAMPLE GIVEN ABOVE IS FROM G. W. SNEDECOR'S 'STATISTICAL METHODS', (5TH ED., 1956), PAGES 122-126. 
OMNITAB 80 TEST F2 REGRESSION ANAL., BESTCP AND SPLIT PLOT. (6.4), (6.5), (6.6) PAGE 4

THE FOLLORING VALUES MUST BE EQUAL TO OR NEAR ZERO.
.00000
.00000
.00000
.00000
.00000
.00000

RESULTS FROM MORTHO

ORTHONORYAL VECTORS

$\begin{array}{ccc}\text { ROF'COL } & 20 & 21 \\ 1 & 4.472136-001 & -6.324555-001 \\ 2 & 4.472136-001 & -3.162278-001 \\ 3 & 4.472136-001 & -4.318716-010 \\ 4 & 4.472136-001 & 3.162278-001 \\ 5 & 4.472136-001 & 6.324555-001\end{array}$

TRANSFORMATION MATRIX

\begin{tabular}{ccc}
$\mathrm{ROR} / \mathrm{COL}$ & \multicolumn{1}{c}{25} & 26 \\
1 & .44721360 & -1.7392527 \\
2 & 0. & .031622776
\end{tabular}

THE FOLLOHING VALUES MUST BE EQUAL TO OR NEAR .89 AID 2.0.

$.89000019 \quad 2.0000000$ 
OMNITAB 80 TEST F2 REGRESSION ANAL., BESTCP AND SPLIT PLOT. (6.4), (6.5), (6.6) PAGE 5 SPLIT PLOT USING J. BARNES DATA.

ANALYSIS OF VARIANCE FOR SPLIT-PLOT EXPERIMENTAL DESIGN

MODEL IS Y(IJK) $=$ MU + R(I) + W(J) + ETA(IJ) + S(K) + WS (JK) + E(IJK),

WHERE ETA AND E ARE RANDOM AND MU, W, S, AND WS ARE FIXED EFFECTS.

$\begin{array}{rlllr}18 & \text { MEASUREMENTS (Y) } & \text { IN COLUMN } & 2 \\ 2 & \text { REPLICATES } & \text { (R) } & \text { IN COLUMN } & 51 \\ 3 & \text { WHOLE-PLOTS } & \text { (W) } & \text { IN COLUMN } & 52 \\ 3 & \text { SPLIT-PLOTS } & \text { (S) } & \text { IN COLUMN } & 53\end{array}$

SOURCE

D.F. SUM OF SQUARES

MEAN SQUARES F-RATIO P(F)

\begin{tabular}{llcrrr} 
(R) COLUMN 51 & 1 & 1.7422231 & 1.7422231 & & \\
(H) COLUMN 52 & 2 & 662.66779 & 331.33389 & .005 & .995 \\
RX W INTERACTION & 2 & 15.221115 & 7.6105574 & & \\
(S) COLUMN 53 & 2 & 2.6677791 & 1.3338895 & .154 & .860 \\
WX S INTERACTION & 4 & 23.395555 & 5.8488889 & .676 & .633 \\
RESIDUAL & 6 & 51.916665 & 8.6527774 & & \\
\hline
\end{tabular}

TOTAL

$17 \quad 757.61112$ 
OMNITAB 80 TEST F2 REgRESSION ANAL., BESTCP AND SPLIT PLOT. (6.4), (6.5), (6.6) PAGE 6 BESTCP STATISTIC STUDY, PAGE 89 OF DANIEL AND HOOD.

C(P) STATISTICS FOR COLUMN 1 AS A LINEAR FLNCTION OF A CONSTANT AND FROM 1 UP TO 4 VARIABLES HITH 13 MEASUREMENTS HITH NONZERO HEIGHTS

$\begin{array}{lllllll}\text { VARIABLE } & 1 & \text { IS COLUMN } & 11, & \text { VARIABLE } & 2 \text { IS COLLMN } & 12, \\ \text { VARIABLE } & 3 \text { IS COLUMN } & 13, & \text { VARIABLE } & 4 \text { IS COLUMN } & 14\end{array}$,

REGRESSION BITH 1 VARIABLE

C(P) STATISTIC VARIABLES

$\begin{array}{ll}138.731 & 4 \\ 142.486 & 2 \\ 202.549 & 1 \\ 315.154 & 3\end{array}$

REGRESSIONS HITH 2 VARIABLES

\begin{tabular}{|c|c|c|}
\hline $\begin{array}{c}\text { VARIABLE } \\
1 \\
2\end{array}$ & $\begin{array}{c}C(P)=2.678 \\
\text { COEFFICIENT } \\
1.4683058 \\
.66225047\end{array}$ & $\begin{array}{l}\text { F RATIO } \\
146.523 \\
208.582\end{array}$ \\
\hline $\begin{array}{c}\text { VARIABLE } \\
1 \\
4\end{array}$ & $\begin{array}{cc}C(P) & =5.496 \\
\text { COEFFICIENT } & \\
1.4399583 \\
-.61395362\end{array}$ & $\begin{array}{l}\text { F RATI0 } \\
108.224 \\
159.295\end{array}$ \\
\hline $\begin{array}{c}\text { VARIABLE } \\
3 \\
4\end{array}$ & $\begin{array}{c}C(P)=22.373 \\
\text { COEFFICIENT } \\
-1.1998512 \\
-.72460013\end{array}$ & $\begin{array}{r}\text { F RATIO } \\
40.295 \\
100.357\end{array}$ \\
\hline $\begin{array}{c}\text { VAR I ABLE } \\
2 \\
3\end{array}$ & $\begin{array}{c}C(P)=62.438 \\
\text { COEFFICIENT } \\
.73132958 \\
-1.0083862\end{array}$ & $\begin{array}{r}\text { F RATI0 } \\
36.683 \\
11.816\end{array}$ \\
\hline $\begin{array}{c}\text { VAR I ABLE } \\
2 \\
4\end{array}$ & $\begin{array}{c}C(P)=138.226 \\
C O E F F I C I E N T \\
.31090473 \\
-.45694190\end{array}$ & $\begin{array}{r}\text { F RATIO } \\
.172 \\
.431\end{array}$ \\
\hline
\end{tabular}

C(P) STATISTIC VARIABLES

$198.094 \quad 1 \quad 3$

REGRESSIONS HIITH 3 VARIABLES

$\begin{array}{crr} & \mathrm{C}(\mathrm{P})= & 3.018 \\ \text { VARIABLE } & \text { COEFFICIENT } & \text { F RATI0 } \\ 1 & 1.4519380 & 154.008 \\ 2 & .41610947 & 5.026 \\ 4 & -.23654049 & 1.863 \\ & \mathrm{C}(\mathrm{P})=3.041 & \\ \text { VARIABLE } & \text { COEFFICIENT } & \text { F RATI0 } \\ 1 & 1.6958901 & 68.716 \\ 2 & .65691487 & 220.547 \\ 3 & .25001752 & 1.832\end{array}$


OMNITAB 80 TEST F2 REGRESSION ANAL., BESTCP AND SPLIT PLOT. (6.4), (6.5), (6.6) PAGE 7 BESTCP STATISTIC STUDY, PAGE 89 OF DANIEL AND MOOD.

\begin{tabular}{|c|c|c|}
\hline $\begin{array}{c}\text { VAR IABLE } \\
1 \\
3 \\
4\end{array}$ & $\begin{array}{cr}C(P) & =3.497 \\
\text { COEFFICIENT } & 1.0518541 \\
& =.41004334 \\
& -.64279614\end{array}$ & $\begin{array}{r}\text { F RATIO } \\
22.113 \\
4.236 \\
208.240\end{array}$ \\
\hline $\begin{array}{c}\text { VARIABLE } \\
2 \\
3 \\
4\end{array}$ & $\begin{array}{rr}C(P) & =\quad 7.337 \\
\text { COEFFICIENT } & -.92341541 \\
-1.4479710 \\
-1.5570444\end{array}$ & $\begin{array}{r}\text { F RATIO } \\
12.427 \\
96.940 \\
41.654\end{array}$ \\
\hline GRESSIONS & WITH 4 VARIABLES & \\
\hline $\begin{array}{c}\text { VARIABLE } \\
1 \\
2 \\
3 \\
4\end{array}$ & $\begin{array}{c}C(P)=5.000 \\
\text { COEFFICIENT } \\
1.5510969 \\
.51016177 \\
.10190346 \\
-.14406672\end{array}$ & $\begin{array}{r}\text { F RATIO } \\
4.337 \\
.497 \\
.018 \\
.041\end{array}$ \\
\hline & & RATION \\
\hline
\end{tabular}


OMNITAB 80 TEST F2 REGRESS ION ANAL., BESTCP AND SPLIT PLOT. (6.4), (6.5), (6.6) PAGE 8

LIST OF DATA, INSTRUCTIONS AND DIAGNOSTICS

SCAN $60 \$$ THIS NILL IGNORE ALL NLMERICS IN CARD COLS 61 AND BEYOND CARD 1 SET $X$ IN COL $11 \quad$ CARD 2 $35,45,55,65,75$

* INFORMATIVE DIAGNOSTIC FOR THE ABOVE INSTRUCTION NRMAX HAS BEEN RESET FROM O TO 5.

SET Y IN COL 37

$114,124,143,158,166$

DEFINE 1.0 IN COLUMN 10

SOUARE COL 11 AND STORE IN COL 12

MULTIPLY COL 11 BY COL 12 AND STORE IN COL 13

SPOLYFIT Y COL 37 HT $=1$. DEG 1 X IN 11 STORE $20 * * * 23,1,24$

FIT Y IN 37 RT IN 102 VEC X IN 10,11 STORE $40 * * * 43,1,44$

MMOVE ROW 1 OF COL 40 SIZE 5 X2 PUT IN ROH' 1 OF COL 48

SUBTRACT COL 41 FROM COL 21 STORE IN COL 41

SUBTRACT COL 42 FROM COL 22 STORE IN COL 42

AVERAGE COL 41 STORE IN COL 41

AVERAGE COL 42 STORE IN COL 42

RESET NRMAX TO 16

$$
\text { . }
$$

* INFORMATIVE DIAGNOSTIC FOR THE ABOVE INSTRUCTION IRMAX HAS BEEN RESET FROM 5 TO 16.

SUBTRACT COL 20 FROM COL 40 STORE IN COL 40

AVERAGE COL 40 STORE IN COL 40

RESET NRMAX TO 12

* INForMative diagNoStic fOR the above isstruction NRMAX HAS BEEN RESET FROM 16 TO 12.

SUBTRACT COL 43 FROM COL 23 PUT IN COL 43

AVERAGE COL 43 STORE IN COL 43

RESET NRMAX TO 8

CARD 4

CARD 5

CARD 6

CARD 7

CARD 8

CARD 9

CARD 10

CARD 11

CARD 12

CARD 13

CARD 14

CARD 15

* INFORMATIVE diagiostic FOR THE ABOVE INSTRUCTION SRMAX HAS BEEN RESET FROM 12 TO 8.

SUBTRACT COL 44 FROM COL 24 PUT IN COL 44

AIERAGE COL 44 PUT IN COL 44

SUBTRACT COL 45 FROM COL 25 PUT IN COL 45

AVERAGE COL 45 PUT IN COL 45

FORMAT D $(1 \mathrm{X}, 1$ P6E13.5)

SCAN ALL 80 COLLMNS OF EACH CARD

SPACE 2

NOTE

SPACE

NOTE THE EXAMPLE GIVEX ABOVE IS FROM G. R'. SNEDECOR'S 'STATISTICAL METHODS',

NOTE (5TH ED., 1956), PAGES 122-126.

SPACE 
OMNITAB 80 TEST F2 REgRESSION ANAL., BESTCP AND SPLIT PLOT. (6.4), (6.5), (6.6) PAGE

LIST OF DATA, INSTRUCTIONS AND DIAGNOSTICS

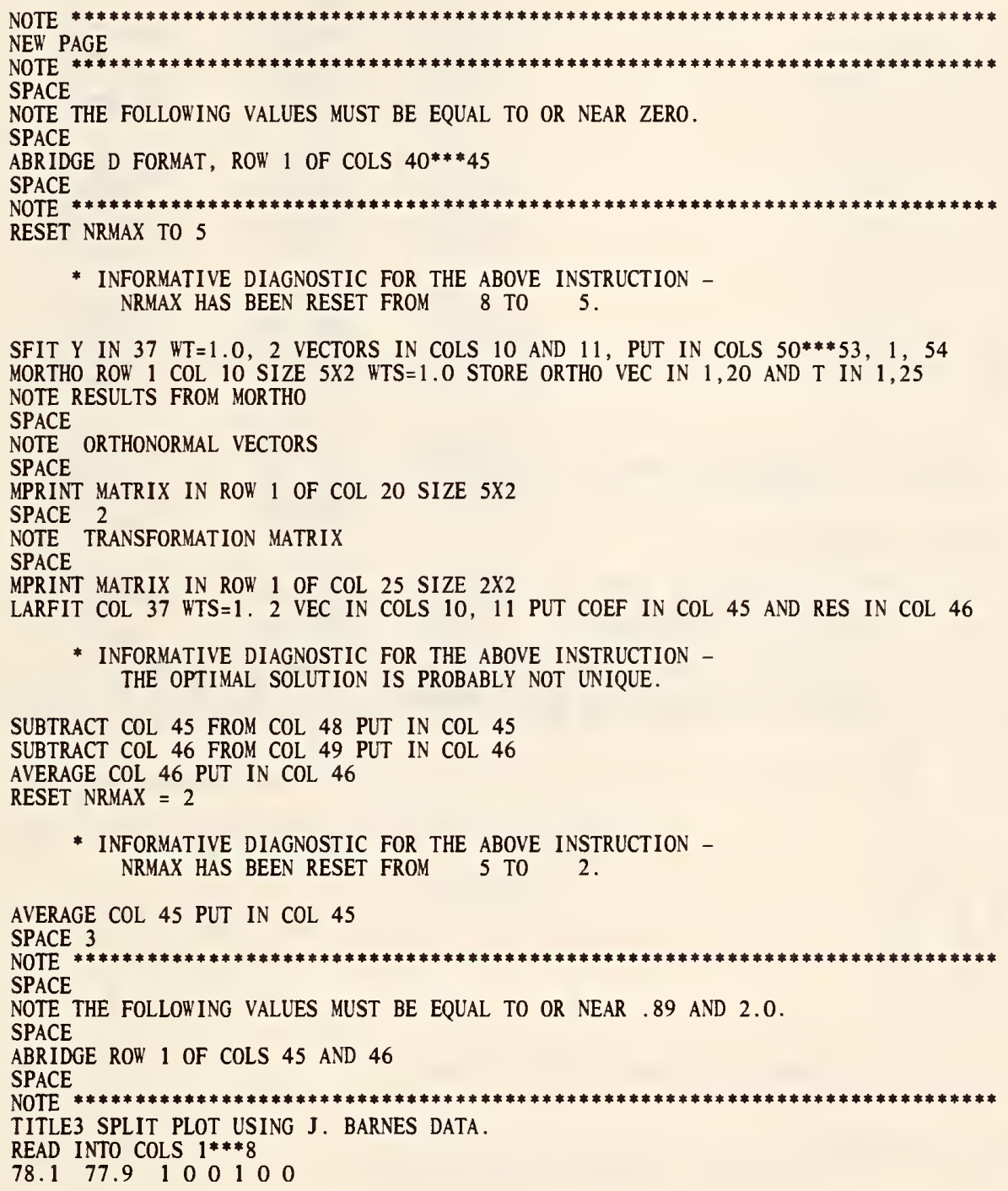


OMNITAB 80 TEST F2 REGRESSION ANAL, BESTCP AND SPLIT PLOT. (6.4), (6.5), (6.6) PAGE 10

LIST OF DATA, INSTRLCTIONS AND DIAGNOSTICS

$\begin{array}{lllllllll}75.2 & 77.0 & 1 & 0 & 0 & 1 & 0 & 0 \\ 74.0 & 73.3 & 0 & 1 & 0 & 1 & 0 & 0 \\ 78.0 & 79.6 & 0 & 1 & 0 & 1 & 0 & 0 \\ 77.5 & 79.2 & 0 & 0 & 1 & 1 & 0 & 0 \\ 77.6 & 79.5 & 0 & 0 & 1 & 1 & 0 & 0 \\ 77.6 & 88.5 & 1 & 0 & 0 & 0 & 1 & 0 \\ 74.0 & 82.1 & 1 & 0 & 0 & 0 & 1 & 0 \\ 75.2 & 83.0 & 0 & 1 & 0 & 0 & 1 & 0 \\ 77.5 & 88.1 & 0 & 1 & 0 & 0 & 1 & 0 \\ 78.0 & 89.0 & 0 & 0 & 1 & 0 & 1 & 0 \\ 78.1 & 86.3 & 0 & 0 & 1 & 0 & 1 & 0 \\ 78.0 & 73.2 & 1 & 0 & 0 & 0 & 0 & 1 \\ 77.5 & 72.3 & 1 & 0 & 0 & 0 & 0 & 1 \\ 77.6 & 72.9 & 0 & 1 & 0 & 0 & 0 & 1 \\ 78.1 & 70.6 & 0 & 1 & 0 & 0 & 0 & 1 \\ 75.2 & 71.6 & 0 & 0 & 1 & 0 & 0 & 1 \\ 74.0 & 67.5 & 0 & 0 & 1 & 0 & 0 & 1\end{array}$

* informative diagiostic for the above instrlction NRMAX HAS BEEN RESET FROM 2 TO 18.

SET REP NTMBER IN COLLMN 51

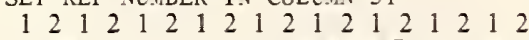

SET RHOLE PLOT TREATMEIT ILMBER IN COLLMN 52

$\begin{array}{lllllllllllllllll}1 & 1 & 1 & 1 & 1 & 1 & 2 & 2 & 2 & 2 & 2 & 2 & 3 & 3 & 3 & 3 & 3\end{array}$

SET SPLITPLOT TREATMENT NTMBER IN COLCYN 53

$\begin{array}{llllllllllllllllll}1 & 1 & 2 & 2 & 3 & 3 & 1 & 1 & 2 & 2 & 3 & 3 & 1 & 1 & 2 & 2 & 3 & 3\end{array}$

SPLIT PLOT COL 2 PLT REP NOS IN COL 51 RHOLE PLOT 10 IN COL 52 SPLIT PLOT NOS 53 TITLE3 BESTCP STATISTIC STLDY, PAGE 89 OF DANIEL AND ROOD.

READ DATA INTO COLLMNS $11,12,13,14$ AND 1

$\begin{array}{lllll}7 & 26 & 6 & 60 & 78.5\end{array}$

$\begin{array}{llllll}1 & 29 & 15 & 52 & 74.3\end{array}$

$\begin{array}{lllll}11 & 56 & 8 & 20 & 104.3\end{array}$

$\begin{array}{llllll}11 & 31 & 8 & 47 & 87.6\end{array}$

$\begin{array}{lllll}7 & 52 & 6 & 33 & 95.9\end{array}$

$\begin{array}{lllll}11 & 55 & 9 & 22 & 109.2\end{array}$

$\begin{array}{llllll}3 & 71 & 17 & 6 & 102.7\end{array}$

$\begin{array}{lllll}1 & 31 & 22 & 44 & 72.5\end{array}$

$\begin{array}{lllll}2 & 54 & 18 & 22 & 93.1\end{array}$

$2147 \quad 4 \quad 26115.9$

$\begin{array}{llllll}1 & 40 & 23 & 34 & 83.8\end{array}$

$\begin{array}{llrrrr}11 & 66 & 9 & 12 & 113.3\end{array}$

$\begin{array}{llllll}10 & 68 & 8 & 12 & 109.4\end{array}$

* isforvatile diagNostic for the abOVE instriction IRMAY HAS BEEY RESET FROM 18 TO 13.

DEFINE 1.0 INTO COLLYY 10

BESTCP Y IS COL 1 , RTS $=1.0$, FOR 5 VARIABLES IN COLS $10 * * 14$

NATIONAL BUREAL OF STANDARDS. FiASHINGTOS, D. C. 20234 OMNITAB 80 VERSION 6.00 MARCH 2,1981 


$\begin{array}{ccc}\text { DEGREE } & \text { ORDINATES } & \text { COEF } \\ 0 . & & \\ 15.000000 & 149.00000 & * \\ 30.000000 & 137.00000 & -1.99831667+02 \\ 45.000000 & 128.00000 & -3.4098809 \\ 60.000000 & 126.00000 & 5.4706860 \\ & 128.00000 & -1.2916662 \\ 75.000000 & 135.00000 & .24975916 \\ 90.000000 & 159.00000 & .74999954 \\ 105.00000 & 178.00000 & .30921129 \\ 120.00000 & 189.00000 & .45833445 \\ 135.00000 & 191.00000 & -.30401961 \\ & & \\ 150.00000 & 189.00000 & -.090117931 \\ 165.00000 & 187.00000 & -.24252383 \\ 180.00000 & 178.00000 & -.083333333 \\ 195.00000 & 170.00000 & -1.2779225+01 \\ 210.00000 & 177.00000 & -1.6624567+01 \\ & & \\ 225.00000 & 183.00000 & -.32322375 \\ 240.00000 & 181.00000 & 1.5155446 \\ 255.00000 & 179.00000 & 1.4616947 \\ 270.00000 & 179.00000 & -2.5833335 \\ 285.00000 & 185.00000 & .32216867 \\ & & \\ 300.00000 & 182.00000 & -.21650584 \\ 315.00000 & 176.00000 & .67678118 \\ 330.00000 & 166.00000 & -.45876074 \\ 345.00000 & 160.00000 & -.63970299\end{array}$

ABOVE PROBLEM IS EXAMPLE FROM J.B. SCARBOROUGH,

NUMER ICAL MATHEMATICAL ANALYSIS (2ND ED., 1950) PAGES 490-491.

VALUE IN THE NEXT ROW MUST BE EQUAL TO OR NEAR ZERO.

$-8.735030-007$ 
LIST OF DATA, INSTRUCTIONS AND DIAGNOSTICS

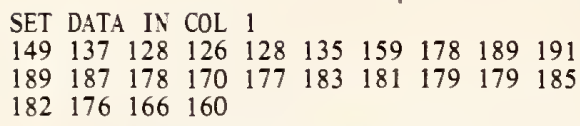

NATIONAL BLREAU OF STANDARDS. HASHINGTON, D. C. 20234 OMNITAB 80 VERSION 6.00 MARCH 2,1981 
OMNITAB 80 TEST F4 SOLVE LINEAR EQUATIONS AND INVERT MATRIX. (8.5) AND (11.5) PAGE 1

MATRIX TO BE INVERTED.

\begin{tabular}{|c|c|c|c|c|c|c|c|c|c|}
\hline 2. & -1 . & 0 . & 0. & 0. & 0 . & 0 . & 0 . & 0. & 0. \\
\hline $\begin{array}{r}-1 . \\
0 .\end{array}$ & $\begin{array}{r}2 \\
-1\end{array}$ & $\begin{array}{r}-1 . \\
2 .\end{array}$ & $\begin{array}{r}0 \\
-1\end{array}$ & $\begin{array}{l}0 . \\
0 .\end{array}$ & $\begin{array}{l}0 . \\
0 .\end{array}$ & $\begin{array}{l}0 . \\
0 .\end{array}$ & $\begin{array}{l}0 . \\
0 .\end{array}$ & $\begin{array}{l}0 . \\
0 .\end{array}$ & $\begin{array}{l}0 . \\
0 .\end{array}$ \\
\hline 0 . & 0 & -1 & 2 & -1 & 0. & 0. & 0. & 0. & 0 . \\
\hline 0. & 0. & 0. & -1 & 2. & -1 & 0 . & 0. & 0. & 0 . \\
\hline 0 . & 0 . & 0. & 0 & -1 & 2. & -1 & 0. & 0 . & 0. \\
\hline 0 . & 0 & 0 . & 0 . & 0 . & -1 . & 2. & -1 & 0. & 0 . \\
\hline 0. & 0 . & 0. & 0 . & 0 . & 0. & -1 & 2. & -1 & 0. \\
\hline 0 . & 0. & 0 . & 0 . & 0 . & 0 . & 0. & -1 & 2 & -1 \\
\hline 0 . & 0 . & 0: & 0. & 0 . & 0. & 0 . & 0. & -1 & 2. \\
\hline
\end{tabular}

INVERSE OF MATRIX.

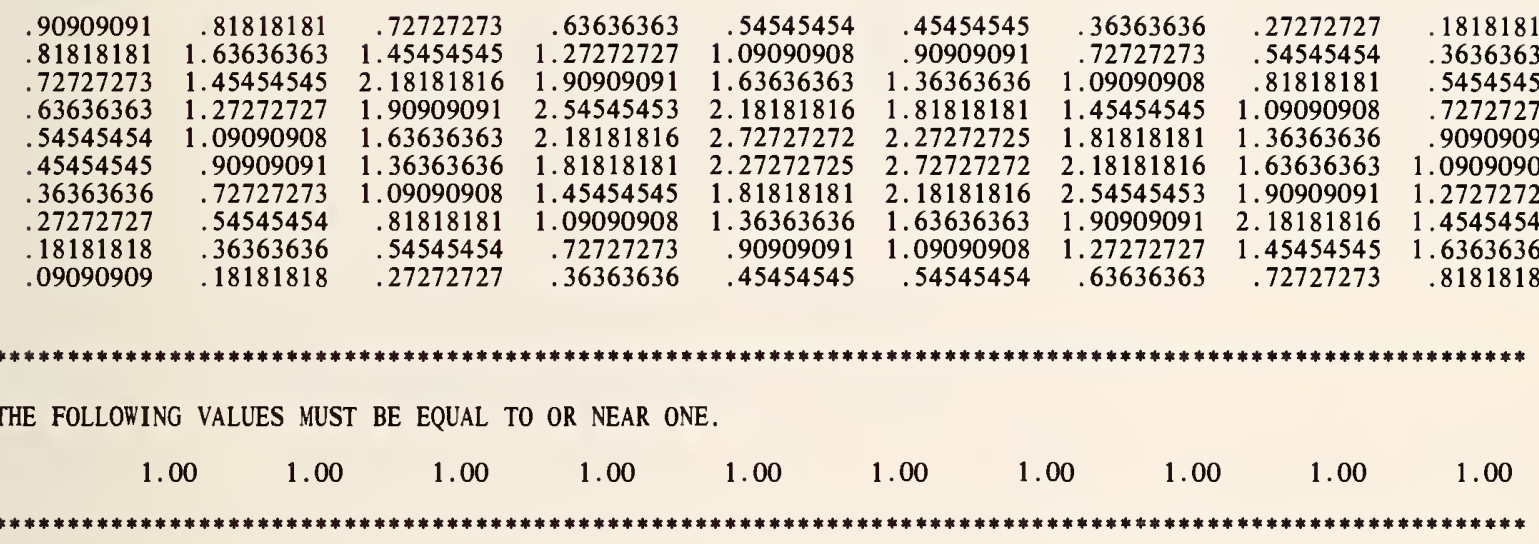


ONIITAB 80 TEST F4 SOLVE LINEAR EQUATIONS AND INVERT MATRIX. (8.5) AND (11.5) PAGE 2

$$
\text { SOLVE } A X=Y
$$

MATRIX A

$$
\mathrm{X}
$$

Y

$\begin{array}{rrrrrrrrrrrr}2 . & -1 . & 0 . & 0 . & 0 . & 0 . & 0 . & 0 . & 0 . & 0 . & 9.9999999-000 & .5 \\ -1 . & 2 . & -1 . & 0 . & 0 . & 0 . & 0 . & 0 . & 0 . & 0 . & 1.9500000-001 & 1.0 \\ 0 . & -1 . & 2 . & -1 . & 0 . & 0 . & 0 . & 0 . & 0 . & 0 . & 2.8000000-001 & 1.5 \\ 0 . & 0 . & -1 . & 2 . & -1 . & 0 . & 0 . & 0 . & 0 . & 0 . & 3.5000000-001 & 2.0 \\ 0 . & 0 . & 0 . & -1 . & 2 . & -1 . & 0 . & 0 . & 0 . & 0 . & 4.0000000-001 & 2.5 \\ 0 . & 0 . & 0 . & 0 . & -1 . & 2 . & -1 . & 0 . & 0 . & 0 . & 4.2500000-001 & 3.0 \\ 0 . & 0 . & 0 . & 0 . & 0 . & -1 . & 2 . & -1 . & 0 . & 0 . & 4.2000000-001 & 3.5 \\ 0 . & 0 . & 0 . & 0 . & 0 . & 0 . & -1 . & 2 . & -1 . & 0 . & 3.8000000-001 & 4.0 \\ 0 . & 0 . & 0 . & 0 . & 0 . & 0 . & 0 . & -1 . & 2 . & -1 . & 3.0000000-001 & 4.5 \\ 0 . & 0 . & 0 . & 0 . & 0 . & 0 . & 0 . & 0 . & -1 . & 2 . & 1.7500000-001 & 5.0\end{array}$

THE FOLLORING VALLE MLST BE EQUAL TO OR MEAR ZERO.

0 . 
OMNITAB 80 TEST F4 SOLVE LINEAR EQUATIONS AND INVERT MATRIX. (8.5) AND (11.5) PAGE 3 MATRIX TO BE INVERTED.

$\begin{array}{crrrrrr}\text { ROH/COL } & 2 & 3 & 4 & 5 & 6 & 7 \\ 1 & 27720.0 & 13860.0 & 9240.0 & 6930.0 & 5544.0 & 4620.0 \\ 2 & 13860.0 & 9240.0 & 6930.0 & 5544.0 & 4620.0 & 3960.0 \\ 3 & 9240.0 & 6930.0 & 5544.0 & 4620.0 & 3960.0 & 3465.0 \\ 4 & 6930.0 & 5544.0 & 4620.0 & 3960.0 & 3465.0 & 3080.0 \\ 5 & 5544.0 & 4620.0 & 3960.0 & 3465.0 & 3080.0 & 2772.0 \\ 6 & 4620.0 & 3960.0 & 3465.0 & 3080.0 & 2772.0 & 2520.0\end{array}$

THE ABOVE MATRIX IS 27720.0 TIMES THE HILBERT MATRIX OF ORDER 6.

INVERSE OF MATRIX.

$\begin{array}{crrrrrr}\text { ROW/COL } & 2 & 3 & 4 & 5 & 6 & 7 \\ 7 & 1.298701-003 & -2.272727-002 & 1.212121-001 & -2.727273-001 & 2.727273-001 & -1.000000-001 \\ 8 & -2.272727-002 & 5.303030-001 & -3.181818+000 & 7.636364+000 & -7.954545+000 & 3.000000+000 \\ 9 & 1.212121-001 & -3.181818+000 & 2.036364+001 & -5.090909+001 & 5.454545+001 & -2.100000+001 \\ 10 & -2.727273-001 & 7.636364+000 & -5.090909+001 & 1.309091+002 & -1.431818+002 & 5.600000+001 \\ 11 & 2.727273-001 & -7.954545+000 & 5.454545+001 & -1.431818+002 & 1.590909+002 & -6.300000+001 \\ 12 & -1.000000-001 & 3.000000+000 & -2.100000+001 & 5.600000+001 & -6.300000+001 & 2.520000+001\end{array}$

THE FOLLGWING VALUES MUST BE EQUAL TO OR NEAR ONE.

HOREVEF IN INVERTING THE MATRIX A, SOME SIGNIFICANCE IS LOST.

IF DONE IN DOUBLE PRECISION OR ON MACHINE RHICH HAS MORE THAN 8

SIGNIFICANT DIGITS, BETTER RESULTS WILL BE OBTAINED.

$\begin{array}{llllll}1.0000044 & 1.0001724 & 1.0119752 & .98724808 & .98523353 & 1.0009356\end{array}$ 
OMNITAB 80 TEST F4 SOLVE LINEAR EQUATIONS AND INVERT MATRIX. (8.5) AND (11.5) PAGE 4

SOLVE $A X=Y$

MATRIX A $X$

27720. 13860. 9240. 6930. 5544. 4620. $-7.7922078-003 \quad 1$.

13860. 9240. 6930. 5544. 4620. 3960. 2.6515152-001 2 .

9240. 6930. 5544. 4620. 3960. 3465. $-2.0606061 \div 000 \quad 3$.

6930. 5544. 4620. 3960. 3465. 3080. 6.0000000-000 4.

5544. 4620. 3960. 3465. 3080. 2772. $-7.2727273-000 \quad 5$.

4620 . 3960. 3465. 3080. 2772. 2520. 3.1000000-000 6.

THE FOLLORING VALUE MUST BE EQUAL TO OR NEAR ZERO.

HOREVER IN INVERTING THE MATRIX A, SOYE SIGNIFICANCE IS LOST.

IF DONE IN DOUBLE PRECISION OR ON MACHINE RHICH HAS MORE THAN 8

SIGNIFICANT DIGITS, BETTER RESULTS RILL BE OBTAINED.

* 7.4212749-05 
LIST OF DATA, INSTRUCTIONS AND DIAGNOSTICS

READ MATRIX DATA IN COLS $1,2,3,4,5,6,7,8,9$ AND 10

2. -1.0 . 0 . 0.0 . 0.0 . 0.0 . 0.0 .

$\begin{array}{llllllllll}-1 \text {. 2. } & -1 . & 0 . & 0 . & 0 . & 0 . & 0 . & 0 . & 0 .\end{array}$

0. $-1.2 .-1.0$. 0.0 .0 .0 .0 .0 .0$.

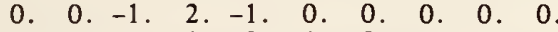

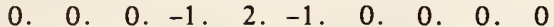

$\begin{array}{lllllllllll}0 . & 0 . & 0 . & 0 . & -1 . & 2 . & -1 . & 0 . & 0 . & 0 .\end{array}$

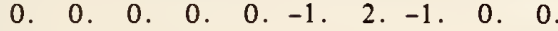

$\begin{array}{llllllllll}0 . & 0 . & 0 . & 0 . & 0 . & 0 . & -1 . & 2 . & -1 & 0\end{array}$

$\begin{array}{lllllllllll}0 . & 0 . & 0 . & 0 . & 0 . & 0 . & 0 . & -1 . & 2 . & -1\end{array}$

$0.0 .0 .0 .0 .0 .0 .0 .-1,2$.

* INFORMATIVE DIAGNOSTIC FOR THE ABOVE INSTRUCTION NRMAX HAS BEEN RESET FROM O TO 10.

MINVERT MATRIX A IN ROW 1 COL 1 SIZE 1OX10 PUT INVERT MATRIX B IN ROW 1 COL 11 $++t+$ SMALLEST ERROR BOUND ON INVERTED MATRIX IS .2-005

NEW PAGE

FORMAT D (1OF12.0)

NOTE MATRIX TO BE INVERTED.

SPACE

MPRINT D FORMAT, MATRIX A IN ROW 1 OF COL 1 SIZE $10 \times 10$

SPACE 2

NOTE INVERSE OF MATRIX.

SPACE

FORYAT B (10F12.8)

MPRINT B FORMAT, MATRIX B IN ROW 1 OF COL 11 SIZE $10 \times 10$

MMULT A IN $R=1 \quad C=1$ SIZE $10 \times 10$ BY B IN $R=1 \quad C=11$ SIZE $10 \times 10$ PUT IN $R=1 \quad C=21$

$1 /$ SUM COL 21 STORE IN COL 21

2/ INCREMENT INSTRUCTION 1 BY 1 AND 1

REPEAT 1 THRU 2, 10 TIMES

SPACE 2

NOTE $1 * * * * * * * * * * * * * * * * * * * * * * * * * * * * * * * * * * * * * * * * * * * * * * * * * * * * * * * *$

NOTE2 $2 * * * * * * * * * * * * * * * * * * * * * * * * * * * * * * * * * * * * * * * * * * *$

PRINT NOTE

SPACE

NOTE THE FOLLOWING VALUES MUST BE EQUAL TO OR NEAR ONE.

SPACE

FORMAT C $(5 X, 10 \mathrm{~F} 10.2)$

ABR IDGE C FORMAT, ROW 1 OF COLS $21 * * * 30$

SPACE

PRINT NOTE

GENERATE Y FROM .5 IN STEPS OF .5 THRU 5. PUT IN COL 12

SOLVE AX=Y, A IN ROW 1 OF COL 1 SIZE $10 X 10$ Y IN COL 12 STORE X IN COL 11

++++ SMALLEST ERROR BOUND ON INVERTED MATRIX IS .2-005

NEH PAGE

NOTE

SOLVE $A X=Y$

SPACE

NOTE

MATRIX A

$\mathrm{X}$

SPACE 
LIST OF DATA, INSTRUCTIONS AND DIAGNOSTICS

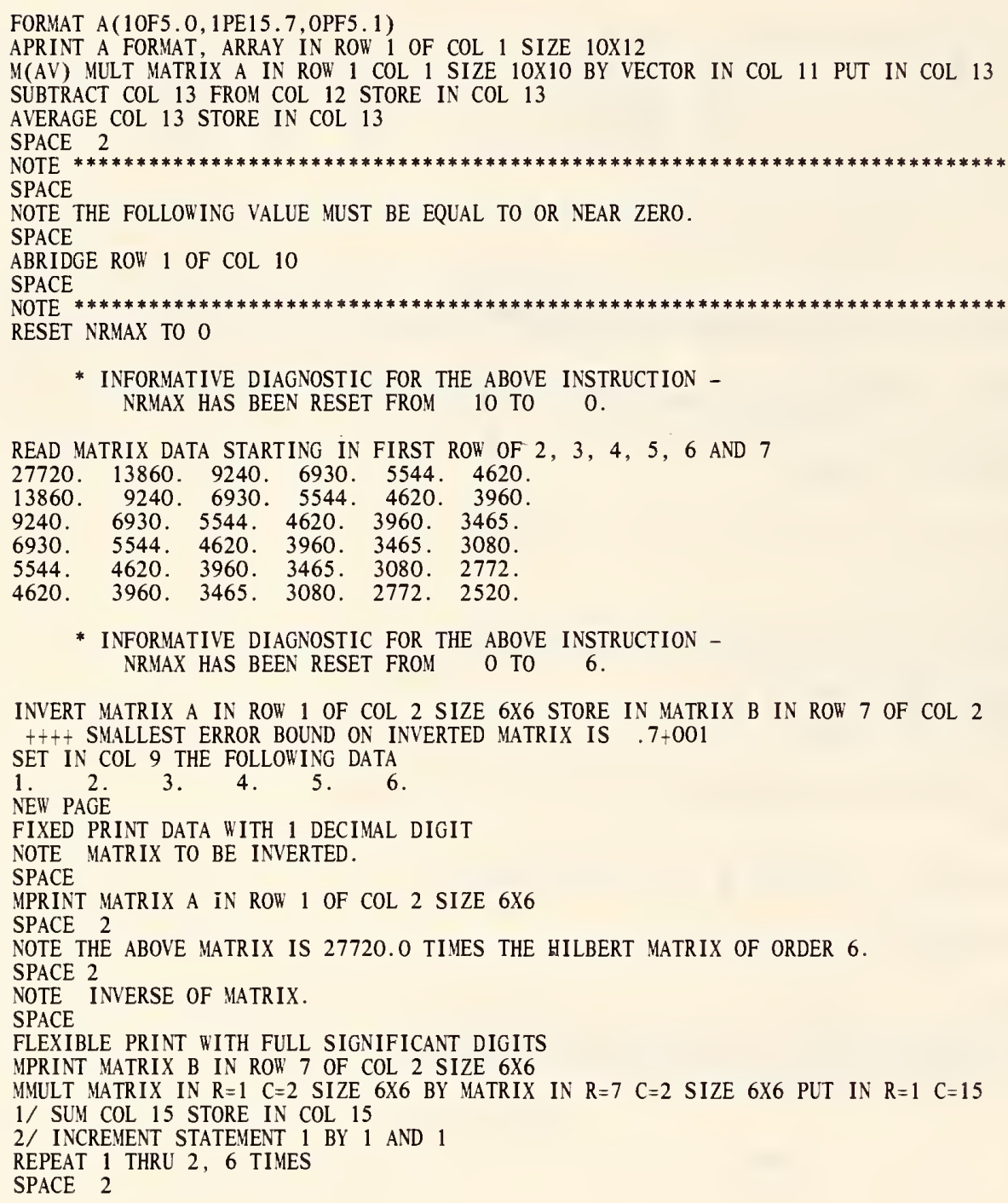


LIST OF DATA, INSTRUCTIONS AND DIAGNOSTICS

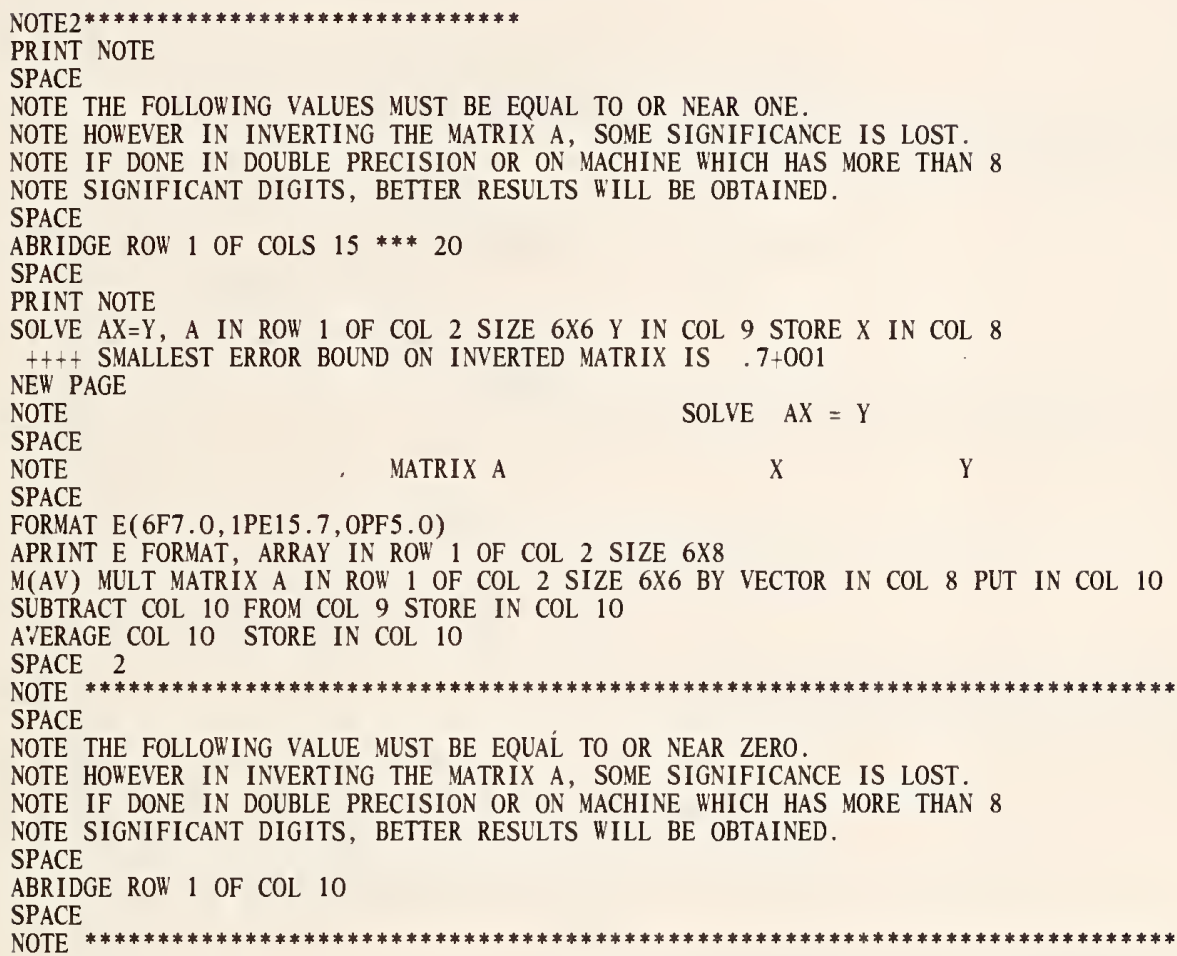

NATIONAL BUREAU OF STANDARDS. WASHINGTON, D. C. 20234 OMNITAB 80 VERSION 6.00 MARCH 2,1981 
THIS IS A TEST ON THE BRANCH COMMANDS.

THUS THE OUTPUT MUST BE AS FOLLOWS.

BECAUSE THE IFGT CONDITION IS TRUE, REPEAT MODE IS TERMINATED

AND THE FOLLOWING STATEMENT IS PRINTED ONLY ONCE.

THE FOLLOWING VALUE MUST BE NEAR OR EQUAL TO 25.

25.0

BECAUSE THE IFGE CONDITION IS TRUE, REPEAT MODE IS TERMINATED

AND THE FOLLOWING STATEMENT IS PRINTED ONLY ONCE.

THE FOLLOWING VALUE MUST BE NEAR OR EQUAL TO 25.

25.0

BECAUSE THE IFLT CONDITION IS TRUE, REPEAT MODE IS TERMINATED

AND THE FOLLOWING STATEMENT IS PRINTED ONLY ONCE.

THE FOLLOWING VALUE MUST BE NEAR OR EQUAL TO 25.

25.0

BECAUSE THE IFLE CONDITION IS TRUE, REPEAT MODE IS TERMINATED

AND THE FOLLOWING STATEMENT IS PRINTED ONLY ONCE.

THE FOLLOWING VALUE MUST BE NEAR OR EQUAL TO 25.

25.0

BECAUSE THE COMPARE CONDITION IS TRUE, REPEAT MODE IS TERMINATED

AND THE FOLLOWING STATEMENT IS PRINTED ONLY ONCE.

THE FOLLOWING VALUE MUST BE NEAR OR EQUAL TO 25.

25.0 
LIST OF DATA, INSTRUCTIONS AND DIAGNOSTICS

GENERATE $X$ FROM 0.0 IN STEPS OF 10.0 THRU 50. IN COL 1

* INFORMATIVE DIAGNOSTIC FOR THE ABOVE INSTRUCTION NRMAX HAS BEEN RESET FROM O TO 6.

ADD COL 1 TO 0.0 STORE IN COL 2

FORMAT $F(50 \mathrm{H}$ THE FOLLOWING VALUE MUST BE NEAR OR EQUAL TO 25./10X,F5.1)

1/ AVERAGE COL 2 STORE IN COL 10

2/ IFGT IF COL 10 IS GREATER THAN 27.0 STOP REPEAT MODE

3/ NULL OTHERWISE CONTINUE

4/ ABRIDGE F FORMAT, ROW 1 OF COL 10

5/ ADD 10.0 TO COL 2 STORE IN COL 2

10/ ADD 0.0 TO COL 1 STORE IN COL 2

NEW PAGE

NOTE THIS IS A TEST ON THE BRANCH COMMANDS.

NOTE THUS THE OUTPUT MUST BE AS FOLLOWS.

SPACE 2

NOTE *

SPACE

NOTE BECAUSE THE IFGT CONDITION IS TRUE, REPEAT MODE IS TERMINATED

NOTE AND THE FOLLOWING STATEMENT IS PRINTED ONLY ONCE.

REPEAT INSTRUCTION 10 THRU 10,1 TIME

KEPEAT INSTRUCTIONS 1 THRU 5, 3 TIMES

SPACE

NOTE $* * * * * * * * * * * * * * * * * * * * * * * * * * * * * * * * * * * * * * * * * * * * * * * * * * * * * * * * * * * * * * * * * * * * * * * * *$

SPACE 2

NOTE $* * * * * * * * * * * * * * * * * * * * * * * * * * * * * * * * * * * * * * * * * * * * * * * * * * * * * * * * * * * * * * * * * * * * * * * * *$

SPACE

NOTE BECAUSE THE IFGE CONDITION IS TRUE, REPEAT MODE IS TERMINATED

NOTE AND THE FOLLOWING STATEMENT IS PR INTED ONLY ONCE.

2/IFGE IF COL 10 IS GREATER THAN OR EQUAL TO 30.0 STOP REPEAT MODE

REPEAT INSTRUCTION 10 THRU 10,1 TIME

REPEAT INSTRUCTIONS 1 THRU 5,3 TIMES

SPACE

NOTE $* * * * * * * * * * * * * * * * * * * * * * * * * * * * * * * * * * * * * * * * * * * * * * * * * * * * * * * * * * * * * * * * * * * * *$

SPACE 2

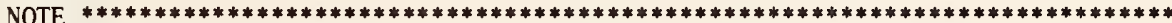

SPACE

NOTE BECAUSE THE IFLT CONDITION IS TRUE, REPEAT MODE IS TERMINATED

NOTE AND THE FOLLOWING STATEMENT IS PRINTED ONLY ONCE.

2/IFLT IF 27.0 IS LESS THAN ALL VALUES OF COL 10 STOP REPEAT MODE

REPEAT INSTRUCTION 10 THRU 10,1 TIME

REPEAT INSTRUCTIONS 1 THRU 5, 3 TIMES

SPACE

NOTE $* * * * * * * * * * * * * * * * * * * * * * * * * * * * * * * * * * * * * * * * * * * * * * * * * * * * * * * * * * * * * * * * * * * * *$

SPACE 2

NOTE $* * * * * * * * * * * * * * * * * * * * * * * * * * * * * * * * * * * * * * * * * * * * * * * * * * * * * * * * * * * * * * * * * * * * * * *$

SPACE

NOTE BECAUSE THE IFLE CONDITION IS TRUE, REPEAT MODE IS TERMINATED

NOTE AND THE FOLLOWING STATEMENT IS PRINTED ONLY ONCE. 
LIST OF DATA, INSTRUCTIONS AND DIAGNOSTICS

2/IFLE IF 30.0 IS LESS THAN OR EQUAL TO ALL VALUES IN COL 10 STOP REPEAT YODE REPEAT INSTRLCTION 10 THRU 10, 1 TIME

REPEAT IISTRUCTIONS 1 THRU 5, 3 TIMES

SPACE

SPACE 2

NOTE

SPACE

NOTE BECAUSE THE COMPARE CONDITION IS TRUE, REPEAT MODE IS TERMINATED

NOTE AND THE FOLLOH'ING STATEMENT IS PRINTED ONLY ONCE.

2/ COMPARE COL 10 HITH VALLE 35. RELATIVE ERROR OF 91E-3

REPEAT INSTRLCTION 10 THRU 10, 1 TIME

REPEAT INSTRLCTIONS 1 THRU 5, 3 TIMES

SPACE

VOTE

NATIONAL BUREAU OF STANDARDS. WASHINGTON, D. C. 20234 OMNITAB 80 VERSION 6.00 MARCH 2, 1981 
OMNITAB 80 TEST F6 ARRAY AND MATRIX INSTRUCTIONS. $(10.1),(10.2),(11.1),(11.3)$ PAGE 1

THE FOLLOWING IS AN EXAMPLE OF THE MKRONECKER COMMAND. MATRIX A' WAS DEFINED BY MDEFINE. MATRIX B WAS DEFINED BY THE MDIAGONAL, MADD, AND AERASE COMMANDS. MATRIX C WAS DEFINED BY THE MKRONECKER COMMAND.

MATRIX A

2.0000000

2.0000000

0 .

0 .
MATRIX B

3.0000000
2.0000000
0.

0 . MATRIX C

ARRAYS

A

2.00

2.00

2.00
2.00

B

3.00

2.00
$D=A * B$

6.00

4.00
4. 0000000

0.

4.0000000

6.0000000

4.0000000
0 .
6.0000000

4.0000000

6.0000000

4.0000000
4. 0000000

4.0000000

ARRAYS

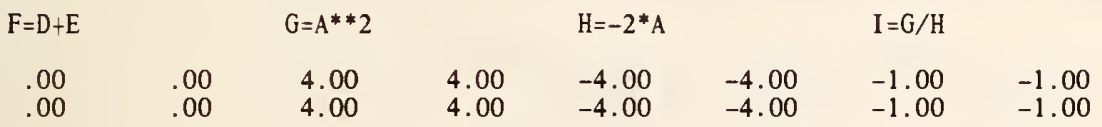

THE FOLLOWING VALUE MLST BE EQUAL TO OR NEAR ZERO.

0 . 
OMNITAB 80 TEST F6 ARRAY AND MATRIX INSTRUCTIONS. (10.1), (10.2), (11.1), (11.3) PAGE

LIST OF DATA, INSTRUCTIONS AND DIAGNOSTICS

MDEFINE EVERY ELEMENT OF MATRIX A IN ROH 1 COL 1 SIZE 2 X2 HITH THE VALLE OF 2.0 MDIAGONAL THE DIAGONAL OF MATR IX B IN ROH 1 OF COL 3 , SIZE $2 \times 2$, IS SET $=1.0$ MADD ADD MAT A IN $R=1 \quad C=1$ SIZE $2 X 2$ TO MATRIX B $R=1 \quad C=3$ SIZE $2 X 2$ PLT IN $R=1 \quad C=3$ AERASE ERASE ALL ELEYENTS OF YATRIX B IN ROF' 2 OF COL 4 SIZE $1 X 1$ MKRONE KRONECKER PROD OF A $R=1 \quad C=1$ SIZE $2 X 2$ BY $B \quad R=1 \quad C=3$ SIZE $2 X 2$ INTO $C R=1 \quad C=5$ RESET IRMAX TO 4

- INFORMATIVE DIAGNOSTIC FOR THE ABOVE INSTRUCTION NRMAX HAS BEEN RESET FRON 0 TO 4.

TITLE1 THE FOLLOWING IS AN EXAMPLE OF THE YRRONECKER COMMAND. MATR TITLE2 IX A RAS DEFINED BY MDEFINE. MATRIX B RAS DEFINED BY THE TITLE3 MDIAGONAL, MADD, AND AERASE COMMANDS. MATRIX C TAS DEFINED TITLE4BY THE MKRONECKER COMMAND.

HEAD COL 1/ MATRIX A

HEAD COL $2 /$

$\mathrm{HEAD} \mathrm{COL} 3 /$

HEAD COL $4 /$

HEAD COL 5/ MATRIX C

HEAD COL 6/

HEAD COL 7/

HEAD COL $8 /$

PRINT COLS $1 * * * 8$

AYULT MULTIPLY ARRAY IN A $R=1 \quad C=1$ SIZE $2 \times 2$ BY ARRAY IN $B \quad R=1 \quad C=3$ PLT IS $R=1 \quad C=9$ MSCALAR MULTIPLY MATR IX B $R=1 \quad C=3$ SIZE $2 X 2$ BY THE SCALER $=-2.0$ PUT IN $R=1 \quad C=11$ AADD ADD ARRAY IS $R=1 \quad C=9$ SIZE $2 X 2$ TO ARRAY IN $R=1 \quad C=11$ SIZE $2 \times 2$ PLT IN $R=1 \quad C=13$ ARAISE EVERY TERY OF ARRAY IN $R=1 \mathrm{C}=1$ SIZE $2 \times 2$ BY THE PORER 2.0 PUT IN $R=1 \mathrm{C}=15$ MSCALAR YULTIPLY MATRIX $R=1 \quad C=1$ SIZE $2 X 2$ BY THE SCALER $=-2.0$ PLT IN $R=1 \quad C=17$ ADIVIDE DIVIDE ARRAY IN $R=1 \quad C=15$ SIZE $2 X 2$ BY ARRAY IN $R=1 \quad C=17$ PLT IN $R=1 \quad C=19$ AMULTIPLY ARRAY B ROH' 1 COL 3 SIZE $2 X 2$ BY THE VALLE 2.0 PUT IN ROH 1 COL 21 ADEFINE ELERY TERM OF ARRAY J IN ROH 1 COL 23 SIZE $2 X 2$ IS SET $=1.0$ ADIV DIVIDE ARRAY E IN $R=1 \quad C=11$ SIZE $2 \times 2$ BY ARRAY J IN $R=1 \quad C=21$ PLT IN $R=1 \quad C=25$ SPACE 2

RESET IRMAX EQUAL TO 2

* INFORMATIVE DIAGNOSTIC FOR THE ABOVE INSTRLCTION NRMAX HAS BEEN RESET FROM 4 TO 2.

YOTE ARRAYS

SPACE
NOTE A B

SPACE

,

FORMAT C (8F10.2)

NPRINT C FORMAT, COLUMNS $1,2,3,4,9,10,11$ AND 12

SPACE 2

NOTE ARRAYS

SPACE

NOTE $\quad F=D-E$

$G=A * 2$

$H=-2 * A$

$\mathrm{I}=\mathrm{G} / \mathrm{H}$

SPACE

FORMAT B $(8 \mathrm{~F} 10.2)$ 
OMNITAB 80 TEST F6 ARRAY AND MATRIX INSTRUCTIONS. (10.1), (10.2), (11.1), (11.3) PAGE 3

LIST OF DATA, INSTRUCTIONS AND DIAGNOSTICS

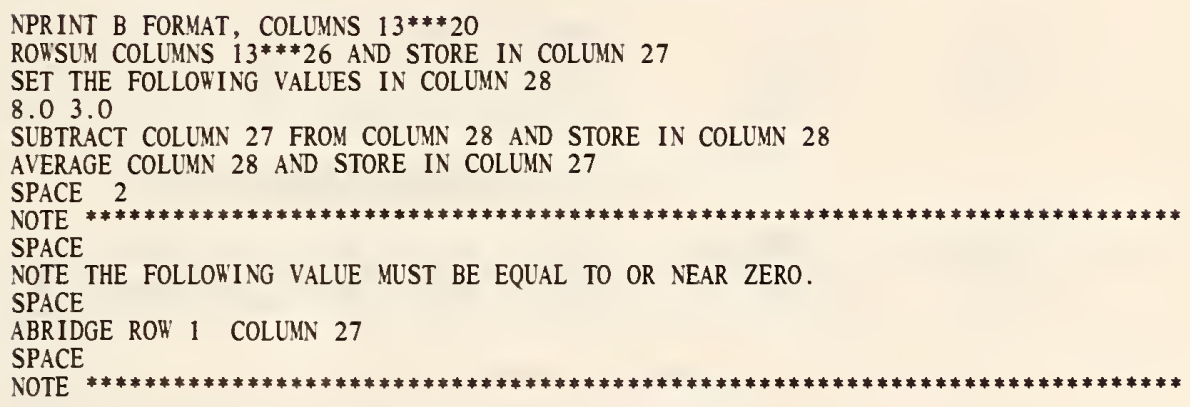

NATIONAL BUREAU OF STANDARDS. WASHINGTON, D. C. 20234 OMNITAB 80 VERSION 6.00 MARCH 2, 1981 
OMNITAB 80 TEST F7 MATRIX INSTRUCTIONS M(AD), M(DA) AND M(V'A), (11.4)

THE FOLLOWING IS AN EXAMPLE OF M(AD) M(DA) AND M(V'A).

\begin{tabular}{|c|c|c|c|c|}
\hline $\begin{array}{l}\text { MATRIX A } \\
\text { ROW/COL } \\
1 \\
2 \\
3\end{array}$ & $\begin{array}{l}1 \\
1.00 \\
2.00 \\
3.00\end{array}$ & $\begin{array}{r}2 \\
6.00 \\
3.00 \\
-1.00\end{array}$ & $\begin{array}{l}3 \\
3.00 \\
2.00 \\
1.00\end{array}$ & \\
\hline $\begin{array}{c}\text { MATRIX B } \\
\text { ROW/COL } \\
1 \\
2 \\
3\end{array}$ & $\begin{array}{r}4 \\
3.00 \\
.00 \\
.00\end{array}$ & $\begin{array}{r}5 \\
.00 \\
-2.00 \\
.00\end{array}$ & $\begin{array}{r}6 \\
.00 \\
.00 \\
1.00\end{array}$ & $\begin{array}{c}\text { DIAGONAL OF MATRIX B } \\
7 \\
3.00 \\
-2.00 \\
1.00\end{array}$ \\
\hline
\end{tabular}

MATRIX C=MATRIX A TIMES THE DIAGONAL OF MATRIX B. COMMAND IS M(AD).

$\begin{array}{ccrr}\text { ROW/COL } & 8 & 9 & 10 \\ 1 & 3.00 & -12.00 & 3.00 \\ 2 & 6.00 & -6.00 & 2.00 \\ 3 & 9.00 & 2.00 & 1.00\end{array}$

MATRIX D=DIAGONAL OF MATRIX B TIMES MATRIX A. COMMAND IS M(DA).

$\begin{array}{crrr}\text { ROW/COL } & 11 & 12 & 13 \\ 1 & 3.00 & 18.00 & 9.00 \\ 2 & -4.00 & -6.00 & -4.00 \\ 3 & 3.00 & -1.00 & 1.00\end{array}$

THE FOLLOWING VALUE MUST BE EQUAL TO OR NEAR ZERO.

.00

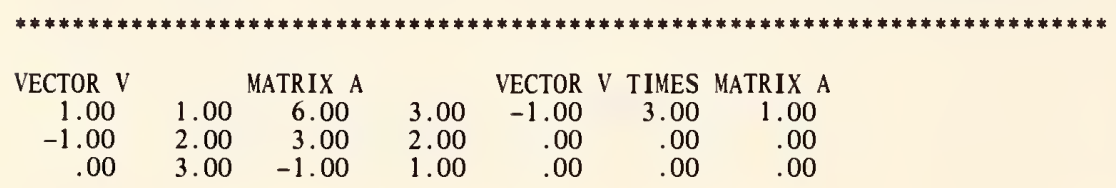

THE FOLLOWING VALUE MUST BE EQUAL TO OR NEAR ZERO.

.00 
LIST OF DATA, INSTRUCTIONS AND DIAGNOSTICS

READ THE FOLLOWING DATA INTO COLUMNS $1 * * * 7$

$\begin{array}{rrrrrrr}1.0 & 6.0 & 3.0 & 3.0 & 0.0 & 0.0 & 3.0 \\ 2.0 & 3.0 & 2.0 & 0.0 & -2.0 & 0.0 & -2.0 \\ 3.0 & -1.0 & 1.0 & 0.0 & 0.0 & 1.0 & 1.0\end{array}$

* INFORMATIVE DIAGNOSTIC FOR THE ABOVE INSTRUCTION NRMAX HAS BEEN RESET FROM O TO 3.

M(AD) POST MULT A IN $R=1 \quad C=1$ SIZE $3 \times 3$ WITH $D$ WHOSE DIAG IS IN COL 7 PUT $R=1 C=8$ $\mathrm{M}(\mathrm{DA})$ PRE MULT A IN $\mathrm{R}=1 \mathrm{C}=1$ SIZE $3 \times 3$ WITH $\mathrm{D}$ WHOSE DIAG IS IN COL 7 PUT $\mathrm{R}=1 \mathrm{C}=11$ TITLE 1 THE FOLLOWING IS AN EXAMPLE OF M(AD) M(DA) AND M(V'A).

NEW PAGE

SPACE

NOTE MATRIX A

FIXED PRINT DATA WIHT 2 DECIMAL DIGITS

MPRINT MATRIX IN ROW 1 OF COL 1 SIZE $3 \times 3$

SPACE 2

NOTE MATRIX B

MPRINT MATRIX IN ROW 1 OF COL 4 SIZE $3 X 4$

DIAGONAL OF MATRIX B

SPACE 2

NOTE MATRIX C=MATRIX A TIMES THE DIAGONAL OF MATRIX B. COMMAND IS M(AD).

MPRINT MATRIX $C$ IN ROW 1 OF COL 8 SIZE $3 X 3$

SPACE 2

NOTE MATRIX D=DIAGONAL OF MATRIX B TIMES MATRIX A. COMMAND IS M(DA).

MPRINT MATRIX D IN ROW 1 OF COL 11 SIZE $3 X 3$

MMULT MULTIPLY A IN $R=1 \quad C=1$ SIZE $3 \times 3$ BY $B$ IN $R=1 \quad C=4$ SIZE $3 \times 3$ PUT IN $R=1 \quad C=14$

MMULTIPLY $B$ IN $R=1 \quad \mathrm{C}=4$ SIZE $3 \times 3$ BY $A$ IN $\mathrm{R}=1 \mathrm{C}=1$ SIZE $3 \times 3$ PUT IN $\mathrm{R}=1 \quad \mathrm{C}=17$

MSUB MATRIX IN $\mathrm{R}=1 \quad \mathrm{C}=8$ SIZE $3 \times 3$ MINUS MATRIX IN $\mathrm{R}=1 \quad \mathrm{C}=14$ SIZE $3 X 3$ PUT IN 1,20

MSUB MATRIX IN $\mathrm{R}=1 \mathrm{C}=11$ SIZE $3 \times 3$ MINUS MATRIX IN $\mathrm{R}=1 \quad \mathrm{C}=17$ SIZE $3 \times 3$ PUT IN 1,23

ROWSUM COLUMNS 20***25 AND STORE IN COLUMN 26

AVERAGE COLUMN 26 AND STORE IN COLUMN 26

SPACE 2

NOTE ***

SPACE

NOTE THE FOLLOWING VALUE MUST BE EQUAL TO OR NEAR ZERO.

SPACE

ABRIDGE ROW 1 OF COLUMN 26

SPACE

NOTE ***

SET THE FOLLOWING VALUES IN COLUMN 27

$1.0-1.0 \quad 0.0$

$M\left(V^{\prime} A\right)$ PRE MULT A IN R=1 C=1 SIZE $3 X 3$ BY TRANS OF $V$ IN COL 27 PUT IN $R=1 \quad C=28$

SPACE

NOTE VECTOR $V$ MATRIX A VECTOR $V$ TIMES MATRIX A

FORMAT C (F8.2,6F8.2)

NPRINT C FORMAT, COLUMNS 27, 1, 2, 3, 28, 29 AND 30

SPACE

ROWSUM COLUMNS 28, 29 AND 30 AND STORE IN COLUMN 31

SUB 3.0 FROM COLUMN 31 AND STORE IN COLUMN 32

SPACE 2 
OMNITAB 80 TEST F7 MATRIX INSTRUCTIONS $M(A D), M(D A)$ AND $M\left(V^{\prime} A\right)$. (11.4)

LIST OF DATA, INSTRUCTIONS AND DIAGNOSTICS

NOTE

SPACE

NOTE THE FOLLOWING VALUE MUST BE EQUAL TO OR NEAR ZERO.

SPACE

ABRIDGE ROW 1 OF COLUMN 32

SPACE

NOTE $* * * * * * * * * * * * * * * * * * * * * * * * * * * * * * * * * * * * * * * * * * * * * * * * * * * * * * * * * * * * * * * * * * * * *$

NATIONAL BUREAU OF STANDARDS. WASHINGTON, D. C. 20234

OMNITAB 80 VERSION 6.00 MARCH 2,1981 
OMNITAB 80 TEST F8 EXAMPLES OF MATRIX INSTRUCTIONS $M\left(X^{\prime} X^{\prime}\right)$ AND $M\left(X^{\prime} A X\right) \cdot(11.4) \quad$ PAGE 1 THE FOLLOWING IS AN EXAMPLE OF $M\left(X A X^{\prime}\right)$ AND $M\left(X^{\prime} A X\right)$.

\begin{tabular}{|c|c|c|c|c|c|c|c|}
\hline MATRIX A & & ATRIX X & & & ATRIX X & & \\
\hline $\begin{array}{r}1.00 \\
2.00 \\
.00\end{array}$ & $\begin{array}{r}3.00 \\
-4.00 \\
.00\end{array}$ & $\begin{array}{r}-2.00 \\
-1.00 \\
3.00\end{array}$ & $\begin{array}{l}.00 \\
5.00 \\
1.00\end{array}$ & $\begin{array}{r}-2.00 \\
.00 \\
.00\end{array}$ & $\begin{array}{r}-2.00 \\
.00 \\
-2.00\end{array}$ & $\begin{array}{r}-1.00 \\
5.00 \\
.00\end{array}$ & $\begin{array}{r}3.00 \\
1.00 \\
.00\end{array}$ \\
\hline
\end{tabular}

MATRIX $B=X^{\prime} X^{\prime}$

( $\mathrm{X}$ IS 3 BY 2, $\mathrm{A}$ IS 2 BY 2)

MATRIX $C=X^{\prime} A X$

( $X$ IS 2 BY 3 , A IS 2 BY 2)

$\begin{array}{rrr}4.0000000 & -28.000000 & -12.000000 \\ -18.000000 & -124.00000 & 4.0000000\end{array}$

10.000000

0 .

10.000000

$-10.000000$

$-100.00000$

8.0000000

$-20.000000$

$-10.000000$

20.000000

20.000000

$-30.000000$

4.0000000

THE FOLLOWING VALUE MUST BE EQUAL TO OR NEAR ZERO.

0 . 
LIST OF DATA, INSTRLCTIONS AND DIAGNOSTICS

DIM DIMENSION HORKSHEET SIZE 3 ROHS BY 26 COLLMS

READ MATRIX A INTO COLS 13 AND 14 , MATRIX X INTO $15^{* * *} 17$, X TRANSPOSE IN $18 * * 20$

$\begin{array}{llllllll}1.0 & 3.0 & -2.0 & 0.0 & -2.0 & -2.0 & -1.0 & 3.0\end{array}$

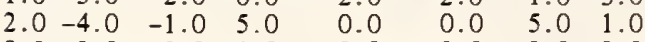

$\begin{array}{llllllll}0.0 & 0.0 & 3.0 & 1.0 & 0.0 & -2.0 & 0.0 & 0.0\end{array}$

* INFORMATIVE DiAgNostic FOR thE ABOVE INSTRLCTION NRMAX HAS BEEY RESET FROM O TO 3.

M(XAX') PREMULT A $(1,13)$ SIZE $2 X 2$ BY $X(1,15)$ SIZE $3 X 2$ POST MULT BY $X^{\prime}$ STORE 1,1 M( $\left.X^{\prime} A X\right)$ PREMULT A $(1,13)$ SIZE $2 X 2$ BY $X^{\prime}(1,15)$ SIZE $2 X 3$ POST YULT BY $X$ STORE 1,4 MMULT X IN ROH 1 COL 15 SIZE $3 X 2$ BY A ROH 1 COL 13 SIZE $2 X 2$ PUT IN ROH 1 COL 21 IMULT XA IN $R=1 \quad C=21$ SIZE $3 \times 2$ BY TRAIS OF $X$ IN $R=1 \quad C=18$ SIZE $2 \times 3$ PUT IN $R=1 \quad C=21$ MMLLT TRAIS OF $X$ IN $R=1 \quad C=18$ SIZE $3 X 2$ BY A IN $R=1 \quad C=13$ SIZE $2 X 2$ PUT IN $R=1 \quad C=24$ MMCLT $X^{\prime} A$ IN $R=1 \quad C=24$ SIZE $3 X 2$ BY $X$ IN $R=1 \quad C=15$ SIZE $2 \times 3$ PUT IN $R=1 \quad C=24$ MSCALAR MULTIPLY THE ARRAY IN ROF 1 COL 21 SIZE $3 X 6$ BY -1.0 PUT IN ROH 1 COL 7 TITLE1 THE FOLLOWING IS AN EXAMPLE OF M(XAX') AND $M\left(X^{\prime} A X\right)$.

NER PAGE

SPACE

NOTE MATRIX A MATRIX X MATRIX X'

SPACE

FORMAT D (8F8.2)

NPRINT D FORMAT, COLLYNS $13 * * * 20$

SPACE

NOTE MATRIX $B=X A X^{\prime}$

NOTE ( $X$ IS 3 BY 2 , A IS 2 BY 2)

SPACE 2

NPRINT COLUMS $1 * * * 6$

DIMEXSION $\mathrm{NROH}=3$ $\mathrm{YCOL}=12$

ROHSLM THE ENTIRE TORKSHEET AND PUT IN COLLMN 1

AVERAGE COLUMN 1 AID STORE IN COLUMY 1

SPACE 2

NOTE

SPACE

VOTE THE FOLLOHING VALLE MIST BE EQLAL TO OR NEAR ZERO.

SPACE

ABRIDGE ROF 1 OF COLLMI 1

SPACE

NOTE

NATIONAL BLREAU OF STANDARDS. HASHINGTON, D. C. 20234 OMNITAB 80 VERSION 6.00 MARCH 2, 1981 


\begin{tabular}{|c|c|c|c|c|}
\hline $\begin{array}{l}\text { OMNITAB } 80 \text { TEST } \\
\text { CENTIGRADE }\end{array}$ & $\begin{array}{l}\text { F9 TEMP. SCALE } \\
\text { FAHRENHEIT }\end{array}$ & $\begin{array}{l}\text { CONVERSION AND } \\
\text { FAHR TO CENT }\end{array}$ & $\begin{array}{l}\text { ATOMIC WT. (13 } \\
\text { CONVERSION }\end{array}$ & $\begin{array}{l}\text { 1) AND (13.3) } \\
\text { ORMULAS }\end{array}$ \\
\hline COLUMN & COLUMN & COLUMN & COLUMN & COLUMN \\
\hline $\begin{array}{c}-10.000000 \\
-5.0000000 \\
0 . \\
5.0000000 \\
10.000000\end{array}$ & $\begin{array}{l}14.000000 \\
23.000000 \\
32.000000 \\
41.000000 \\
50.000000\end{array}$ & $\begin{array}{l}-9.9999996 \\
-4.9999997 \\
0 . \\
4.9999997 \\
9.9999996\end{array}$ & $\begin{array}{l}14.000000 \\
23.000000 \\
32.000000 \\
41.000000 \\
50.000000\end{array}$ & $\begin{array}{l}-9.9999996 \\
-4.9999997 \\
0 . \\
4.9999997 \\
9.9999996\end{array}$ \\
\hline $\begin{array}{l}15.000000 \\
20.000000 \\
25.000000 \\
30.000000 \\
35.000000\end{array}$ & $\begin{array}{l}59.000000 \\
67.999999 \\
76.999999 \\
85.999999 \\
94.999999\end{array}$ & $\begin{array}{l}15.000000 \\
19.999999 \\
24.999999 \\
29.999999 \\
35.000000\end{array}$ & $\begin{array}{l}59.000000 \\
67.999999 \\
76.999999 \\
85.999999 \\
94.999999\end{array}$ & $\begin{array}{l}15.000000 \\
19.999999 \\
24.999999 \\
29.999999 \\
34.999999\end{array}$ \\
\hline $\begin{array}{l}40.000000 \\
45.000000 \\
50.000000 \\
60.000000 \\
70.000000\end{array}$ & $\begin{array}{l}104.00000 \\
113.00000 \\
122.00000 \\
140.00000 \\
158.00000\end{array}$ & $\begin{array}{l}40.000000 \\
45.000000 \\
50.000000 \\
59.999999 \\
69.999999\end{array}$ & $\begin{array}{l}104.00000 \\
113.00000 \\
122.00000 \\
140.00000 \\
158.00000\end{array}$ & $\begin{array}{l}39.999999 \\
44.999999 \\
49.999999 \\
59.999999 \\
69.999998\end{array}$ \\
\hline $\begin{array}{c}80.000000 \\
90.000000 \\
100.00000\end{array}$ & $\begin{array}{l}176.00000 \\
194.00000 \\
212.00000\end{array}$ & $\begin{array}{l}79.999999 \\
89.999999 \\
99.999999\end{array}$ & $\begin{array}{l}176.00000 \\
194.00000 \\
212.00000\end{array}$ & $\begin{array}{l}79.999998 \\
89.999998 \\
99.999998\end{array}$ \\
\hline
\end{tabular}

THE FOLLOWING VALUES MUST BE EQUAL TO OR NEAR ZERO.
*-5 .3644180-07
0. *-8.5433324-07 
OMNITAB 80 TEST F9 TEMP. SCALE CONVERSION AND ATOMIC WT. (13.1) AND (13.3) PaGE 2

$\begin{array}{rrl}\text { ELEM. NO. } & \text { ATOMIC WT. } & \text { ELEMENT } \\ & & \\ 5 . & 10.81000 & \text { BORON } \\ 10 . & 20.17900 & \text { NEON } \\ 15 . & 30.97376 & \text { PHOSPHORUS } \\ 20 . & 40.08000 & \text { CALCIUM } \\ 25 . & 54.93800 & \text { MANGANESE } \\ 30 . & 65.38000 & \text { ZINC } \\ 35 . & 79.90400 & \text { BROMINE } \\ 40 . & 91.22000 & \text { ZIRCONIUM } \\ 45 . & 102.90550 & \text { RHODIUM } \\ 50 . & 118.69000 & \text { TIN } \\ 55 . & 132.90540 & \text { CESIUM } \\ 60 . & 144.24000 & \text { NEODYMIUM } \\ 65 . & 158.92540 & \text { TEBIUM } \\ 70 . & 173.04000 & \text { YTTERBIUM } \\ 75 . & 186.20000 & \text { RHENIUM } \\ 80 . & 200.59000 & \text { MERCURY } \\ 85 . & 210.00000 & \text { ASTATINE } \\ 90 . & 232.03810 & \text { THORIUM } \\ 95 . & 243.00000 & \text { AMERICIUM } \\ 100 . & 253.00000 & \text { FERMIUM }\end{array}$


LIST OF DATA, INSTRUCTIONS AND DIAGNOSTICS

GENERATE FROM - 10. IN STEPS OF 5. THRU 50. AND STEPS OF 10. THRU 100. IN COL 1

* INFORMATIVE DIAGNOSTIC FOR THE ABOVE INSTRUCTION NRMAX HAS BEEN RESET FROM O TO 18.

CTOF CONVERT CELSIUS IN COL 1 TO FAHRENHEIT AND PUT IN COL 11

FTOC CONVERT FAHRENHEIT IN COL 11 TO CELSIUS AND PUT IN COL 12

SUBTRACT COL 1 FROM COL 12 STORE IN COL 13

MULTIPLY COL 1 BY 1.8 MULT BY 1.0 ADD 32. STORE IN COL 14

DIV 5. BY 9. STORE IN COLUMN 8

SUBTRACT 32.0 FROM COL 11 MULT BY COL 8 ADD 0.0 STORE IN COL 24

SUBTRACT COL 1 FROM COL 24 STORE IN COL 25

TITLE 1 CENTIGRADE FAHRENHEIT FAHR TO CENT CONVERSION

TITLE2 FORMULAS

PRINT COLS $1,11,12,14$ AND 24

SUBTRACT COL' 11 FROM COL 14 STORE IN COL 15

AVERAGE COL 15 STORE IN COL 15

AVERAGE COL 13 STORE IN COL 13

AVERAGE COL 25 STORE IN COL 25

SPACE 2

NOTE *

SPACE

NOTE THE FOLLOHING VALUES MUST BE EQUAL TO OR NEAR ZERO.

SPACE

ABR IDGE ROW 1 OF COLS 13,15 AND 25

SPACE

NOTE

ERASE

* INFORMATIVE DIAGNOSTIC FOR THE ABOVE INSTRUCTION NRMAX HAS BEEN RESET FROM 18 TO 0 .

ATOMIC MASSES OF ALL ELEMENTS STORE RESULTS IN COL 61

* INFORMATIVE DIAGNOSTIC FOR THE ABOVE INSTRUCTION NRMAX HAS BEEN RESET FROM O TO 103.

GENERATE FROM 1. IN STEPS OF 1. THRU *NRMAX* IN COL 2

SEPARATE COL 61 EVERY 5TH ROW START WITH ROW 5 STORE IN COL 3

SEPARATE COL 2 EVERY 5TH ROW START WITH ROW 5 STORE IN COL 4

RESET NRMAX TO 20

* INFORMATIVE DIAGNOSTIC FOR THE ABOVE INSTRUCTION NRMAX HAS BEEN RESET FROM 103 TO 20.

FORMAT E (4A3)

READ E FORMAT, NEXT 20 LINES IN COLS 5, 6, 7 AND 8

20 DATA CARD(S) READ BUT NOT LISTED

TITLE1

TITLE2 
OMNITAB 80 TEST F9 TEMP. SCALE CONVERSION AND ATOMIC KT. (13.1) AND (13.3) PAGE 4 LIST OF DATA, INSTRUCTIONS AND DIAGNOSTICS

NEW PAGE

NOTE ELEM. NO. ATOMIC WT. ELEMENT

SPACE

FORMAT D $(2 \mathrm{X}, \mathrm{F} 5.0,3 \mathrm{X}, \mathrm{F} 12.5,5 \mathrm{X}, 4 \mathrm{~A} 3)$

NPRINT D FORMAT, COLS $4,3,5,6,7$ AND 8

NATIONAL BUREAU OF STANDARDS. WASHINGTON, D. C. 20234 OMNITAB 80 VERSION 6.00 MARCH 2,1981 
OMNITAB 80 TEST F10 PHYSICAL CONSTANTS. (13.2) CENTIMETER-GRAM-SEC SYSTEME-INTERNATIONALE CGS SI

$\begin{array}{ll}\text { PI } & 3.141593+000 \\ \text { E } & 3.521976+000 \\ \mathrm{C} & 2.997925+010 \\ \mathrm{Q} & 1.602100-020 \\ \mathrm{~N} & 6.022520+023 \\ \text { ME } & 9.109100-028 \\ \text { MP } & 1.672520-024 \\ \text { F } & 9.648700+003 \\ \text { H } & 6.625600-027 \\ \text { ALPHA } & 7.297200-003 \\ \text { QME } & 1.758796+007 \\ \text { RINF } & 1.097373+005 \\ \text { GAMMA } & 2.675190+004 \\ \text { MUB } & 9.273200-021 \\ \text { R } & 8.314300+007 \\ \text { K } & 1.380540-016 \\ \text { CONE } & 3.741500-005 \\ \text { CTWO } & 1.438790+000 \\ \text { SIGMA } & 5.669700-005 \\ \text { G } & 6.670000-008\end{array}$

$3.141593+000$

$3.521976+000$

$2.997925+008$

$1.602100-019$

$6.022520+023$

$9.109100-031$

$1.672520-027$

$9.648700+004$

$6.625600-034$

7.297200-003

$1.758796+011$

$1.097373+007$

2. $675190+008$

$9.273200-024$

$8.314300+000$

1.380540-023

3. $741500-016$

$1.438790-002$

5. 669700-008
$6.670000-011$
PAGE

PHYSICAL CONSTANTS

PI

BASE OF NATURAL LOGS

SPEED OF LIGHT IN VACUUM

ELEMENTARY CHARGE

AVOGADRO CONSTANT

ELECTRON REST MASS

PROTON REST MASS

FARADAY CONSTANT

PLANCK CONSTANT

FINE STRUCTURE CONSTANT

CHARGE TO MASS RATIO FOR ELECTRON

RYDBERG CONSTANT

GYROMAGNETIC RATIO OF PROTON (CORRECTED FOR H20)

BOHR MAGNETON

GAS CONSTANT

BOLTZMANN CONSTANT

FIRST RADIATION CONSTANT

SECOND RADIATION CONSTANT

STEPHAN-BOLTZMANN CONSTANT

GRAVITATIONAL CONSTANT 
OMNITAB 80 TEST F10 PHYSICAL CONSTANTS. (13.2)

LIST OF DATA, INSTRUCTIONS AND DIAGNOSTICS

CGS USE PHYSICAL CONSTANTS IN CGS (CENTIMETER-GRAM-SECOND) SYSTEM RESET NRMAX TO 1

* INFORMATIVE DiagNoSTIC FOR THE ABOVE INSTRUCTION NRMAX HAS BEEN RESET FROM O TO 1.

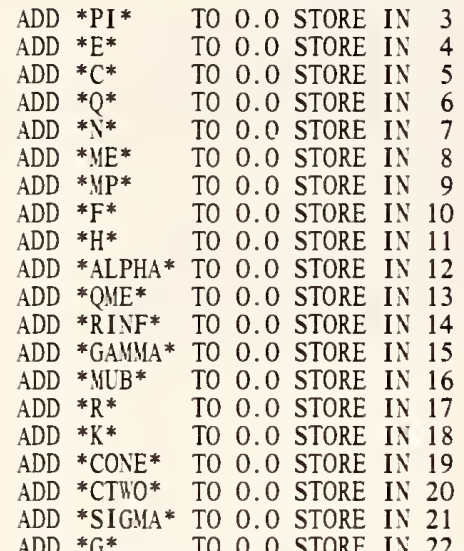

ADD *G* TO 0.0 STORE IV 22

MTRANSPOSE VECTOR IN ROK 1 OF COL 3 SIZE 1 X2O PUT IN ROW 1 OF COL 1 SI LSE PHYSICAL CONSTANTS IN SYSTEME INTERNATIONAL

ADD *PI* TO 0.0 STORE IN 3

ADD *E* TO 0.0 STORE IN 4

$\mathrm{ADD} *^{*} \mathrm{C}^{*}$ TO 0.0 STORE IN 5

ADD * $0^{*}$ TO 0.0 STORE IN 6

ADD * N $^{*}$ TO 0.0 STORE IN 7

ADD *ME* TO 0.0 STORE IN 8

ADD *YP* TO 0.0 STORE IV 9

ADD *F* TO 0.0 STORE IN 10

ADD *H* TO 0.0 STORE IN 11

ADD *ALPHA * TO 0.0 STORE IY 12

ADD *QME* TO 0.0 STORE IN 13

ADD *RINF* TO 0.0 STORE IN 14

ADD *GAMYA* TO 0.0 STORE IN 15

ADD *YUB* TO 0.0 STORE IN 16

ADD $* R^{*}$ TO 0.0 STORE IN 17

ADD * $\mathrm{K} * \quad$ TO 0.0 STORE IN 18

ADD *CONE* TO 0.0 STORE IN 19

ADD *CTHO* TO 0.0 STORE IN 20

ADD *SIGMA* TO 0.0 STORE IN 21

ADD * $\mathrm{G}^{*} \quad$ TO 0.0 STORE IN 22

MTRAYSPOSE IECTOR IN ROR 1 OF COL 3 SIZE 1 X2O PUT IN ROW 1 OF COL 2 FORMAAT F $(2 \mathrm{~A} 3,4 \mathrm{X}, 16 \mathrm{~A} 3)$ 
OMNITAB 80 TEST F10 PHYSICAL CONSTANTS. (13.2)

LIST OF DATA, INSTRUCTIONS AND DIAGNOSTICS

READ F FORMAT, 20 LINES INTO COLS $3 * * * 20$

* informative diagnostic for the aboVE instruction NRMAX HAS BEEN RESET FROM 1 TO 20.

20 DATA CARD(S) READ BUT NOT LISTED

FORMAT B $(5 \mathrm{X}, 2 \mathrm{~A} 3,5 \mathrm{X}, 1 \mathrm{PE} 15.6,8 \mathrm{X}, \mathrm{E} 15.6,10 \mathrm{X}, 16 \mathrm{~A} 3)$

TITLE 1 CENTIMETER-GRAM-SEC SYSTEME-INTERNATIONALE

TITLE2 PHYSICAL CONSTANTS

TITLE3 CGS

PRINT B COLS $3,4 \quad 1,2 \quad 5 * * * 20$

SI

STOP

NATIONAL BUREAU OF STANDARDS. WASHINGTON, D. C. 20234

OMNITAB 80 VERSION 6.00

MARCH 2,1981 
Index Of OMNITAB Commands Used

* Command is used in more than three test problems; only first three uses are 1 isted.

\begin{tabular}{|c|c|c|c|c|}
\hline $\begin{array}{l}\text { AADD } \\
\text { AAVERAGE }\end{array}$ & & \multicolumn{3}{|l|}{ BETA DENSITY } \\
\hline $\begin{array}{l}\text { AAVERAGE } \\
\text { ABR IDGE }\end{array}$ & $\begin{array}{r}224 \\
* 11,33,35\end{array}$ & $\begin{array}{l}\text { BETA RANDOM } \\
\text { BINOMIAL CU }\end{array}$ & $\begin{array}{l}\text { M } \\
\text { UMULATIVE }\end{array}$ & $\begin{array}{l}179 \\
170\end{array}$ \\
\hline ABRIDGE A & 280 & BINOMIAL DEI & $\begin{array}{l}\text { ENSITY } \\
\text { ENT }\end{array}$ & 156 \\
\hline ABR IDGE C & 285 & BINOMIAL PEI & ERCENT ILE & 170 \\
\hline ABR IDGE D & 277 & BINOMIAL RA: & ANDOM & 179 \\
\hline ABR IDGE $\mathrm{F}$ & 289 & BIONE & & 233 \\
\hline ABS & 37 & BIZERO & & 233 \\
\hline ABSOLUTE & 43 & BJONE & 1 &, 233 \\
\hline ACCURACY & 43,212 & BJZERO & 194,2 & 245 \\
\hline ACOALESCE & 224 & BKONE & & 233 \\
\hline ACOS & 43 & BKZERO & & 233 \\
\hline$A \operatorname{COSD}$ & 48 & BOLDISTRI BU & UTION & 254 \\
\hline $\mathrm{ACOSH}$ & 51 & BRIEF & & 108 \\
\hline ACOT & 43 & BYONE & & 233 \\
\hline ACOTD & 48 & BYZERO & & 233 \\
\hline ACOTH & 51 & CADD & & 64 \\
\hline ADD & $* 6,11,33$ & CAUCHY CUMUI & ULATIVE & 162 \\
\hline ADEFINE & 292 & CAUCHY DENS & SITY & 162 \\
\hline ADIV & 292 & CAUCHY PERCI & CENTILE & 162 \\
\hline ADIVIDE & 292 & CAUCHY PLO & & 30 \\
\hline AERASE & 292 & CAUCHY RAND & DOM & 179 \\
\hline ALABEL & 220 & CDIVIDE & & 64 \\
\hline AMOVE & 71 & CEIONE & & 241 \\
\hline AMULT & 292 & CEIZERO & & 241 \\
\hline AMULTIPLY & 292 & CEKONE & & 241 \\
\hline ANTILOG & 37 & CEKZERO & & 241 \\
\hline APR INT & 221 & CENSOR & & 77 \\
\hline APRINT A & 286 & CENSOR & & 78 \\
\hline APRINT E & 287 & CENSOR & & 78 \\
\hline APROPERTIES & 220 & CENSOR & & 78 \\
\hline ARAISE & 292 & CENSOR LE & & 78 \\
\hline ASIN & 43 & CENSOR & & 78 \\
\hline ASIND & 48 & CENSOR & & 78 \\
\hline ASINH & 51 & CERF & & 186 \\
\hline ASUB & 67,71 & $\operatorname{cGS}$ & & 304 \\
\hline ASUBTRACT & 220 & CHANGE & & 35 \\
\hline ATAN & 43 & CHISQUARED & CUMULAT IVE & 174 \\
\hline ATAND & 48 & CHISQUARED & PERCENTILE & 174 \\
\hline ATANH & 51 & CHISQUARED & RANDOM & 179 \\
\hline ATOM IC & 301 & CHOOSE & & 91 \\
\hline ATRANSPOSE & 221 & CIONE & & 240 \\
\hline AVERAGE & $* 43,47,51$ & CIZERO & & 240 \\
\hline AZERO & 222 & CKONE & & 240 \\
\hline BEG IN & 199,212 & CKZERO & & 240 \\
\hline BESIN & 245 & CLOSE UP & & 267 \\
\hline BESJN & 245 & CMULTIPLY & & 65 \\
\hline BESKN & 245 & CODE & & 98 \\
\hline BESTCP & 278 & COMPARE & & 290 \\
\hline BETA CUMULATIVE & 175 & CONTINGENCY & & 134 \\
\hline
\end{tabular}

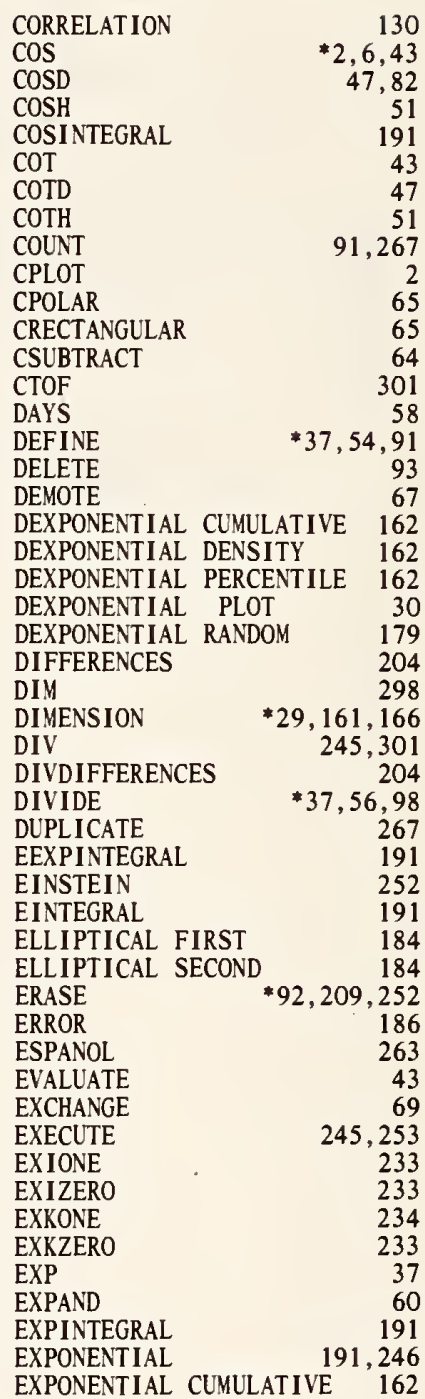




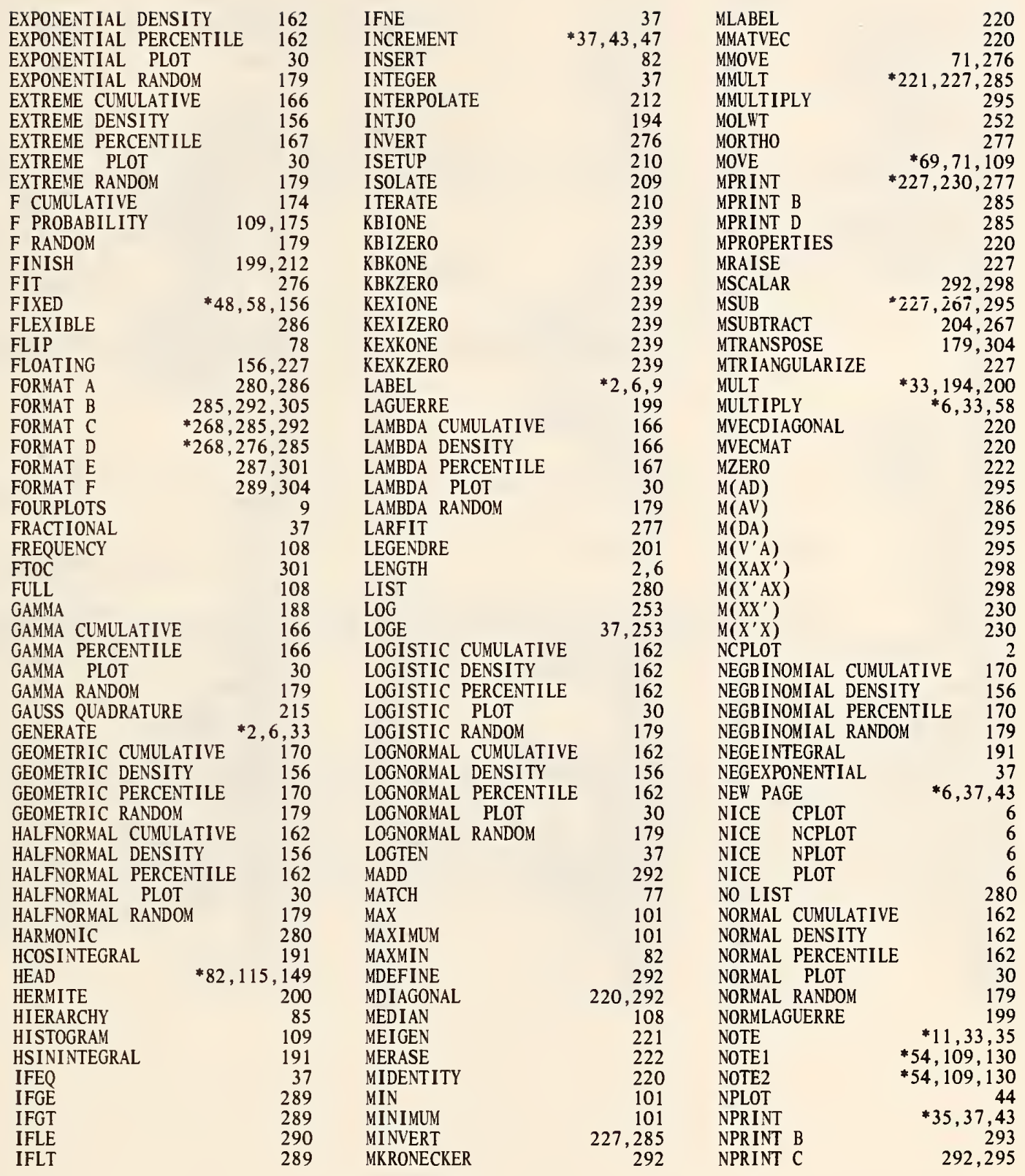




\begin{tabular}{|c|c|c|c|c|c|}
\hline NPRINT D & $268,298,302$ & READ C & 268 & STRUVE ZERO & 194 \\
\hline NTABLE AVERAGE & 150 & READ E & 301 & STHOHAY & \\
\hline NTABLE CPERCENTAGE & 152 & READ $\bar{F}$ & 305 & SUB & $* 11,56,60$ \\
\hline ITABLE CPROPORTION & 153 & RECIPROCAL & 47,51 & SUBTRACT & $* 33,37,47$ \\
\hline NTABLE FREQLENCY & 149 & RECODE & 98 & SLM & $* 11,33,56$ \\
\hline NTABLE MAXIMLY & 151 & REPEAT & $37,44,47$ & T CUYULATIVE & 17 \\
\hline NTABLE MEDIAN & 151 & REPLACE & 98 & T PERCENTILE & \\
\hline NTABLE MINIMUM & 150 & RESET & $* 47,60,71$ & T RANDOM & \\
\hline NTABLE PERCENTAGE & 151 & RESET ' $V$ ' & $11,91,240$ & TABLE AVERAGE & \\
\hline NTABLE PROPORTION & 152 & RESTORE & 37 & TABLE CPERCENTAGE & \\
\hline NTABLE RANGE & 151 & RETAIN & 92 & TABLE CPROPORTION & \\
\hline NTABLE RPERCENTAGE & 152 & RYS & 56 & TABLE FREQUENCY & \\
\hline NTABLE RPROPORTION & 153 & ROUND & 54,191 & TABLE MAXIMCM & \\
\hline NTABLE STDDEV & 150 & ROF SUM & $149,180,220$ & TABLE MED IAN & \\
\hline NTABLE SLM & 149 & ROHSLM & $* 33,35,77$ & TABLE MINIMCY & \\
\hline NULL & 289 & SAMPLE ITHOUTR & 182 & TABLE PERCENTAGE & \\
\hline OMIT & 92 & SAMPLE RITHR & 182 & TABLE PROPORTION & \\
\hline ONNITAB & $* 2,6,9$ & SAPROPERTIES & 67 & TABLE RANGE & \\
\hline ONEHAY & 121 & SCAN & 276 & TABLE RPERCENTAGE & \\
\hline ORDER & 85 & SCORRELATION & 9,130 & TABLE RPROPORTION & \\
\hline PAGE PLOT & 44 & SDIFFERENCES & 204 & TABLE STDDEV & \\
\hline PARETO CLMULATIVE & 166 & SDIVDIFFERENCES & 204 & TABLE SUM & \\
\hline PARETO DENSITY & 156 & SEARCH & 77 & TAN & \\
\hline PARETO PERCENTILE & 167 & SELECT & 77 & TAND & \\
\hline PARETO PLOT & 30 & SEPARATE & 82,301 & TANH & \\
\hline PARETO RANDOM & 179 & SET & $* 11,13,29$ & TCHEBYSHEV & 19 \\
\hline PARPRODLCT & 56 & SFIT & 124,277 & TITLEX & $2,6,4$ \\
\hline PARSLY & $* 56,163,167$ & SHORTEN & 60 & TITLEY & $2,6,4$ \\
\hline PARTFLNCTION & 254 & SI & 304 & TITLE1 & $* 6,9,3$ \\
\hline PERCENTAGES & 58 & SIN & $* 2,6,43$ & TITLE2 & $* 33,47,6$ \\
\hline PERFORM & $* 51,54,124$ & SIND & 47 & TITLE3 & $* 13,33,5$ \\
\hline PFATOMIC & 254 & SINH & 51 & TITLE4 & $* 33,54$, \\
\hline PFTRANSLATIONAL & 252 & SININTEGRAL & 191 & THOPLOTS & \\
\hline PLOT & 44 & SMPROPERTIES & $71,220,267$ & TWOF'AY & \\
\hline POISSON CLMULATIVE & 170 & SOLVE & 285 & UCHEBYSHEV & \\
\hline POISSON DENSITY & 156 & SONEKAY & 121 & UNIFORM CLMULATIVE & \\
\hline POISSON PERCENTILE & 170 & SORT & 85 & UNIFORM DENSITY & \\
\hline POISSON PLOT & 30 & SPACE & $* 2,6,11$ & UNIFORM PERCENTILE & \\
\hline POISSON RANDOM & 179 & SPLIT PLOT & 278 & UNIFORMＰLOT & \\
\hline POLYFIT & 115 & SPOLYFIT & 27 & UNIFORM RANDOM & 18 \\
\hline PRINT & $* 33,35,54$ & SQRT & $* 56,60,200$ & VOCABLLARY & \\
\hline PRINT B & 305 & SQUARE & $* 37,47,51$ & REIBULL CLYULATIVE & 16 \\
\hline PRINT NOTE & $* 54,109,130$ & SSTATISTICAL & 108 & REIBULL DENSITY & \\
\hline PRODUCT & 33 & SSTEM LEAF & 11 & REIBULL PERCENTILE & 16 \\
\hline PROMOTE & 67,149 & STATISTICAL & 108 & REIBULL PLOT & \\
\hline PROPORTIONS & 58 & STATPLOTS & 13 & MEIBULL RANDOM & 17 \\
\hline RAISE & 200 & STDDEV & 108 & HIDTH & $* 2,6$, \\
\hline RANGE & 108 & STEM LEAF & 11 & ZEROS BJONE & 24 \\
\hline RANXS & 108 & STOP & 305 & ZEROS BJZERO & 24 \\
\hline READ & $, 35,56$ & STRUVE ONE & 194 & & \\
\hline
\end{tabular}


NBS-114A (REV. 2-8C)

U.S. DEPT. OF COMM.

BIBLIOGRAPHIC DATA

SHEET (See instructions)

1. PUBLICATION OR REPORT NO.

TN 1147

2. Performing Organ. Report No f 3. Publication Date

November 1981

4. TITLE AND SUBTITLE

Test Problems and Results for OMNITAB 80

5. AUTHOR(S)

Sally T. Peavy and Shirley G. Bremer

6. PERFORMING ORGANIZATION (If joint or other than NBS, see instructions)

7. Contract/Grant No.

NATIONAL BUREAU OF STANDARDS

DEPARTMENT OF COMMERCE

WASHINGTON, D.C. 20234

3ype of Report \& Period Covered

9. SPONSORING ORGANIZATION NAME AND COMPLETE ADDRESS (Street, City, Stote, ZIP)

same as no. 6

10. SUPPLEMENTARY NOTES

Supersedes Technical Note 552

$\square$ Document describes a computer program; SF-185, FIPS Software Summary, is attached.

11. ABSTRACT (A 200-word or less foctual summary of most significant information. If document includes a significant bibliography or literature survey. mention it here)

The lack of test problems and results for many computer software packages is a great hindrance to both the systems programmer and the general user. In this publication a set of 69 test problems and results for the OMNITAB 80 system is provided to assist individuals in checking the installation of the OMNITAB 80 system on their particular computer. The general user will also find these descriptive examples instructive in the use of the OMNITAB 80 system.

12. KEY WORDS (Six to twelve entries: alphabetical order: copitalize only proper names: ond separate key words by semicolons)

Accuracy; ANS FORTRAN; computer system installation; examples; OMNITAB 80; software; test problems.

13. AVAILABILITY

X] Unlimited.

$\square$ For Official Distribution. Do Not Release to NTIS

X] Order From Superintendent of Documents, U.S. Government Printing Office, Washington, D.C. 20402.

Order From National Technical Information Service (NTIS), Springfield, VA. 2216
14. NO. OF PRINTED PAGES 316

15. Price 





\section{NBS TECHNICAL PUBLICATIONS}

\section{PERIODICALS}

JOURNAL OF RESEARCH-The Journal of Research of the National Bureau of Standards reports NBS research and development in those disciplines of the physical and engineering sciences in which the Bureau is active. These include physics, chemistry, engineering, mathematics, and computer sciences. Papers cover a broad range of subjects, with major emphasis on measurement methodology and the basic technology underlying standardization. Also included from time to time are survey articles on topics closely related to the Bureau's technical and scientific programs. As a special service to subscribers each issue contains complete citations to all recent Bureau publications in both NBS and nonNBS media. Issued six times a year. Annual subscription: domestic $\$ 16$; foreign $\$ 20$. Single copy, $\$ 3.75$ domestic; $\$ 4.70$ foreign.

NOTE: The Journal was formerly published in two sections: Section A "Physics and Chemistry" and Section B "Mathematical Sciences."

DIMENSIONS/NBS-This monthly magazine is published to inform scientists, engineers, business and industry leaders, teachers, students, and consumers of the latest advances in science and technology, with primary emphasis on work at NBS. The magazine highlights and reviews such issues as energy research, fire protection, building technology, metric conversion, pollution abatement, health and safety, and consumer product performance. In addition, it reports the results of Bureau programs in measurement standards and techniques, properties of matter and materials, engineering standards and services, instrumentation, and automatic data. processing. Annual subscription: domestic \$11; foreign $\$ 13.75$.

\section{NONPERIODICALS}

Monographs-Major contributions to the technical literature on various subjects related to the Bureau's scientific and technical activities.

Handbooks-Recommended codes of engineering and industrial practice (including safety codes) developed in cooperation with interested industries, professional organizations, and regulatory bodies.

Special Publications-Include proceedings of conferences sponsored by NBS, NBS annual reports, and other special publications appropriate to this grouping such as wall charts, pocket cards, and bibliographies.

Applied Mathematics Series-Mathematical tables, manuals, and studies of special interest to physicists, engineers, chemists, biologists, mathematicians, computer programmers, and others engaged in scientific and technical work.

National Standard Reference Data Series-Provides quantitative data on the physical and chemical properties of materials, compiled from the world's literature and critically evaluated. Developed under a worldwide program coordinated by NBS under the authority of the National Standard Data Act (Public Law 90-396).
NOTE: The principal publication outlet for the foregoing data is the Journal of Physical and Chemical Reference Data (JPCRD) published quarterly for NBS by the American Chemical Society (ACS) and the American Institute of Physics (AIP). Subscriptions, reprints, and supplements available from ACS, 1155 Sixteenth St., NW, Washington, DC 20056.

Building Science Series-Disseminates technical information developed at the Bureau on building materials, components, systems, and whole structures. The series presents research results, test methods, and performance criteria related to the structural and environmental functions and the durability and safety characteristics of building elements and systems.

Technical Notes-Studies or reports which are complete in themselves but restrictive in their treatment of a subject. Analogous to monographs but not so comprehensive in scope or definitive in treatment of the subject area. Often serve as a vehicle for final reports of work performed at NBS under the sponsorship of other government agencies.

Voluntary Product Standards-Developed under procedures published by the Department of Commerce in Part 10, Title I5, of the Code of Federal Regulations. The standards establish nationally recognized requirements for products, and provide all concerned interests with a basis for common understanding of the characteristics of the products. NBS administers this program as a supplement to the activities of the private sector standardizing organizations.

Consumer Information Series-Practical information, based on NBS research and experience, covering areas of interest to the consumer. Easily understandable language and illustrations provide useful background knowledge for shopping in today's technological marketplace.

Order the above NBS publications from: Superintendent of Documents, Government Printing Office, Washington, DC 20402.

Order the following NBS publications-FIPS and NBSIR's-from the National Technical Information Services, Springfield, VA 22161.

Federal Information Processing Standards Publications (FIPS PUB)-Publications in this series collectively constitute the Federal Information Processing Standards Register. The Register serves as the official source of information in the Federal Government regarding standards issued by NBS pursuant to the Federal Property and Administrative Services Act of 1949 as amended, Public Law 89-306 (79 Stat. 1127), and as implemented by Executive Order 1 I717 (38 FR 12315, dated May I I, I973) and Part 6 of Title 15 CFR (Code of Federal Regulations).

NBS Interagency Reports (NBSIR) - A special series of interim or final reports on work performed by NBS for outside sponsors (both government and non-government). In general, initial distribution is handled by the sponsor; public distribution is by the National Technical Information Services, Springfield, VA 22161, in paper copy or microfiche form. 
U.S. DEPARTMENT OF COMMERCE

National Bureau of Standards

Washingtan. D.C. 20234

POSTAGE AND FEES PAID

OFFICIAL BUSINESS

U.S. OEPARTMENT OF COMMERCE

COM-215

SPECIAL FOURTH-CLASS RATE BOOK 